DOE/EV-0032

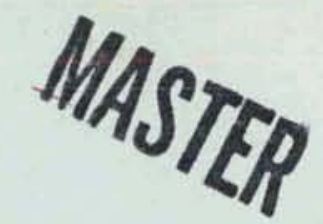

\title{
Report on the Explosion, Fire, and Oil Spill Resulting in One Fatality and Injury on September 21, 1978, at Well 6 of Cavern 6 at the West Hackberry, Louisiana, Oil Storage Site of the Strategic Petroleum Reserve
}

November 1978

U.S. Department of Energy Washıngton, D.C. 20545

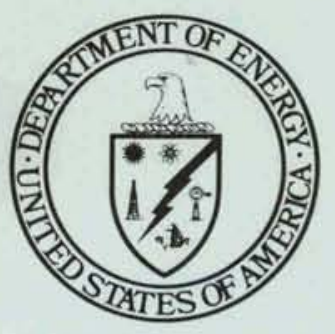




\section{DISCLAIMER}

This report was prepared as an account of work sponsored by an agency of the United States Government. Neither the United States Government nor any agency Thereof, nor any of their employees, makes any warranty, express or implied, or assumes any legal liability or responsibility for the accuracy, completeness, or usefulness of any information, apparatus, product, or process disclosed, or represents that its use would not infringe privately owned rights. Reference herein to any specific commercial product, process, or service by trade name, trademark, manufacturer, or otherwise does not necessarily constitute or imply its endorsement, recommendation, or favoring by the United States Government or any agency thereof. The views and opinions of authors expressed herein do not necessarily state or reflect those of the United States Government or any agency thereof. 


\section{DISCLAIMER}

Portions of this document may be illegible in electronic image products. Images are produced from the best available original document. 
The following report is the independent product of the Accident Investigation Committee which was commissioned by the Department of Energy following the accident on September 21, 1978, at the Strategic Petroleum Reserve site at West Hackberry, Louisiana. This Committee is charged with the task of determining the nature, extent, and causes of that accident and the need for corrective action. The discussion of the facts, as determined by the committee, and the views expressed in this report do not assume and are not intended to establish the existence of any duty at law on the part of the Government, its employees or agents; the Government's contractors, their employees or agents; or subcontractors of any tier, or their employees or agents. In this report, the Committee has made no determination of legal liability and none shall be implied. 


\section{Report on the Explosion, Fire, and Oil Spill Resulting in One Fatality and Injury on September 21, 1978, at Well 6 of Cavern 6 at the West Hackberry, Louisiana, Oil Storage Site of the Strategic Petroleum Reserve}

Volume I

November 1978

\section{U.S. Department of Energy}

Washington, D.C. 20545
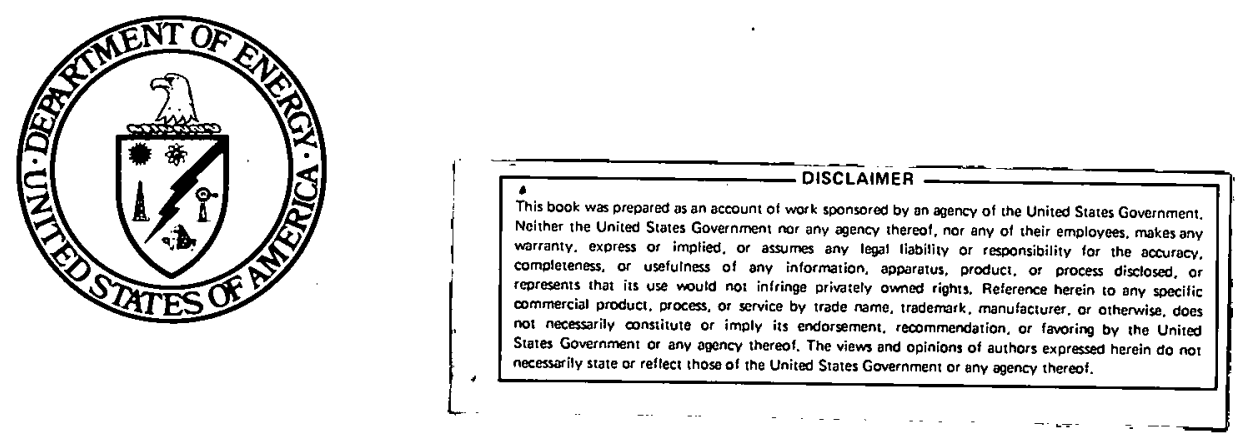

For sale by the Superintendent of Documents, U.S. Government Printing Office

Washington, D.C. 20402

Stock Number 061-000-00202-2

ESTRIBUTIOA OF THIS DOCUMENT IS UALIMITEO 
VOLUME I

CONTENTS

GLOSSARY

$\underline{\text { Page }}$

I. SUMMARY 1

II. SCOPE

III. FACTS 9

A. BACKGROUND 9

B. SEQUENCE OF KEY EVENTS 43

C. OBSERVATIONS $\quad 54$

D. CONSEQUENCES $\quad 59$

E. PHYSICAL EVIDENCE 61

F. EMERGENCY RESPONSE $\quad 71$

G. RELATED OBSERVATIONS 93

H. PUBLIC ANNOUNCEMENTS 95

IV. ACCIDENT ANALYSIS 97

A. TECHNICAL ANALYSIS 97

B. MANAGEMENT ANALYSIS 111

C. EMERGENCY PREPAREDNESS AND 130

RESPONSE ANALYSIS

D. HUMAN FACTORS 136

V. CONCLUSIONS 141

VI. SIGNATURE PAGE 151

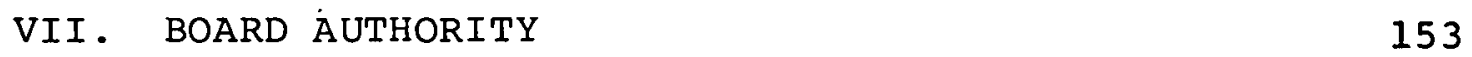




\section{ILLUSTRATIONS}

Figure

1

2

3

\section{$3 a$}

$4 \mathrm{~A}$

$4 \mathrm{~b}$

5

6

$6 a$

$6 \mathrm{~b}$

7

8

9

10

11

12

$12 \mathrm{a}$

13

14

15

16

17

$18 \mathrm{~A}-18 \mathrm{~B}$

$19 A-19 B$

20

Strategic Petroleum Reserve Showing

Page

West Hackberry Facility

West Hackberry Site Before Accident -

Looking South

West Hackberry Site Before Accident Looking North

Site Plan at Time of Accident

Cavern 6 Site Before Accident

Cavern 6 Cross Section

Overall Configuration of Well 6

19

Cactus and Pelican Rigs on Cavern 6

20

Prior to Accident

22

Well 6 Well Head Configuration Before Workover

TAM set Inflatable/Retrievable Packer

Safety Valve for Use as Stabbing Valve as

Made Up for Well 6

31

Organization Chart at Time of Accident

44

of Ignition to Arrival of On-Scene Commander

45

Emergency Response Organization from Time of

Arrival of On-Scene Commander to the securing of Well 6

Site During Fire

Site 3 Hours After Ignition

Site During Fire

Site After Fire

58

Property Damage

60

Smoke Plume

62

Oil Spill

63

Physical Evidence - Well Head

$65-66$

$67-69$

70

21A-21E Firefighting

73-77 
ILLUSTRATIONS (Cont)

Figure

22

23

$24 \mathrm{~A}-24 \mathrm{C}$

25

$26 \mathrm{~A}-26 \mathrm{C}$

$27 \mathrm{~A}-27 \mathrm{C}$

28

29

30
Well Control - Phase I - Stinger

Well Control - Phase II - Packer

Well Control - Phase III - Final Capping

Dike system

oil Containment

Oil cleanup

Initial Hydraulic Forces on the Packer

Hydraulic Forces when the Packer Failed

Analysis of Workover Operations (Events Sequence Chart) $\underline{\text { Page }}$

80

81

$82-84$

85

87-89

90-91

101

103

112 


\section{TABLES}

Table

Page

1 Personnel at Cavern 6 at Time of Accident 27

2 Recent Changes in Management (1978) 33

3 Timeline of Key Events - Prior to 46

4 Timeline of Key Events -- From Ignition 50

5 Timeline of Key Events -- From Arrival of

On-Scene Commander to Securing of Well 6 (Post-Accident)

6 Apparent Related Management Issues 
VOLUME II

APPENDICES

CONTENTS

Appendix

-Page

I

List of Witnesses

A-3

I I

Letters

A-9

III

Master Files List

A-19

IV

Environmental Damage Report

$A-23$

V

Medical Data

$A-65$

VI

Analysis \& Estimates of Losses

$\mathrm{A}-71$

VII

Metallurgical Report

$A-83$

VIII

Consultants' Analyses

A-123

IX

Press Releases

$A-187$

$\mathrm{X}$

Newspaper Stories

$A-199$

$X I$

TAM Brochure \& TAM International Service Record

$A-227$

Workover Procedures

$A-243$

Drilling Reports

$A-265$

$X I I I$

List of Organizations Helping at Fire

A-281

XIV

List of Injured

$A-287$

XV

U.S. Accounting office \& Comptroller

$A-291$ General Reports

XVII

Management Oversight Risk Tree Analysis

A -359

XVIII

Copy of oct. 17, 1978, TWX, white to

$A-363$ 


\section{GLOSSARY}

Annular space

Bag-type blowout preventer

Blind ram blowout preventer

Blowout

Blowout preventer

Casing

Casing seat

Casing string
The volume between the wall of the inner casing suspended in the center of the well and larger casing surrounding the inner one.

A mechanical device that seals off a casing using inflatable chambers.

A mechanical device that uses rubber and steel plungers to close off casing when drill pipe is not in the hole.

A sudden, violent escape of gas and oil (and sometimes water) from a drilling well when high pressure gas is encountered and preparation to prevent or to control the escape has not been made.

A mechanical device or a combination of mechanical devices secured to the top of a well casing, including valves, fittings, and control mechanism connected therewith, designed to prevent a blowout.

Steel pipe of a particular size and type used in drilling operations.

The lowermost point of any string of casing or pipe in a drilled hole.

A series of lengths of casing joined to form a tubing for down-hole operations. 
GLOSSARY (Cont)

Cavern

Inflatable packer

Kill the well

Mud (mixing mud)

Mud return line

OSHA-type safety

duties

Packer
A cavity formed by the leaching of the center of a salt deposit in such a way as to leave an empty space surrounded by the original salt formation.

A mechanical device having a bladder that can inflate with fluid, and which can plug a casing.

The process of stabilizing the pressure in the casing using drilling mud.

The preparation of drilling fluids from a mixture of water and one or more of the various dry mud-making materials such as clay. Used to counterbalance oil pressure from the bottom of the well.

A pipe used to transport drilling fluid returns from the drill hole back to a storage basin.

Inspection for compliance to the requirements of the Occupational safety and Health Act.

A mechanical device inserted in a section of casing (can be retrieved) as a plug. There are a variety of types of packers each with specialized functions. 
Ram-type blowout preventer

Rig

Roughneck

SPR

SPRO

Stabbing

Stabbing valve

Stinger
A mechanical device consisting of a "stack" containing blind rams and pipe rams that. are designed to fit around pipe in the hole.

Básically includes hoisting equipment, prime movers, and auxiliary equipment necessary to well drilling.

A driller's helper and general all-around worker on rig.

Strategic Petroleum Reserve.

Strategic Petroleum Reserve Office -New Orleans.

An oil field term used to describe the physical action of screwing sections of casing or any kind of pipe together or inserting a piece of equipment through a well head or casing.

A manually installed safety valve which must be screwed into an open casing to stop the flow of oil or mud.

An extension of a piece of equipment generally smaller (but not necessary) in diameter than that piece that it is going to be connected to. 


\section{GLOSSARY (Cont)}

Tool pusher

Well head

Workover
A supervisor in charge of a drilling operation.

Valves and fittings at the top of a well to control the flow of gas or oil.

one or more of a variety of remedial operations on a well. 


\section{SUMMARY}

On September 21, 1978, Pelican Well Service Company's

Rig Il, in the workover operation, was engaged in pulling 5-1/2-inch casing out of well 6 of oil storage Cavern 6 at the West Hackberry, Louisiana, oil storage site. After pulling 14 joints of casing out of the hole, the mud from within the 5-1/2inch casing started flowing from the top of the casing in the hole. The mud and a packer, previously set in the lower sections of the casing, apparently were being forced up the inside of the casing to the surface by pressure from below exerted by oil under pressure in the storage cavern and mud in the annulus between the $5-1 / 2-i n c h$ casing and the outer 9-5/8-inch casing.

The flow of mud from the 5-1/2-inch casing could not be controlled by workers on the rig, continuing unchecked until the packer. blew out of the casing followed by a flow of oil. An oil mist or fumes, formed from the flow of oil, were drawn into the air manifold intakes of the diesel engine on the rig and nearby engines causing them to overspeed. Upon hearing the engines overspeeding, several of the Pelican Well Service Company personnel began shutting down the diesel engines while other personnel on the site began to evacuate the area.

An explosion and fire occurred at approximately 3:55 p.m. while two Pelican Well service employeês were still trying to shut down the rig engine; both men were severely burned, and one later died from his injuries.

The two injured men escaped from the immediate area of the fire, got into a car, and drove it until they were intercepted by a Parsons-Gilbane employee who arranged for a helicopter to take the two injured men to the hospital in Lake Charles, Louisiana. Both men were later flown by helicopter from Lake Charles to a burn center at a hospital in Baton Rouge. 
The fire burned for 5 days. A channel was dug from Black Lake to a point near a Cavern 6 pad to furnish water for the firefighting operations. The control and prevention of the spreading of the fire was accomplished by local volunteer firemen under the overall direction of the Boots \& Coots oil well firefighter team. This was done by blanketing the burning well with foam and finally plugging the well.

The Pelican Rig, a dragline, a cement pump truck, a vacuum tank truck, two automobiles, a pickup truck, two house trailers, two water tank trailers, a skid-mounted "dog house" (a small shelter on the rig), and other equipment were destroyed by the fire. The cactus Drilling Company rig over another hole in the Cavern 6 pad was damaged. A nonburning oil spill went into nearby Black Lake, but was contained by the deployment of a series of oil spill containment booms and a prevailing wind from the northeast that kept the oil spill in a restricted area near shore. This oil was recovered during and immediately after the firefighting operations.

Cavern 6 initially contained approximately 7,000,000 barrels of oil at a pressure of 650 psig measured at the well head. As of September 29, 1978, the Strategic Petroleum Reserve office--New orleans (SPRO) estimated that oil expulsion from Cavern 6 was 67,510 barrels. Of this, 34,620 barrels of oil are accounted for, including 31,200 barrels of oil released into Black Lake and subsequently recovered. The remainder $(32,890$ barrels) was assumed by SPRO to have been burned. Because of the rapid and effective containment and cleanup of the oil spill by the Rapid Response Team, it appears very likely at this time that Black Lake will not sustain any permanent environmental damage.

The total loss is presently estimated by the Accident Investigation Committee's consultant to be $\$ 12$ million. 
Technical findings of the Committee, in addition to the above, included exposure to single point failure at the cavern and well head, failure to follow the written workover procedure, an inadequate safety valve on the rig, and inadequate emergency response equipment and procedures onsite.

The cause, which clearly needs correction, was inadequate attention to critical safety problems, procedures, and emergency response capability.

Deficiencies in management on the part of DOE/SPRO, which may have contributed at least indirectly to the accident, included: (1) a policy of giving predominant priority to getting "oil-in-theground" which was allowed to override prudent safety and contingency planning and implementation; (2) lack of established standards, review approval and monitoring procedures, and the oil field expertise which might have compensated for previous two; (3) an organizational lineup that split onsite responsibility, and was weak in attention to safety, quality assurance and technical inputs. Many of these carried over to impact the management approach of Parsons-Gilbane, the construction management contractor. In addition, ParsonsGilbane clearly had problems getting up to full staff complement; and their internal coordination and communications appeared weak. Most of these problems can be attributed to the speed with which the Strategic Petroleum Reserve (SPR) program has been undertaken with all its mammoth size and complexity. The corrective measures needed are self-evident. 


\section{SCOPE}

\section{A. COMMITTEE CHARTER}

On the afternoon of september 21, 1978, an accident involving the release of oil and subsequent fire occurred at the strategic Petroleum Reserve site at West Hackberry, Louisiana. Since the accident involved loss of life, injury, and significant property damage, the Department of Energy convened an Accident Investigation Committee which was charged with investigating the accident and submitting a report to the Assistant Secretary for Environment.

The purpose of the investigation was to obtain information necessary to determine:

- The nature and extent (including costs and programmatic efforts) of the accident;

- The causes of the accident; and

- An appropriate judgment of needs which require actions in order to preclude similar occurrences.

The Committee was appointed on September 23, 1978, and was requested to submit a report in 30 days. The committee and its membership were independent of the line organization responsible for the strategic Petroleum Reserve program.

\section{B. MEMBERSHIP, CONSULTANTS, AND SUPPORTING ELEMENTS}

The committee was constituted as follows:

Philip C. White, Private Consultant, Chairman George P. Dix, DOE/Operational and Environmental Safety

John N. Murphy, U.S. Bureau of Mines

Glen Stafford, DOE/Energy Technology

Phillip Lowe, DOE/Inspector General 
Carl Caves, DOE, was appointed as Committee Secretary.

The Committee was augmented by technical consultants, as follows: Gerald Slaughter and Bob Gray, Oak Ridge National Laboratory -- Metallurgical Studies

W. A. Rehm, Maurer Engineering, Inc. -- Technical Analysis of Workover

R. W. Leutzinger, Factory-Mutual Enginnering, Co. -Cost Estimates of Damage

J. F. McKenna, Private Consultant -- Safety Procedures and Standards Robert J. Nertney, EG\&G/Idaho -- Analysis of Accident Paul A. Crosetti, United Nuclear Industries, Inc. -Analysis of Accident Tim McCreary, EG\&G/Nevada -- Photographic Scientist

The Committee report was edited by:

Carl Mora, Technical Writer, Sandia Laboratories Phil Mead, Technical Writer, Sandia Laboratories

SPRO provided excellent support to the Committee both at the west Hackberry Site and in New Orleans.

The DOE-Dallas Regional Office provided general logistic and administrative support to the Committee, in particular Mr. Curtis Carlson and $\mathrm{Mr}$. Charles Pfeiffer.

Mr. David Patterson of DOE provided invaluable support and liaison for the Committee from Washington. 
C. SCOPE OF THE INVESTIGATION

The scope of the technical investigation was limited to the West Hackberry Facility of the Strategic Petroleum Reserve and, in particular, to Cavern 6 of that facility.

The scope of the management investigation encompassed the Office of the Assistant Secretary for Resource Applications (ASRA), the Strategic Petroleum Reserve program, the Strategic Petroleum Reserve Project office in New Orleans and its site office at West Hackberry, and SPRO contractor organizations.

The scope was to determine the facts surrounding the accident, to analyze its causes, and recommend corrective actions.

\section{COMMITTEE PROCEDURES}

The Committee generally utilized standard accident investigating procedures and checklists in its investigation as specified in Interim Management Directive 5001, Chapter 0502, "Notification, Investigation, and Reporting of Occurrences." In some respects, the Committee had to adapt its procedures to the specific nature of the accident.

The Committee proceeded initially with personal interviews of about 90 individuals, involving several thousand pages of unsworn testimony using court recorder techniques. These data are digested and analyzed in the following text. A list of witnesses is shown in Appendix I. Any data or discussions herein by the Committee on sites other than west Hackberry were derived from the testimony of witnesses. The committee did not physically investigate other sites.

The site was secured by the Committee to collect physical evidence such as the well head, packer, and casing from well 6 . The Committee inspected the site, both during and after the fire, and released the site after evidence was obtained and marked for shipment to DOE analytical laboratories. 
Plans and procedures and other key documentation were reviewed. The Committee requested data in writing from SPRO and others, as listed in Appendix II. A number of organization charts were collected and reviewed. A listing of the master files of the committee is set forth in Appendix III.

A Management Oversight Risk Tree (MORT) approach (see Appendix XVII) was utilized to track the sequence of both technical and management events and their interactions.

Extensive photographic techniques, involving several thousand documentary photographs from aircraft, helicopters, and ground surveys, were utilized.

A number of supporting functional analyses were performed in the investigation, including environmental studies, loss analysis and safety, metallurgical analysis of evidence, documentation analysis and a well hydraulic analysis. These are contained in Appendices IV, VI, VII, and VIII.

\section{E. SCHEDULE OF COMMITTEE ACTIVITIES}

The following Committee events occurred:

\begin{tabular}{|c|c|}
\hline Sept. 22,1978 & Committee members selected \\
\hline Sept. 23,1978 & $\begin{array}{l}\text { Committee appointed; briefing of } \\
\text { Committee by Deputy Assistant Secretary } \\
\text { for Environment (EV) }\end{array}$ \\
\hline Sept. 24,1978 & $\begin{array}{l}\text { Committee leaves Washington; arrives at } \\
\text { West Hackberry Site }\end{array}$ \\
\hline $\begin{array}{l}\text { Sept. } 30,1978 \\
\text { Oct. } 6-10,1978\end{array}$ & $\begin{array}{l}\text { Committee arrives at New Orleans (SPRO) } \\
\text { Committee conducts Washington interviews }\end{array}$ \\
\hline Oct. 10,1978 & $\begin{array}{l}\text { Committee assembles in Dallas to prepare } \\
\text { report }\end{array}$ \\
\hline Oct. & Committee draft report to $\mathrm{DOE} / \mathrm{EV}$ \\
\hline
\end{tabular}


III. FACTS

\section{A. BACKGROUND}

1. Strategic Petroleum Reserve

Public Law 94-163, The Energy Policy Conservation Act of December 22, 1975, mandated that the Federal Energy Administration (FEA) establish a strategic Petroleum Reserve to protect against future emergencies from supply interruptions. The 6-year program was to store oil in the following three steps:

(1) 250 million barrels (MMB) by the end of 1978

(2) 500 MMB by the end of 1980

(3) 1 billion barrels by the end of 1983

Subsequent analysis showed that the maximum fill for 1980 was $325 \mathrm{MMB}$, and an expansion plan became effective on April 18, 1978, to provide for increased storage to 1 billion barrels, the maximum size recommended by the President in the National Energy Plan.

When DOE became operational on October 1, 1977, this FEA program became part of DOE. Within DOE, the SPR program is administered for the Assistant Secretary for Resource Applications by the SPR program director in Washington. The SPR Project Management office in New Orleans (SPRO) reports to the SPR program director.

The initial goal of 250 MMB by the end of 1978 was revised downward successively to $125 \mathrm{MMB}$ and is presently set at $107 \mathrm{MMB}$.

2. West Hackberry Operations and site

West Hackberry, in the Texoma Pipeline Complex, is one of several.Gulf Coast salt dome sites whose total combined existing capacity is 250 MMB. The existing Texoma Complex consists of Sulphur Mines and West Hackberry. At these sites, oil is stored 
in leached salt caverns which normally contain brine. As each cavern is filled, the oil displaces the existing brine which is disposed of in various ways.

The current schedule for filling West Hackberry, both existing capacity and including expansion, is as follows: I/

\begin{tabular}{rc} 
MMB & YEAR END \\
\cline { 2 - 2 } 41 & 1978 \\
51 & 1979 \\
62 & 1980 \\
96 & 1981 \\
131 & 1982 \\
145 & 1983 \\
176 & 1984 \\
211 & 1985
\end{tabular}

The expansion plan calls for leaching 16 new caverns of $10 \mathrm{MMB}$ each at West Hackberry. Currently West Hackberry has 5 caverns (nos. 6, $7,8,9$, and 11) certified for oil storage by the Gulf Interstate Engineering Company (GIEC) on November 8, 1977.

As of September 12, 1978, the total oil stored in West Hackberry was about $14.2 \mathrm{MMB}$. 2/

Figure 1 shows the West Hackberry Site which is located southwest of Lake Charles, Louisiana. Figure 2 shows the site and environs looking south from Black Lake; Figure 3 shows a view of the site looking north, prior to the fire; and Figure $3 a$ is a site plan at the time of the accident.

1/ DOE, Execution Phase Project Plan for Expansion Sites, September 27,1978 .

2/ DOE, Monthly Site Report, West Hackberry, September 1978 . 


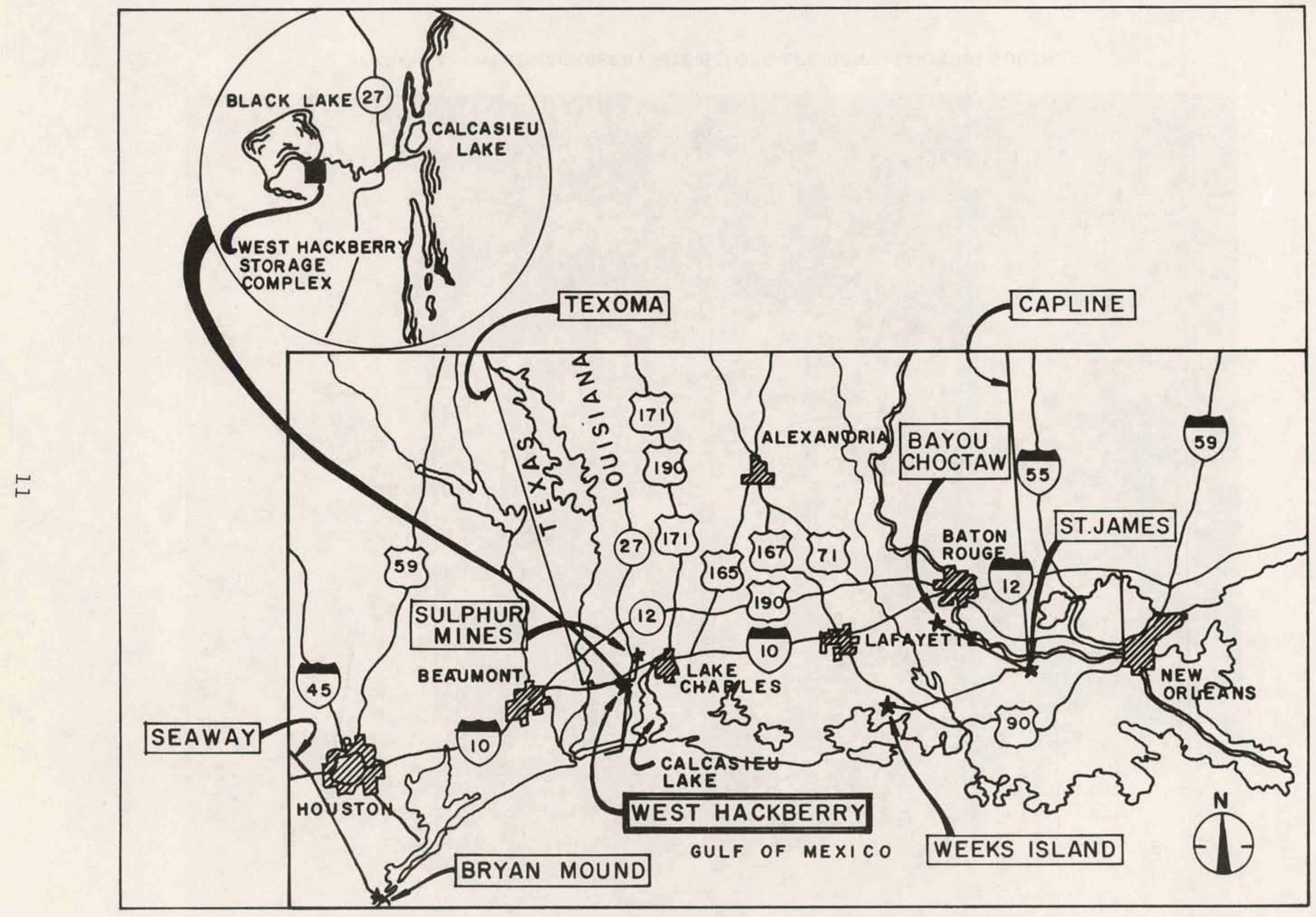

Figure 1. Strategic Petroleum Reserve Showing West Hackberry Facility 


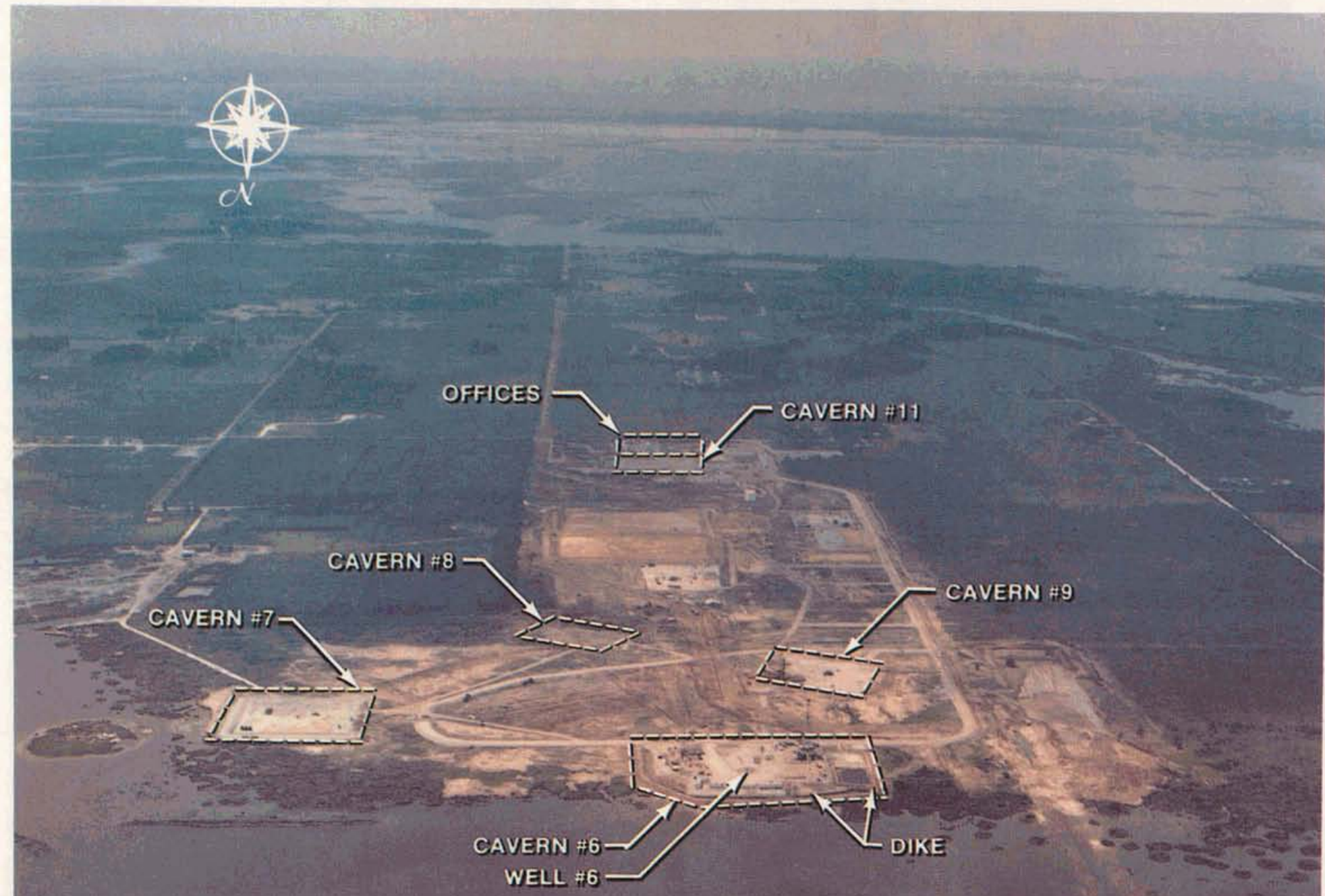

BLACK LAKE

FIGURE 2. WEST HACKBERRY SITE BEFORE ACCIDENT - LOOKING SOUTH. 


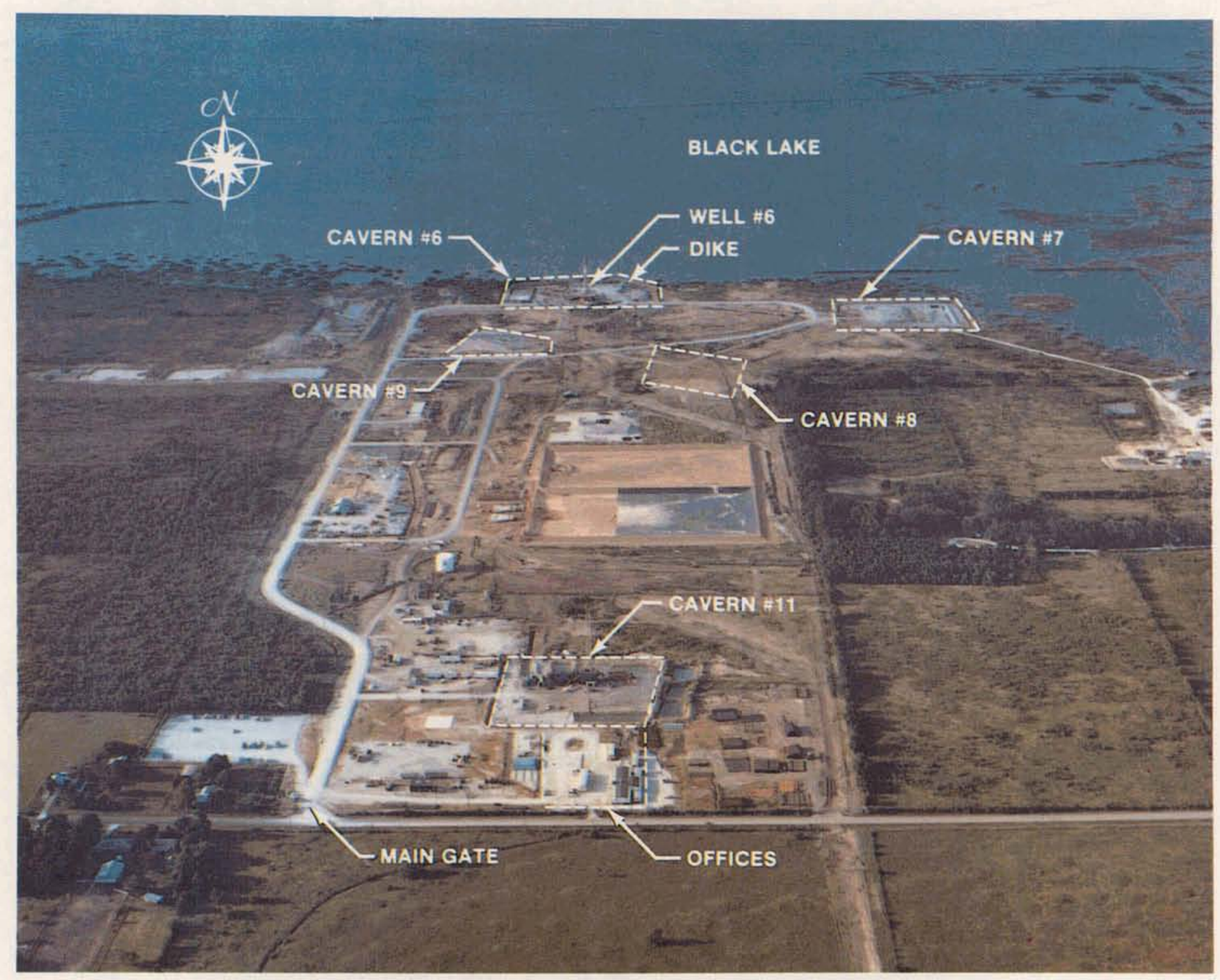

FIGURE 3. WEST HACKBERRY SITE BEFORE ACCIDENT, LOOKING NORTH. 


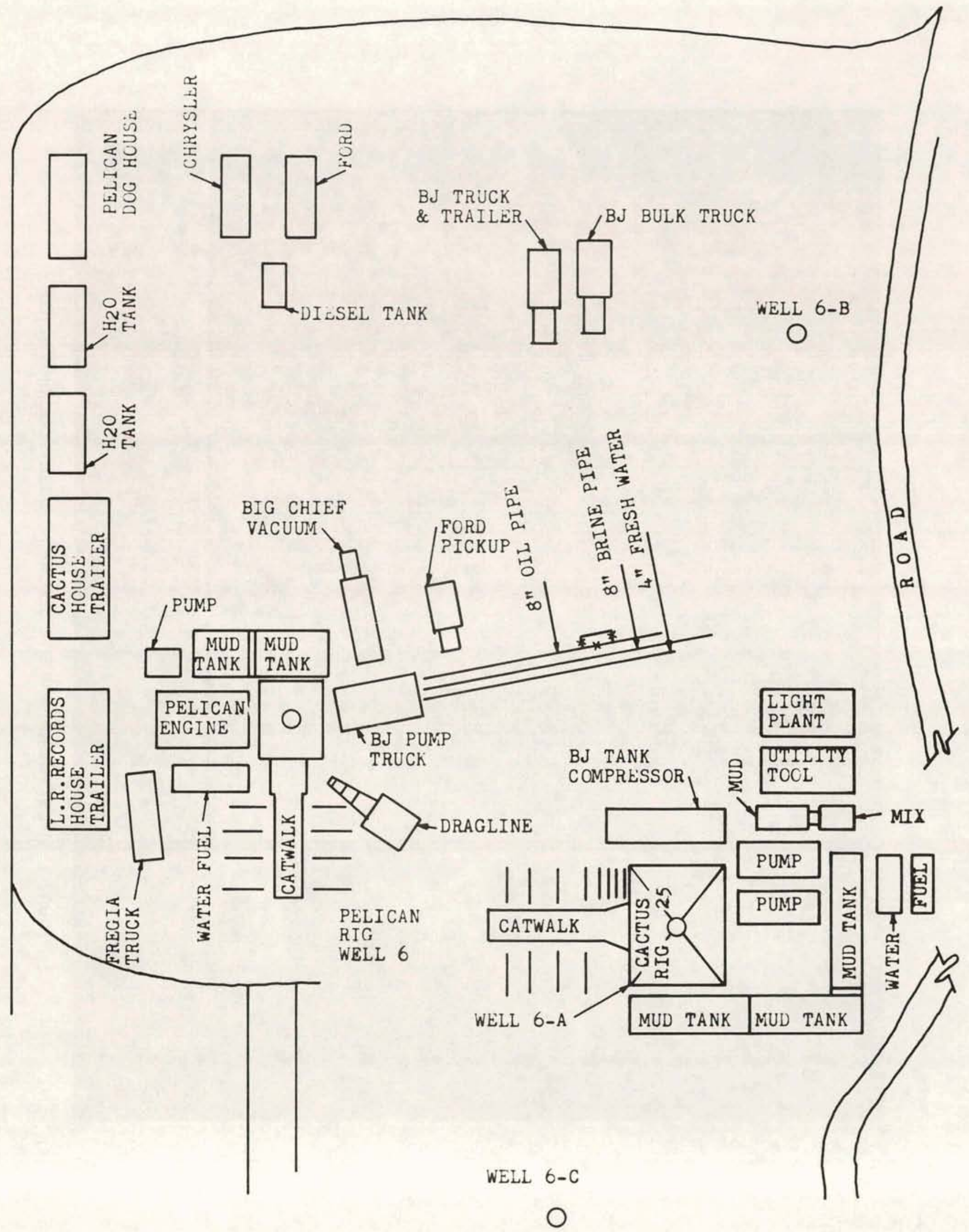

Figure 3a. Site Plan at Time of Accident 


\section{Cavern 6}

The surface and subsurface details of Cavern 6 are shown in Figures $4 \mathrm{a}$ and $4 \mathrm{~b}$, respectively. At the time of the accident, Cavern 6 contained about 7 MMB of oil and had a fill schedule of 11.9 MMB under the Interim Fill Program.

Cavern 6 has four well locations (Wells 6, 6a, 6b, and 6c). Well 6 is the one involved in the accident and is the original well into Cavern 6. It was formerly used by the olin corporation to extract salt by dissolving it with fresh water.

Remedial work, testing, and investigations were conducted on caverns, prior to being used for oil storage, under the direction of GIEC, starting on May 7, 1977, and terminating on July 23, 1977. A certification of Underground Cavern Usability and Integrity was issued by GIEC on November 8, 1977. $3 /$

Cavern 6 is 153 feet in height and has a maximum diameter of 839 feet with the ceiling and floor essentially flat. (All elevations are referenced to the Braden Head Flange (BHF) on the well head, the lowermost flange.) It has a volume of 12.2 MMB. There are 1,288 feet of salt between the cavity ceiling and the top of the salt, and there are 315 feet of salt horizontally between the walls of Caverns 6 and 9 .

\section{Well 6 Prior to Workover $3 /$}

When Cavern 6 was originally created for solution mining, a 16-inch surface casing was set at 1,640 feet and cemented to the surface. A 24-inch conductor casing was installed at a depth of 87 feet. A 12-3/4-inch casing was set to 2,632 feet and cemented to the surface. When Cavern 6 was adapted for oil storage, a 9-5/8-inch

3/ Gulf Interstate Engineering Company, "Solution Cavern Certificates of Usability and Integrity for the Strategic Petroleum Reserve Program - West Hackberry Site," November 8, 1977. 


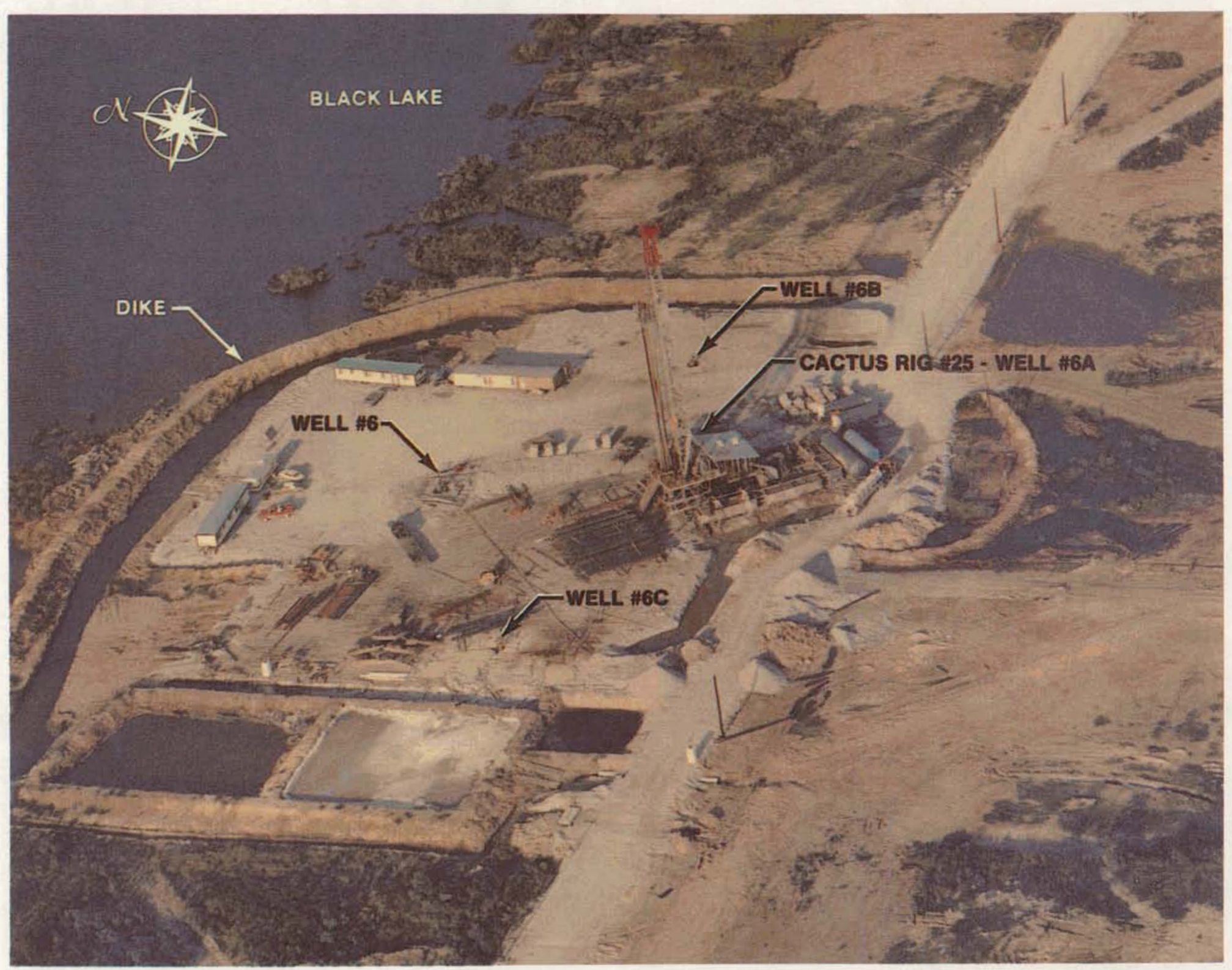

FIGURE 4A. CAVERN \#6 SITE BEFORE ACCIDENT 


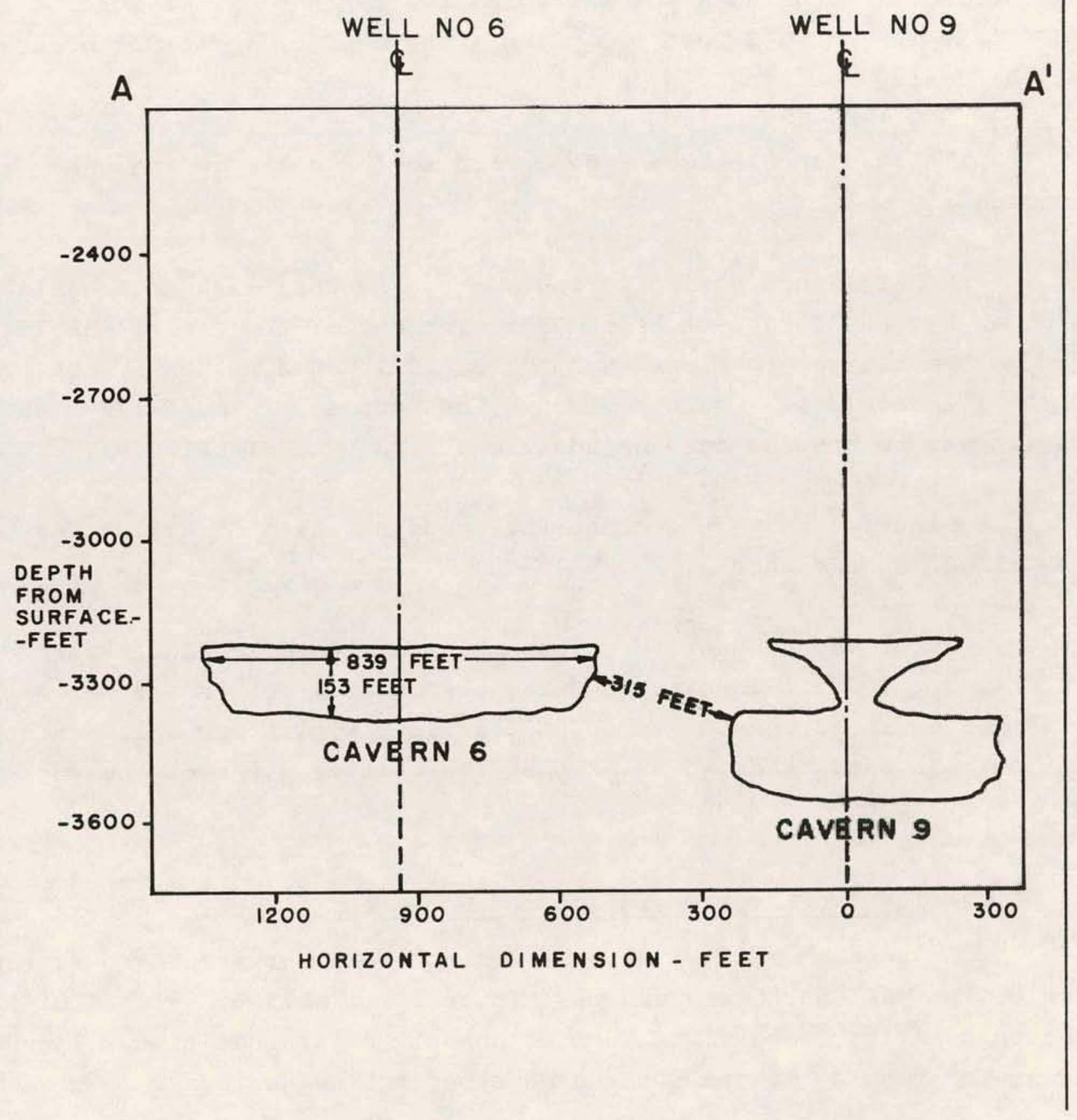

Figure 4b. Cavern 6 Cross Section 
casing was set at 2,603 feet inside the original 12-3/4-inch casing and cemented back to the surface. The new 9-5/8-inch casing was then pressure-tested to 1,000 psig before drilling out the cement plug at the bottom of the casing. After the plug was drilled out of the casing, the cavern was hydrostatically tested to 715 psig at the surface. Assuming a specific gravity of crude oil of 0.802 (892 psig for a 2,603-foot oil column) the maximum operating pressure at the casing seat is 1,607 psig.

The distance between the cavern roof and the casing seat is 605 feet.

A 5-1/2-inch casing string was run in the 9-5/8-inch casing and was set at 3,380 feet below BHF. The end of the casing was 15 feet above the cavern floor on July 23, 1977. The bottom 5 feet of the 5-1/2-inch casing were slotted. The purpose of the 5-1/2-inch casing was to provide for the addition or removal of brine.

Figure 5 shows the subsurface configuration of Well 6 , as described in Reference 3.

After the new well head assembly was installed and secured on July 23, 1977, 1-inch tubing was subsequently put in the well for fresh water injection to reduce salt buildup within the 5-1/2-inch casing. It was withdrawn as part of the initial steps of the workover operation.

\section{Well 6 Workover Operation and Equipment}

On September 13, 1978, the Pelican Well Service Workover Rig 11 arrived at West Hackberry and was rigged up to Well 6 . Rig 25 of the Cactus Drilling Company was located on Well $6 \mathrm{a}$ at that time. Figure 6 shows the rigs on Cavern 6 three days before the accident. 


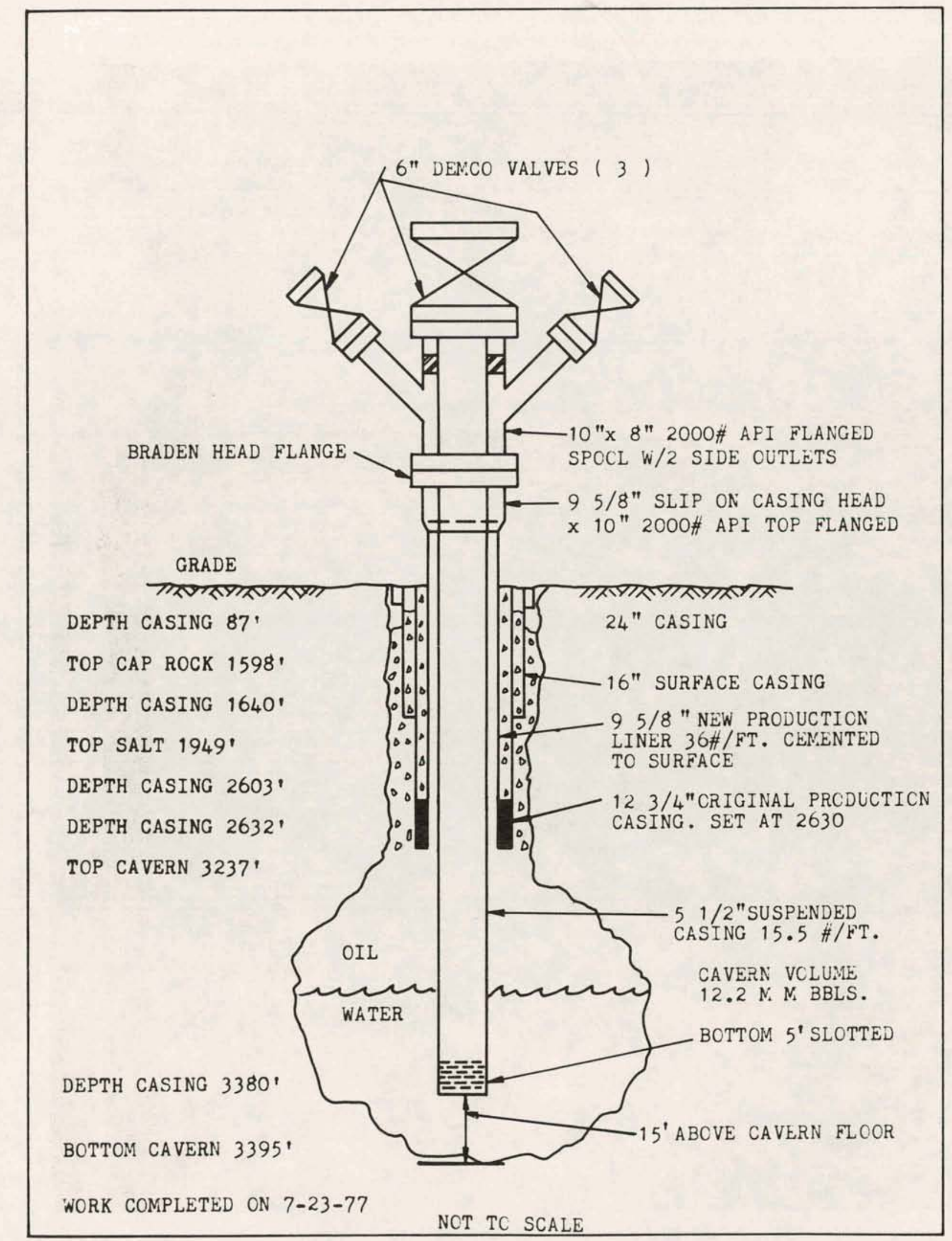

Figure 5. Overall Configuration of Well 6 


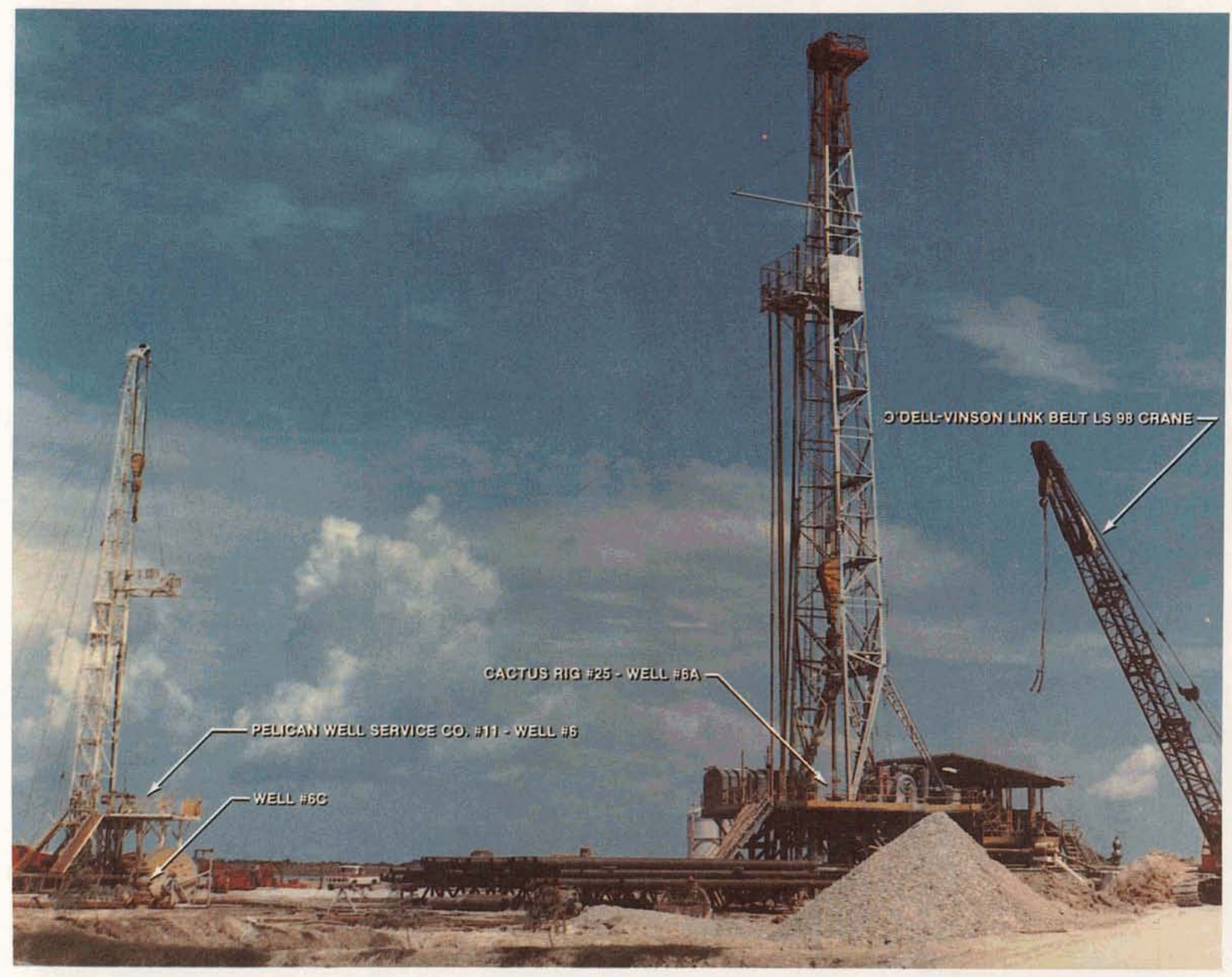

FIGURE 6 CACTUS AND PELICAN RIGS ON CAVERN 6 PRIOR TO ACCIDENT. 
The workover procedure for Wells 6 and 11 submitted by Louis Records to Parsons-Gilbane and the Louis Records Daily Drilling Progress Report are included in Appendices XII and XIII.

The overall configuration of Well 6 is shown in Figure 5 . The procedure called for making well 6 a "slick hole" (removal of the 5-1/2-inch casing) and for repair of the well head, which had leaked previously.

Figure $6 \mathrm{a}$ shows the configuration of the well head before workover started with piping for brine removal, a 2,000 psi Larkin Head, and 1-inch tubing for fresh water.

Figure $6 \mathrm{~b}$ shows Well 6 at the time of the blowout with a bagtype blowout preventer, a ram preventer, the mud return line, and packer.

Figure 7 shows the TAM Set Inflatable/Retrievable Packer. The inflatable element is normally inflated by water pressure to 500 psi at the setting depth to conform to the hole and then increased slowly to about 2,000 psi to fully set the packer and shear the setting ball through the choke, opening the mandrel for fluid flow. The packer can be deflated by a quarter turn to the left (positive stop) to release the modified J-type latch which allows the mandrel to move upward. The water then flows back into the mandrel and the packer deflates for retrieval or relocation.

Figure 8 shows the safety valve used on the rig at the time of the accident. The device consists of a 5-1/2-inch by 2 -inch casing swage with a 2-inch ball valve. To be utilized as a safety valve, it must be screwed into the top of the 5-1/2-inch casing to control the flow of fluids. 


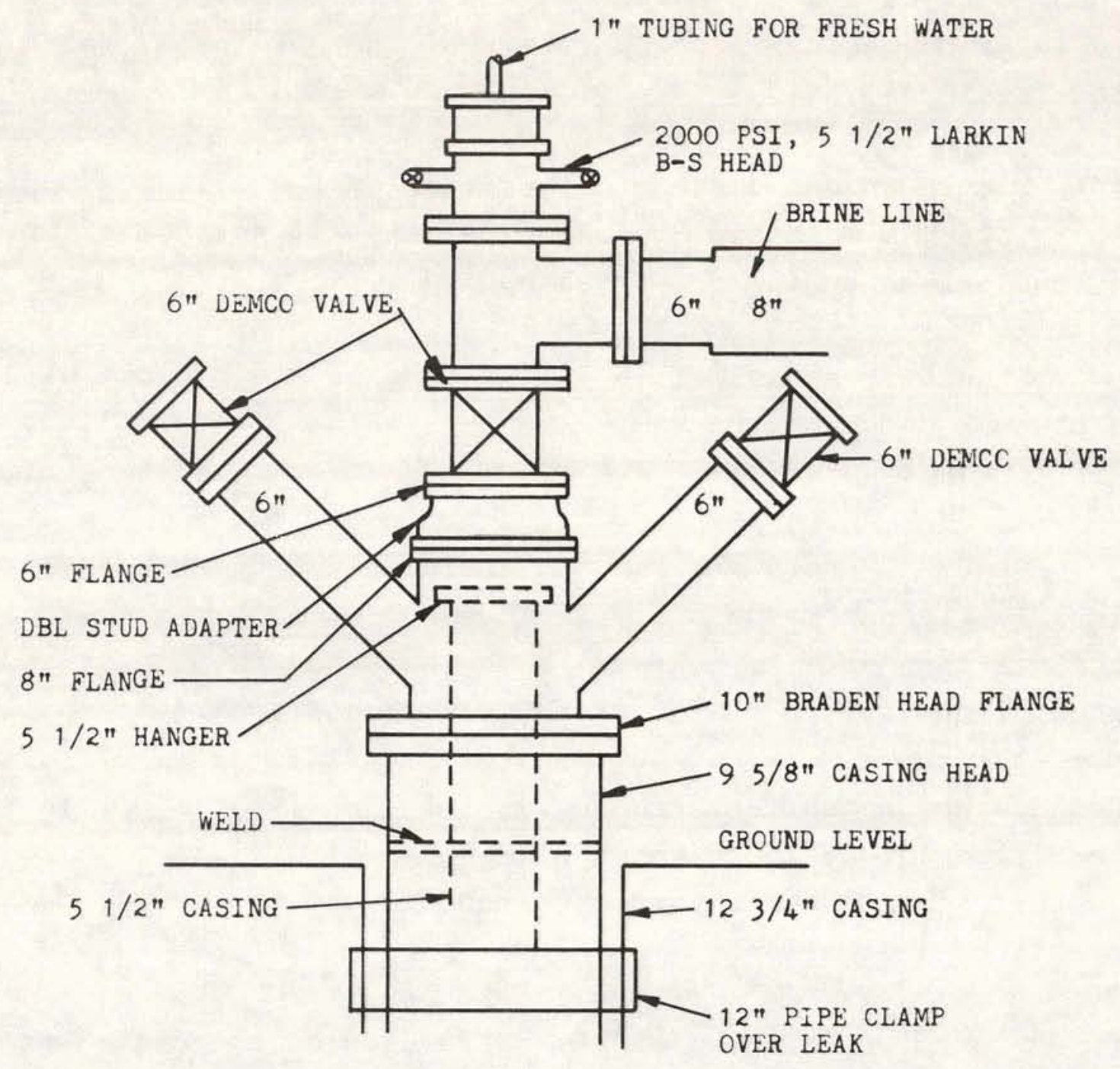

NOT TC SCALE

Figure 6a. Well 6 Well Head Configuration Before Workover 


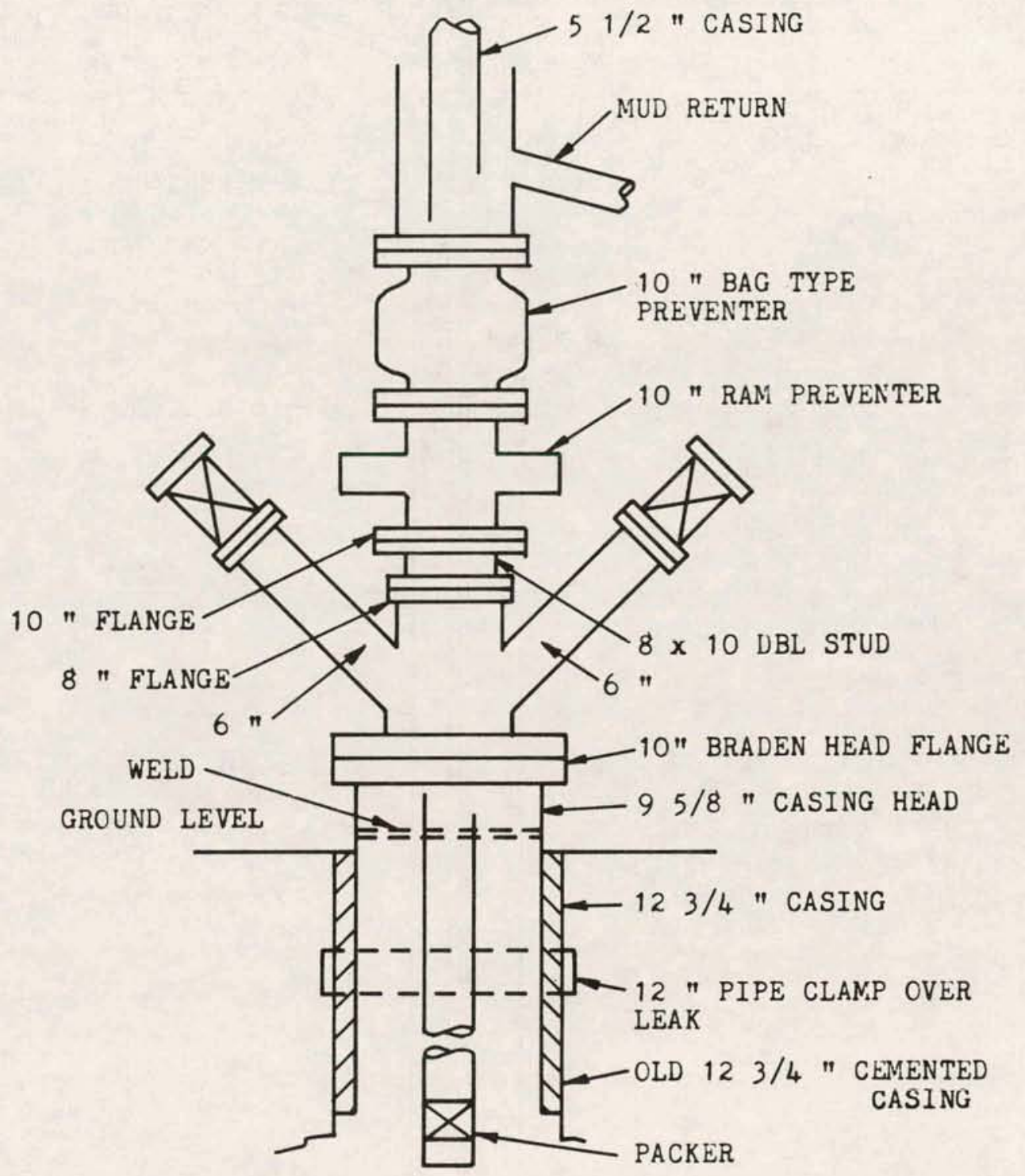

NOT TO SCALE

Figure 6b. Well 6 Configuration at Time of Blowout 


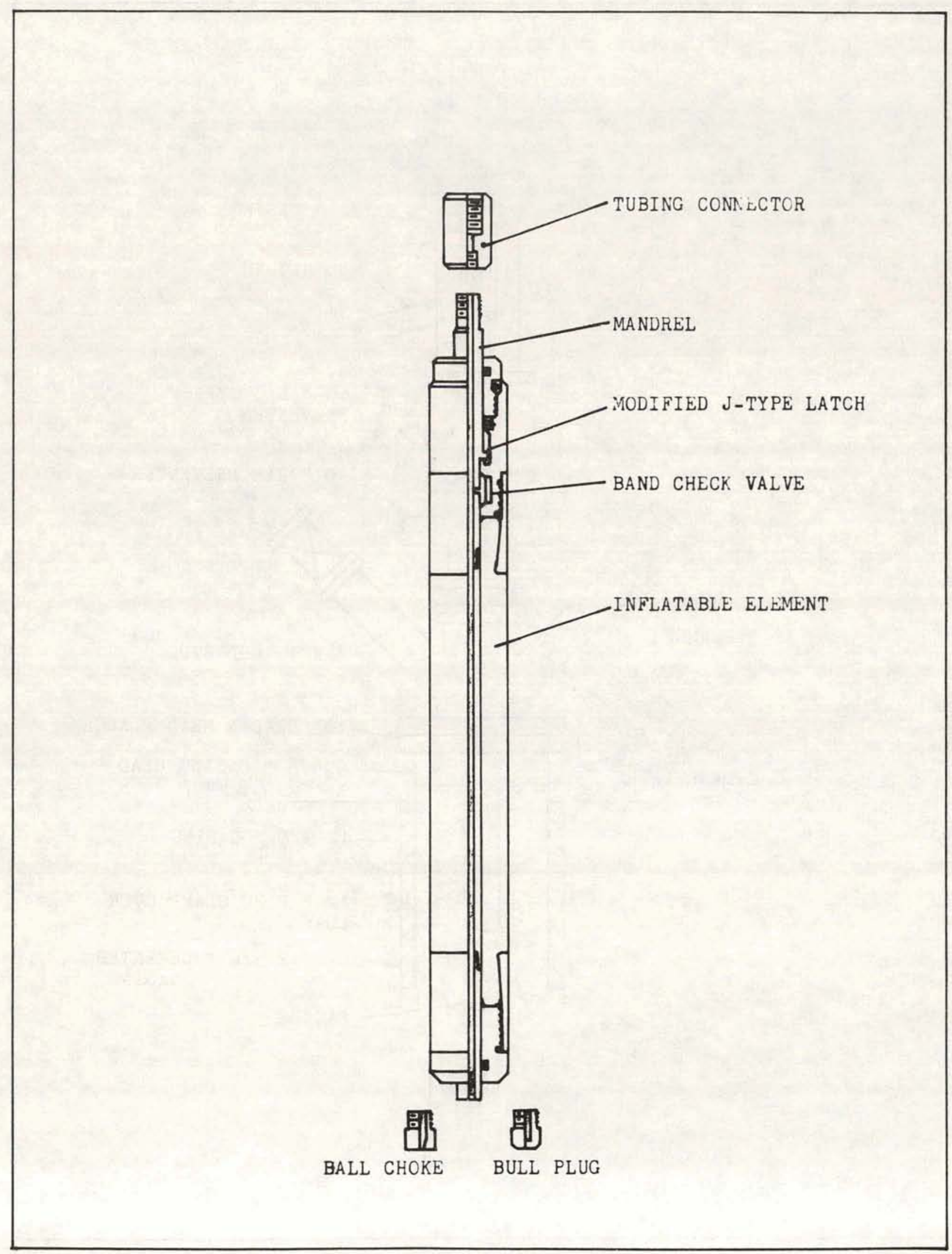

Figure 7. TAM Set Inflatable/Retrievable Packer 


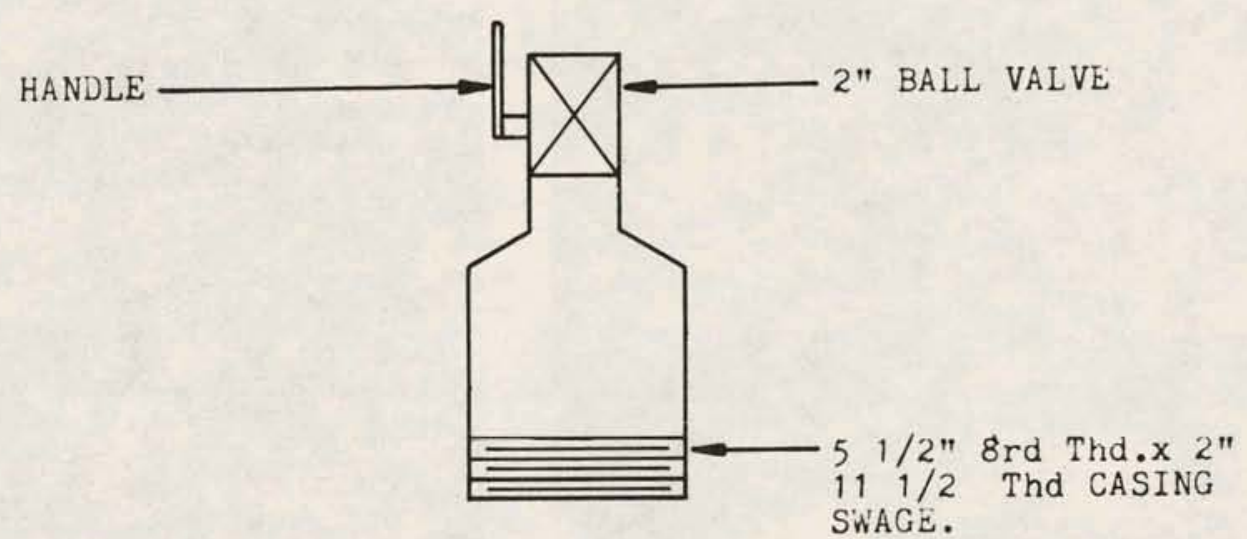

Figure 8. Safety Valve for Use as Stabbing Valve as Made up for Well 6 


\section{Personnel at Cavern 6 at Time of Accident}

Twenty-six people were in proximity of Cavern 6 at the time of the accident. Table 1 lists their organization, job title, location, name, and response. Figure 31 shows the Cavern 6 site layout at the time of the fire. Figure 15 shows the Cavern 6 layout after the fire and some of the initial locations of personnel when Well 6 blew out.
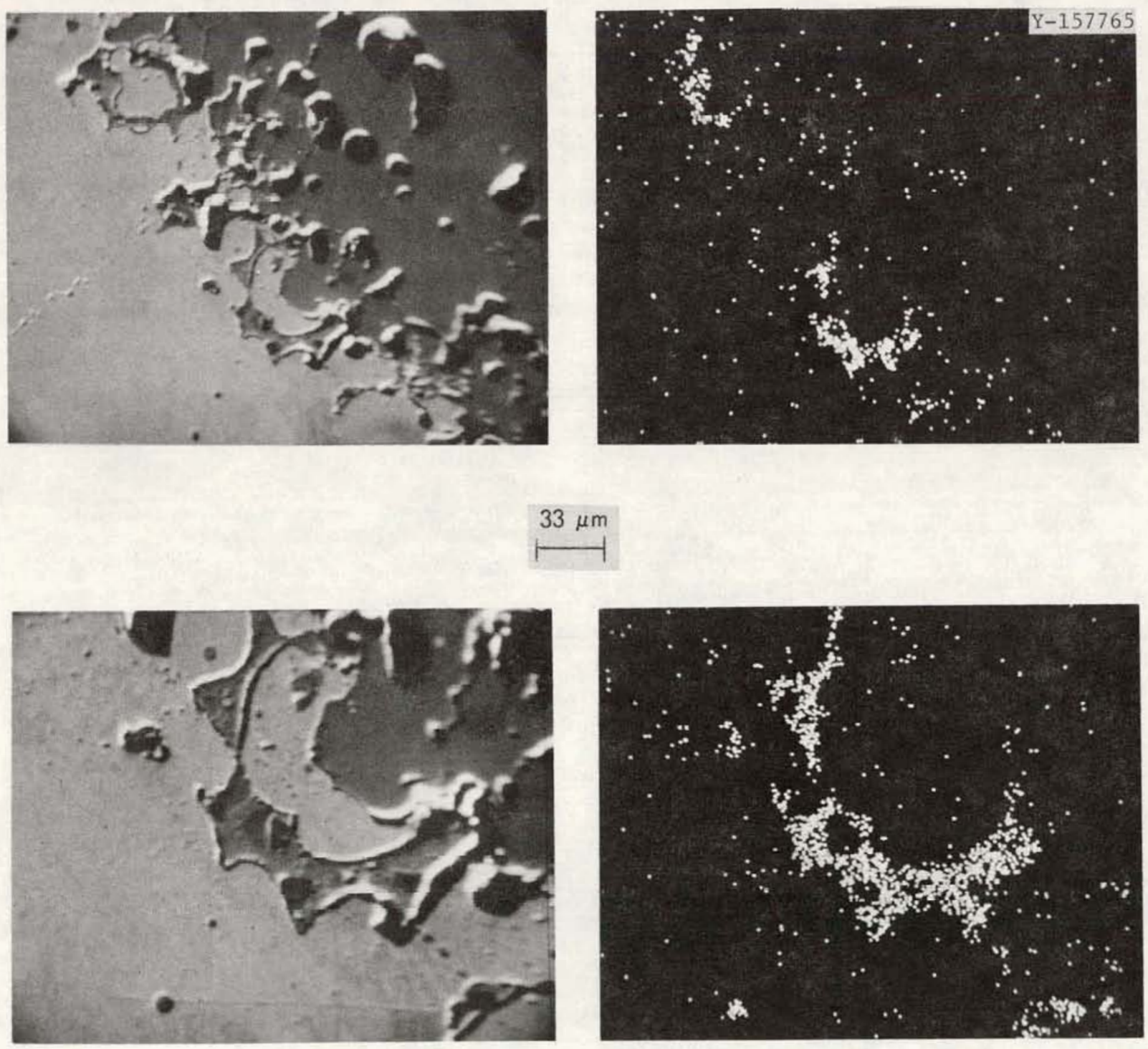

$1.5 \mu \mathrm{m}$ 
TABLE 1

PERSONNEL AT CAVERN 6 AT TIME OF ACCIDENT

\begin{tabular}{|c|c|c|c|c|}
\hline Organization & Job Title & Location & Remarks & Name \\
\hline \multirow[t]{5}{*}{ Pelican Well Service } & Toolpusher & Pelican Rig & $\begin{array}{l}\text { Injured (fatally); shut } \\
\text { down engines. }\end{array}$ & Simon \\
\hline & Derrickman & Pelican Rig & $\begin{array}{l}\text { Injured, tried to install } \\
\text { safety valve. Shut down } \\
\text { engines; was with Simon } \\
\text { at ignition. }\end{array}$ & Bergeron \\
\hline & Roughneck & Pelican Rig & $\begin{array}{l}\text { Tried to install safety } \\
\text { valve; ran when motors } \\
\text { overspeeded. }\end{array}$ & Simmons \\
\hline & Roughneck & Pelican Rig & $\begin{array}{l}\text { Tried to install safety } \\
\text { valve; ran when motors } \\
\text { overspeeded. }\end{array}$ & Johnson \\
\hline & Driller & Pelican Rig & $\begin{array}{l}\text { Tried to install safety } \\
\text { valve; ran when motors } \\
\text { overspeeded. }\end{array}$ & Dorsey \\
\hline Crump Welding Service & Welder & $\begin{array}{l}\text { Louts } \\
\text { Records } \\
\text { Trailer }\end{array}$ & $\begin{array}{l}\text { Left location while crew } \\
\text { was trying to install } \\
\text { safety valve. Drove } \\
\text { welding truck off location; } \\
\text { saw mud change to oil; } \\
\text { saw Ignition. }\end{array}$ & Crump \\
\hline \multirow[t]{2}{*}{ Benton Casing Service. } & Manager & $\begin{array}{l}\text { Pickup } \\
\text { truck parked } \\
\text { near Loufs } \\
\text { Records } \\
\text { Trailer }\end{array}$ & $\begin{array}{l}\text { Was watching crew pull } \\
\text { casing; was timing operation; } \\
\text { saw well blow out; saw } \\
\text { packer land; saw mud turn } \\
\text { to oil; heard engine over- } \\
\text { speed; ran; saw Ignition. }\end{array}$ & Ortega \\
\hline & Truckdriver & $\begin{array}{l}\text { In pickup } \\
\text { truck with } \\
\text { Ortega }\end{array}$ & $\begin{array}{l}\text { Saw mud flow start; moved } \\
\text { plckup truck off location. }\end{array}$ & Richard \\
\hline International Hammer & Toolpusher & $\begin{array}{l}\text { Floor of } \\
\text { Pelican Rig }\end{array}$ & $\begin{array}{l}\text { On floor when mud started; } \\
\text { helped try to install } \\
\text { safety valve; left rig } \\
\text { floor; heard engines over- } \\
\text { speed as he ran from } \\
\text { location. }\end{array}$ & Robin \\
\hline
\end{tabular}


TABLE 1 (Cont.)

$\begin{array}{lll}\text { Organization } & \text { Job Title } & \text { Location } \\ \text { Tong Operator } & \begin{array}{l}\text { Floor of } \\ \text { Pellcan Rig }\end{array}\end{array}$

Remarks

Name

On floor when mud started; Schexnider helped try to Install safety valve; left rig floor; heard engines overspeed as he ran from location.

Floorhand

Pelican Rig

On floor when mud started

flowing. Helped try to install safety valve; left floor rig to wash mud from eyes; heard motor overspeed; ran; saw Simon shut off engine; saw ignition; ran.

Floorhand

Pelican Rig

Saw mud flow start; helped make three attempts to install safety valve; heard engine overspeed; ran; saw Ignition.

Big Chief Vacuum Trucks

TAM International

0'Del1-Vinson 011

Louls Records \& Associates, Inc.
Truckdriver

Service

Manager

Dragline Operator

oller

Consultant drilling
Heard instructions to run; ran; heard ignition whlle running.

On Vacuum truck

In Pelican Toolpusher's Trailer

On Dragline

Was asleep; awakened by explosion; saw fire; drove pickup truck off location

Was on dragline helping lay down casing when mud started flowing; heard Fregia say to shut down the engines; shut down dragline engine; saw packer blow out of the hole and land on catwalk of rig.

Was helping to lay down casing; saw packer blow out and oil igntion; ran.

Was in trailer when mud Hogue started flowing; ran to rig; tried to install safety valve; helped Pelican toolpusher activate closure of Shaffer hydril type BOP; washed mud out of eyes; saw packer blow out; heard engines overspeed.

White
Records tratler
Pelican Rig Catwalk

.

Forrestier

Thibodeaux

Armstrong 
TABLE 1 (Cont.)

\begin{tabular}{|c|c|c|c|c|}
\hline Organization & Job Title & Location & Remarks & Name \\
\hline & $\begin{array}{l}\text { Consultant - } \\
\text { drilling }\end{array}$ & $\begin{array}{l}\text { Louis } \\
\text { Records } \\
\text { trafler }\end{array}$ & $\begin{array}{l}\text { Saw mud flow start; ran to } \\
\text { rig; saw crew attempting to } \\
\text { install safety valve; ran } \\
\text { to traller; called Horn; } \\
\text { ran to rig; saw packer blow } \\
\text { out; heard engines overspeed; } \\
\text { saw Ignition; ran. }\end{array}$ & Fregia \\
\hline Loulsiana Mud Co. & $\begin{array}{l}\text { Mud } \\
\text { Engineer }\end{array}$ & $\begin{array}{l}\text { Louis } \\
\text { Records } \\
\text { trailer }\end{array}$ & $\begin{array}{l}\text { Saw mud flowing; saw packer } \\
\text { blow out; saw oil follow } \\
\text { packer; was moving car out } \\
\text { of area at ignition. }\end{array}$ & Coleman \\
\hline \multirow[t]{2}{*}{ B. J. Hughes } & Supervisor & Pump Truck & $\begin{array}{l}\text { Saw mud start to flow; saw } \\
\text { crew attempt to install } \\
\text { safety valve; saw crew run; } \\
\text { shut down pump truck motor; } \\
\text { ran to pickup truck; drove } \\
\text { off location. }\end{array}$ & Magnon \\
\hline & $\begin{array}{l}\text { Pump } \\
\text { Operator }\end{array}$ & $\begin{array}{l}\text { Near pump } \\
\text { truck }\end{array}$ & $\begin{array}{l}\text { At Magnon's instructions } \\
\text { took squeeze valve to rig } \\
\text { floor; crew trying to install } \\
\text { safety valve already on floor; } \\
\text { saw Hogue try to stab safety } \\
\text { valve; left rig floor; ran } \\
\text { to truck; shut down truck } \\
\text { motor; ran to pickup truck; } \\
\text { left with Magnon. }\end{array}$ & Goutreaux \\
\hline \multirow[t]{5}{*}{ Cactus Drilling } & Toolpusher & $\begin{array}{l}\text { Cactus } \\
\text { trailer }\end{array}$ & $\begin{array}{l}\text { Was lying down; saw mud flow } \\
\text { start; saw crew attempt to } \\
\text { install safety valve; heard } \\
\text { engine overspeed; started to } \\
\text { run; heard explosion and saw } \\
\text { fire. }\end{array}$ & Perkins \\
\hline & Driller & $\begin{array}{l}\text { Cactus Rig } \\
25, \text { rig } \\
\text { floor }\end{array}$ & $\begin{array}{l}\text { Saw mud flow; saw oil flow; } \\
\text { ran (car was burned up). }\end{array}$ & Henry \\
\hline & Floorhand & $\begin{array}{l}\text { Cactus Rig } \\
\text { Floor }\end{array}$ & $\begin{array}{l}\text { Saw flow and smoke (oil } \\
\text { mist?); ran. }\end{array}$ & Mason \\
\hline & Floorhand & $\begin{array}{l}\text { Cactus Rig } \\
\text { mud pits }\end{array}$ & $\begin{array}{l}\text { Was mixing mud; told to run } \\
\text { by Mason; ran. }\end{array}$ & Tibbets \\
\hline & Derrickman & $\begin{array}{l}\text { Cactus } R i g \\
\text { mud pits }\end{array}$ & $\begin{array}{l}\text { Was mixing mud; heard driller } \\
\text { yell; heard explosion; saw } \\
\text { flre; ran. }\end{array}$ & Ashworth \\
\hline
\end{tabular}




\section{Organization and Management}

The SPR program was organized by the government in 1977 . Figure 9 shows the organization chart at the time of the accident. The New Orleans Project office was formed early in 1978. SPRO's two suborganizational elements principally concerned with the execution of physical work at the various project sites are construction and operations. Neither has been assigned the specific responsibility for drilling operations; rather, drilling responsibility was transferred back and forth depending on whether the drilling resulted in new wells (construction) or the reworking of existing wells in caverns containing oil (operations). SPRO has a staffing allowance of 113 of which three are permanently assigned to the West Hackberry Site. There is, however, a frequent personnel influx from the New Orleans office to the site.

Parsons-Gilbane (the contractor with the responsibility for construction management) was organized at the government's request to structurally parallel SPRO. There is a distinct effort to have a management counterpart for each SPRO office or official in the ParsonsGilbane organization. However, the drilling responsibility was separately assigned within the Parsons-Gilbane organization. There is also a support function shown in Figure 9. It is technical in nature and is located both at the site and in the New orleans office. The most recent detailed organization charts (not shown here) revealed many vacancies and personnel changes. The government has attempted to strengthen and expand the Parsons-Gilbane organizational responsibility, and on August 1, 1978, transferred well drilling responsibility from another contractor to Parsons-Gilbane. In addition, the government has been urging Parsons-Gilbane to accept responsibility for the overall integration management (systems integration) of all contractors working on the Early Strategic Reserve (ESR) phase of SPRO. 


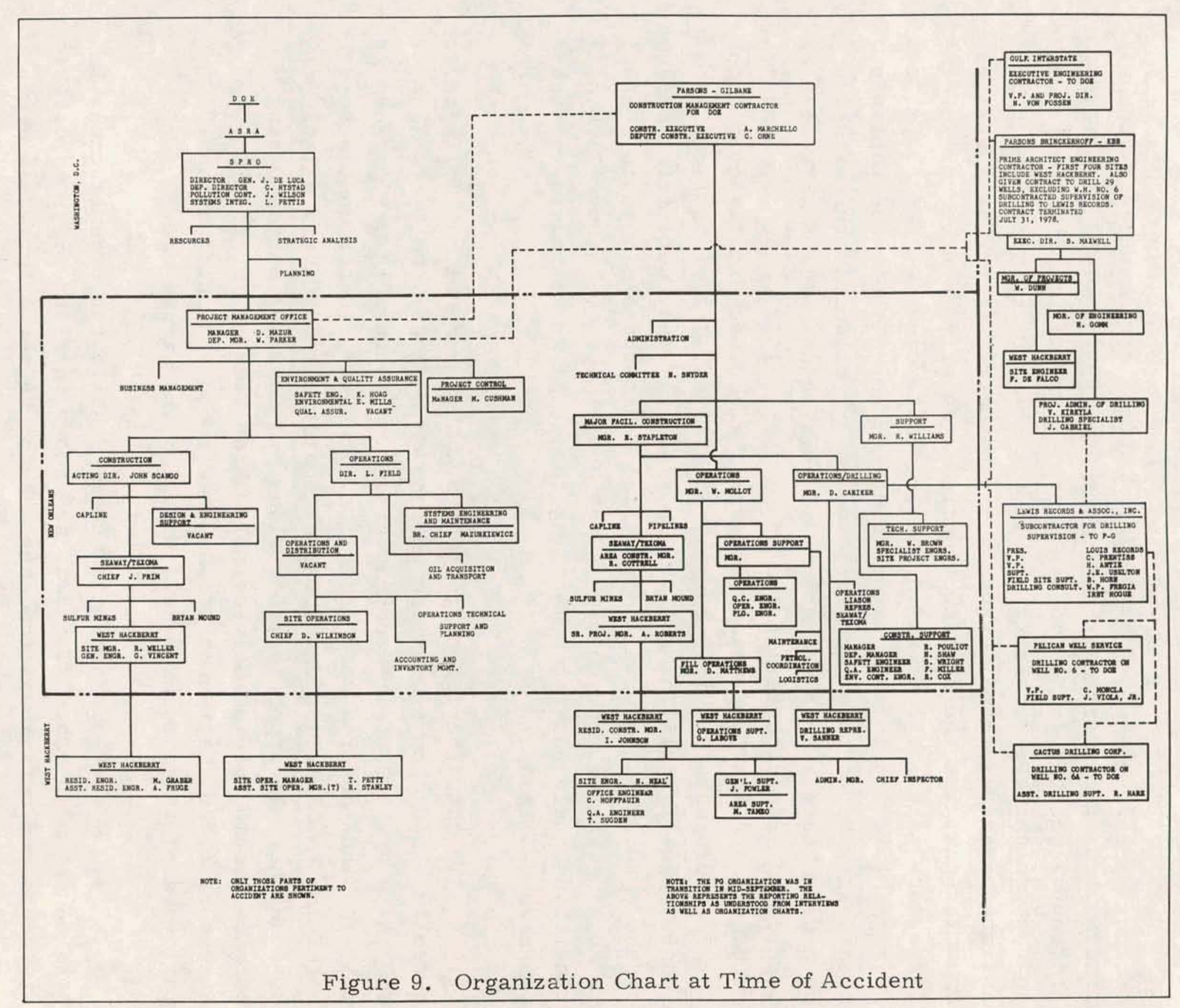


Other contractors also played a significant role in support of SPRO. Gulf Interstate Engineering Company prepared the original conceptual design of the storage system. The firm continues to serve as the executive engineering contractor to SPRO, providing technical assistance as requested. Parsons Brinkerhoff-Kavernen Bau-Betribes, $\mathrm{GmbH}(\mathrm{PB}-\mathrm{KBB})$ was the architect engineering prime contractor for the first four sites, all of which involved salt caverns. KBB is a German firm specializing in salt cavern construction. Their contract was later extended to cover the drilling of 29 wells into the existing caverns, although this extension did not include Well 6 at West Hackberry; the extension terminated on August 1, 1978. Both ParsonsGilbane and $\mathrm{PB}-\mathrm{KBB}$ are joint ventures formed specifically to bid on the SPRO project. Louis Records \& Associates, Inc. is a firm specializing in drilling and well workovers. They were first engaged as the agent to supervise the drilling contracts assigned to $\mathrm{PB}-\mathrm{KBB}$. On August 1, 1978, they became a sub-contractor to Parsons-Gilbane and subsequently have been managing the drilling contracts assigned to Parsons-Gilbane.

The actual drilling contractors were the Pelican Well Service on Well 6, and Cactus Drilling Company on Well 6a. Both of these companies are SPRO prime contractors. The Cactus Rig was damaged in the fire and the crew were among the witnesses. Other contractors servicing the drilling and workover operations on Cavern 6 include: B. J. Hughes, Incorporated; Louisiana Mud Company; Benton Casing Service; Crump Welding Service; Big Chief Vacuum; International Hammer Services (Patterson Casing Crew); and TAM International. Employees of these firms were also among the witnesses.

a. Recent management changes -- While the organizations in existence on September 21, 1978, are shown in Figure 9, some of this structure and certain assignments were of recent origin. As shown in Table 2, there were recent contract changes, organizational changes, and personnel shifts in groups involved prior to the accident. 
TABLE 2

RECENT CHANGES IN MANAGEMENT (1978)

July:

I. Contractual Changes

Pelican shifted from workover of Well 8 using Rig 15 to Well 6 with Rig 11 .

July $31:$

PB-KBB's contract to supervise well drilling terminated (except for wells underway, which were completed by Sept. 15).

August 1:

Parsons-Gilbane's contract was expanded to include drilling.

Louis Records' contract as agent for PB-KBB was replaced by a subcontract to Parsons-Gilbane, effective Sept. 1.

July 14 :

II. Organizational Changes

Parsons-Gilbane establishes a drilling function reporting to the manager-construction in preparation for contracts change.

Oct. 1:

Parsons-Gilbane combines "Operations" with "Drilling", still reporting through construction. The staff department previously designated "Support" redesignated "Engineering", with minor changes. While charts are dated 9/15, change was not fully effective until october 1.

\section{A. SPRO}

\section{Personnel Changes}

June:

Acting manager of construction given special assignment. Replaced by Seaway/Texoma branch chief on temporary basis while retaining responsibility for seaway/Texoma and Capline (also acting).

Sept. 12:

SPRO's safety engineer reports to work. 


\section{TABLE 2 (Cont.)}

B. Parsons-Gilbane

\section{January:}

Original site safety engineer transferred to New orleans. Second site safety engineer arrives.

April 1:

Second site safety engineer departs.

May:

Departing site engineer's duties transferred to area superintendent responsible collaterally for three construction contracts, security, and safety at West Hackberry.

June/July:

OSHA-type safety duties taken over by office engineer and estimator.

Early July:

First Manager of Drilling appointed.

June 12-July 31:

Two safety engineers report for work in New Orleans.

Early August:

Manager of Operations shifted to Drilling, replacing original Manager of Drilling.

Early sept.:

New Operations Manager appointed. 
(1) Contracts

Pelican Well Service originally had a contract to workover three specific wells. However, when a space utilization problem arose from having two different contractors working on adjacent wells, Pelican's contract to workover Well 8 using Rig 15 was shifted to Well 6 . For this they brought in Rig 11 which heretofore had not been used in workover operations for DOE.

The major contract change was a termination of $\mathrm{PB}-\mathrm{KBB}$ 's contract. for well drilling. This was formally terminated at the end of July 1978. At that time, Parsons-Gilbane picked up well drilling and at the same time Louis Records was shifted over to be a subcontractor to Parsons-Gilbane whereas they formerly had been under contract as an agent serving as drilling consultant for $\mathrm{PB}-\mathrm{KBB}$.

(2) Organizations

In connection with the above contractual change, Parsons-Gilbane also underwent certain organizational changes. In early July, they established a drilling function which was set up to report to the manager of construction. This was in preparation for Parsons-Gilbane taking over the drilling responsibility. Then, during september, they made a decision to have a further shift in the organizational arrangement. They combined operations with drilling although the two were 
still reporting through the manager of construction. At the same time, one of the support departments previously designated as support was redesignated as engineering with certain minor changes. Organizational charts were available to the committee showing these changes as of September 15; however, the management of Parsons-Gilbane indicated that the changes did not become fully effective until October $1,1978$.

\section{(3) Personnel changes}

Certain personnel changes also took place in the months immediately preceding the accident (see Table 2). For SPRO, the acting manager of construction was given a special assignment. His regular duties were transferred to the branch chief for the Seaway/Texoma complex of sites. This individual was asked to retain his responsibility for the seaway and Texoma complexes, and at the same time he was acting branch chief for the capline complex.

The major Parsons-Gilbane moves were related to the organizational change. In July, they appointed a manager for drilling. Then in early August, they replaced this manager with the former manager of operations and a new operations manager was appointed. 


\section{b. Safety and quality assurance --}

\section{(1) Safety}

The Assistant Secretary for Resource Applications stated that, as a matter of policy, safety functions were decentralized in ASRA and delegated to the field programs where the operations occurred. ASRA assumed that safety support at the DOE level was provided by the Assistant secretary for Environment.

SPRO, from its inception, had recognized the need for a safety engineer. However, the first and only safety engineer joined SPRO only 9 days before the accident. Some SPRO safety inspections were performed by DOE's Inspector General. SPRO did not assign safety responsibility to one of its staff prior to the arrival of its safety engineer on september 12, 1978. SPRO relied totally upon Parsons-Gilbane for safety prior to the accident. Safety was primarily OSHA-oriented and a system safety function was not found by the Committee to exist in the SPRO organization.

Parsons-Gilbane had frequent turnovers in its safety staff and transfers of safety responsibilities. In its New Orleans office, there were several personnel changes in the safety staff. Parsons-Gilbane had hired two fulltime safety engineers in mid-June and late July who were not yet totally familiar with the operations when the accident occurred. These safety engineers had recommended in August 1978 that a full-time safety engineer be assigned at West Hackberry. At West Hackberry, safety was a 
part-time collateral duty and shifted from person to person. In May, the duties relinquished by the former site safety Representative were given to the Area Superintendent, who at the same time was designated Security officer and handled three contracts. In June/July, the onsite OSHA safety function was taken over by the office engineer and estimator. Emphasis was on OSHA safety and a systems safety approach was not visible in Parsons-Gilbane.

Louis Records and Pelican Well Service did not have anyone designated as safety engineers in their respective organizations. However, Louis Records has had extensive safety experience.

\section{(2) Quality assurance}

From its inception, SPRO had also recognized the need for a quality assurance engineer. It does not have a quality assurance engineer on its staff and aside from the ongoing quality control efforts on the quality of the oil being stored, no comprehensive SPRO quality assurance program was visible.

In Parsons-Gilbane, a quality assurance engineer exists under the construction support manager. Parsons-Gilbane issued a Quality Control Procedures (Inspection) Manual (undated) which was received by SPRO on september 18, 1978. It is a comprehensive manual, but has not been 
approved or issued officially. ParsonsGilbane has three quality assurance engineers in their New Orleans office with plans for a total of six. Parsons-Gilbane stated that they sent out a SMART (Support Management Review Team) group to each site periodically to review safety, security, quality control, and material records. Parsons-Gilbane has a visible quality assurance program on surface construction and has a quality assurance engineer at West Hackberry for surface construction activities. Specific to West Hackberry, Parsons-Gilbane stated that they did not have quality control or assurance in effect on the drilling and workover operations or rigs, but that they concentrated on welds, pumps, and material control associated with surface construction.

Louis Records and Pelican Well service did not have a formal quality assurance or control system on well 6 .

Metallurgical analyses indicated at least three poor quality welds on the well head at Well 6 .

\section{Emergency Preparedness}

The following is a summary of facts on the degree to which the West Hackberry Site and SPRO were prepared to cope effectively with a major accident. The specific facts are as follows: 
- There was no contingency plan for the West Hackberry site to cope with a major accident (i.e., no plan to follow and no clear delineation of responsibility), although some individual emergency instructions existed.

- There were no provisions onsite to fight a fire of major proportions; there was no foam onsite, the emergency water supply had not been installed, and firefighting equipment onsite was insufficient for the accident.

- There are no provisions to protect the well heads in the event of a catastrophic failure from a hurricane or impact with earthmoving equipment.

- There was, at best, minimal preparedness to cope with an oil spill (i.e., inadequate or incomplete dikes around well heads, and no oil booms onsite).

- Security measures, personnel control, and communications were inadequate.

Amplification of these facts is as follows:

a. No contingency plan for site -- There were no provisions to formally cope with a major accident, not even to the extent of defining who was in charge of the West Hackberry site. The potential of a hurricane was recognized and there were discussions, studies, and limited documentation on procedures to be followed in the event of a hurricane.

There was a list of emergency telephone numbers in the guardhouse at the main gate, but this list did not, for example, list oil well firefighting services. Additionally, it is not clear who 
was responsible for notification of the authorities, the guard, SPRO management, Parsons-Gilbane management, etc. Also, the list did not designate which telephone numbers should be called for a given type of emergency. In summary, while a plan is necessary for effective and coordinated implementation of the response to a disaster, there was no formal plan available for West Hackberry.

b. No firefighting capability -- While there are plans for a future water distribution system to provide firefighting capability, this portion of the construction has not been completed. Additionally, supplies (e.g., foam) and equipment were essentially nonexistent; the site had planned to depend on the local volunteer fire company to handle any contingency without actually assessing the latter's capability to cope with a fire of the size of the one at West Hackberry. There had been prior contacts made with local organizations, but no formal agreement had been reached as to the conditions under which SPRO could expect support from those organizations.

c. No well head protection -- There are no provisions to protect well heads from mechanical damage; if a well head were dislodged due to impact with construction equipment or from a hurricane, an oil spill could occur of the same general magnitude as the West Hackberry accident. Provisions have not been made for a second line of defense such as storm chokes on the wells or earthen embankments around the well heads. Future plans call for the installation of earthen embankments around well heads, but they will not be implemented until the construction is completed so that access to the wells will not be constrained.

d. Ability to cope with oil spill -- There was essentially no onsite capability to cope with an oil spill, especially one of major proportions. Also, no prearrangements had been made to have 
contractor support in the event of a spill. A number of site personnel had attended a training course on oil spills in New Orleans the day before the accident, and it has been suggested that this training helped them to respond effectively to the problem.

The installation of dikes for oil containment was incomplete, primarily due to the need for additional construction activities, and due to the scheduling problems with the concurrent activities. In the case of Cavern 6 , the dike was constructed but had a defect in it; this defect was reportedly identified by the site environmental people but no action was taken to correct it. The dike had not been sized to accommodate a spill of the magnitude encountered.

The Rapid Response Team, under U.S. Coast Guard leadership, had a generic plan and it was well executed on the Black Lake oil spill.

e. Security, personnel control, and communications --

Entrance to the West Hackberry site is through a gate from the public road. Where the site adjoins the road, a cyclone-type fence is installed, but the remainder of the site has no fence at all. The Committee was advised that the ultimate plans call for the entire site to be fenced but the current schedule would call for installation late in the construction program.

Upon the arrival of the Committee, onsite safety personnel had accounted for 16 people in the vicinity of Well 6; the Committee identified 26 people that were there at the time of the fire. Immediately following the accident, there was no central command and control of the emergency response organization from the time of the accident until the arrival of the on-scene commander as shown in Figure 10. The organization, after his arrival, is shown in 
Figure 11; response to these organizations is covered in section III-F. Additionally, there were inadequate communications for the security activities and the oil recovery operations. One guard testified that there are dead spots on the site that impair radio communications and the personnel handling the oil containment boom had trouble deploying it until the coast Guard provided radios. At West Hackberry, two warning horns were recently installed and signals were sounded.

B. SEQUENCE OF KEY EVENTS

Table 3 lists the sequence of key events prior to ignition (Pre-Accident).

Table 4 lists the sequence of key events from ignition to arrival of the on-Scene Commander (Accident).

Table 5 lists the sequence of key events from arrival of the on-Scene Commander to the securing of Well 6 (Post-Accident). 

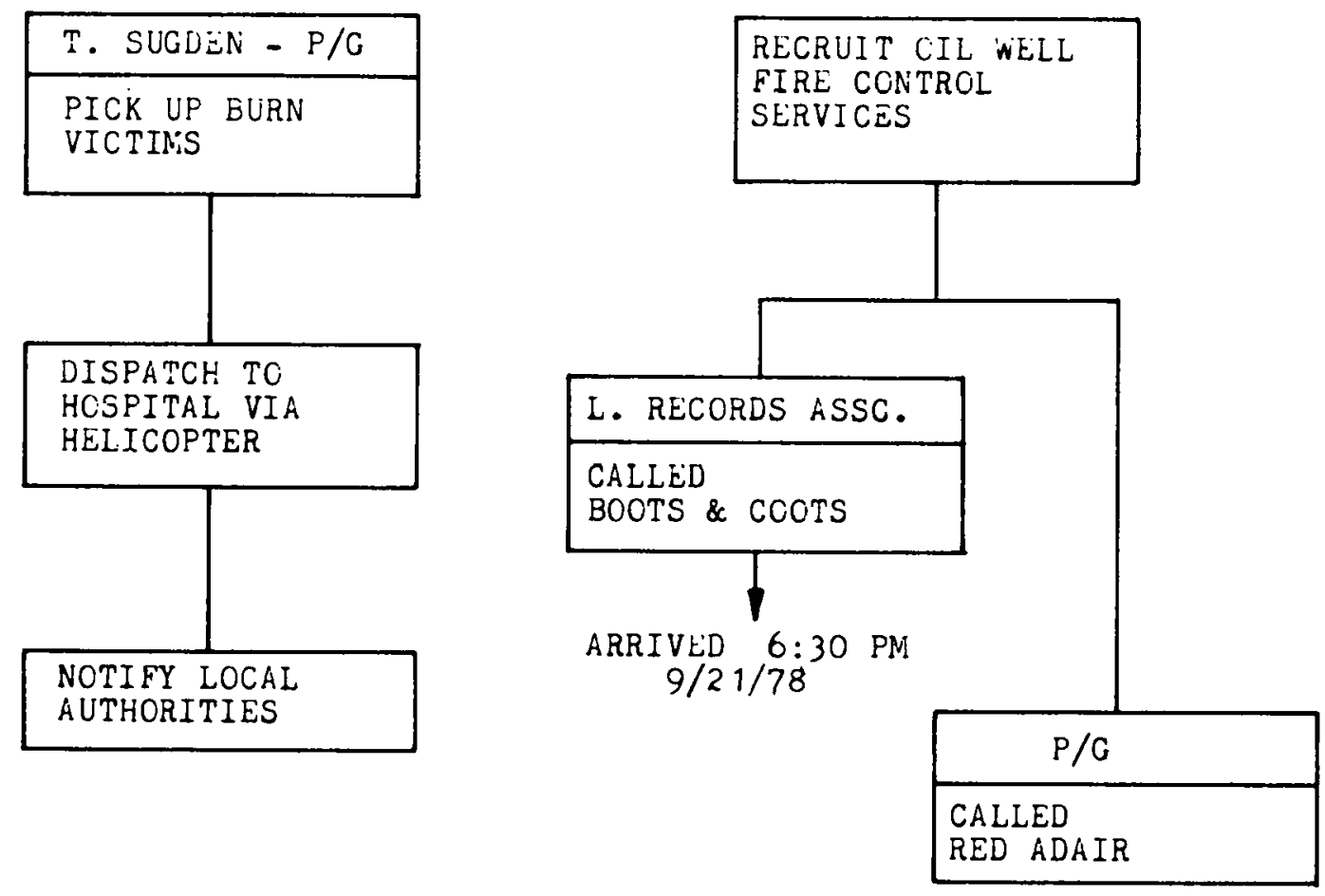

\begin{tabular}{l}
\hline S. LOWERY - P/G \\
V. SANINER - P/G \\
M. BOUDREAUX - D\&M \\
\hline OIL BOOM \\
DEPLOYMENT \\
\hline
\end{tabular}

\begin{tabular}{l}
\hline CITADEL SECURITY \\
A. FRUGE - SPRO \\
M. TANEO - P/G \\
LAW ENFCRCEIENT AGENCIES \\
\hline SITE SECURITY - \\
TRAFFIC CONTROL. \\
\hline
\end{tabular}

\begin{tabular}{|l|}
\hline SPRO $-P / C$ \\
\hline SUFPORT SERVICES \\
PROCLRE SUPPLIES \\
\hline
\end{tabular}

\begin{tabular}{|l|}
\hline G. LANDRY HVFD \\
\hline FIRË FIGHTINC - \\
VOLUNTEER FIRE DEPARTMIENTS \\
\hline
\end{tabular}

Figure 10. Emergency Response Organizations

from Time of Ignition to Arrival

of on-Scene commander 


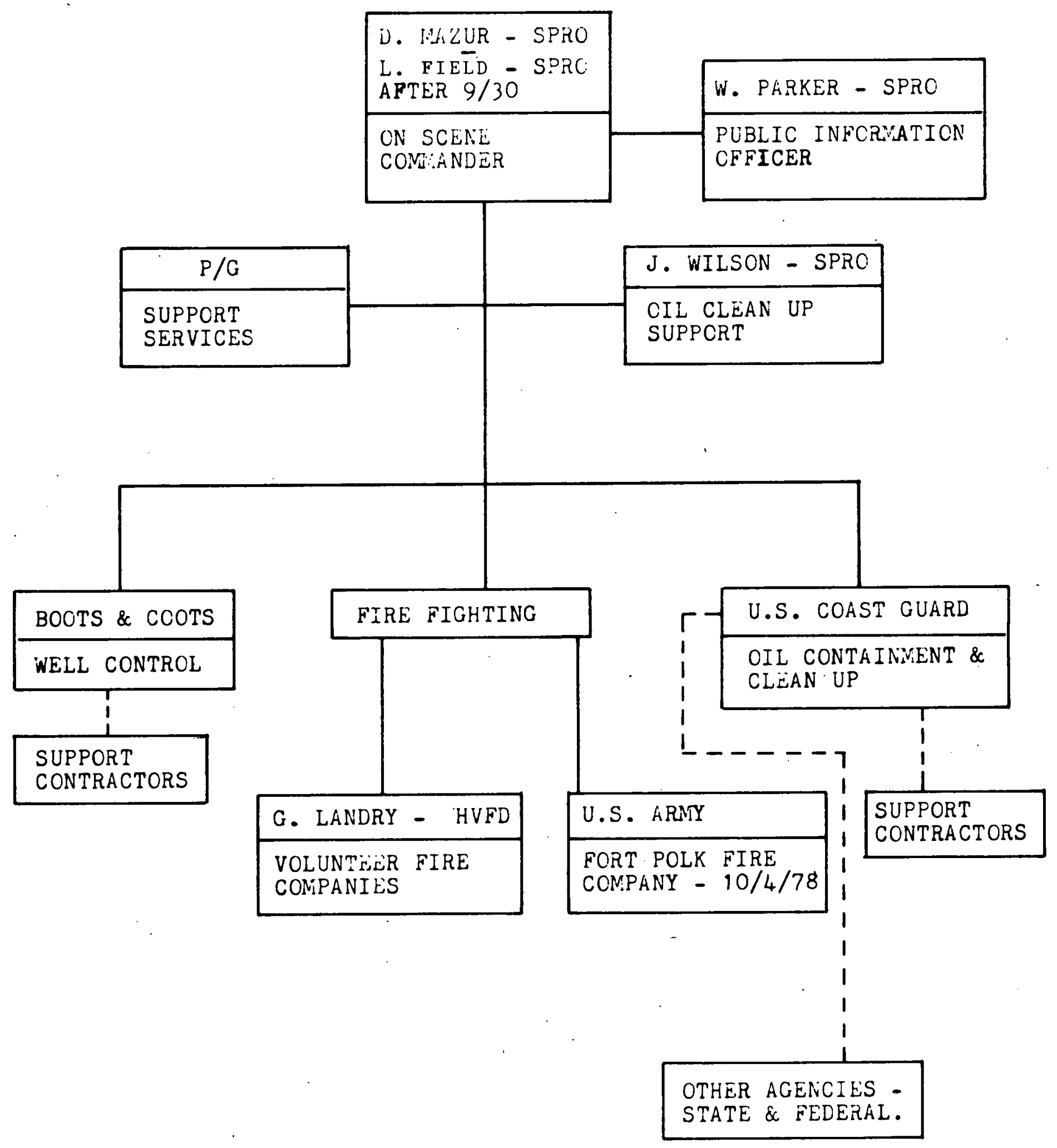

Figure 11. Emergency Response Organization from Time of Arrival of on-Scene Commander to the securing of We 116 
TABLE 3

TIMELINE OF KEY EVENTS--PRIOR TO IGNITION OF WELL 6

(PRE-ACCIDENT)

\begin{tabular}{|c|c|c|}
\hline Item & Date & Event \\
\hline 1 & Spring 1977 & $\begin{array}{l}\text { Well } 6 \text { reworked; new } 9-5 / 8 \text { in. casing cemented } \\
\text { in. }\end{array}$ \\
\hline 2 & Spring 1977 & $\begin{array}{l}\text { Well } 6 \text { well head had surface cracks and oil } \\
\text { leakage. Fires occurred during Well } 6 \text { welding } \\
\text { repairs. Temporary patch placed over leak. }\end{array}$ \\
\hline 3 & July 23 & $\begin{array}{l}\text { New 1-in. piping for fresh water injection } \\
\text { placed inside } 5-1 / 2 \text { in. pipe. }\end{array}$ \\
\hline 4 & July & $\begin{array}{l}\text { Cavern } 6 \text { activated for interim oil fill. } \\
\text { There are no requirements for formal contin- } \\
\text { gency plans before operations are initiated. }\end{array}$ \\
\hline 5 & oct. 1 & DOE formed. \\
\hline 6 & Nov. 8 & $\begin{array}{l}\text { Cavern } 6 \text { certification of Usability and } \\
\text { Integrity issued. (Tests conducted May } 7 \\
\text { to July } 23,1977 . \text { ) }\end{array}$ \\
\hline 7 & Late 1977 & $\begin{array}{l}\text { Louis Records supervises drilling operations } \\
\text { as agent for } \mathrm{PB} / \mathrm{KBB} \text {. Drilling plans receive } \\
\text { extensive technical review. }\end{array}$ \\
\hline 8 & Jan. I, 1978 & $\begin{array}{l}\text { SPR office formed. Decision made for SPR to } \\
\text { accept standard industrial practices as com- } \\
\text { pared to imposing government standards. }\end{array}$ \\
\hline 9 & January & $\begin{array}{l}\text { SPRO decision made to have separate management } \\
\text { chains for each site and site function. Chains } \\
\text { follow construction and operation separately. } \\
\text { Only point where the total site responsibilities } \\
\text { come together is under the director of the sPRo } \\
\text { project. }\end{array}$ \\
\hline 10 & January 19 & $\begin{array}{l}\text { Parsons-Gilbane joint venture accepted by letter } \\
\text { contract. Parsons-Gilbane selected to manage } \\
\text { surface construction for interim and ESR fill. } \\
\text { Parsons-Gilbane organized parallel to SPRO } \\
\text { organization. Separate chains of command for } \\
\text { each site for operations and construction. } \\
\text { The first manager under whom the total site } \\
\text { responsibility comes together is the Parsons- } \\
\text { Gilbane construction executive. }\end{array}$ \\
\hline
\end{tabular}


TABLE 3 (Cont.)

\begin{tabular}{|c|c|c|}
\hline Item & Date & Event \\
\hline 11 & July 25 & $\begin{array}{l}\text { SPRO construction division director given } \\
\text { temporary assignment; Seaway/Texoma branch } \\
\text { chief assumes responsibility for construction } \\
\text { division and capline branch and retains respon- } \\
\text { sibility for seaway/Texoma branch. }\end{array}$ \\
\hline 12 & Aug. 1 & $\begin{array}{l}\text { Drilling responsibility transferred from } \mathrm{PB} / \\
\text { KBB to Parsons-Gilbane. Louis Records con- } \\
\text { tracts to Parsons-Gilbane to supervise drilling. } \\
\text { Parsons-Gilbane initiates a separate organiza- } \\
\text { tion to manage drilling. The first manager } \\
\text { with responsibility for all site activities } \\
\text { remains as the construction executive. }\end{array}$ \\
\hline 13 & August & $\begin{array}{l}\text { Based upon immediate availability, Pelican } \\
\text { Rig } 11 \text { substituted for Rig } 15 \text {. Crew of Rig } 11 \\
\text { has no prior experience working with government } \\
\text { or on cavern workovers. }\end{array}$ \\
\hline 14 & Aug. 30 & $\begin{array}{l}\text { Louis Records sent a workover procedure to } \\
\text { Parsons-Gilbane. No engineering support pro- } \\
\text { vided. Parsons-Gilbane verbally approved } \\
\text { procedure. }\end{array}$ \\
\hline 15 & Sept. 1 & $\begin{array}{l}\text { Parsons-Gilbane changed manager responsible } \\
\text { for drilling. }\end{array}$ \\
\hline 16 & September & $\begin{array}{l}\text { Decision made to move up by } 2 \text { weeks the } \\
\text { schedule for well } 6 \text { workover. Decision made } \\
\text { not to reduce cavern pressure by transferring } \\
\text { Cavern } 6 \text { oil into Cavern } 7 \text {. }\end{array}$ \\
\hline 17 & sept. 13 & Pelican Rig 11 moved onsite. \\
\hline 18 & Sept. 15 & $\begin{array}{l}\text { Field crew discovered valve on top of well } \\
\text { head was frozen. It was partially freed but } \\
\text { was not full opening and it could not accept } \\
\text { the bridge plug called for in the workover } \\
\text { procedure. Field crew improvised a safety } \\
\text { valve with material on hand. }\end{array}$ \\
\hline 19 & Sept. 15 & $\begin{array}{l}\text { Louis Records modified workover plan to in- } \\
\text { stall an inflatable TAM packer. }\end{array}$ \\
\hline
\end{tabular}


TABLE 3 (Cont.)

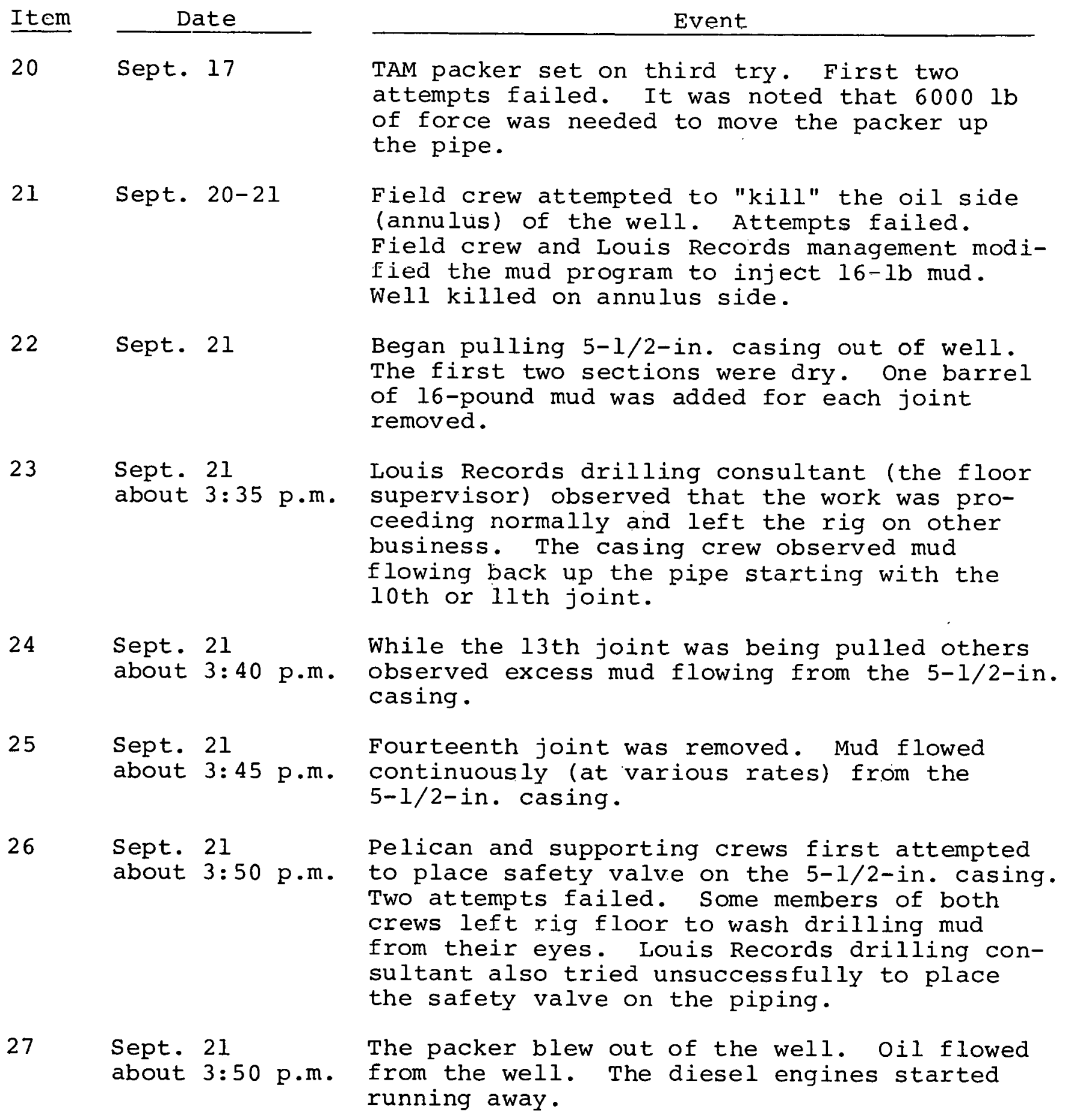


TABLE 3 (Cont.)

Item

28

29
Date

Sept. 21 about $3: 50 \mathrm{p} . \mathrm{m}$.

Sept. 21 about 3:55 p.m.
Event

Many people evacuated area. Several of the crew tried to shut down both rig and mudpump engines.

Two men continued to shut down engine. There was an explosion and fire. Two men badly burned. 
TABLE 4

\section{TIMELINE OF KEY EVENTS--FROM IGNITION TO ARRIVAL OF \\ ON-SCENE COMMANDER (ACCIDENT)}

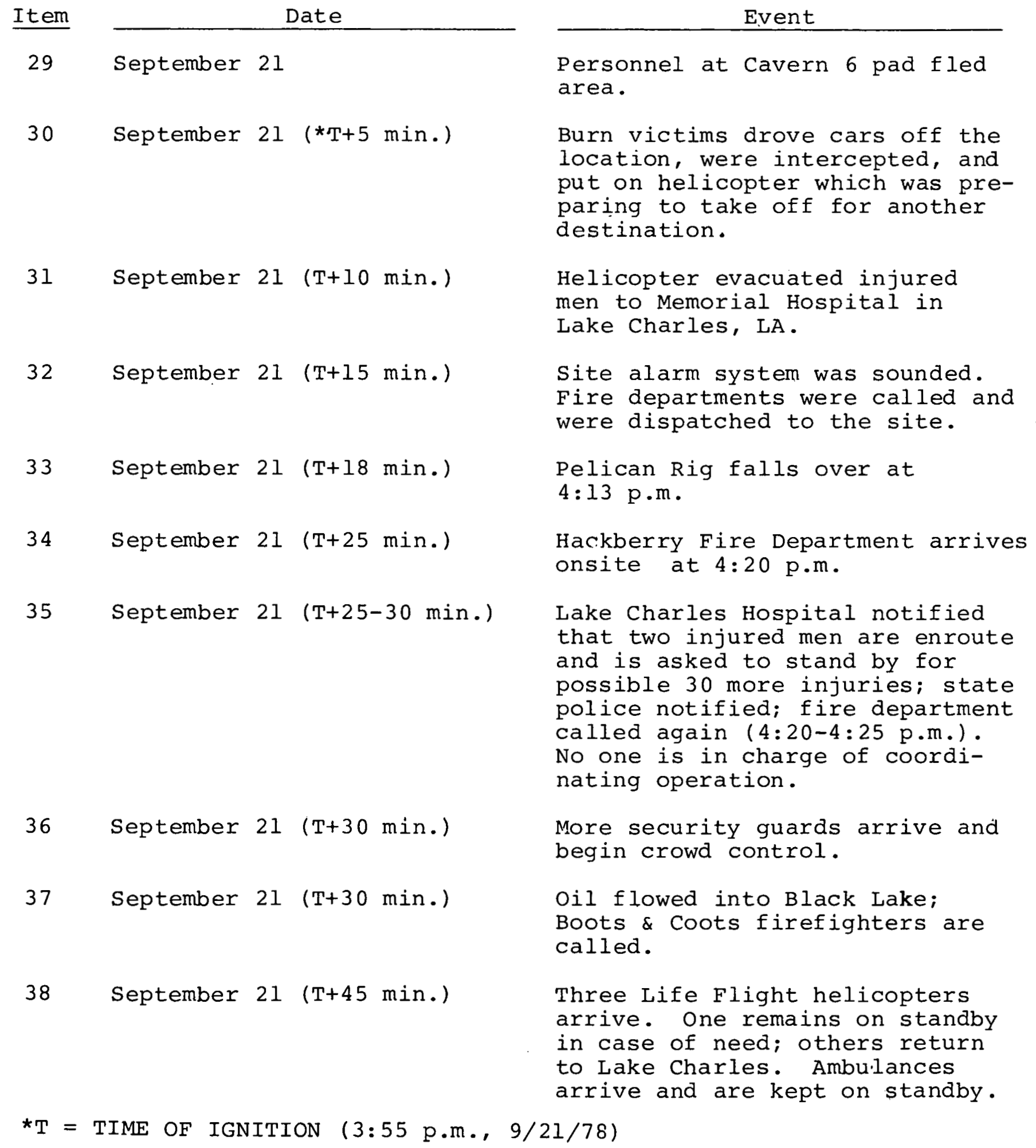


TABLE 4 (Cont.)

Item

39 September 21 ( $\mathrm{T}+65 \mathrm{~min}$.
Event

Firemen respond from Hackberry, Sulphur, Carlyss, Cameron, Moss Bluff, West Lake, and Lake Charles arriving onsite at approximately 5:00 p.m. Seventy firemen called from Calcasieu and Cameron Parishes.

40 September 21 ( $T+3$ hrs 5 min.)
SPRO Project Manager arrives at site at approximately 7:00 p.m. and assumes role of on-scene Commander; 200 firemen fighting fire. 
TABLE 5

\section{TIMELINE OF KEY EVENTS--FROM ARRIVAL OF ON-SCENE COMMANDER TO SECURING OF WELL 6 (POST-ACCIDENT)}

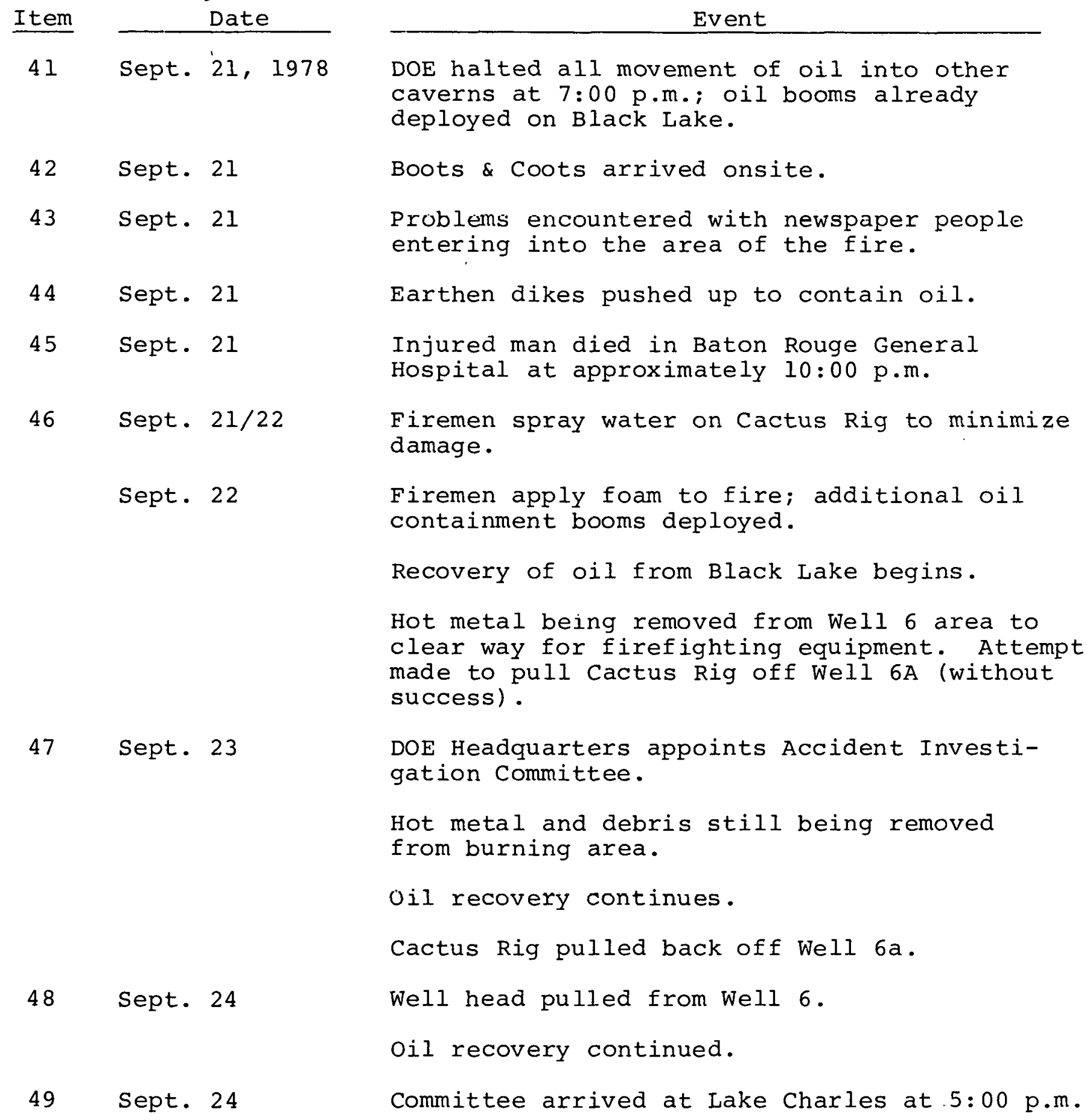


TABLE 5 (cont.)

\begin{tabular}{|c|c|c|}
\hline Item & Date & Event \\
\hline 50 & Sept. 24 & $\begin{array}{l}\text { Boots \& Coots attempted to kill well } 6 \text { with } \\
\text { brine injected in top of well. }\end{array}$ \\
\hline 51 & Sept. 25 & $\begin{array}{l}\text { Second attempt to extinguish fire by applying } \\
\text { foam around burning area. }\end{array}$ \\
\hline & & $\begin{array}{l}\text { Cleanup of area and application of foam } \\
\text { continued. }\end{array}$ \\
\hline 52 & Sept. 26 & $\begin{array}{l}\text { Specially built TAM packer arrives onsite } \\
\text { at } 6: 00 \mathrm{a} . \mathrm{m} \text {. }\end{array}$ \\
\hline & & $\begin{array}{l}\text { Boots \& Coots installs packer in } 9-5 / 8 \text { in. } \\
\text { casing of well and oil flow stops at } 9: 00 \text { a.m. } \\
\text { Foam blanket applied to extinguish burning oil }\end{array}$ \\
\hline 53 & Sept. 26 & $\begin{array}{l}\text { Fire reignited. Firefighters return. Fire- } \\
\text { fighters from Fort polk called out. }\end{array}$ \\
\hline 54 & Sept. 27 & $\begin{array}{l}\text { Fire is again extinguished. Cleanup of oil } \\
\text { continues. }\end{array}$ \\
\hline 55 & Sept. 27 & $\begin{array}{l}\text { Operations by Boots \& coots initiated to cut } \\
\text { off top of casings in preparation for instal- } \\
\text { lation of new well head assembly. }\end{array}$ \\
\hline 56 & Sept. 28 & $\begin{array}{l}\text { Installation of well head. Cleanup of oil } \\
\text { continues. }\end{array}$ \\
\hline 57 & Sept. 29 & $\begin{array}{l}\text { Installation of well head. Cleanup of oil } \\
\text { continues. }\end{array}$ \\
\hline 58 & Sept. 30 & $\begin{array}{l}\text { New head installation completed; packer } \\
\text { retrieved from well and Well } 6 \text { is shut in. } \\
\text { Boots \& Coots firefighters leave the site. }\end{array}$ \\
\hline
\end{tabular}


C. OBSERVATIONS

The Committee reviewed more than 2,000 photographs of the site and its environs, which are maintained in the permanent files on record at the Department of Energy. This section of the report will present several representative documentary photographs.

\section{Pre-Accident}

Figures 2 and 3 are photographs taken on August 27, 1978. They are oblique aerial views of the West Hackberry site. Figure $4 a$ shows the Cactus Rig located on Well 6a. The figure also shows the temporary earthen dike that had been constructed to help protect Black Lake from oil spills. Figure 6 shows the rigs on Cavern 6 3 days before the accident.

\section{Accident}

Figures 12, $12 \mathrm{a}$, and 13 are photographs of the fire scene; $12 \mathrm{a}$ on september 21, and 12 and 13 on September 22, 1978. Figure 12 is a view of the site taken by helicopter. It shows the Cactus Rig on Well $6 \mathrm{~A}$ prior to its being pulled back off the well head with a water stream being sprayed on the rig in an attempt to keep it cool in order to minimize fire damage. Several items which were destroyed by the fire are also evident in the picture. In the top right corner are the oil booms deployed to help contain the oil spill on Black Lake. Figure 13 is a closeup photograph of the fire and was taken from the Cavern 6 pad.

\section{Post-Accident}

Figure 14 is a representative helicopter photograph of Pad 6 after the fire had been extinguished. It was taken on september 27 , 1978. The new well head had not yet been placed on Well 6 . It shows that the oil spill cleanup operations had recovered almost all the oil which had spilled onto Black Lake. 


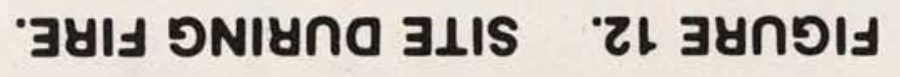

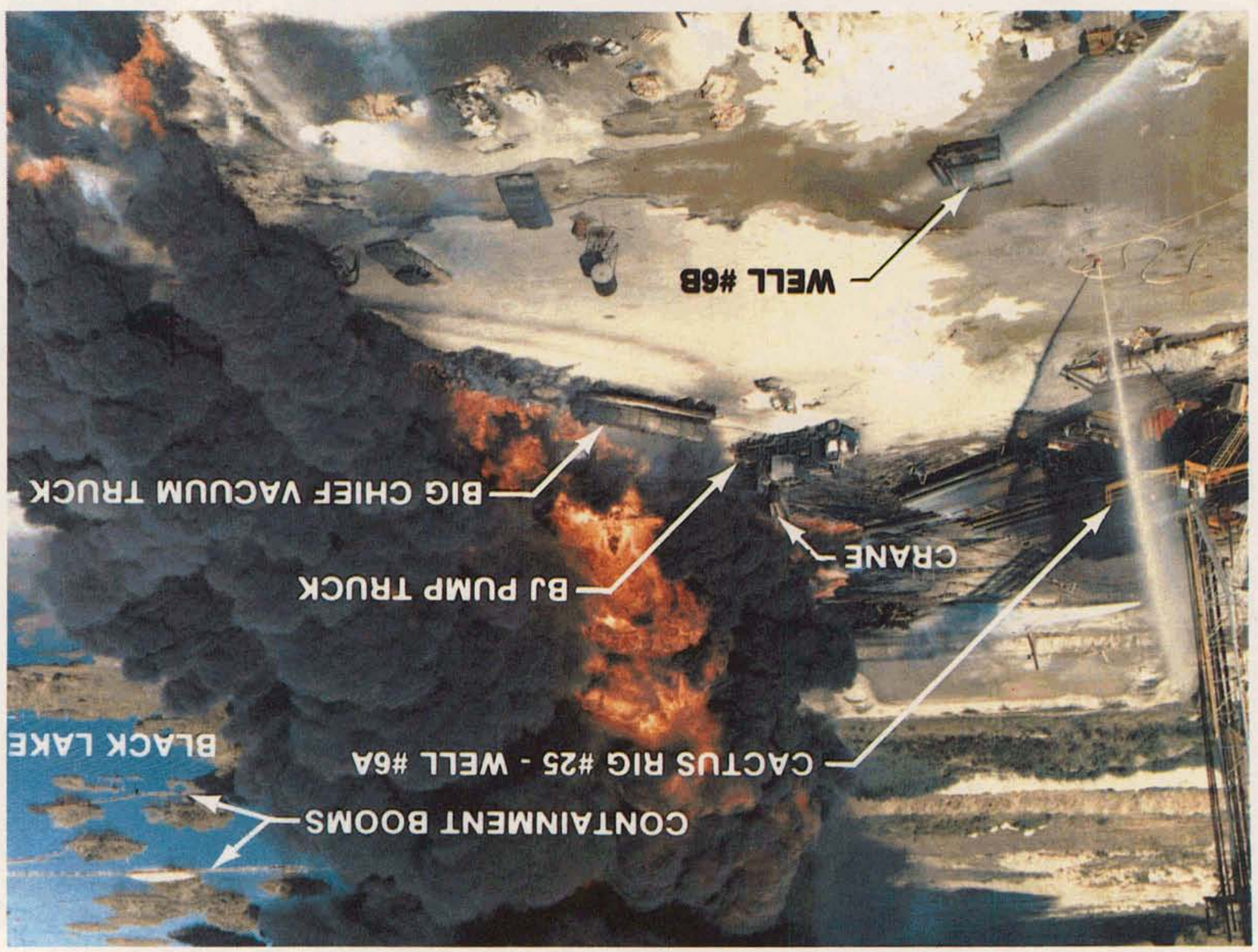




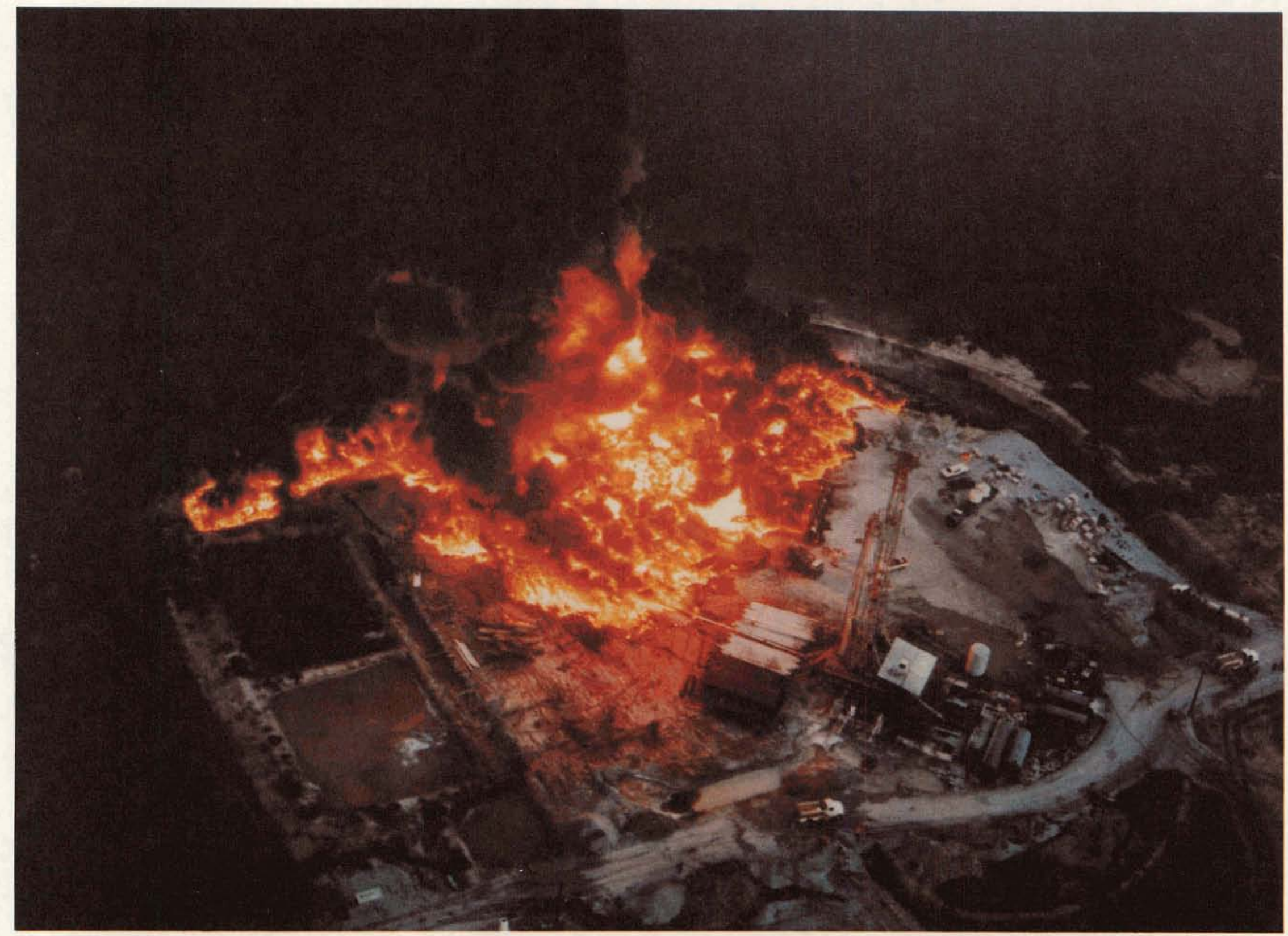

FIGURE 12a. SITE 3 HOURS AFTRR IENITION 


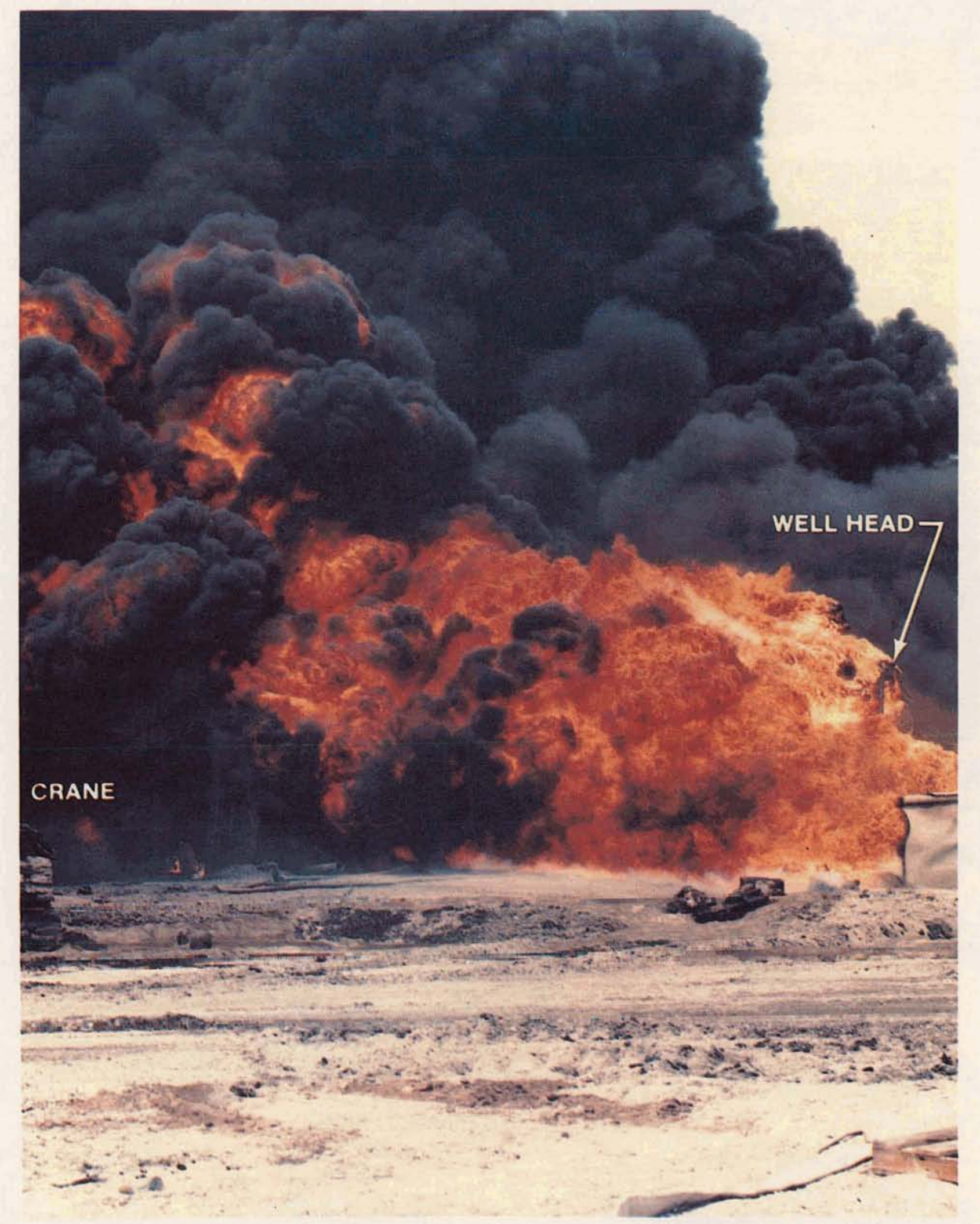

FIGURE 13. SITE DURING FIRE. 


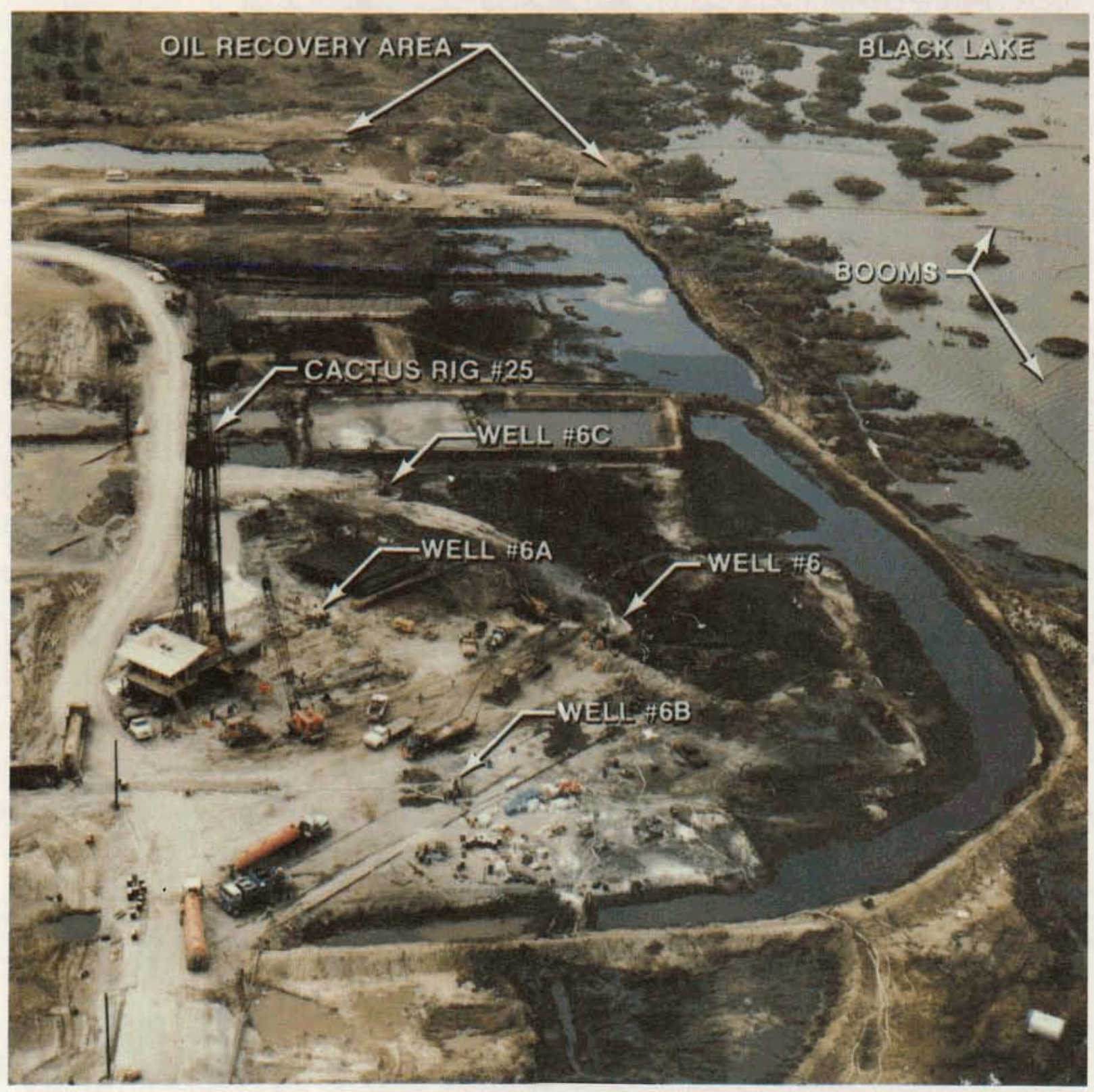

FIGURE 14. SITE AFTER FIRE. 


\section{CONSEQUENCES}

\section{Fatality/Injury}

Two Pelican Well Service men were badly burned in the initial flash. One died in the hospital that evening. The second is recovering. He was discharged from the hospital on October 11 and is undergoing outpatient treatment. A minor cut sustained by the Louis Records consultant required three stitches.

Medical data are contained in Appendix $\mathrm{V}$.

\section{LosS}

The current total loss estimate is summarized as follows:

\section{Loss Cost Estimate Summary}
a. Onsite Property Damage
$\$ 3,300,000$
b. Onsite Fire Control, Debris Removal, Cleanup
$2,300,000$
c. Onsite/Offsite Environmental Control
$4,200,000$
d. Operations Interruption 900,000
e. Onsite Personnel and offsite (Third Party) Liabilities

A detailed breakdown of the above estimates submitted by the Committee's consultant is shown in Appendix VI. It is not the Committee's conclusion as to liability or property damages for losses and costs resulting from the accident investigated. Figure 15 shows the degree of property damage at Well 6 .

\section{Oil Release}

The following SPRO estimate of the oil release was as of September 29, 1978: 


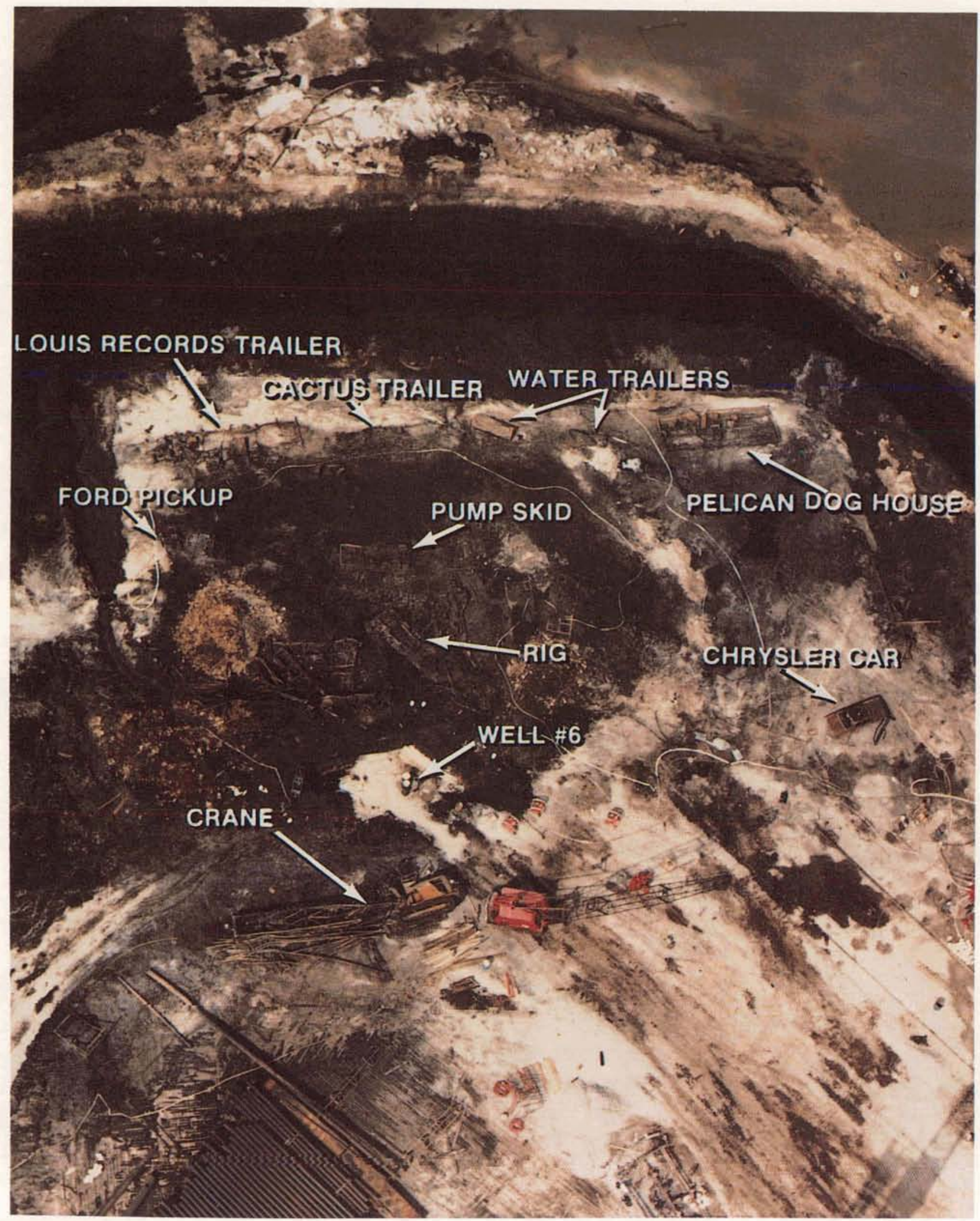

FIGURE 15. PROPERTY DAMAGE. 
(Barrels)

Oil Expulsion

Decompression of salt

Decompression of brine

Decompression of oil

Oil Accounted For

Black Lake

Pumped to Cavern 7

In shell on pad

In soil
67,510

38,030

6,680

22,800

34,620

31,200

2,100

530

790

$\underline{32,890}$

\section{Environmental Impacts}

Potential environmental impacts arose from the oil release into Black Lake adjacent to the well and from air pollution and surface contamination due to the smoke plume downwind from the site (Figure 16). Figure 17 shows the oil spill in Black Lake. An environmental assessment team, which included both DOE and other Federal and State agencies, was assembled to investigate environmental damage. Approximately 50 people participated in the data gathering during the period of September 29 to October 1 . Their preliminary report is included as Appendix IV. Due to the nature of the investigation, which is very extensive and time consuming, a final report on the environmental consequences will not be available for many weeks. It appears very likely at this time, however, that no permanent environmental damage to Black Lake will be sustained because of the rapid and effective containment and cleanup of the oil.

E. PHYSICAL EVIDENCE

1. Well Head

The well head was pulled off the well during the early stages of the fire-control efforts and was, therefore, recovered essentially 


\section{APPROXIMATE CONDITIONS:}
TEMPERATURE
WIND $\ldots \ldots \ldots \ldots \ldots \ldots \ldots \ldots$ KNOTS
DIRECTION ............... FROM $50^{\circ}$

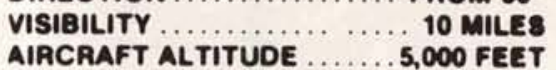

FIGURE 16. SMOKE PLUME. 


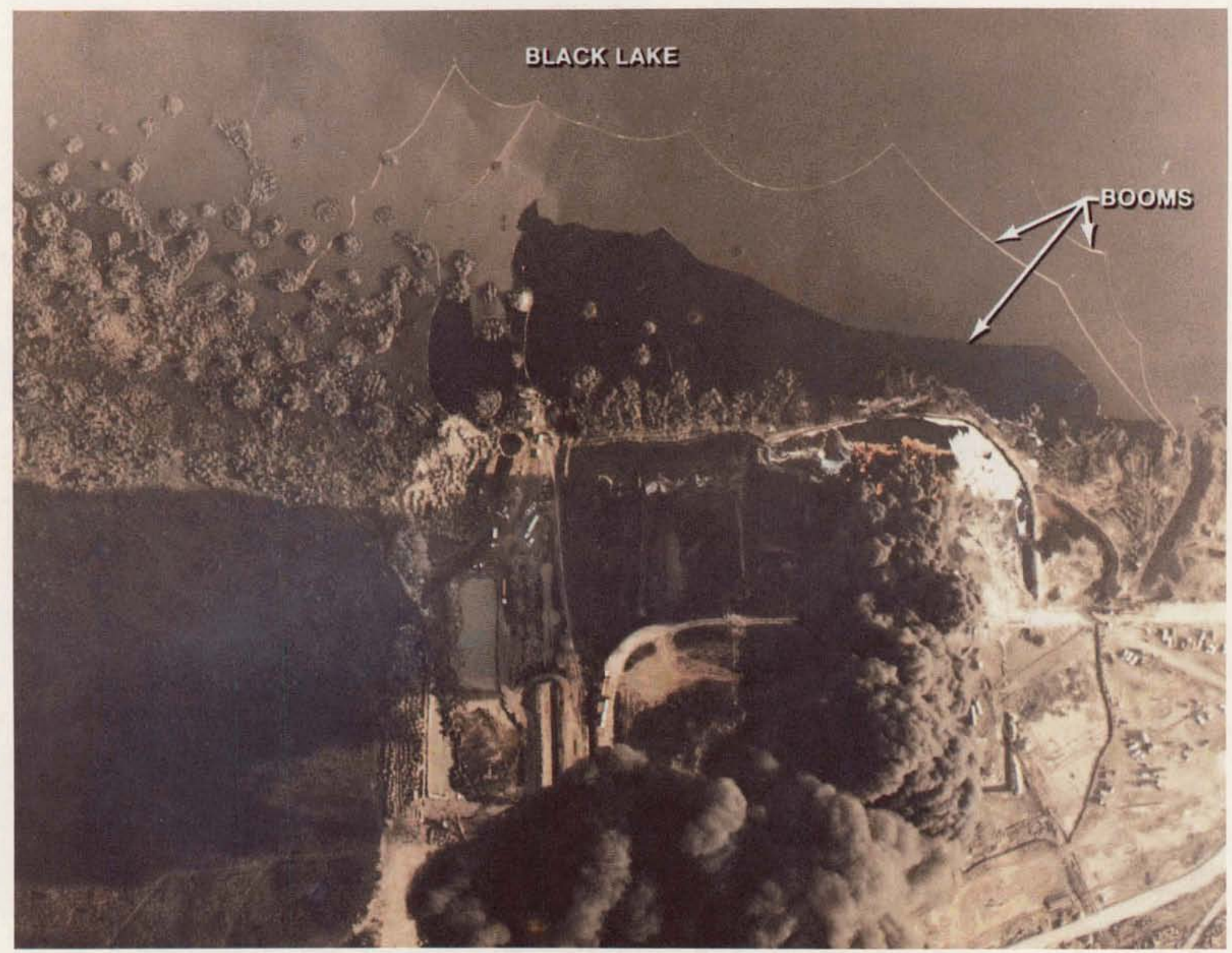

FIGURE 17 . OIL SPILL. 
intact. (See Figures 18a \& 18b.) The clamp that held a rubber sleeve over a leak in the outside casing can be seen at the extreme left of the picture. The single set of blowout preventers is visible in the right half of the picture.

The appearance of the fracture of the 9-5/8-inch inner casing (Figure 18b) led the Committee to suspect that it represented an old crack that may have been the cause of the original leak. That hypothesis was based upon the fact that a part of the crack exposed bright shiny metal, and another part (believed to be an old crack) had considerable oxidation (discoloration and deterioration). Metallographic examination of samples from the well head were conducted by Oak Ridge National Laboratory (Appendix VII). The metallurgical examination could not establish the time when the crack was formed. However, it revealed several leak paths in the weldings which attached the flange to the 9-5/8-inch casing, and in the longitudinal weldings of the 12-3/4-inch outer casing. These flaws were such as to represent a credible source for the seepage leak that had been observed at the well head prior to the workover. However, they also represented a very low quality of workmanship, and a clear-cut lack of quality control on the welding.

\section{5-1/2-Inch Casing}

The workover operation that was underway at the time of the fire involved removal of the 5-1/2-inch casing, section by section. Since this was the pipe from which the packer blew out, the Committee tried to determine whether the condition of the pipe contributed to the packer's release. Based on the appearance of many of the sections that had been exposed to the fire (Figure 19a), such seemed likely to be the case. However, section 14, the last one removed, 


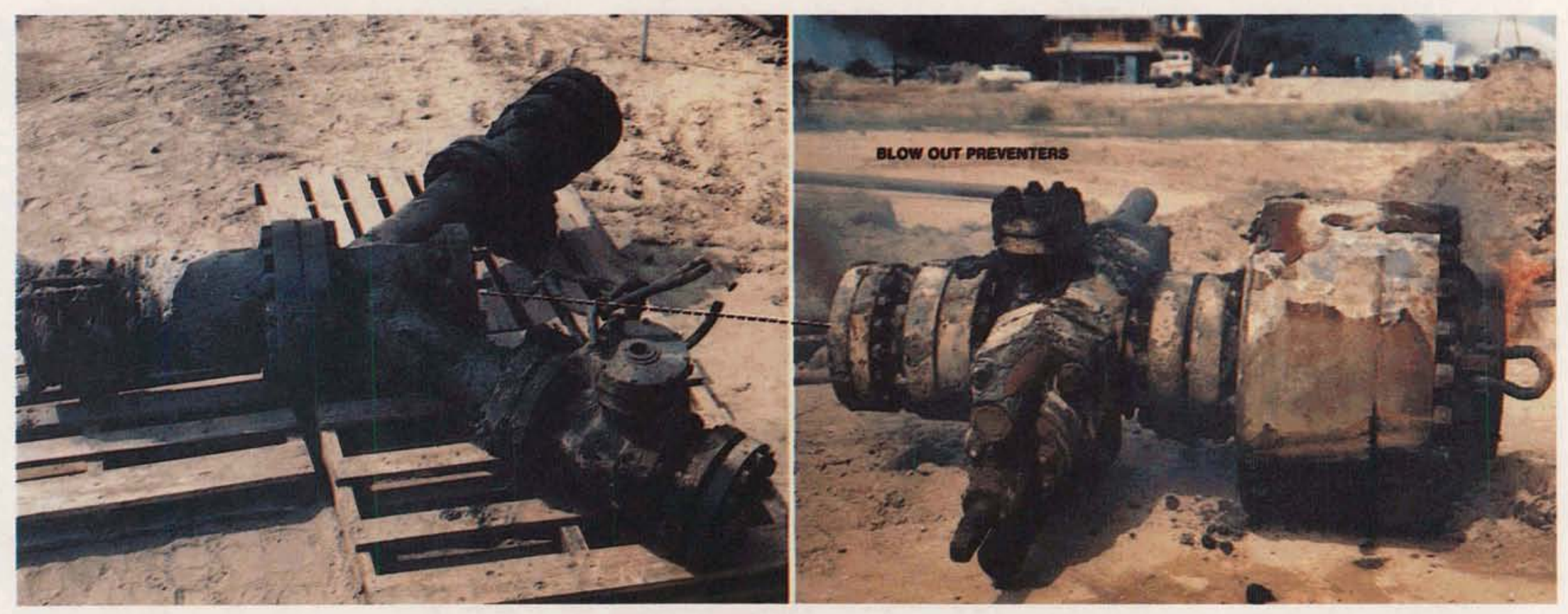

FIQURE 18A. PHYSICAL EVIDENCE - WELL HEAD. 


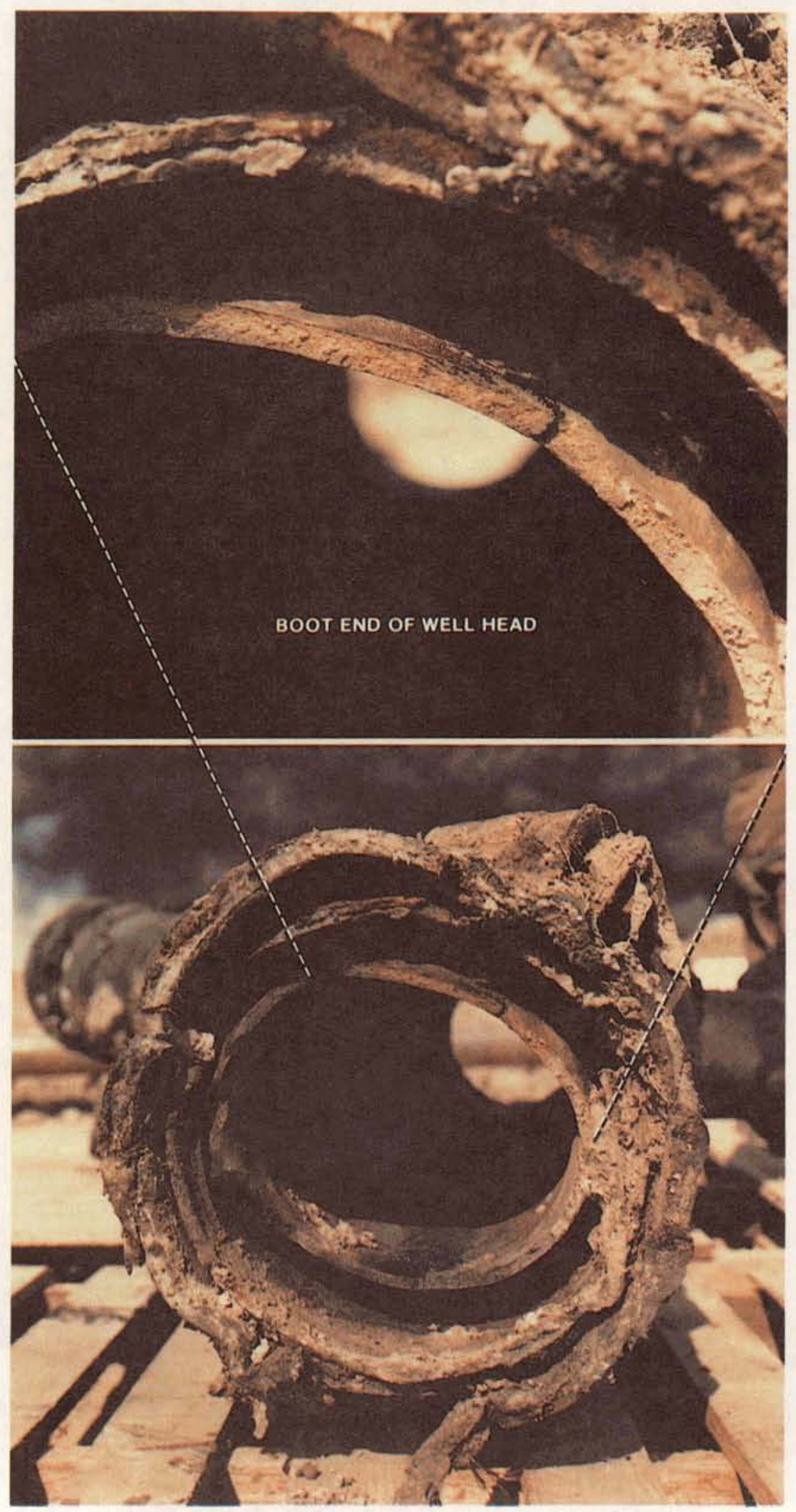

FIGURE 188. PHYSICAL EVIDENCE - WELL HEAD. 


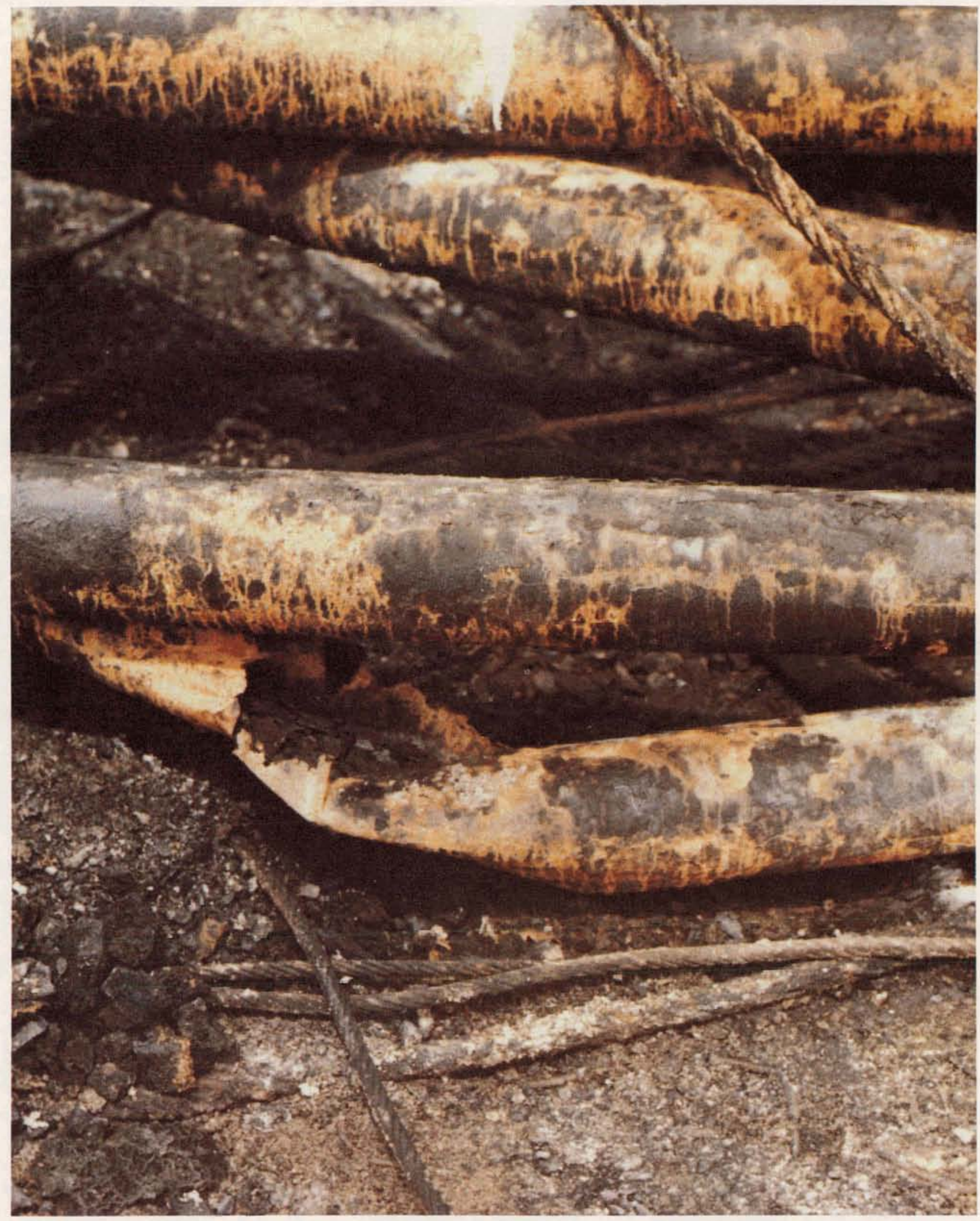

FIGURE 19A PHYSICAL EVIDENCE - 5 $\frac{1}{2}$ INCH CASING. 
was still in the V-door of the drilling rig when the rig collapsed (see Figure 19b). It is assumed that the section protected from the fire when the crane collapsed was section 14 . It suffered very much less fire damage than the exposed sections. Analysis of section 14 (Appendix VII) showed it to be in good condition, with a minimum of internal scale and salt-induced corrosion. Furthermore, laboratory tests confirmed that the sulfur present in the pipe deposits, whether from the sour crude or sulfates in the brine, was sufficient under the temperature conditions of the fire to cause the severe corrosion observed in the exposed sections.

\section{Packer}

Numerous witnesses stated that they saw the inflatable packer blow out of the well. While initially there was some skepticism on this point, site inspection after the fire uncovered the packer (Figure 20). The inflatable rubber sleeve had, of course, been consumed. Examination revealed that the packer, as recovered, was still in the set position. Thus, accidental opening of the valve and subsequent deflation of the packer did not appear to be a plausible failure mode. 


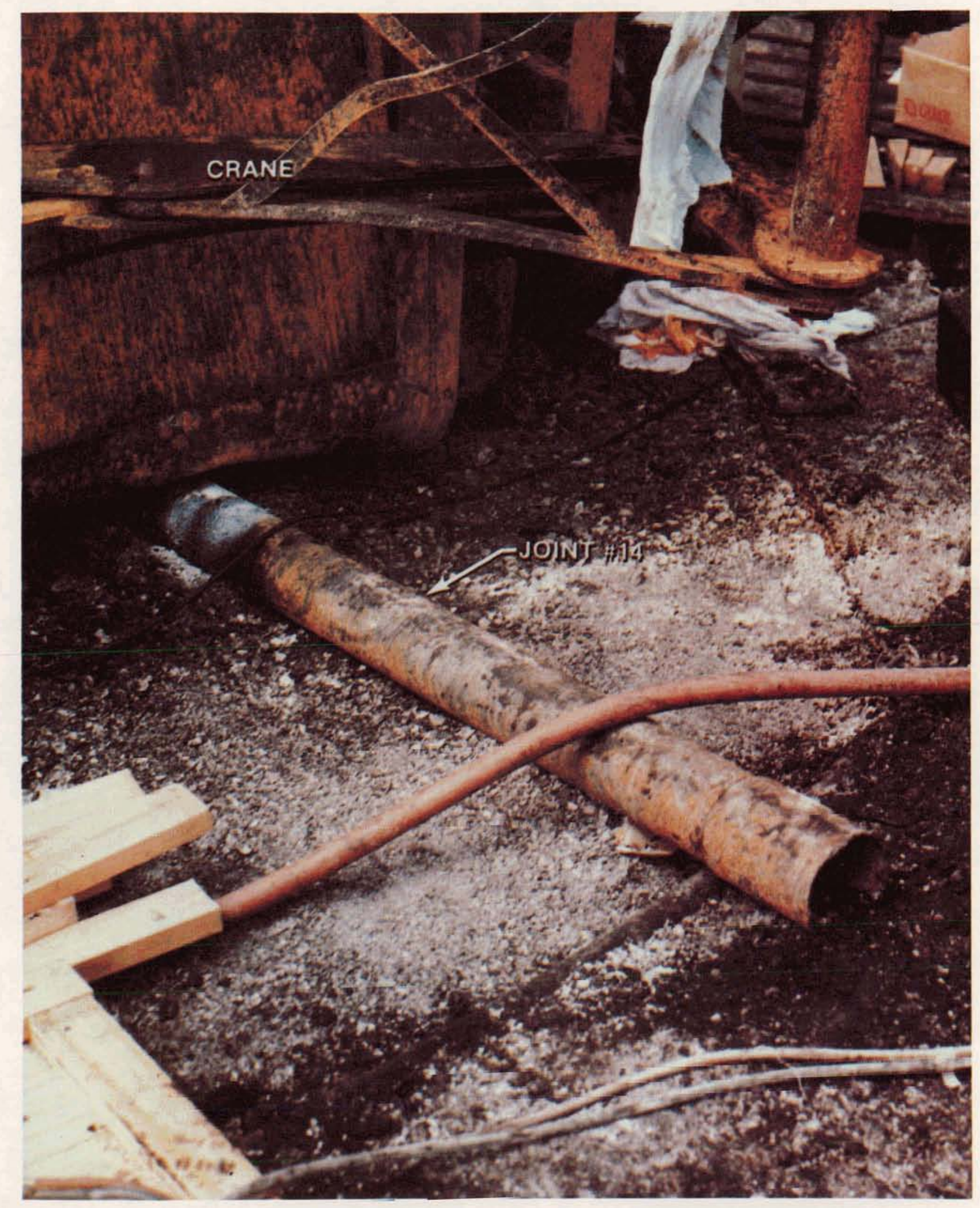

FIGURE 19B PHYSICAL EVIDENCE - 51/2 INCH CASING. 


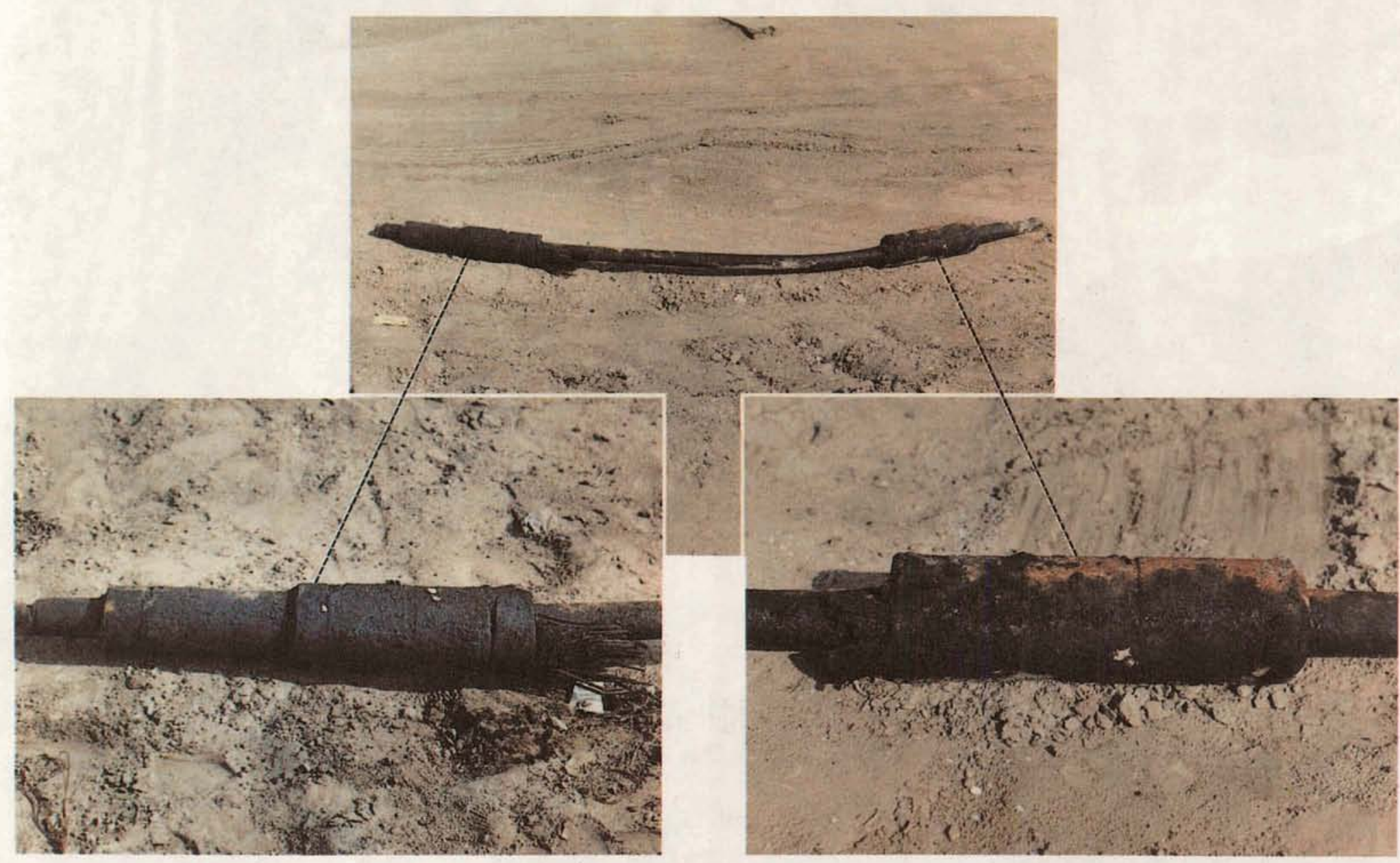

FIGURE 20. PHYSICAL EVIDENCE - PACKER (BURNED) 
F.

EMERGENCY RESPONSE

The chronological sequence of events following the fire is shown in Tables 3, 4, and 5, and thus is not repeated here; the salient events surrounding the emergency response are set forth as follows:

- Immediate removal of the two burn victims from the area of the fire and their dispatch via helicopter to the hospital.

- Dispatching medical aid, ambulances, and medical helicopters to the site to aid what was thought at the time to be 30 persons, who were reported to be working in the vicinity of Cavern 6 .

- Attempt to secure the gate so that only authorized personnel would be on the site; these efforts did result in some problems with the volunteer firemen and the press.

- Procurement of emergency support services, like oil cleanup crews and supplies, and foam for firefighting.

- Participation of numerous groups, individuals, and other agencies, especially the volunteer firemen and the U.S. Coast Guard.

- SPRO project office assumes control of the site upon arrival of on-Scene Commander.

1. Personnel Protection

At the time the well blew out, Mr. Thomas Sugden, the Parsons-Gilbane quality assurance engineer, was at the pump pad near Cavern 6. He had just started walking toward the Well 6 pad when the oil ignited. He met the burn victims, C. Simon and B. Bergeron, who had just driven from the accident site in a car. Sugden drove the victims to the helicopter pad and directed the helicopter pilot, who fortunately was onsite, to take the injured men to the hospital. Mr. Sugden then proceeded to the Parsons-Gilbane site office and, with the help of several of the secretarial staff, called the local 
hospital to notify it that two burn victims were on the way. He instructed the hospital to send medical assistance back with the helicopter, and told them to anticipate up to 30 burn victims. The time response to these calls was reported as being good.

As the small number of those initially injured became clear to him, Mr. Sugden's involvement continued as he made decisions to retain at the site the ambulances and one Life Flight helicopter in the event of secondary explosions. He called the hospital again to tell them there would be no more burn victims and directed that the helicopter return the medical assistance to the hospital.

\section{Firefighting}

The response by the local volunteer firemen was commendable in terms of timeliness, as well as dedication. Most notable of the contributions by the volunteer firemen was that of Chief G. Landry of the Hackberry Volunteer Fire Department, who served as site coordinator for the many fire companies that participated. In the early stages of the fire, there were some problems with site access for volunteer firemen as discussed below. Additionally, no foam was available onsite for firefighting, nor were there adequate water supplies, hoses, etc. The majority of these supplies and services were obtained rapidly because of the high density of oil-related industries in the immediate area and the equipment provided by the local fire departments.

The firefighting operations consisted of the application of foam and/or water to the site and adjoining equipment in order to cool the equipment and minimize the spread of fire on pools of oil. In addition to fire control, the foam was used to protect the equipment and personnel involved in the well control operation. Various stages of the firefighting operations are shown in Figures $21 \mathrm{~A}-21 \mathrm{E}$. 


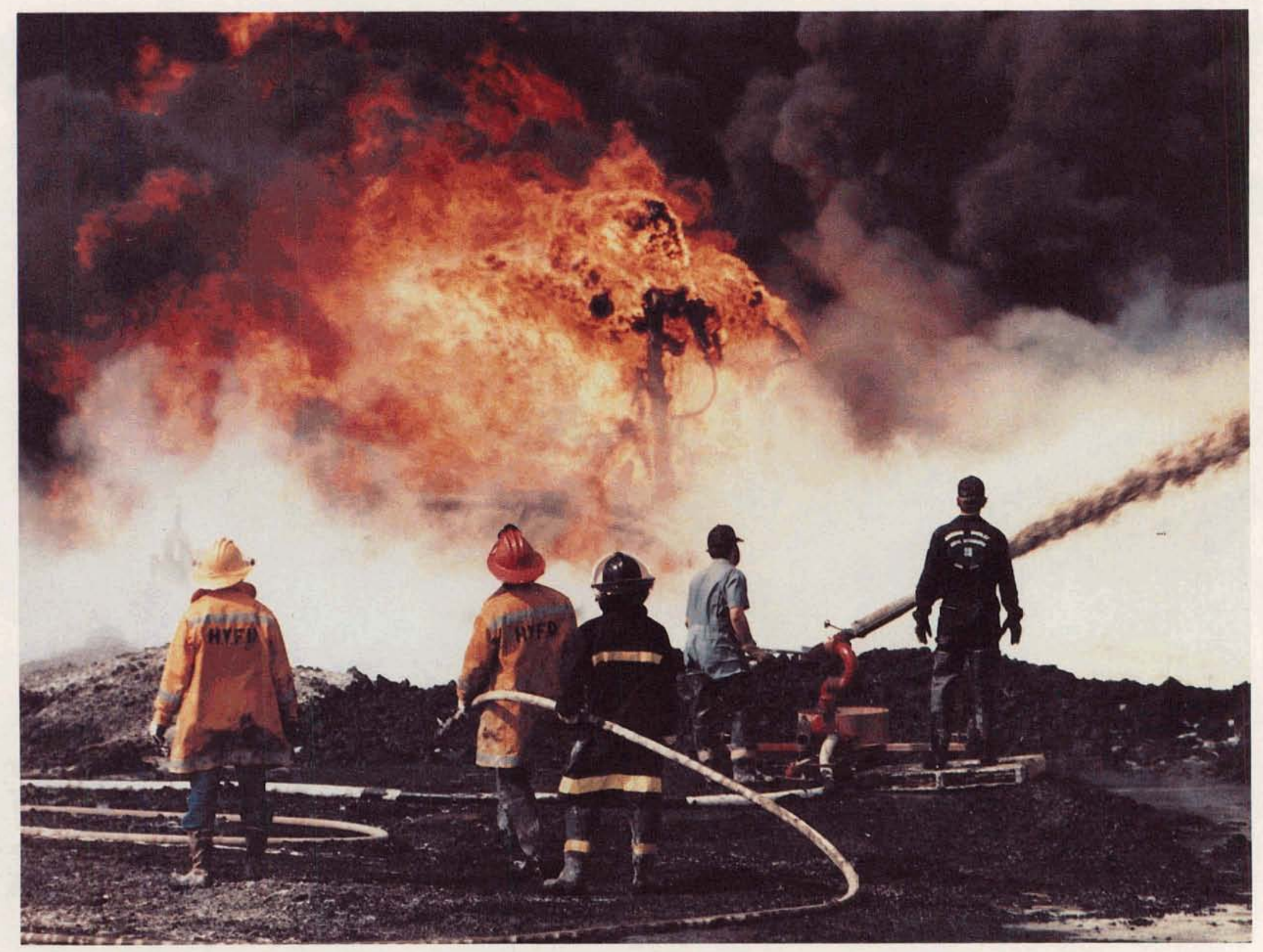

FIGURE 21A. FIRE FIGHTING. 


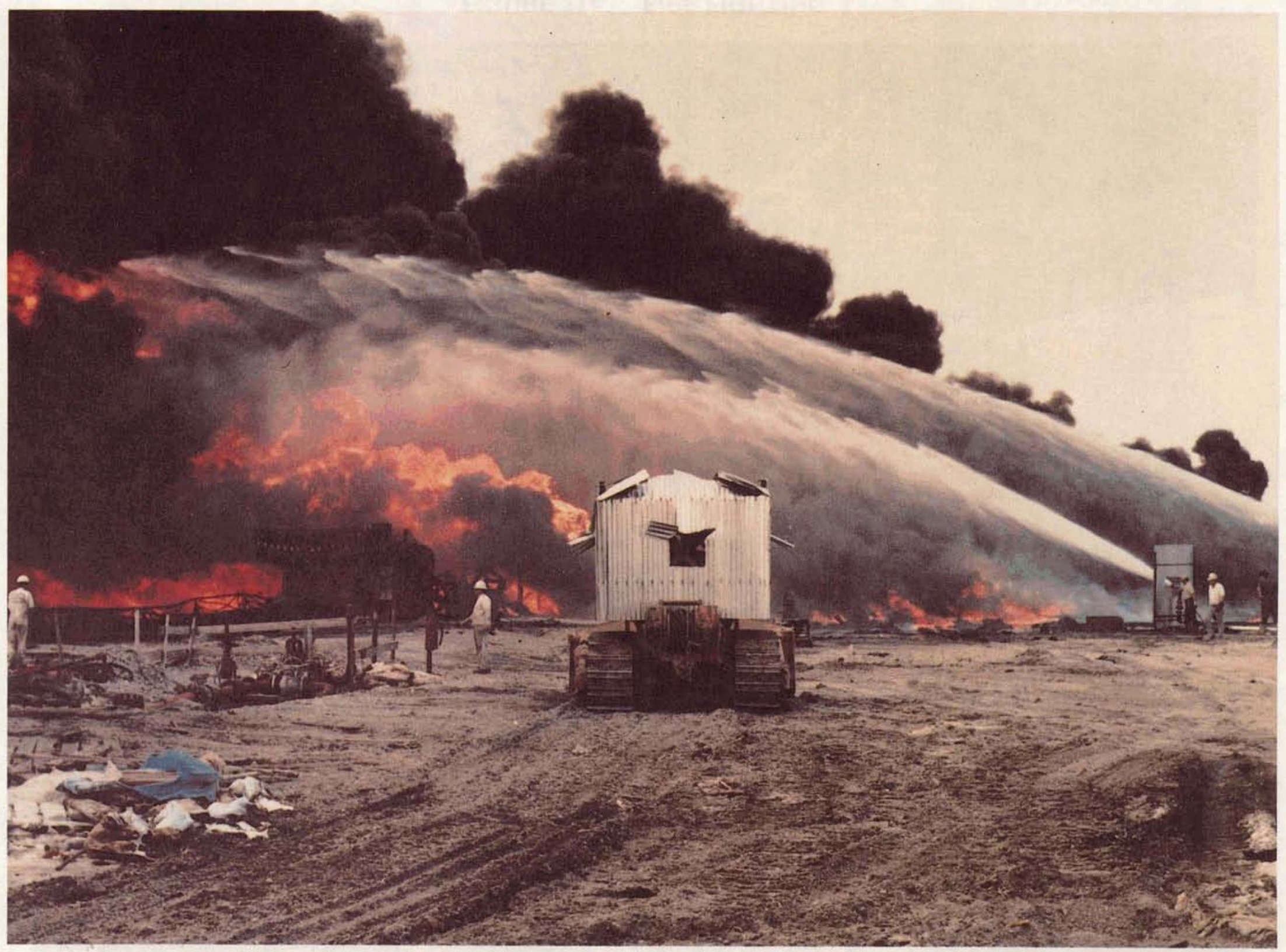

FIGURE 21B. FIRE FIGHTING. 


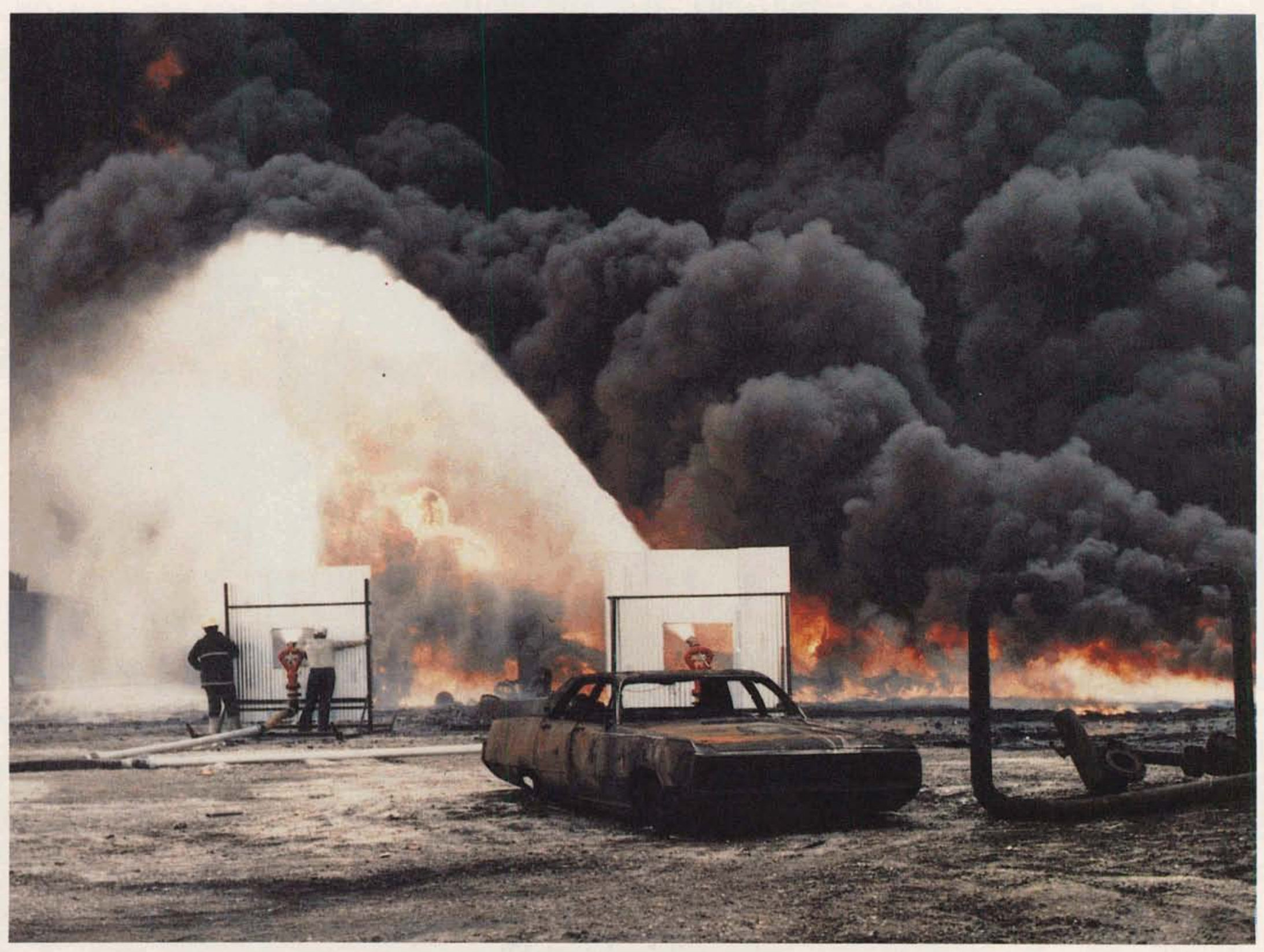

FIGURE 21C. FIRE FIGHTING. 


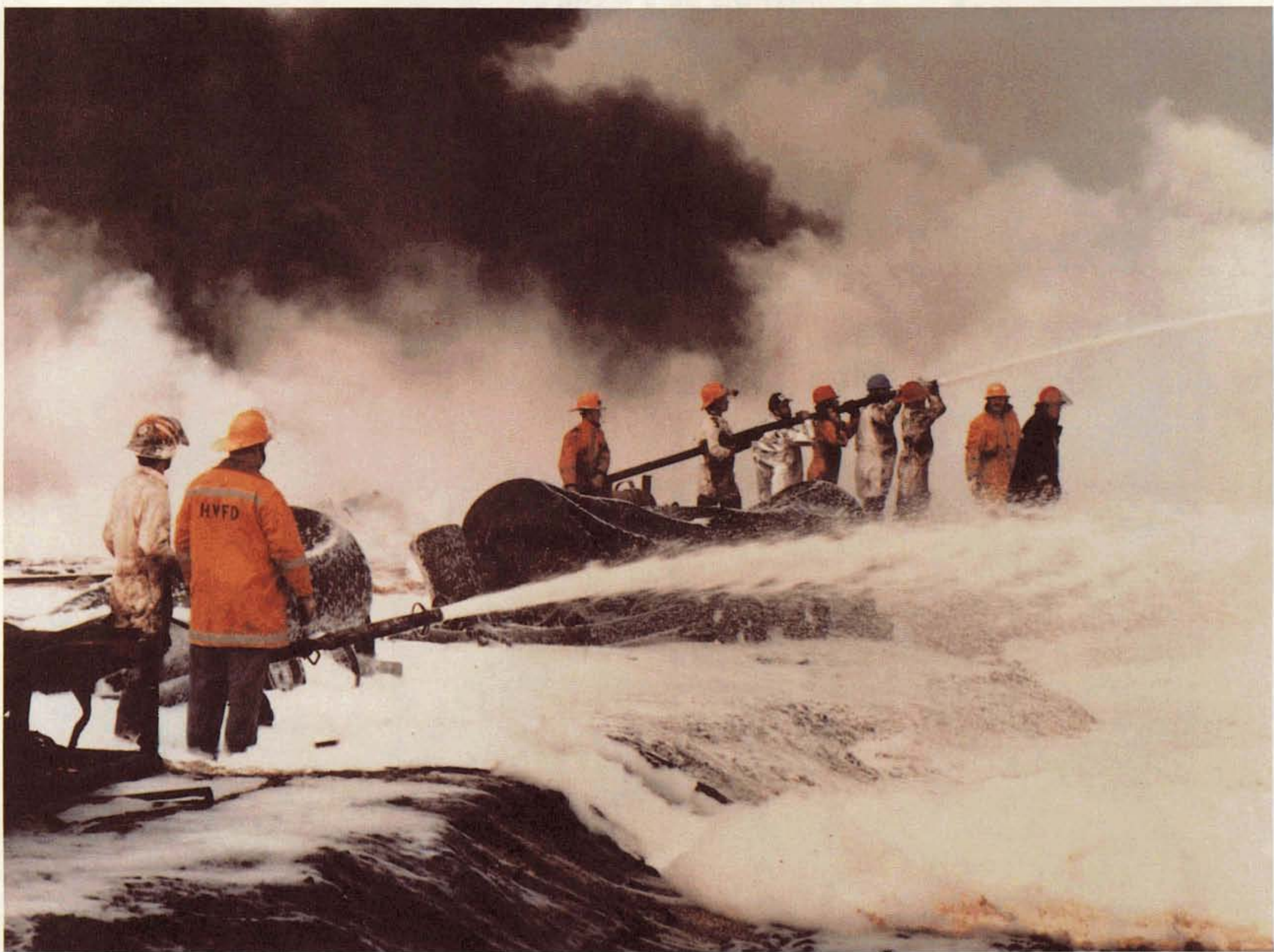

FIGURE 21D. FIRE FIGHTING. 




FIGURE 21E. FIRE FIGHTING. 
After the well was plugged on Tuesday morning, September 26 , the fire companies, through the use of foam, controlled the fires on the pools of oil in the dike around well 6. By evening, the firemen had departed but the hot oil later reignited. After some delay, SPRO made arrangements for military firemen and equipment from Fort Polk to provide the continued fire protection necessary until the oil had cooled and ignition sources were eliminated. The Fort Polk personnel arrived during the early morning hours on Wednesday, September 27.

\section{Well Control}

Louis Records assumed the responsibility for contacting the oil well firefighters, Boots \& Coots, but concurrently the New Orleans office of Parsons-Gilbane was establishing contact with Red Adair. Louis Records also contacted other officials, such as sheriffs, state police, etc., again duplicating the efforts of Parsons-Gilbane personnel.

The well-plugging operation was under the direction of Boots \& Coots and supported by onsite personnel, as well as outside contractors specifically recruited for the fire control activities. Boots \& Coots were contacted in Houston at approximately 5:00 p.m., on September 21, and arrived at the site between $6: 15 \mathrm{p} . \mathrm{m}$. and $6: 30$ p.m. on the same day.

In order to reduce the pressure on Cavern 6 , double 2-7/8-inch tubing was laid from Well $6 \mathrm{~b}$ to Cavern 7 , and 2,100 barrels of oil were pumped by a B. J. Hughes pump truck into Cavern 7. As the cavern pressure was reduced, the intensity of the fire decreased. Efforts were initiated to clear the debris from around well 6 so that the site would be accessible and hot ignition sources would be eliminated once the well was plugged. In the course of the cleanup operation, while attempting to remove the rig substructure, the Well 6 head was pulled loose approximately 1 foot below the pad elevation. 
The first attempt to extinguish the fire at the well was with a 2-3/8-inch stinger. The stinger was stabbed into the well remotely from a boom, and brine was pumped through the stinger into the well, but it did not stem the flow of oil. Figure 22 shows the stinger being lowered into the well.

The second attempt to extinguish the fire was with a 7-inch inflatable TAM packer which would be inflated to the internal diameter of the 9-5/8-inch casing. At this time, the fire was confined to an area of approximately $20 \times 50$ yards and was burning at approximately one-third of its original intensity. The packer was lowered 10 feet into the well (Figure 23) with the boom used in the previous attempt; when in place, the packer was inflated with 2,000 psi and the packer was set. The well was killed at 9:30 a.m. on september 26, and the firefighters extinguished the fire at the site with foam and water.

After the fire was extinguished and the area cooled sufficiently, the final capping operation was implemented; the tops of the old casings had to be cut away with a mechanical casing cutter (Figure 24a) and the new well head (Figure 24b), complete with blowout preventers (BOP), installed. After the well head was in place, the pipe attached to the packer could be removed as shown in Figure $24 \mathrm{~b}$ and then the BOP was removed (Figure 24c). On September 30 , Well 6 was secured and Boots \& Coots departed.

\section{Oil Cleanup}

There was a dike in place around Cavern 6 as shown in Figure 25, but the dike was inadequate to contain the spill from Well 6; additionally, there was a defect in the dike which had not been repaired. When the spill into Black lake occurred, the initial boom was obtained from Amoco's adjacent facility and was installed by Parsons-Gilbane personnel with subsequent assistance from the U.S. Coast Guard when they arrived on the scene. Additional backup 


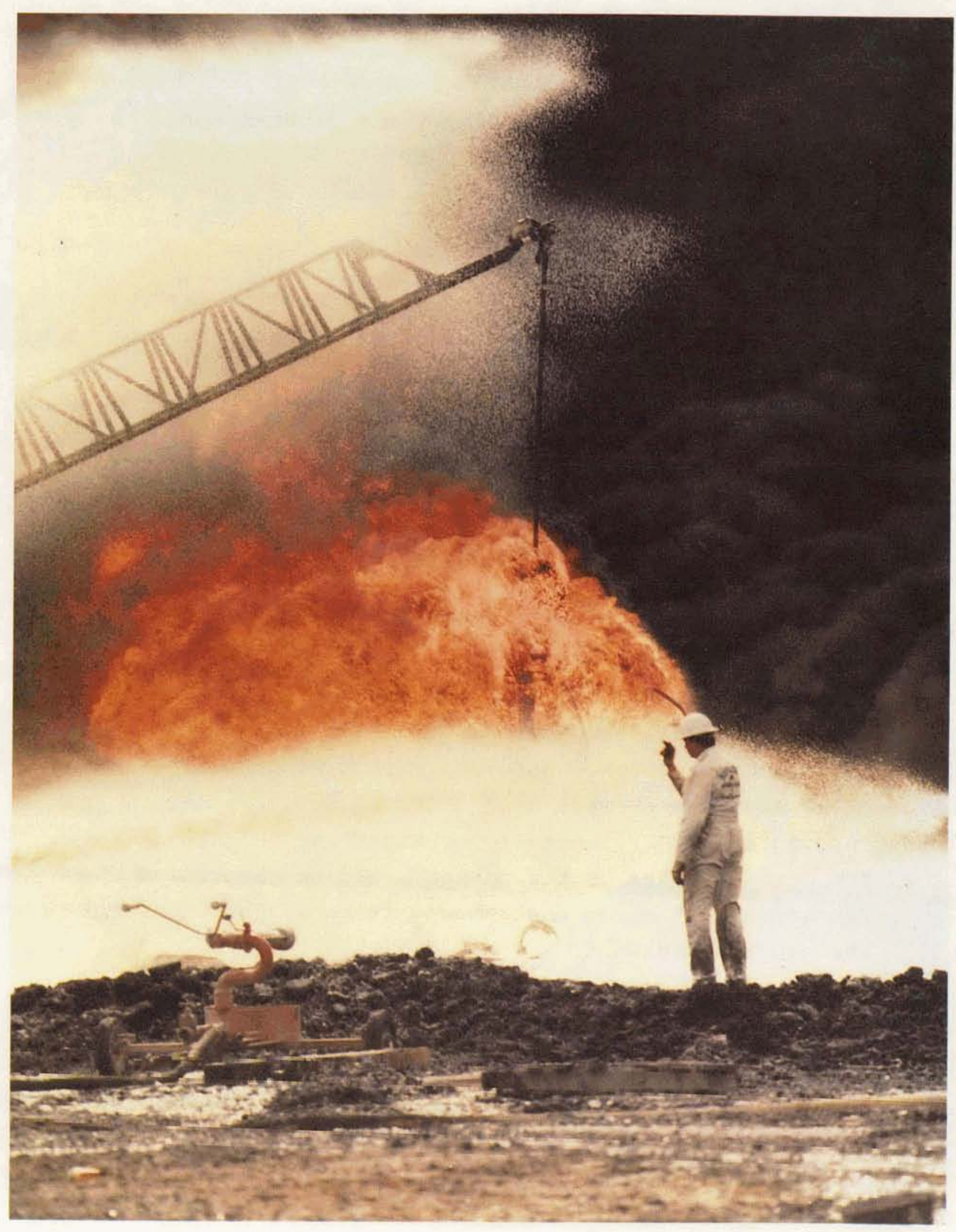

FIGURE 22. WELL CONTROL - PHASE I - STINGER. 


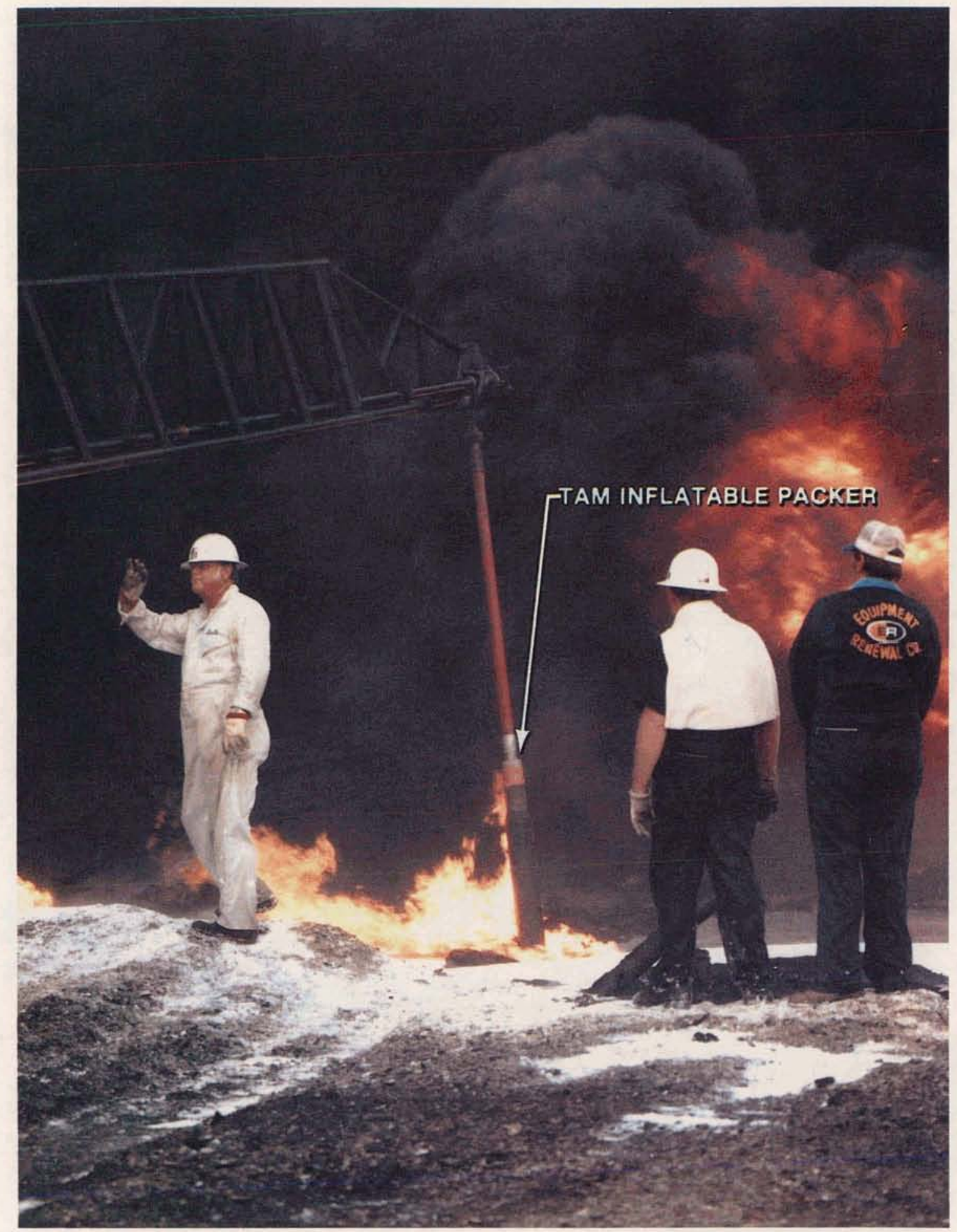

FIGURE 23. WELL CONTROL - PHASE II - PACKER. 


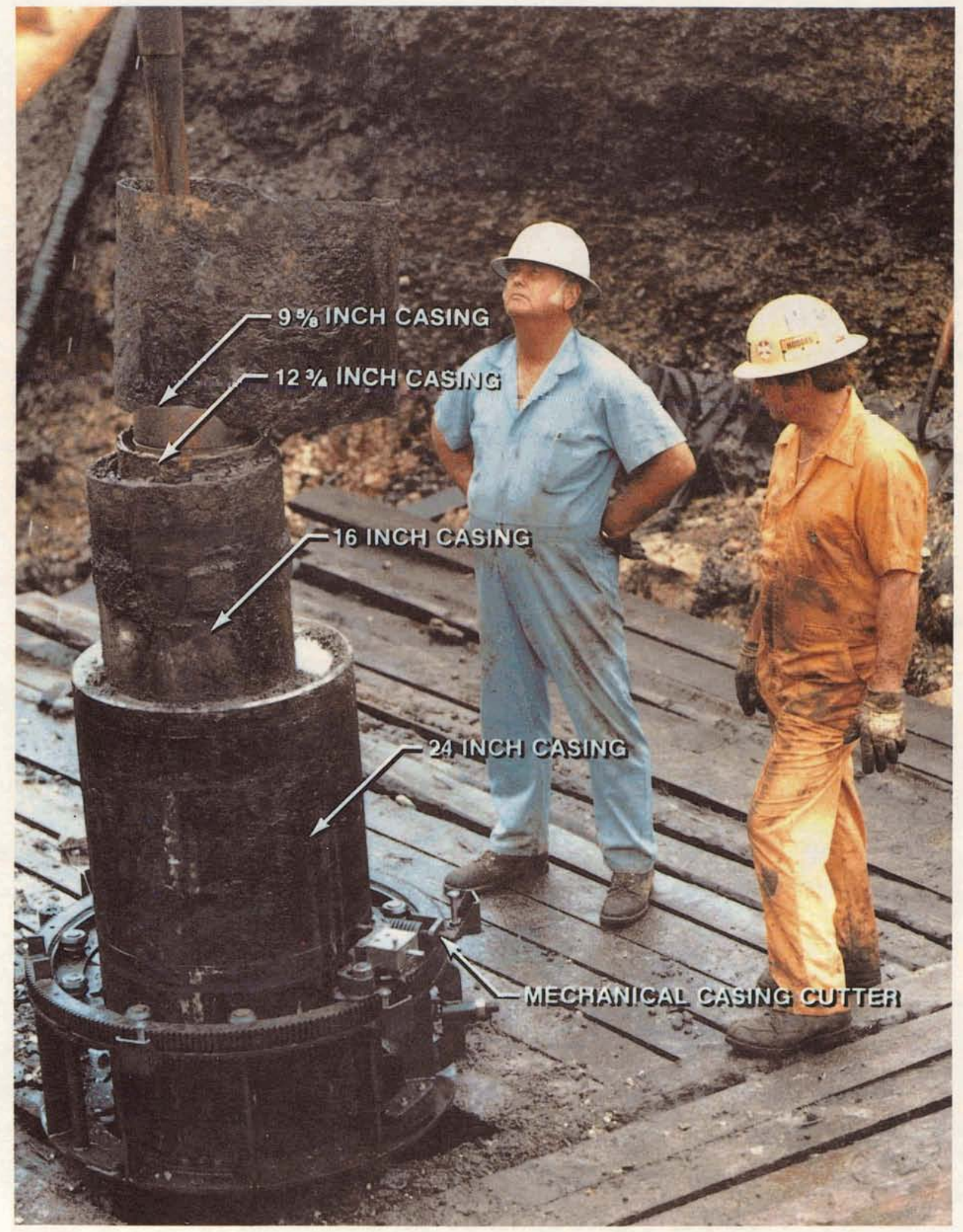

FIGURE 24A. WELL CONTROL - PHASE III - FINAL CAPPING. 


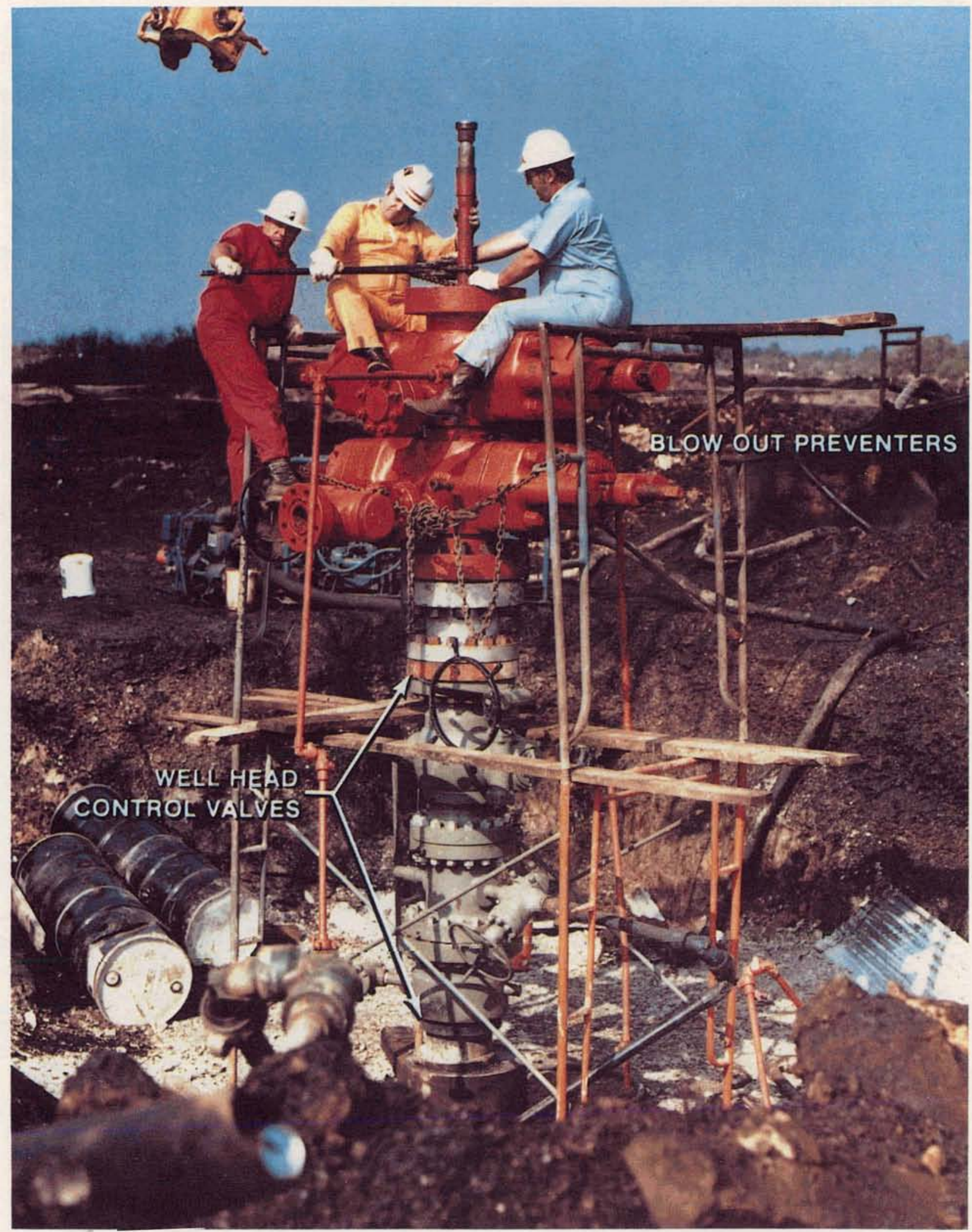

FIGURE 24B. WELL CONTROL - PHASE III - FINAL CAPPING. 


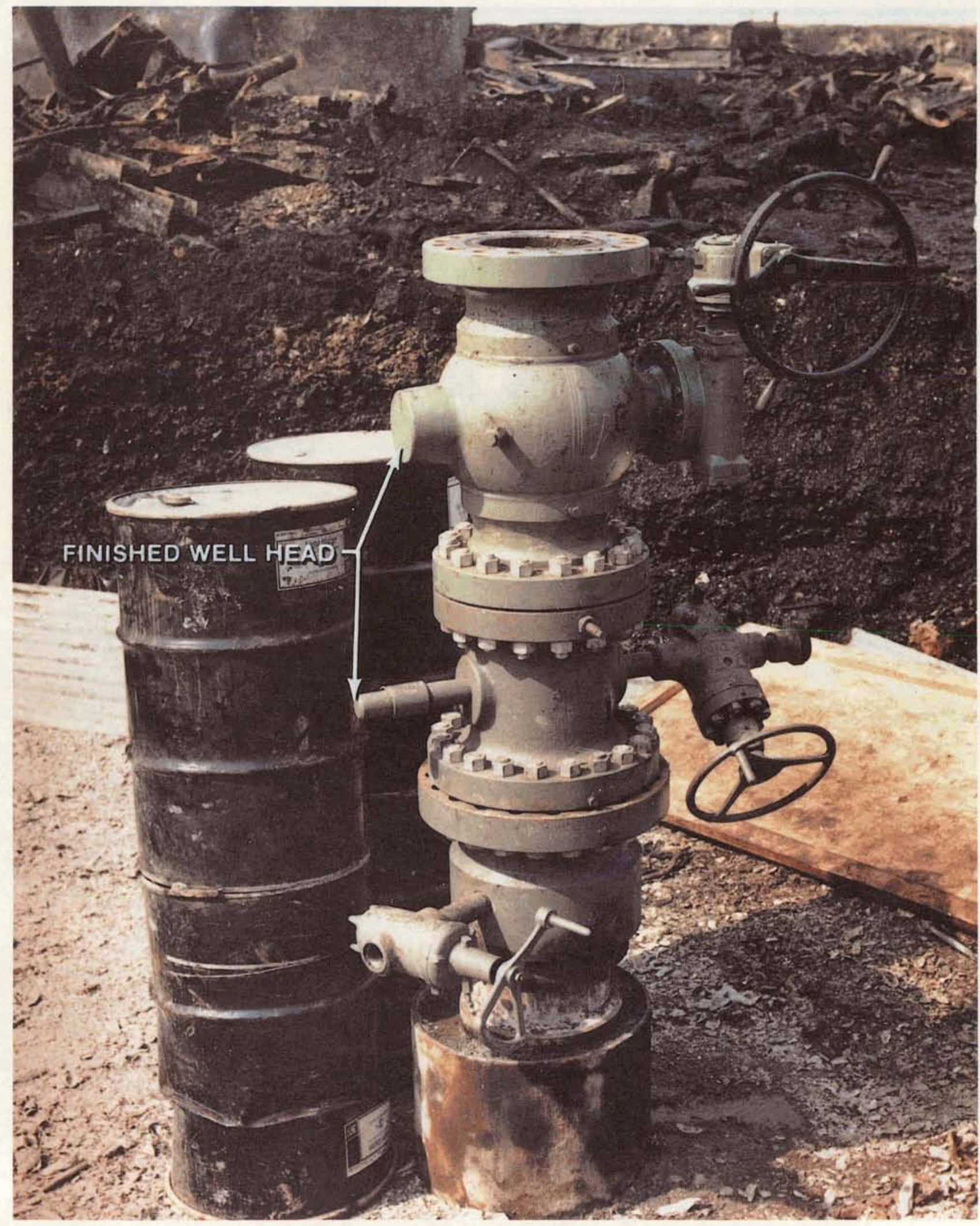

FIGURE 24C. WELL CONTROL - PHASE III - FINAL CAPING. 


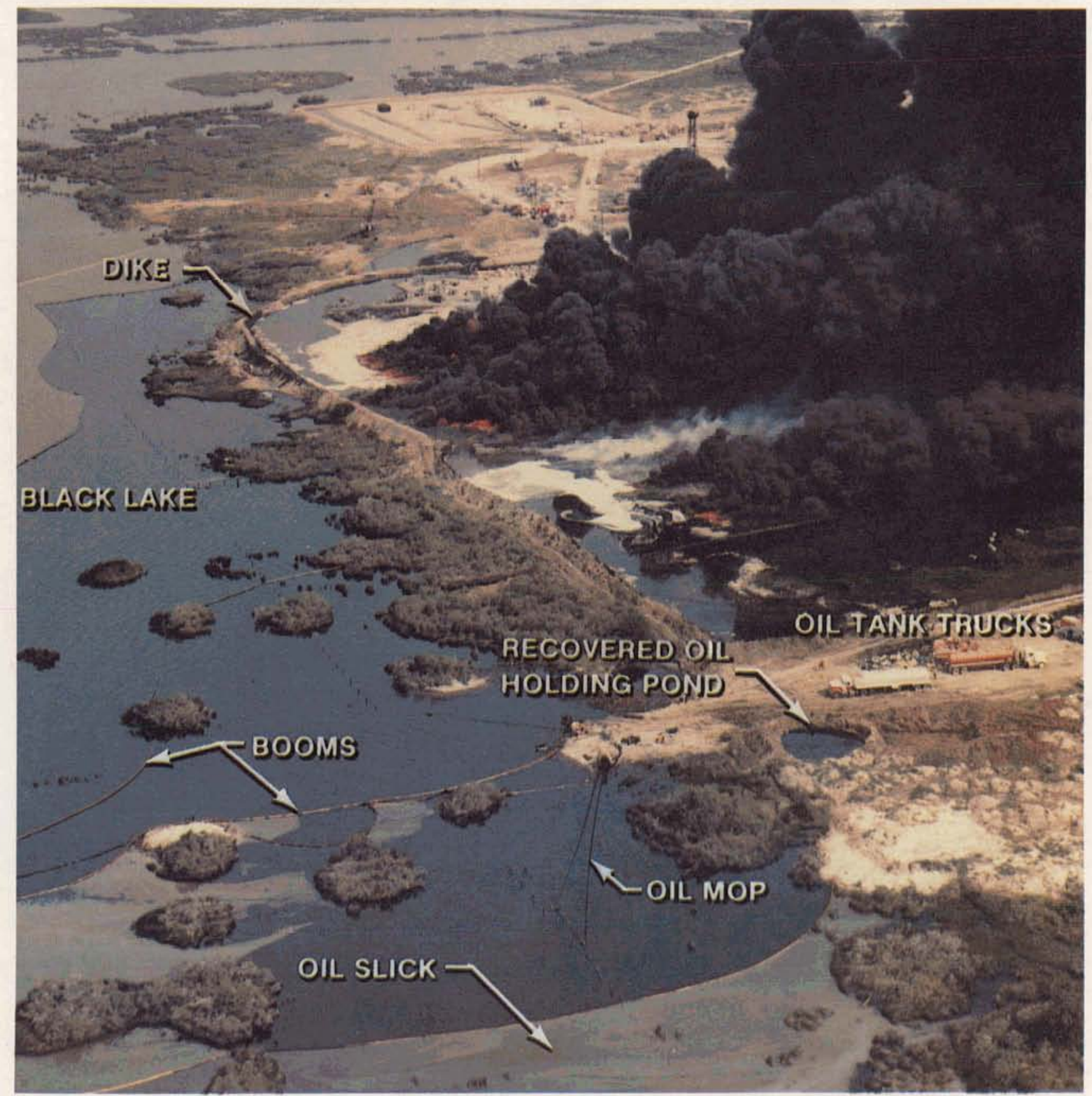

FIGURE 25. DIKE SYSTEM. 
booms were obtained from and installed with the assistance of local cleanup contractors. Figure 25 also shows some of the oil tank trucks which were used to remove the oil collected from the site.

Figure 26a shows the details of boom emplacement which initially was complicated by the lack of radio communications; Figure $26 \mathrm{~b}$ is an aerial view of the site showing the oil containment system, the remaining oil slick, and the dike; Figure 26c shows the site toward the end of the oil cleanup. In testimony by the U.S. Coast Guard, they stated that this was a classic in oil containment from a major spill.

The recovery of oil contained within the booms was through the use of oil skimmers and mops; the recovered oil was placed in temporary holding ponds and trenches for subsequent pickup by oil tank trucks and offsite disposition. One of the skimmers (Figure 27a) was in the vicinity prior to the accident for a demonstration and was put into service soon after the spill; other skimmers and oil mops (Figure 27b) were brought in by contractors. Progress on oil cleanup is shown in Figure $27 \mathrm{c}$.

\section{Security}

Efforts were made to secure the main gate immediately after the fire; however, testimony indicated that for some time after the accident there were major traffic tieups on the road within the site. In order to control the number of people on the site, the decision was made to deny admission to additional volunteer firemen who had been instructed to wait in a church parking lot in case they were needed.

There were several unhappy incidents with members of the media who had gained access to the site, apparently through the gate. In one case a newspaper reporter, and in another a network cameraman were forced off the site with the expected hostile reactions. In the first instance, a SPRO employee's rash statements to the reporter were printed in the local newspaper. 


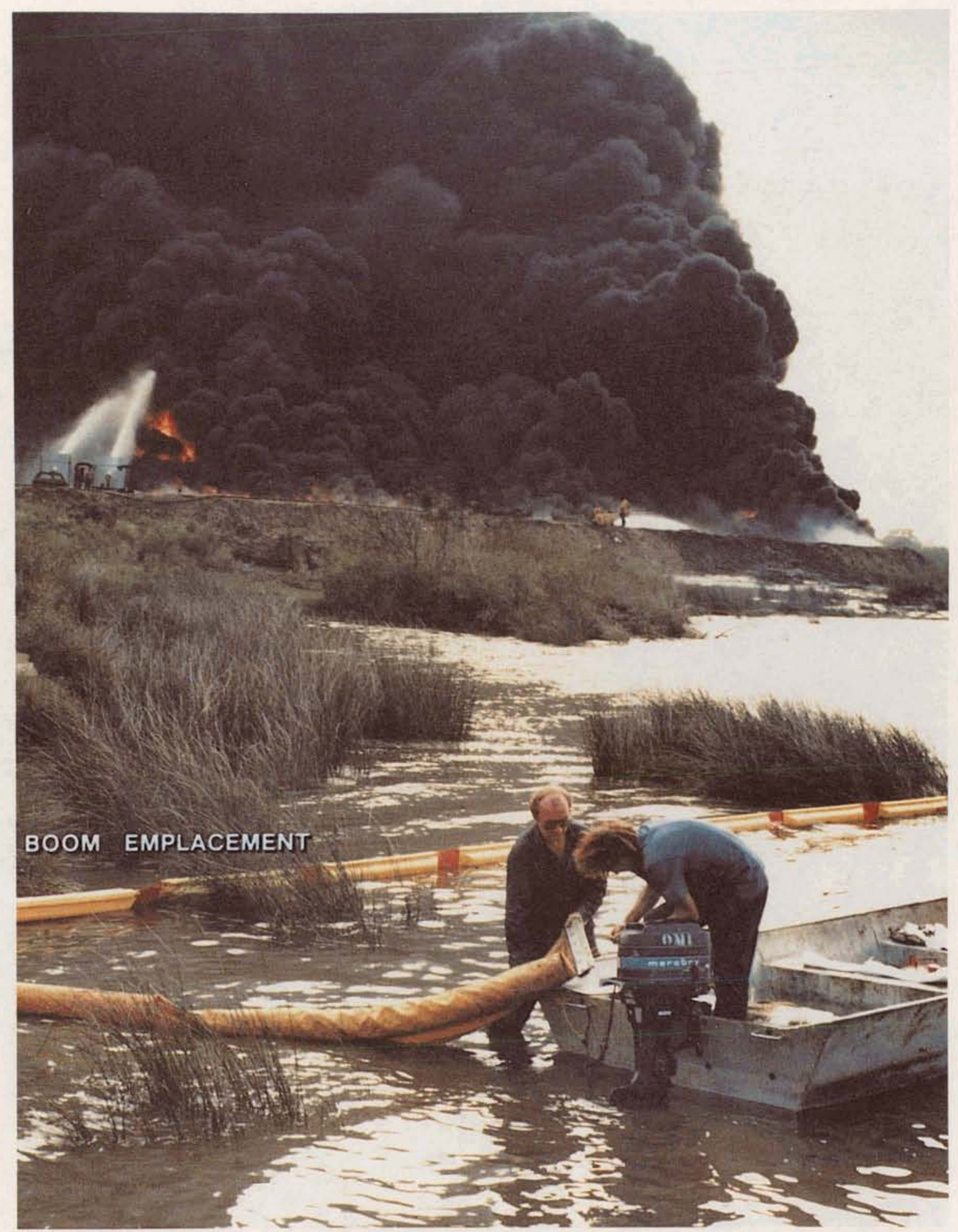

FIGURE 26A. OIL CONTAINMENT. 


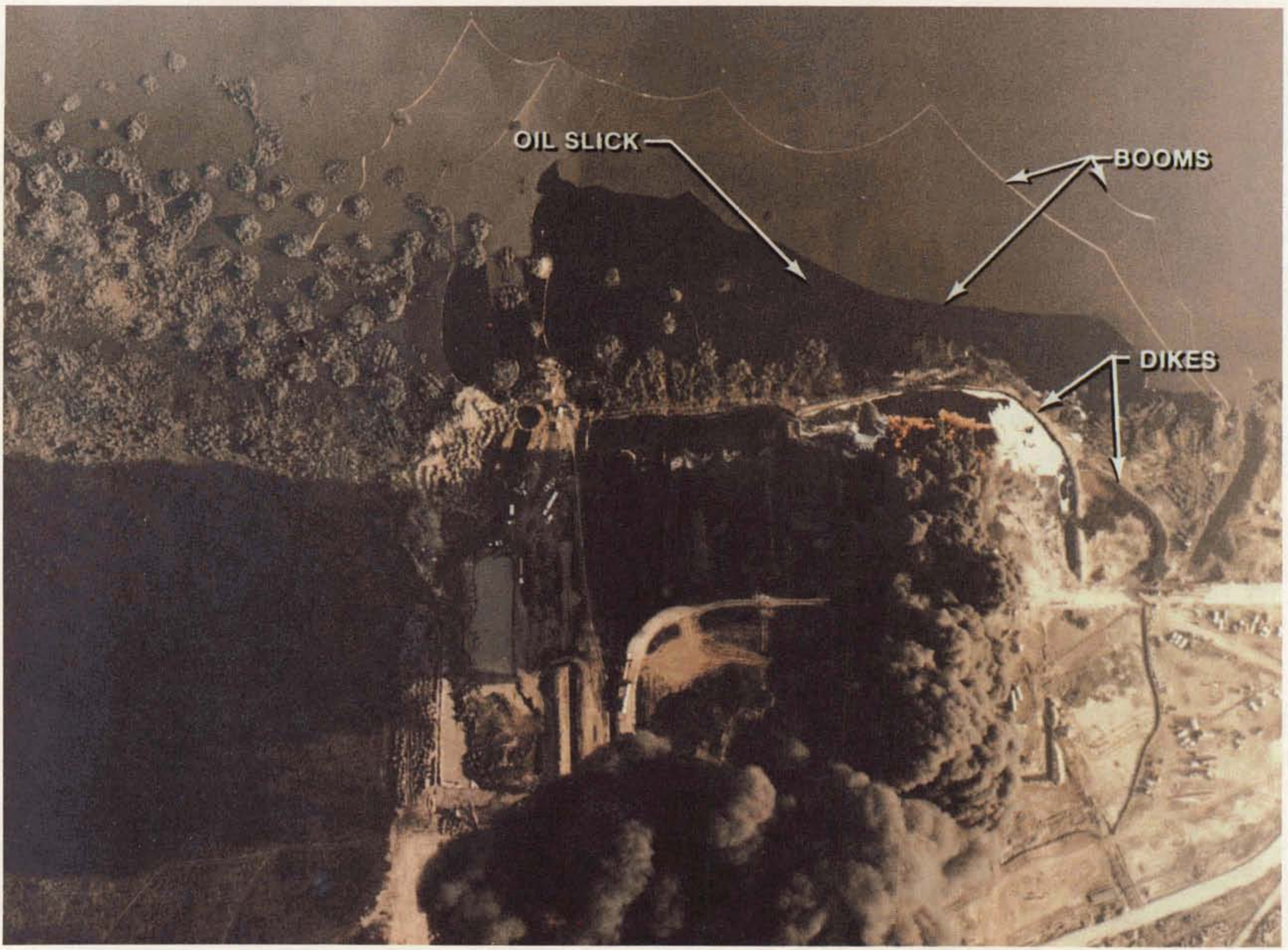

FIGURE 26B. OIL CONTAINMENT. 


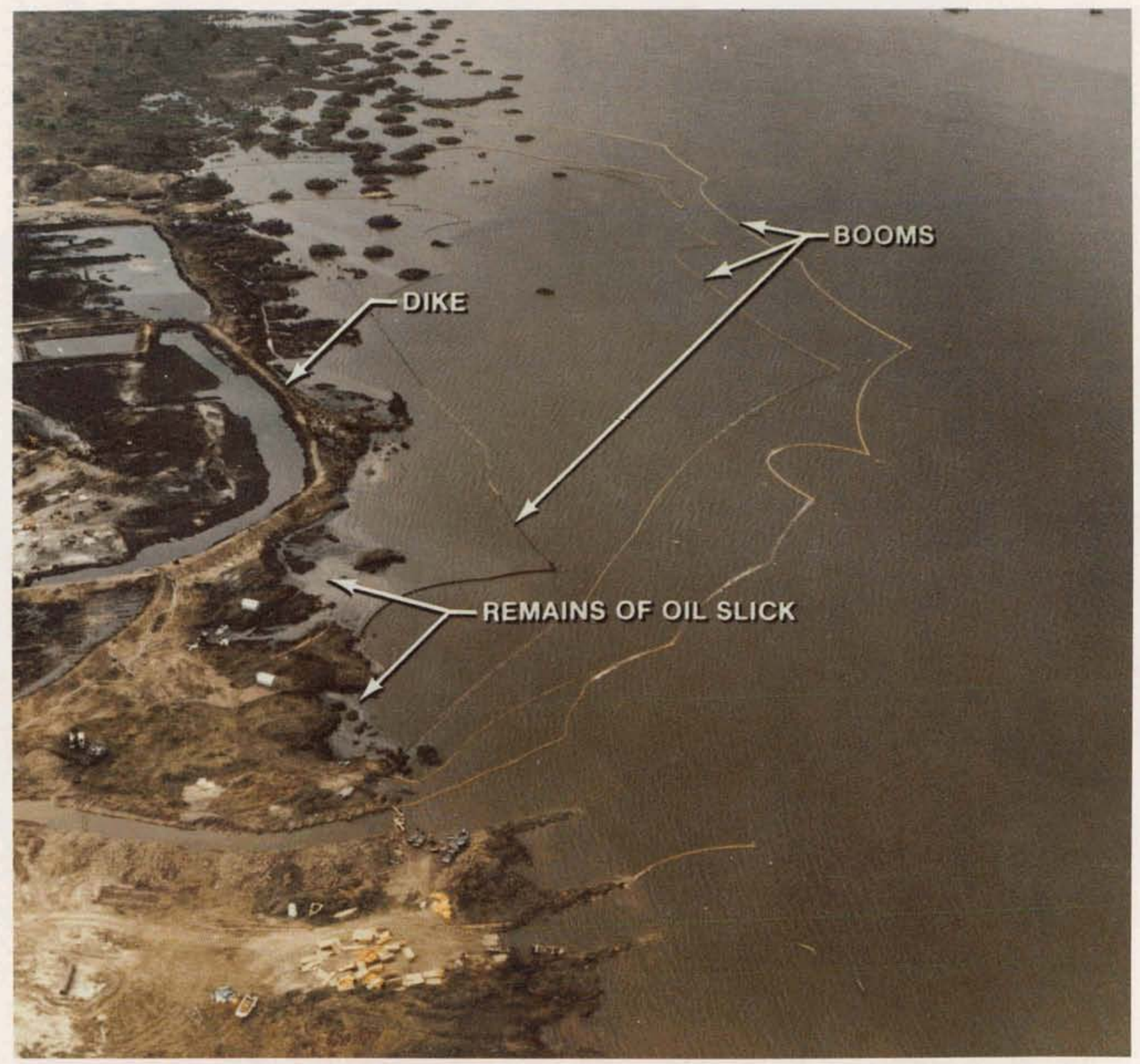

FIGURE 26C. OIL CONTAINMENT. 


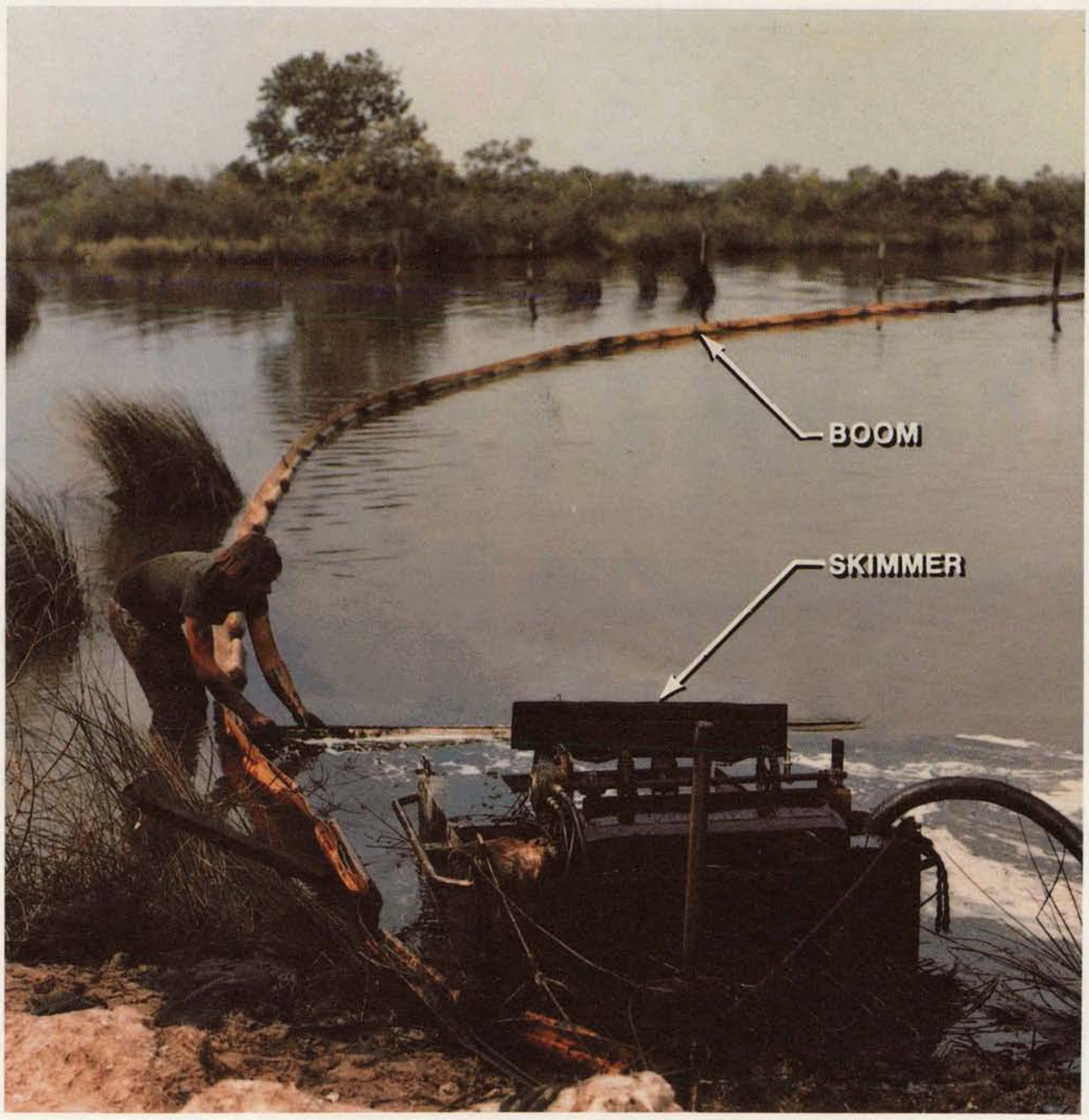

FIGURE 27A. OIL CLEANUP. 


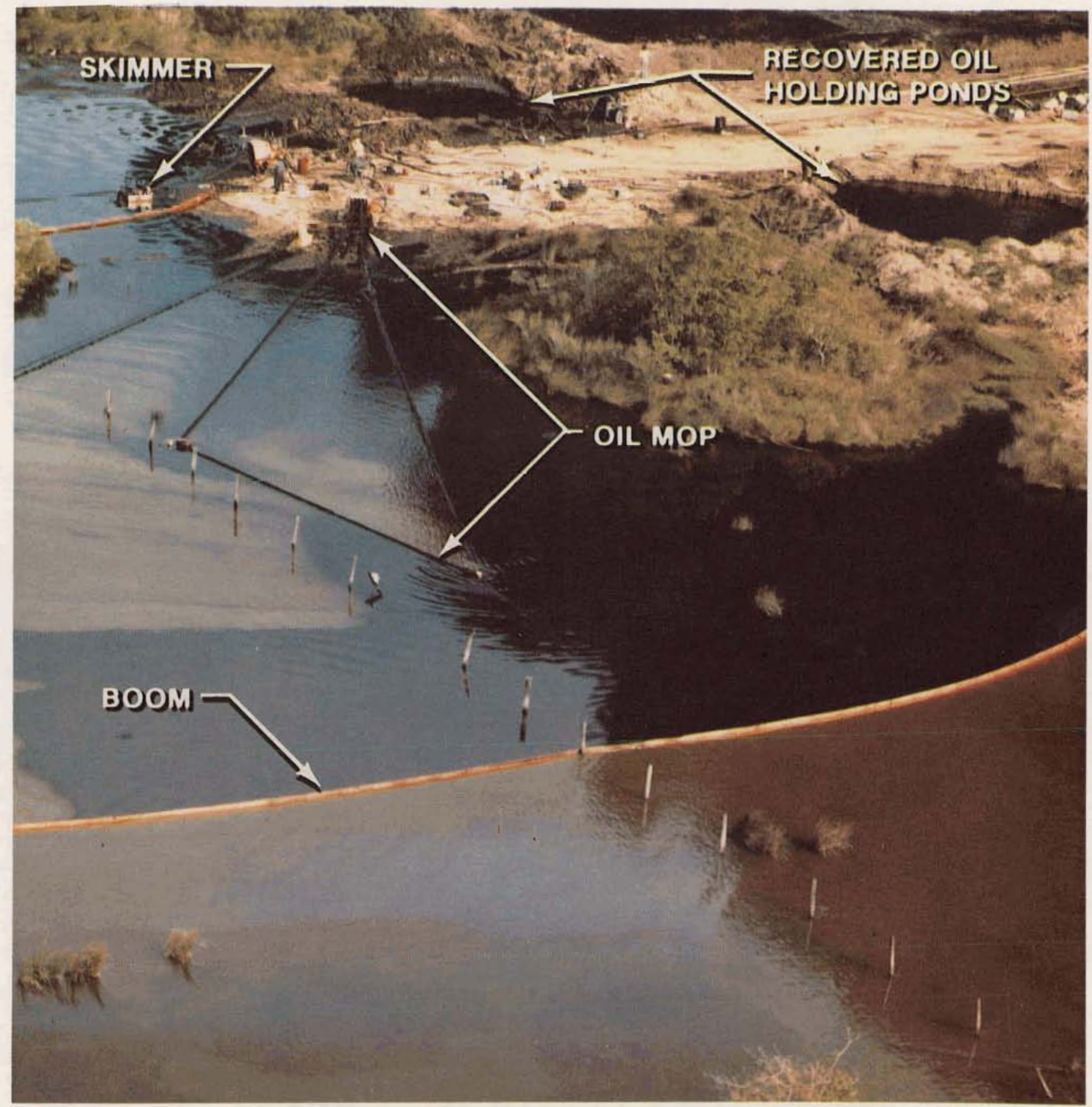

FIGURE 27B. OIL CLEANUP. 

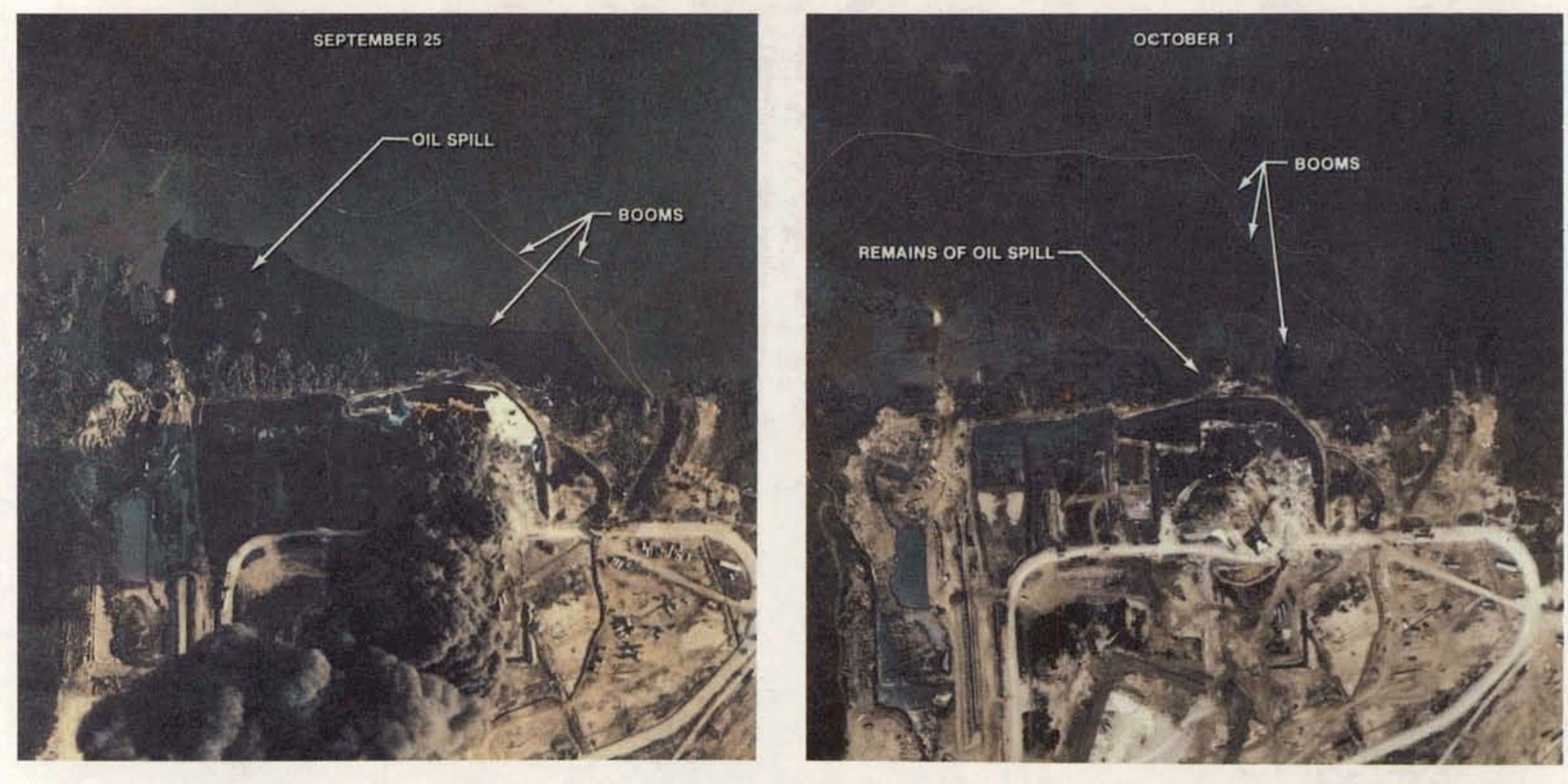

Figure 27C. OIL Cleanup. 


\section{Site Control}

Upon being notified of the problem at West Hackberry, senior SPRO personnel flew by helicopter to the site from New Orleans and the SPRO project manager assumed control of the site at about 7:00 p.m., on september 21. Testimony revealed that the rationale for this was that contracting authority in excess of the financial limit that site personnel have was necessary to implement the firefighting and oil cleanup operations; hence, the individual with the contracting authority had to be on the scene and in command.

\section{G. RELATED OBSERVATIONS}

During its review, the Committee has noted several items which bear upon the accident but are not directly related to specific accident events. These items are presented in this section of the report.

\section{Management Philosophy}

Attention of management at all levels has been focused on operations (getting oil in the ground). It has been recognized that working with very large quantities of crude oil is a dangerous activity. However, no specific design, construction, or operational requirements have been provided to address this generally stated understanding. No risk analyses and subsequent plans of action have been taken in order to reduce the inherent danger, outside of relying on "standard oil field practices."

\section{Facilities}

The metallurgical analysis conducted by Oak Ridge National Laboratory personnel (Appendix VII) of the well head from Well 6 provided several items of concern. The well head appears to have several field-fabricated (or jury-rigged) features, including the use of field-fabricated spacers and field welding on the well casings. Several weldings showed a significant lack of penetration 
and weld porosity -- both characteristics of inadequate welding procedures and the failure of the construction quality assurance program to detect and correct such occurrences. The subsequent filling of Cavern 6 , when it was known that only a rubber patch with a clamp was preventing well 6 from leaking, is also an indication of management overemphasis on operations and the inadequate field execution of needed system safety and quality assurance responsibilities. It was also noted by the Committee that at least one other well head on Cavern 11 had a 150-pound flange connected to the well head. A pressure in excess of 600 psi was observed on the well head. The Committee also noted that Cavern 6 had been operated above its operational pressure limit as set by the cavern certification. Such field practices clearly indicate a need for SPRO to assess its emphasis on "Oil in the ground" relative to the need to assure safe facilities through the implementation of proper construction and operational requirements. The committee is concerned as to whether what was found on the Well 6 well head is representative of other well heads which may have been field fabricated.

A second facility feature that the Committee was concerned about, but did not evaluate as a part of this specific accident, was the system safety features, risk analyses, and subsequent emergency contingency planning which have supported the design, construction, and future operation of the 11-inch and 42-inch pipelines, On the surface, these appeared to be problem areas similar to the well 6 problems.

While the Committee did not investigate SPRO sites other than West Hackberry, testimony indicated that they were in a similar state of minimum emergency preparedness to respond to a major oil spill and/or fire. 
H. PUBLIC ANNOUNCEMENTS

The Department of Energy issued four press releases in the days following the accident at Well 6 of the West Hackberry facility. Copies of these press releases are included as Appendix IX and are listed as follows:

1. Press release issued by Gene Campbell of DOE-SPRO, New Orleans. This describes the accident, the extinguishing of the fire, and the subsequent oil spill cleanup operations; undated and untitled.

2. "DOE Statement on West Hackberry Fire," DOE, Washington, D.C., September 22, 1978.

3. "DOE Appoints Board to Investigate Strategic Petroleum Reserve Fire," DOE, Washington, D.C., September 25, 1978.

4. "DOE Establishes Claims Office at Site of strategic Petroleum Reserve Fire in Louisiana," DOE, Washington, D.C., October 3, 1978. 
IV. ACCIDENT ANALYSIS

\section{A. TECHNICAL ANALYSIS}

Cavern 6 contained approximately 7 MMB of oil at a 650 psig pressure measured at the well head. The well-killing operations, the setting of the packer, and the pulling of the 5-1/2-inch casing by the Pelican crew on Rig 11, under the supervision of Louis Records \& Associates, Inc., was within the normal industry practices inherent to south Louisiana. But since the well blew out, it is evident that overall procedures were not adequate.

The blowout could have been avoided by: (1) bleeding the cavern pressure to zero; or (2) using a blowout preventer stack containing shear rams.

The blowout could probably have been avoided by: (1) setting a second plug in the tubing or casing -- the second plug could have been another packer or could have been cement; (2) the use of a full opening safety valve with handles or wheels for handing and stabbing to facilitate: the stabbing of the valve; (3) the use of a double safety valve so as to keep the valve on the top of the tubing most of the time; (4) bleeding the cavern pressure below the pressure exerted by a column of salt water in the annulus, or approximately $410 \mathrm{psi}$; (5) the utilization of 16-pound mud inside the 5-1/2-inch casing whenever it was determined that 16-pound mud outside the casing in the annulus was needed to kill the well.

From the testimony and the fact that the packer was blown out of the tubing and was later recovered after the fire, there is little doubt that the packer failed to hold against the upward pressure from the bottom of the casing. The mud pumped into the 5-1/2-inch casing above the packer should have been heavy enough to dominate 
the cavern pressure without the need for the packer.

The mud put inside the 5-1/2-inch casing should have been at least as heavy as the mud that was used in the annulus to kill the oil side of the well. The annulus or oil side of the well (between the 9-5/8-inch and the 5-1/2-inch casings) was open and there is no indication that pressure developed in the annulus.

The only plausible explanation is that the heavy mud in the annulus created a differential pressure when balanced against the lighter mud in the 5-1/2-inch casing, and that caused the packer to slip. The upward slipping of the packer would account for the mud flowing back up to the surface. It is hypothesized that the packer was moved up by the pressure below it, and the mud was driven out of the 5-1/2-inch casing; when the packer would momentarily bind in the 5-1/2-inch casing the mud flow from the casing would temporarily recede or stop. The TAM packer is shown in Figure 7.

The TAM inflatable packer is held in the hole by the frictional force of the packer rubber set against the wall of the casing or the wall of the hold. The TAM International advertising material (Appendix XI) indicates that the 4-1/4-inch packer used would withstand pressures of $5,000 \mathrm{psi}$. It appears that the packer did not burst or deflate since it was blown out of the hole and the witnesses agree that the oil came out of the casing immediately behind the packer.

It is unlikely that the packer deflated, since the packer to deflate must be rotated one quarter turn to the left and then the mandrel picked up. The investigation of the burned packer element at the TAM International plant in Houston did not indicate that the packer pressure was released. The packer, as inspected in the plant, was still in the set position. 
The history of the well indicates a previous problem with the buildup of salt in the bore of the 5-1/2-inch casing. So it is assumed that the packer was, in all probability, set in an area that had salt scale on the inside of the 5-1/2-inch casing.

The first two attempts to set the packer at 3,289 feet indicate that there was a scale or a problem in the casing. Since the packer slipped the first time it was set and was recovered and pulled up the hole while inflated with an indicated 6,000 pounds of additional weight registered on the weight indicator, the packer obviously would move with that 6,000 pounds of force.

There is a further indication that the packer could have slipped downward before the mud started coming out of the hole with the 5-1/2-inch casing, because the first 100 feet of the casing was reported to have been dry with no mud in it. However, it is not unusual that in these types of operations the casing is not filled completely. So the possibility remains that the casing was not completely full. However, the fact remains that the packer did slip on the first attempt to set it and was pulled up the hole (with 6,000 pounds of force) to be reset. Once the packer started slipping up the casing there was no mechanism to stop the movement.

The use of a proper stabbing valve or the use of safety valves while pulling the pipe could have probably prevented the blowout. On low-pressure workovers the use of safety valves when pulling tubing or casing is not a standard industry procedure and is done normally only at the request of the operator. The stabbing valve or safety valve on the floor is standard industry procedure, but quite often it is of a minimum design such as the one made up for the Pelican Rig and depicted in Figure 8. 


\section{Probable Well Bore Conditions}

An assessment was made of the pressures existing in the well bore that would lead to packer movement (Appendix VIII); this assessment was based on the following conversion factors and data taken from Halliburton Cementing Tables, a standard handbook in oil and gas drilling and workover operations:

$$
\begin{aligned}
& \text { 5-1/2-in., 15,5-1b/ft K55 tubing } \\
& \text { Inside Diameter }=4.950 \mathrm{in} \text {. } \\
& \text { Capacity }=0.0238 \mathrm{bbls} / \mathrm{lin} \text {. ft } \\
& =42.01 \mathrm{ft} / \mathrm{bbl} \text {. } \\
& \text { Volume between 5-1/2-in. casing and 9-5/8-in. K55, 36-lb/ft } \\
& \text { casing } \\
& \text { Annular Volume }=0.0479 \mathrm{bbls} / 1 \mathrm{in} \text {. ft } \\
& =20.87 \mathrm{ft} / \mathrm{bbl}
\end{aligned}
$$

\begin{tabular}{|c|c|c|c|c|}
\hline Mud Wt & Pressure/ft & & Mud Wt & Pressure/ft \\
\hline $\begin{array}{r}7.0 \\
10.0\end{array}$ & $\begin{array}{l}0.3633 \\
0.5190\end{array}$ & $\begin{array}{l}\text { (oil) } \\
\text { (salt } \\
\text { water) }\end{array}$ & $\begin{array}{l}11.3 \\
11.6\end{array}$ & $\begin{array}{l}0.5865 \\
0.6020\end{array}$ \\
\hline 11.0 & 0.5709 & & 16.0 & 0.8304 \\
\hline
\end{tabular}

Pressure exerted by a mud column

The highly viscous mud that became a semisolid plug when mixed with salt water and oil was used to form a plug at the end of the annulus and casing to prevent the mud column from falling out into the cavern. This seems to be a reasonable approach and has been proven effective on other wells drilled into the caverns at the West Hackberry Site.

The analysis of the well bore conditions when the packer was set, before the tubing was pulled out of the hole, is shown in Figure 28. The U-tube representation of the hole shows that 
THE CONFIGURATION (F THE CASING IS SHCWN IN FIGURE 6. THE DRAWING WAS TAKEN FROM A SKETCH DRAWING LABELED "GULF INTERSTATE ENGINEERING COMPANY" AND DATED 2/9/78. THE CASING WEIGHT AND GRADES WERE TAKEN FRCA. CTHER GULF INTERSTATE ENGINEERING COMPANY RECORDS. THE DETHSS AND SIZES FRCN FIGURE 6 WILL BE USED IN THIS DRAWING.

\section{U TUBE ANALYSIS}

THE CONDITIONS IN WELL 6 CAN BE REPRESENTED AS A NUN TUBE FOR THE PURPOSE CF TLLUSTRATING THE HYDRAULIC PRESSURES ON THE' TAM PACKER.

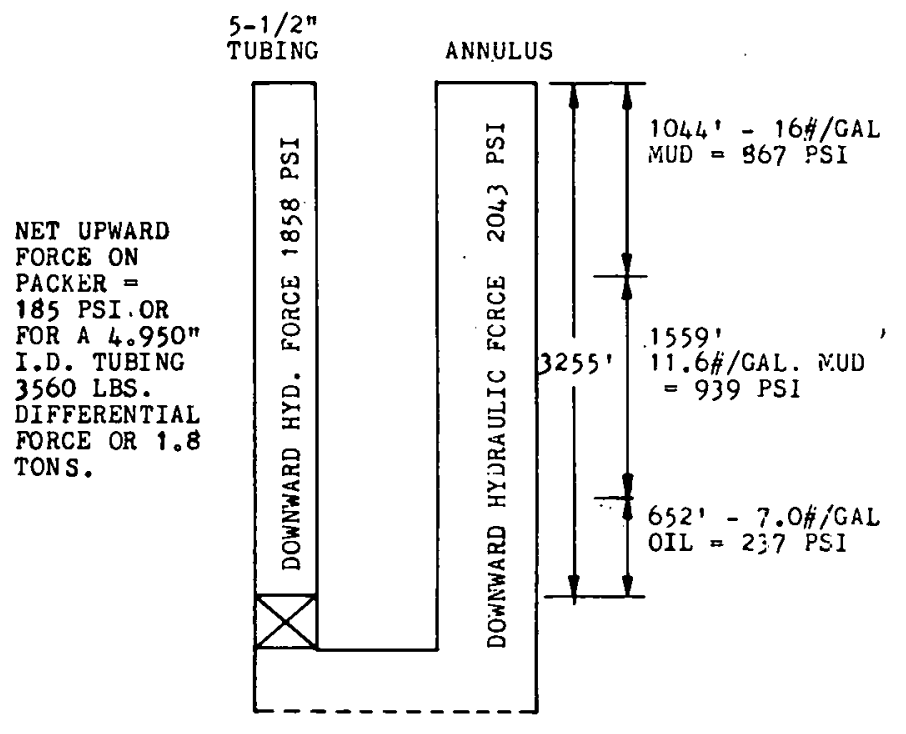

WELL 6 AS A "U" TUBE
CASING CONFIGURATION ON. WELI 6

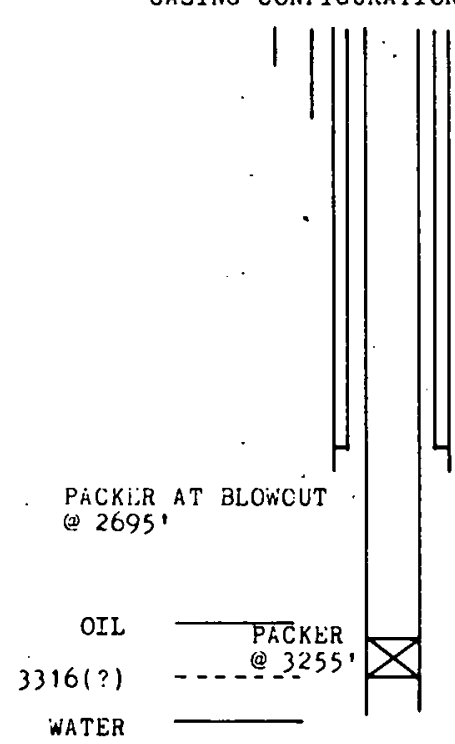

24n@87'

16"@16.41'

9-5/8" K55, 36\#/ft.@2603

CEMENTEU TO SURFACE

$12-3 / 4^{\prime \prime} @ 2532$

TOP OF CAVERN @ 3237.

$5-1 / 2 ", K 55,15.5 \# / F T @ 3379.54$

CAVERN FLCGR 3395

Figure 28. Initial Hydraulic Forces on the Packer 
there was a 185-psi differential across the packer or a total differential force of 3,560 pounds. When 14 joints of tubing had been pulled out of the hole and the packer had been moved up the hole with the bottom of the pipe to 2,820 feet, the hydraulic forces were as shown in Figure 29. The U-tube representation of the forces within the hold at that point indicate that there was a 367-psi differential or a 7,063-pound total differential force being exerted upward on the packer.

In tests conducted in Houston at the TAM International plant and witnessed by Maurer Engineering personnel, an identical packer to the one used in Well 6 was tested as follows with the following results:

a. Test No. $1^{--}$The packer was set with 2,500-psi inflation pressure in dry casing. Pressure was applied from below the packer with a hydraulic pump using water.

Result: The packer held without slipping at a pressure of 3,000 psi.

b. Test No. 2 -- The packer was set with 2,500-psi inflation pressure in a casing filled with saturated salt water.

Result: The packer slipped at 800-psi pressure.

c. Test No. 3-- The oil-coated packer was set with 2,500-psi inflation pressure in an oil-coated casing.

Result: The packer slipped at 550-psi pressure.

Obviously, from the above test results, the environment that the packer is set in will largely determine the holding capability of the packer.

Since the packer had moved in well 6 with a 6,000-pound 
THE CCNFIGURATICN OF THE CASING IS SHCWN IN FIGURE 6. THE DRAWING WAS TAKEN FR $M$ A SKETCH DRAWING LABELED "GULF INTERSTATE GNADES IING CO:PANY" AND DATED 2/9/78. THE CASING WEICHT AND RECORDS. THE DEPTHS AND SIZES FRCF FIGURE 6 WILL BE USED IN THIS DR:INING.

CASING CONFIGURATION ON WELLL 6

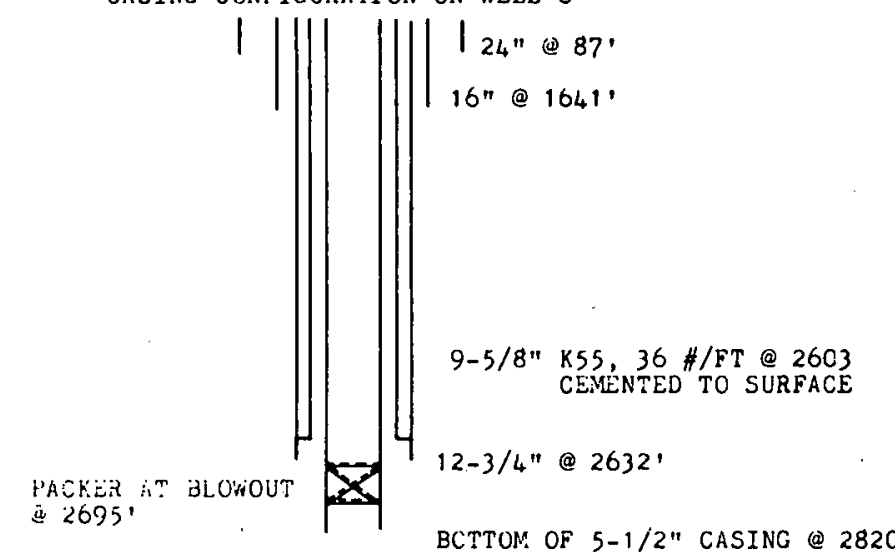

WELL 6 AS A "U" TUBE

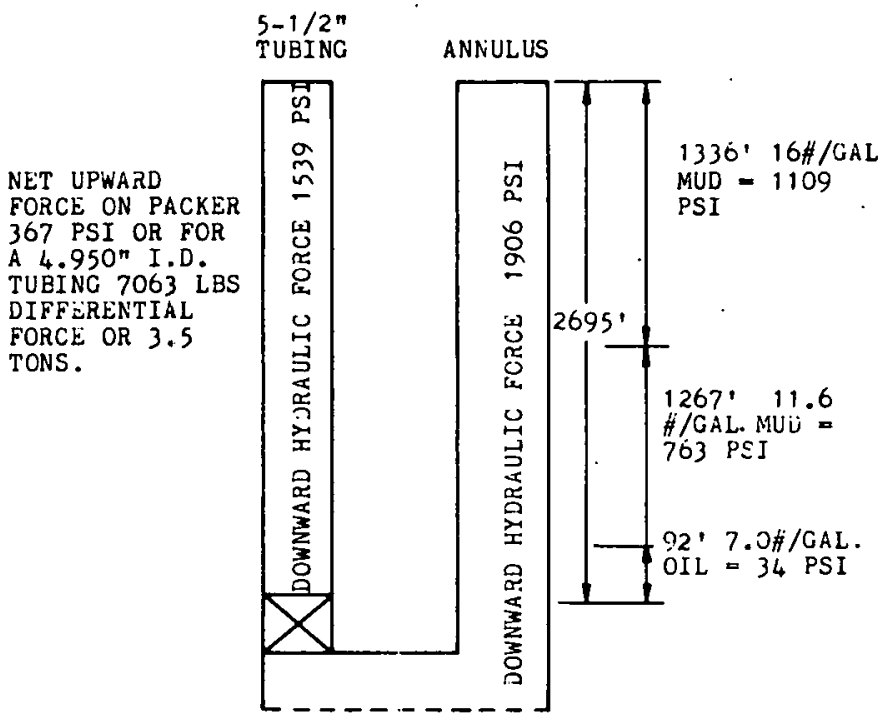

$3316(?)$

TOP OF CAVERN @ 3237'

जค'

CAVERN FLCOR $@ 3395^{\circ}$

Figure 29. Hydraulic Forces When the Packer Failed 
upward force when it had been previously set, it is assumed that the 7,063-pound total differential force exerted beneath the packer at that point in time, shown in Figure 29, caused the packer to slip up the hole and ultimately to be ejected from it.

Judging from the available data and testimony, it is evident that the packer failed because of a poor packer seat in the 5-1/2-inch casing due probably to salt or scale. It is unlikely that any design failure occurred with the TAM packer.

The method of killing the well using viscous mud appears to be a reasonable approach to prevent the mud from falling out into the cavern, and in the past has proven to be successful on other wells.

From the testimony concerning the initiation of flow from the 5-1/2-inch casing, the blowout could have been prevented either by the use of a full opening safety valve with stabbing handles or with dual safety valves being utilized, one for each joint. The blowout could have been controlled by the use of shear rams in the blowout preventer, which would have been able to shear off the pipe and close the hole. However, it would be unusual in this particular kind of work to find a set of shear rams in a blowout preventer. It is not a normal or standard workover practice in the industry. The blowout could have probably been avoided by reinforcing the packer with either a second packer or a cement plug. However, this was not readily evident at the time that the plug was set.

The concept of drilling into or. working over wells drilled into storage caverns under pressure does not appear to be unusually 
hazardous or different from other workover operations conducted daily by the oil industry as long as the work is pursued in a prudent manner. In this particular case the use of an inflatable packer in an environment and application it was not designed for, with no provision for "backup" safety equipment, allowed the failure of the packer to become a catastrophic event.

\section{Failure Modes Considered}

Testimony from several witnesses at the scene indicated that the packer did come out of the 5-1/2-inch casing. Furthermore, the packer was recovered at the location where the witnesses indicated it had landed. A number of candidate failure modes were considered by the Committee in order to fully analyze the sequence of events that led to the West Hackberry accident. The failure modes are listed as follows and discussed below:

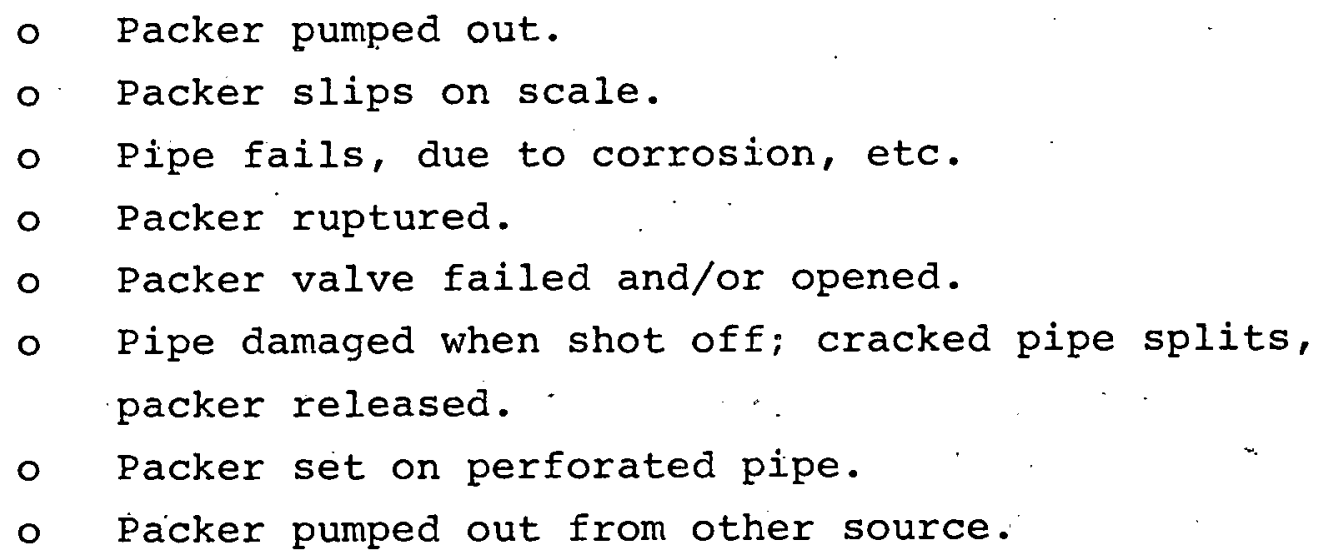

a. Packer pumped out of hole -- Differential pressure across the packer can be calculated based on the testimony given and the daily drilling progress reports supplied by Louis Records. The important point is that the differential pressure was continuously varying as the $5-1 / 2-i n c h$ casing was raised from the cavern and 16-pound mud was being added to the annulus between 
the 5-1/2-inch and 9-5/8-inch casings. A detailed analysis of the changing hydrostatic pressures was performed for the committee by Maurer Engineering and a copy of their analysis is included in Appendix VIII. TAM International provides product literature for the packer used which shows a maximum recommended differential pressure of 4,900 psi. Analysis of the physical configuration at Well 6 shows that the maximum differential pressure across the packer was $367 \mathrm{psi}$ or a total upward force of 7,063 pounds. While this pressure is less than the maximum recommended pressure, review of the testimony and Louis Records' daily drilling reports showed that the packer was moved up the hole with 6,000 pounds of force which is equivalent to a differential pressure of 312 psi. Hence, the packer placed in this particular casing could slip with a differential pressure considerably less than the recommended maximum pressure. Presumably the recommended pressures are for clean, dry pipe. Experiments conducted for the Committee at TAM International using an identical packer in the same size casing showed that it held at 3,000 psi when the pipe was dry and it moved up the hole at $550 \mathrm{psi}$ when the packer and the pipe were lubricated with crude oil.

\section{b. Packer slips on scale or scale releases -- Testimony} indicated that the accumulation of both scale and salt within the 5-1/2-inch casing had been encountered previously. Also, it had been suggested that the accumulation of salt in the lower portion of the 5-1/2-inch casing was heavier than in the top portion. The packer potentially could be released because the scale and/or salt did not adhere to the casing, and the packer could have decreased holding capacity. If the accumulation of scale were less in the higher portions of the casing, the packer would effectively be moving into a larger diameter pipe which would decrease the internal 
setting pressure of the packer. This, in turn, would decrease the holding capacity of the packer.

The casing the packer was set in dropped into the cavern and it is extremely unlikely that this casing can ever be recovered. for physical inspection. The fourteen 40-foot lengths of casing from the top of the hole that were recovered were subjected to severe fire damage so that the amount of scale and salt accumulation of scale and/or salt accumulation on the inside of this casing is difficult to determine. While the accumulation of scale and/or salt in the casing bottom is likely, it is not anticipated that there would be rapid changes in the diameter of the pipe; hence, we would not expect a rapid change in pipe diameter. If the packer did slip on the material accumulated on the interior of the casing, it would be due to other external forces such as high differential pressure across the packer or jarring of the 5-1/2-inch casing as it was being removed from the hole. It is not believed that the debris on the inside of the hole released without any external stimuli.

c. Pipe fails -- Some witnesses suggested that the packer released because the badly corroded pipe failed. Others suggested that the corrosion of the pipe was minimal. The casing recovered from the well prior to release of the packer was available for inspection. Thirteen joints of casing had been subjected to the fire and, while they appeared to be in poor condition after the fire had been extinguished, the metallurgical analysis revealed that the damage was principally due to the fire. The "fourteenth joint" was protected from the fire and was found to be in good condition. Details of this analysis are included in Appendix VII. 
While the pipe in the area where the packer was set is now at the bottom of the cavern and not available for inspection, judging from the metallurgical analysis of "joint fourteen" there is no indication that the pipe would undergo corrosion-induced failure with the pressures and forces exerted upon it:

\section{d. Packer ruptured -- The packer did hold for 4 days} from the time it was placed until it was released. While the packer was recovered, the rubber was destroyed in the fire and cannot be physically tested to ascertain if it did rupture. TAM International product literature recommends an internal working pressure of 1,800 to 2,200 psi; the Louis Records Daily Drilling Progress Report of September 17, 1978, shows the packer was set at a depth of 3,289 feet with 2,000 psi of internal pressure.' Several attempts were made to set the packer but with force being exerted on it from either a hydrostatic head or force from the 2-7/8-inch pipe attached to the packer, it would move down the hole. Finally, the packer was set at 3,255 feet and tested with 800 psi where it held satisfactorily. In the course of trying to set the packer and to ascertain that it was properly set, the inflated packer was pulled up the hole with 6,000 pounds of force over the static load of the 2-7/8-inch pipe.

Items of concern include whether the packer could be damaged by sliding it up the casing while inflated; examination of packer construction drawings and similar packers have led the committee to believe that the packer should not have been damaged by such activities. Furthermore, the fact that the packer did hold for 4 days after it was set is further indication of the unlikely possibility that the packer could have been damaged by the above activities. 


\section{e. Packer valve failed and/or opened -- The packer}

valve was actuated by rotational motion of the 2-7/8-inch tubing inserted from the top of Well 6. Three revolutions are required to close the valve and a quarter revolution is required to open it. Hence, if the valve was not properly closed or was opened by some action the packer would have deflated and then released.

If the valve failed or was opened by unknown activities, physical inspection of the packer valve would have revealed this. While the released packer was subjected to heat, the valve assembly, despite its exposure to fire, could still be examined to reveal if the valve had been functional at the time it was released. The recovered packer was inspected by sawing open the valve assembly and the evidence showed that the valve was still closed at this time. Hence, this is not a probably failure mode for the packer release.

f. Pipe damaged -- Some testimony indicated that the lower two joints of the 5-1/2-inch casing had previously been modified to permit increased flow during fill operations. There is conflicting testimony as to whether the bottom two joints were shot off with an explosive charge or whether they were perforated. The committee ascertained that the bottom 5 feet of the casing had been slotted. The packer was placed above the area that had been modified.

It is conceivable that the pipe was fractured by a perforation operation. However, one would not expect that this fracture would propagate beyond the joint between the second and third lengths of pipe. There is no physical evidence available to ascertain if this failure mode could have contributed to the accident. But it is unlikely that this could be a contributory mode unless the packer was in the same joint where the explosive was placed. Testimony indicates this was not the case. 
9. Packer set on perforated pipe -- If the pipe had been perforated as some testimony suggested and the packer had been on the perforations, the packer would be expected to leak from the time it was set. Judging from the zone of the casing which could have been perforated and the known location of the packer, this becomes an improbable scenario for the release of the packer.

h. Packer pumped out from another source -- If there were some other activities occurring in Cavern 6 which could have created an additional pressure source, they might have been a contributory cause to the release of the packer from well 6." At the time of rework on well 6 , testimony revealed that there were no other activities ongoing that connected to Cavern 6; specifically, the Cactus Rig on Well $6 a$ had not penetrated into the cavern and there were no oil introduction or withdrawal operations going on from any other well heads. Hence, there are no other contributory sources that could have affected the release of the packer.

From the evidence presented, the technical analyses that have been conducted, and examination of the above candidate failure modes, it is the opinion of the committee that the packer did not have the capability to withstand the recommended differential pressures under the conditions in which it was being used. Differ- . ential pressures in excess of 367 psi which were continually increasing as the casing was raised from the hole and 16-pound mud being added caused excessive differential pressure which probably forced the packer from the 5-1/2-inch casing. Once the packer was moved within the casing, it is likely that it would continue to move up the pipe. 


\section{B. MANAGEMENT ANALYSLLS}

Key physical events were discussed in the previous section (IV.A). This section discusses key managerial actions and decisions. In some cases a managerial decision can be traced directly to a physical event. In many instances managerial actions merely established working environments which contributed indirectly to the physical events. In the broad sense, the Committee feels that all managerial actions discussed were important consideration in the ultimate accident, but it is clearly recognized that in many cases there is not a direct cause/effect relationship.

\section{Management Analysis of the Workover Procedure}

\section{a. Management actions related to workover activity --} There are a number of key management activities and decisions that contributed to developing the events surrounding the accident. This section of the report is divided into two major subsections: (1) a description of 11 key events; and (2) the management actions relative to those events. Figure 30 shows the relationships between these events. Attachment I gives a much more detailed representation. The analysis in this section goes up to the beginning of the fire $(T=0)$. The next section of the report carries the discussion on through the emergency response period $(T=0)$.

$$
\text { b. Events -- Following are the } 11 \text { key events surrounding }
$$
the fire and oil spill at the West Hackberry Site.

(1) DOE directed the workover of Well 6 .

(2) Louis Records planned the workover procedure and sent the plans to the field for implementation. 


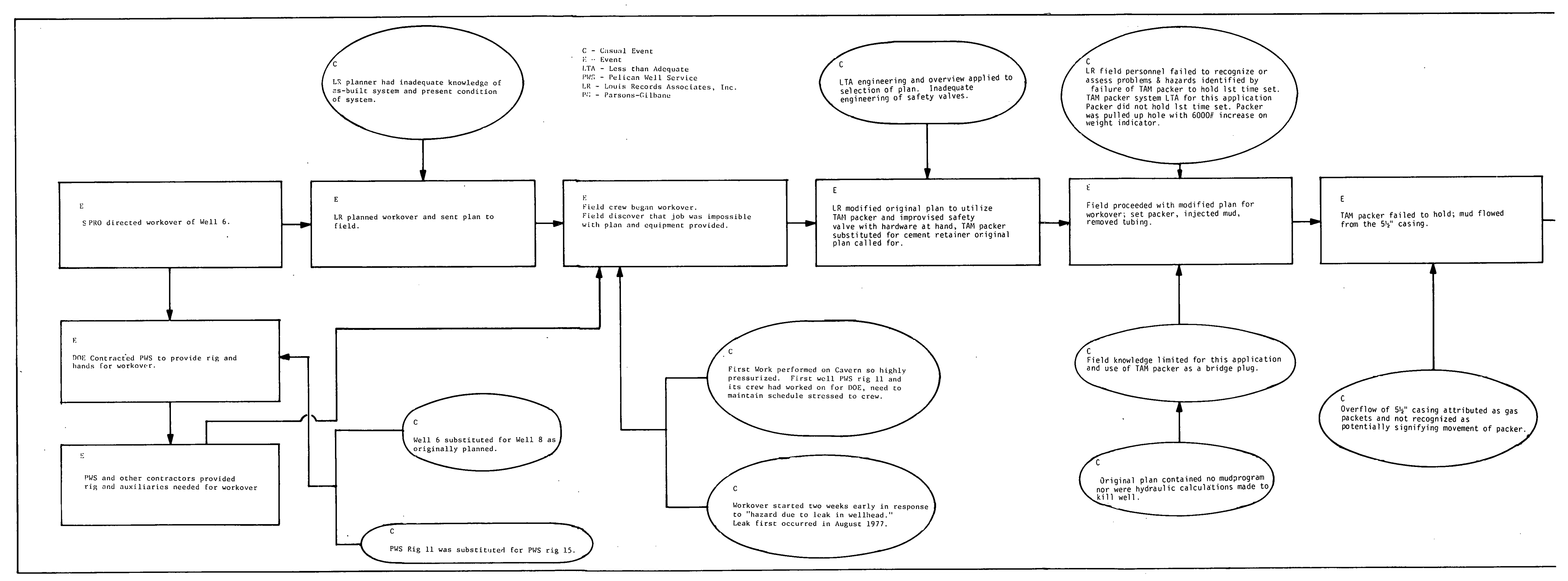

Figure 30. Analysis of Workover Operations (Events Sequence Chart) 


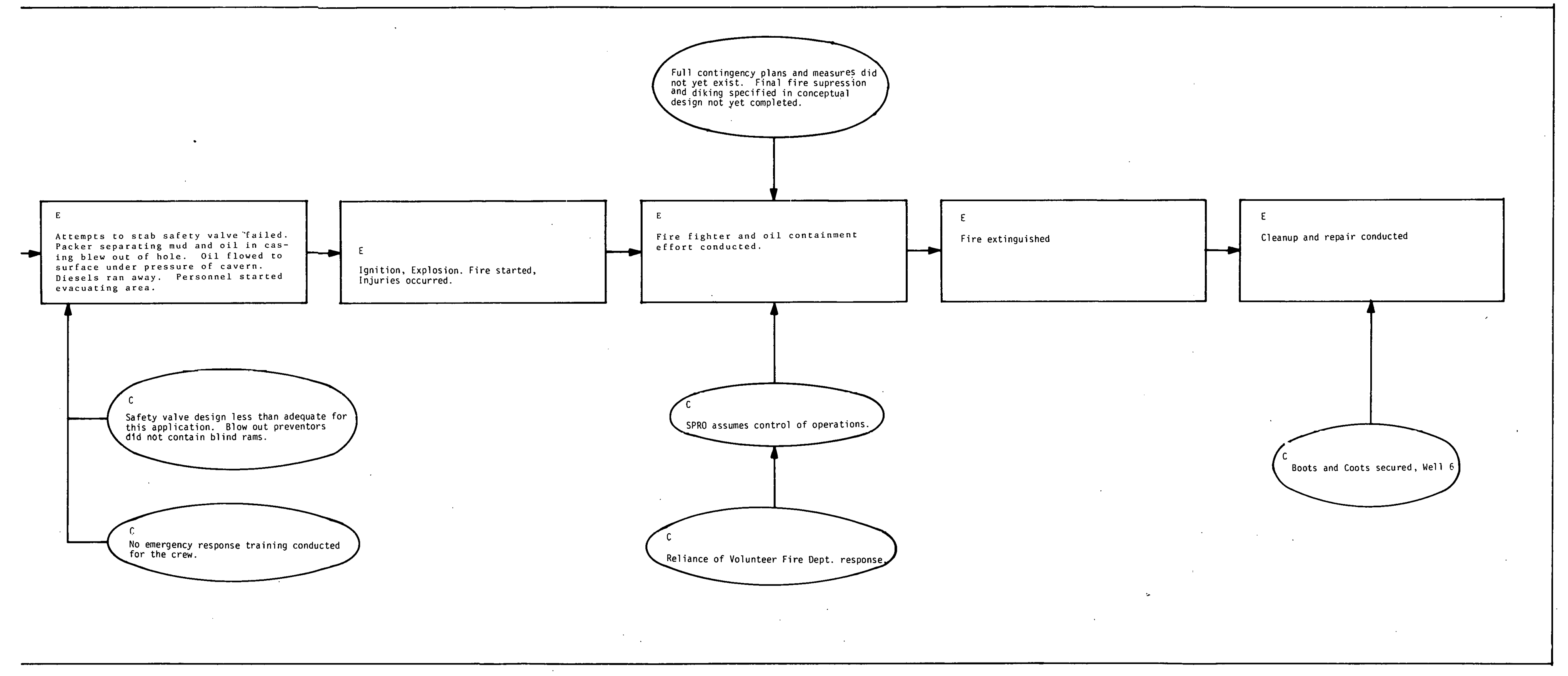

Figure 30. Continued 
(3) The Pelican Well Service field crew began to execute the workover procedures and discovered they could not perform the job according to the procedures because of the well hardware conditions encountered and the equipment available.

(4) Louis Records' main office and field management participated in developing a modified plan using a TAM packer. No other safety backup was utilized except for a manually controlled safety valve improvised at the site.

(5) The Pelican crew implemented the new plan and found it would not kill (equilibrate the pressure of) the oil side of the well. The field manager modified the mud injection program (from 11 to 16-pound mud), killed the well, and commenced to remove the 5-1/2-inch casing.

(6) The TAM packer failed to hold and mud flowed up out of the 5-1/2-inch casing.

(7) Three attempts to install the safety valve on the 5-1/2-inch casing failed. The packer was ejected from the casing, nearby diesel engines started to overspeed, attempts were made to shut off all engines, and the rig and mud pump engines were in the process of being shut down.

(8) Ignition occurred, an explosion took place, and the fire began, resulting in injuries.

(9) The emergency response commenced; firefighting and oil containment activities were initiated. 
(10) The fire was extinguished and the well was secured.

(11) Cleanup and repair continued.

c. Specific management activities related to the events network --

Event 1 -- After DOE was formed, the FEA and ERDA policies and procedures that governed oil field activities such as drilling and oil handling practices were administratively cancelled and an integrated DOE policy and procedural directive system was not developed subsequently. Shortly thereafter, SPR was transformed from a planning activity into an operational program, with SPRO being formed early in 1978. Prior individual ERDA and FEA procedures and standards were available for reference but were not mandatory. A policy decision was made, though not formalized as a written statement, to use "good oil field practices" to the maximum extent possible.

- Early on in the SPR program, management in Washington decided on a generic basis to work on caverns while they were under pressure. The Committee has seen no evidence that any technical analysis or engineering study supported this decision. It is noted that this condition, the decoupling of technical and engineering studies from the management decision process, is prevalent in the SPR activities.

tractors who applied "good oil field practices" which can be characterized as involving a complex interconnection of contractors, a lack of formalization of work control, heavy reliance on experience and on-the-spot field decisions and field changes, and 
informal management practices. However, the oil companies themselves typically provide the detailed technical and safety direction for drilling and oil handling activities. DOE/SPRO accepted these industrial practices; however, SPRO was unable to provide, in-house, the traditional oil company technical management expertise needed for guidance of such contractor activities. SPRO attempted to provide the program with this capability through contracting with various firms. Another management decision was that SPRO, not Washington, was given responsibility for administering the design, construction, fill, operation, and maintenance contracts. All this occurred under extremely heavy pressure and accelerated schedules to fill the caverns with oil.

Parsons-Gilbane and $\mathrm{PB} / \mathrm{KBB}$ were joint ventures formed specifically for the purpose of constructing the SPR. ParsonsGilbane became responsible for the initial filling operations as well as surface construction; on August 1, 1978, it was given responsibility for drilling, workover subsurface construction, and fill operations. It appears that Parsons-Gilbane was being directed in steps by SPRO to become the overall systems integration contractor for the total spectrum of SPRO activities. Unfortunately, ParsonsGilbane, being newly formed, had no innate organizational experience with respect to oil field or cavern activities. Also, many of the key staff lacked specific oil field or cavern experience. Their experience was predominantly in the area of routine surface construction.

There has been a strong and overriding emphasis from the highest level of management to get oil in the ground. SPRO did: not have a safety engineer until 9 days before the accident and SPRO delegated safety to Parsons-Gilbane. Parsons-Gilbane lacked 
safety expertise and was suffering staffing and turnover problems in their own safety staff, both in New Orleans and at West Hackberry. Similar parallel problems occurred on drilling, workover, and quality assurance functions. SPRO did not aggressively monitor Parsons-Gilbane activities to see that they were emphasizing safety. : Contingency and emergency plans and training were not emphasized. As a result, many plans were either inadequate, ignored, unapproved, or not prepared at all.

Review and approval cycles were not well specified and were not formalized. The change control Board (CCB) focused primarily on changes that require contractual cost action to effect and not upon resolving such things as field-initiated changes (unless such changes required contractual modification). The clear emphasis of the CCB was on scheduling and then cost control, and not on the control of a technical or design baseline (no baseline design exists for the West Hackberry facilities). There is a significant amount of staff overtime required and, frequently, key staff collaterally fulfill several important managerial positions. Final safety systems were not in place when the initial field operations began. There was no evidence of a study having been made to determine periods of risk and consequences, and to assure that the adequate safety response capability existed.

SPRO had Parsons-Gilbane establish a similar parallel organization. The organizations structurally followed parallel lines of authority to the field to cover the operations, drilling, and surface construction. The first organizational point that all the field activities of a specific site (e.g., west Hackberry) were drawn together was at the level of the SPRO Project Manager and the Parsons-Gilbane Construction Executive. Communications between 
New Orleans and the field sites emphasized separate lines. Field. staffs involved in construction were told they were in charge of the site, but eventually the operational personnel currently under their control would be given site responsibility. These decisions and actions weakened the site managers' sense of responsibility for controlling the entire site. In fact, no single sPRO or Parsons-. Gilbane manager in the field expressed the opinion that he was responsible for the entire site activities at West Hackberry.

With this as a background, SPRO worked with Louis Records to select drillers who were eventually placed directly under DOE contract. Safety requirements, such as safety valves required to be maintained by the rig, were notspecified in the contract or in procedural documents. Subsequently, the rig on Well 6 did not have adequate safety equipment. Since the drillers were under contract to'SPRO and not to Louis Records, the latter's staff expressed the opinion that they could not insist that drilling contractors provide specific equipment. Louis Records could shut down unsafe activities, but there was constant emphasis from the top SPRO manager on down to maintain the very tight schedules. Louis Records' contract was changed on August 1,1978 (at the Government's direction), from $\mathrm{PB}-\mathrm{KBB}$ to Parsons-Gilbane. During this transition, Parsońs-Gilbane had management problems in implementing their management overview of Louis Records and on September 1, 1978, changed the manager responsible for managing the Louis Records drilling and workover activities. At the time of the accident, Parsons-Gilbane had not implemented an effective organizational method to technically monitor the Louis Records activities.

Event 2 - Louis Records, on the basis of their reputation and acknowledged experience, had been selected to manage the drilling 
operations. The firm in the past had provided generic procedures for conducting reentry and workover activities. There was evidence of extensive technical review of these processes conducted by Louis Records' previous manager, $\mathrm{PB}-\mathrm{KBB}$. As stated above, ParsonsGilbane then assumed responsibility for drilling and negotiated a contract with Louis Records to have the latter continue to manage actual drilling operations.

Parsons-Gilbane had received technical data relative to Cavern 6. It included such things as the well certification report, the well history, and cavern pressure conditions and governed items such as drilling, fill, operations, and maintenance. ParsonsGilbane had not distributed that information to Louis Records. Thus, Louis Records suffered in that the organization had an inadequate knowledge of the as-built condition of Cavern 6 . Louis Records went ahead with the information it had and developed a workover procedure (Appendix XII) and in response to ParsonsGilbane submitted the workover procedure to them for review and approval. This procedure was much abbreviated as compared to the prior generic procedure which had been submitted to PB-KBB. The procedure contained no calculations, no mud program, and no operational safety limits. Louis Records apparently received verbal approval from Parsons-Gilbane to use the procedure. ParsonsGilbane did not request or obtain outside expert technical support to help review the procedure. The approval went directly to Louis Records, bypassing the Parsons-Gilbane and SPRO field management, which contributed to the field management's feeling that they were not responsible for this activity. In fact, ParsonsGilbane field management's principal activity relative to drilling was simply to validate billings submitted by Louis Records as being factual representations of the work done. The Parsons-Gilbane 
review process was effected by two principal factors: (1) the staff who received the procedure did not have detailed engineering knowledge of the process and did not seek engineering support elsewhere in the SPRO contractor organization; (2) the workover procedure was not perceived by the reviewing official as being anything unusual and in fact was generally considered as simply another "good oil field practices" activity that was essentially being conducted at a low pressure as compared to pressures routinely encountered in oil fields. The fact that this was the first well workover in a cavern containing oil at such a high pressure (over 600 psi on oil side) was not considered significant. Nor was the fact that in a cavern (as contrasted to the normal oil well), there is, in effect, an infinitely large "loss of circulation zone" located directly beneath the well.

Event 3 -- The field personnel involved in executing the workover were under the clear impression that there was (as was usual on other jobs) a high degree of schedule pressure to effect progress. Less attention was placed on collateral but key technical or safety activities. The field management responded with several key decisions. Operations had previously approved a procedure whereby a leak in well 6 had been patched in a manner counter to oil field practice. The patch, however, was expedient in that it was quickly achieved. It was also noted by the Committee (see Appendix VII) that the well head had been placed using very poor work practices and nonstandard equipment. This is evidence of poor quality assurance on critical components and is also interpreted as a reflection of the actual response to the schedule emphasis. When the cavern was turned over to drilling operations, there was no checkoff or control activity involved in the turnover. No time was taken to depressurize the brine side of the cavern to the usual practice of a 50-psi pressure (the brine side had about 200-psi pressure when the workover procedures were begun). A decision was also made not 
to increase the rate at which Cavern 6 could be depressurized by transferring oil (sour crude) into Cavern 7 (sweet crude). It is noted that, during the fire, oil was so transferred to Cavern 7 in order to reduce the discharge of oil from Well 6 . When they rigged up the equipment over Well 6 , the crew was not required to install a blind ram blowout preventer. It was decided to fabricate a safety valve with material on hand, and thus, they had a nonstandard manual emergency valve available for any future contingencies. Finally, the crew of Rig 11 had no prior experience on workover of caverns. Thus, the prior policy decision of relying on "good oil field practices" and experienced personnel broke down in this particular case. The final decision occurred when the crew actually encountered a stuck valve on top of the well head on Well 6 . The decision was made not to continue to try. to free the valve, but to seek a more expedient way of plugging the 5-1/2-inch casing. The requirement for an alternative plugging method came about because a partially open valve would not permit insertion of the bridge plug called for in the approved workover procedure. During this time, the Louis Records field management submitted daily field reports to the Louis Records office in Lafayette and the Parsons-Gilbane, New Orleans offices. They received no traceable feedback from Parsons-Gilbane on the problems noted in the daily drilling progress reports (Appendix XIII). Other than the interactions that the Louis Records site representative had with his site supervisor, there was no indication that the Louis Records management provided feedback in the actual site problems noted in these reports.

Event 4 -- The field management at Well.6, after some consultation with Louis Records senior management officials, decided to utilize a TAM packer because it could fit through the as-existing opening of the valve on top of the well. It was also decided not 
to obtain and install or have available backup equipment, except for a manually attached safety valve. This is an example of a field-initiated change that did not have to go through the CCB. These field-approved changes were made without a documented. engineering analysis to support the packer selection. Such actions appear typical of "standard oil field practice" in that the "company man" is in the field directing the rig crews. At Well 6, the Louis Records official was recognized as the "company man." It should be noted that both the SPRO and Parsons-Gilbane site staff were unaware of these workover progress details because they felt that they lacked the professional ability to judge the information received and, therefore, were not paying any particular attention to reviewing the daily progress reports. In effect, their decision was to rely upon the Louis Records organization to manage the work. Also contributing to this decision by DOE and ParsonsGilbane was the fractured or parallel management structure previously discussed. There was not within the sPRo or Parsons-Gilbane site management an identification with the requirement to manage or follow drilling operations. The well crew thus proceeded with the field-modified plan for workover, set the packer after considerable trouble, and injected mud into the annular space.

Event 5 -- When the crew found that the original mud procedure would not kill the pressure in the annular space (the oil side of Well 6), a new modification or field change was again made without engineering review. That modification was to change the weight of the mud and to put 16-pound mud in the annular space on top of the 11.6-pound mud that had been used previously; this killed the well. Once the well was killed, the 5-1/2-inch casing removal began. As each section of casing was removed, another barrel of 16-pound mud was added to the annular space. As the operation 
appeared to be proceeding without incident, the Louis Records onsite representative left the rig and went to conduct other business in one of the onsite trailers; the casing removal continued:

Event 6 -- It was stated that during the removal, several joints before the final failure occurred, mud bubbled up the 5-1/2-inch casing for short periods of time. This was not recognized by the drilling crew as an indication that the packer system was failing. They consequently continued to withdraw casing and after they'withdrew the 14 th joint, the mud started to flow out of the casing (in a pulsating manner) with the subsequent well failure.

Event 7 -- It should be noted that Events 5 and 6 occurred in a relatively short period of time so that there was not time available to arrive at management decisions that were thoroughly thought out. There were, however, the following critical management implications. Emergency procedures had not been discussed and rehearsed with the crew prior to initiating the workover procedure. Thus, when the actual emergency occurred the crew was not prepared to deal with it. They attempted and failed to stab the "jury-rigged" safety valve on the 5-1/2-inch casing against high mud pressures. The packer was ejected from the hole followed by oil, and the diesel engines started to overspeed. Attempts were made to shut off all rig engines and while that activity was going on, there was ignition, explosion, fire, and attendant injuries to personnel.

Events 8, 9, 10, and 11 -- These events are discussed in Section IV. C. below. 


\section{Analysis of Management Issues}

The Committee's investigation revealed a number of management issues which the committee felt may have contributed at least indirectly to the accident. The information on which this analysis was based was gleaned almost exclusively from approximately 90 interviews conducted by the committee. These issues, which apply primarily to SPRO, Parsons-Gilbane, and Louis Records, are summarized in Table 6.

DOE-SPRO -- SPRO has been organized in a way that, on the face of it, appears to be very logical. The line organizations responsible for construction are separate from the line organizations involved in the operational aspects which include filling of the storage caverns. If all physical facilities were to be completed before any operations would be expected, this organizational separation would work very well. Such has not been the case, however, and drilling wells into the existing caverns and workover of existing wells seems to have been considered more part of the operations than of construction. The problem is compounded by SPRO's request to their primary program management contractor, Parsons-Gilbane, to parallel the SPRO organization with matching positions in the Parsons-Gilbane organization.

A collateral decision with the DOE was to proceed with the Interim Fill program. Under this program, oil is being stored in caverns while reentry wells to the caverns are still being drilled and the existing wells are still being worked over. This broad policy decision may well be in the national interest, but since the Interim Fill program has preceded any systematic provisions for safety or quality assurance, it has involved a degree of risk which 
perhaps has not been fully appreciated.

There appears to be no systematic procedure for the appropriate levels in the SPRO organization to review and approve the steps taken by the contractors and subcontractors carrying on actual operations. Attention of the SPRO management, both in New Orleans and onsite, appears to have been focused more on schedule and cost control than on the actual execution of the operational plans. This is exemplified by the fact that the procedure for the workover of Well 6 was duly submitted to ParsonsGilbane and DOE, but no evidence has come to the attention of the Committee that this procedure was even informally approved, much less critically reviewed.

If there are technical engineering or safety standards to which the SPRO contractors are expected to adhere, the committee was unable to ascertain what those standards were or find any documentation to substantiate them. Even if there were standards in effect, it seems evident that the SPRO organization was not staffed in the field to monitor compliance with any such standards. There were repeated references in the interviews to the effect that the SPRO organization, and even their management contractors, were relying on "good oil field practice as normally carried out by industry." It was obvious that those individuals in the SPRO organization who had extensive oil field experience were very few and far between. The committee interviewed numerous witnesses who commented that what was really needed was "someone around here who knows something about the oil business."

The Committee noted that SPRO did not have a quality assurance organization or staff although they had a staff vacancy. 
The Committee noted that SPRO's safety engineer arrived 9 days before the fire. Thus, these vital functions did not permeate downward through SPRO and its contractors.

Parsons-Gilbane -- There were a number of ways in which Parsons-Gilbane's response to DOE directives was not fully effective. The particular instance which is critical to this investigation was the effort made by Parsons-Gilbane to develop competence in the drilling field. Parsons-Gilbane was requested by SPRO, in the late spring, to build up a competence to enable Parsons-Gilbane to take over the drilling activity. They first hired a man from one of the major oil companies. This turned out to be an unsatisfactory choice and the man was replaced by another individual on September 1 . This man, alone with a single arilling representative at the West Hackberry Site, appeared to constitute Parsons-Gilbane's effort to develop its drilling competence, at least as it existed at the time of the accident.

Parsons-Gilbane did have an organization devoted to safety, but there were significant personnel changes in the safety staff, both in New Orleans and the field. There was no full-time safety engineer at West Hackberry. This appears to be the OsHA-type personnel safety function as opposed to system safety, and it reports at a low level in the organizational structure. It was apparent, however, from numerous individuals interviewed, that there was no attempt to carry out a study of the systems safety problems of the oil storage program. In addition, Parsons-Gilbane did not have a quality control or assurance program on Cavern 6 and its attendant subsurface or surface hardware and operations.

A major role for Parsons-Gilbane was as a construction engineer for the designs prepared by either Gulf Interstate or 
PB-KBB. The division was that Title II work was done by one of these contractors and then much of the onsite Title III work was done by Parsons-Gilbane. The Committee saw little evidence that Parsons-Gilbane exercised great care in fulfilling their responsibilities for the Title III-type work under their contract. It is recognized, however, that this impression of the committee may have been aggravated, in the well drilling area, by the fact that Parsons-Gilbane had taken on this responsibility so recently.

There appeared to be severe problems of communication and coordination throughout Parsons-Gilbane. Perhaps this was due to the recent creation of the joint venture and its very rapid expansion. This appeared to be exemplified in the case of the drilling operations manager. It seems clear that most levels of upper management looked to him to make the key decisions on drilling and exercise control over Louis Records, the contractor for drilling supervision. The manager, on the other hand, made the statement that he had little or no control over Louis Records. The resident construction manager had some rather disparaging remarks to make about the former's knowledge of affairs at West Hackberry.

Parsons-Gilbane is to be commended for developing a very broad and apparently well-conceived organization in most respects. Unfortunately, however, this organization still exists largely on paper. There are many vacancies and it is clear that staffing has been a serious problem. As a result, some key supervisory individuals are stretched extremely thin, and are clearly unable to keep up with the assignments that are currently shown to be their responsibility. It is a problem to which the only short-term solution would appear to be additional contracting. 
The Committee found no evidence that Parsons-Gilbane had prepared any detailed program plan in spite of the evolving nature of their basic assignment. The Committee feels that such a plan, properly developed, would have provided a baseline for a more thorough engineering analysis of potential problems, as well as a base from which deviations in the plan could be highlighted and evaluated.

Louis Records -- Louis Records appears to be a wellestablished firm in the field of well workovers and it has a very good reputation in southern Louisiana. It is, however, a small concern which operates very informally under the day-to-day direction of its owners and senior managers. The Committee found no evidence that there are any clearly established guidelines or policies which would provide a framework in which this informal operation could take place.

A systematic safety approach by Louis Records might well have given more emphasis to the critical matter of maintaining an adequate margin of safety. with regard to the pressure at the bottom of the cavern reentry holes. In the workover of well 6 , it would appear that this pressure had exceeded the Cavern 6 certification pressure prior to the accident. It also might have focused greater attention on the importance of maintaining equalized pressure at the bottom of a casing which is being removed during workover while the casing is plugged with a single inflatable packer.

Louis Records does not have a designated safety or quality assurance organization or staff.

Contracts -- The Parsons-Gilbane-SPRO/DOE contract contains general references to health and safety, but these references are inadequate in that they do not require the contractor to comply 
TABLE 6

APPARENT RELATED MANAGEM ENT ISSUES

\section{DOE/SPRO}

A. Lack of attention and emphasis on systems and personnel safety.

B. Organizational structure that separated operations from construction and left drilling/workover responsibility ambiguous.

C. Decision to proceed with interim oil fill prior to completion of safety facilities and procedures, including repeated emphas is on maintaining fill schedule.

D. Weakness or absence of review and approval procedures.

E. Absence of standards and compliance monitoring.

F. Limited oil field experience either in New Orleans or on site.

G. Failure to develop a Project Technical Baseline and to assure that technical studies were available to support managerial decisions.

H. Failure to have quality assurance organization or staff.

I. Safety organization's scope is only OSHA-type safety; system safety is not in place.

\section{PARSONS-GILBANE}

A. Weakness in capability to manage or even monitor drilling/workover operations.

B. Lack of attention to systems safety problems.

C. Weakness in implementing Title III engineering responsibilities.

D. Weakness in management linkages and communications, both horizontally and vertically:

E. Staffing deficiencies.

F. Absence of clear-cut program plan. 1 .

G. Safety staff turnover in New Orleans and field excessive; no designated full-time site safety engineer.

H. Quality assurance staff does not cover drilling/workover operations and/ or hardware.

\section{LOUIS RECORDS}

A. Lack of clear-cut policies and guidelines.

B. Lack of identification of safety considerations. 
with any required health and safety standards. Monitoring of safety for assurance is mainly left to regulatory agencies having jurisdiction, such as U.S. Department of Labor inspectors from the Occupational Safety and Health Administration (OSHA) and the Mine Safety and Health Administration (MSHA). These agencies do not conduct regularly scheduled inspections of any locations, but rather rely on spot-type inspections for enforcement. OSHA had not visited any of the SPRO sites prior to the accident, indicating the inadequacy of depending on these inspections for assurance of safe operations. MSHA had visited at least one of the other SPRO sites and had serious difficulties with operations at that site. This topic was the subject of a General Accounting Office report to DOE (Appendix XVI).

The absence of an adequate safety and health clause in the Parsons-Gilbane contract precludes any flowdown of a similar clause from Parsons-Gilbane to Louis Records as a subcontractor to Parsons-Gilbane. 


\section{EMERGENCY PREPAREDNESS AND RESPONSE ANALYSIS}

The degree to which the West Hackberry Site was prepared for an emergency of the scale encountered is detailed in Background Section III.A.8. Similarly, the response sequence is described in section III.F. The committee reached the inescapable conclusion that there was in fact little preparation, either formal or informal, and the effective reaction to this disaster was in large part due to numerous individual efforts, which are discussed in detail below.

The emergency response organization, from the time of the accident until 2 hours later, is shown in Figure 10; there was little organization and, as stated above, implementation of neeessary actions was due to individual initiative. Several hours after the accident, when the on-scene commander arrived, the organization changed as shown in Figure 11.

The lack of preparedness was complicated by the dual functions of the West Hackberry Site, namely construction and operations (interim fill), and by the management organizations that had been created to support each of these functions. The management aspects, clear lines of authority -- or lack of them -- are discussed elsewhere in this report, but it is apparent that there was no individual at the West Hackberry Site who had total site responsibility over both construction and operations. The situation is complicated by the fact that there are parallel organizations for SPRO and Parsons-Gilbane, which will be further complicated by the recent selection of a new operations contractor.

The following inferences were drawn from testimony heard by the Committee, as they relate to various aspects of emergency preparedness and response. These amplify the facts as detailed in Section III. 


\section{No Contingency Plan}

The hurricane contingency plan was the reference most commonly cited, but it only addressed procedures for the New Orleans office. Although the New Orleans office had documentation to show that hurricane procedures (primarily dealing with personnel safety) had been distributed to the field, the Parsons-Gilbane field management was unaware of any such instructions.

The emergency phone number list in the guardhouse does not indicate if all numbers are to be called in all emergencies. Such planning/decision-making is left to those actually involved in the emergency. In addition, it is not clear who was responsible for notification of the authorities, security guards, SPRO management, Parsons-Gilbane management, etc. Testimony revealed that one of the senior staff members from Louis Records had a list in his desk drawer of phone contacts, but only after he was advised by telephone of the incident at West Hackberry did the other Louis Records personnel become aware of the list. Using this list, they called one oil well firefighting service, while ParsonsGilbane in New Orleans was calling another. Although it is noted that the site personnel were able to present several different types of emergency instructions (Appendix VIII), it was evident that the information in the plans had not been digested and reacted to by the site personnel. In addition, there was no single repository where all emergency instructions could be located. In the final analysis, the instructions, except for telephone listings, were not used during this emergency.

In summary, while a plan is necessary for effective and coordinated implementation of the response to a disaster, a formal plan was not available for west Hackberry. 
2. No Onsite Firefighting Capability

While there are plans for a water distribution system to provide firefighting capability, this portion of the construction has not been completed. Furthermore, questions were raised during the investigation as to the adequacy of the planned system to cope with a fire of the magnitude of the one at West Hackberry; the Committee did not attempt to assess the capabilities of the planned system, but it is clear that the lack of a system currently is unsatisfactory.

While supplies such as foam could be and were obtained from the local oil community, none were available onsite as there should have been. The site staff had made contact with the local firefighting organizations; however, no formal agreements had been developed. An example of the type of problem arising out of such informal arrangements is that the volunteer firefighters left the scene after the fire was out and before the metal had cooled. In addition, Parsons-Gilbane personnel had also left the site. When the hot metal subsequently rekindled the fire after the well was plugged, there was minimal equipment and no personnel available to fight the blaze. As it happened, a couple of New Orleans-based safety engineers and several of the accident investigation staff were the only personnel initially available to respond to this situation.

\section{No Well Head Protection}

Lack of well head protection and dikes, during construction, while it may be normal procedure, does not appear to be consistent with the risk associated with concurrent interim fill and construction at the same site. Similarly, the vulnerability of operational oil and brine pipe systems to damage from construction equipment, sabotage, or natural disaster should be questioned. 


\section{Ability to Cope with Oil Spill}

No prior arrangements had been made to have contractor support in the event of a spill although the staff had familiarized themselves.with the local contractor capabilities to control oil spills. Efforts were underway to have a support contractor on board but, because of problems in the procurement cycle, the contractor selection process had been delayed. Site personnel were able to react quickly and effectively because of the accessibility of oil booms in the immediate area and the fact that an oil skimmer was at the adjacent dock for demonstration purposes. As per the requirements of the "National Oil and Hazardous Substances Pollution Contingency Plan," Title 40 CFR, Part 1510, other agencies, especially the coast Guard, participated in the oil cleanup. It would appear that SPRO and/or Parsons-Gilbane personnel were aware of these legislative requirements prior to the West Hackberry accident.

5. Inadequate Security, Personnel Control, and Communications The effectiveness of the guards at the gate during the accident is somewhat questionable, but this could have been anticipated in that they were not given any criteria as to who should be admitted.

Although efforts were made to secure the main gate immediately after the fire, it appears as though some of the spectators and press representatives gained access to the site via the unfenced borders. Testimony indicated that for some time after the accident there were major traffic tieups on the road within the site.

Warning horns were used after the fire started, but it is not clear if enough site personnel were trained in the meaning of the signals to appreciate the significance of the warning. 
While order appeared to increase with time, there were two types of incidents worthy of note:

a. The first of these incidents concerns the additional volunteer firemen who were requested to wait in a church parking lot in the event they were needed. The Committee did not attempt to ascertain how many firemen were onsite or if more could have contributed to the fire control operation, but it is clear that if SPRO expects to continue to rely on the resources of the area's volunteer firemen, specific arrangements need to be made beforehand as to the method of and criteria for admission to a site. Otherwise, the responsiveness and morale of the area's volunteer firefighting units may be significantly lower the next time they are needed, an observation that is, of course, not limited to the West Hackberry area.

b. In the incidents with the press, where in each of the cases cited here, they had apparently gained access to the site through the gate; it is not clear if the failure of security was at the gate or the fact that the fence at West Hackberry is only on the side of the property adjoining the road; anyone who wants to walk through the adjacent fields can gain access to the site.

The Committee noted that onsite managers did not know how many were at Well 6 when it ignited. Personnel accountability was inadequate.

\section{Other Sites}

While the Committee did not investigate in detail the other SPRO sites, the testimony did indicate that they are in the same nominal state of preparedness to respond to an oil spill and/or fire. 


\section{Procurement of Support Services}

No formal arrangements had been made to engage the services of an oil cleanup contractor; efforts had been underway prior to the accident to enter into a contract for this type of support, but procurement delays had been encountered. Additionally, no foam was available onsite for firefighting, nor were there adequate water supplies, hoses, etc. The majority of these supplies and services were obtained rapidly from other oil-related industries in the immediate area.

8. Participation of Numerous Groups, Individuals, and Agencies The firefighting, well capping, and oil cleanup efforts were implemented effectively and efficiently through numerous individual efforts; these contributions were especially significant immediately following the accident.

It is clear that the environmental impact on the lake and the shoreline would have been more extensive if the oil containment booms had not been deployed as rapidly as they were and the wind had been unfavorable. The West Hackberry oil spill was defined as a "major discharge" under the definitions of the "National Oil and Hazardous Substances Pollution Contingency Plan." still Lt. Commander J. Phaup, the Coast Guard on-scene coordinator, termed the control and cleanup as the best response he had ever seen. This was accomplished through the efforts of many onsite personnel, as well as numerous contractors and the capable assistance and guidance of the coast Guard. Federal and State agencies which were represented at the West Hackberry Site included the following: Envirønmental Protection Agency, Corps of Engineers, National Oceanographic and Atmospheric Administration, Fish and Wildlife Service (Department of the Interior), Department of Agriculture, Louisiana Department of Wildlife and Fish, Louisiana Stream Control Commission, and Louisiäna Office of Conservation. 
The firefighting operation was conducted by volunteer firemen of the adjoining communities. They worked long hours and many missed days of work to maintain the fire brigade. When the fire began, there were inadequate water supplies and tank trucks had to be used; then a pit was excavated so that the brackish water from the lake could be used, although the sait in this water did have an adverse effect on the fire companies' equipment. Standalone pumps were obtained to supplement the fire companies' equipment.

Testimony revealed that the largest problem in the Boots \& Coots operation was multiple coordination with various site personnel; the need for a single point of contact was identified.

\section{SPRO Assumes Site Control}

It has already been pointed out that upon being notified of the problem at West Hackberry, senior SPRO personnel flew by helicopter to the site from New orleans and the spRo project manager assumed control of the site. Alternatively, it could be argued that such a procedure would be impractical in a multisite accident as a result of hurricane damage; or that site personnel who are acquainted with the details of the site should be in charge of the operation. This question is only part of the overall management issue addressed elsewhere in this report, but relative to procedures for other emergencies a detailed analysis of the pros and cons of these approaches is necessary.

\section{HUMAN FACTORS}

There are problems related to human factors which might have contributed to the occurrence and/or the severity of the accident. These problems relate both to the workplace environment and man-machine relationships. 


\section{Workplace Environment (General)}

A large number of the SPRO, contractor, and subcontractor personnel had been working a significant amount of overtime for an extended period. The requirement for the extra hours is attributed to understaffing and schedular pressures. In addition, there were a number of new and unacquainted personnel and frequent staff changes which did not.facilitate communications, coordination and continuity. Factors such as fatigue, workload pressures, and job insecurity were observed in witnesses. Many of these factors were compounded when many of the same people had to respond to the accident for an extended period.

The SPRO office was organized in January 19.77, and ParsonsGilbane was brought onboard more recently and, at the time of the accident, the program had grown rapidly because of the urgency to get oil in the ground. The rapid growth of the program outran the orderly development and implementation of management systems and key functions. (e.g., safety, quality assurance). Because construction and operations were running concurrently, the responsibilities and authorities of site managers were often unclear (e.g., for West Hackberxy). In addition, there appeared to be numerous instances where the existing lines of authority and responsibility were not followed (e.g., various levels of management were routinely bypassed); causing managers not to feel accountable and causing morale problems. For example, the bypassing of site management in the approval of the workover at Well 6 weakened the site management's sense of responsibility for that activity.

In addition, the lack of drilling and workover experience within SPRO and Parsons-Gilbane impeded the ability to review and approve key documents and critical operations. 


\section{Workplace Environment (Field)}

Long working hours were routine at west Hackberry. The Pelican drilling crew, for example, worked a 12-hour shift, and they had to drive an hour or more each way to and from their homes. On the day of the accident, the crew began their shift at 6:00 a.m.; so when the accident happened, they were 80 percent through their shift. Previous experience shows that the probability of human error increases toward the end of the shift and on extended work hours.

The Louis Records rig supervisor's schedule of duty was 24 hours a day for 3 weeks, with the fourth week off. Minimal provisions were made for getting some sleep at the site, and in this particular case the supervisor lived in close proximity to the West Hackberry Site. The Louis Records rig supervisor was not on the rig when the mud initially flowed from the casing.

Crew training was never accomplished in terms of general rig practices, or specifically, in terms of the workover procedure and hazards associated with the Well 6 workover. Perhaps such training could have permitted the crew to recognize, from the events and indicators that were presented, that the packer was moving in the 5-1/2-inch casing. The training also could have covered the methods to deal with the problems that were being encountered. SPRO and Parsons-Gilbane did call a meeting of drilling contractors to discuss safety work practices before the accident, but Pelican Well Service was not invited and did not attend.

Because there was no training on emergency procedures, those of the crew who had prior oil field experience reacted according to their experience; others not experienced reacted instinctively. There were indications that those experienced personnel in proximity to Well 6 warned other workers to leave when the mud first came from the casing, probably minimizing the loss of life and injury. 


\section{Human Engineering of Equipment}

There was some previous concern that hydrogen-sulfide gas might have been encountered in the drilling operations on Cavern 6 , so arrangements were made to have a vendor bring in some life support equipment; however, there was no instrumentation to give an early warning of hydrogen-sulfide gas. The drill crew would have had very little time in which to react to the hydrogensulfide, and then put on gas masks.

The availability and design of safety equipment on the Pelican Rig was unsatisfactory; from the human engineering viewpoint, the safety valve used as the stabbing valve was made up from a 5-1/2-inch $\times 2$-inch swage ball valve. As a manual safety valve, the valve, as made up, had two deficiencies:

a. The valve had no handles to facilitate quick installation on the casing.

b. The valve should have been full-opening. A restriction in the valve caused additional counter pressure against the valve, making it even more difficult to seat and screw it into the casing.

The additives in the mud that was being discharged from the casing caused burning in the crew's eyes at the critical stage of the operation which, in turn, impaired their vision and effectiveness. In retrospect; since the available safety valve probably could not have been installed under the actual conditions encountered, the fact that some of the crew left the drill platform to wash their eyes may have prevented them from being burned. 


\section{CONCLUSIONS}

\section{A. TECHNICAL FINDINGS}

\section{West Hackberry Site Findings}

a. Finding -- The well head/cavern storage complexes are subject to single-point failures.

(1) Probable causes: Comprehensive critical failure mode and effects analyses have not been performed and problems have not been identified for correction.

(2) Judgment of needs: Analyses should be performed. Critical failure modes should be identified. Redundant safety fixtures should be designed to mitigate failures and consequences.

b. Finding -- The written workover procedures were consistent with "standard oil field practices" in: the south Louisiana region.

(1) Probable cause: The contractor, Louis Records, was experienced with practices in the region.

(2) Judgment of needs: Applicable standards should be specified. Programs and procedures should be reviewed against the standards.

c. Finding -- The written workover procedure was not followed.

(1) Probable cause: The partially closed well head valve prohibited use of the bridge plug specified in the procedure.

(2) Judgment of need: Initiate a field-level change review and approval system. 
a. Finding -- Field manager substituted a packer for the bridge plug.

(1) Probable cause: Same as 1.c.(1) above.

(2) Judgment of need: Same as 1.c.(2) above.

e. Finding -- There was a single, inadequate safety valve on the rig.

(1) Probable cause: No requirement for safety valves or their performance characteristics was specified.

(2) Judgment of needs: Workover and drilling operation should not be initiated unless adequate safety equipment is available.

f. Finding -- Packer slippage was the most probable failure mechanism and was inadvertently induced by hydraulic imbalance caused by the mud program.

(1) Probable cause: The packer was not designed for this application. Mud weights and limits were not specified in the procedure.

(2) Judgment of needs: Safety-critical hardware and.procedures should be reviewed and approved prior to the onset of operations.

g. Finding -- The firefighting, oil containment systems, and site security systems at West Hackberry were inadequate to promptly mitigate the effects of the accident.

(1) Probable cause: Such an accident and its consequences were not anticipated in order to input the emergency planning and preparedness process. 
(2) Judgment of need: The contingency planning, equipment, and procedures should be continually upgraded.

B. MANAGEMENT FINDINGS

1. DOE Headquarters

a. Finding -- There are no policies or procedures for specifying standards applicable to the SPR program.

(1) Probable cause: Previous mandatory policies and procedures were relegated to guidance status with the advent of DOE.

(2) Judgment of needs: Policies and procedures should be developed and an assurance program to monitor their implementation should be established.

2. $\quad$ SPRO

a. Finding -- SPRO did not monitor Parsons-Gilbane drilling activities.

(1)

Probable causes: There is limited in-house drilling or workover expertise. Overview responsibility delegated by SPRO to ParsonsGilbane. SPRO did not have operational feedback on critical field workover operations and practices.

(2) Judgment of needs: SPRO policy on the degree and type of monitoring of Parsons-Gilbane needs clarification and implementation. A system for reporting to management significant observations or unusual occurrences affecting safety is needed. 


\section{b. Finding -- Mission urgency (oil-in-the-ground) has}

dominated the ongoing safety and quality assurance programs to the point where the safety and quality assurance efforts are inadequate.

(1) Probable causes: The schedule has been developed without sufficient technical. input. In trying to meet the schedule, there has been a management failure to emphasize safety and quality assurance activities.

(2) Judgment of needs: Strong systems safety, occupational safety, and quality assurance programs need to be aggressively implanted in SPRO and their contractors.

c. Finding -- There is inadequate coupling between managerial decisions and technical evaluations.

(1) Probable cause: Same as 2.b.(1) above.

(2) Judgment of needs: The management staff must solicit and integrate technical input into schedules and facility development programs.

d. Finding -- There is inadequate oil field expertise and staff resources.

(1) Probable causes: Recruitment of staff was aifficult and slow, particularly personnel with oil field experience. Other possible resource options were not utilized. Frequent personnel changes have occurred.

(2) Judgment of needs: Use support contractors and/or consultants. Intensify recruitment and training activities. 
e. Finding -- Fill operations were authorized before design and hardware safety aspects were analyzed, the needs identified, and proper equipment and procedures put in place.

(1) Probable causes: Same as 2.b.(1) above.

(2) Judgment of needs: A realistic assessment of potential safety problems and followup action is needed.

f. Finding -- Responsibility and authority for the sites is not delegated to single points for accountability.

(1) Probable cause: The organizational structure under the project manager does not provide for single points of accountability with the attendant authority to implement programs.

(2) Judgment of needs: Although function management organizations may be desirable for SPRO, site management should be the responsibility of a single onsite manager.

g. Finding -- SPRO contingency planning is inadequate.

(1) Probable causes: The urgency of operations and understaffing resulted in less than adequate attention to contingency planning.

(2) Judgment of need: Comprehensive contingency plans should be developed. Training on the execution of the plans should be provided.

h. Finding -- The SPRO change control system did not adequately control field-initiated changes or onsite changes of a principally technical nature. 
(1) Probable causes: A technical baseline design was never developed, so the mechanism to control technical changes did not permeate the field operations.

(2) Judgment of needs: A comprehensive baseline design is needed. The change process should be extended to critical field activities, hardware, operations, and. facilities.

i. Finding -- There is no orderly system for assuring review, approval, followup, and closure of management requirements.

(1) Probable cause: There are inadequate management policies and procedures.

(2) Judgment of needs: The existing management system needs improvement to provide for policies and procedures for review, approval, followup, and closure of management decisions.

j. Finding -- SPRO had not established an organizational element to effect systems safety and quality assurance.

(1) Probable cause: Same as 2.i.(1) above.

(2) Judgment of need: Establish a capability and staff these organizational elements independently of operations and program pressures.

k. Finding -- The interactions with the public and press were less than satisfactory. 
(1) Probable cause: Same as 2.i.(1) above.

(2) Judgment of need: A public information plan is needed.

\section{Parsons-Gilbane}

a. Finding -- Parsons-Gilbane's performance, after accepting responsibility for drilling and workover operations, was inadequate.
(1) Probable causes: Drilling management changes occurred several weeks before the accident. Emphasis was on scheduling drilling rather than on techinical manage- ment.
(2) Judgment of need: Reinforce drilling organization and its capabilities.

b. Finding -- Parsons-Gilbane did not obtain available technical expertise and data, and utilize these on workover operations.
(1) Probable causes: There was insufficient motivation from SPRO and insufficient initiative from Parsons-Gilbane manage- ment. The transition from previous contractors was inadequate. The program schedule outpaced staff capability buildup.
(2) Judgment of need: Same as 3.a.(2) above. Use of engineering analyses to support operational decisions needs to be emphasized.

c. Finding -- Horizontal and vertical communication, coordination, and feedback within Parsons-Gilbane were less than adequate. 
(1) Probable cause: Same as 3.b. (1) above.

(2) Judgment of need: Managers and/or the management system needed to emphasize communications, coordination, and feedback loops.

d. Finding -- Same as 2.f. above.

(1) Probable cause: Same as 2.f.(1) above (but applies to Parsons-Gilbane construction executive).

(2) Judgment of need: Same at 2.f.(2) above (but applies to Parsons-Gilbane organization).

e. Finding -- Staffing is less than adequate; total quantity is below the expected number and there have been excessive turnovers and/or reassignments within the Parsons-Gilbane organization.

(1) Probable cause: Same as 3.b. (1) above.

(2) Judgment of needs: Same as 3.a.(2) and 3.b. (2) above.

f. Finding -- There was an inadequate management control process, including work authorization, change control, and the tracking of approved actions.

(1) Probable cause: Same at 3.b.(1) above.

(2) Judgment of needs: Develop a detailed management system, including work authorization, change control, and progress tracking procedures and provide staff to carry out these tasks. Documentation of same is essential. 
g. Finding -- Safety and quality assurance organizations were not involved in top-level management and technical decision-making process.

(1) Probable cause: The safety and quality assurance functions do not receive sufficient management emphasis and report. too low in the organization.

(2) Judgment of need: Give greater visibility and support to safety and quality assurance. functions.

4. Louis Records \& Associates, Inc.

a. Finding -- Louis Records failed to develop a workover plan adequate to prevent the accident. One factor was their failure to obtain key technical data on Cavern $6 /$ Well 6 .

(1) Probable causes: Scheduling pressures and insufficient overview were primary causal factors.

(2) Judgment of needs: Formalized review and analysis processes for drilling and workover activities need to be established. Review and approval feedback from SPRO and Parsons-Gilbane is needed.

b. Finding -- Louis Records failed to ensure that adequate safety equipment was available at Well 6 .

(1) Probable cause: Inadequate understanding and/or execution of Louis. Records' responsibilities and authority was a primary causal factor. 
(2) Judgment of needs:. Louis Records should. review each operation and job site. for the adequacy of safety equipment and certify that the equipment is present and functionally adequate. 
VI. SIGNATURE PAGE
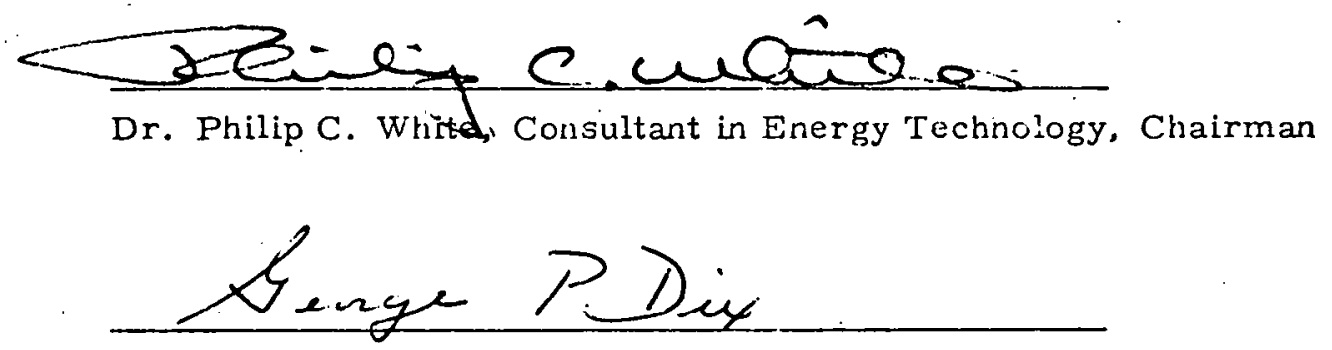

Mr. George Dix, Assistant Director, Systems and Programs,

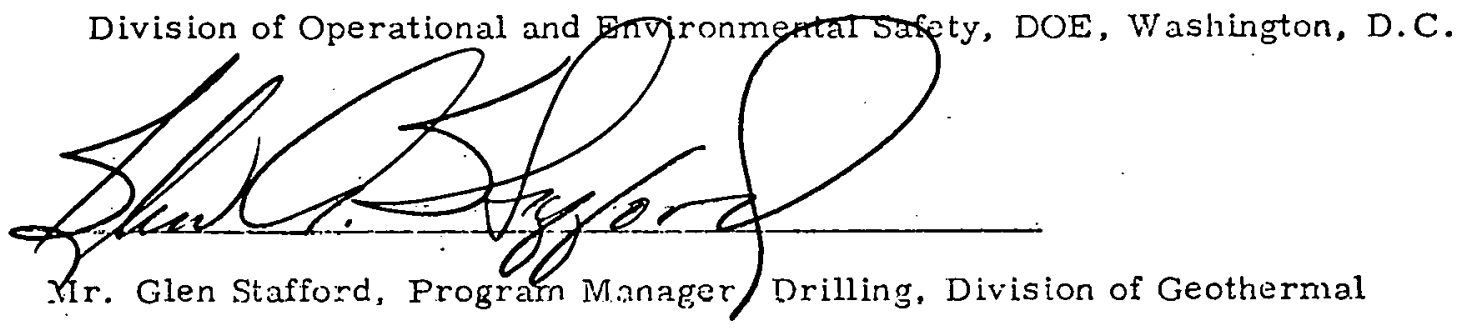

Energy, DOE, Washington, D.C.

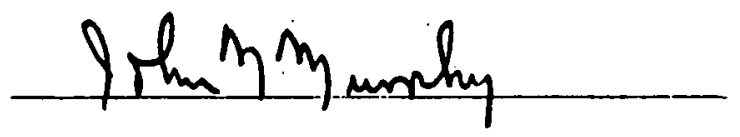

Mr. John Murphy, Research Director, Pittsburgh Mining and Safety Reserarch Center, Bureau of Mines

Philip a. Lowe

Dr. Phillip I: owe, Director, Technical Inspections, Inspector General, DOE, Washington, D.C.

151 


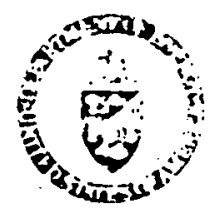

Department of Energy

Washington, D.C. 20545
VII. BOARD AUTHORITY

Ykillip C. White

INVESTIGATION OF OCCURRENCE AT THE WEST HACKBERRY SITE OF THE DOE STRATEGIC PETROLEUM RESERVE--NEW ORLEANS, LOUISIANA

Due to the importance of the explosion and fire that occurred last night at the West Hackberry site of the Strategic Petroleum Reserve in Louisiana, I have decided to form a Headquarters investigation committee. This committee will report directly to me and the Investigation is to take preference over all other prior commitments of the committee members. Therefore, I am appointing you as chairman of the committee to investigate this accident. The following are appointed as members of your committee:

John N. Murphy, Bureau of Mines, Member George Dix, OES, Nember Glen Stafford, ET, Member Phillip Lowe, IG, Member

The investigation and reporting are to be conducted in accordance with IMD 5001 insofar as circumstances associated with this subject permit. The purpose of the investigation is to obtain information necessary to determine:

a. the nature and extent (including costs and programmatic efforts) of the accident;

b. the causes of the accident; and

c. an appropriate judgment of needs which require corrective actions in order to preclude similar occurrences. 
I am also designating the following to assist the committee as consultants:

\author{
Jack McKenna \\ R. W. Leutzinger
}

In addition, I have requested Carl Caves to serve as your executive secretary. If any other assistance or resources are needed, please advise me of your negds.

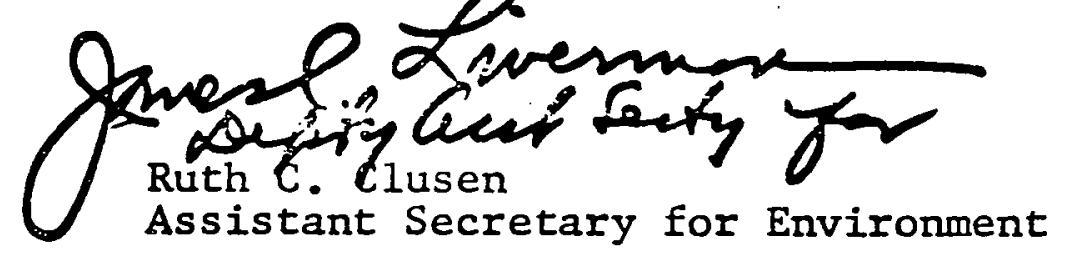

cc: John N. Murphy, Bureau of Mines

George Dix, OES

Glen Stafford, ET

Phillip Lowe, IG

Jack McKenna, Consultant

R. W. Leutzinger, Consultant

Roger Morkle, Director, Bureau of Mines

Dale Myers, US

Robert D. Thorne, ET

J. Kenneth Mansfield, IG

George S. McIsaac, RA

Hal Hollister, OES 


\section{Report on the Explosion, Fire, and Oil Spill Resulting in One Fatality and Injury on September 21, 1978, at Well 6 of Cavern 6 at the West Hackberry, Louisiana, Oil Storage Site of the Strategic Petroleum Reserve}

Volume II

November 1978

U.S. Department of Energy Washington, D.C. 20545

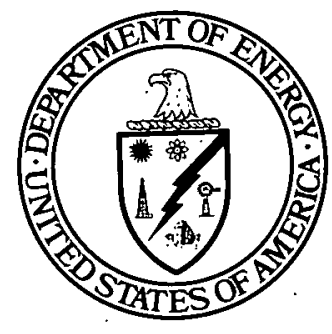


THIS PAGE

\section{WAS INTENTIONALLY LEFT BLANK}


APPENDIX I

List of Witnesses

A -3 
THIS PAGE

\section{WAS INTENTIONALLY LEFT BLANK}




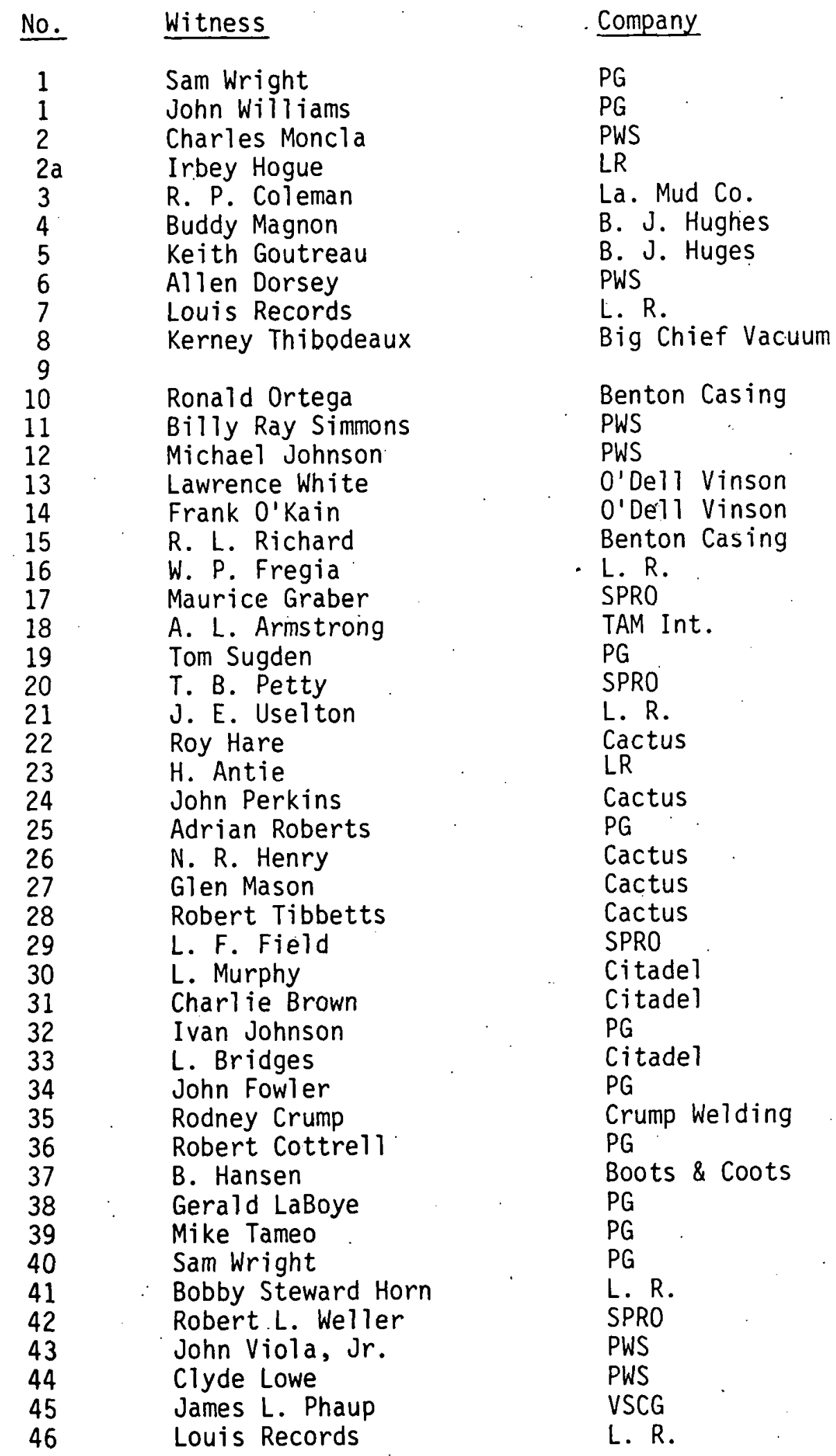




\begin{tabular}{lll} 
No. & Witness & Company \\
\hline 47 & Guy R. Broussard & La. Dept. Cons. \\
48 & Jack E. Wilson & SPRO \\
49 & John Walther & U. S. Fish \& Wildlife \\
50 & Fred DeFalco & PB-KBB \\
51 & Robert Forrest & EPA \\
52 & Vernon Paul Sanner & PG \\
53 & Kim Hoag & SPRO \\
54 & Carl Hoffpauir & PG \\
55 & Charles Frank Dudley & PG \\
56 & Robert E. Cox & PG \\
57 & John H. Poole & AMOCO, Dep. Sheriff \\
58 & Allen Fruge & SPRO \\
59 & Neal Van Fossen & G. I. \\
60 & Mark Boudreaux & Dames \& Moore \\
61 & Herbert Frog Antie & LR \\
62 & Irbey Hogue & LR \\
63 & Gordon Ashworth & Cactus \\
64 & John Robin & INT Hammer \\
65 & Bobby Allen Schexnider & INT Hammer \\
66 & Jesse Bihm & INT Hammer \\
67 & Harold Forrestier & INT Hammer \\
68 & William M. Molloy, Jr. & PG \\
69 & John Gabriel & PB-KBB \\
70 & Samuel Maxwell & PB-KBB \\
71 & W. D. Cariker & PG \\
72 & Charles A. Orne, Jr. & PG \\
73 & Rugg Stapleton & PG \\
74 & Hartmut Gomm & PB-KBB \\
75 & Michael A. Cushman & SPRO \\
76 & Wallace Dunn & PB-KBB \\
77 & Antonio Maichello & PG \\
78 & John Scango & SPRO \\
79 & JimPrim & SPRO \\
80 & R.Pouliot & PG \\
81 & Don Mazur & SPRO \\
82 & Dave Mathews & PG \\
83 & Bill Parker & SPRO \\
84 & George McIsaacs & DOE \\
85 & Joe DeLuca & SPRO \\
86 & Lawrence Pettis & SPRO \\
87 & Dobey Langenkamp & DOE \\
88 & Bradley Bergeron & PWS \\
89 & Herbert Antie & \\
& &
\end{tabular}




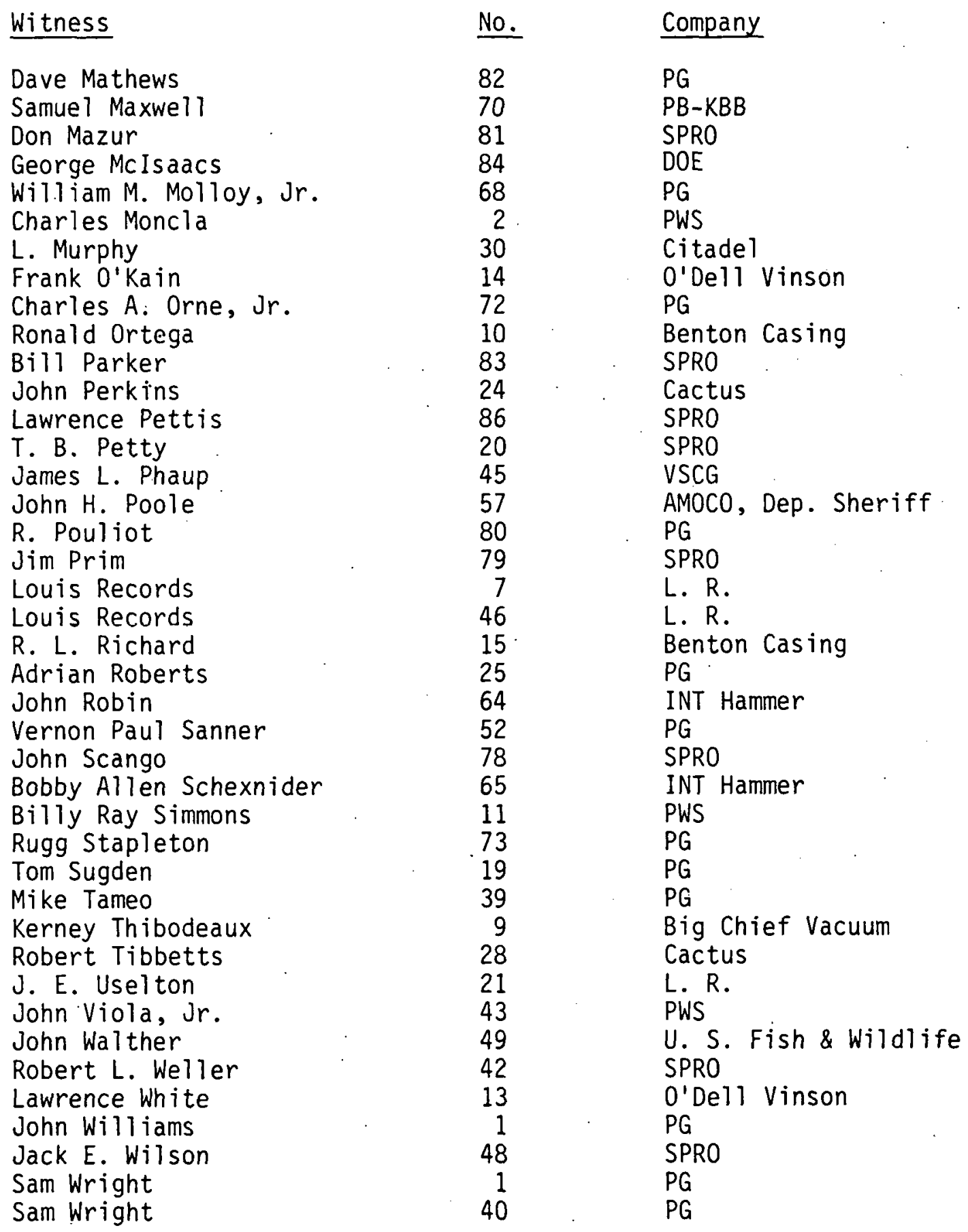


Witness

H. Antie

Herbert Frog Antie

A. L. Armstrong

Gordon Ashworth

Jesse Bihm

Mark Boudreaux

L. Bridges

Guy R. Broussard

Charlie Brown

W. D. Cariker

R. P. Coleman

Robert Cottrell

Robert E. Cox

Rodney Crump

Michael A. Cushman

Fred DeFalco

Joe Deluca

Allen Dorsey

Charles Frank Dudley

Wallace Dunn

L. F. Field

Robert Forrest

Harold Forrestier

Neal Van Fossan

John Fowler

W. P. Fregia

Allen Fruge

John Gabriel

Hartmut Gomm

Keith Goutreau

Maurice Graber

B. Hansen

Roy Hare

N. R. Henry

Kim Hoag

Carl Hoffpauir

Irbey Hogue

Irbey Hogue

Bobby Steward Horn

Ivan Johnson

Michael Johnson

Gerald LaBoye

Dobey Langenkamp

Clyde Lowe

Buddy Magnon

Antonio Maichello

Glen Mason
No.

Company

LR

LR

TAM Int.

Cactus

INT Hammer

Dames \& Moore

Citadel

La. Dept. Cons.

Citade 1

PG

La. Mud Co.

$P G$

$P G$

Crump Welding

SPRO

PB-KBB

SPRO

PWS

$P G$

$P B-K B B$

SPRO

EPA

INT Hammer

G. I.

$P G$

L. R.

SPRO

PB-KBB

$P B-K B B$

B. J. Hughes

SPRO

Boots \& Coots

Cactus

Cactus

SPRO

$P G$

LR

LR

LR

$P G$

PWS

$P G$

PWS

B. J. Hughes

$P G$

Cactus 
APPENDIX II

\section{Letters}

A -9 


\section{THIS PAGE}

\section{WAS INTENTIONALLY \\ LEFT BLANK}


September 27,1978

Mr. Donald Mazur, Manager

Strateg1c Petroleum Reserve Project

Management off $1 \mathrm{ce}$

U.S. Department of Energy

900 Commerce Road East

New Orleans, Loulstana 70123

Dear Mr. Mazur:

Th1s letter 18 to confirm the September 26, 1978, verbal request of Mr. J. N. Murphy, member of the West Hackberry S1te Investigation Committee for you to provide the following material:

(1) written descriptions of all gites in the Seaway, Texoma, and Capline Systems; Included In the above will be simple sketches of such site.

(2) coples of operating procedures for the above sites, opecificaliy descriptions and-procedures for driling site caverns, well work over, -etc.

Please send this literature to the committee by September 28 . 1978 .

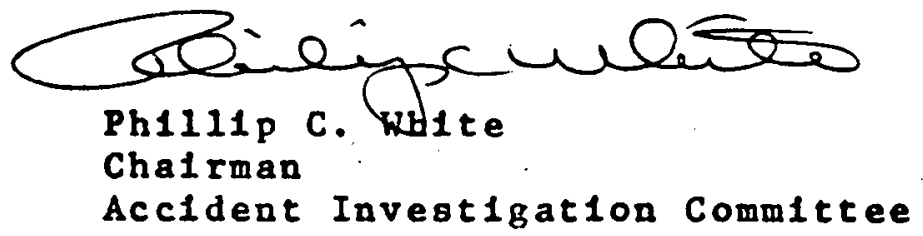


OCT $3 \quad 1978$

MEMORANDUM FOR DONald W. Mazur Project Manager

SUBJECT: Documentation Concerning Cavern No. 6 , Well No. 6

The investigation Comittee requests that you provide the following documentation by Wednesday noon on October 3 , 1978.

This is spectflc to Cavern 6, Well. 6, for the period August 1 through October $1,1978$.

1. All correspondence dispatched by SPRO to its contractors and subcontractors.

2. All corresponcience received by SPRO from its contractors and subcontractors.

3. All design, enginecring and system safety analyses performed by all parties prior to and after the accident.

4. All correspondence to Parsons-Gilbane from all parties.

It is essential that these data be entered into tho comintee's records to be correlated with transcripts of testimony.

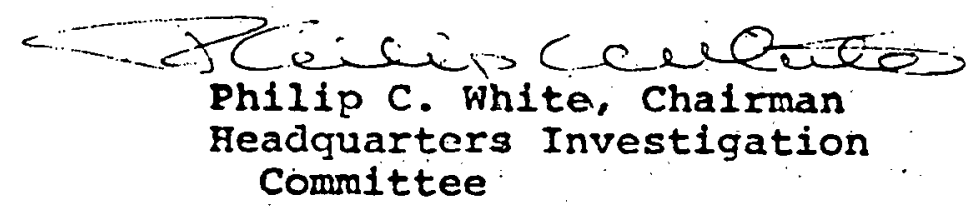

cc:

Kim Hoag 
MEMORANDUM TO DON MAZOR

PROH: Dr. Phillip C. White, Chairman

Accident. Investigation Commitee

SUBJECT: $\quad$ Request for Support

Please provide the following support to the Headquarters Accident Investigation Comittee:

1. Transport the remalning portion of the burned IAM Packer via "hot shot" truck to:

TAM International, Inc.

4047 Hol11ater

Houston, Texas 77080

Atta: Mr. Larry Sanford

marked "Hold for B111 Rehm".

2. Provide for the committee's use a set of "Design Drayings of Pacilities" for the West Hackberry site Erom $P B / R B B$.

3. Provide for the comittee's use the Driling and Completion Program Design document from $\mathrm{PB} / \mathrm{KBB}$ and Louls Records, Inc.

4. Provide fot the comnittee's use a copy of the "Cavern 16 Certification Book from Gulf Interstate Englneerting Co.

Thank you. 
September 26,1978

Don W. Mazur

Profect Manager

Strateglc Petroleum Reserve Project

Management office

900 Commerce Road East

New. Orleans, Louls1ana 70123

\section{REQUEST FOR INFORMATION}

It Is requested that you provide the West Hackberry Accident Investigation Comittee with the following information:

1. A detalled, current organization chart for your off 1 cer.

2. A detalled, current organization chart for the Parsons-Gilbane New Orleans office.

3. A detalled, current organization chart for the Backberry site government office.

4.: A detalled, current organ1zation chart for the Hackberry site Parsons-Gilbane offlce.

5. An organization chart showling contractual relationships between the government, Parsons-gilbane, drillers, etc.

Also provide a short paragraph that defines the principal responsibilities and authorities of each contractor.

Phili1p C. White, Chalrman

Accldent Investigation Combltee

cc: K1m Hoag 
Mr. Foger Modtle, Director

Bureau of Mines

2401 E Street, N.W.

Washingtion, D.C. 20241

Dear Mr. Morkle:

I do appreciate your approval to allow Mr. John N. Murphy, Research. Director, P1ttaburgh Mining and Safety Research Center, to serve an the Department of Energy comittee to investigate the fire and explosion which occurred at the Strateglc Petroleum Reserve, hest Hackberry, Iouisiona, on September 21, 1978.

The comittee, including Mr. Muphy, was fomally appointed by me on september 23, 1978. I have enclosed for your infonation a copy of the appointment memorandum. I an sure that with his background and experience with the Bureau of Mines, Mr. Murphy will be a great asset to the investigation.

Again, I would like to thank you for your copperation and assistance in making Mr. Muphy avallable to us on such short notice.

Sincerely,

Stgöned Bi?

Ruth C. Clusen

Assistant secretary for Enviromment

Enclosure

cc: Jahn N. Manphy

Dale Myers, us 
September 28,1978

MEHORANDUM TO:

FROM:

SOBJECT :
Haurice Graber

Dr. Phillp C. White, Chalrman

Accident Investigation Committee

- Completion of Hell S1ta Inspection

Th18 w11 advise that the Comittee has now finlshed its Inspection of the well site and hereby releases lt for further clean-up and reconstruction, subject to the following conditions:

Specific lengths of the $5 \frac{1}{2}$ inch casing, marked for ddentiflcation by Mr. K1n Hoag, are to be removed and set aside for lnspection by Dr. Slaughter, metallurglst from Oak Ridge National Laboratory.

The well head, now off to one side, 1s to be dismantled, and the $9 \frac{1}{2}$ lach $p 1 p e$ and other components removed and made avaliable to Mr. Slaughter. We will likely need assistance in taking samples, packaglng them and ahipping them to Oak Ridge National Laboratory.

All metal debris 18 to be stored somewhere on the West Hackberry slte, and not used or sold for scrap unt1l formally relesied by DOE Washington. Th1s vill be done as $800 n$ as the Commltee's report 18 completed and accepted.

ce: Mr. K̈Im Hög 
September 28,1978

Mr. Donald Mazur, Manager

Strategic Petroleum Reserve Profect

Management office

900 Commerce Road East

Hew Orleans, Loulsiana 70123

Dear Mr. Mazur:

We would like to have Mr. K1m Hoag as a contact for the commlttee members and the consultants at the West Hackberry -1te. In the event that he 19 unable to stay at Weat

Hackberry we would like to arrange for a substitute. Thlo 1a not to preclude the fact that we may have to return to th1s site:

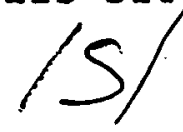

George D1x

Acting Cha1rman

Accident Investigation Commitee 


\section{OCT 21978}

Gearge S. MaIsaac

Asaiotant Secretary for

Besource Appllations

INVESIIGAIICA CF OCOURRENCE AT BEST HACKBERRXI, IA

As you are anare, Dale Mrers has directed me to concuct an Investigation of the fire at the hest Hackberry facility. A comittee, chaired by Fill hinites, has been appointed and is already at the site. A copy of the pqointment memoranch is exclosed.

I lonow this is an extremely trying time for you and your staff, and I appreclate very much the cooperation you have given us in getting. this investigation started. I am sure I can count on your fleld staff to provide Fill hite and his comittes every possible assistince.

Signed by Ruth C. Clusen

Puth C. Clusen

Assistant Secretary for Ervirament

Enclosure

c: Dale Myers, us 
APPENDIX III

Master Files List

A-19 

A. ADMINISTRATIVE
B. SITE TECHNICAL AND OPERATIONAL REPORTS
C. ENIIROMIENTAL: SAFETY \& HEALTH: QUALITY CONTROL
D. MANAGEMENT
E. CONSULTANT REPORTS
F. CONSTRUCTION \& JOB SITE PROCEDURES
G. NEWSPAPER \& OTHER MEDIA REPORTS
H. REFERENCES (TECHNICAL)
I. CONTRACTS
J. WITNESSES 
(Delegation of Authinity; Investigating Committec; State, Federcl oficicls)

Letter to Mazur from White, re: Info: request (see MC $18 \& 26$ )

$M M-2 \quad M C-18 \& 26$

Letter from Murohy to White, re: Site 'management

$M-3$

Memo to White from Murphy, re: Background info. on other sites

MM-4 $\quad$ MC-15

Letter from White to Committee, etc. delegating authority to.

Mr. Dix.

MC -17

List of State, Federal, Parsons-Gilbane, officials \& mișc. people. MM- 6

Letter from Dr. White to Maurice Graber, re: releasing of site $\quad M M-8 \quad M C-7$ inspection for clean up

Letter to Don Mazur from George Dix, re: retaining Hoags as MM-9 MC-2 contact for committee

Letter to Mazur from White, re: Documentation concerning Cavern MM-15 No. 6, Well No. 6 .

Work breakdown structure and schedules

$M M-21$

Management transcripts 1 ist.

$M-22$

Letter to Don Mazur from P. C. White, re: request for info. for. MM-27 West Hackberry Accident Investigation Committee

Letter to Baton Rouge General Hospital from P. C. White, re:

Info. request on the late Clarence Simon (involved in fire)

$M-45$

Types of Investigation : $\quad$ MM-46

Table of Contents; Report of Investigating Committee; Draft by Mike Dix, 10-10-78

Schedule for New Orleans and Dallas

MC-1

Letter to Mazur from Dix, re: contact at SPRO site when

MM-9 MC-2 comittee leaves

Wednesday's agenda

MC-6

Memo to White from Graber releasing site for clean, up

MM-8 MC-7

Dallas information

MC-10

Telephone numbers

MC- 14 


\section{ADMINISTHAIII (continued)}

Management Review - lines of Inquiry

$M-1 \quad M C-20$

Letter from White to PG, re: making transcripts available

MC-21

Job description - Div. of Labor committee members

MC -24

Temporary agenda for all days

$M C-25$

Working checklist

$M C-28$

List of names and addresses of comnittee $\&$ consultants

$M C-31$

Letter from White to Mazur, re: request of additional info.

MC-36

Letter to B.R. Gen. Hospital from P.C. White, re: Requesting M-45 info on the late Clarence Simon (involved in fire)

Table of Contents: Report of Investigating Committee, draft $M$ by Mike Dix, 10-10-78

Letter \& records: Cariker - PG, 9-1-78

$M-53$

PG Employees, 1-18-78

$M-58$

Transmittal letter for EG \& G photos. McCreary to white,

$M-78$ dated $10-10-78$

List of Visual Aids for Report, 10-13-78

MM-90

PG Memo announcing establishment of PR Section and advising

$M M-105$ $P / O$ personnel of their furictions. Dated 4-6-78. - 10-13-78

Comprehensive lists of witnesses alphabetically and in chronological order. 10-17-78

MM-106

TWX White to Clusen regarding interim precautions necessary

$M-153$ for cavern operations under pressurized storage conditions sent $10-17-78,10-21-78$ 
Memo to White from Murphy, re: background info on other sites

MM-4 MC-15

West Hackberry Daily Operations Report figures in barrels

MM-28

Seaway Complex

MM-31

Letter to Dr. Sam Maxwell from Louis Records, re: meeting

MM-32 cavern entry. for re-entry wells.

Letter to Mr. Scango from G. Ford for Neal E. Van Fossan, re: MM-33 Re-entry borehole tebniques.

Letter to Mr. Vic Kirkyla from Louis Records, re: meeting with $M-34$ Bob Weller, DOE; G. Ford; Neil Van Fossan; Giec, in Laf/LA

Letter to Sam Maxwell from Louis Records, re: tests of mixtures MM-35 of drilling mud and blanket on Feb. 6, 1978.

Memo. to Louis Records from Grant Schmit, re: Cavern entry - MM-36 We11 \#9A

PG file copy of Well \#6 daily drilling progress report for MM-38 period, 9-13 to 9-28-78 (separate folder)

N.0. review team report on Bayou Choctaw visits, 8-15-78. MM-41

PG-N.0. review team report on W. Hackberry visit, 7-31-78 MM-42

Drilling program final submitted 11-1-77, Bayou Choctaw Complex MM-47

Drilling program, Hackberry Site, 10-5-77 MM-48

Drilling program, Bryan Mound Complex, 10-16-77 MM-49

Daily drilling progress reports Louis Records. $9 / 12-9 / 21 / 78 \quad M M-60$

Daily operations report. W. Hackberry figures in barrels - M M-62 $9 / 15-9 / 29 / 78$

Pelican Well Service daily report $\quad$ MC-12

Memo from Murphy to White, re: visit to accident site $9 / 26 / 78$ MC-19

$\begin{array}{lr}\text { Xerox map of fire site } & \text { MC-22 }\end{array}$

Daily drilling progress report - 9/13 - 9/20/78 MC-23

Exhibit No. 6. As-Built Storage Well, West Hackberry MC-16 
Daily Operations Report, W. Hackberry figures in barrels

$M-62$

9-15-78 to $9-29-78$

Construction safety plans for W. Hackberry, 8-1-77

$M M-59$

Daily drilling progress reports, 9-12-78 to 9-21-78

MM-60 Louis Records

Sketch of Wellhead top by "Frog" Antics, dated 9-28-78. 10-13-78

SPRO diagram showing SPRO sites in Texas \& La. 10-13-78

$M-84$

GAO report. Need to minimize risks of using salt caverns for SPRO, 1-9-78. 10-13-78

$M-94$

Draft of 93 above

Site plans for SPRO:

MM-96
A. Bayou Choctaw
B. Weeks Island
C. St. James
D. West Hackberry
E. Bryan Mound
F. Sulphur
G. Sulphur

Designer Concept Operating Manual from PB/KBB for W.H. site,

$M M-101$ dated 9-15-78 - 10-23-78

(includes sections on safety, functional systems, fire protection, etc.)

Designer Concept Operating Manual PB/KBB for Bayou Choctaw 10-13-78

Designer Concept Operating Manual for Bryan Mound Preliminary 10-13-78

Cover memo from PG transmitting 96-103 above dated 10-2-78

- in response to Committee memo dated 9-28-78. 10-13-78

Letter: Louis Records to Doug Cariker, 10-2-78, describing:

1. Procedure followed in workover Well \#6 at W.H.

2. Hydraulic conditions at blow out.

3. List of damaged equipment.

4. 3 sketches of well \#6, W.H., showing wellhead detalls.

5. Sequence of reporting of blow out at WH. \#6. 10-14-78

Purchase orders for wellhead $\# 6$, W.H. Includes fittings \&

MM-108 valves. 
Letter: Louis Records to Maxwell PB/KBE, re: meeting minutes in Mi-109 $\mathrm{NY}$ on drilling entries into present caverns. DOE, $P G, P B / K B B$. GIE and CR present, 2-6-78. 10-14-78

Letter: Scango to Louis Records transmitting GIE's serious $M M-110$ reservations of the method of completion into an "oil-filled cavern". Only cover letter received here; no comments are attached. Dated 12-7-77. 10-14-78

Letter: Van Fossan - GIE Scango, re: expressing scepticism over MM-112 $\mathrm{PB} / \mathrm{KBB}$ re-entry procedure and proposing a test to reassure everyone, dated 3-1-78. 10-14-78

Memo: Grant Schmit to Louis Records discussing tests of re-entry procedures in cavern 9, dated 2-23-78. 10-14-78

MM-113

Letter: Louis Records to Maxwe11, $P B / K B B$, re: tests of mixtures of drilling mud and (oil) blanket conducted 2-9-78. Dated 2-20-78. 10-14-78

Letter: Louis Records to Kirkkyla $\mathrm{PB} / \mathrm{KBB}$ reporting meeting 2-23-78 on entry procedures into caverns and results of experiments for viscous plug outers in a simulated well base. Dated 3-3-78. 10-14-78

DOE comments on GAO report (Questionable suitability of certain salt caverns, etc. ..."). DRAFT 10/15/78

Technical report on the workover procedure on Well 6c SPRO W. H. etc. dated 10/4/78. "Rehm Report" 10/15/78

Memo, P. G. Robert to Weller requesting interim fire pump Installation at $W$. H. site dated $9 / 11 / 78$. 10/15/78

Monthly site report (PG) West Hackberry site for September 1978. $10 / 18 / 78$

Expansion execution plan for SPRO. DRAFT. 10/18/78

$M-143$

List of Louis Record's project managers (organizational

$M-144$ chart for Louis Records).

Construction drawings for WH-24 and WH-6, WH-10 and WH-21 WH-21, 7 of 33, sheets 3 to 9 of 37 , WH-10, sheets 3 to 7 of 20 , WH-6, WH-24, 1 to 7 of 7

Monthly site report, Bryan Mound, September 1978. 10/21/78 
Monthly site report, Sulpher Mines, September 1978. 10/21/78 M-149

Monthly site report, Bayon Choctaw, September 1978. 10/21/78 MM-150

Monthly site report, Weeks Island, September 1978. 10/21/78 MM-151

Monthly site report, St. James, September 1978. 10/21/78 MM-152

SPRO briefing material regarding extent of WH fire. 10/21/78 MM-154

PG memo Kiggs Mazur to local organizations that assisted in $\quad$ M-157

WH oil fire, dated 10/13/78. 10/21/78

Region VI memo to Hughes, ASIR, on regional activities for $M M-158$

September 1978. With list of injured at fire in WH, dated

$10 / 11 / 78$. $10 / 21 / 78$

Rough preliminary report of accident and fire by PG dated MM-160 9/28/78. 10/30/78 
Findings: "Valve Blocking System for the Site Oil Pipeline" M-18

Findings: "Safety" $\quad M$

Council on Environmental Quality-National $0 i l$ and Hazardous $\quad M-20$ Substances Pollution Contingency Plan

Chapter 0502 - "Notification, Investigation and Reporting MM-23 of Occurrences"

Loss Control Manual (see manual) MM-26

Safety Procedures for Rig Sites (separate folder) MM-37

$\begin{array}{ll}\text { PG drill reg. safety meeting, 9-18-78 MM-40 } & \text { M }\end{array}$

Fire protection during construction, 8-17-78 MM-43

Letter - SUNOCO to DOE, re: "Safety Precautions and $\mathbb{M}-52$

Regulations" for SUNOCO pipeline construction by SPRO, 12.-2.?-77

Announcement for Red Cross safety classes from Carl Hoffpauir- MM-54 2-15-78

Parsons' safe practice rules (undated) for employees MM-55

Parsons Gilbane West Hackberry safety inspection report MM-56 done by PG Houston engineer

PG Safety Manual for SPRO West Hackberry, La., and cover MM-58 memo from Cariker to PG employees, 1-18-78

Construction safety plans for W. Hackberry, 8-1-77 MM-59

LA. Dept. of Conservation, Guy Broussard's report, undated. MM-61

OSHA regulations for construction from AGC reprint MM-64

Report by LA. Dept. of Conservation, Inspection \& Enforcement MC-8 Div. filed by Louis Records for Cavern \#6

Environmental Assessment, West Hackberry, La. MC-13

Letter of Promulgation, Safety Policy Manual, dated 1-18-78 MC-32

PG - A joint venture SPRO-construction safety plan. MC-33 
Fire protection during construction, dated 8-17-78 Mi-43

PG emergency procedures to all sites, dated 8-11-78 Mvi-44

Letter: Sunoco - DOE, re: "Safety Precautions \& Regulations" Mi-52 for SUNOCO pipeline construction by SPRO, 12-22-77

Announcement for Red Cross safety classes from

PG Q/C procedures (Inspection) Manual, Copy of Copy $\$ 6$ MM-63

West Hackberry safety meeting held 1-4-77 and attachments M-75

1. Motor vehicle requirements

2. Speed limit sign, P.O. request safety

Recommended fire protection plan for interim fill for each MM-76 site (SPRO site), 8-10-78 10-13-78

PG emergency call sheets for SPRO sites MM-81

A. W. Hackberry

B. Bayou Choctaw

C. Bryan Mound

D. Sulphur

E. Weeks Island

F. St. James

W. Hackberry telephone list. (emergency \& other Nos.) 10-13-78 MM-85

W. Hackberry fire procedures posted 10-13-78 MM-86

Emergency signals list, $W$. Hackberry 10-13-7,8 MM-87

PG construction safety plan, West Hackberry, 8-1-78, 10-13-78 M-83

PG emergency procedures - hurricane, tornado. W. Hackberry MM-88

site. $\quad 10-13-78$

John Murphy's draft on emergency preparedness, dtd MM-123

10/10/78. 10/14/78 


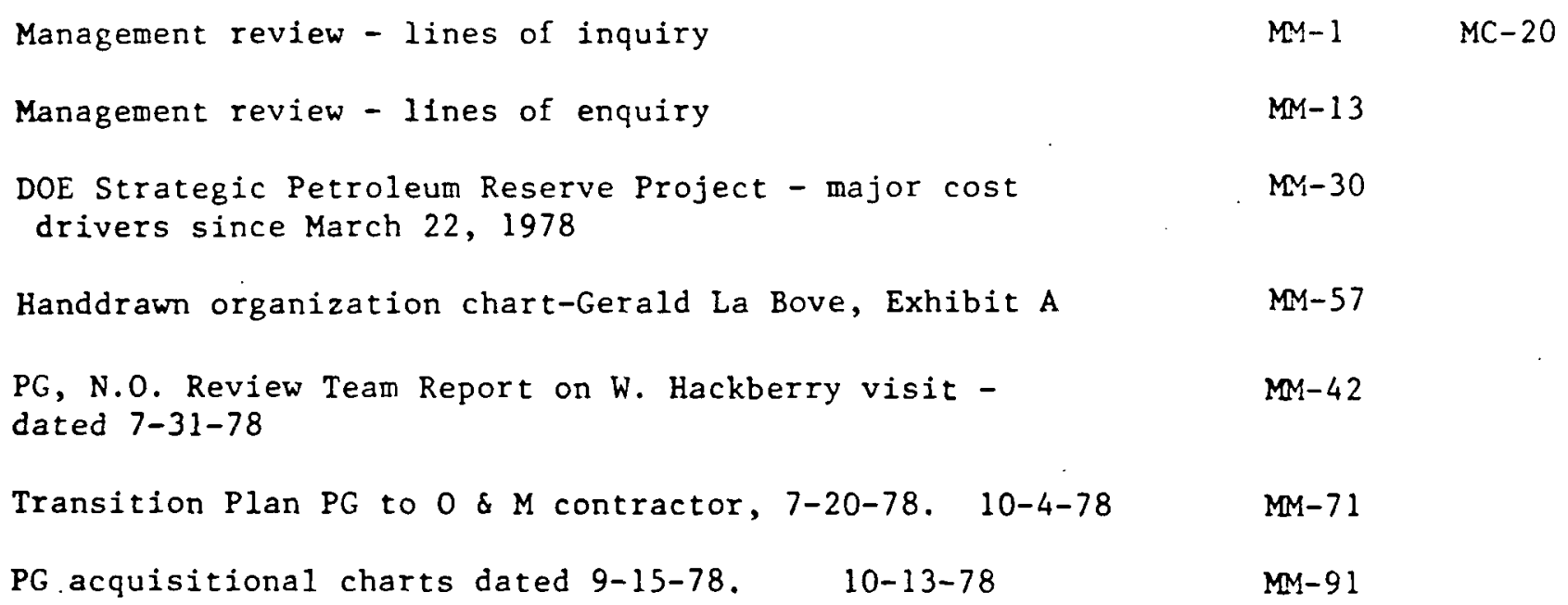


Letter fro leutzinger to White, re: comments on working

$M C-29$

check list.

Letter from McKenna to White, re: working checklist

$M C-30$

McKenna's report on PG safety program. 10-13-78

MM-92

ORNI metallurgical pictures for report and ORNL briefing.

MM-127 thru

141

Environmental Report by Cece, ECT, dated 10/6/78. 10/21/78 MM-156

Leutzinger's report on (1) loss estimates, (2) insurance summary, and (3) general observations, dated 10/10/78.

$M-159$ $10 / 21 / 78$ 
Expansion execution plan (see manual) M M-24

Solution Cavern (see manual) MM-25PG

Emergency procedures to all sites $\quad$ MM-44

Jobsite procedures - E-11 Electrical Safety Control and Danger M-51 Tag System, 8-9-78

Workover procedures: Well \#6 W. Hackberry, letter \& records, MM-53 Louis Records to Cariker, 9-1-78

PG - Quality Control Procedures (Inspection) manual. MM-63 Copy of Manual \#6

$\mathrm{MC}-3$

Construction Plan for SPRO Site $\quad$ MC-5

West Hackberry workover procedure, DOE Wel1 非, 8-30-78 MC-9

SITREP 1 and SITREP $2 \quad$ MC -34

Letter to Vic Kirkkyla from Louis Records, re: meeting with : MM-34

Bob Weller, DOE; G. Ford; Neil Van Fossan, Giec, in Laf/La.

PG Well \#6 workover procedures dated 9-1-78 MM-39

Drilling program final submitted, 11-1-77, Bayou Choctaw Complex M-47

Drilling program, W. Hacjberry site, 10-5-77 M M-48

Operations Manual for interim fill at W.H. Site. 10-13-78 MM-97

Drilling program, Bryan Mound $\quad$ MM-98

Operations Manual for interim fill at Bayou Choctaw. 10-13-78 MM-99

Operations Manual for interim fill at Bryan Mound. 10-13-78 MM-100

Cavern re-entry procedure, w.H. Well \#9A. 10-14-78 MM-114 


\section{Newsclippings}

1. Lake Charles American Press, 9-28-78

2. Beaumont Enterprise, 9-29-78

3. Beaumont Enterprise, 9-28-78 - Oil Dome Fire Damage Less than

4. The Washington Star, 9-22-78

Thought

5. Beaumont Enterprise, 9-28-78-Dome Fire Site Cools

6. Lake Charles American Press, 9-24-78

7. Beaumont Sunday Enterprise, 9-24-78

8. Austin American-Statesman, 9-22-78

9. Austin Citizen, 9-22-78

10. Lake Charles American Press, September 26, 1978 Try Scheduled to

11. Beaumont Enterprise, 9-27-78

12. Article on special foam readied to control dome blaze

13. Lake Charles - Salt dome fire is acid test for firemen

14. Star, 9-25-78-Effort to Control Oil Fire Fails - MM-14

15. Newsclipping provided by Delucca regarding La. Governor's stop order on pressurized dome work (TIMES/PICAYUNE CAPITAL BUREAU) date unknown, 10-14-78- MM-117

16. Newsclipping Washington Star, "0il Storage Fire Rages On" dtd 9-25-78, 10-15-78- MM-120

17. All news releases put out by PI on fire at WH, 10-15-78 There are 4 releases, A,B,C,D - MM-12]. 


\section{References}

1. DOE-5001, DOE - Environment, Safety, and Health Manual

2. IMD No. 5001 dated September 29,1977

3. ERDA Chapter 0502 - Notification, Investigation, and Reporting of Occurrences

4. Petroleum Safety orders - Drilling and Production, State of California, 10/15/78-MM-124

5. Mine Safety Orders - State of California, 10/15/78 - MM-125 
SPRO Contracts - one half of contents for. West Hackberry contracts.

PG contract. 10-13-78.

$M-66$

Pelican contract $10-13-78$

M-67

Louis Record contract, w/Parson/Gilbane

$10-13-78$

MM-68

Gulf Interstate contract.

$10-13-78$

$M M-69$

Gulf Interstate contract amendments

$10-13-78$

$M-70$

Subcontract Agreement for well drilling program.

$P G$ and Louis Records, 7-17-78.

$10-13-78$

MM-80

Boots \& Coots' contract with SPRO dated $9 / 21 / 78$. 10/15/78

$M-118$

Isolated drawings for above contracts, $10 / 21 / 78$

MM-146

Construction drawings for WH-11 bound in red folder -

MM-147

large set, $10 / 21 / 78$ 


\section{WITNESSES}

1. Classified Witness List for Committee

2. List of Feds and State Officials

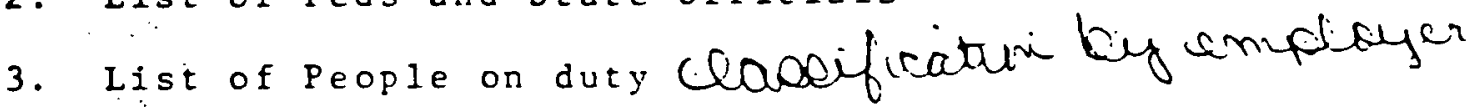

4. List of Witnesses dated $9 / 27 / 78-M M-7$

5. Federal officials, state officials, Contractors, and Misc. List

6. List of In Delivery Vehicles

7. Gruy Federal, Inc., Witnesses

8. Response to committee request for data from hospital on the late Clarence Simon dtd $10 / 14 / 78-10 / 21 / 78$ 


\section{Louis Records, Inc.}

1. Figure 1-Re-Entry Well No. 6C 9-7-68

2. West Hackberry Workover Procedure, DOE We11 \#6, 8-30-78

3. Daily Drilling Progress Report for 9-12-78

4. Letter from Records to Mr. Cariker re: Workover Procedure on WeIls $\# 6$ and \#11

5. DOE As-built Storage Well

6. Sequence of Reporting with Respect to Blow Out at wo $\$ 6$

7. Gulf Interstate Engineering Co - dated $2 / 9 / 78$

8. West Hackberry-Cavern Well No. 6, Before Workover Started 


\section{Williams/hight}

1. Letter to White from Williams re: enclosing statements from witnesses regarding the fire and explosion at Well Pad \#6 
Iam International

1. Job Report

2. General Catalog 
1. Travel. schedule: Lake Charles - New Orlears - Dallas

2. Lix to Mazur letter requesting Kim Hoag as SPRO liaison with Committee.

3. \#6 hiell Control Procedure and Well Head cross sevtion signed by Herbert Artie, 9-28-78.

4. Statement of Ronald S. Ortega, Manager; Bentor Casing Service, Inc.

5. SPRO Construction Plan - West Hackberry Site

6. Interview Shcedule - Wednesday, 9-27-78

7. White to Graber memo re: Release of \#6 We11 site for clean-up.

8. Statement of Vernon P. Sanner, Drilling Site Rep., Parsons-Gilbane.

9. We11 $\$$. 6 Workover Procedure; and Pelican Well Service daily reports; 9-1-378 thru 9-20-78.

10. Information sheet on Dallas travel accommodations.

11. List of phone calls within 5-10 minutes of initial explosion; made by Tom Sugden, Parsons-Gilbane.

12. Pelican Well Service Daily Reports, 9-13-78 thru 9-20-78.

13. Environmental Assessment Plan and list of Assessment Team Members; Sign-in sheet for Rapid Response Team meeting of Wednesday, 9-27-78.

14. 8 sheets from Parson-Gilbane Bulletin Board giving phone numbers, emergency procedures, security provision, etc.

15. Murphy to White Memo re: Interview with Mazur on the various SPRO sites.

16. Cross sections of \#6 Well and Well Head.

17. Chairman White to Committee Members Memo re: delegation of authority to Dix.

18. White to Mazur Letter re: confirmation of Murphy's request for information on sites and procedures.

19. Murphy to White memo re: 9-26-78 Visit to accident site by Murphy, Caves and Pam Ickes. 
20. Management Review/Lines of Inquiry Outline dated 9-27-78.

21. White to Parsons-Gilbane letter re: making interview transcripts available to Parsons-Gilbane.

22. Xerox Copy of West Hackberry and 非 6 Well Sites.

23. Daily Drilling Progress Reports of Louis Records and Assocs., Inc., dated September $13,15,16,17,18, \& 20,1978$.

24. Sheet Outlining Responsibilities of Committee Members, Consultants, DOE/Dallas and Contractors.

25. Interview Shecudle - September 26, 27, and 28, 1978 .

26. White to Mazur letter requesting 5 organizalion charts and information.

27. Listing of $1 / 1$ of the SPRo/W. Hackberry Contracts; Louis Records contracts not included. Also includes hand-witten list of contractors.

28. Comittee "Working Checklist" dated 9-25-78.

29. Leutzinger to White Memo re: Comments on "Working Checklist".

30. Mckenna to White Memo re: Comments on "Working Checkiist".

31. Name and Address list of Committee Members and Consultants.

32. Safety Policy Manual for West Hackberry, promulgated by Parsons-Gilbane.

33. Construction Safety Plan for West Hackberry, promulgated by Parsons-Gilbane.

34. SITREP (Situation Report) No. 1., dated 9-27-78,.4:00 p.m.; is a SPRO report re: (1) Cavern 6 events, (2) Pollution Abatement and Control Actions and (3) Site Status. Also, SITREP (siluation report) No. 2, dated 9-28-78, 4:00 p.m. updating 3 items shown for SITREP No. 1.

35. Hand-drawn Organization Chart by Gerald La Bove.

36. White tc Mazur Memo re: Request for support, i.e. transport burned TAM Packer, provide 3 documents. 
APPENDIX IV

Environmental Damage Report 
THIS PAGE

\section{WAS INTENTIONALLY LEFT BLANK}


OCT 061978

James L. Livexman, DASET

THRT: W11Lion B. Het, Director, RCr

Robert Catlin, scting Director, Osco

INCIDEAT AT WRST HACRBZRZT, IA

BACERGROUID

On Septenber 25 the SPZO Paject Office requeated wy presence at Vent Eackberry to establish a montorlng progra for activitles related to the recent fire and oll opsil. Tou $13 s w e d$ written orders to proceed lamediately to Weat Hackberry to support the SPBO Project Office. Professor Hason H1130n, UxI, and I arrived in West lackberry during the afternoon of Tuesday, September 26.

\section{DISCUSSIOA}

Opon arrival at the Fegt Hackberry bite I was assigned the task ef determintag the enviromental imact of the incident. Tha twodiate task vas to draft an Buviromental Assessuent Plan which would be outtablo to: the On-Scene Comiandex, Don Hazur; the Reglonal Responea Teas (BTT); and the varlous other environnentallsts (ubo had gathared on-scene) representing Federal agencies, State agencies, and anvariety of environental groupit

It took approxinataly 24 hours to: draft the plan; present it to the assemblage and assure then that DOB will address the oltuation properly; get thelr blessing; and then get to work.

During the perlod Septenber 26 - Occober 6 approximately 50 different people particlpated in the data gatherfing effort pithe Bnviromental Assessment Team. On Briday, Saturiay, Sunday, (Septenber 29 - Cetober 1) 40 people worked each day from 7 AX to 9 PH obtalning the majority of the more than 500 sclentific saples upon whlch the prellations assessment wlll be based. Initial sampling was corpleted on Detober 5; re-sappling is reconnended in 3,6 , and 12 months so that the full inpact may be completely described. 


\section{OPINIONS}

1. Oplnions specifle to the Wegt Hackberry IneIdent are contained in Iy Teport to the SPRO Project Managar (aee attached),

2. If the EIS's For the other SPBO gites are as deflclent as the Heat Hackberry BIS, I cee nothing but erouble for this projeet and BOB. This is aspoelalls true if there is a recurrence of incidents of this nature.

\section{RECOMRENDATIONS}

1. Recomendations specif1c to tha West Rackbarry Incident and general to SPHO are contalned in wy report to the SPRO Project Manager (ser artachad).

2. That Euture EV revlews of BIS'B be certatn to lnclude coments conceralng the adequacy of baseline inforation.

3. That EF te prepared to participate/respond to future Incldents of this nature.

Some phots and alldes are avallable if you desire a short briefing.

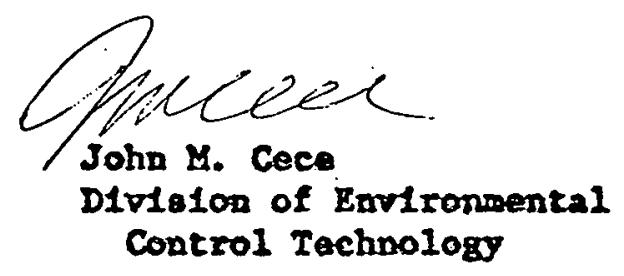

Attachont:

Cece report to SPRO Piroject Manager (datad Oct. 3)

ECT :NNP

JMCece: $\int \mathrm{df}$

$10 / 6 / 78$ 
Department of Energy

Strategic Petroleum Reserve Project Management Office

900 Commerce Road East

New Orleans, Louisiana 70123

October 3, 1978

To: $\quad$ SPRO Project llanager, New Orleans

From: J.M. Cece, Division of Environmental Control Technology

Subject: Report of Environmental Assessment Effort of West Hackberry incide

\section{BACKGROUND}

On Thursday, September 2I, 1978, there was a fire and release of oil at the West Hackberry site. On Monday, September 25, 1978, you requested assistence in establishing an envrionmental monitoring program for activities related to the incident. Professor Mason lilison and I arrived is West Hackberry late on Tuesday, September 26.

\section{DISCUSSION}

Tuesday, $9 / 26 / 78$

After our brief discussion with Hr. Jack Wilson you decided to proceed with an intensive environmental assessment. The DOE presentation of the environmental assessment plan to the RRT that evening indicated that they still had reservations about the details of the DOE intentions.

Wedne sday, $9 / 27 / 78$

The environmental assessment team, now consisting of State and Federal (DOE, EPA, etc.) environmentalists deliberated during the morning to 
develop the plan in more detall. An afternoon presentation to the re-assembled RRT resulted in their expression of favor for the intended DOE actions.

Thursday, $9 / 28 / 78$

This day involved all members in preparing an action plan, gathering equipment and sending for additional people.

Friday, $9 / 29 / 78$

Although some miscellaneous environmental data was collected as early as Sunday, $9 / 24$, this was the first day of organized collection of certified data. On this day we also responded to a DOE oil spill on Kelso Creek and an AMOCO oll spill on Black Lake.

Saturday. $9 / 30 / 78$

Vigorols over sampling of the environment continued. During an afternoon brief I eluded to the lack of baseline data; and presented the environmental assessment plar. You indicated general acceptance of the plan with a definite commitment to proceed with Phases I \& II commensurate with the development of meaningful scientific data.

Sundey, $10 / 1 / 78$

Sampling continued. Don Turphy visited site to assure contractors that their expenses will be covered by DOE. Their various proposals will be submitted as soon as possible. We continued development of detailed plans for the chemistry, biology, meteorology, and hydrology aspccts of the program.

Nonday, $10 / 2 / 78$

Sampline pröram continues. Reccived prelininary color photographs from EG \& G overnight of $10 / 1$. 
Tuesday, $10 / 3 / 78$

Completed final arrangements for custody transfer of samples to Dames \& Moore, Houston. Made final tour of site; departed site.

OPMIONS:

1. A very preliminary indicationis that the insult to the environment was minirial.

2. That quick reaction by site personnel and extremely favorable weather. conditions averted an environmental disaster.

3. That baseline environmental information does not exist for the West Hackberry site.

4. That the environnental assessment of this incident will be hampered because:

a. Baseline environmental informationis not available.

b. Four (4) difierent ciude oils were stored in the cavern and released during the incident. Difficulty is expected in differentiation these from oil (s) believed to exist in Black Lake because of other, non DOE, incidents. Additional complications are expected because of the partial pyrolysis caused by the fire.

c. The environmental assessment. was not begun until 5 days after the incident.

5. That the cooperation among govt. agencies reached unprecedented height during this operation. Your assistance and support were superb and provided the Impetus for what we expect to be a successful program. 


\section{RECOMIEIDATIONS:}

1. That the enylronmental assessment outlined in the previously submitted plan proceed and only be curtailed for technical reasons.

2. That the assembled environmental assessment team be given a semipermanent status:

a. to assist in developing environmental baseline for all SPRO. sites, and

b. to become familar with SPRO sites and available for response to similan incidents.

c. to modestly equip a portable trailer for use in baseline program and Immediate response to similar incidents.

3. That consideration be given to "tagging" DOE oil if it is determined that differentiation from other oils is impossible.

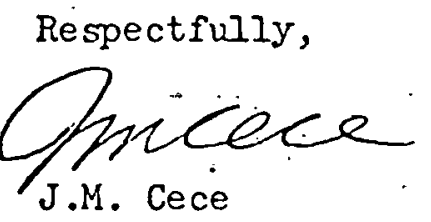

Attachments
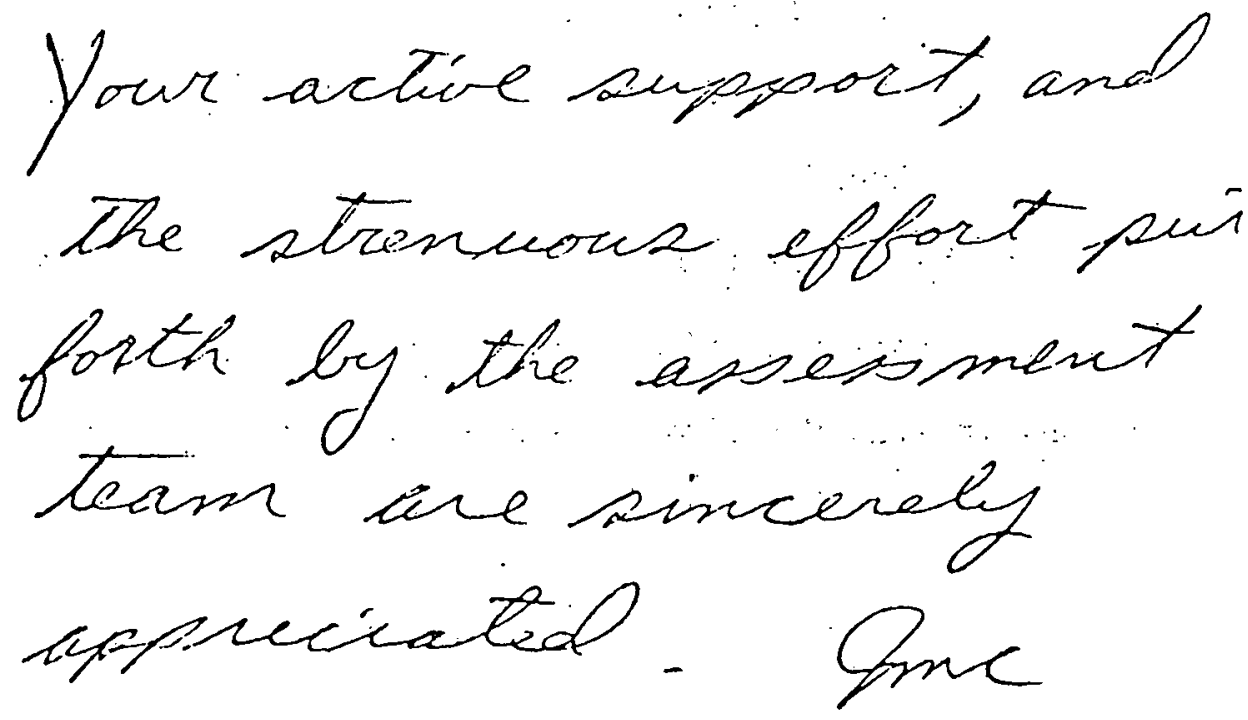
October 3, 1978

ATTACHEEITS TO CECE REPORT

1. Travel authorization dated Sept. 25

2. Activity $\log$

3. Environmental Assessment Team Organization $(10 / 1 / 78)$

4. Environmental Assessment Plan

(Preliminary - 9/27/78)

5. Environmental Assessment Plan (Interim - 9/30/78)

6. chemistry Plan $-10 / 1 / 78$

7. Biological Survey Work Plan - Sept./Oct. - 1978

8. Oil Expulsion - Accounted for \& Burn ( $/ / 29 / 78)$.

9. Procedures for establishing (sampling) stations

10. Field loz

11. Record of Chain of Sample Custody

12. Environmental Assessment Team (names and addresses of participants).

13. Cece report to Liverman \& Mott (10/2/78)

.44. Attendees - RRT mtg. 9/26/78 


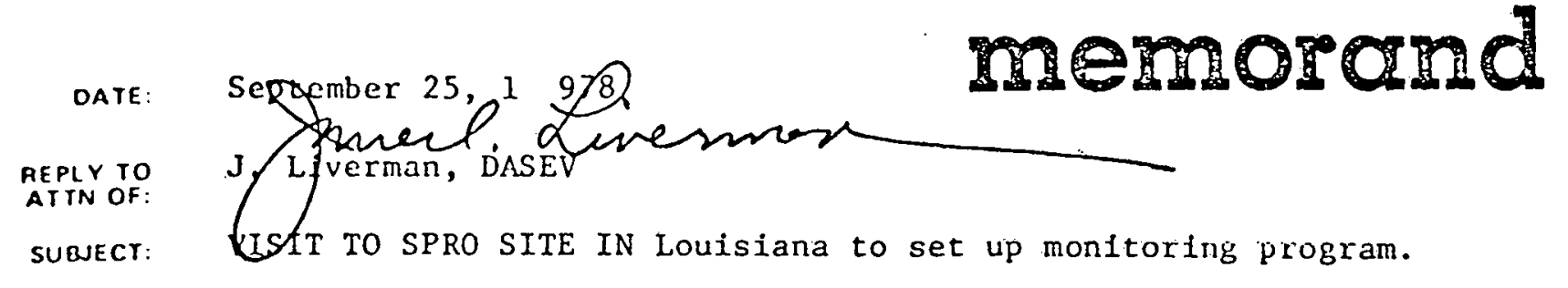

ro: JOHN . CECE, ECT

You are hereby directed to proceed immediately to West Hackberry La for the purpose of supporting the SPRO Project office in setting up a monitoring program for activities related to the recent fire.

Because of the urgent departure tonight with our offices being closed, you should proceed on your own credit with the knowledge that travel orders will be signed to cover you. 
J.M. Cece

Activity Log

Monday, $9 / 25 / 78$

11:00 a.m. - Alerted by OES and SPRO that my presence was requested ASAP at West Hackberry, IA .

12:00 - 3:00 p.m. - Discussed situation with various SPRO and OES personnel.

- Alerted Kason Wilson, Univ. of Rhode Island, who is presently under DOE contract conducting oil spill research.

5:00 p.m.- J.I. Liverman typed and signed emergency orders to proceed to West Hackberry, IA.

8:00 p.m.- Ecology Aucit, Lake Charles, IA. on scene to take air samples (8:00 p.m., 9/25 - 8:00 a.m., 9/26) 
Tuesdgy, $9 / 26 / 78$

8:00 8.m. - Departed Washington

12:00 p.m. - University of New Orleans brought to scene by EPA

2:00 p.m. - Arrived Lake Charles, IA.

4:00 p.m. - Arrived West Hackberry, IA.

5:00 p.m. - Met with Jack Wilson, SPṚO; requested that an environmental assessment team be assembled so that damage to environment can be assessed.

5:30 p.m. - Met with Bob Forrest, EPA; Bob Pavia NOAA, and otheis to develop assessment plan.

6:00 p.m. - Alcrted On-Scene-Coordinator (OSC) Don Mazur, SPR Project lianager, that we could perform two types of assessments:

(1) Scientific,

(2) Scientific with certified data gathering (able to be used in court of law).

6:30 p.m. - OSC decided to conduct certified scientific assessment.

- Notified URI data team to proceed to scene

8:00 p.m. - Presented outline of assessment plan to Regional Response Team (RRT) which. functions under Natl. Contigency Plan to monitor oil spill clean-up, disposal, assessment, etc.

- RRT not satisfied with outline of plan; requested more written detail.

10:00 p.m. - Scheduled meeting of various environmental groups for Wednesday a.m. 
Wednesday, $9 / 27 / 78$

8:00 a.m. - Met with various environmentalists on-scene to draft environmental assessment plan (see attached attendance list).

- Drafted, re-drafted, argued and discussed throughout morning

2:00 p.m. - Presented plan to RRT; plan accepted by:RRT; they wish to be kept Informed of changes in the plan and results of assessment.

4:00 p.m. - Requested on-scene Dames \& Moore personnel to.bring in more help

- Requested clerical assistance from on-site contractor.

5:00 p.m. - Requested that EG \& G scietrfic plane fly over site to get updated aerial photograph (for mapping purposes) and multi-spectral IR scan of entire affected area to assist in determing extent of root and oil dispersion downwind:- Discussed same with Tim McCreary, EG \& G; he will check availability of plane and schedule the flight. 
Thursday, $9 / 28 / 78$

- Spent day developing plans for sampling (what type samples, where take samples)

- Gathered people and equipment

- Established office and procedure for custody transfer of samples 
Friday, $9 / 29 / 78$

7:00 a.m. - Met with environmental assessment team to discuss data gathering;

- Emphasized that all data collected was the property of DOE, was to be properly witnessed and tagged;

- Made it very clear that individual entreprenaurs were prohibited from collecting their own data for their ow future publication; prohibited form publishing and/or commenting upon DOE data until after DOE data analyzed, Interpreted correlated, reviewed, and published (all team members to participate in this process).

- Basic philosophy is to over sample in both affected and unaffected areas

- Discussed environmental aspects of oil clean-up operation; advised OSC that heavy equip. not be permitted in marsh.

- Discussed site for temporary storage of waste materials; advised OSC to minimize area of contamination and select storage area near area already contaminated.

- At this time team consists of approx. 25 people:

8:30 a.m. - Active sampling begun in critical areas

7:00 p.m. - All sampling groups returned; began checking and storing samples 10:00 p.m. - Secured for night

4:00 a.m. - DOE oil spilled on Black Lake Bayou (Kelso Creek) at. LaBove dock (Shell pile) during transfer of sludge oil to barge.

9:30 a.m. - Assessment team notified of Kelso Creek spill; investigation begun 1:00 p.m. - Obtained scicntiflc samples of Kelso creck spill.

2:00 p.m. - Informed that AN,OCO production platform on Black Lake was leaking oil. Obtained semplc(s) of the slick and the ofl from the leaking tank. 
Saturday, $9 / 30 / 78$

7:00 a.m. - Active sampling continaes; two surveying teans on-scene to log location(s) where samples obtained;

- Have stressed taking chemical and biological samples at each station, as feasible:

- Presently utilizing approx. 40 peple in this effort.

- Excellent cooperation from all concerned.

1:00 p.m. - Briefed Don Hazur, SPRO Program lanager, New Orleans, an environmental effort. Fold him that SPRO made serious error by not gathering baseline info. before project started. Discussed scope of environmental effort and obtained his approval to hire contractors and proceed with Phases - I andII for an estimated $\$ 1.5$ million

- Assured on-scene sclentists and support personnel they will be paid for their efforts

- Requested DOE contracting officer on-scene to commit Govt. to pay worters

5:00 p.m. - Continued refining chemistry and biology portions of assessment plan

- Sampling continues

- Finished for the day; logging samples

- Established that "Rick" Taylor of Dames \& loore (Houston will be Assessment Team lanager (see attached) 
Sunday, $10 / 1 / 78$

8:00 a.m. - Active sampling continues with 40 people involved in progran (2 survey teams working to establish positons of sampling stations).

10:00 a.m. - Don Nurphy, DOE Contracting Officer with SPRO project, New Orleans, on site to assure contractors Univ. of Rhode Island, Univ. of New Orleans, and Dames \& Moore that they will be payed for their efforts. Requested that their proposals be submitted as soon as possible (Cece to review for technical content)

1:00 p.m. - Informed that dike around wellhead $\# 6$ was leaking acidic; stagnant, oil preganted water into Black Lake; obtained samples of said leaking water.

2:00 p.m. - Checked same and suggested that measures be taken to stop leak;

- EG \& G fly over for aerial photography and multi-spectral scan of dowmwind sector

- Obtained biology team plan from Bob Forrest, EPA, and Bob Pavia, NOAA.

- Obtained chemistry team plan from Ed Overton, Univ. of New Orleans 5:00 p.m. - Univ. of New Orleans team departed 


\section{Monday, $10 / 2 / 78$}

8:00 a.m. - Sampling program continues with approx. 30 people involved. Daily operations turned over to "Rick" Taylor; Dames \& Moore

10:00 a.m. - Received preliminary photos from EG \& G overfilght of 10/1. Put photos as mosaic to be able to pinpoint locations of sample stations. IR photographs being analyzed; results will be sent to D.C. 
Tuesday, $10 / 3 / 78$

8:00 a.m. - Some scientific samples transferred via custody recelpt to Dames \& Moore, Houston. Samples are to be inventoried, cataloged, and plotted on map(s). Sarmples will be divided Into high, medium, and low categories. High priority samples. will be analyzed and interpreted as soon as possible to determine preliminary extent of impact.

5:00 p.m. - Made final tour of site. Filed this report, and departed the site 


\section{ENVIRONENTAL ASSESSMENT TEAM}

WEST HACKBERRY INCIDפT T
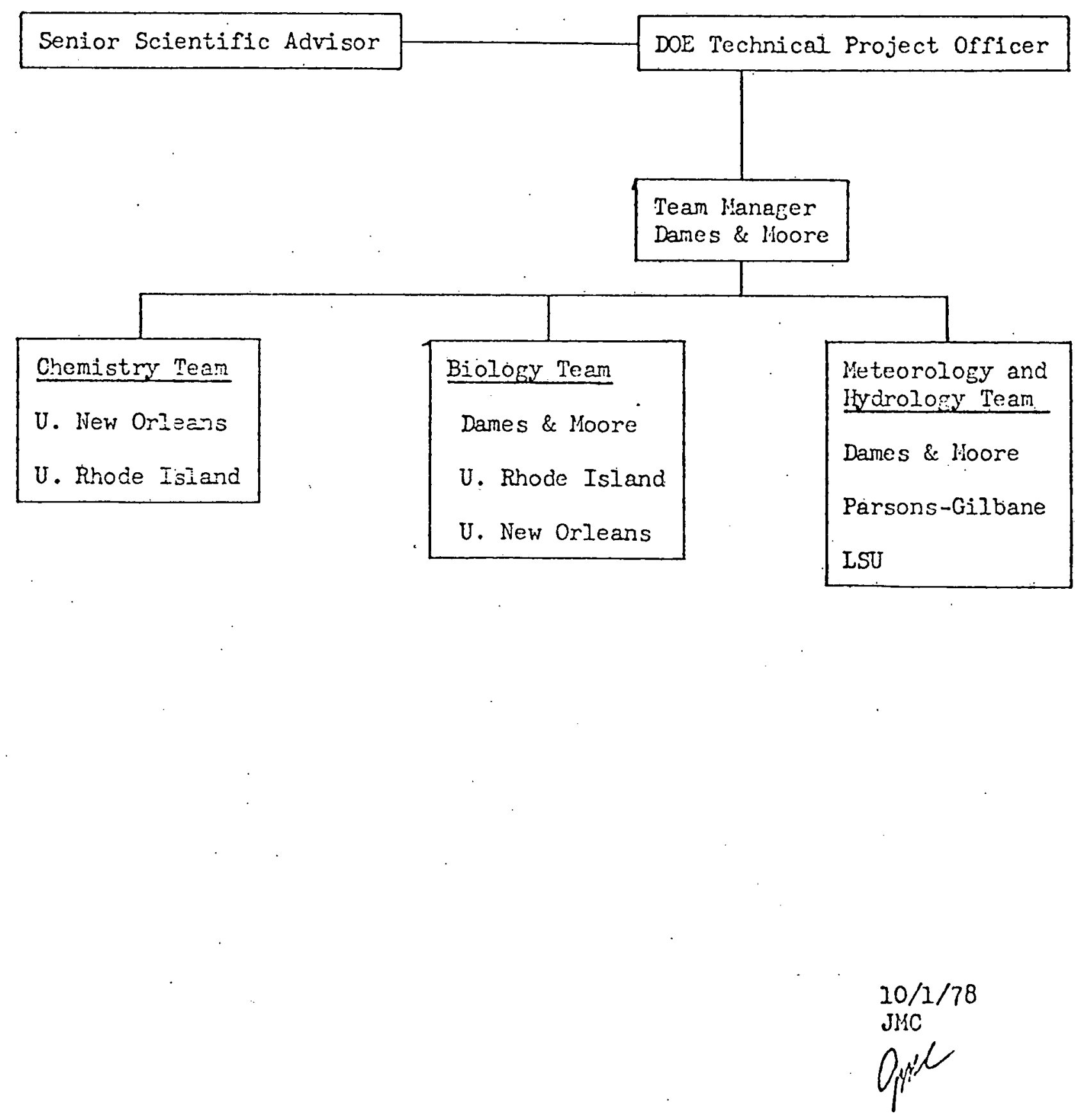


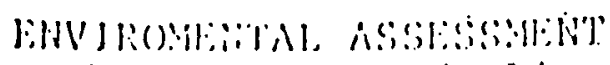

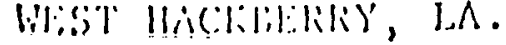

OBJFE'TTVES

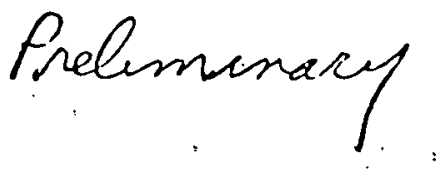

A. WHERE IS 'THE: $\mathrm{BO}$ : OTL

B. ASSLSS DAIMCE
A. Watcr
B. Harsh
C. Inland

\section{GENERAL:}

1. Examine both affected and inaffected area

2. Document as possibje, the enviromental status before the incident.

3. Interview neàby residents to be DOE tasks.

4. Include on-sjete damage, injurics, deaths, as part of assessment.

5. Socio-licononic Impact
A. Lost recreational benefits
B. Lost commercial production 


\section{ASSESSIIENT TENH}

$9-27-78$

\section{INTER}

Grid network; precise locations

Surface

Water Column

Sediment
Distribution of hydrocarbons (Primarily sediments)

Marine Organisms as possible near sampling stations

Affected and unaffected areas

"Tight" sampling near run off points

Hydrology model?--recommend hydrology made not be developed

Repeated sampling as $F$ ( $t$ ime)

Impact of higher forms of life

(e.g. muskrats, birds, shrimp, crab, barnacles)

Wind movement of surfaep water.

Downwind water fallout (see INLAND section)

Note: Unaffected aiea (mostly likely northest area of Black Lake) 
2. MARSH

Affected marsh area is relatively small

1 mile $\times 200-300$ yards

Grid. netwrok; semi-precise locations

Surface

Hater.culumn

Sediment

Marine organisms - - Plants

Determine affected and unaffected (area IR Photo)

Terrestrial organisms (Plants and Animals)

Terrestrial samples (2 $\mathrm{MH}, 2 \mathrm{CH})$ Soil

Repcated sampling- F (Time)

J.F the marsh is burned:

(Sample before)

(Sample after)

Extent of presence of oil

Stake out piece of land and monitor as F (Time)

Usage by migratory waterfowloirds? (appears very low 
3. INLAHO (PIUME)

(Affected vs unaffected areas).

Map extent of fallout

(oil extent)

(soot extent)

Grid sampling as F (Time)

Affect on terrestrial life

(Cows affected)

(Wilk. affected)

Lake area (downwind)

(Same as for water)

Terrestrial life-

(Plant life)

(Domestic animals)

Farms/vegetable downind

Physical effect

(Soot on cars)

(0il on cars) 


\section{ENVIRONYENTAI ASSESSIEIT PINH YEST HACKBERRY, LA.}

Reference: Environmental Assessment Plan

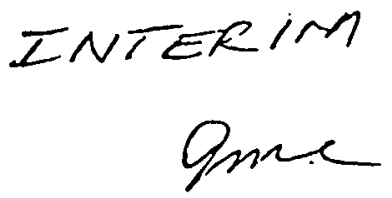

OBJECTTVES

A. Determine geographical area covered by DOE effluent.

B. Assess Environmental impact caused by DOE effluent.

1: Water

2. Marsh

3. Inlard (plume fallout)

GEIVERA

A. Document, as possible, the environmental status before the incident.

B. Letermine acute and chronic impact upon the environment.

C. Include

1. On-site environmental Impact, injuries, death.

2. Dost recreational benefits and commercial production.

D. Re-sample $(2$ at 3,6 , and 12 months.

(Consider results of initial and subsequent samples to determine extent of analyses). 


\section{PHPSE I (months $0-6$ )}

1. Vigotous chemical and blological sampling (over sampling) of water, marsh and terrestrial (plume fallout) areas. Meteorlogical and geological sampling as needed and as opportunities permit. (Estimate 440 samples: 200 chemical, 200 biological, 20 meteorlogical)

2. Establish viability of chemical analyses in both qualitative and quantitative separation of DOE oil from other sources.

3. Analyze approximately $80 \%$ of samples obtained (336 analyses (2) $\$ 3000=\$ 1,000 \mathrm{~K}) \quad($ Replicate $10 \%$ of samples, $\$ 100 \mathrm{~K}$ ).

4. Publish preliminary assessment Collate and interpret data Publish report (month 10-12)

PHASE II (months $3-6$ )

1. Re-sample at those stations indicated appropriate by preliminary results from Phase I. (Estimate 320 samples: 160 chemical, 160 biological, no meteorological)

2. Analyze and interpret approximately. $80 \%$ of Phase II samples (130 sanples $\otimes \# 3000=\$ 780 \mathrm{~K}$ ) (Replicate $10 \%$ of samples - $\$ 78 \mathrm{~K}$ )

3. Reporting

A. Prepare avallable interpreted data for preliminary assessment.

B. Prepare remaining interpreted data for final assessment. 


\section{PHASE III $\cdot$ (months 6 - 9)}

2. Re-sample at those stations lndicated by preliminary results from Phase II. (Estimate 200 samples: 100 chemical, 100 blological)

.2. Analyze approximately $80 \%$ of these samples (160 samples (1) $\$ 3000=\$ 480 \mathrm{~K})$ (Replicate $10 \%$ of samples $\$ 48 \mathrm{~K}$ )

3. Reporting

a. Prepare correlation of chemical and blological data. b. Prepare correlation of past samples as function of time.

PHASE IV (months $12-15$ )

1. Re-sample, as before (estimate 160 samples; 80 chemical, 80 biological)

2. Analyze and interpret samples ( 120 samples $(3 \$ 3000=\$ 360 \mathrm{~K}$ ) (Replicate $10 \%$ of samples $=\$ 36 \mathrm{~K}$ )

3. Reporting

a. Correlate chemlcal and biological data.

b. Correlate $w /$ previous interpreted data. 


\section{PHASE V (months $12-16$ )}

1. Overall correlation, interpretation and review of findings by environmental assessment tean.

2. Overall review within DOE.

3. Overall review by other involved agencies.

4. Publish final report. 


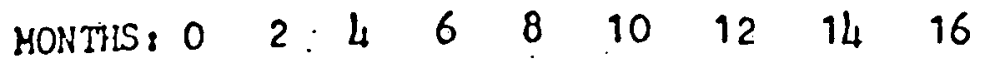

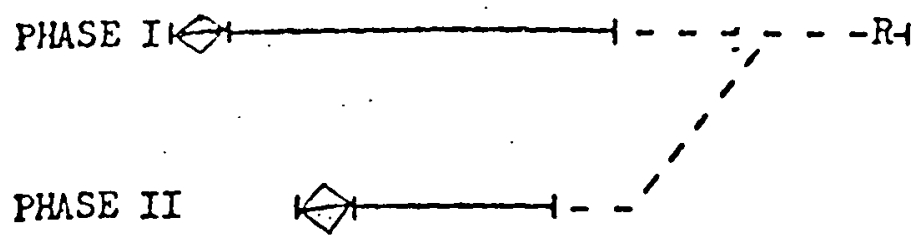

PHASE III

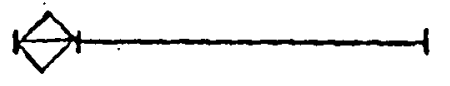

PHASE IV

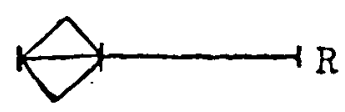

PHASE $\nabla$

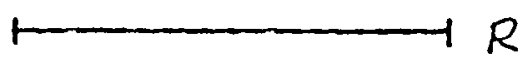

$\forall$ indicates data collection periods

$\mathrm{R}$ Indicates formal report 


\section{CHEMISTRY PLAN}

Objective: 1) distingulsh between DOE o11 in the environiont and South Ia. crude

i) attempt to quantitate amount of DOE oil in sample

3) attempt environmental assessment

\section{SAMPIDNG}

a) take area - 40-50 stations in grid network across lake from flre site

b) marsh and affected area - grid network in affected area

c) down wind - selected sampie site near roads or in accesable water area

d) saimple type

1) sediment

2) wator

3) biota

4) alr

5) foliage

6) DOE \& South Ia. crude oil

7) surface slicks

8) foans

\section{ANALYTICAI TECHIIOUES}

8) GC \& CCHS

8) extract samples and fractionate into hexane $30 \% \mathrm{CH}_{2} \mathrm{Cl}_{2}$ in hexane and $\mathrm{CH}_{3} \mathrm{OH}$ fractions

b) anslyze hexare and $30 \% \mathrm{CH}_{2} \mathrm{Cl}_{2}$ in hexane fracticta using high resolutions glass capizlary GC techniques

c) select certain samples for GCMS analysis

d) examine and interpret data

1) establish high resolutions glass capillary GC patterms for hexane and $30 \% \mathrm{CH}_{2} \mathrm{Cl}_{2}$ in: hexane fraction

2) identify majority of components in these fractions

3) identify components unique to DOE oil

4) search for these components in environmental samples

5) apply cluster analysis to data

6) display dats in 3D plotting format

7) observe affects of weathering on DOE and South La. crude oil

8) apply "other" parameter such as homotogue distribution plots, otc. to Identify DOE oil in environental samples

b) IR Analysis

c) Traco Metal Analysis 
CORROLATTNG DATA

Data and interpretcd results will be complied at meeting between participating scientist. CBO will write report for DOE on final evaluation of these analysis. 


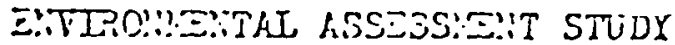

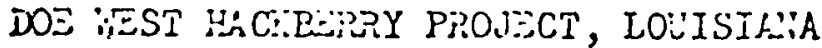 \\ SEPR./OCT. 2978}

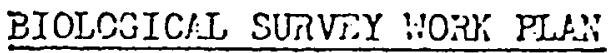

\section{OBJECTIVES}

A. To delivicte, in corjunction with cherical ar:2ljsis, the extent of DOE oil coniamiration in three oenseil habitsts adjacent to. the oil spill and fire plune.

B. To chamecterise each hebitat es to the corrurity types present.

c. To monitor over tine how the hebitats in areas affected by the dil soill and sire flune rag change rith reference to sirilar unafrected areas.

II HORK PIAH

A. Samitis kill te conducted in three rajor hajitats including:

(1) $I=\div e$

a) Felagic

b) Eentinos (irifaunal; epi fainol)

(2) :2rsh
a) Plazis
b) Bsntios (irfanrial, epi faurol)

(3) Terresinizid

a) Planis

b) Soil (íraunal, epi fauriol)

B. Black Lve Senging

(1) Pelaric

a) Sexpline for FHC in tissues will be cerried out in three areas, using Eill reets:

i) Control area uplind from spili.

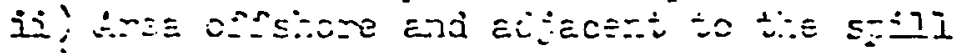

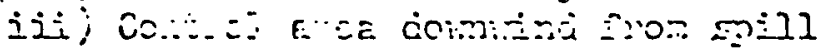

Situe Sennies

7

i

1

b) Frotorranis of zill net cotches to illüsuret.e size classes of fisin.

(2) Der:ticic

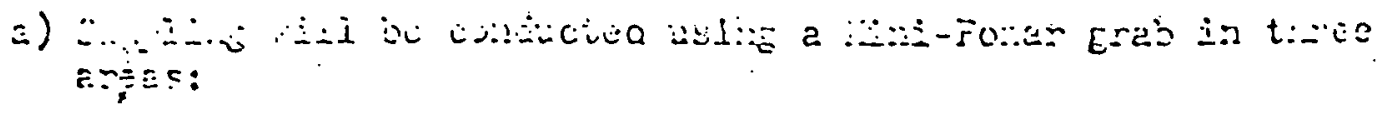


1) Cantrol area usind

ii) Onfshore, acjacent to soill

ili.) Control area dommind fror spill

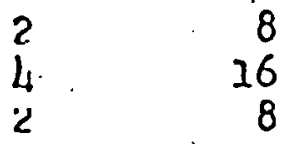

b) ft each sErole site, four replicate samoles will be taken

1) Three saiples for l:aititat ciantification

ti) O.e saiple for PiC analysis

c). Ons seived sasple will be saved for Erain sizie distribution aralysis.

\section{Jarsh Saroling}

(1) Lok liarsh - generally deijised as that persh zone contigious with open laire creas and chenacterized by shallow weter with

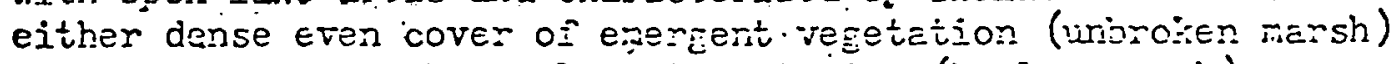
or scattered siall hamoct:s of vagetzition (broken rersi).

e) Use grid systen, selecting areas in the broten rensh (oifshore) -and unbroken nersi areas for detailec anaysis. Winth each

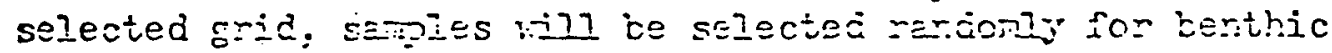

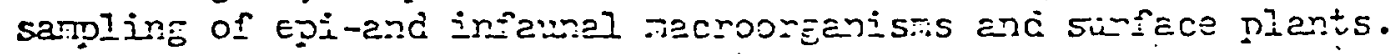
Sarigles wili be collected in three riejor areas:

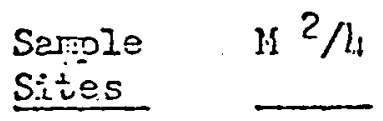

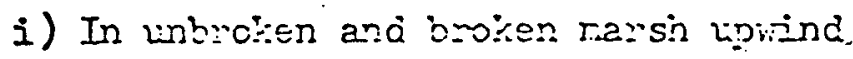
of spill

ii) In uribroisen and broi:en remsh aojacent to soill

iii) In unjotien and brolen narsh donntind of:spill

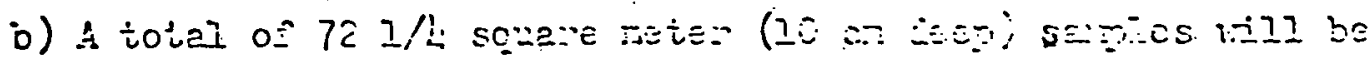
collected.

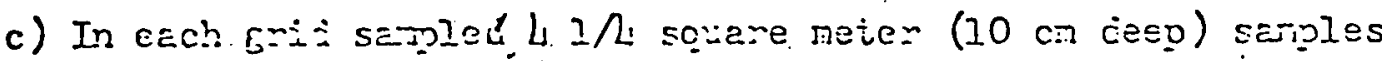
vill be taiten por Grid:

i) Trree se?ples for cuantiric:tion

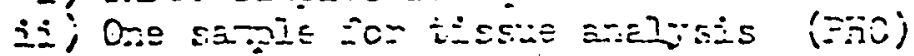

d) Qualitative descriptions of each erea sspled iill be iafien.

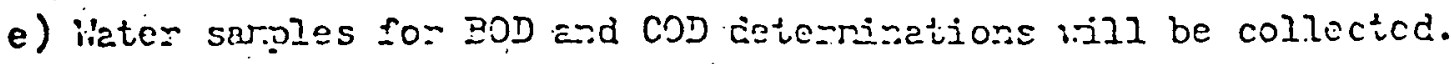




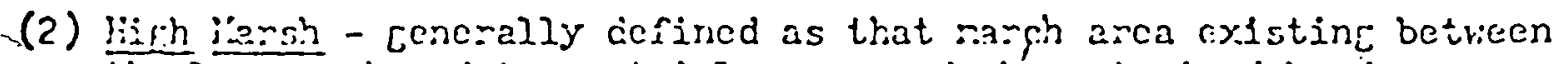
it.e lol: :arsh and terrestrial zones and claracterlacd by dense vecetation in shallo: water or areas intertituently poocicd during ticial cycles.

e) Sanples vill be collectid by minning transects throuch the marsh. iguarter sous re reter sarples (4), $10 \mathrm{~cm}$ deep, will be obtiined on both sides of a transect line, ho neter's lonis, at selected intervals:

$\begin{array}{ll}\text { Nio. Sample } & \text { Total } \\ \text { Sites } & \underline{1 / 4 !^{2}}\end{array}$
i) Uprind
ii) Adjaccit
3
6
72
24
iii) Dormrind
3.12

\section{Terrestrial Sempling}

(1) Sempling will be conducted using transects continiting the sane lines be oun in the nigh rarsh.

Tinee areas will be sempled:

\begin{tabular}{|c|c|c|}
\hline & $\begin{array}{l}\text { Sitple } \\
\text { Sites } \\
\end{array}$ & $\begin{array}{l}\text { No. of } 1 / 411^{2} \\
\text { (10 cm deed) }\end{array}$ \\
\hline $\begin{array}{l}\text { a) Upirind control } \\
\text { b) fdizcent inicid areas }\end{array}$ & 4 & 16 \\
\hline c) Domitind control & $\begin{array}{l}4 \\
4\end{array}$ & $\begin{array}{l}16 \\
16\end{array}$ \\
\hline
\end{tabular}

(E) Serpling will also be conciucted in vooded uplends, nastures and.

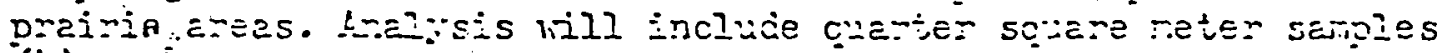
(4), $10^{\circ} \mathrm{cm}$ deep, on each sice of the iransect at selected inievials.

(i) fit sites where collection has done for chenical ar.alysis, a description of veretation tufes and a characteriation of land use vill be performec. In adiition, at selected locations at these sites, siall ramil trajs vill be set to obtain tissue samles foi cinemical aralysis. 
3. Fiysicurflituilcal lieasurenents

(1) R:easurements rill pri-a-ily be obtained by resident project environrental personzel.

\begin{tabular}{|c|c|c|c|}
\hline $\begin{array}{l}\text { Yater } \\
\text { Colunn }\end{array}$ & $\begin{array}{l}\text { LeV:e } \\
\text { SEsinent }\end{array}$ & $\begin{array}{l}\because \text { arsh } \\
\text { Sedi-ient }\end{array}$ & $\begin{array}{l}\text { Terucst:ial } \\
\text { Ssil }\end{array}$ \\
\hline
\end{tabular}
a) Romography
b) Tenpenature
c) Salinity
d) $\mathrm{pH}$
c) $\mathrm{DO}$
f) Fiedox

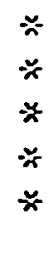

\begin{tabular}{|c|c|c|}
\hline$\approx$ & $\not{*}$ & $\approx$ \\
\hline$*$ & 은 & $\approx$ \\
\hline$*$ & $*$ & \\
\hline
\end{tabular}




\begin{tabular}{|c|c|c|}
\hline $\begin{array}{c}\text { WEST HACKBERRY } \\
\text { ACCIDENT }\end{array}$ & $\begin{array}{l}\text { STRATEGIC PETROLEUM } \\
\text { RESERVE PROJECT } \\
\text { OTI EXPLUSTON, ACROUN'TED IOR \& BURN }\end{array}$ & $\begin{array}{l}\text { NAME: } \\
\begin{array}{l}\text { B. MAZURKIEWIC2 } \\
\text { DATE: } \\
\text { SEPTEMBER 29, } 1978\end{array}\end{array}$ \\
\hline
\end{tabular}

attached is a project office summarv of the amount of oil expelled, accounted for.

burned durina the West Hackberry $\| 6$ cavern decompression accident. Ihese fiqures

:e formulated by Messrs. Ford and Mason (GIEC), Lorenzen (PB/KBB), Snyder (RMP), Ilen, Mazurkiewicz (DOE), and represent the project office position on the accident's quantities.

(Barrels)

0il Expulsion,.................................67,510
- Decompression of salt $=38,030$
- Decompression of brine $=6,680$
- Decompression of oil $=22,800$

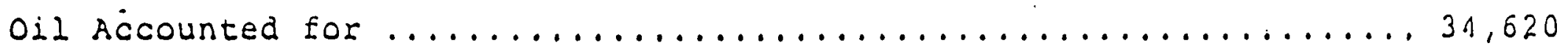
- Elack Lake
$=3.2,200$
- Puinped to Cavern $\# 7=2,100$
- In Sheli on Pad
- 530 (fourd to be veny low ectirnate)
- Soit
$=790$
Grie $10 / 3 / 28$

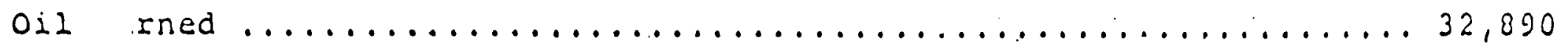


Please follow the following procedures for labcling stations

$$
\underset{\substack{\text { statoon } \\
\text { number }}}{ }-\frac{30}{\text { day }}-\frac{c}{\begin{array}{l}
\text { established by } \\
\text { chemical } \\
\text { sample }
\end{array}}
$$

If a biolozy Eroup samples.aftemard at the chemistry station, retain the original $C$ ard add a $B$, then we'll know that both biological and chemical samples were obtained at the same site, and the station should read.as

$$
2--30-C
$$

Please follow this sequence, reversing the sequence vill lead to erroneous labeling. If the biolocy group should establish a station, then it should be

$$
2-30-B
$$

which should be a corpeltely different station than $2-30-C$. If you sample at a station established in a previous day use the date on which it was established and not the current date. The date the samplè is taken appears elserihcre on the card.

SAIPLE MUITEEREIMC

If you take a number of different samples at the same stations and wish to designate them: First, use the number on the tag as follows:

$$
\frac{157}{\text { tag }} \underset{\begin{array}{c}
\text { number } \\
\text { three } \\
\text { sample }
\end{array}}{\frac{3}{\text { Bumber }}} \frac{B \text { Analysis }}{\text { Ansical }}
$$

Do. not usc a tag for more tiran one sample.

RENIYIDER: Your cooperation in recording your visual observations for the diur are cxt:erely useful in recreating a composite description of the sp1ll. 


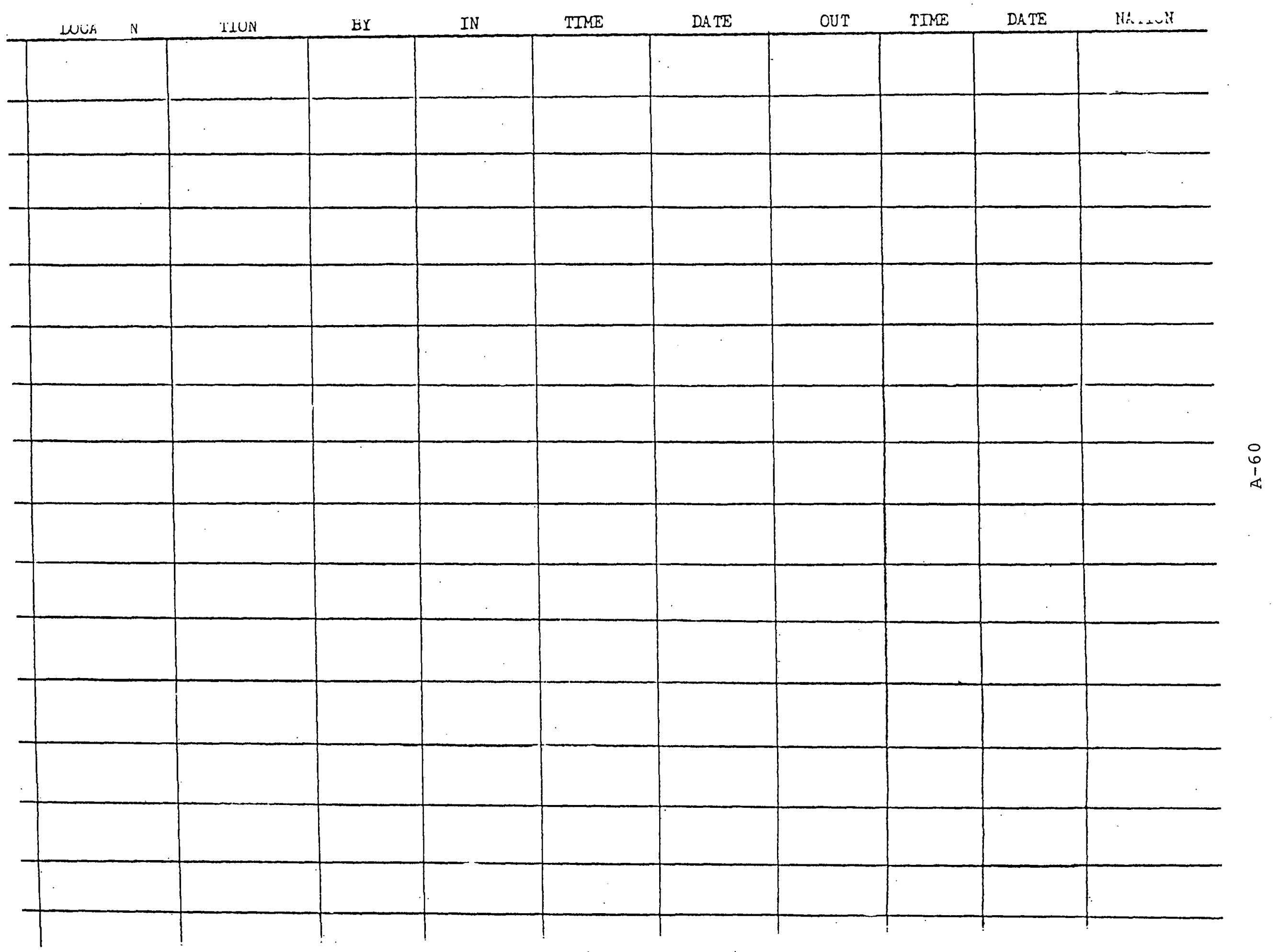


SALIPLE HO.

LOCATION OF SNIPLE

כATE

TIIE

TIE. SAHPLE WAS TAKEN.

DESCRIPTIOII OF SAYPLE

TO BE SEIT TO

INAE OF SAIPLER

WITHESS TO TAIING SAIPLE

PRESARVATIVE

TRAISGFER AUD STOORAGE

SAIPIE RECEIVED BY

DATE

TIVE

SAIPLE RECEIVED FROS

PURPOSE OF TRNASFER

SAIPLE RECEIVED BY

DATE

TIN

SAIPLE FECETVED FROY

PUIPOS: OF TRUISFER

SNPPLO FECIVID BY

DATE

TIIE

SAIPLE RECEIVED FRO:1

PURPOSE OT TRANSFUR

SNUPLE RECEIVED EY

DATE

TIVE

SAMPLE RECEIVED FROH

PURPOSE OF TRAISTER

DISPATCH OF SAMPIE

DATE OBTAIHED

TIME OB'ATED

source

DATE DISPATCIEDD

TIUE DISPATCIED

IRTHOD SHIPPED

\section{MINLYSIS}




NAIE
John Cece
DOE

Mason P. Wilson, Jr., Drector UNIVERSITY OF RHODE ISTAND

Mark Ahmadjian.

UNIVERSITY OF RHODE ISLAND

Gina Garofalo

UNIVERSITY OF RHODE ISLAND

Chris Ordzie

UNTVERSITY OF RHODE ISLAND

Alex Pszenny

UNIVERSITY OF RHODE ISLAND

Chris Brown

UNIVERSITY OF RHODE ISTAND

Patricia Lynch

UNIVERSITY OF RHODE ISTAND

Mark Boudreanx

DAHES AHID YOOPE

Plary Kutac

DAIES AID KOORE

Rick Taylor

DALES NID LIOORE

Robert E. Cox

PARSO:IS-GILBANE

Glenn A. Killer

PAISOII-GILBAIS
BUSINESS ADDRESS

DIV. OF ENVIRONMIENTAL CONTROL TECHNOLOGY

MAILROON E-20I

U.S. DEPT. OF ENERGY

HASHDIGTON, D.C. 20545

401-792-2330

CENTTER FOR ENERGY STUDIES

WALES HALI

UNIVERSITY OF RHODE ISLAND

KINGSTON, RHODE ISLAND 02881

$401-792-2369$

DEPT. OF CHEIISTRYY

UNIVERSITY OF RHODE ISLAND

KINGSTON, RHODE TSIAND 0?RRI

401-792-2481

401-783-2304

401-792-2481

$4.01-783-2304$

$401-792-6256$

$401-792-2369$

401-792-2369

$318-862-4706$

231 WOODIIARD HAII

UNIVERSITY OF RHODE ISLAND

KINGSTON, RHODE ISIAND 02681

DEPT. PINNT PATH \& ENTOYOLOGY

UNIVERSITY OF RHODE ISLAND

KINGSTON, RHODE ISLAIID 02881

BOX 48

GRAD. SCHOOL OF OCEANOGRAPHY

UNIVERSITY OF RHODE ISLAITD

KINGSTOIR, RHODE ISLAND 02881

DEPT. OF CHEMISTRY

UNIVERSITY OF RHODE ISLAND

KMNGSTON, RHODE ISLAND 02881

DEPT. OF CHCMISTRY

UNIVERSITY OF RHODE ISLAND

KDIGSTON, RHODE ISLAIID 02881

WH-SITE

$504-733-5142$

800 COIRERCE ROAD WEST

NEW ORLEAIS, IA. 70183

2020 WORTH LOOP WEST

HOUSTON, TEXAS 77018

$504-733-5142$

800 COIDERCE ROAD WEST

P.0. BOX 23702

WEW ORLENHS, IA. 70183

$504-733-5142$
WH-SITE \& .

800 COMPERCE ROAD HEST

P.O. BOX 23702

NE!: ORLEANS, IA. 70183 
NAIE

Bob Forrest

EPA

John Iaseter

UNIVERSITY OF NEW ORLENHS

ERIPVESTIY OF IEN ORLEANS

Charles Steele

UNIVERSITY OF NEI ORLEAIS

Patrick Remele

UNTVERSITY OF NET ORLEANS

Jim Kartin

RET, U.S. CORPS OF EIGDVERS

Robert Pavia

NORA/RESA

Larry D. Racca

LA. STREAI CONTROL COMIISSION

Jake Valentine

U.S. FISH \& WIIDLIFE SERVICES

John R. Walther

U.S. FISH \& HIIDIIFE SERVICES

Charles thite

IA. DEPT. OF WILDLIFE

Geoffrey Scott
BUSMIESS TELEPHONE

$214-767-2720$

FTS 729-2720

$504-283-0645$

$504-283-0645$

$504-283-0545$

$504-283-0645$

$504-865-1721$

$601-688-3333$

$318-436-366 i^{\circ}$

$318-762-5135$

$318-436-3661$

$803-559-0372$

$713-688-4541$
BUSTIESS ADDPESS

EPA REGION VI, Ist. DNTNATL.

$B L D G$.

1201 ELLI

DALLAS, TX 75270

CENTER FOR BIOORGANIC STUDIES

UNIV. OF IVEW ORLEANS

IAKEFRONT

NEW ORIEAHS, LA. 70122

CENTER FOR BIOORGANIC STUDIES

UNTV. OF NEW ORTEAIS

IAKEFRONT

NEW ORLENIS, IA. 70122

CENTER FOR BIO-ORGAIIC STUDIES

UNIV. OF HEN ORLESTIS

IAYEFRONT

HEI ORLEAIS, LA. 70122

CEITTER FOR BIO-ORGANIC STUDIES

UNITV. OF INEI ORLEAINS

LAKE FTONT

INEN OPLEAIS, IA. 70122

NEi ORLEAHS, IA.

NOAA/ERT/IESA

NSTL STATION, US 39529

IAA. STREAH CONTROI COIOISSION

$2213 \mathrm{~N}$. LAKESHORE DR.

IAAYE CHARLES, ILA. 70601

LAFAYETTE, IA.

MANAGER, SABITE WTLDLIFE REFUG:

$1213 \mathrm{~N}$. IASKESHORE DR. LAYE CHARLES, LA. 70501

EPA-GULF BPEEZE ERL, BEARS BLUFT FIELD STA. P.0. BOX 368

JOHN'S ISLAND, S.C. 29455

2020 N. LOOP WEST HOUSTON, TEXAS 77018 
To: James L. Liverman, DASEV (Germantown)

William E. Mott, Direstpr, ECT

From: J.M. Cece, ECT
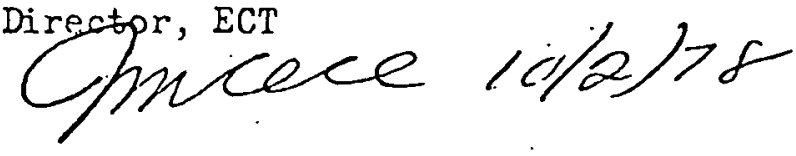

\section{WEST HACKBERRY IINCIDENT}

At SPRO request have:

1. Assembled environmental assessment team to assess environmental impact of West Hackberry incident.

2. Developed environmental assessment plan (with NOAA and EPA input) to determine acute and chronic impact of incident.

OPINIONS: Environmental assessment will be hampered because:

1. Baseline environmental information not available.

2. Four (4) different crude oils were stored in cavern and released curing the incident. Difficulty is expected in differentiating these from oil (s) believed to exist in Black lake from other, non DOE, incidents.

3. Environmental assessment not begun until 5 days after incident.

SPRO further requests approximately $10 \%$ of my time for next 12-16 months to monitor completion of assessinent.

Excellent cooperation obtained from existing contractors, DOE personnel and site contractors. Progrem proceeding vell.

Expect to return to office Thursday, October 5, 1978. Will file trip report at that time.

cc: SPRO Project Office, New Orleans 
APPENDIX V

Medical Data

A -65 
THIS PAGE

\section{WAS INTENTIONALLY LEFT BLANK}




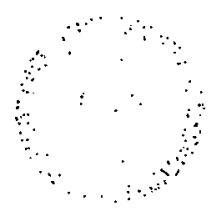

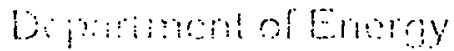

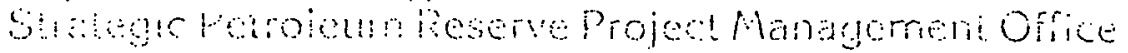

ofommonedent

Hew Onens, Lonsian 70123

October 4, 1978

Beton Ponge General Hospital

Hedical Recorcis Deportment

i. O. P.or 2511

Bator Roilge, LE 70821

Gentlemen:

The Departnent of Energy is conducting an investigation into the fire at the west. Hackbarry petroleum Reserve site on Septemiser 2l, 1979 . As chaimen ofi that comities, I am reguired to coiled and evaluate ali pertinent data related to thet incident:

I would appreciate receiving from you a copy of the discharge sumary ana history of the late Wr. Clarence simon Who was involved in the fire and treated at your hosping. I would appieciate copies of the death certificate and any autopsy reports that may have been performed.

I thank you for your cooperation.

sincercly,

Philip C. White, Chaiman Headguarters Investigation Comitioe 
This pieiont was involved in a burn incident on an oil ris approximately $3: 30$ today, He was brought to the hospital in Lake Chates, Louisianir and treated achenly and when he was thought to be stabiliged he was transfered to the Burn Unit at the baton houge Goneral fospital via helicoptot. On arrival to the Burn

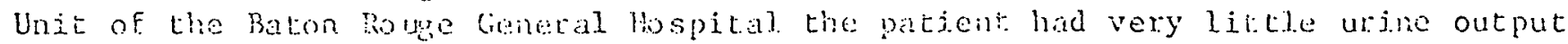
and was found to hive appoxinately $65 \%$ total burns with approxinatedy $35 \%$ of this being full thickness. The patient had fuli thickess buras of ooth upper extremities from just below the axilla and the del toid proninence to the

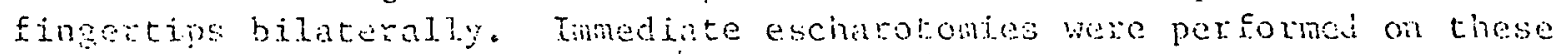

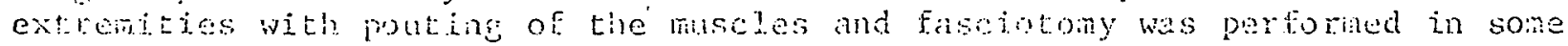
areas. This did not scen ro relieve the $i$ schema of the fingers but as prevously stated the ingors and hands hat full thichess burrs. Escharotonies were bejng planned for individual fingers and then the hand. Ateention was turied to the fact that the petient had circumoral and circumasal burns,

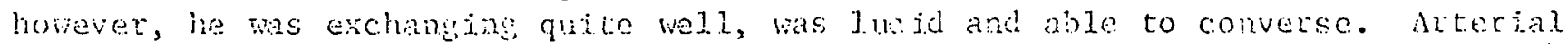
blood gaose were obtained and the patient had a 102 of 118 . Becalue of the

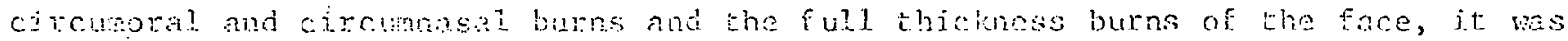

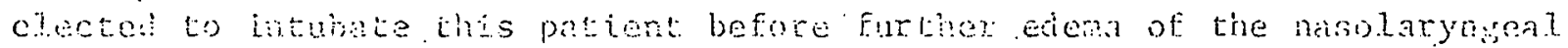

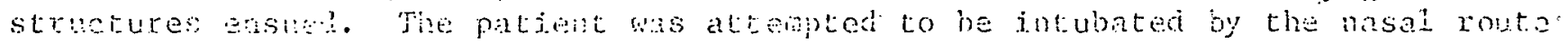

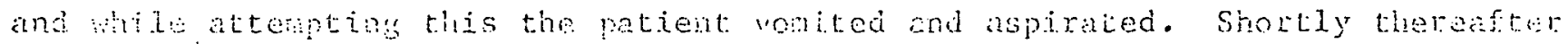

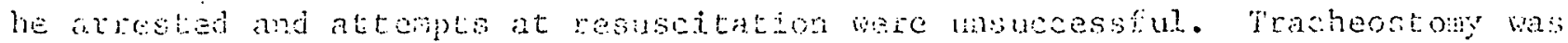

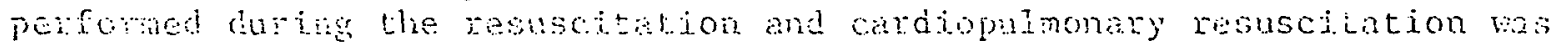
ariningered.

$\mathrm{DC} / \mathrm{s}:$

$9-22-78,9-25-78$

c.

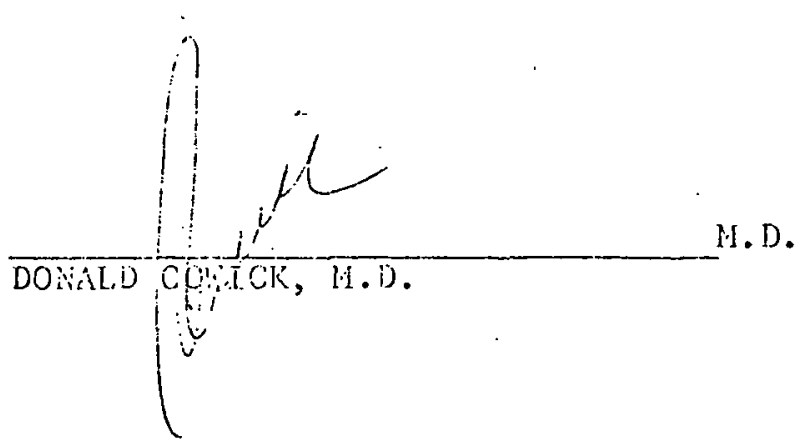


BATON ROUGE GENERAL HOSPITAL

Baton Rouge, Louisiana
SIMON, CLARENCE

Admitted: $9 / 21 / 78$

Dr. D. R. Cowick

PLEASE SEE THE DEATH SUMIARY FOR ADEQUATE

HISTORY \& PHYSICAL EXAMINATION.

DRC : mps

DONALD R. COWICK, M.D.

DD: $10 / 13 / 78$

DT: $10 / 17 / 78$

cc: Dr. Cowick 
PROGRESS NOTES

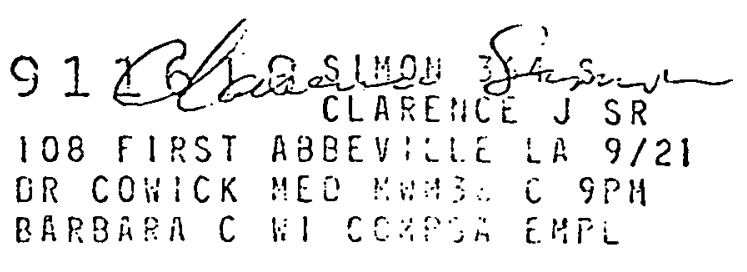

DATE

NOTES

Biter it Shote - Death Note -

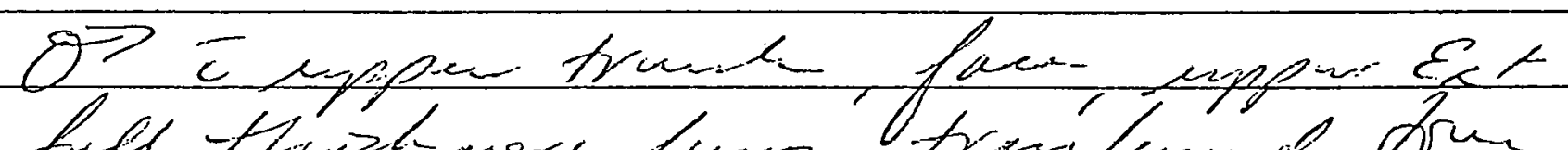

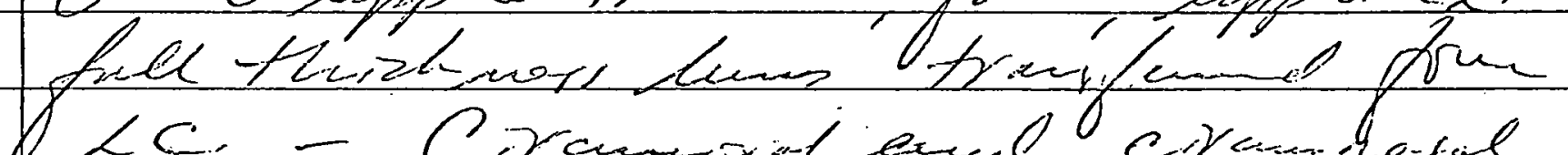

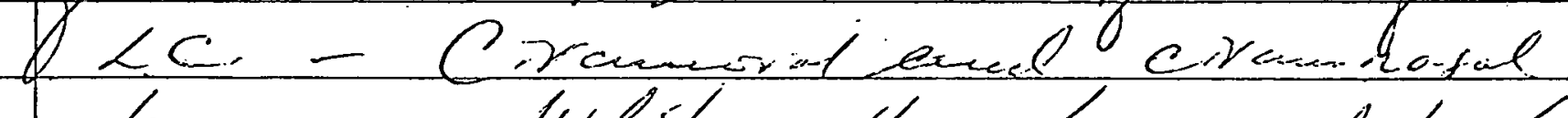

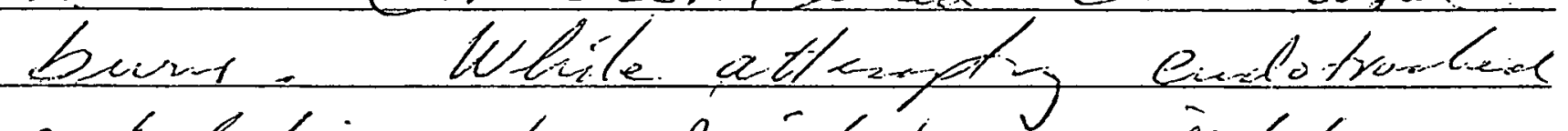

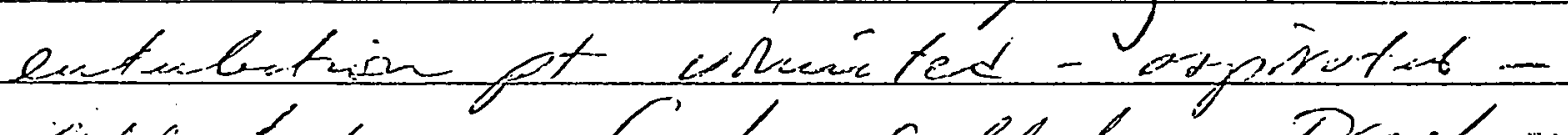

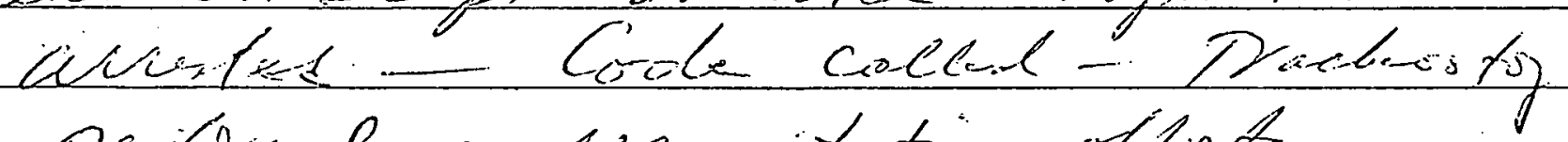
prifonel - rescraitatine ff orts

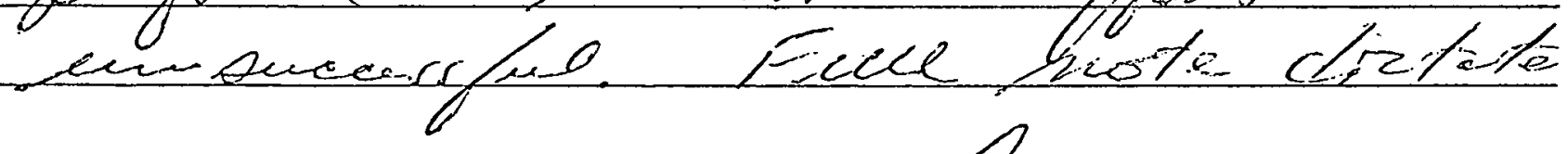

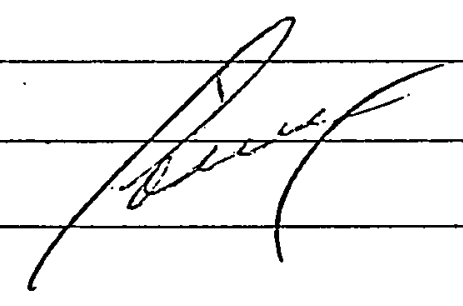

FORM NO. NS- 104

EVERY ENTRY IS TO BE SIGNED

$A-70$ 
APPENDIX VI

Analysis \& Estimates of Losses

$A-71$ 
THIS PAGE

WAS INTENTIONALLY

LEFT BLANK 
October 17,1978

Dr. Philip C. White, Chairman

Accident Investigating Committee

Re: DOE/SPRO - W. Hackberry, La Site

Blowout/Fire - 21 Sept. 1.978 - Cavern/Wellhead \#6

Dr. White,

Attached are summaries, developed from the onsite visit during the week of 24 September 1978, as you requested:

- Incident Loss Cost Estimate.

- Site Insurance Summary.

- General Observations re Risk Management and Hazard Loss Control.

I briefly explored, via various insurance sources, your query re loss experience (fire and extended coverage) for workover rigs vs. drilling rigs in the oil industry. Consensus indicates little difference between the two modes, over the long-term.

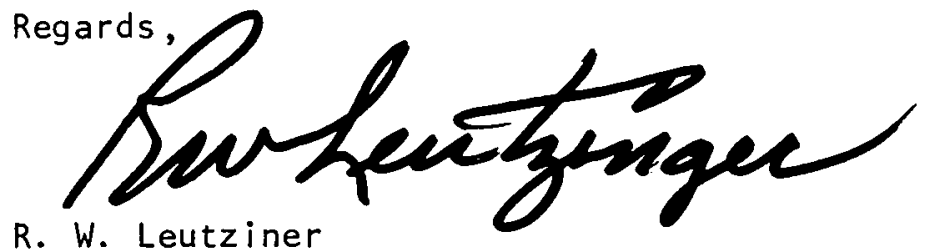

Staff Engineer

Engineering Division - M. 0 .

$\mathrm{RL} / \mathrm{bmw}$

Attachments

cc: Dr. P. C. White W/Att.

W. W. Maybee, Fire Prot. Engr. - DOE, Wash. Office (Hdqrs.) w/Att.

H. L. Bryant, FMEA - Norwood w/Att.

N. S. Parks, FMEA - Norwood w/Att.

R. W. L. W/Att. 
Page 1 of 5

R.W. Leutzinger

\author{
DOE/SPRO - W. HACKBERRY, LA SITE \\ Blowout/Fire - 21 September 1978 - Cavern/Wellhead \#6
}

LOSS COST ESTIMATE (SUMMARY)*

1. Onsite Property Damage

2. Onsite Fire Control, Debris Removal, Cleanup

3. Onsite/Offsite Environmental Control

4. Operations Interruption

5. Onsite Personnel \& Offsite (Third-Party) Liabilities

TOTAL

$\$ 12,000,000$

*See Pages 2-5, for greater detail of cost estimates. 
A. Destroyed By Fire, Negligible Salvage.

Workover Rig \#ll, owned by Pelican

1,200

- Kabot, $102 \mathrm{ft}$. derrick, $210 \mathrm{k} \mathrm{lb.}$ hook load capacity.

Major vehicular support equipment

- Odell Vinson/dragline

- BJ Hughes/pump truck, 2-tank trucks

- Big Chief Vacuum/mud tank truck

\section{Auxiliary operating apparatus}

- wellhead, blowout preventers, hydril, HCR valves \& choke, spider, slips, tongs, elevators, drill bits \& collars, openers, shoes, tam packer

- 3500 ft. $\mathrm{PH}-62 \frac{3}{8}$ tubing, 11 jnts $4 \frac{1}{2} "$ hvy 3 pipe, 100 jnts $4 \frac{1}{2} "$ " $\frac{8}{8}$ drill pipe, $3400 \mathrm{ft} .13 \frac{3}{8} "$ pipe, $2400 \mathrm{ft}$. 16" pipe, misc. hoses ( 2 \& $4 ")$

- mud storage, 2-1000 gal water storage tanks \& pump, 5000 gal diesel fuel storage tank, deck boards storage

- field office (2-house trailers) \& contents, 2 pickup trucks \& 3 antos (employee owned)

B. Fire Exposure Damage, Repairable

Drill rig, at Wellhead \#6A, owned by Cactus

- National Draw-works "7-11", 142 ft. derrick, $650 \mathrm{k} 1 \mathrm{~b}$. hook load capacity.

c. Crude oil loss (burned of non-recoverable - $20 \mathrm{k} \mathrm{bbl}$ ) 
2. ONSITE FIRE CONTROL, DEBRIS REMOVAL, CLEANUP

(Ex Environmental Control)

A. Fire Control

Initial response/7-volunteer companies $(9 / 21-9 / 26), \quad 850$ includes apparatus damage during fire

Retained fire control standby $(9 / 27-10 / 3)$

Boots \& Coots, Inc. (Wild well control specialists)

Foam supplies $(22 \mathrm{k}$ gal. $\mathrm{XL}-3,12 \mathrm{k}$ gal. AFFF)

Standby ambulances (2), extra security, etc.

B. Debris Removal, Cleanup

Extra personnel \& equipment rental

- construction crews (7), draglines (2), dozers (7), heavy trucks (8), equipment trailers (4), back-hoes (2), marsh buggy; winch trucks (2), tank trucks (8), pump trucks (2), oil mop, oil recovery barges ( 3 ), welders (5)

Dig pit to contain slop oil recovery ( $18 \mathrm{k}$ cuyd)

Remove \& restore $30 \mathrm{~K}$ cuyd oil saturated fill

(a) Wellhead \#6

C. Miscellaneous Support Services

Extra office equipment/supplies/personnel/etc.

Catering

Incident investigation groups (ex environmental)

TOTAL

$\$ 2,300,000$ 
3. ONSITE/OFFSITE ENVIRONMENTAL CONTROL

$\underline{\mathrm{k}}$

Ongoing activities of Regional Response

$4,20 n$

Teams (headed by DOE/Environmental

Task Force, including Federal/State

Environmental Agencies, us Coast Guard, Contract Environmentalists, etc.

- intensive infield sampling of soot/oil fallout effects on water bodies, marshes, and sparsely populated land areas (mostly grazing and farm lands) influenced by the smoke/oil plume (approx 10-15 miles southwest of site). Initial intensity over 3 weeks period, with ongoing readouts for 3-6 months minimum. Includes installation/ removal of temporary dike in Black Lake to contain spread of existing bank/bottom contamination (approx. 18).

TOTAL

$\$ 4,200,000$ 
Prepurchased oil flow @ $70 \mathrm{k}$ B/D.via tankers/barges/pipelines into onsite. ... caverns interrupted for 12 days $(9 / 22-10 / 3)$.

- tanker demurrage

- off-loading barges (7) demurrage

- extra cost to divert incoming oil to interim rental storage facilities (extra sailing costs, port fees, etc.)

- interim rental storage costs

(45 days to reabsorb in flow. train)

- extra cost to return interim oil storage

5. ONSITE PERSONNEL \& OFFSITE (THIRD PARTY) LIABILITIES

A. Onsite Personnel Liabilities

Clarence Simon (Age 38) Abbeville, La/Severe burns

(fatal)

- Toolpusher, Pelican Well Service died 8:40 P.M. @ Baton Rouge, La General Hospital

Bradley Bergeron, New Iberia, La/Severe burns

- Derrick-hand, Pelican Well Service intensive care @ Baton Rouge, La General Hospital other minor injuries

- Irby Hogue, Drilling Supervisor/Louis Records Assoc., Inc.

facial cuts (not hospitalized).

B. Offsite (Third-Party) Liabilities

Miscellaneous effects from oil/soot

fallout in sparsely populated area

via damages to buildings, equipment, grazing/farm lands, domestic animals, etc.

TOTAL

$\$ 1,300,000$ 
DOE/SPRO - W. HACKBERRY, LA SITE

Blowout/Fire - 21 Sept. 1978 - Cavern/Wellhead \#6

\section{SUMMARY OF INSURANCE}

(Via telcon, during week of 2 October 1978, with Art Sidereas and Steve Donley of Parsons-Gilbane Insurance Dept., New Orleans and Jimmy Ray of DOE/SPRO

Contracts Office, New Orleans).

PARSONS-GILBANE INSURANCE COVERAGE

Statutory Workmens Compensation

Employers Liability to $\$ 1 M$.

Comprehensive General Liability, incl. Automobile Bodily Liability, $\$ 1 \mathrm{M}$ per occurrence, combined single limit.

Third-party Liability (ex Automobile), \$1M per occurrence, combined single limit.

Third-party Liability (Automobile), $\$ 250 \mathrm{k}$ per occurrence.

Excess Cover Umbrella, combined liability to $\$ 10 \mathrm{M}$ (ex. \$1M).

Definitized Clause of Limited Liability, with Government indemnifying at site or in transit.

PARSONS-GILBANE CONTRACTURAL REQUIREMENTS

Statutory Workmens Compensation.

Comprehensive General Liability, as above.

Third-party Liabilities, as above.

Excess Cover Umbrella, as above.

Certificate of Insurance required of all sub-contractors.

Sub-contractor Clause, holding harmless Parsons-Gilbane.

DOE/SPRO CONTRACTURAL REQUIREMENTS

(Drill \& Workover Rigs)

Statutory Workmens Compensation, to $\$ 500 \mathrm{k}$ limit, all contractor's

employees.

Comprehensive Public Liability, Personal - \$1M death/injury per person.

Comprehensive Public Liability, Property - \$1M.

Public Liability, Automobile - $\$ 100 \mathrm{k} / \mathrm{I}$, ea. person; $\$ 300 \mathrm{k} / \mathrm{I}$, ea. accident; $\$ 100 k$ Property, ea. accident.

Umbrella Liability (TPL), to $\$ 10 \mathrm{M}$ (ex. \$1M), naming DOE as additional insured. 
(Comments are based only on limited involvement in the investigation of the subject incident; hence, they do not constitute an in-depth analysis of all facets of a risk management/hazard loss control program for the varied operations onsite. Comments are not intended to detract from numerous commendable actions taken by individuals, acting as individuals, several of whom "just happened to be there", during the subject incident; rather, they point to a need for a comprehensive preplanned activity program to minimize the hazard risk and limit extent of hazard loss potential.)

1. An intensive risk analysis study of all site opertions should be launched toward establishing the DOE desired level of hazard loss control. Then, actively develop a clear policy defining the program of management/ emergency organization, with one man heading the program, accountable to meet the desired level. Clearly one man alone can not control the hazard loss exposure of a large crude oil storage/handling facility; but, he must be the liaison leader in relating the work of Administration, Safety, Security, Engineering, Insurance, Oil Storage, Equipment Maintenance, Fire Protection, Personnel, Training, Public Relations, etc., to loss control goals of the program. A valuable adjunct of the program would be a selected group of qualified specialists representing engineering, maintenance, firesafety, systems reliability, etc., to review for approval the safe operations aspects of proposed equipment installations, materials selection, drilling and workover operations, pipeline routings, etc. Responsibilities, authority and accountabilities should be clearly assigned and understood. The existing apparent environment of divided responsibilities seems conducive to safe operations "falling through the cracks."

2. Supplemental to the foregoing safe operations program, unit operating manuals and emergency procedures should be prepared and continually updated to guide operators/supervisors in safe conduct as related specifically to site operations. A brief review of existing "safety manuals" indicates little more than classic textbook generalities, valuable for general reference; but, not directed to specific unit operations onsite.

3. Development of a disaster preparedness manual (continually updated) should be considered. "What to do", "Who to call for outside assistance", etc., as related to the need for fire equipment, earth-moving equipment, extra security forces, public relations, medical facilities, etc. Albeit, disasteraid response to the subject incident was favorable, much was due to coincidental onsite presence of construction contractors, with heavy equipment and oil field hazard experience. 
4. An improved wellhead design should be considered carefully. The existing unguarded high silhouette is conducive to being broken-off by vehicle traffic or flying debris from hurricane or explosion. The hanging string concept (an apparent hangover from previous brine recovery operations) is not the best design for down-hole safety shut-off emergency capability (albeit, an annular valve is available, but expensive). Consider:

a. Eliminate the hanging string. Multiple entries to each cavern lends to adopting "slick-holes" with certain wellheads dedicated to only oil and others to only brine/water.

b. Lower the Xmas-tree silhouette as much as possible and otherwise protect from flying debris or vehicular damage.

c. Provide double-block valves on Xmas-tree wings, in addition to the master block.

d. Provide a down-hole safety valve (storm choke) on each wellhead.

e. Materials selection should be carefully supervised (e.g. a 150 psig flanged fitting noted on Wellhead \#6, mounting a 2000 psig valve).

f. Consider an impervious material around wellheads (the existing deep shell is an oil sump, interfering with prompt spill removal).

g. Provide dikes around wellheads designed to contain maximum potiential accidental oil release from cavern.

h. Eliminate unnecessary congestion around wellheads (nonessential piping, equipment, employees vehicles, field offices, house trailers, etc.) to avoid interference with emergency activities.

5. Provide adequate fire protection equipment onsite, sufficient for first response control, prior to arrival of supplemental outside aid. For example, fixed fire pumps and firewater distribution piping, with appropriate monitor nozzles, hydrants, automatic sprinklers/waterspray at critical buildings/pump stations, etc. Also, provide onsite sufficient fire hose, foam supplies, etc., to handle first response.

6. Similarly, provide onsite sufficient oil boom to limit spread of oil spills on exposed lakes and waterways. (At time of subject incident, there was little if any oil boom onsite. A two-hour round-trip was necessary to bring in sufficient quantities. Fortunately, a favorable wind direction limited early spread on Black Lake).

7. A study should be made to assure appropriate onsite safety apparatus (eg., apparently there was no combustible gas analyzer onsite for testing the incident wellhead area prior to welding on the restoration cap --- a unit was borrowed from a distant refinery). 
THIS PAGE

\section{WAS INTENTIONALLY LEFT BLANK}


APPENDIX VII

Metallurgical Report

$A-83$ 
THIS PAGE

\section{WAS INTENTIONALLY \\ LEFT BLANK}




\section{OAK RIDGE NATIONAL LABORATORY \\ OPERATEO BY \\ UNION CARBIDE CURPURAIIUN \\ NUCLEAR DIVISION \\ tertater \\ POST OFFICE BOX $X$ OAK RIDGE. TENNESSEE 37830}

DATE: $\quad$ October 24,1978

SUBJECT: Metallurgical Analysis of Samples from Fire at U.S. Strategic Petroleum Reserve Supply (SPRO) Facility.

TO: $\quad$ Distribution

FROM: R. J. Gray, G. M. Slaughter, J. C. Griess and C. W. Houck

At the request of the Department of Energy Accident Investigation Committee, metallurgical assistance was provided by the Metals and Ceramics Division, Oak Ridge National Laboratory in the investigation of part of the wellhead assembly and brine pipe associated with a fire at Lake Charles (West Hackberry), Louisiana. This fire seriously disrupted operations at the U.S. Strategic Petroleum Reserve office (SPRO) storage facility.

The objectives of the examination were (1) to provide information concerning the origin of a seeping petroleum leak in the wellhead and (2) to assess the condition of the brine casing prior to fire damage. A definite leak path through welds in the wellhead was found; another leak path through a possible fracture in the casing wall is only speculative. The gross attack of the brine pipe was attributed to hot corrosion during the fire. Although of course we cannot be certain, it is improbable that brine pipe in other regions of the facility is as severely damaged as the samples investigated. 


\section{INTRODUCTION}

Following a fire which seriously disrupted operations at the U.S. Strategic Petroleum Reserve Office (SPRO) facility in West Hackberry, Louisiana, the Department of Energy (DOE) Accident Investigation Committee requested metallurgical studies of selected components. The fire had started over No. 6 storage cavity on September 21,1978 and was not extinguished until september 26. The metallurgical studies were (1) investigation of a wellhead seeping leak and (2) investigation of the possibility that some of the $0.14-\mathrm{m}-\mathrm{diam}(51 / 2-i n$.$) brine pipe$ had lost its integrity before the fire as a result of corrosion by brine, $\mathrm{H}_{2} \mathrm{~S}$, etc. Selected samples were identified by G. M. Slaughter, Consultant to the Committee on his visit to the SPRO site on September 28-29, 1978. The samples were delivered to Oak Ridge National Laboratory (ORNL) by truck on October 4 .

\section{WELLHEAD INVESTIGATION}

A photograph made at the SPRO site of the wellhead assembly and upper pipe attachments is shown in Fig. 1. The lower section of the wellhead assembly that was delivered to ORNL is shown in Fig. 2. To assist in the location of the various areas that were examined and to show the wellhead design, a drawing (Fig. 3, ORNL-DWG-78-19903) was prepared of the assembly delivered to ORNL. The $0.24-m$-diam (9 5/8-in.) inner casing (API-155 steel) is shown in an end view of the lower section of the assembly in Fig. 4. Clearly evident is the fractures of the outer and inner casings that resulted when the wellhead assembly, shown in Fig. 1, was torn loose from the below ground section. Apparently this action was essential to remove the assembly from the immediate vicinity of the fire. Also evident in Figs. $1-4$ is the clamp and elastomer gasket around the outer casing. This field repair had been installed in December, 1977 in an attempt to stop a seeping leak. An internal bore weld (Fig. 3, Weld A) joining the inner 0.24-m-diam (9 5/8-in.) to the outer jacket is also evident in Fig. 4. After partial dissection of the wellhead assembly with a band saw, dye-penetrant inspection of this weld revealed severe cracking and a leak path completely through it (Fig. 5). To verify the characteristics of the leaking weld, wedge-shaped cuts were made through the area which had shown evidence of a leak by the dye-penetrant test. These wedge-shaped sections are shown in Fig. 6. After additional cutting, a metallographic specimen was prepared of the defect. A photomicrograph showing a complete separation of weld A (see Fig. 3) is presented in Fig. 7.

A flame-cut spacer which had been welded between the heavy walled wellhead and the thinner walled outer casing is shown in Fig. 8. Photographs showing end and side views of one of the dissected segments revealed this ring spacer. The welds making this attachment of the spacer are identified as Welds $C$ and $D$ (Fig. 3). Dye-penetrant inspection of the inner weld (Weld B, Fig. 3) which attaches the 0.24 -m-diam (9 5/8-in.) pipe to the heavy pipe section of the wellhead revealed severe cracking and a through-leak. A longitudinal view of the area containing Welds 
B, C and D can be seen in the photographs shown in Fig. 9. Likewise, a through-leak was found in a longitudinal weld in the outer casing (Figs. 10 and II) which were 1nrated under the clamp type patch. This longitudinal weld is identified as Weld E (Fig. 3). Thus, a potential leak path for petroleum was found leading from the inside of the $0.24-\mathrm{m}-$ diam (9 5/8-in.) pipe through the internal bore weld (Weld A, Fig. 3) into the annulus between the inner and outer casing, through the weld (Weld B, Fig. 3) at the end of the annulus and to the outside through the longitudinal weld of the outer casing.

Another potential and less tortuous leak path was through a possible fracture around part of the 0.24 -m-diam ( 9 5/8-in.) inner casing (Fig. 4) which was ripped off by a drag-line during the fire. The end of this casing after sectioning with a band saw is shown in Fig. 12. A close-up of the origin of fracture is shown in Fig. 13. The origin is indicated by the chevron-type fracture. In ductile-type fractures the chevron fracture pattern points to the fracture origin. The area of origin of the fracture shown in Fig. 13 was examined in detail for any defect or flaw in the pipe wall which might have contributed to the fracture origin. The only defect that could be found was a sub-surface fissure which is shown in Fig. 14 .

\section{INVESTIGATION OF $0.14-M-D I A M(5$ 1/2-IN.) BRINE PIPE}

Several sections of pipe that had been subjected to the fire were brought to ORNL for examination. These included (1) relatively undamaged pipe, which was partially protected by turned-over equipment; (2) some relatively good but fire-damaged pipes; and (3) some severely damaged pipes (with massive holes completely through the wall). Several of these pipes were dissected and examined, and the results are reported below.

\section{Relatively Undamaged Pipe}

The pipe designated as Pipe 14 was dissected by sawing to facilitate metallographic examination and is shown in Fig. 15. A section of this pipe is shown in Fig. 16. The microstructure is shown in Fig. 17; although some scale is evident on the inside surface, the wall is essentially undamaged.

\section{Relatively Sound But Fire-Damaged Pipes}

A typical pipe of this type designated as Pipe 2, was dissected to permit further examination and is shown in Fig. 18. The extensive amount of loosely adherent internal scale (powder) is evident in Fig. 19. Considerable variation in the wall thickness can be seen in Fig. 20. Typical microstructures of Pipe 2 is shown in Fig. 21. The black loosely-adherent powder reaction product found in Pipe 2 was extremely light weight and contained sufficient magnetic material in it to be attracted by a magnet. Although $x$-ray diffraction showed the metallic oxide to be primarily $\mathrm{Fe}_{2} \mathrm{O}_{3}$, undoubtedly some magnetic $\mathrm{Fe}_{3} \mathrm{O}_{4}$ and/or metallic $\mathrm{Fe}$ was present. Approximate chemical analysis of the powder showed $40 \% \mathrm{Fe}, 17 \% \mathrm{C}$, and $600 \mathrm{ppm} \mathrm{Cl}$. 


\section{Severely Damaged Pipes (with Massive Holes Completely}

Through the Tube Wal1)

A typical pipe of this condition designated as Pipe 3 (Fig. 22) was dissected to permit further examination. A photograph of this pipe with a typical hole is shown in Fig. 23. Figure 24 shows the hole and gross oxidation-corrosion on the interior. Very little of the metallic wall remains. A typical photomicrograph of a section of remaining metal and the adherent scale is shown in Fig. 25.

In view of the severe oxidation/corrosion noted on Pipe 3 and several similar pipes, a modest examination was undertaken of the interior scale and underlying base metal. Three oxides of iron $\left(\mathrm{Fe}_{3} \mathrm{O}_{4}, \mathrm{Fe}_{2} \mathrm{O}_{3}\right.$ and $\left.\mathrm{FeO}\right)$ were noted in relatively large amounts by $x$-ray diffraction analysis. In contrast with the results on Pipe 2, chemical analysis of the scale on Pipe 3 showed a relatively small amount of carbon. An approximate analysis of a sample of scale taken from the pipe interior revealed $75 \% \mathrm{Fe}, 870 \mathrm{ppm}$ $\mathrm{C}$ and $230 \mathrm{ppm} \mathrm{Cl}$.

A eutectic composition was evident in the underlying base metal of a section of pipe shown previously in Figs. 22, 23 and 24. This eutectic condition in the microstructure of Pipe 3 is shown in Fig. 26. This condition was evident in all sections of pipe showing considerable reduction of the wall.

An electron microprobe analysis of the interfor scale and underlying base metal was also made. Using energy dispersive $\mathrm{x}$-ray analysis, qualitative determination of the elements present was performed. Figure 27 is a backscattered electron image of the scale-metal interface. Area A, of course, was basically iron, (Fig. 28). Area B, significantly, also shows a high concentration of sulfur (Fig. 29), an element known to vigorously promote hot corrosion. The scale (area C) also was, of course, rich in iron; no sulfur was evident (Fig. 30). A cathode ray tube (CRT) display showing a qualitative distribution of sulfur is shown in Fig. 31 .

To determine the origin of the sulfur, a laboratory test for sulfur (i.e., addition of a barium salt) was made to a concentrated brine sample taken from the oil storage cavern. A moderate amount of flocculent precipitate resulted.

\section{DISCUSSION AND PRELIMINARY CONCLUSIONS}

\section{Wellhead Investigation}

As a result of this study, we have determined that two leak paths were possibly present and would permit petroleum to seep from inside the 9 5/8-in. inner casing to the outside of the wellhead. One potential path is through a tortuous route involving cracked welds. Another path (speculative) is through what may be a. fatigue fracture around part of the circumference of the inner casing. The source of the stresses for this type of fracture is unknown at this time. 
Investigation of $0.14-\mathrm{m}$-diam (5 1/2-in.) Brine Pipe

The extensive fire damage to the brine pipe samples makes it impossible to develop a positive set of conclusions. Gross amounts of scaling and corrosion products are evident on the inside of most of the pipes; the attack is much worse than on the outside of the pipes. Differences in location during the fire undoubtedly created wide variations in the amount of carbonaceous products and temperatures present on the inside of the pipes. This is thought to account for the differences noted in carburization of the interior metal surfaces and in the total carbon content of the oxidation-corrosion products. Carbon probably increased the attack during the fire as did residual chloride from brine transfer.

However, we feel that the primary reason for the gross attack was the sulfur (sulfate) in the brine that had been transferred through the pipe during normal operation. Sulfur is a noted promoter of hot corrosion and its deleterious influence during the fire is considered major. There is well-documented evidence that rapid oxidation of mild and low alloy steels can occur in furnace atmospheres containing sulfur dioxide and that this rapid oxidation is accompanied by intercrystalline penetration of the metal by an iron/iron-sulfide eutectic. ${ }^{1}$ An experience has been reported ${ }^{2}$ that is highly significant to our findings in the behavior of scales during the burning of sulfur-containing fuel oil. Oxy-sulfide complex structures not unlike what we have shown in this presentation were reported. Another significant accounting describes the rapid penetration of iron sulfide during the carburization of stee 1.3

Although of course we cannot be certain, it is improbable that brine pipe in other regions of the facility is as severely damaged as the samples investigated. Since they were not placed into service until June 1977 , and the maximum temperature in service is only approximately $50^{\circ} \mathrm{C}$ $\left(120^{\circ} \mathrm{F}\right)$, relatively minor corrosion would be expected. The severe attack noted in our samples, which is partially verified by the relatively small amount of attack in Pipe 14, is believed to have resulted from the fire.

\section{ACKNOWLEDGMENT}

The authors wish to acknowledge the extensive cooperation of many individuals at the SPRO site in identifying and providing the samples for our investigation. We also acknowledge the significant information obtained from, and the interest shown by, the DOE Accident Investigation Committee. Finally, we recognize the major efforts of several members of the Metals and Ceramics Division, especially C. P. Haltom, K. F. Russell, T. L. Marlar, O. B. Cavin, R. S. Crouse, and J. H. DeVan, without whose enthusiasm and hard work this study could not have been conducted. We also offer our thanks to Linda Croff for the preparation of this report. 
1. J. Stringer, Hot Corrosion in Gas Furnaces, Metals and Ceramics Information Center (MClC Report 72-08) Battelle Columbus Laboratories, June 1972.

2. A. Preece, Scaling of Gas-Turbine Alloys, Iron and Steel Institute, Spec. Rpt. No. 43, 1951.

3. A. Preece and K. J. Irvine, "Sulphide Penetration in the Carburization of Steel", Joumal of the Iron and Steel Inst., November 1947, Vol. 157, pp. 336-43. 


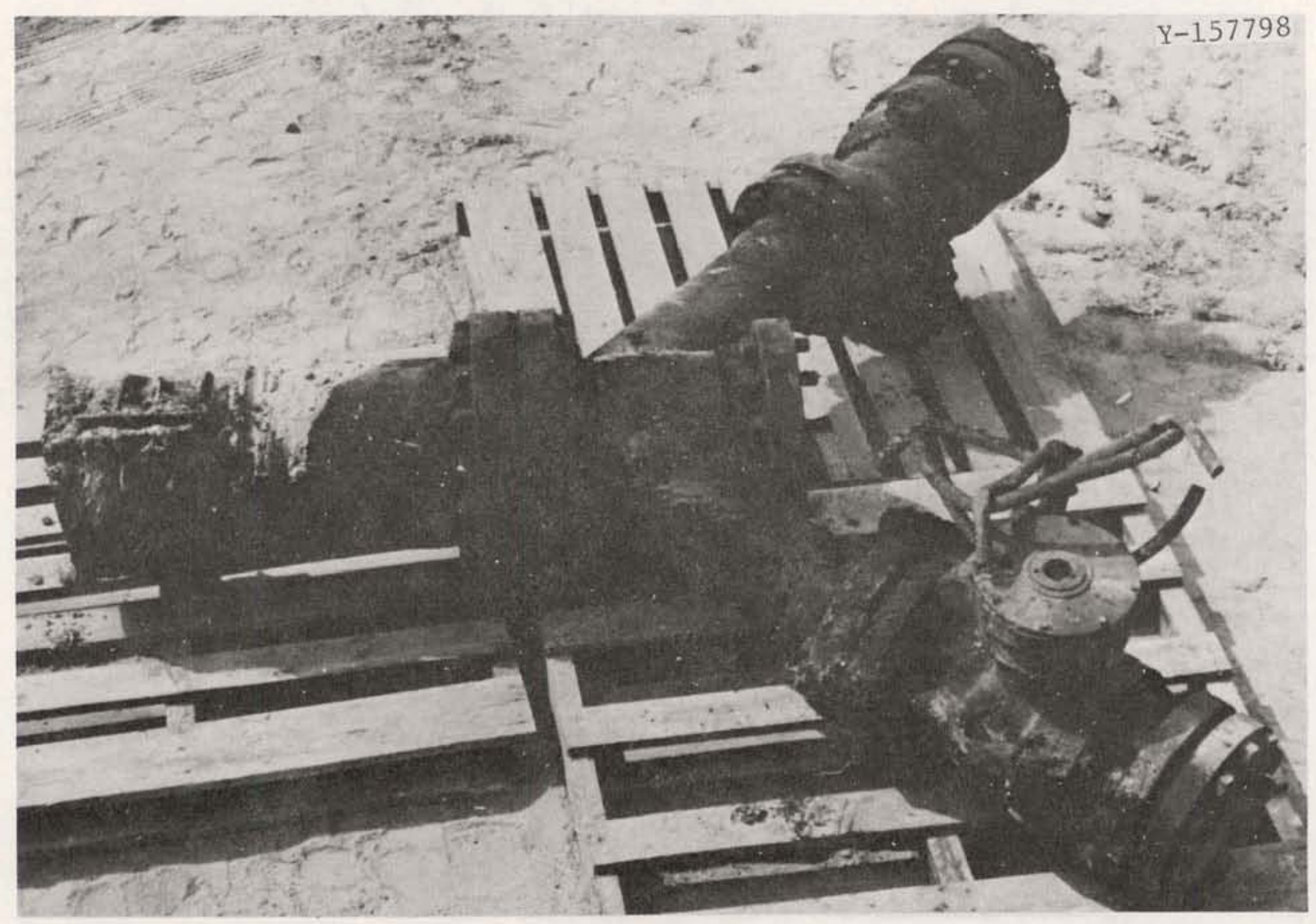

Fig. 1. Wellhead Assembly Including Upper Pipe Attachments as Photographed at SPRO Site. The assembly examined at Oak Ridge is the lower section of the " $Y$ " configuration. A patch clamp, attached prior to the fire to constrain the leak, can be seen at left. 


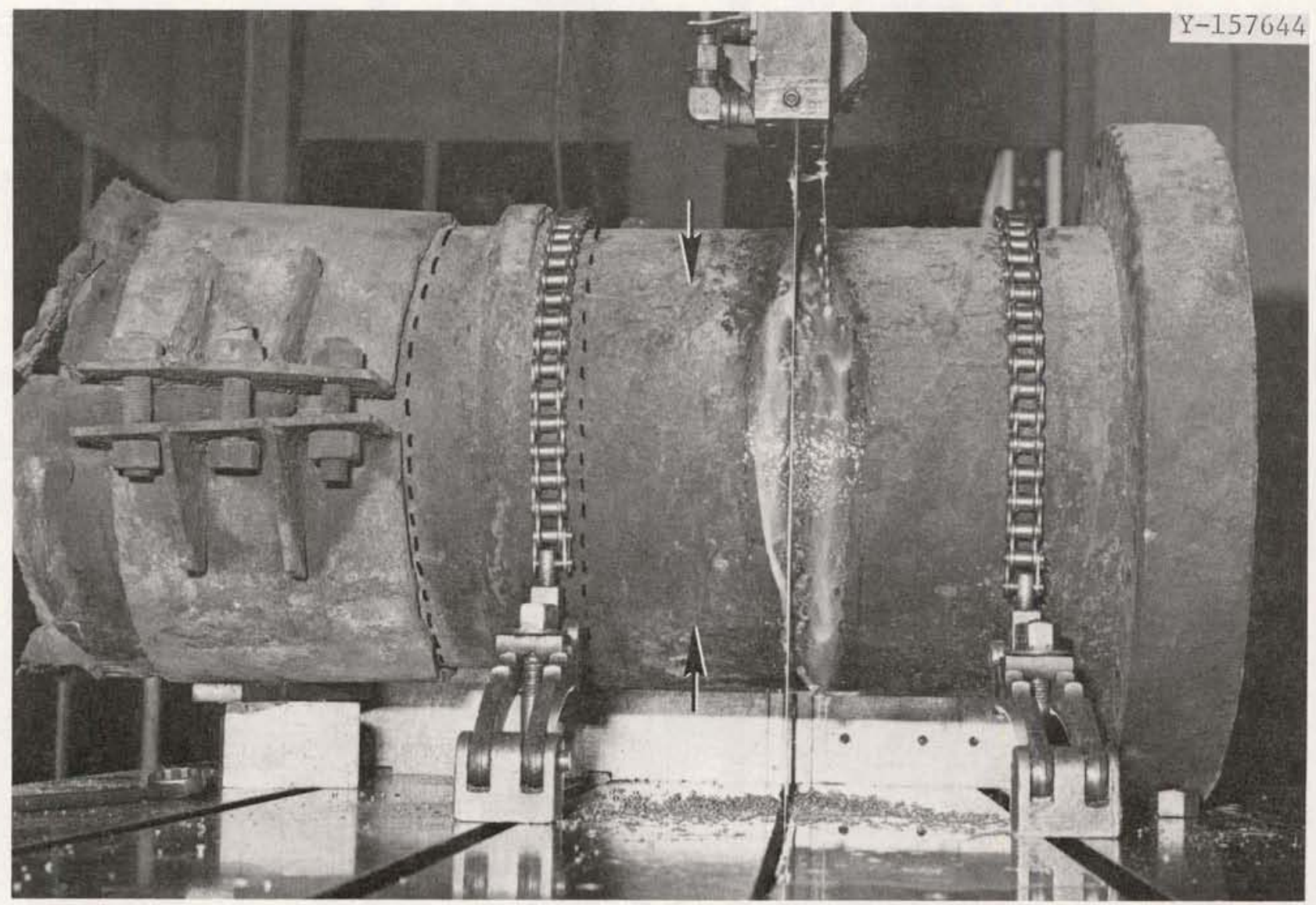

Fig. 2. Wellhead Assembly as Delivered to ORNL. Assembly is positioned for cutting. Arrors point out location of internal weld between $0.24-m$-diam (9 5/8-in.) pipe and outer casing. Cutting lines are indicated. 


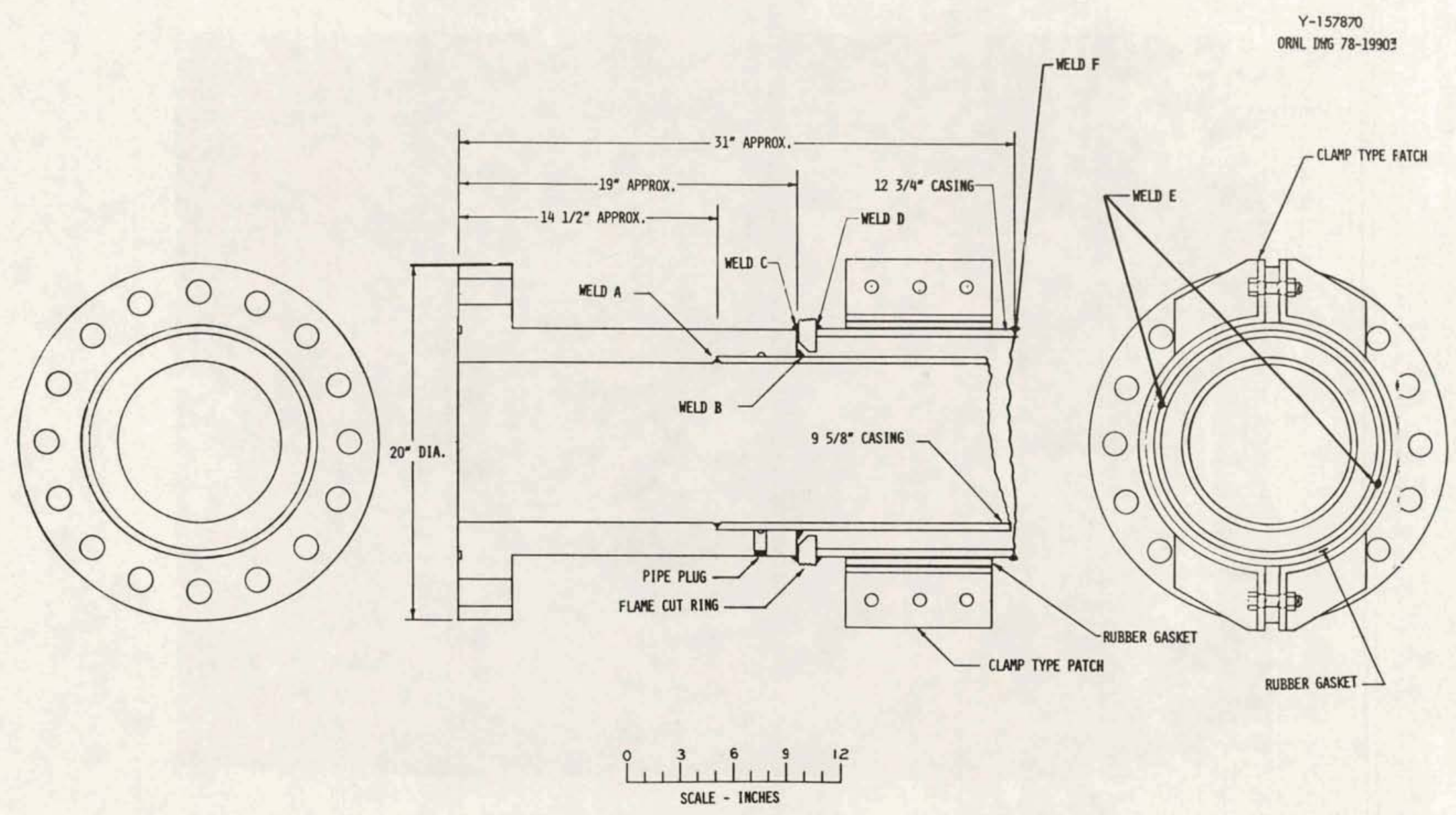

Fig. 3. Drawing of Wellhead Assembly Received at Oak Ridge National Laboratory. 


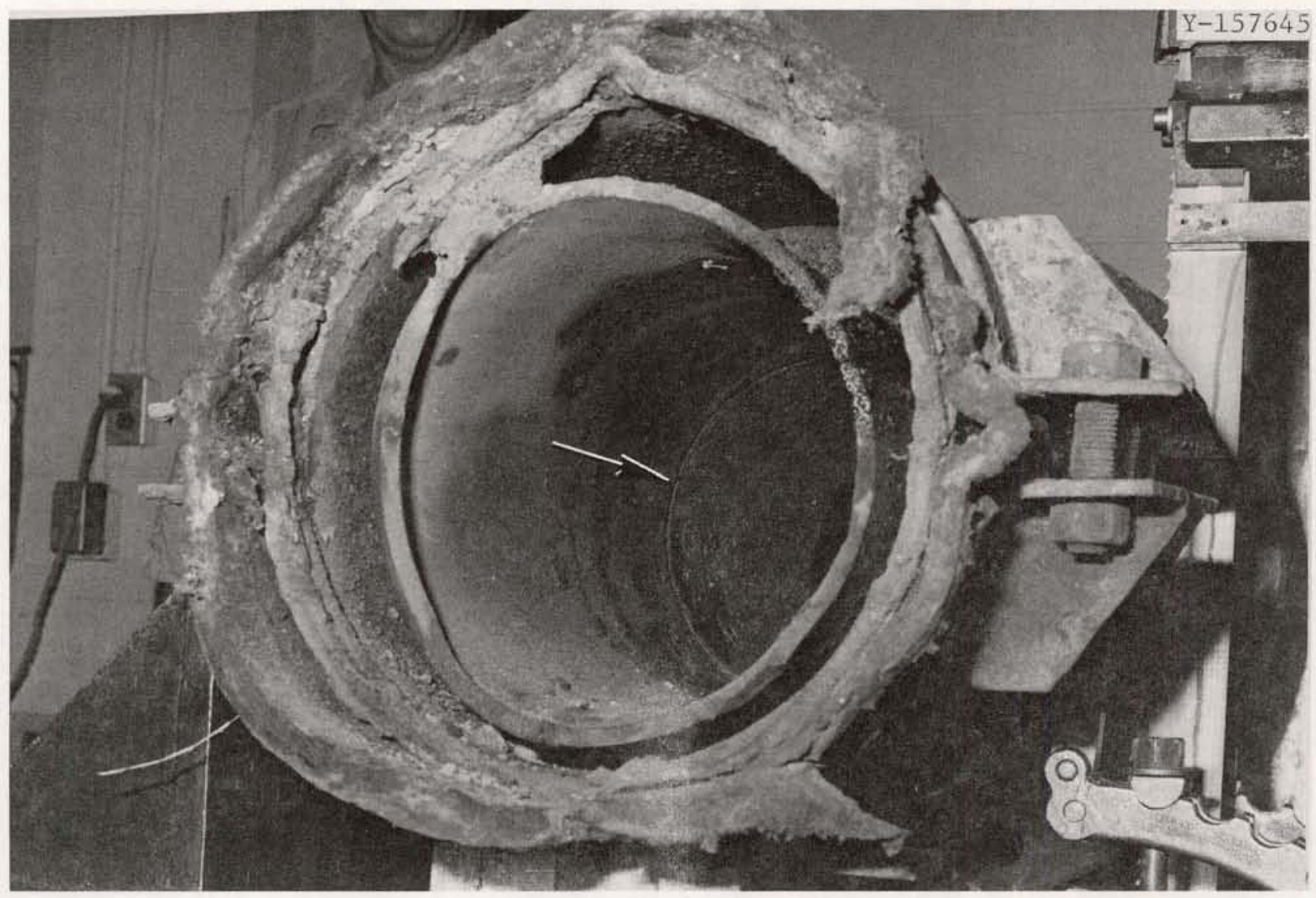

Fig. 4. Wellhead Assembly Showing Internal Bore Weld (arrow) Joining the Inner Casing to the Outer Jacket. 


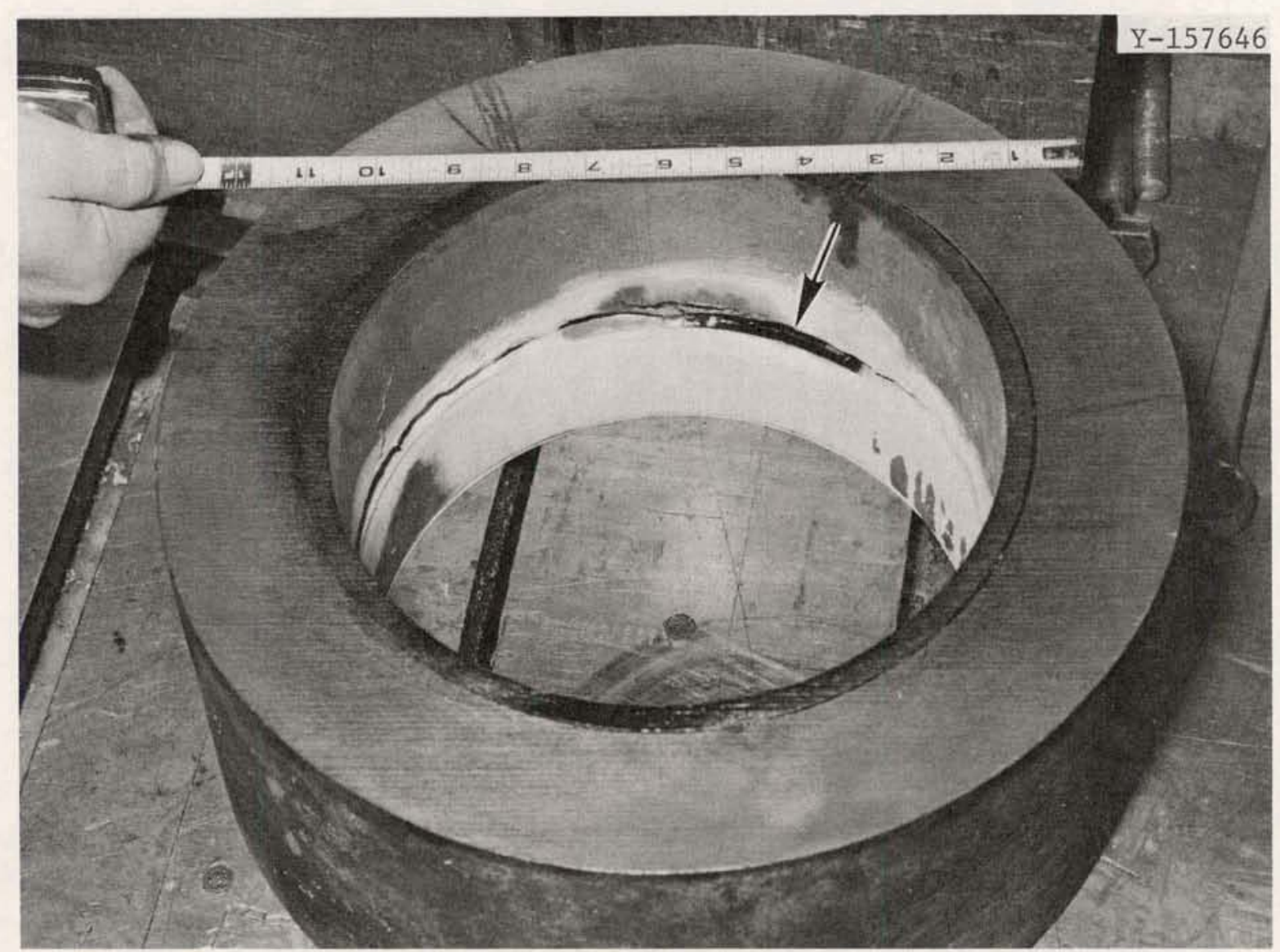

Fig. 5. Dye-Penetrant Inspection of Internal Bore Weld Reveals Gross Cracking and Through-Weld Leak. 


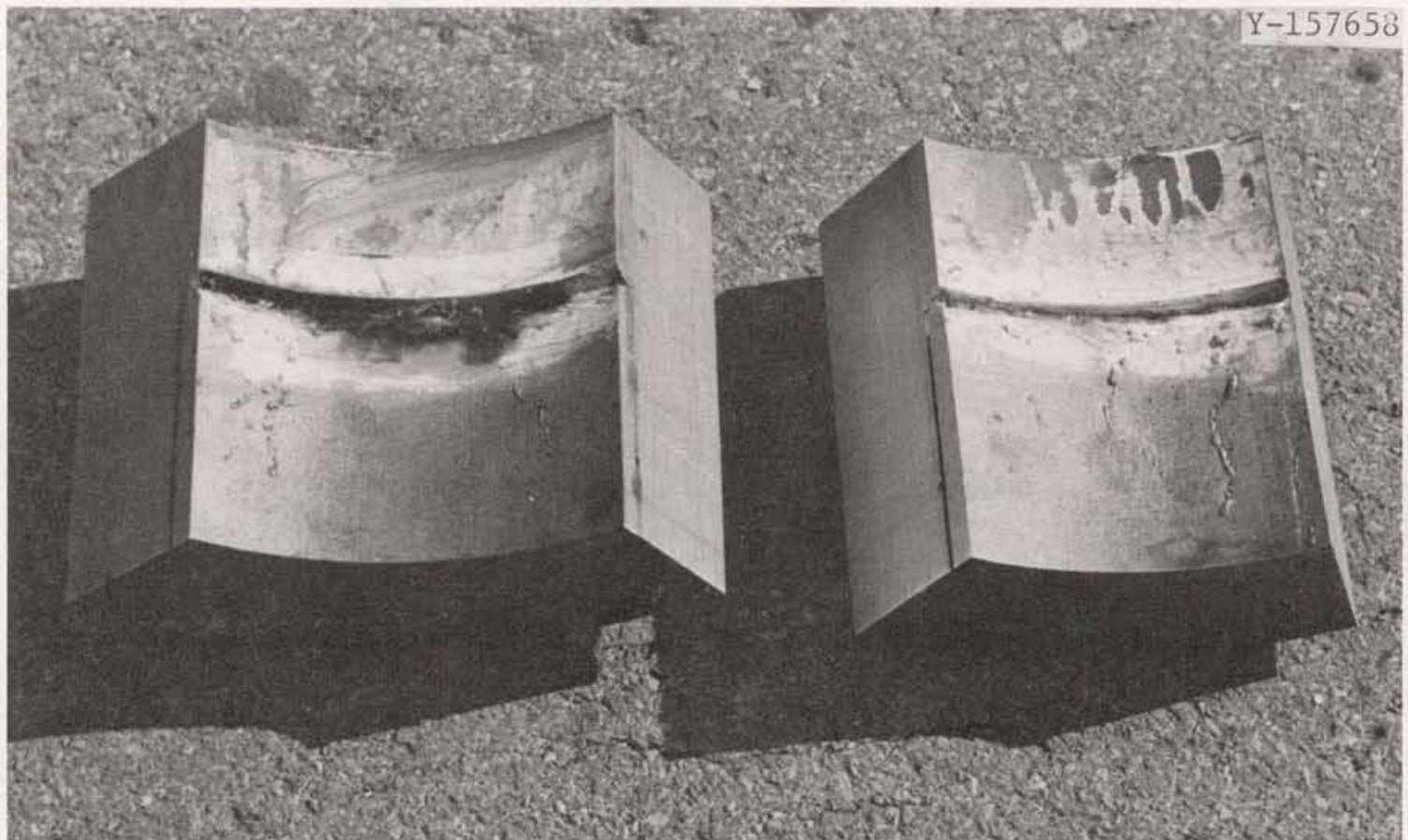

Fig. 6. Longitudinal Sections of Bore Weld Between 0.24-m-diam (9 5/8-in.) and Heavy Wall Pipe. Weld A in drawing Fig. 3. 


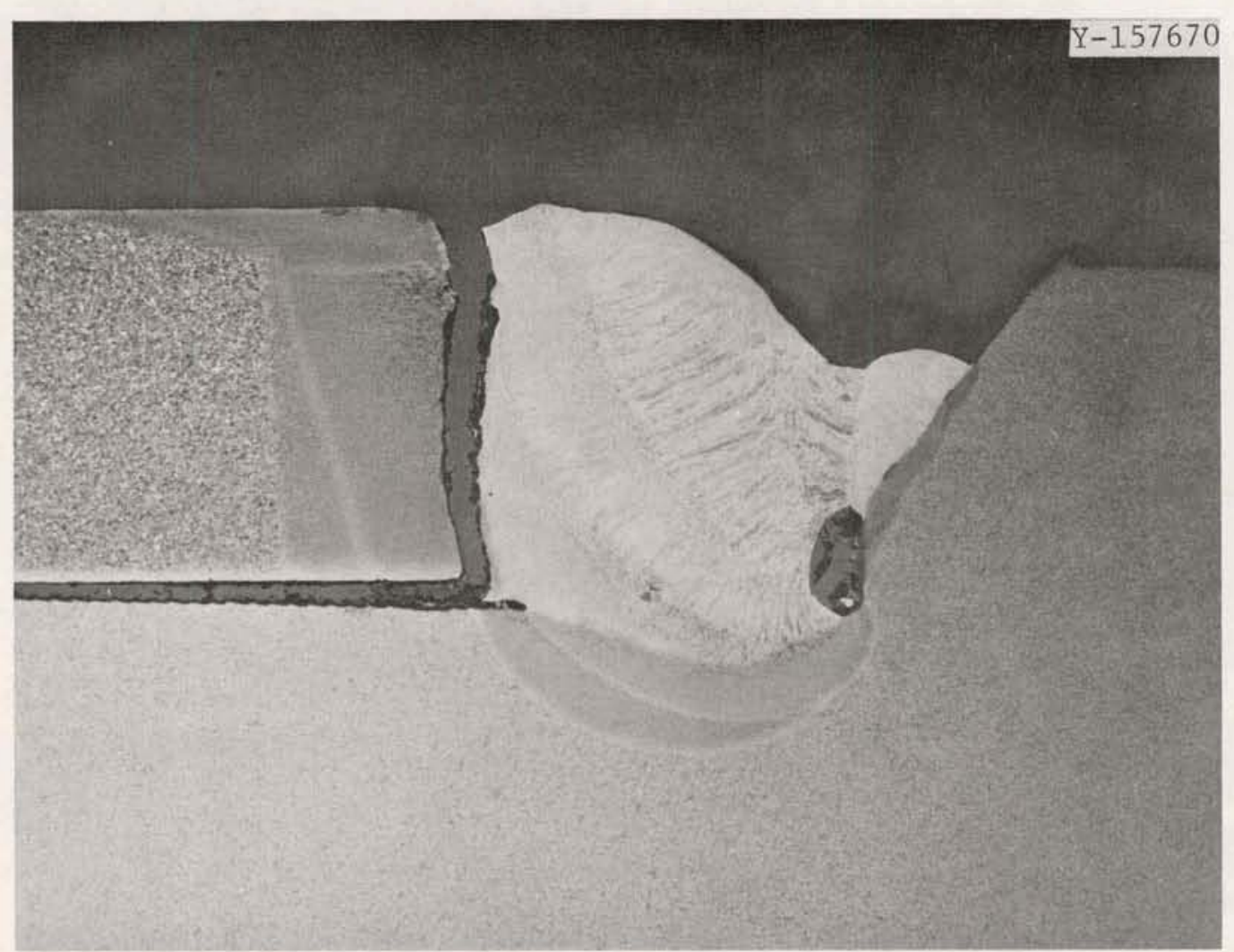

Fig. 7. Photomicrograph of Bore Weld in Wellhead. Note fracture has occurred in fusion line of Weld A (Fig. 3) and 0.24-m-diam (9 5/8-in.) casing. 

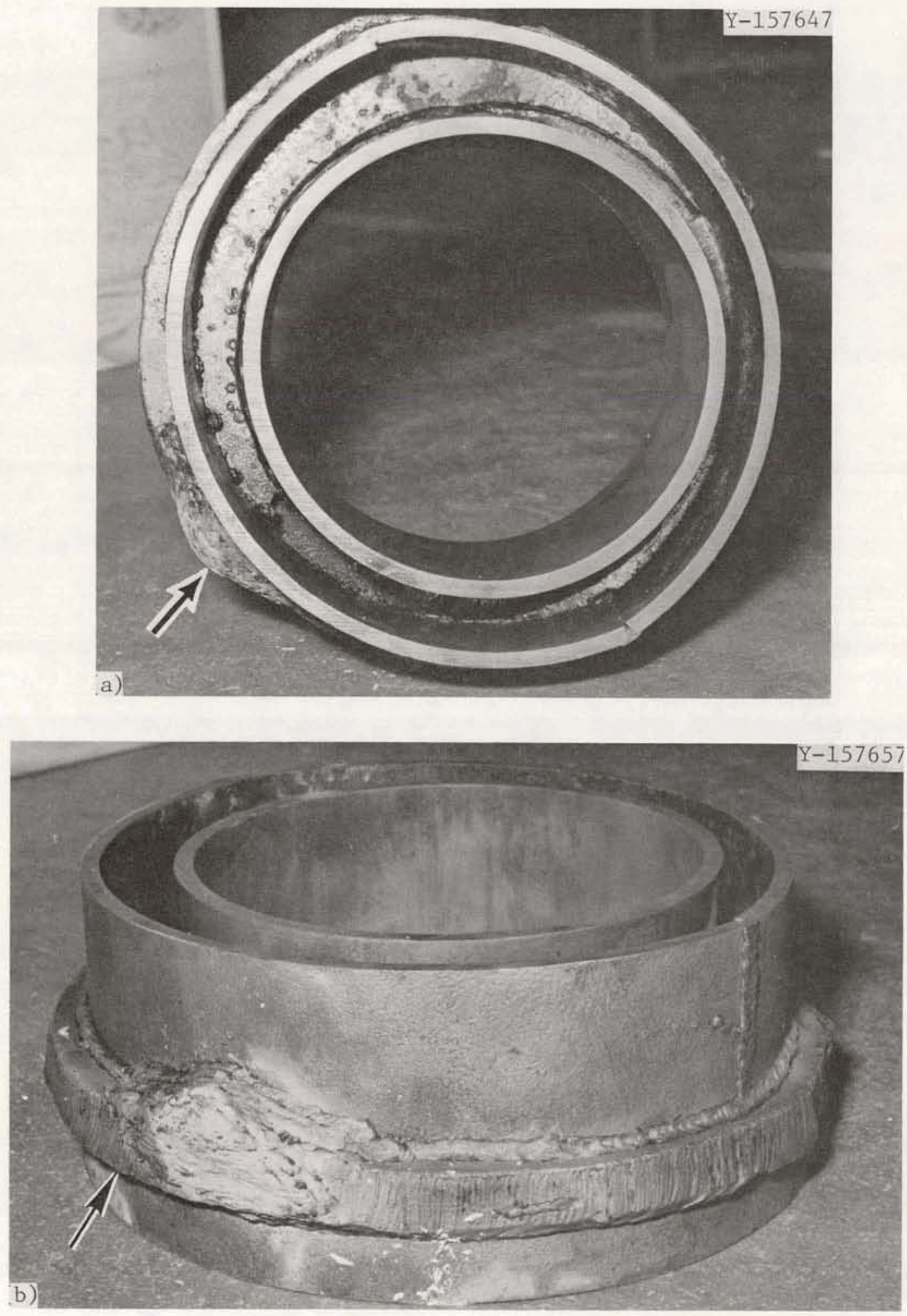

Fig. 8. Two Views of Section of Wellhead Assembly Containing Flame Cut Spacer Ring (Arrows) Which had been Welded Between the Heavy Walled Wellhead and Outer Casing (see Fig. 3, Welds C and D). 

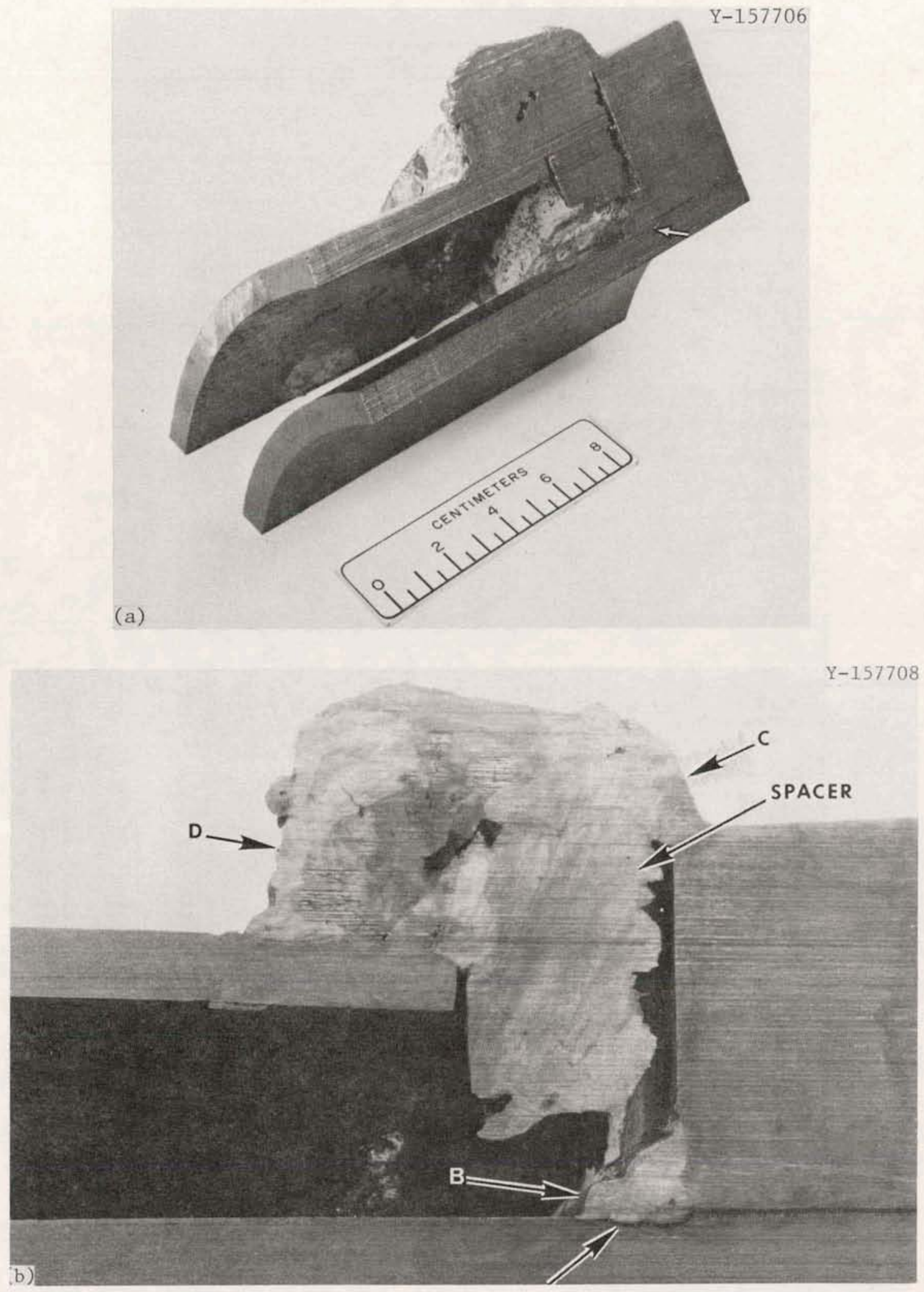

Fig. 9. (a) Longitudinal Views of Cuts Made Through Welds B, C and D (Fig. 3). Reduced $6 \%$ (b) Dye-penetrant tests pointed out these locations as through-leaks. Reduced $11 \%$. Note the complete fracture of weld $B$ indicated by arrow. 


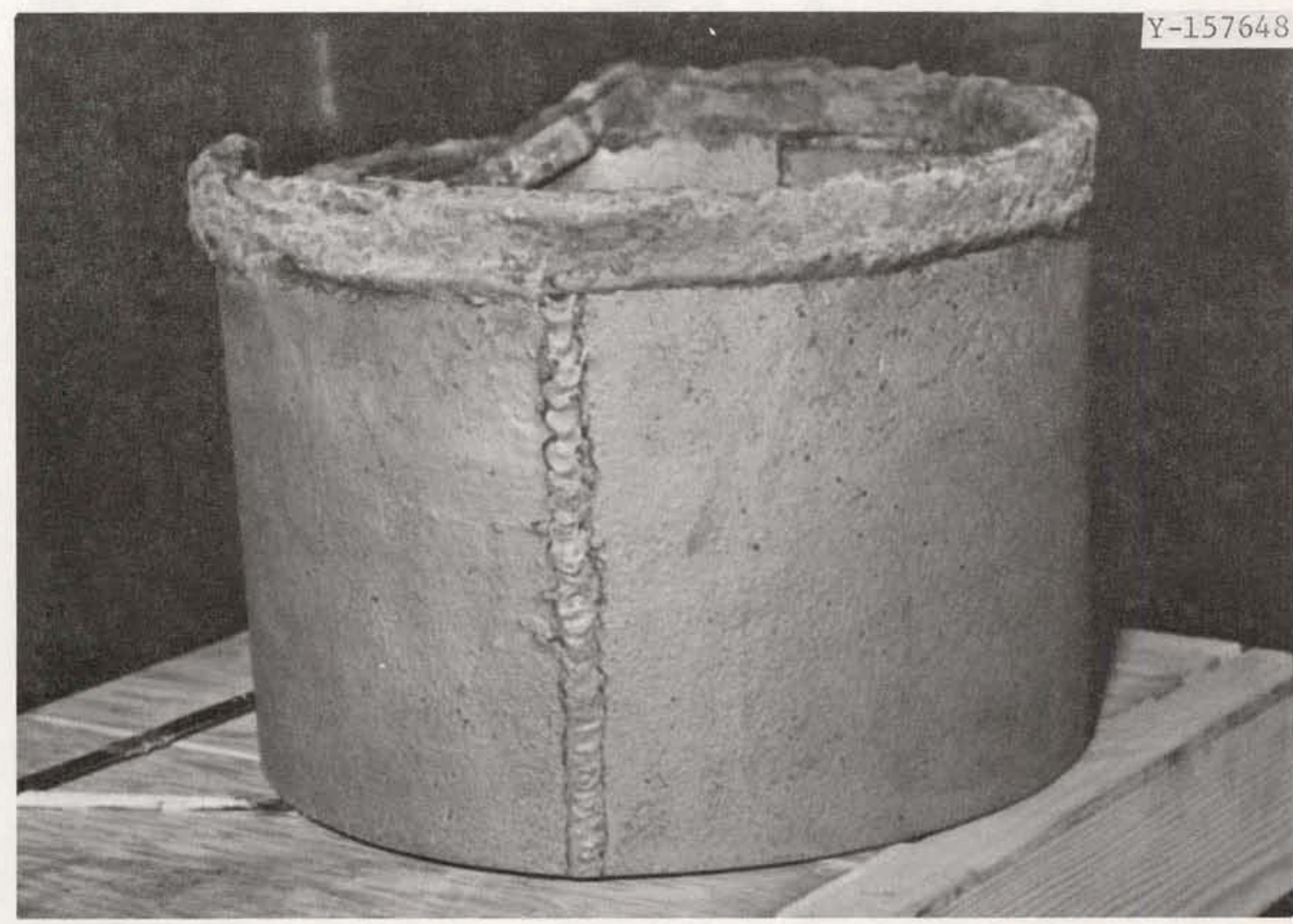

Fig. 10. Exterior of Outer Casing Showing Longitudinal Weld. Dye-penetrant inspection revealed a through-weld leak. It should be noted that the clamp and elastomer gasket were located over this region at the time of the incident. 


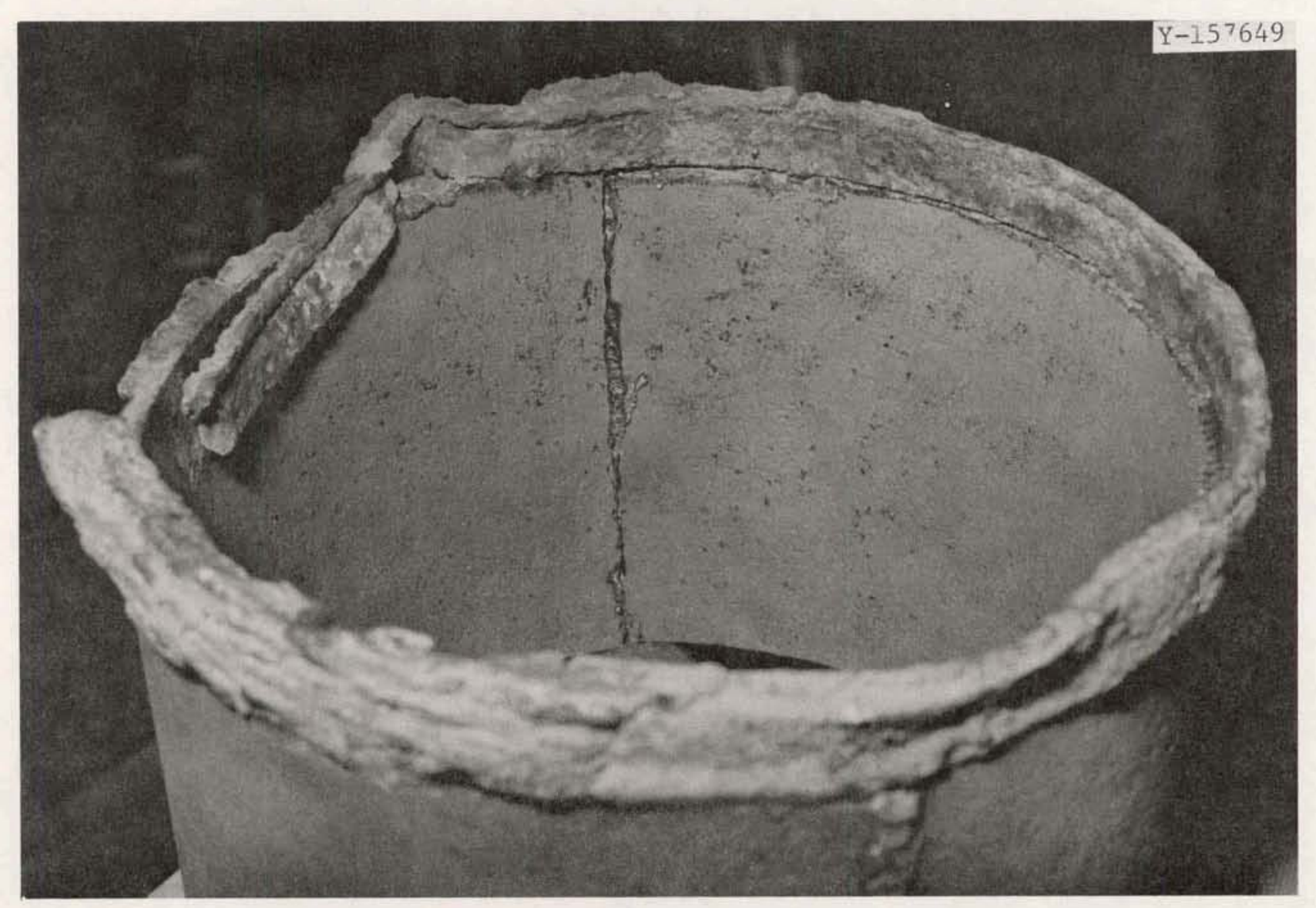

Fig. 11. Interior Surface of Outer Casing Showing Longitudinal Weld. 


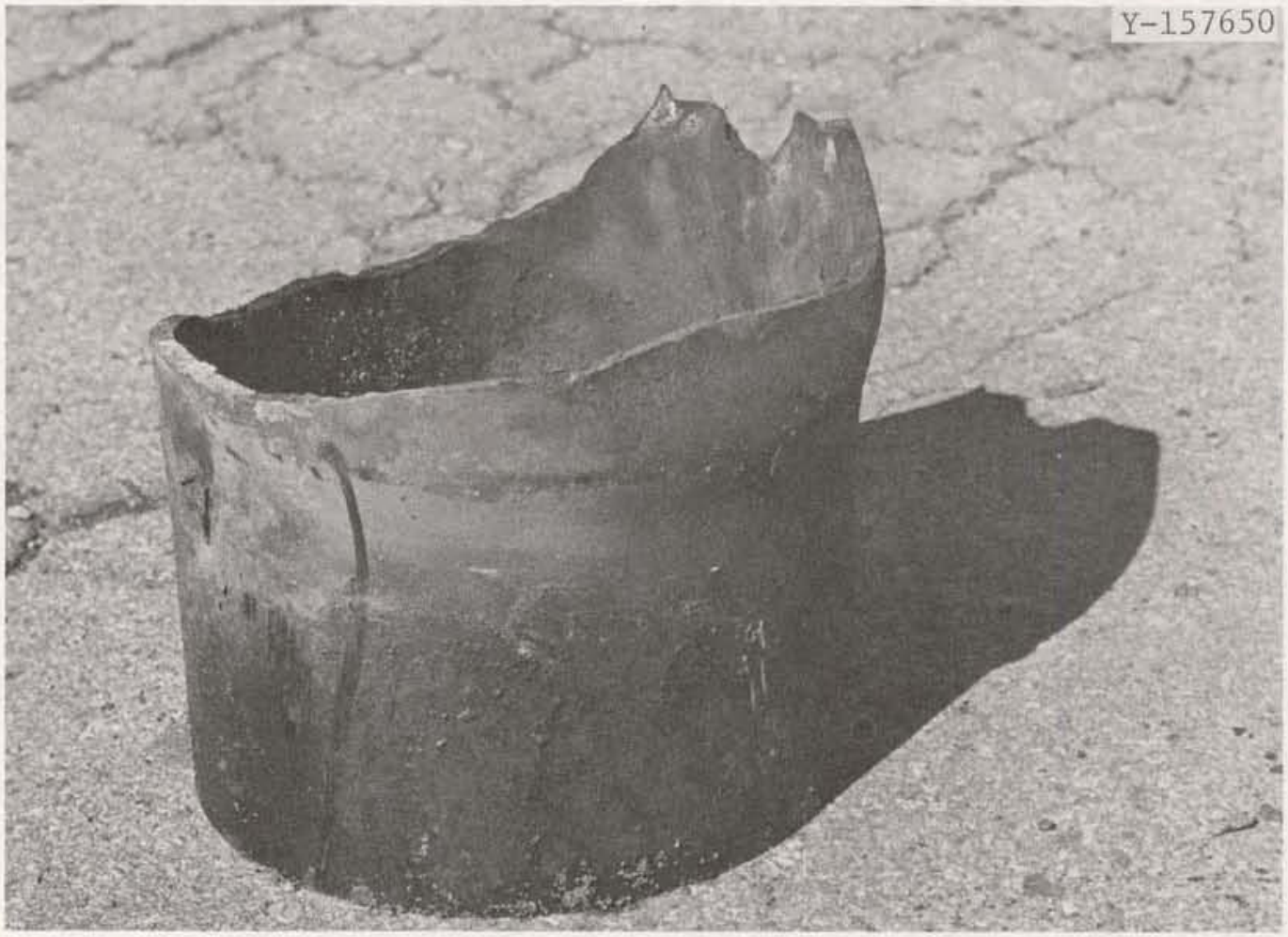

Fig. 12. 9 5/8-in. Inner Casing After Removal From Remainder of Wellhead Assembly. 


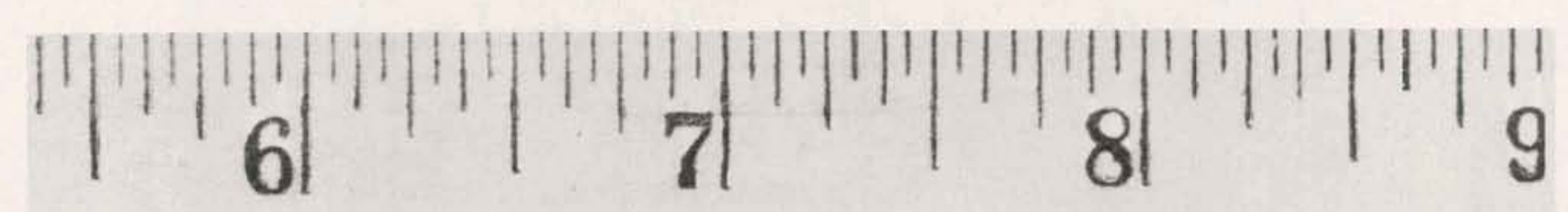

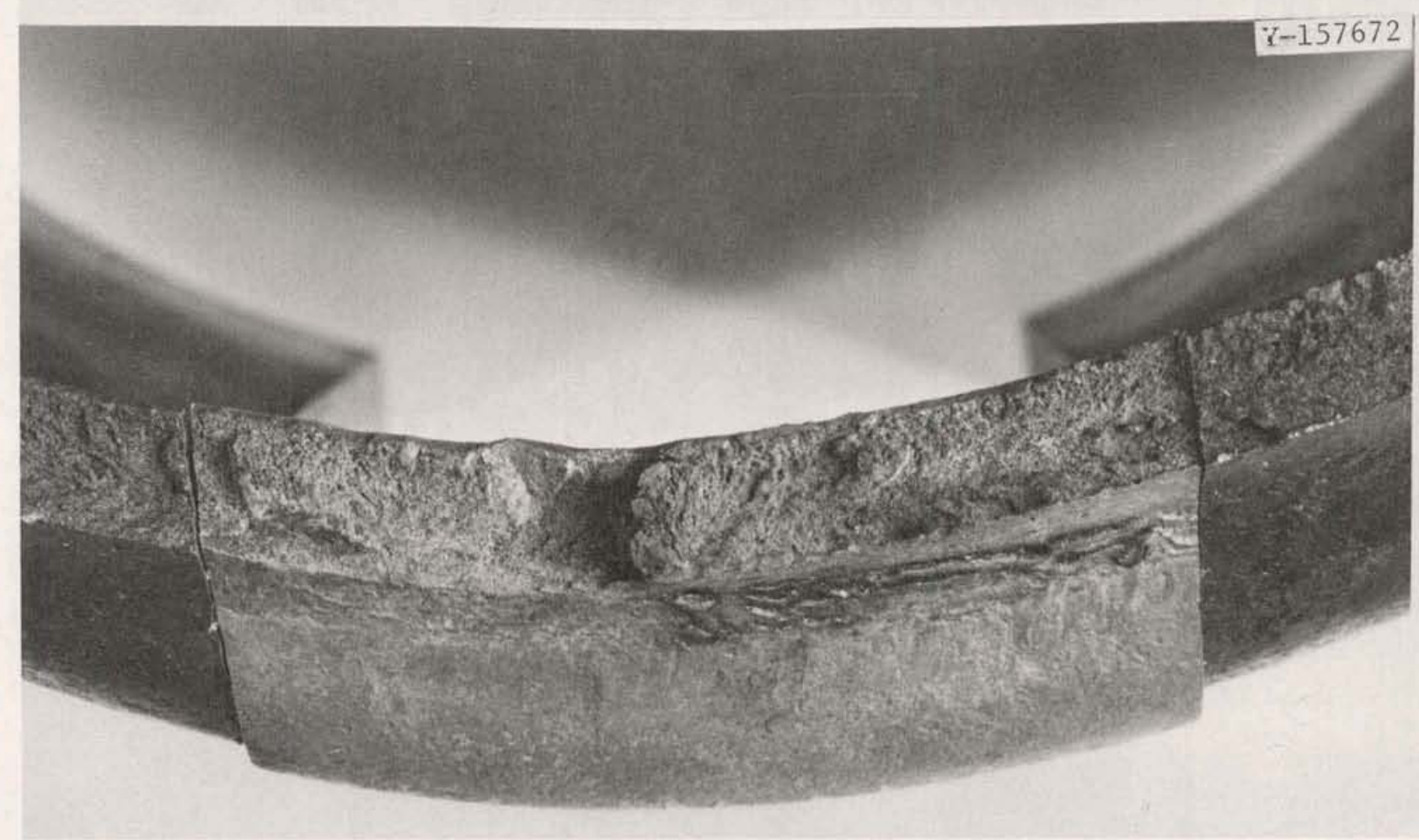

Fig. 13. Fracture Surface. Photograph shows section removed for netallographic examination. 


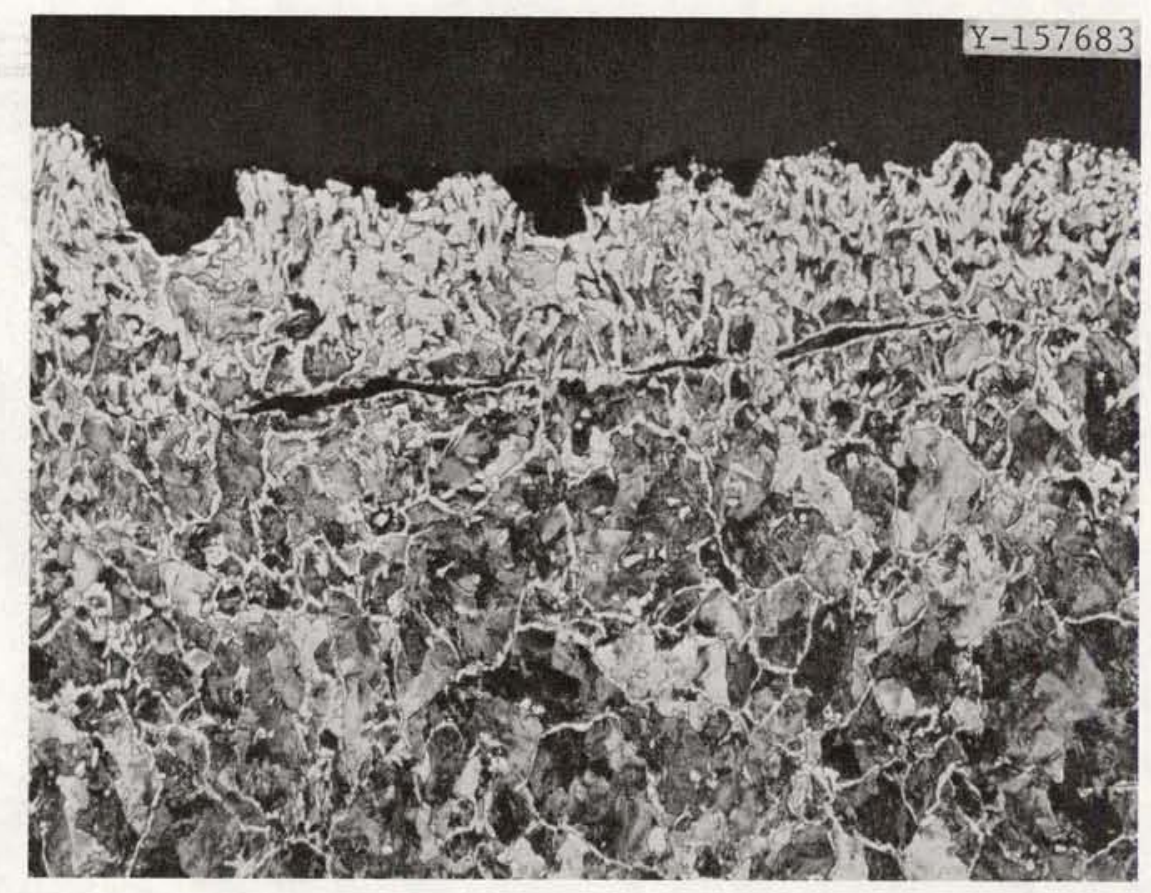

Fig. 14. Photomicrograph of Fracture Edge Showing Small Fissure Slightly Below the Plane of Fracture. 


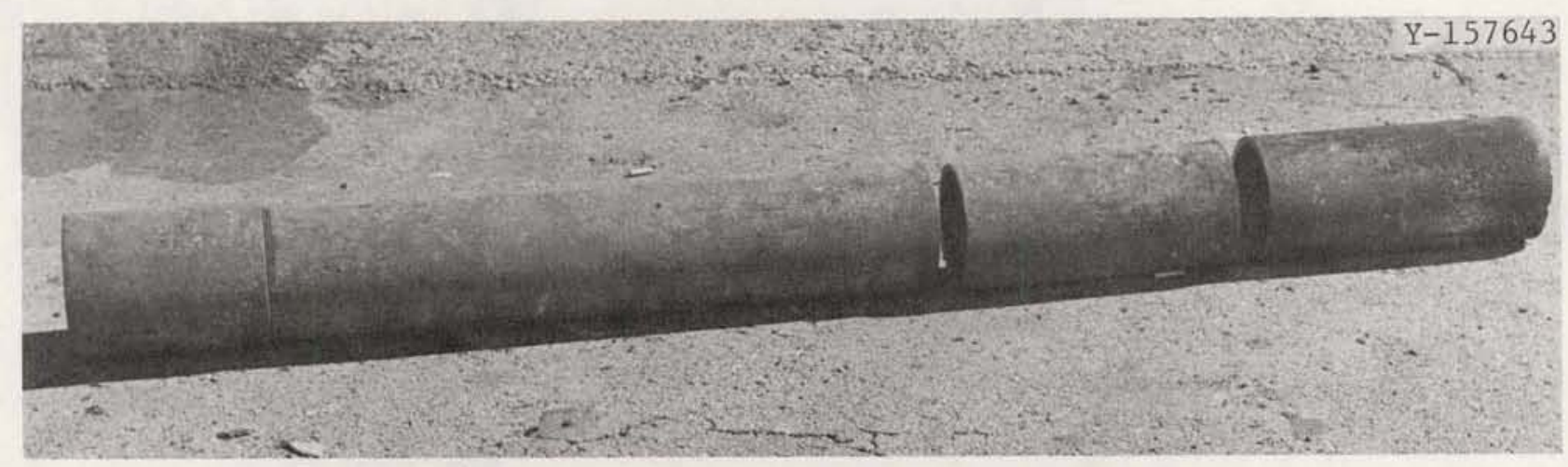

Fig. 15. Pipe 14. 


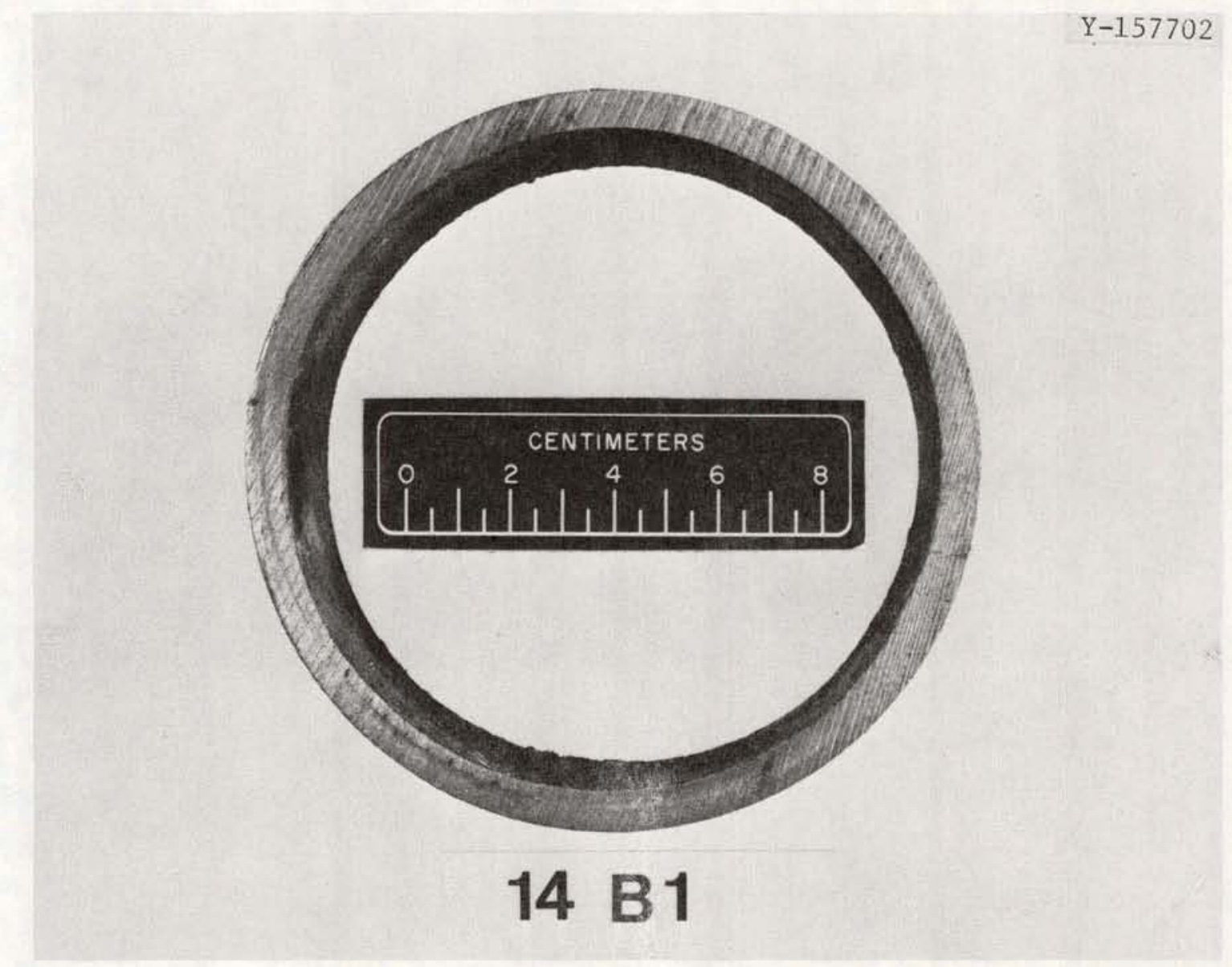

Fig. 16. Section of Pipe 14 Showing Essentially Undamaged Wall. 


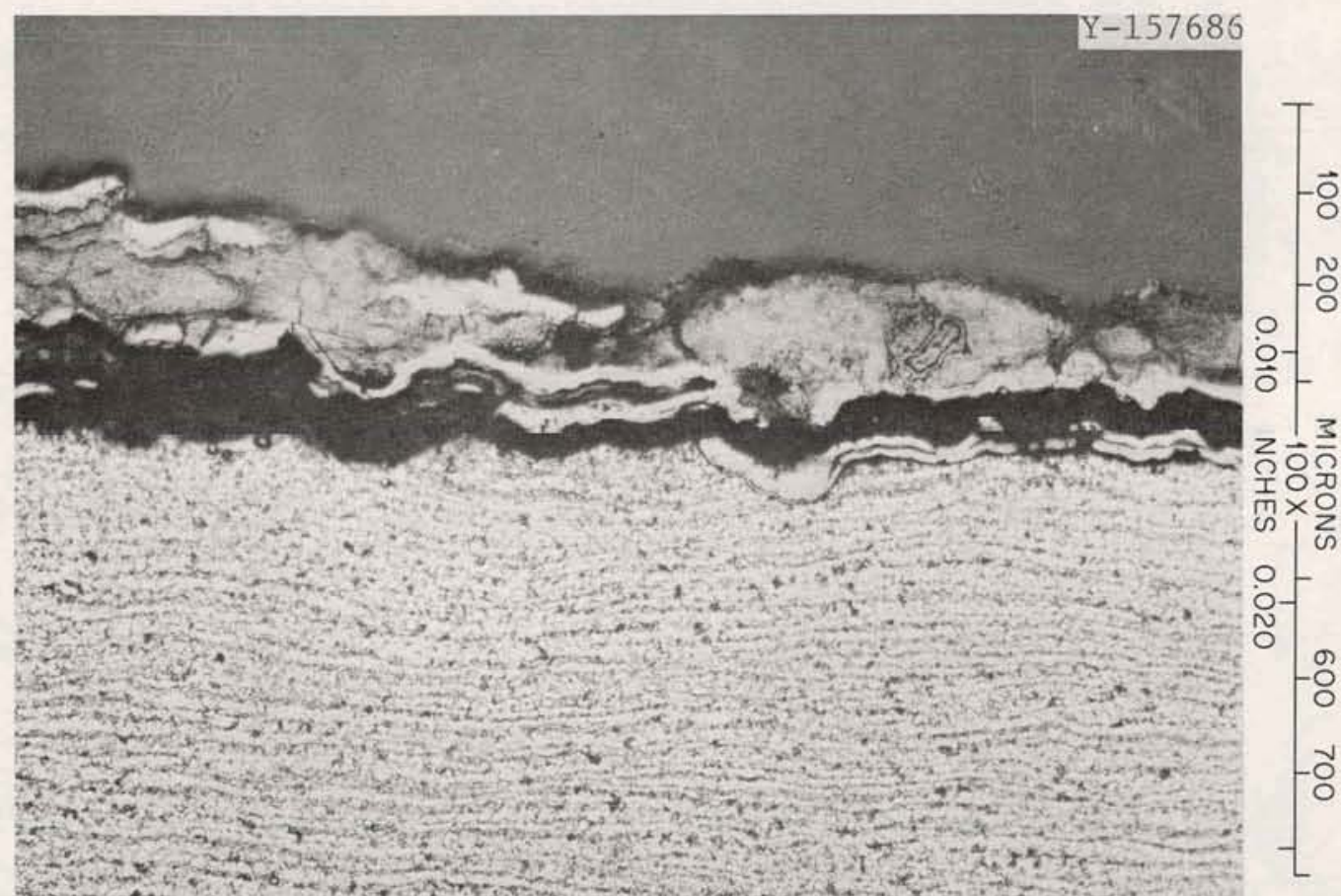

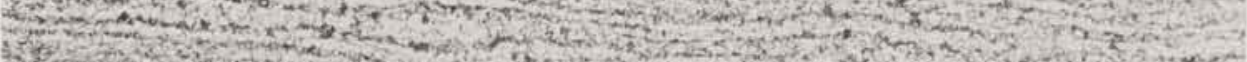

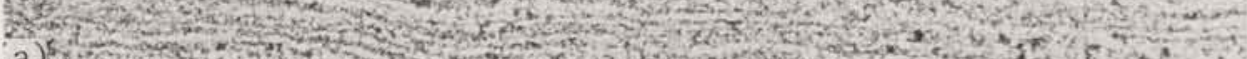

a) $x^{2}$.

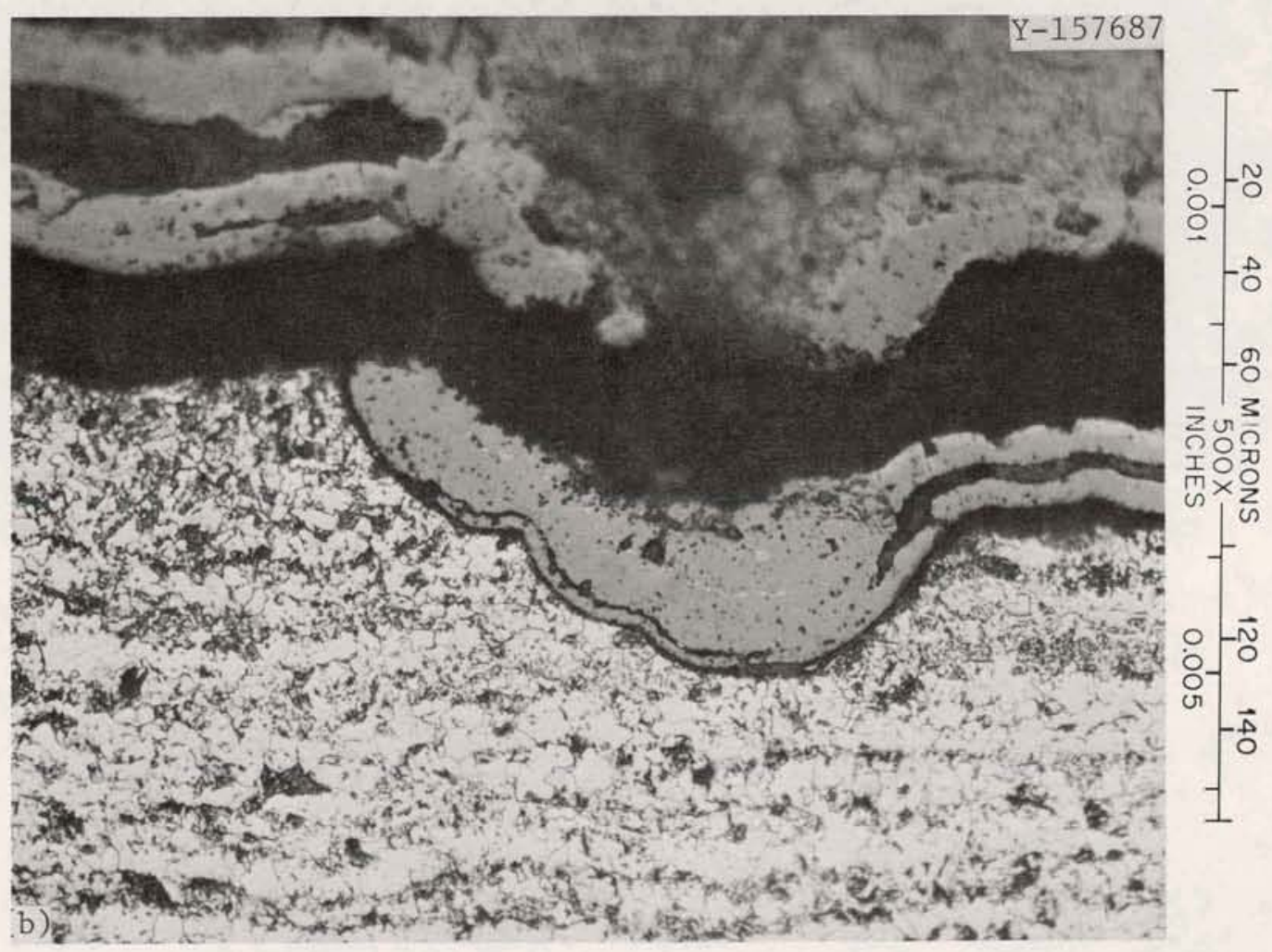

Fig. 17. Microstructure of Pipe 14. Photomicrograph was made at exterior surface. Some oxidation can be seen, but the wall is essentially undamaged. 


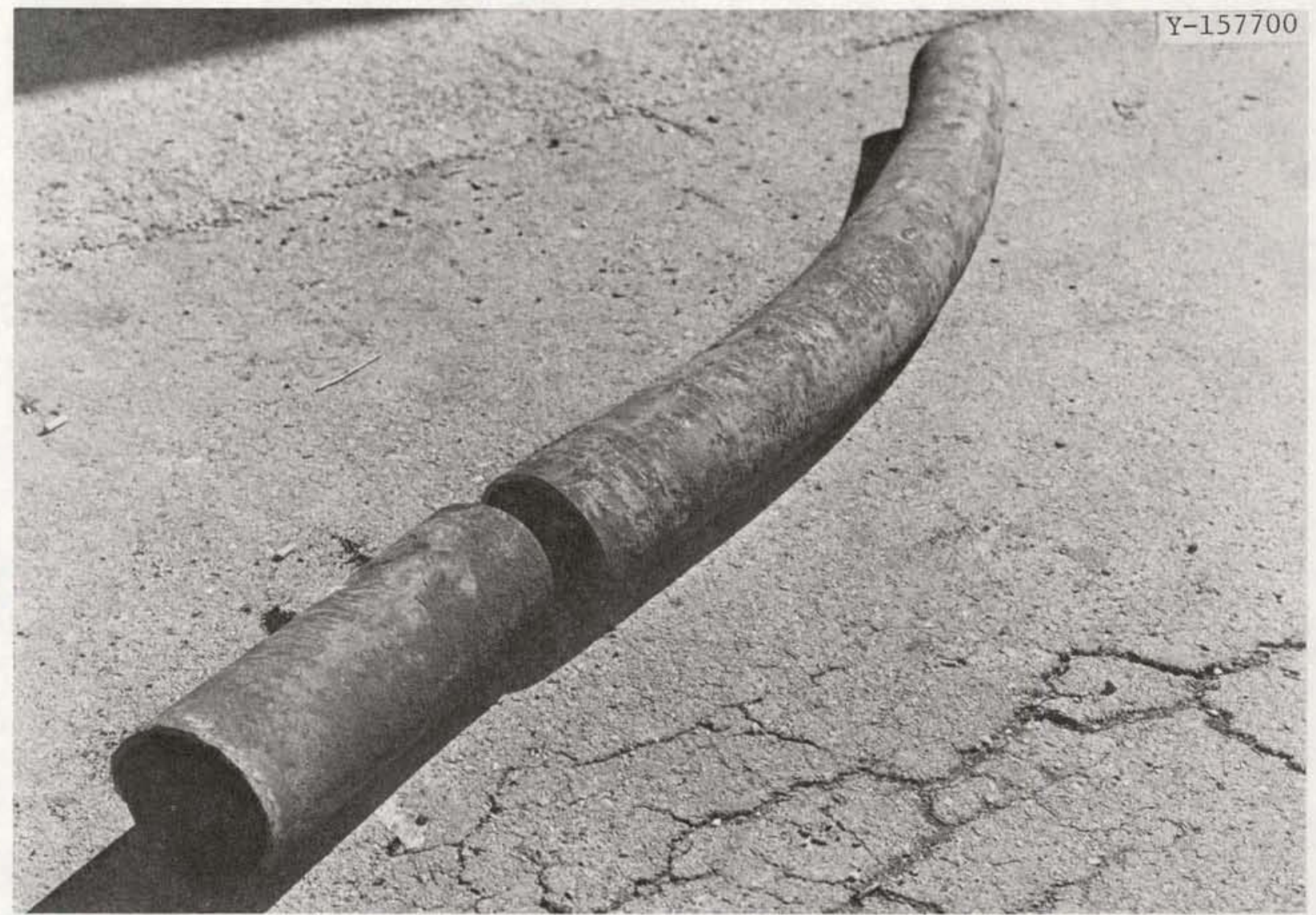

Fig. 18. Pipe 2. 


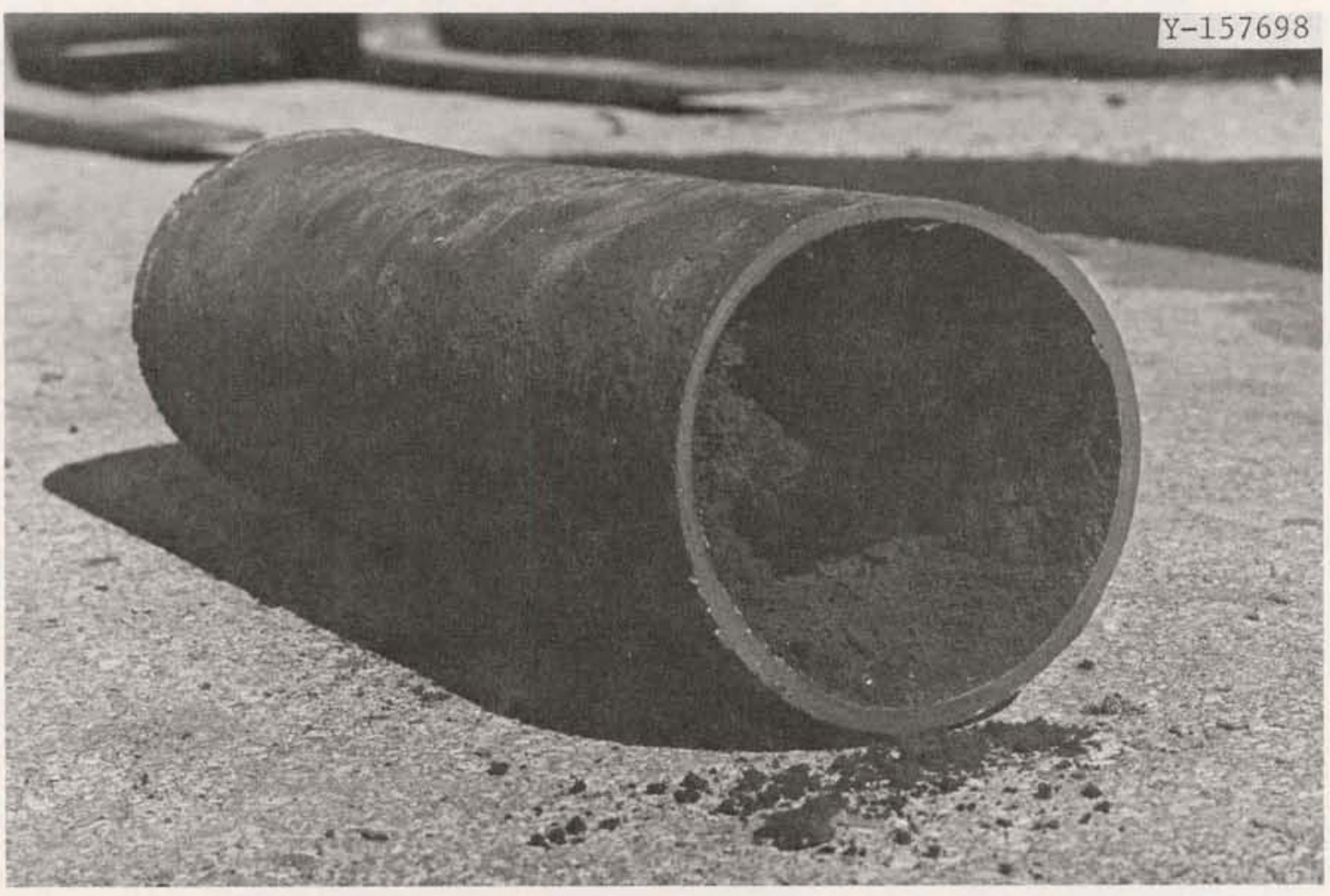

Fig. 19. Segment of Pipe 2 Showing Extensive Amount of Loosely Adherent Scale. 


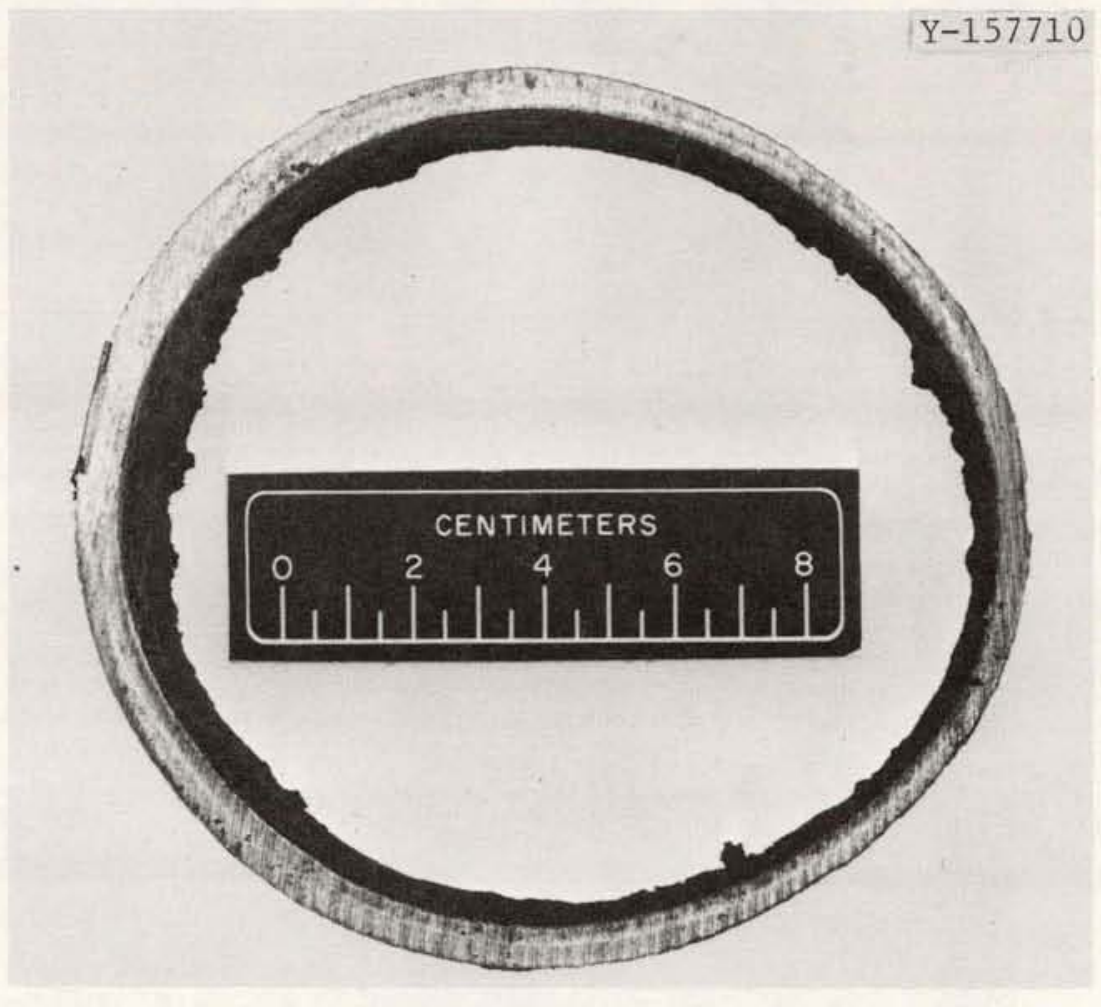

Fig. 20. Section of Pipe 2 Showing Wall Thinning. 

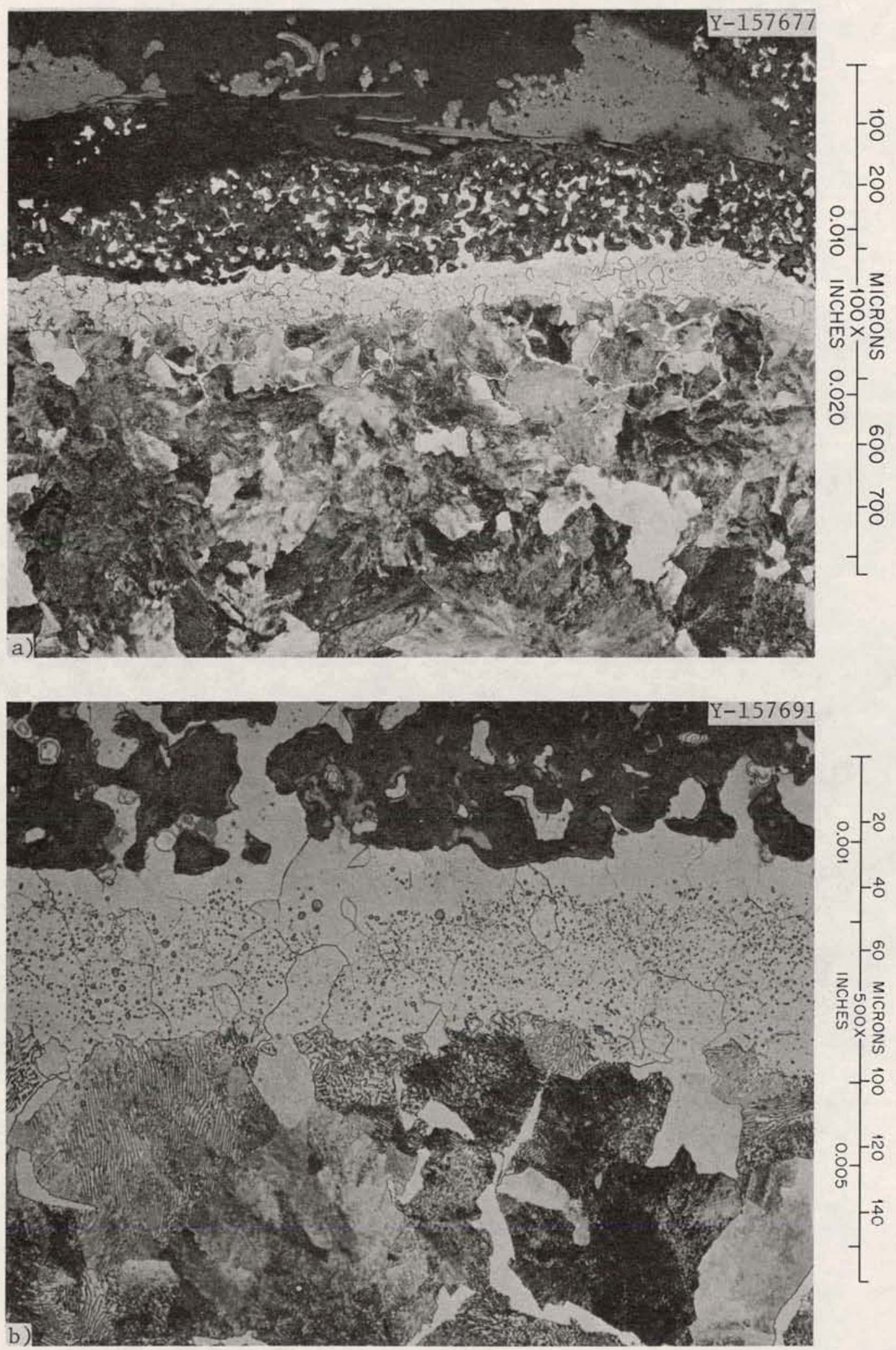

Fig. 21. Microstructure of Pipe 2. Note the carburized condition of the microstructure as compared with Pipe 14 (Fig. 17). A decarburized layer at the inner surface of the pipe wall near a reaction product can be seen. 


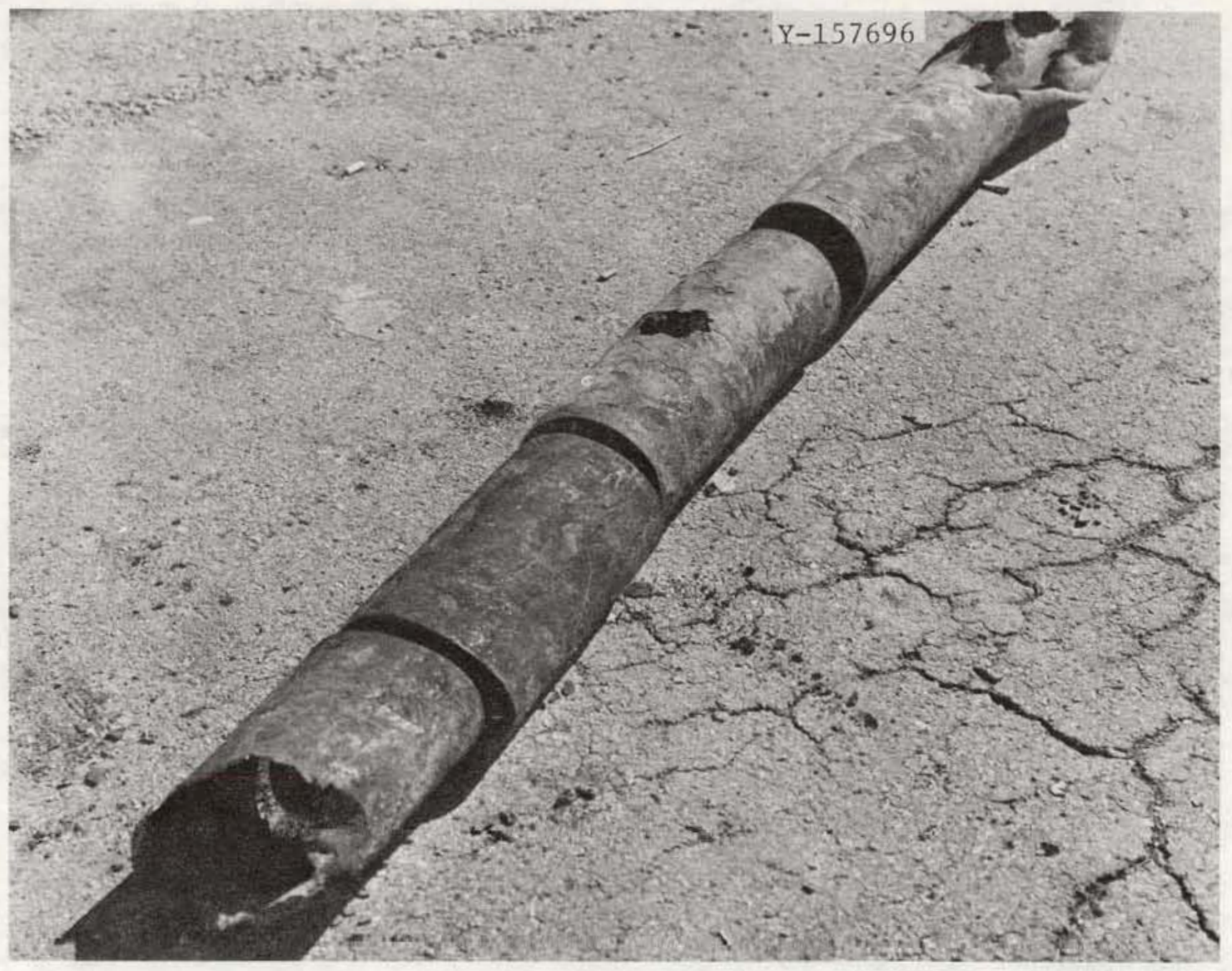

Fig. 22. Pipe 3. 


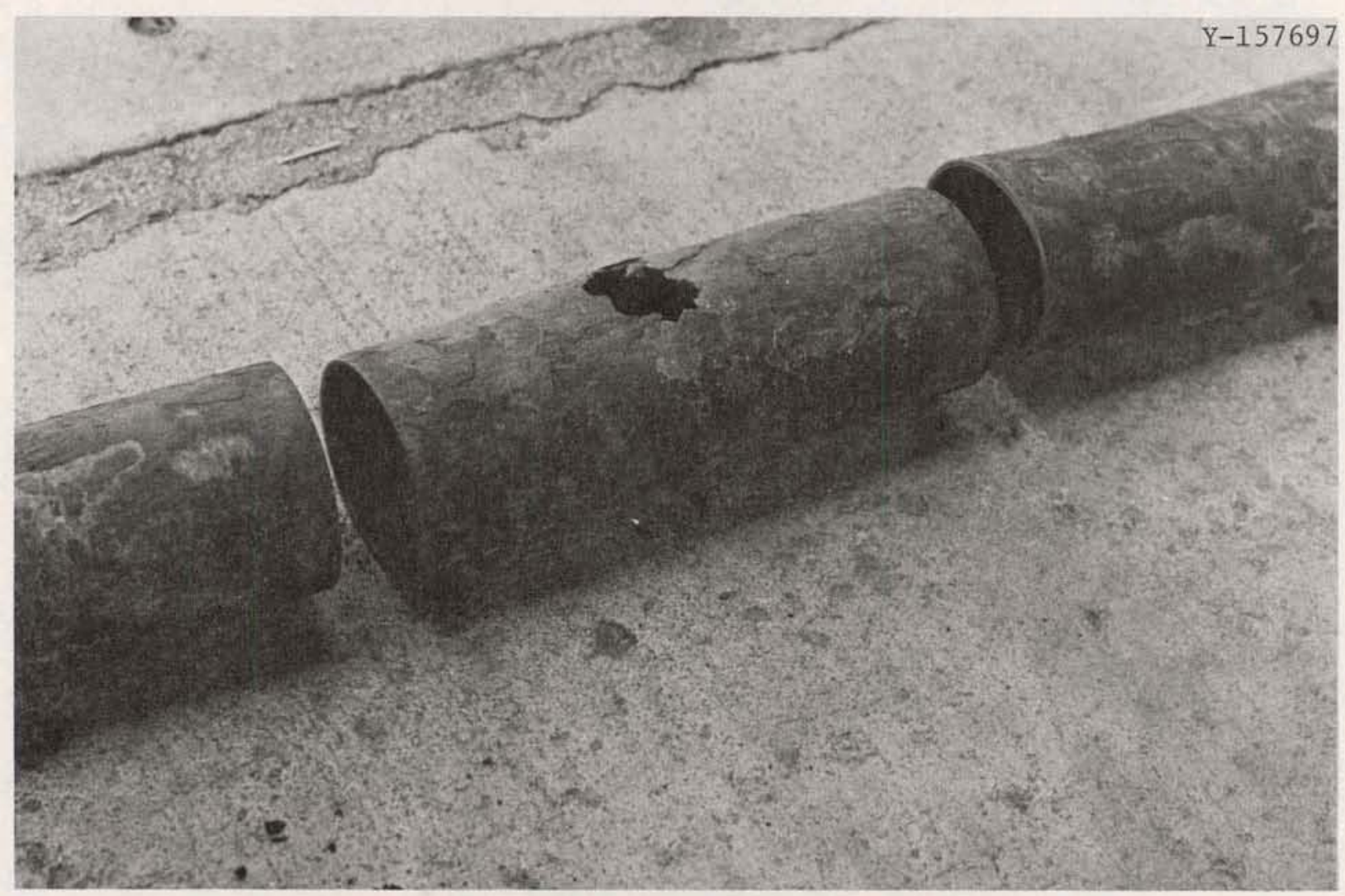

Fig. 23. Pipe 3 Showing Hole in More Detail. 


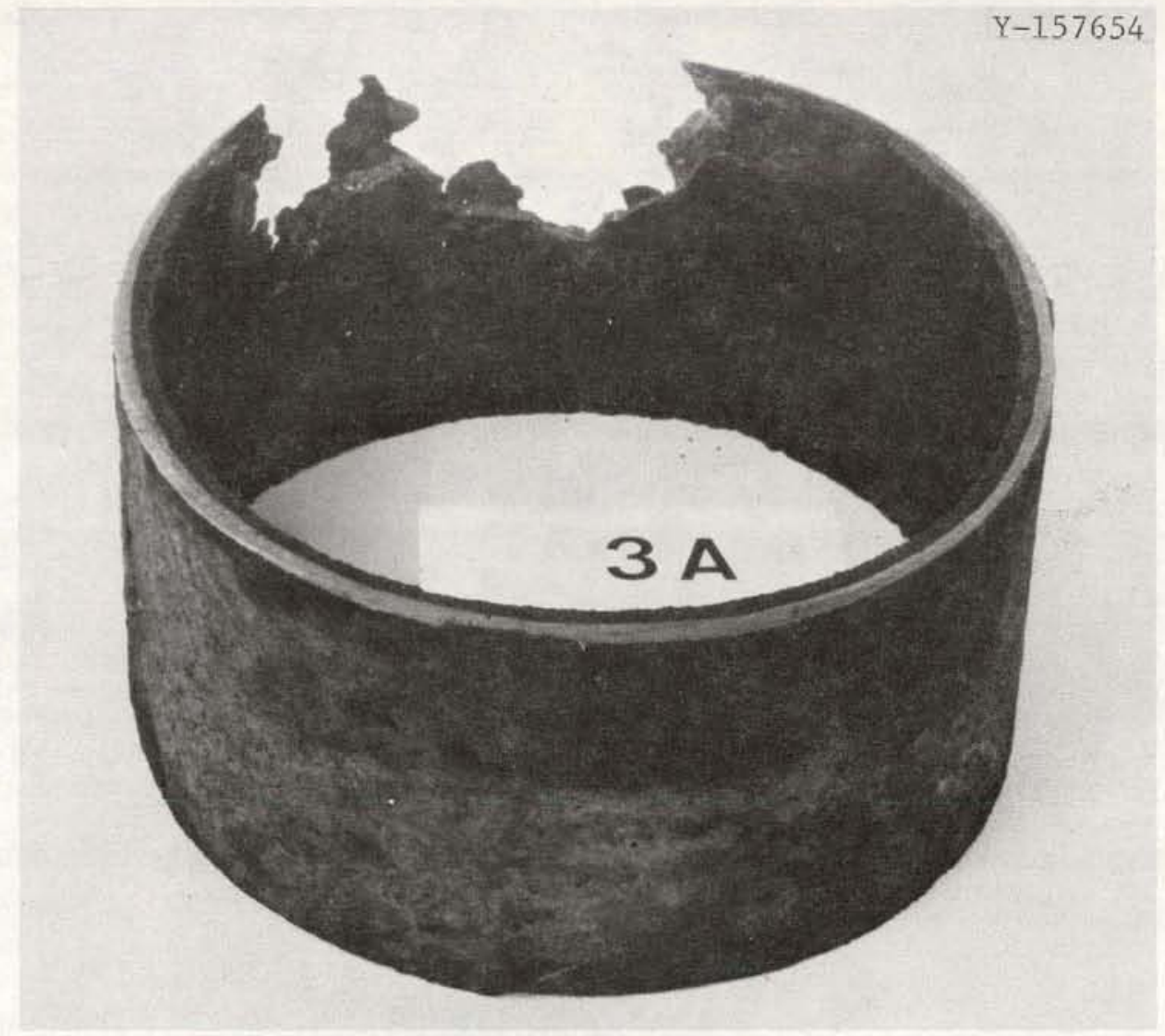

Fig. 24. Segment of Pipe 3 Showing a Hole and Gross Oxidation/Corrosion. 


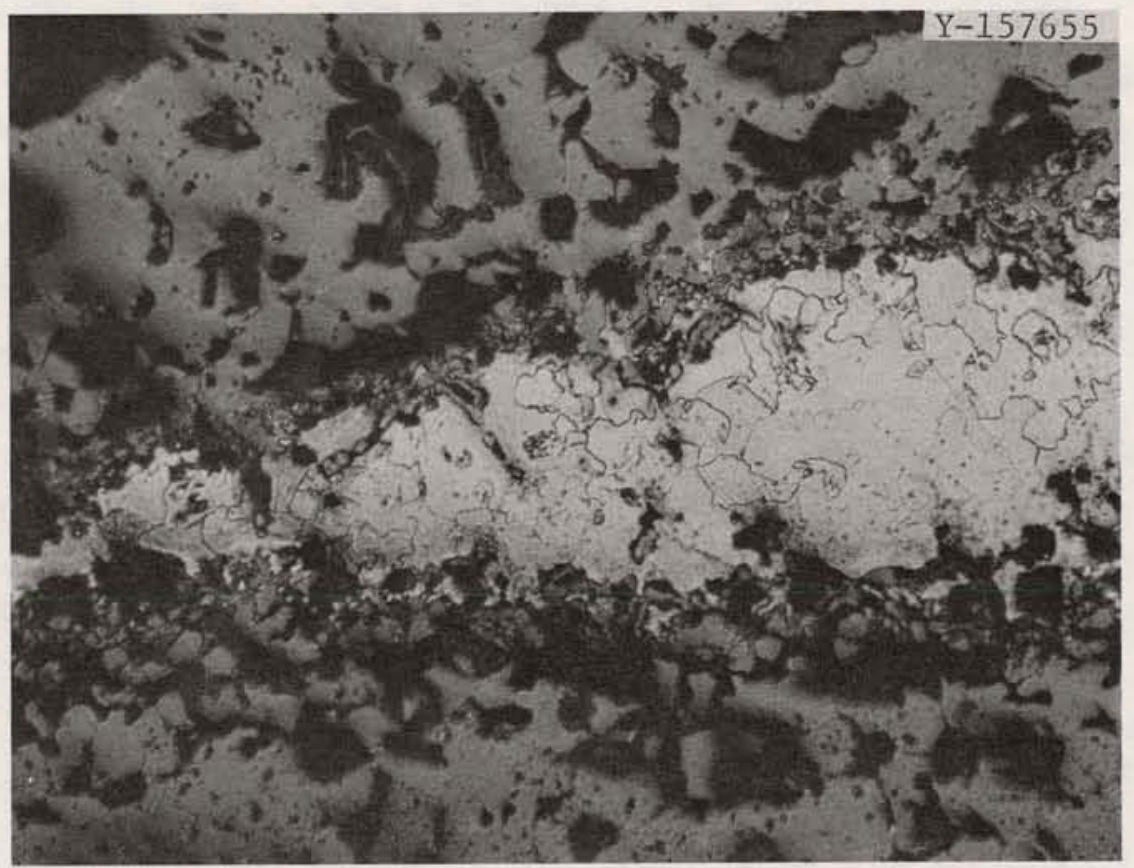

Fig. 25. Photomicrograph of Pipe 3 Showing Remaining Metal Wall and Adherent Scale. 


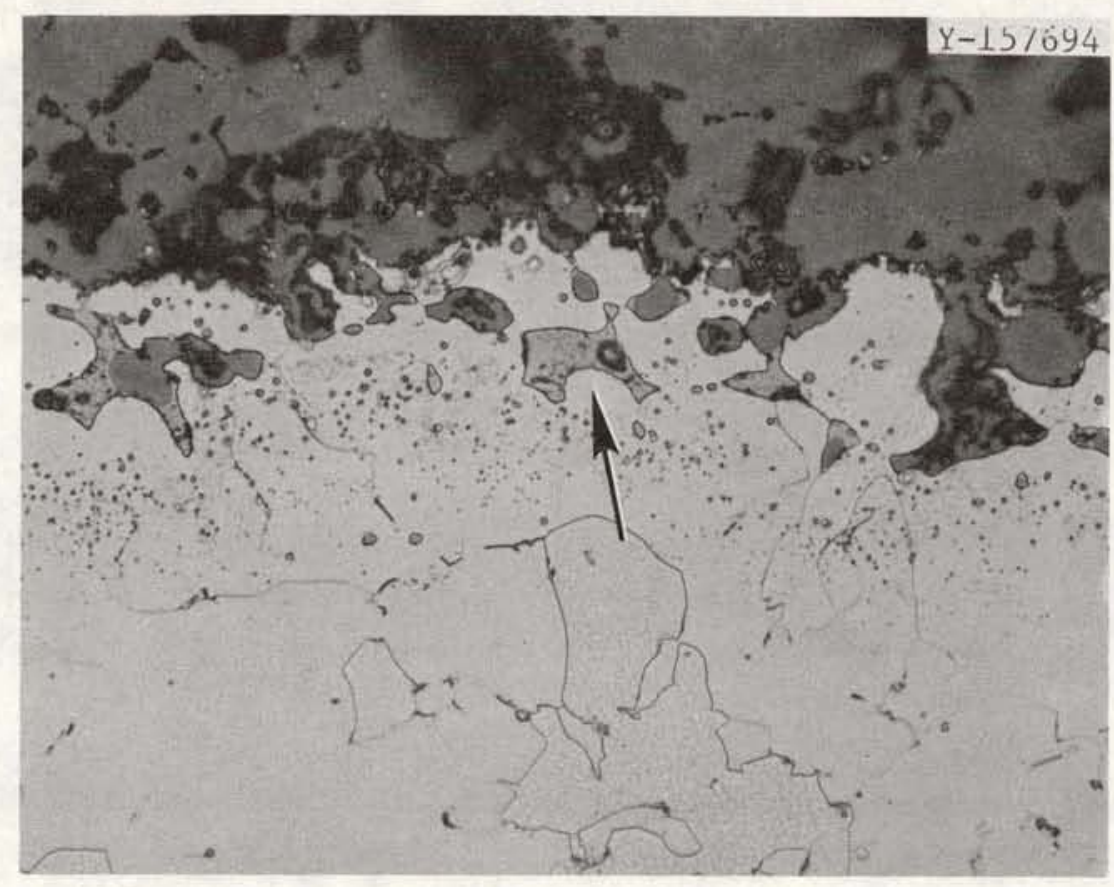

Fig. 26. Pipe 3, Eutectic Structure (arrow) in the Base Metal Near the Deposit. 500x 


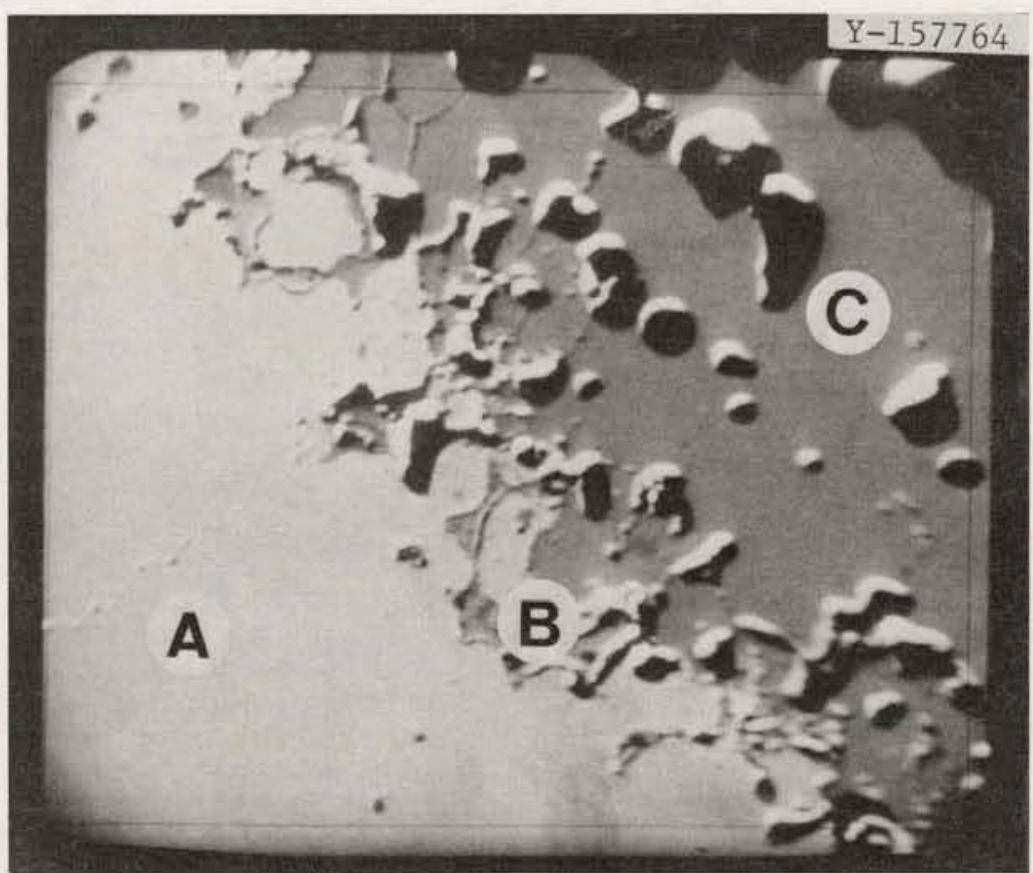

Fig. 27. Backscattered Electron Image of Scale-Metal Interface. A, B and C indicate locations from which $\mathrm{x}$-ray spectra were taken. 


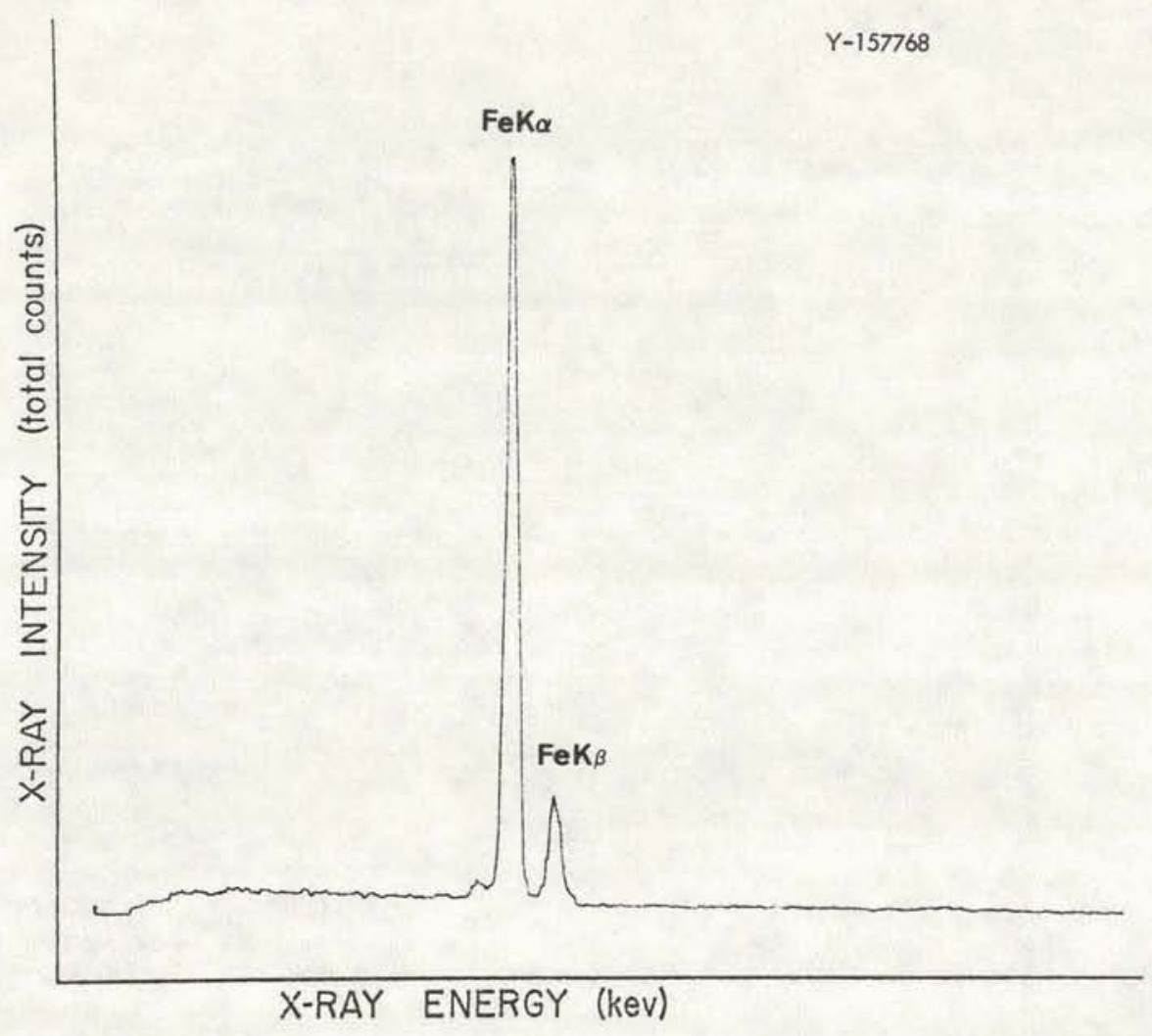

Fig. 28. Pipe 3 Wall (Area A, See Fig. 27). 


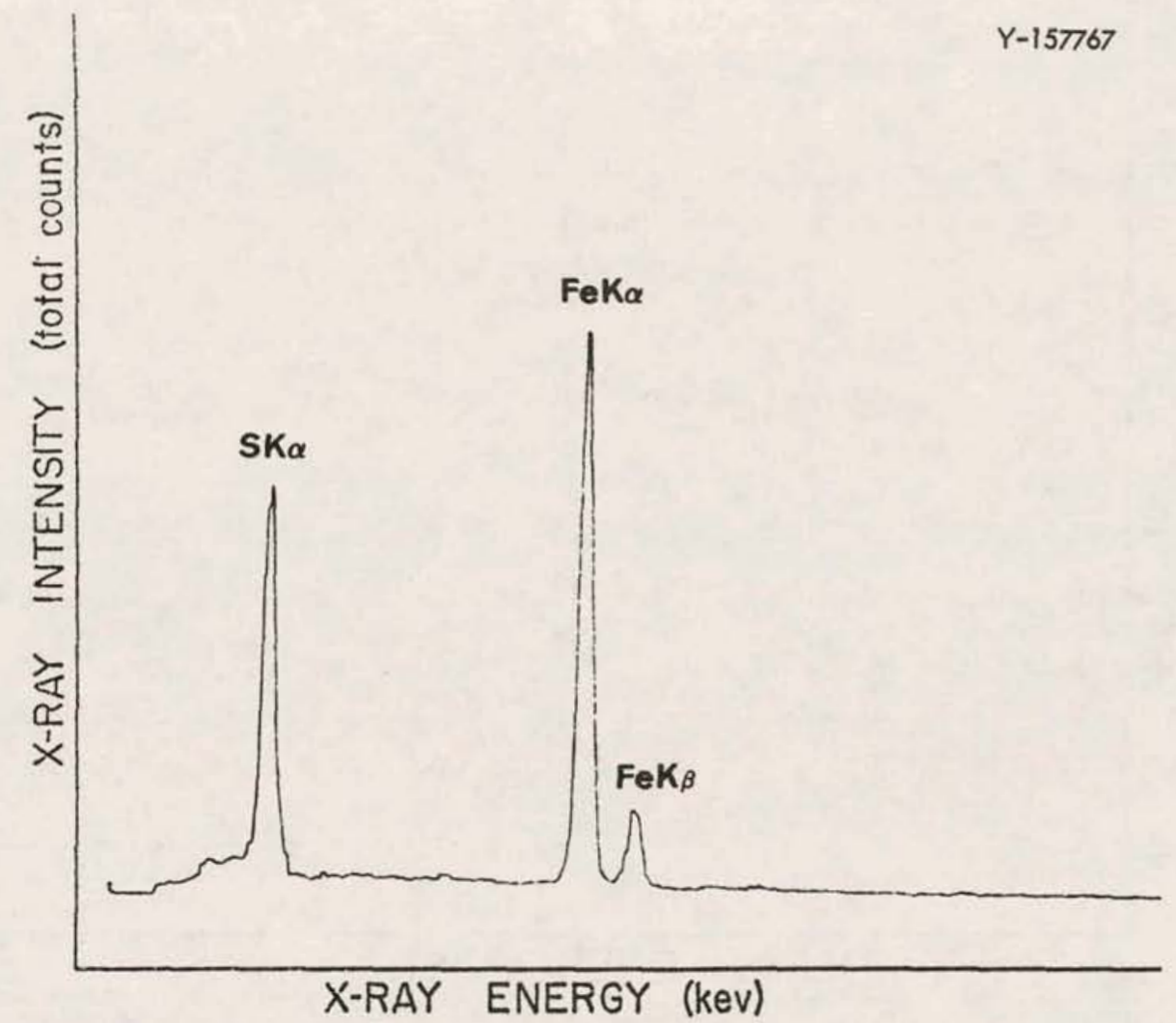

Fig. 29. Pipe 3 Eutectic Composition (Area B, See Fig. 27). 


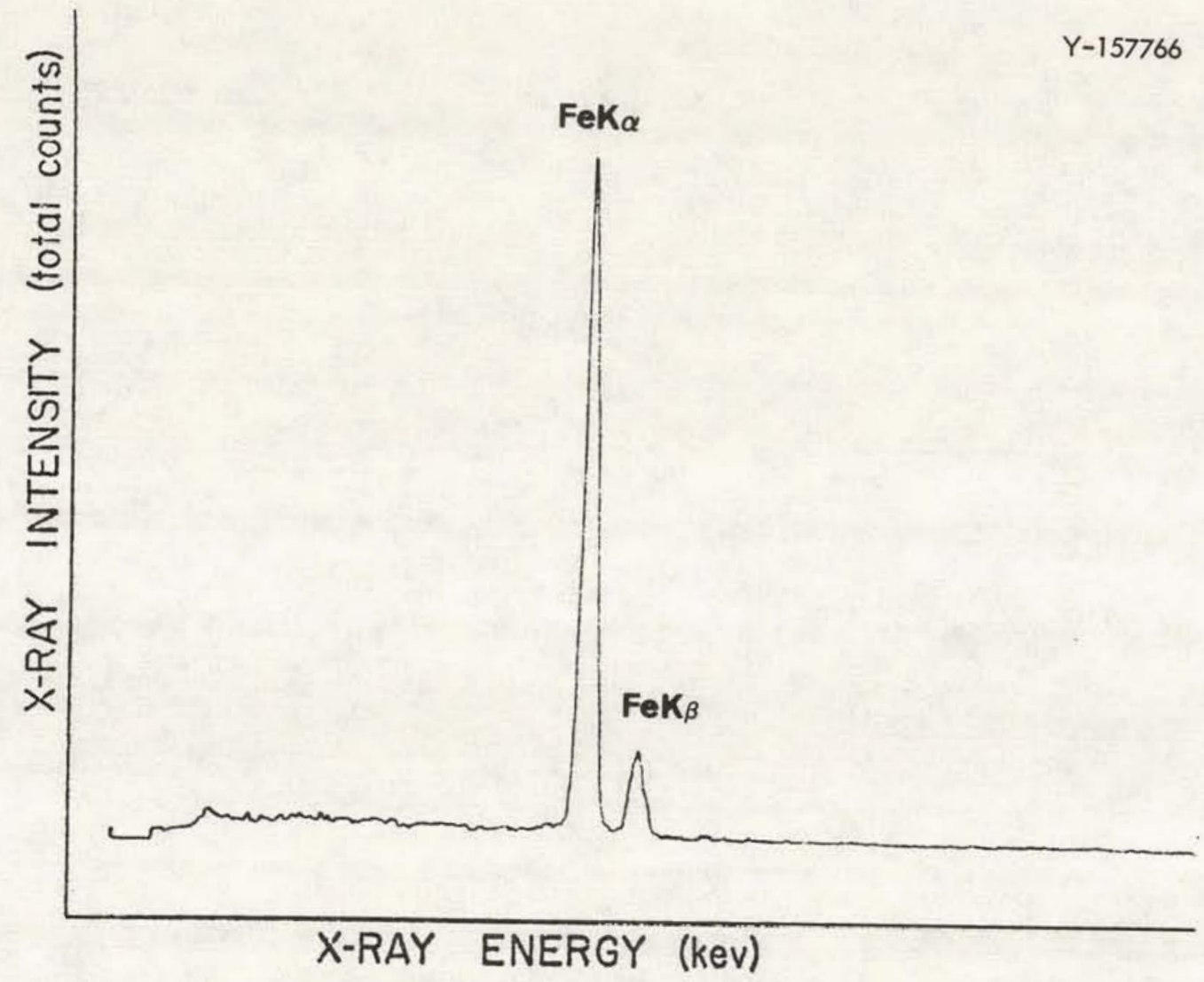

Fig. 30. Pipe 3 Scale on Inside of Pipe (Area C, See Fig. 27). 

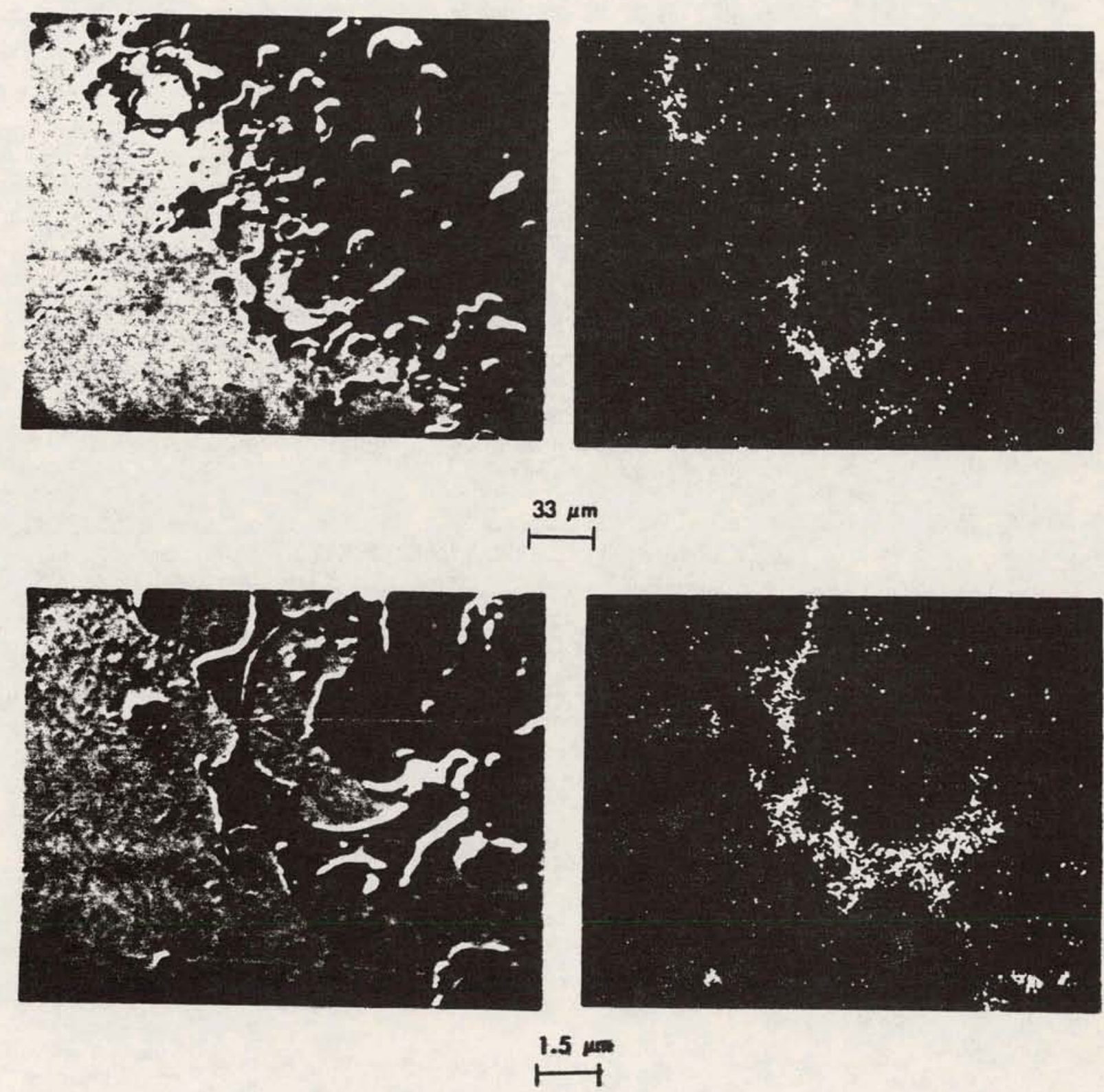

Fig. 31. Sulfur Distribution at Scale-Metal Interface as Determined by Electron Microprobe X-Ray Dot Map Display. 


\title{
DISTRIBUTION
}

\author{
1. G. M. Adamson \\ 2. C. R. Brinkman \\ 3. J. E. Cunningham \\ 4. J. H. DeVan \\ 5. R. G. Donnelly \\ 6-11. R. J. Gray \\ 12. J. C. Griess \\ 13-18. K. M. Haythorn (ORO) \\ 19. M. R. Hill \\ 20. C. W. Houck \\ 21-23. Laboratory Records \\ 24. Laboratory Records-RC \\ 25. C. J. McHargue \\ 26-41. C. Mora (Sandia) \\ 42. Patent Office \\ 43-45. G. M. Slaughter \\ 46. D. B. Trauger \\ 47. J. R. Weir, Jr.
}


APPENDIX VIII

Consultants' Analyses

A-123 


\section{THIS PAGE}

\section{WAS INTENTIONALLY LEFT BLANK}




\author{
JACK F. MCKENNA \\ SAFETY CONSULTANT \\ 440136 th STREET NORTH \\ ARLINGTOIN, VIRGINIA 22207
}

October 4, 1978

Dr. Philip C. White, Chairman

Accident Investigation Committee

U.S. Department of Energy

2625 Mocking Bird Lane

P. O. Box 35228

Dallas, TX 75235

$\mathrm{RE}: \quad$ Sub Investigating Committee Revorts

Dear Phil:

In response to your request, enclosed is a ver $\because$ hurried report of my findings pertaining to the safety prozmen, in place, at the West Hackberry site of the DOE StratE Reserve.

I do apologize for not having it better orgarized, but due to the time element and the request that it be suomitis to you at Dallas by October 5 , the report is more or less $\equiv$ narrative account of my activities and participation as a sミfety consultant to the Investigating Committee.

It is my opinion that except for a very basic "bari-aid" type program, Parsons-Gilbane has not initiated a vonthinile safety program at the West Hackberry site.

In order to prevent a similar recurrence of incident, DOE should immediately initiate a systems saîty analysis of the entire operation; construction, drilinis ard operations.

I found some conflicts in the statements by $\equiv .3$. cersonnel. Ifr. Ivan Johnson, Resident Construction Manager, $s i \equiv t e d$ that he did not have a safety engineer, but that he had a recomendation in since June 7 to employ one. He also stated that Carl Hoffpauir was an office engineer -- not a safety engineer. C-iars, as well as Carl Hoffpauir, stated he was the site safety enzinser.

In my report, I recommended that DOE, in accoriance with order 5001.1 be responsible for establishing a sa:ezy program and holding the contractors responsible for its implemeritation. I don't know whether this is possible, but DOE, not ? is the big loser when an accident, such as the recert incident, occurs. 
Dr. Philip C. White

October 4, 1978

Page 2

You have my telephone number so if I can be of any further service to the Committee when you come to :washington, please give me a call.

JFMc : dg

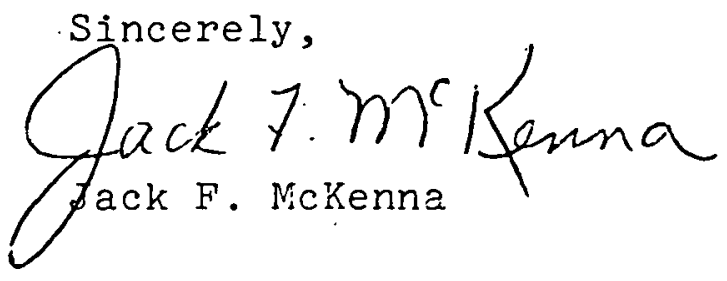

A-126 


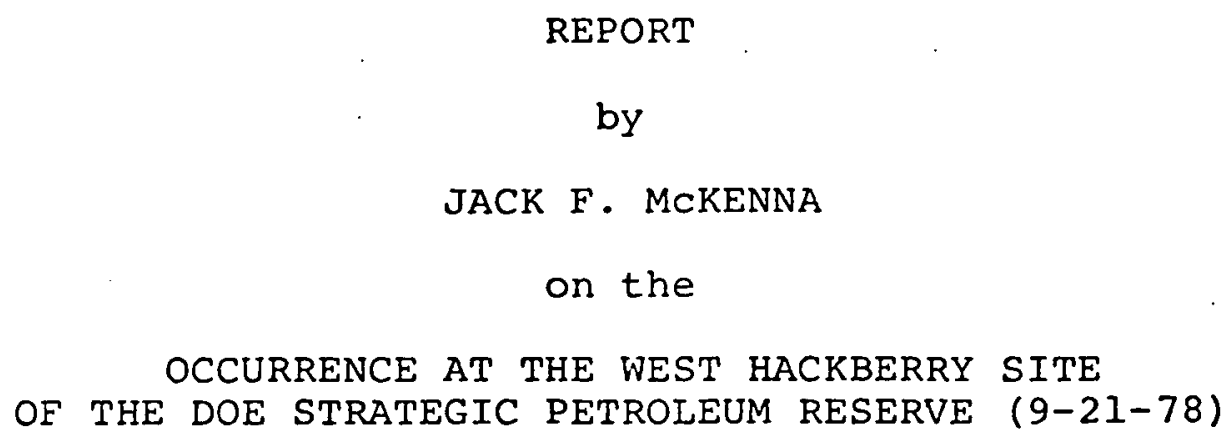

At the initial meeting of the Investigating Committee at the West Hackberry site on Tuesday, September 26, I was given copies of the following:

1. Dr. Janes Livermore's letter, dated 9/23/78, to Dr. Phillip $C$. White concerning the appointment and responsibilities of the Accident Investigating Committee.

2. DOE Order 5001.1 , dated $7 / 18 / 78$, establishing the Environment, Safety, and Health Program of the Department of Energy.

3. Working Check List - Guidelines to be used by the committee in its investigation of the West Hackberry incident.

I was instructed to review the material and prepare a list of comments and recommendations as to how I could best serve the committee in my capacity as a safety consultant.

In as much as my expertise is in the accident and fire prevention areas, I check those items pertaining to these subjects. I was assigned to work under Dr. Phillip Lowe who instructed me to review and comment on the adequacy of the site manuals, procedures, emergency plans, etc., pertaining to "safety".

I was introduced to Thomas B. Petty, site Manager (DOE) who showed me where the publications were kept, and I was told to use his office and facilities as long as I needed. Mr. Gerald LaBove, Site Operations Manager (Parsons-Gilbane) was away from his office, but the personnel there informed Dr. Lowe that they would gladly supply me with material they had on the subject. . I was given copies of the following Parsons-Gilbane manuals:

1. Safety Policy-Manual

2. Construction Safety Plan 
Both publications pertain specifically to the West Hackberry site. The duties and responsibilities of the site Safety Engineer are detailed. Although the manuals apply primarily to employee or personnel safety, they do contain policy statements and procedures covering the following:

1. Fire Protection

2. $\mathrm{H}_{2} \mathrm{~S}$ Escape

3. Severe Weather Alert

4. Welding - written permit is required. However, after the fire, a gas test could not be made until an Explosimeter. was obtained from the pipeline station.

I next met Mr. Sam. Wright, Parsons-Gilbane Safety Engineer from New orleans. I questioned $M r$. Wright regarding the implementation of the two publications. Mr. Wright stated that he had never seen either of the publications. He stated that it was his understanding that they had been prepared for Parsons-Gilbane by an outside consultant prior to his employment. Also, he stated that both manuals had been superceded by the Parsons-Gilbane "Loss Prevention Manual" which he referred to as the P-G "Bible" which is in use at all Parsons-Gilbane sites. Both Robert Leutzinger, another committee consultant, and I reviewed the manual and it is our opinion it would not be worthwhile to reproduce this voluminous tome for committee use. Its coverage is too general and not specifically applicable to the West Hackberry site. Mr. Wright commented that on paper there is a safety engineer on the site, but that was all it was on paper. He stated that he had been trying to employ a safety engineer who could take the Loss prevention Manual and rewrite portions of it to make it applicable to West Hackberry.

It.was interesting to learn that an employee Mike Tameo, an area superintendent for Parsons-Gilbane also had the title of Safety and Security Officer. On September 26, Mr. Tameo was relieved of his superintendent and safety title and made responsible only for Site Security. A Mr. Carl Hoffpauir office Engineer and Estimator, I understand has inherited the safety officer title. However,. Mr. Wright assured me that it was a "paper title".

I was informed by Dr. Lowe that one of the persons interviewed by the committee referred to an emergency procedure plan for disasters. In trying to run this down, I learned that this subject is covered in the safety Policy Manual, dated 1/18/78, which is referred to earlier in my report. Also, I learned that there was an emergency procedure plan for hurricanes. I located such a document titled, "Emergency Procedures-Hurricanes INindstorm-Flooding". This procedure applies to the office employees located in the P-G office at New Orleans. For those employees who are required to remain on duty they are advised to stay away from window areas and remain in the inner area of the building. Factitiously, our trailer at West Hackberry was not even anchored to the ground. 
In Mr. Petty's office; I reviewed eight excellent DOE Inspection and Maintenance Manuals covering the following subjects.

1. Cathodic Equipment and controls

2. Electrical Equipment and Controls

3. Measurement Equipment and controls

4. Mechanical Equipment and controls

5. Pipelines

6. Pipeline coating and Inhibitors

7. Paint

8. Tanks and Pressure Vessels Equipment and Controls

I learned that the above manuals are in tentative form, and revisions to the eight manuals have been distributed to key DOE personnel by Gulf Interstate Engineering Company, manual developer Ior review and comments by october I1, 1978. It is proposed that final editions of the eight manuals will then be issued.

It is my opinion that the above manuals, when finalized, will serve a very usefil purpose in the development of a much needed preventative maintenance and inspection program in an overall systems safety analysis.

In each of the above publications, the following paragraph appears in the introduction on page 1.

\subsection{Safety}

It is in the best interest of all employees to be safetyconscious at all times. The safety procedures Manual is the best reference to safety rules and procedures, and should be referred to often by maintenance personnel. This Inspection and Maintenance Manual does contain information pertaining to equipment safety. However, it does not replace the safety Procedures Manual, which pertains to personnel safety.

It is my understanding that the Safety Procedures Manual has not been developed. At least, Messrs. Hoag and Caves knew nothing of its existence. It is my recommendation that in accordance with DOE Order 5001.1 the Division of Operational and Environmental Safety of DOE immediately undertake the development of this important project.

Also, it is important that a site systems safety anàlysis be conducted at the West Hackberry site to prevent a recurrence of the recent blow-out and fire. For example, it is known that there are two and possibly more 150 lb. rated flanges on well head equipment that is being operated at much higher pressure. I am confident that recommendations concerning the testing and inspection of all drilling and oil handling equipment and procedures will be forth comming from those members and consultants specializing in this area. 
$-4-$

I will be glad to provide additional comments or information regarding this report.

Respectfully submitted,
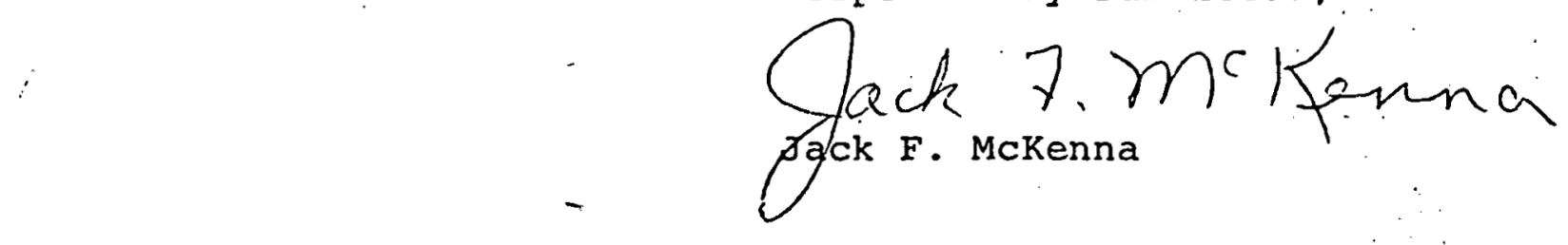

A -130 
TECHNICAL REPORT ON THE WORKOVER PROCEDURE

ON WELL 6, STRATEGIC PETROLEUM RESERVE, WEST HACKBERRY,

CAMERON P.ARISH, LOUISIANA

by

WILLIAM A. REHM

$\operatorname{TR} 78-32$

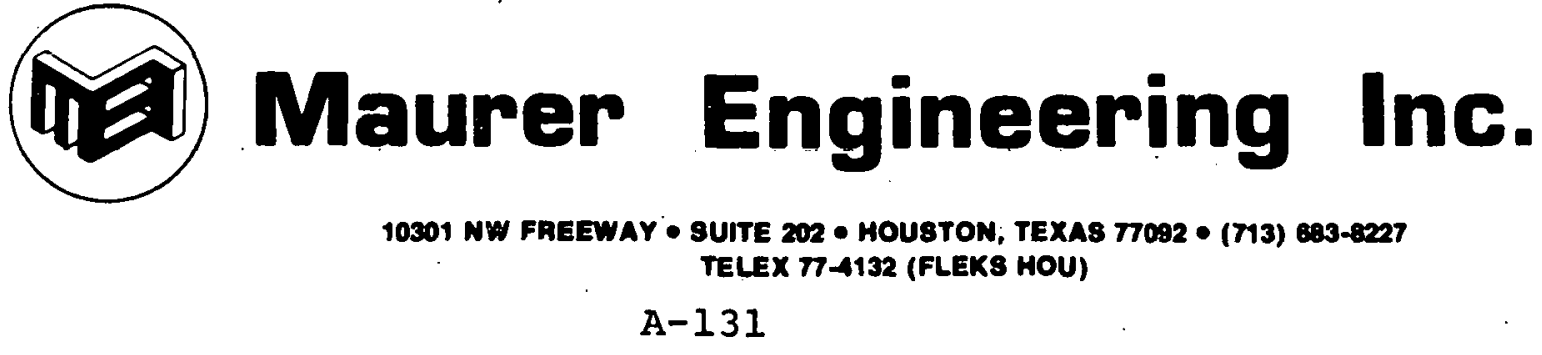


THIS PAGE

WAS INTENTIONALLY

LEFT BLANK 
TECHNICAL REPORT ON THE WORKOVER PROCEDURE

ON WELL 6, STRATEGIC PETROLEUM RESERVE, WEST. HACKBERRY, CAMERON PARISH, LOUISIANA

by.

William A. Rehm

Maurer Engineering Inc.

$\operatorname{TR} 78-32$

$A-133$ 
TABLE OF CONTENTS

TASK NO.

PAGE

PRELIMINARY - - - - - - - - - - - - - 1

SUMMARY - - - - - - - - - - - - - 3

1 ANALYSIS OF THE PACKER OPERATION AND PULLING

OF THE 5-1/2" TUBING - - - - - - - - 5

CHRONOLOGY OF EVENTS - - - - - - - - - - 9

CAUSE OF THE BLOWOUT- - - - - - - - - - 15

SAFETY VALVES - - - - - - - - - - - - 19

Safety Valve- - - - - - - - - - - 19

Safety Valves for Pulling or Running Pipe - 21

PROBABLE WELLBORE CONDITIONS- - - - - - - 23

The Mud - - - - - - - - - - - 23

The Annulus Analysis- - - - - - - - 24

The Tubing Analysis - - - - - - - - 28

U TUBE ANALYSIS - - - - - - - - - - - 29

CONCLUSIONS - - - - - - - - - - $-{ }_{-}-{ }_{-}$

2 ANALYSIS OF THE PACKER OPERATION AND PULLING

OF THE 5-1/2" TUBING IF THE ANNULUS PRESSURE WERE REDUCED TO BELOW 200 PSI AND THE CAVERN PRESSURE WAS THE MINIMUM PRACTICAL PRESSURE

OF $50 \mathrm{PSI}-\ldots-\ldots-\ldots 32$

The Annulus Pressure Analysis - - - - 32

The Tubing Analysis - - - - - - - - 36

U TUBE ANALYSIS - - - - - - - - - - 37

CONCLUSION - - - - - - - - - - - - 39

3 ARRANGE FOR AND WITNESS PACKER TESTS IN TAM

INTERNATIONAL PLANT - - - - - - - - - 40

4 ARRANGE FOR AND WITNESS THE DISASSEMBL.Y AND

INSPECTION OF THE PACKER BODY USED- - - - - 47 
TASK NO.

PAGE

5 ASSESSMENT OF THE ADEQUACY AND/OR SAFETY

FEATURES OF THE. WELLLHEAD AND/OR DOWNHOLE

ASSEMBLIES PRESENTLY. INSTALLED AT THE

WEST HACKBERRY SITE - - - - - - - - - 48

RECOMMENDATIONS FOR AVOIDING FUTURE BLOWOUTS

ON WORKOVER OPERATIONS - - - - - - - - - 49 
PRELIMINARY

The West Hackberry Site (Federal) Investigation Committee, chairman, Dr. Phillip C. White, requested that 1 serve as a technical advisor to the committee. I arrived in Lake Charles, Louisiana, at 5:00.a.m. on September 28, 1978, and met 0 r. White, Mr. Glen Stafford, and other committee members. The 28 th and 29 th of September were spent on the site listening to testimony, observing the site and location of the fire, and talking with those who were involved in the incident.

Further work in Houston. Texas, was pursued independently. Mr. Larry Sanford, president of TAM International Inc., manufacturer of the packer used in the well, and employees of TAM International Inc., did considerable testing and analysis of the burned packer at my direction.

The following report is based on several sources of information. First, transcripts and documents furnished by the committee; second, my observations and conversations with the personnel at the West Hackberry site; third, the information obtained at the TAM plant in Houston; and last, by further background discussions with people knowledgeable about workover procedures in South Louisiana, including Mr. Inmann Dabney of Dabney Engineering, formerly Drilling and Production Manager for Exxon, U.S.A. in New Orleans, and Mr. W. O. Brown, P.E. Consultant. 
The following tasks were requested by Dr. White in conference with Mr. Glen Stafford and were further clarified by Mr. Stafford.

"The Scope of Work for Rehm"

1. "Engineering analysis of the packer operation and. pulling of the $5 \frac{1}{2} "$ tubing with drawings and calculated pressures and differentials as the operation was conducted."

2. "Same as above with cavern pressures reduced to below 200 psi."

3. "Arrange for and witness packer tests in TAM. International plant."

4. "Arrange for and witness the disassembly and inspection of the packer body used."

5. "Prepare an assessment of the adequacy of the safety features of the wellhead and/or down hole assemblies presently installed at the West Hackberry site." 
SUMMARY

The well-killing operation, the setting of the packer, and the pulling of the 5-1/2"itubing by the Pelican Workover Rig \#Il under the supervision of I rby Hogue of Louis Records and Associates, Inc. was within normal industry standards for South Louisiana. The industry standards would include:
1. Planning
2. Supervision
3. Rig type and condition
4. Operational procedure
5. Other equipment used

Since the well blew out, it is evident that the overall procedures were not adequate.

The blowout could have been avoided by:

1. Bleeding the cavern pressure to "0". However, it appears that it is impractical to reduce cavern pressure to below 50 to 100 psi because of flexing of the cavern roof. The annulus pressure could, however, be reduced to 100 psi or less.

2. Using a BOP stack with shear rams. This is not a normal procedure.

The blowout might have been avoided by:

1. Setting a second plug in the tubing. The second plug could have been another packer or cement. 
2. The use of a full opening safety valve with handles or a. wheel for handling and stabbing.

3. The use of double safety valves to keep a valve on the top of the tubing most of the time.

4. Bleeding the cavern pressure to 100 psi or less and replacing the salt water in the tubing with oil. 


\title{
TASK 1 - ANALYSIS OF THE PACKER \\ OPERATION AND PULLING OF THE 5-1/2" TUBING.
}

The procedure for killing and working over well \#6 is shown as figure 1. Only the first nine steps are shown since the blowout occurred during step \#9. The procedure is from documents furnished by Louis Records and Associates.

\author{
WEST HACKBERRY \\ WORKOVER PROCEDURE \\ DOE WELL \#6 \\ $8-30-78$
}

1. Move in workover rig.

2. Bleed pressure off the $1^{\prime \prime}$ tubing or pump heavier water into the $1^{\prime \prime} \times 5-1 / 2$ " annulus.

3. Nipple up BOP's on the 6"' $2000 \mathrm{flange.}$

4. Remove l'l tubing.

5. Run a 5-1/2" cement retainer and set at the bottom of the $5-1 / 2^{\prime \prime}$ casing.

6. Kill the well between the $5-1 / 2^{\prime \prime} \times 9-5 / 8^{\prime \prime}$ annulus.

7. Nipple down the $6112000 \times 10^{\prime \prime} 2000$ casing spool.

8. Nipple up the $10^{\prime \prime} B O P^{\prime}$ 's.

9. Pull the $5-1 / 2^{\prime \prime}$ casing out of the hole.

Figure 1 . 
The configuration of the casing is shown in Figure 2. The drawing was taken from a sketch drawing labeled"Gulf Interstate Engineering Company"and dated 2/9/78. The casing weight and grades were taken from other Gulf Interstate Engineering Company records. The depths and sizes from Figure 2 will be used in this report.

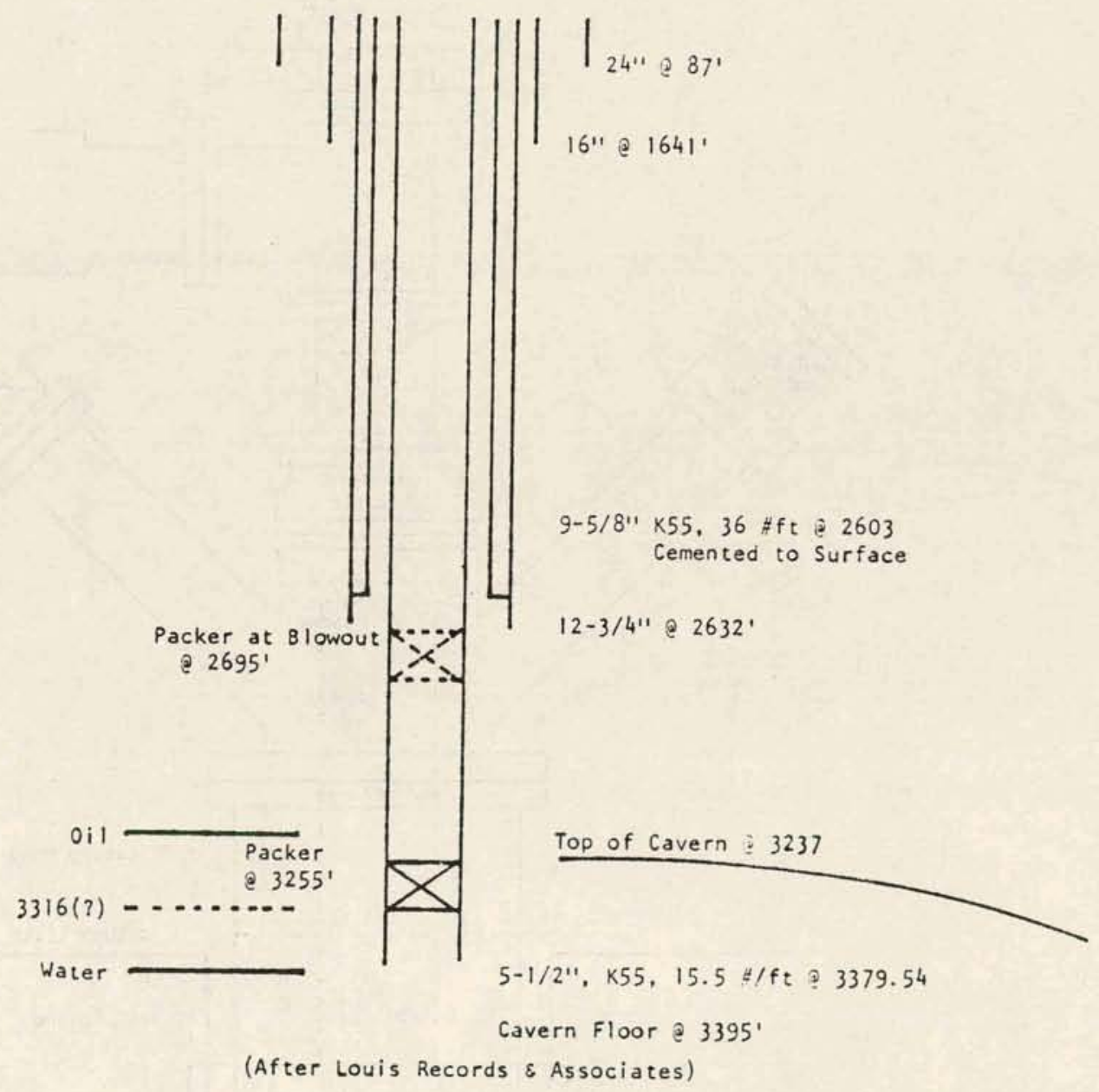

Figure 2. Casing Configuration on Well 6. 
The configuration of the wellhead before the workover started is shown in Figure 3. The original sketch is with documents provided by Gulf Interstate Engineering Company and Louis Records and Associates. Figure 4 is a photograph of Well \#1l that is supposed to be similar in all respects to the wellhead that was on Well \#6. The photograph was taken September 29, 1978, at my direction by photographers assigned to the investigative committee.

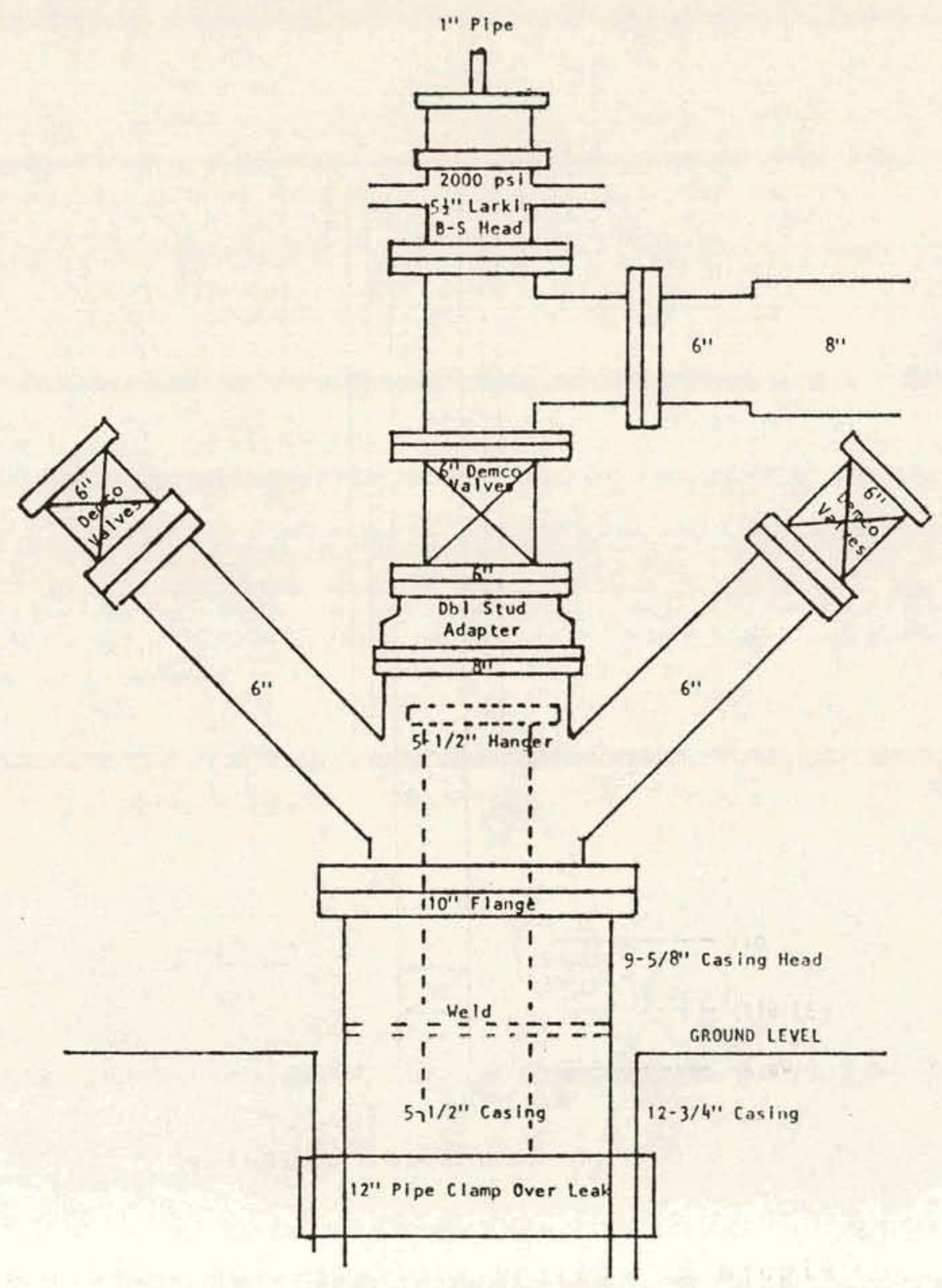

Figure 3. WEST HACKBERRY - CAVERN WELL NO. 6 BEFORE WDRKOVER STARTED

(after Louis Records 5 Assoc.) 


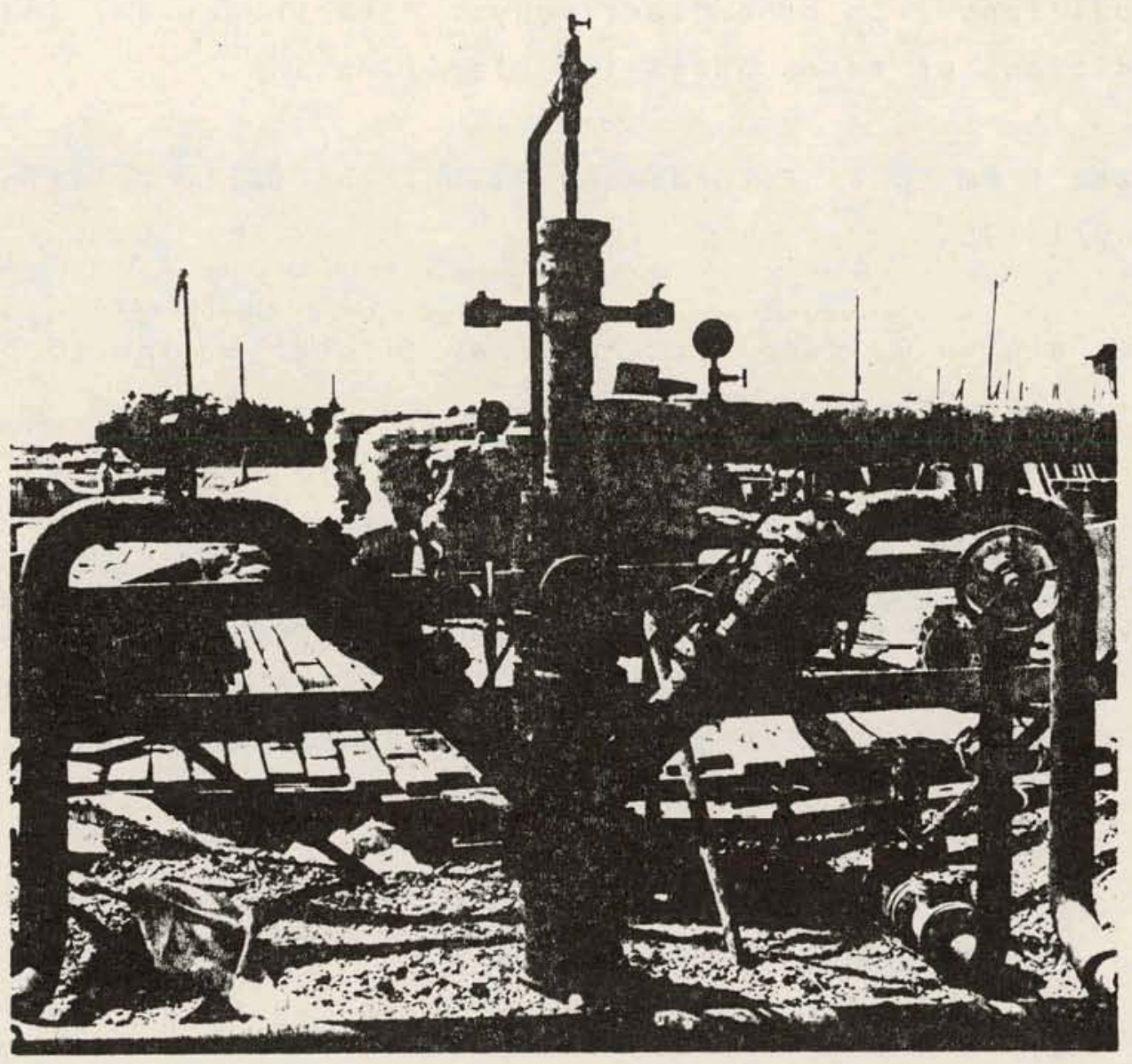

Figure 4. West Hackberry Well \#11

(essentially similar to Well 6). 


\section{CHRONOLOGY OF EVENTS}

The following chronology of events leading to the blowout was taken mainly from the Louis Records Daily Drilling Report with additions from other testimony. Parentheses ( ) indicate the additions or terms added for clarification.

Data from Louis Records and Associates Daily Drilling Report $9 / 15 / 78$

1. Rig up BJ pump truck and lay discharge line to pit.

2. Shut $8^{\prime \prime}$ salt water line.

3. Pumped in 75 bbls-11 \#/gal, 150 vis mud into 5-1/2" at $1-1 / 2-2 \mathrm{bbls} / \mathrm{min}$. l" open to pit. Good salt-water returns. (Salt-water disposal well dead.)

4. Removed $1^{\prime \prime}$ slips from Larkin stripper head.

5. Came out of the hole with 7 joints $1^{\prime \prime}$ upset pipe; 82 joints 1-1/4"'; and perforated short joint.

6. Shut the 6" Demco ball valve (master valve) but it would not hold (leaked).

7. Pumped 34 bbls, 11 \#/gal, 150 vis mud into $5-1 / 2 "$.

8. 5-1/2" still flowed back.

9. Made a plate and installed it in the Larkin head (to close the 5-1/2" tubing since the valve leaked).

10. Valve on $8^{\prime \prime}$ salt-water line leaking.

11. Shut in well (operations) wait for daylight.

12. Filled rig tanks with 400 bbls of 11.6 \#/gal 150 viscosity salt gel mud.

13. Waiting on stripping rubber for Larkin head. Unable to run 2-7/8" tubing and packer in 5-1/2" tubing until stripping rubber arrives. 
1. There was 165 psi on the salt-water line (to the 5-1/2" tubing; 465 psi on annulus oil).

2. (After working the valve back and forth) the 5" (Demco) ball valve would close and hold pressure.

3. The $3^{\prime \prime}$ valve on the salt-water line now holding:

4. Rigged down the BJ pump truck.

5. Removed the Larkin head.

6. Installed blowout preventers. (This was a rig-supplied 6" BOP stack consisting of a Shaffer rotating head, a Cameron QRC pipe ram with 2-7/8" ram blocks and a Cameron QRC blind ram on the bottom of the BOP stack.)

7. Prepared the rig to run 2-7/8"i tubing into the hole.

8. Mixed 570 bbls of 11.3 \#/gal 150 vis mud.

$9 / 17 / 78$

1. Shut the bilind (pipe?) rams

2. Pumped 30 bbls $11.0^{\prime \# / g a l ~} 150$ vis mud into $5-1 / 2 "$ tubing.

3. Tubing is dead.

4. Went in the hole with a $\left(4-1 / 4^{\prime \prime}\right)$ TAM inflatable packer (see second testimony of Irby Hogue).

5. Set TAM packer at 3289'. with 2000 psi (hydraulic pressure).

6. (Pulled 2-7/8" tubing off of packer and) pressured $\left(5-1 / 2^{\prime \prime}\right)$ to $500 \mathrm{psi}$. Pressure leaked off to "0".

7. Latched (2-7/8" tubing) back into packer. Had to add one joint of tubing to catch packer (packer slipped down the hole).

8. Reset packer back at $3289^{\circ}$ with 4000 psi hydraulic pressure. Packer would slide down hole. "Retested with pressure in 5-1/2" but the packer would not hold. 
9. Pulled back up to 3255'. Set packer.

10. (Pulled 2-7/8" tubing out of packer) and tested 5-1/2" tubing at 800 psi. Pressure would hold.

11. Pulling 2-7/8" tubing out of hole.

$9 / 18 / 78$

1. Finished pulling $2-7 / 8^{\prime \prime}$ tubing out of hole (and laid in on the racks).

2. Prepared to pump into the annulus between. the $5-1 / 2^{\prime \prime}$ tubing and $9-7 / 811$ casing.

3: Pumped 155 bbls of 11 \#/gal, 165 vis mud into annulus. Annulus dead (has no pressure).

4. Removed: 6" BOP stack

5" Demco ball valve

5. Rigged up $10 "$ BOP stack (10" Shaffer annular preventer over a 10" Cameron QRC ram with 5-1/2". ram blocks). Incorrect flanges, had to obtain new flanges.

$9 / 19 / 78$

1. Reinstalled $5^{\prime \prime}$ Demco ball valve while waiting on flange.

2. Annulus pressure had built to 40 psi. (When opened) bled down to 0 psi in three hours and then started blowing viscous mud and oil. When shut in, it built back up to 40 psi.

3. Received proper flange and installed BOP.

$9 / 20 / 78$

1. Finshed installing BOP.

2. Prepared tubing tools to pull 5-1/2" tubing. 
3. Pumped 60 b.bls 16 \#/gal, 180 vis mud into annulus (between 5-1/2" and 9-7/8"'). Annulus is not dead.

Getting oil flowing back. Pressure built up to 150 psi.

4. Stopped operations until morning.

5. Pressure in annulus built up to 250 psi.

\section{$9 / 21 / 78$}

1. Hooked up BJ pump truck and pumpedinto the annulus (between 5-1/2" and 9-7/8") 108 bbls. of 11.6 \#/gal. i 85 viscosity salt mud.

2. (After pumping) the pressure was 250 psi.

3. Bled back 10 bbls of mud and pressure was 150 psi.

4. Pump into annulus 68 bbls of 11.6 \#/gal 185 vis mud and flowed back 10 bbls.

5. Pumped in $50 \mathrm{bbls} / 16$ \#/gal, $185 \mathrm{vis}$ mud.

6. Well was dead on annulus.

7. Well was dead on 5-1/2" tubing.

8. Opened B.O.P.

9. Pulled 5-1/2" casing up (10') and removed casing hanger, short joint (pup) and safety valve.

10. Pulled 2 joints $\left(40^{\prime}\right.$ each) of $5-1 / 2^{\prime \prime}$ tubing. Tubing was dry.

11. Tubing was wet on 3 rd joint. The mud had been about 100 ' down in tubing.

12. Pulled a total of 13 joints of tubing. All the rest were full of mud. (Pulled tubing at about $4-1 / 2$ minutes per 40' joint - see testimony of Robert ortega.) (Testimony of the casing crew indicates that some mud flowed back from the 5-1/2" tubing on the 12 th and 13 th joints or approximately 9 or 10 minutes before the main kick. The casing crew comments further indicate that the flowback was brought to the attention of the $B J$ 
cementer, Buddy Magnon, and he said to continue pulling tubing. Mr. Magnon testified that he brought a $5-1 / 211$ $x 2$ "cementing swedge from his truck to the floor at this time.)

13. Added 1 bbl of 16 \#/gal 185 vis mud into the annulus as each joint of pipe was pulled (to make up for displacement of pipe and keep the annulus full).

Here ends the copy of data from the Louis Records and Associates Drilling Report. The following testimonies describe the first minutes of the blowout.

14. With 14 joints (560') of tubing out of the hole, the $14 \mathrm{th}$ joint was unscrewed from the drill string. The mud box was put around the connection and the joint was picked up off the tubing string. The joint of pipe apparently gave up the proper amount of mud which flowed into the mud box and back to the pits.

15. The 14th joint was then swung out of the $V$ door to be laid down on pipe racks when the tubing in the rotary table started to flow. The flow came in heads four or five feet high, receded and headed five or six feet high.

16. Bradley Bergeron, the derrickman on the Pelican rig said that he tried to install a $5-1 / 2^{\prime \prime} \times 2 "$ swedge with a ball valve (Figure 7) at this time, but was unable to push it down over a $3^{\prime-3-1 / 2 ' ~ h i g h ~ b a c k ~ f l o w ~ f r o m ~}$ the tubing.

17. The floormen tried to put the safety valve on the top of the tubing string, but he could not install it because of the flow from the pipe. 
18. Irby Hogue ran up on the floor and helped the floorman try to install the safety valve. The flow was too great. They were able to get the valve down to the tubing joint, but then it blew out of their hands.

19. The mud blew out of the 5-1/2" tubing followed by the packer and then oil.

20. The vaporized oil caused. one of the diesel engines to overspeed and then explode. At that time the well caught fire. 


\section{CAUSE OF THE BLOWOUT}

From the testimony and the fact that the packer was blown out of the tubing and was recovered after the fire, little doubt remains that the packer failed to hold against the pressure from the bottom of the tubing.

The mud pumped into the tubing above the packer should have been heavy enough to dominate the cavern pressure without the need for the packer.

The annulus of the well between the $9-7 / 8^{\prime \prime}$ casing and $5^{\prime \prime}$ tubing was open and no indication exists that pressure developed in the annulus.

The only possible explanation is that the heavy mud in the annulus created a differential pressure when balanced against the light mud in the tubing, causing the packer to slip. The upward slipping of the packer would account for the mud heading at the surface. As the packer was shoved up by the pressure below it, the mud was driven out of the $5-1 / 2$ " tubing. When the packer momentarily held, the mud flow from the $5-1 / 2$ " tubing. temporarily receded.

The TAM packer is shown in Figure 5 and as it was in the hole in Figure 5-A.

The TAM inflatable packer is held in the hole by the frictional force of the rubber set against the tubing or hole. The TAM International Working Pressure Chart as shown in Figure 6 indicates that the 4-1/4" packer used should have withstood a differential pressure of approximately 5000 psi. It appears the 
packer did not burst or deflate since it was blown out of the hole, and the witnesses agreed that the oil came out of the tubing behind the packer.

It is unlikely that the packer deflated since to deflate the packer, it must be rotated one-quarter turn to the left and then the mandril picked up. Investigation of the burned packer at the TAM plant in lloustondid not indicate that the packer pressure was released.

The packer must have slipped as a result of being set on the scale and salt that was inside the tubing. The tubing recovered from the well as well as other tubing and casing recovered from other wells at the site indicate that scaling is a significant problem. The first two attempts to set the packer at $3289^{\prime}$ indicate that there was scale in the tubing. There is a further indication that the packer must have slipped previous to the starting out of the hole with the $5-1 / 2$ " tubing because the first 100' of tubing were reported to have been "dry".

Once the packer started slipping, it had no mechanism to stop movement and hence continued to move up the tubing. 
TamSet Inflatable/Retrievable Packer

$$
\begin{aligned}
& \text { 4-1/4" Packer Inflated } \\
& \text { in the } 5-1 / 2^{\prime \prime} \text { Tubing } \\
& \left(5-1 / 2^{\prime \prime} \text { Tubing has } 5^{\prime \prime} 1.0 .\right)
\end{aligned}
$$
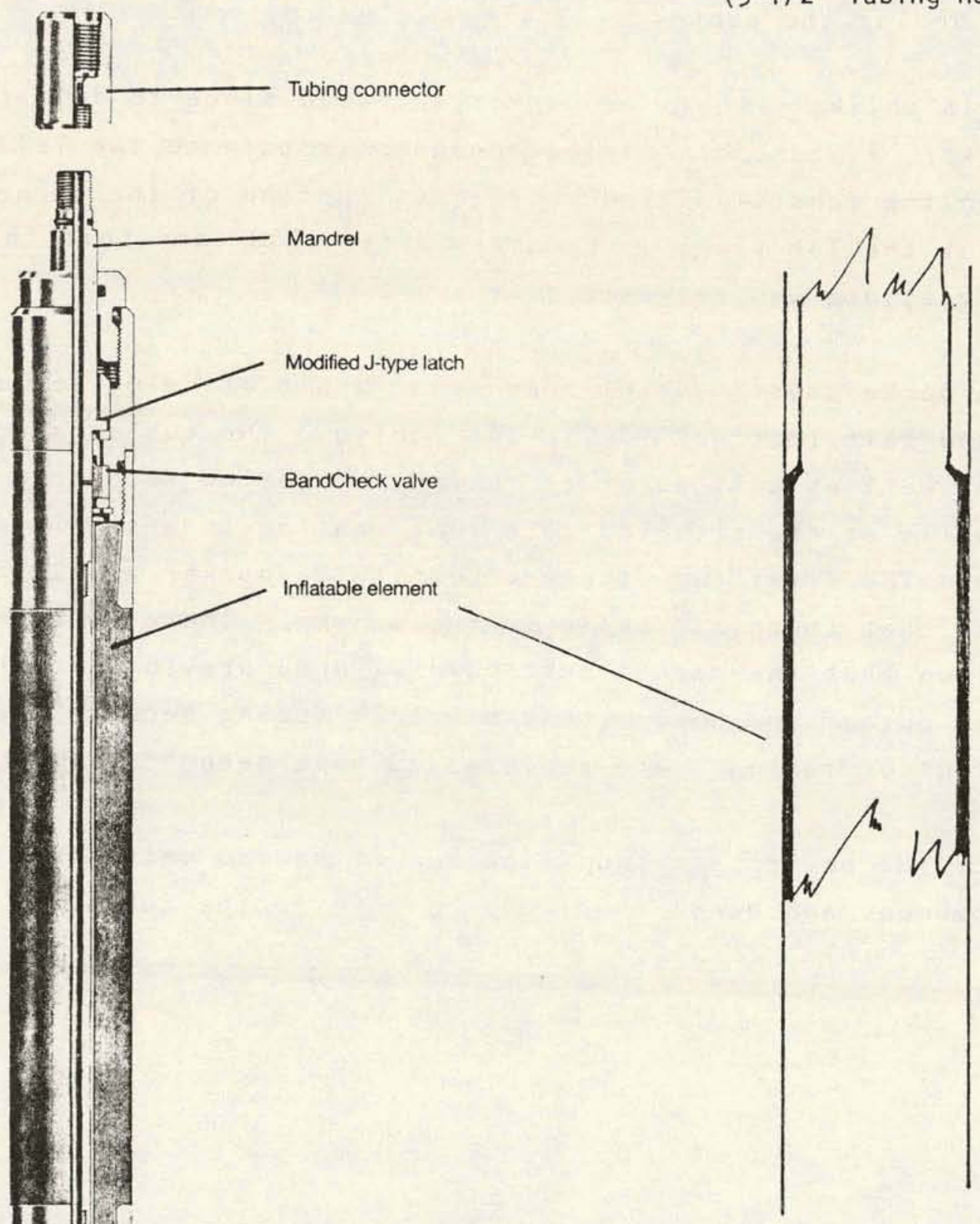

Figure 5-A

Figure 5

Bull Plug 


\section{TAM7 \\ wrramantoum}

How to Use the Working Pressure Charts

Use these charts to select the proper size of TamSet or TamCap inflatable elements for your application. For the TamSet, for example, if the hole size is $6 \frac{1}{4}$ inches, any of five inflatable element sizes could be used, from $37 / 8$ O. D. to $5 \frac{1}{2}$ O.D. The $5 \frac{1}{2}$ O.D. would withstand the highest differential pressure $(5,200$ psi as shown by the dotted line). The rated working pressure decreases as the O.D. of the inflatable element decreases.

\section{Standard TamSet Sizes}

\begin{tabular}{lcccccccccccc}
\hline O.D. & $21 / 2$ & $2^{1} / 8$ & 3 & $31 / 2$ & $37 / 8$ & $41 / 4$ & 5 & $51 / 4$ & $51 / 2$ & $61 / 4$ & 7 & $71 / 4$ \\
\hline I.D. & 1 & 1 & 1 & $11 / 2$ & $11 / 2$ & $11 / 2$ & $11 / 2$ & $11 / 2$ & $21 / 4$ & $21 / 4$ & $21 / 4$ & $21 / 4$ \\
\hline
\end{tabular}

All TAMSET packers are approximately 81 inches overall. Larger inside diameters are available on request. Consult TAM International for special inflatable packer requirements.

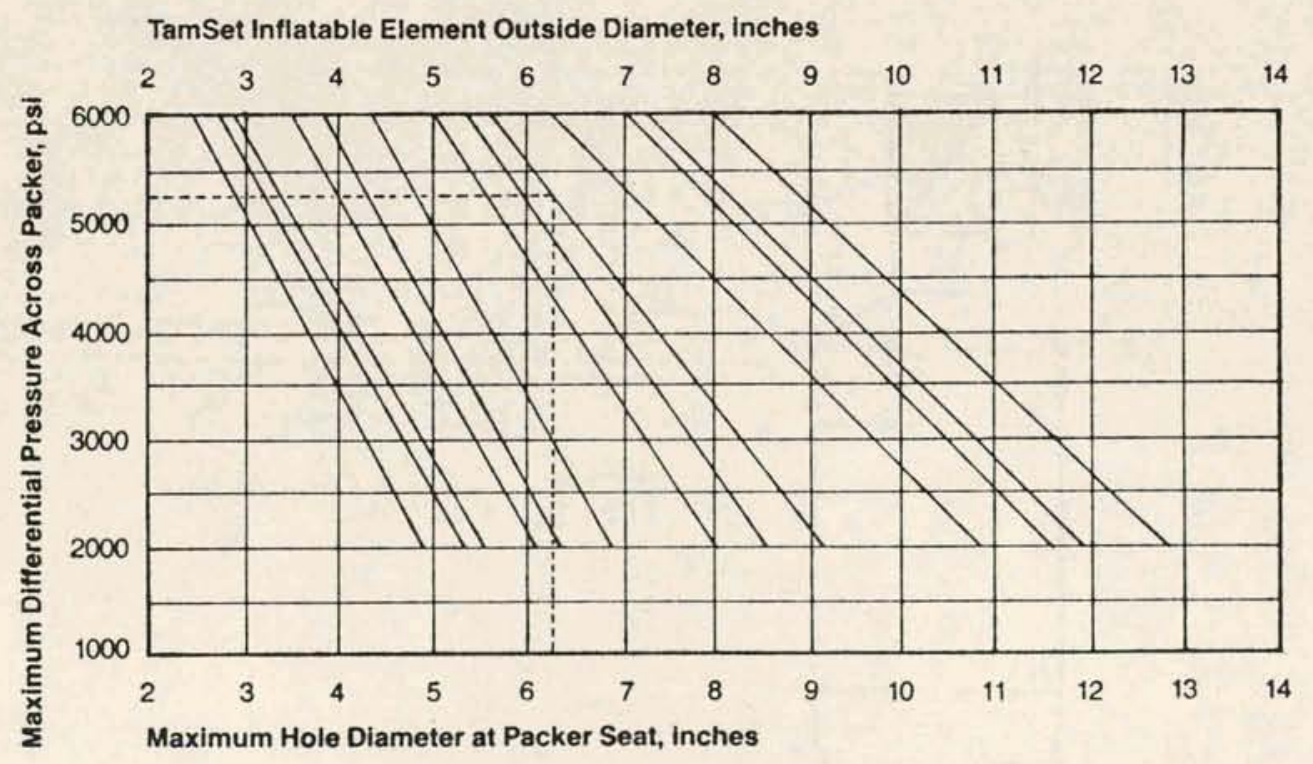

Figure 6. TAM International Working Pressure Chart 


\section{SAFETY VALVES}

Safety valves are full opening valves installed in a short piece of pipe. The valve is generally a ball valve because of size and weight requirements. The purpose of the safety valve is to stop the flow of fluid up the tubing.

\section{Safety Valve}

The safety valve used as a stabbing valve on the Pelican rig was assembled by the drilling foreman, Mr. I rby Hogue, from a short "pup" joint of 5-12/" tubing and a 2 " ball valve from the wellhead (Figure 7). The BJ cementer testified he brought up a 5-1/2"1 $\times 2^{\prime \prime}$ cementing head when the well started to flow. The cementing head would be essentially similar to the drawing in Figure 7 .

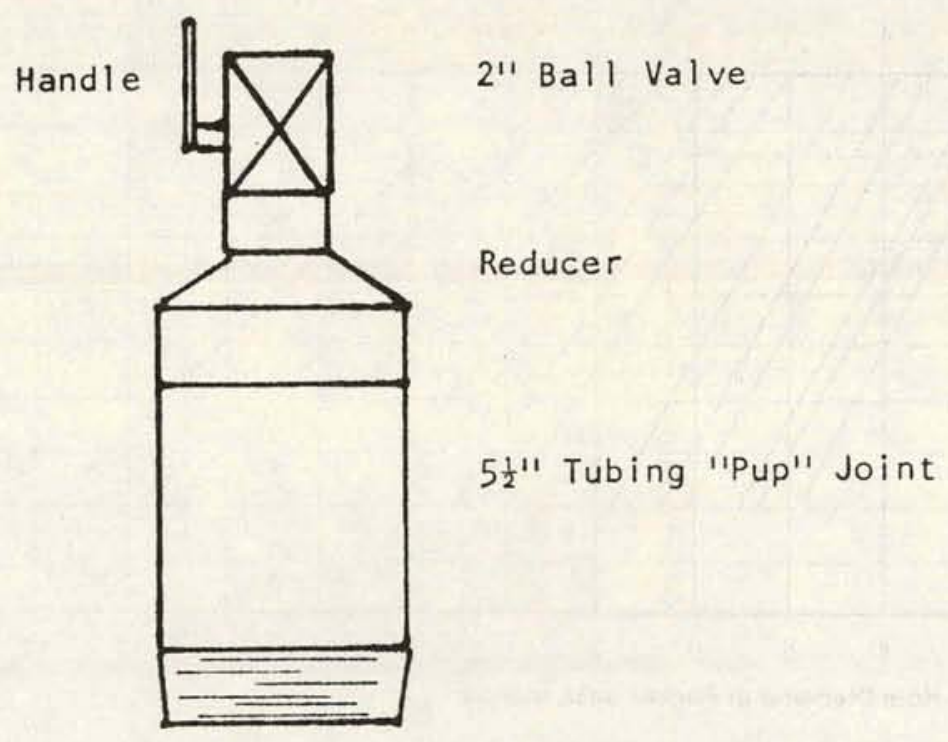

Figure 7. Safety Valve for use as stabbing valve as made up for Well 6 . 
As a stabbing safety valve, the valve as made up has two difficiencies:

1. The valve has no handles to facilitate its being quickly installed on the tubing.

2. The valve should be full opening. A restriction in the valve will build a back pressure when the valve is being stabbed that will make it difficult to install on the flowing tubing.

Items 1 and 2 were what happened according to Mr. Hogue's testimony. He and the crew could not get the valve down on tubing threads. This was because of the restriction in the valve and the lack of handles. However, it needs to be noted here that a 5-1/2" safety valve is not a standard (off the shelf) piece of equipment.

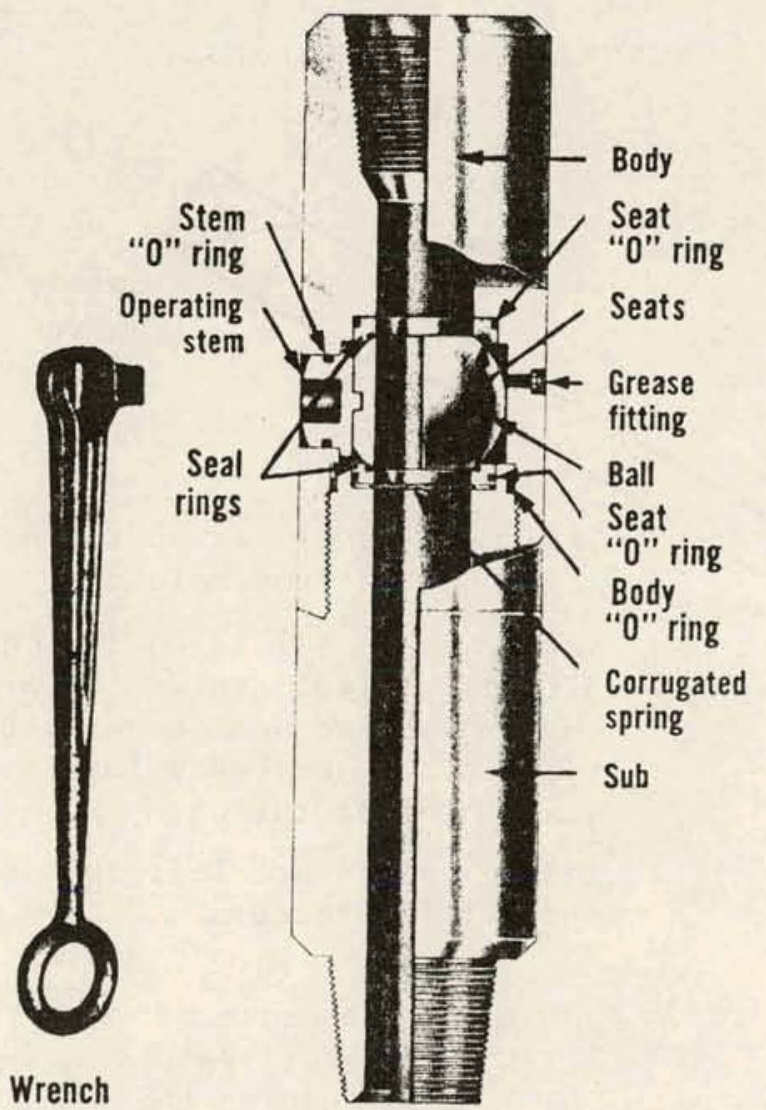

Courtesy T.I.W.

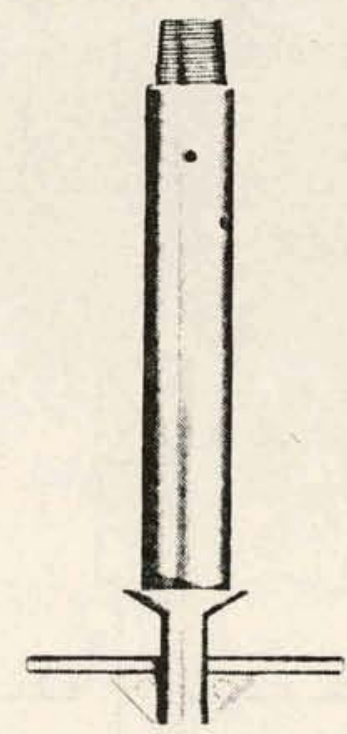

As Stabbing Valve With Handles Courtesy Hydril

Figure 8. Recommended Safety Valve for Use as a Stabbing Valve. 
Safety Valves for Pulling or Running Pipe

The safety valves for pulling or running pipe fit the casing joint. When the pipe is pulled out of the hole, one safety valve is installed on the top joint of pipe in the hole. at all times (see Figure 9). As soon as the top joint of pipe is unscrewed, a safety valve is screwed onto the joint of pipe remaining in the hole. The valve that was on the top of the joint pulled from the hole is removed and returned for the next joint of pipe. The sequence of installing the safety valves is reversed when running the pipe. The safety valve is kept open so that any flow of mud or fluid from the well can be seen.

The safety valves for pulling or running pipe are more flexible in design than the stabbing valve. A safety valve consists of a short length of pipe with a full opening ball valve installed like the stabbing valve; however the safety valve can be assembled in a number of different configurations.

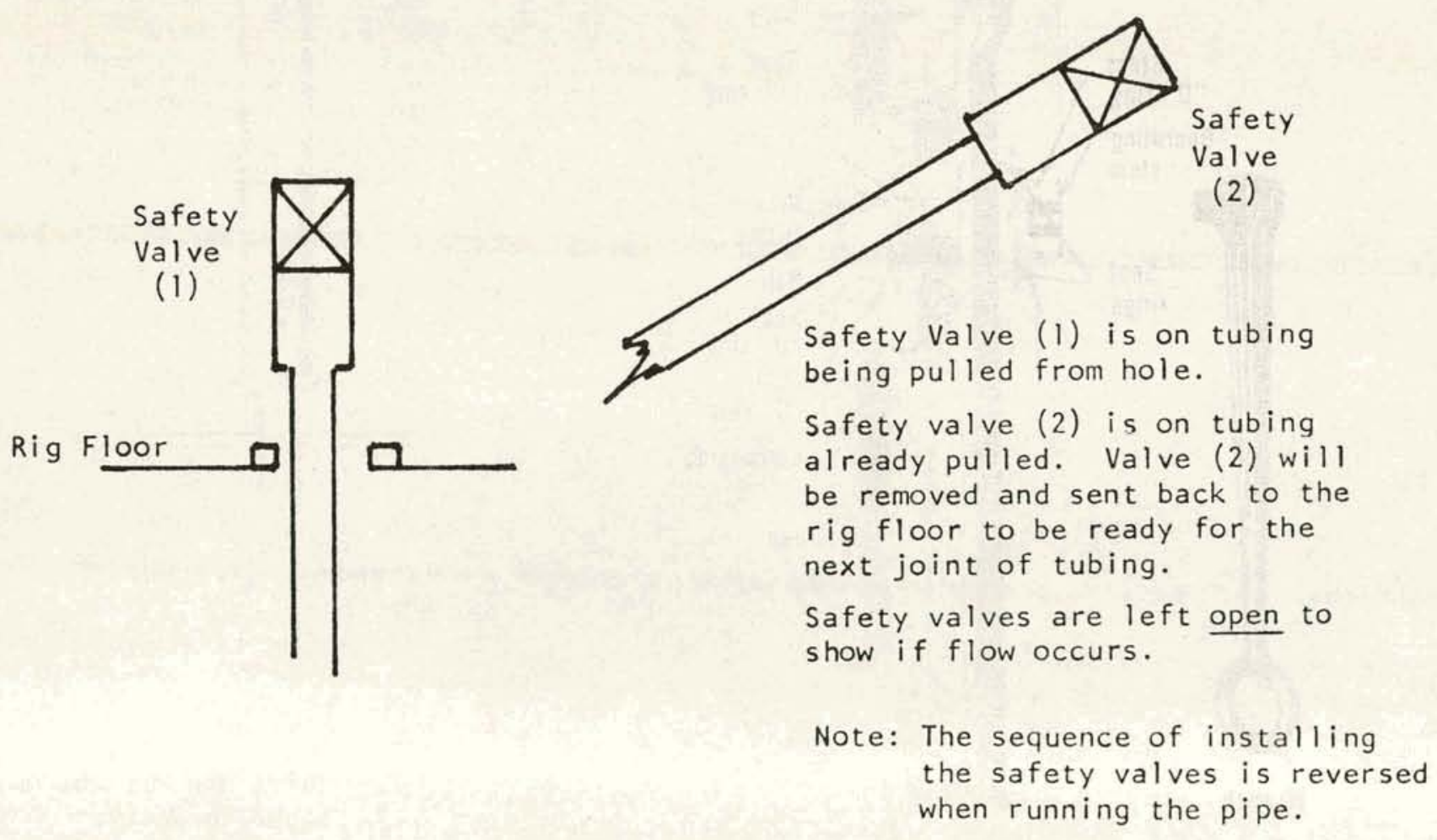

Figure 9. Use of Double Safety Valves

When Pulling Tubing. 
The proper use of the stabbing valve or the safety valves while pulling the pipe might have prevented the biowout.

On low-pressure workovers, the use of safety valves when pulling tubing is not standard industry-procedure. Normally, safety valves are used only. at the request of the operator.

The use of a stabbing valve on the floor of the rig is standard industry procedure, but often the design of the valve is minimum such as the valve assembled for the Pelican Rig. 
PROBABLE WELLBORE CONDITIONS

The following is an estimate of the pressures existing in the wellbore that would have lead to the movement of the packer.

The following conversion factors and data was taken from Halliburton Cementing Tables, a standard handbook in oil and gas drilling and workover operations.

$$
\begin{aligned}
& 5-1 / 2 " 15.5 \mathrm{H} / \mathrm{ft} \mathrm{K5} 5 \mathrm{tubing} \\
& \text { Inside Diameter } 4.950^{\prime \prime} \\
& \text { Capacity }=.0233 \mathrm{bb} 1 / 1 \mathrm{in} \mathrm{ft} \\
&=42.01 \mathrm{ft} / \mathrm{bbl}
\end{aligned}
$$

\begin{tabular}{|c|c|c|}
\hline Mud $W t \# / g a l$ & Pressure & $\mathrm{psi} / \mathrm{ft}$ \\
\hline 7.0 & .3633 & $(0 ; 1)$ \\
\hline 10.0 & .5190 & (salt water) \\
\hline 11.0 & .5709 & \\
\hline 11.3 & .5365 & \\
\hline 11.6 & .6020 & \\
\hline 16.0 & .8304 & \\
\hline
\end{tabular}

Volume between 5-1/2" tubing and 9-5/8" $\mathrm{k55}, 36$ \#/ft casing

$$
\begin{aligned}
\text { Annular Volume } & =.0479 \mathrm{bbl} / \mathrm{in} \mathrm{ft} \\
& =20.88 \mathrm{ft} / \mathrm{bbl}
\end{aligned}
$$

Pressure exerted by a mud column

\section{The Mud}

Very viscous mud that became a semisolid plug. When mixed with salt water or oil was used to form a plug at the end of the annulus and tubing to prevent the mud column from falling into the cavern. This seems to be a reasonable approach. 
The Annulus Analysis

The annular area between the 5-1/2" tubing and the $9-5 / 8 "$ casing was $2603^{\prime}$ long and thus contained 125 barrels (Figure 2-A).

$$
2603^{\prime} \times .0479 \mathrm{bbl} / \mathrm{ft}=125 \mathrm{bbls} .
$$

According to the Daily Drilling Report the following mud was pumped: into the annulus on $9 / 21 / 78$.

\begin{tabular}{|c|c|c|c|c|c|}
\hline I tem & No. & Wt. & Pumped & Flowed Back & Total \\
\hline 1 & & $11.6 \mathrm{k} / \mathrm{gal}$ & $108 \mathrm{bbls}$ & & 108 \\
\hline 3 & & : & $\therefore$ & $10 \mathrm{bbls}$ & 98 \\
\hline 4 & & $11.6 \mathrm{H} / \mathrm{gal}$ & $68 \mathrm{bbls}$ & $10 \mathrm{bbls}$ & 156 \\
\hline 5 & & $16.0 \# / g a l$ & $50 \mathrm{bbls}$ & & 206 \\
\hline 13 & & 16.0 \#/.ga.l & $1.4 \mathrm{bb} 1 \mathrm{~s}$ & $(f i \mid l-u p$ mud $)$ & 220 \\
\hline
\end{tabular}

From the above data it can be calculated that before the well kicked the 5-1/2-9-5/8" annulus which had a capacity of 125 bbls contained 50 bbls of 16 \#/gal mud and 75 bbls of 11.6 \#/gal mud (Figure 2-A).

$125 \mathrm{bbls}$ capacity - $50 \mathrm{bbls} 16$ \#/gal mud $=75 \mathrm{bbls} .11 .6$ \#/gal mud

To calculate the pressure exerted by the mixed column of 16 \#/gal and 11.6 \#/gal mud:

$11.6 \# / g a l ~ m u d=75 . b b l s \times 20.88 \mathrm{ft} / \mathrm{bbl} \times .6020 . \mathrm{psi} / \mathrm{ft}=942 \mathrm{psi}$

$16 \mathrm{\# /gal} \mathrm{mud}=50 \mathrm{bbls} \times 20.88 \mathrm{ft} / \mathrm{bbl} \times .8304 \mathrm{psi} / \mathrm{ft}=867 \mathrm{psi}$ pressure exerted by mixed column of mud $=1,809$ psi 
16 \#/gal mud

$50 \mathrm{bbls} \times 20.881 / \mathrm{bbl} \times .8304 \mathrm{psi} / \mathrm{ft}$

$=.867 \mathrm{psi}$

$\therefore \quad 1 ! .6$ \#/gal mud

$75 \mathrm{bbls} \times 20.881 / \mathrm{bbl} \times 60 \% \mathrm{psi} / \mathrm{ft}$

$=942 \mathrm{psi}$

7 \#/gal oil

$6521 \times .3633 \mathrm{psi} / \mathrm{ft}=237 \mathrm{psi}$
1

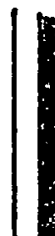

|| $24^{\prime \prime} @ 87^{\prime}$

$16 "$ '1641'

$2603^{\prime} \times .0479 \mathrm{bbl} / \mathrm{ft}=125 \mathrm{bbls}$

816 \#/gal mud

( $\quad 11.6$ \#/gal mud

$9-5 / 8 \prime \prime k 55,36 \# f t @ 2603$

Cemented to Surface

$12-3 / 4^{\prime \prime} 巳 2632^{\prime}$

Top of Cavern 23237
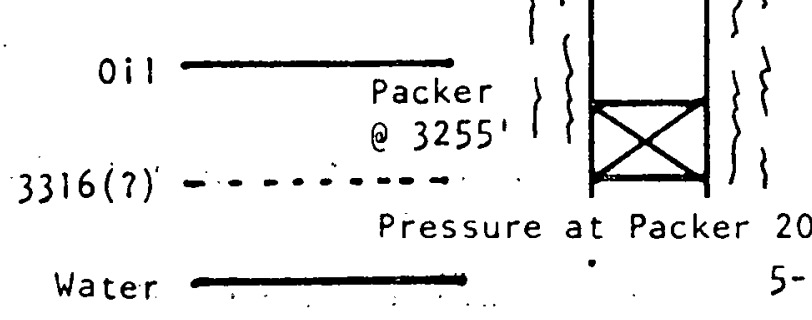

at Packer 2016 psi

$5-1 / 2^{\prime \prime}, \mathrm{K} 55,15.5 \# / \mathrm{ft} @ 3379.54$

'Cavern Floor @ 3395'

(After Louis Records \& Associates)

Figure $2-A^{-\cdots}$

Condition on Well 6 with Well Dead

Before Casing was Pulled. 
The pressure at the bottom of the 5-1/2" tubing was the annulus pressure just developed plus the pressure of the oil and water columns in the cavern. Assuming the cavern to be half full of oil, the packer was set in the tubing opposite the oil.

oil. Column Height was:

$$
3,255^{\prime}-2,603^{\prime}=652^{\prime}
$$

oil Column Pressure was:

$$
652^{\prime} \times .3633 \mathrm{psi} / \mathrm{ft}=237 \mathrm{psi}
$$

The pressure opposite the packer would then be 2,046 psi (Figure 10 ).

$$
1809+237=2 ; 046 \text { psi. (Figure 10) }
$$

When the well blew out the packer was at 2,695' (see the Tubing Analysis). The annulus pressure must be corrected for the depth of the packer opposite the oil in the cavern plus the mud used for fill-up (figure 2-B).

The pressure from the oil column is:

$$
\begin{aligned}
& 2695 \text { (packer depth) }-2603 \text { (annular length) }=92^{\prime} \\
& 92^{\prime} \times .3633 \mathrm{psi} / \mathrm{ft}=33 \mathrm{psi} \text {. }
\end{aligned}
$$

Correcting the annulus pressure, as developed, for 14 bbls of 16 \#/gal mud which was added as fill-up mud

11.6 \#/gal mud $(75 \mathrm{bbls}-14 \mathrm{bbls}) \times 20.88 \mathrm{ft} / \mathrm{bbl} \times .6020 \mathrm{psi} / \mathrm{ft}=767 \mathrm{psi}$

$16 \# / g a l m u d(50 \mathrm{bbls}+14 \mathrm{bbls}) \times 20.88 \mathrm{ft} / \mathrm{bbl} \times .8304 \mathrm{psi} / \mathrm{ft}=1109 \mathrm{psi}$

0 il Column $=-33$ psi

Pressure of Annular Column, $=1909$ psi

(FIgure II) 
$14 \mathrm{bbis} 16$ \#/gal fill-up mud Pressure exerted by 16 \#/gal mud $14 \mathrm{bbls} \times 20.88 \mathrm{ft} / \mathrm{bbl} \times .8304 \mathrm{psi} / \mathrm{ft}$ $=242 \mathrm{psi}$

$50 \mathrm{bbls} 16 \# / g a l$ mud Pressure exerted by 16 \#/gal mud $50 \mathrm{bbls} \times 20.88 \mathrm{ft} / \mathrm{bbl} \times .8304 \mathrm{psi} / \mathrm{ft}$ $=867 \mathrm{ps} \mathrm{i}$

75. bbls 11.3 \#/gal mud - 14 bbls probably displaced out into the cavern by the 14 bbis of fill mud $61 \mathrm{bbls} 11.3 \mathrm{\# /gal}$ mud Pressure exerted by 11.3 \#/gal mud $61 \mathrm{bbls} \times 20.88 \mathrm{ft} / \mathrm{bbl} \times .6020 \mathrm{psi} / \mathrm{ft}$ $=767 \mathrm{psi}$

92' of oil. to packer Packer at

Pressure exerted by 7 \#/gal oil $92^{\prime} \times .3633 \mathrm{psi} / \mathrm{ft}=33 \mathrm{psi}$
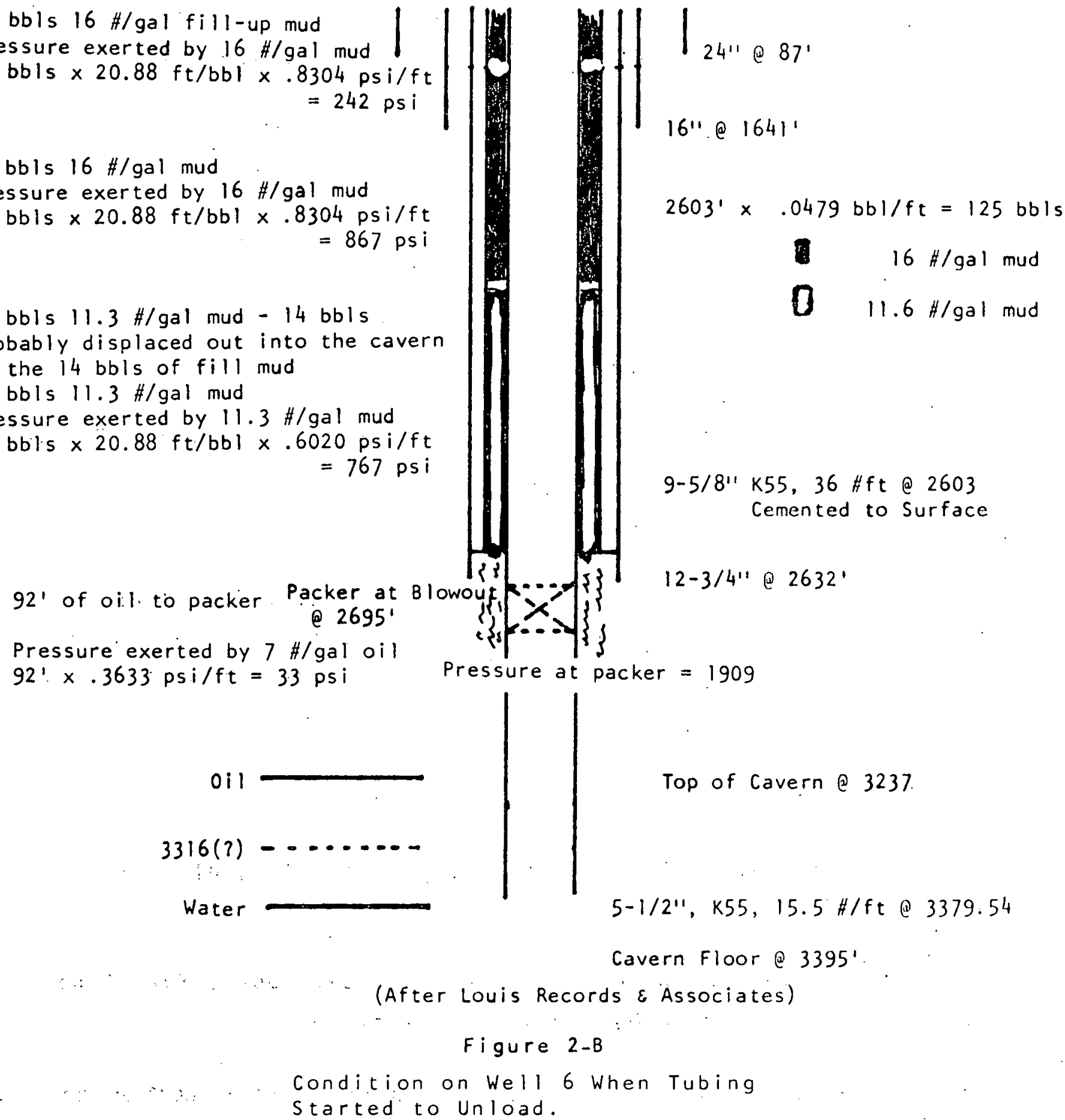
The Tubing Analysis

The 5-1/2" tubing contained $.0238 \mathrm{bb} / \mathrm{s} / \mathrm{ft}$ and the packer was set at $3,255^{\prime}$. So the tubing contained 77 bbls of mud

$$
3,255^{\prime} \times .0238 \mathrm{bbl} / \mathrm{ft}=77 \mathrm{bbls} / \mathrm{mud}
$$

The Daily Drilling Report indicated 139 bbls of 11.0 \#/gal mud was pumped into the 5-1/2" tubing.

Date Item No. Mud Wt. Mud Volume

$\begin{array}{llll}9 / 15 / 78 & 3 & 11.0 & 75 \text { bbls. }\end{array}$

$\begin{array}{llll}9 / 15 / 78 & 7 & 11.0 & 34 \mathrm{bbls} .\end{array}$

$9 / 17 / 78 \quad 21.030 \mathrm{bbls}$.

From the record, it could be assumed that the tubing was full of 11.0 \#/gal mud.

Initial downward hydraulic force on the TAM packer was 1,876 psi (figure 10).

$$
3255^{\prime} \times .5709 \mathrm{psi} / \mathrm{ft}=1859 \mathrm{psi}
$$

Downward hydraulic force on the packer when the packer failed was 1,538 psi (figure 11 ).

$$
2695^{\circ} \times .5709 \mathrm{psi} / \mathrm{ft}=1538 \mathrm{psi}
$$


U TUBE ANALYSIS

The conditions in Well. 6 can be represented as a "u" ctube for the purpose of illustrating the hydraulic pressures on the TAM packer.

$$
\text { Well } 6 \text { As A "U" Tube }
$$

INITIAL HYDRAULIC FORCES ON THE PACKER

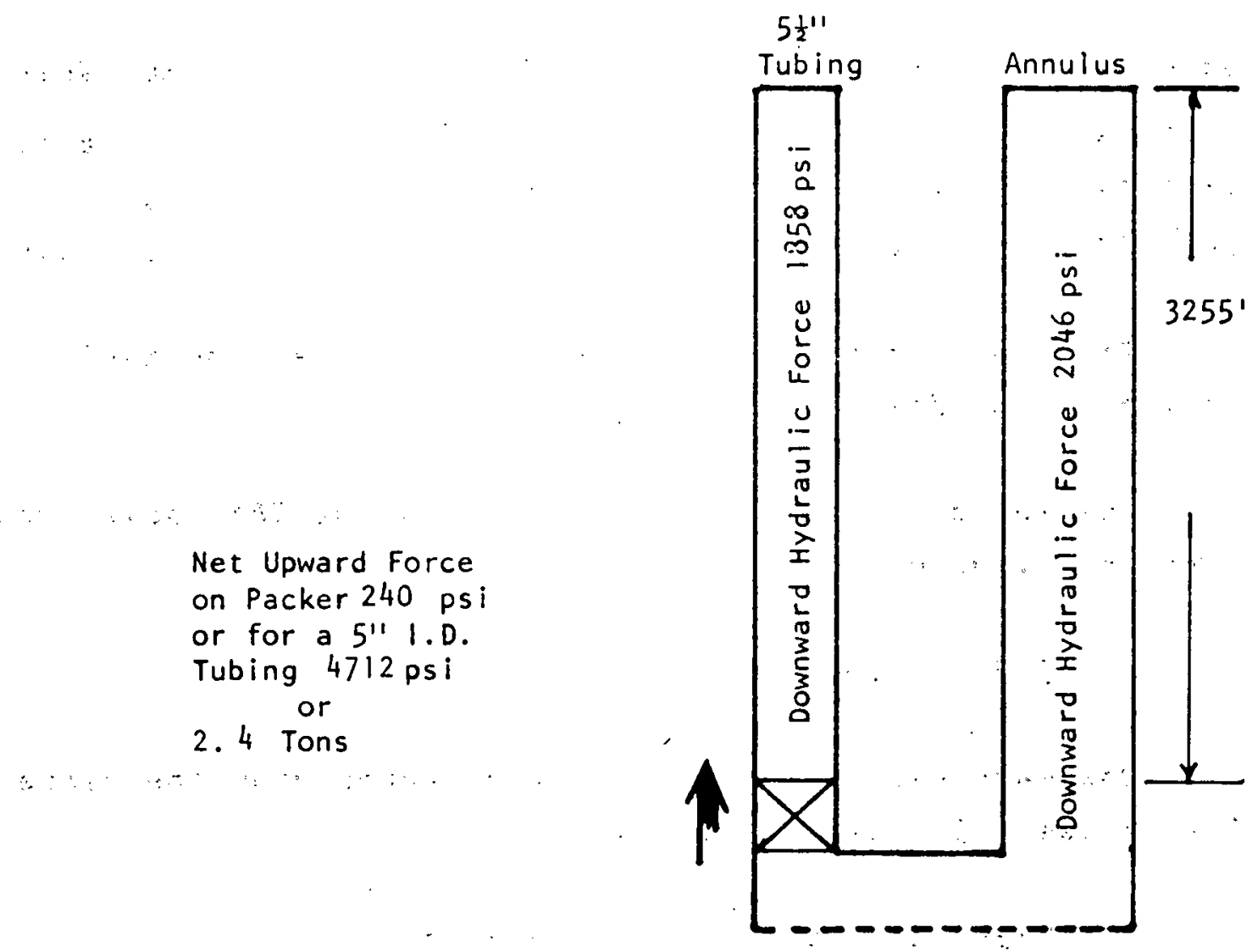

Figure 10. 
WeII 6 AS A "U". Tube
HYDRAULIC FORCES WHEN THE PACKER FAILED

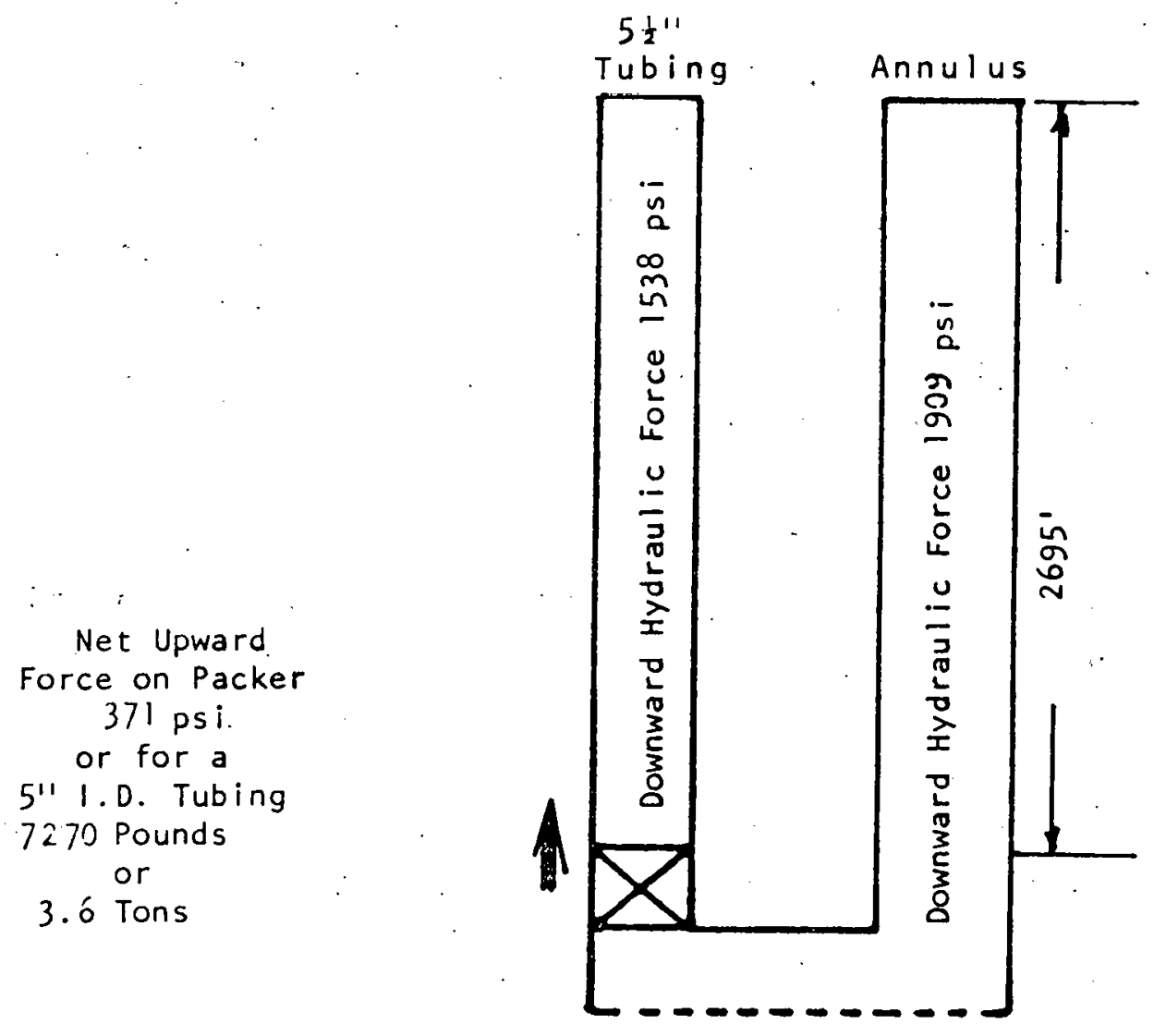

Figure 11. 


\section{CONCLUSIONS:}

1) From the available data it is evident that the packer failed because of a poor packer seat in the 5-1/2"1 tubing probably due to scale or salt.

2) It is unlikely that any design failure occurred with the TAM packer.

3) The method of killing the well using viscous mud appears to be a reasonable approach to prevent the mud from falling out of the casing into cavern.

4) From the testimony concerning initiation of flow from the 5-1/2" tubing, the blowout could have been prevented by either the use of a full opening safety valve with stabbing handles or dual. safety valves.

5). The blowout could have been controlled by the use of shear rams in the BOP stack which would have been able to shear the pipe and close the hole. This is not a standard piece of equipment for a land workover rig.

6) The blowout could have been avoided by reinforcing the packer with a second packer or a cement plug. 
TASK 2 - ANALYSIS OF THE PACKER OPERATION AND

PULLING OF THE 5-1/2" TUBING IF THE ANNULUS PRESSURE

WERE REDUCED TO BELOW 200 PSI AND THE CAVERN PRESSURE

WAS THE MINIMUM PRACTICAL PRESSURE OF 50 PSI

This analysis follows the analysis of Task 1 and comments and mathematics are the same except the pressures are reduced. If the tubing was filled with oil, the pressure on the annulus could have been reduced to the cavern pressure, in this example 50 psi.

The Annulus Pressure Analysis

With the anriulus full of oil and the pressure drawn down to 50 psi on the cavern and annulus, it would have required the addition of 4 bbls of 11.6 \#/gal mud to the annulus to reduce the annular pressure to "0"

$$
\begin{aligned}
.6020 \mathrm{psi} / \mathrm{ft} \times(\mathrm{Y}) \mathrm{ft} & =50 \mathrm{psi} \\
(\mathrm{Y}) \mathrm{ft} \text { of mud } & =83^{\prime}
\end{aligned}
$$

and

$$
83^{\circ} \times .0479 \mathrm{bbl} / \mathrm{ft}=4 \mathrm{bbls}
$$

Before pulling the 5-1/2" tubing, the hydraulic pressure in the annulus opposite to the packer would have been 1295 psi (Figure 12) (Figure 2-C).

$$
\begin{aligned}
& 11.6 \text { \#/gal mud } 83^{-1} \times .6020 \mathrm{psi} / \mathrm{ft} \cdot=50 \mathrm{psi} \\
& 7 \text { \#/gal (oil) }\left(2603-83^{\prime}\right) \times .3633 \mathrm{psi} / \mathrm{ft}=915 \mathrm{psi} \\
& \text { 7. \#/gal (oil) (3255-2603) x.3633 psi/ft }=237 \mathrm{psi} \\
& \text { pressure below packer }=1202 \mathrm{psi}
\end{aligned}
$$


4 bbl 11.6 \#/gal fill-up mud Pressure exerted by 11.6 \#/gal $83^{1} \times .6020 \mathrm{psi} / \mathrm{ft}=50 \mathrm{psi}$

$2520^{\prime}$ of 7 \#/gal oil in annulus Pressure exerted by oil $2520^{\prime} \times .3633=915$ psi
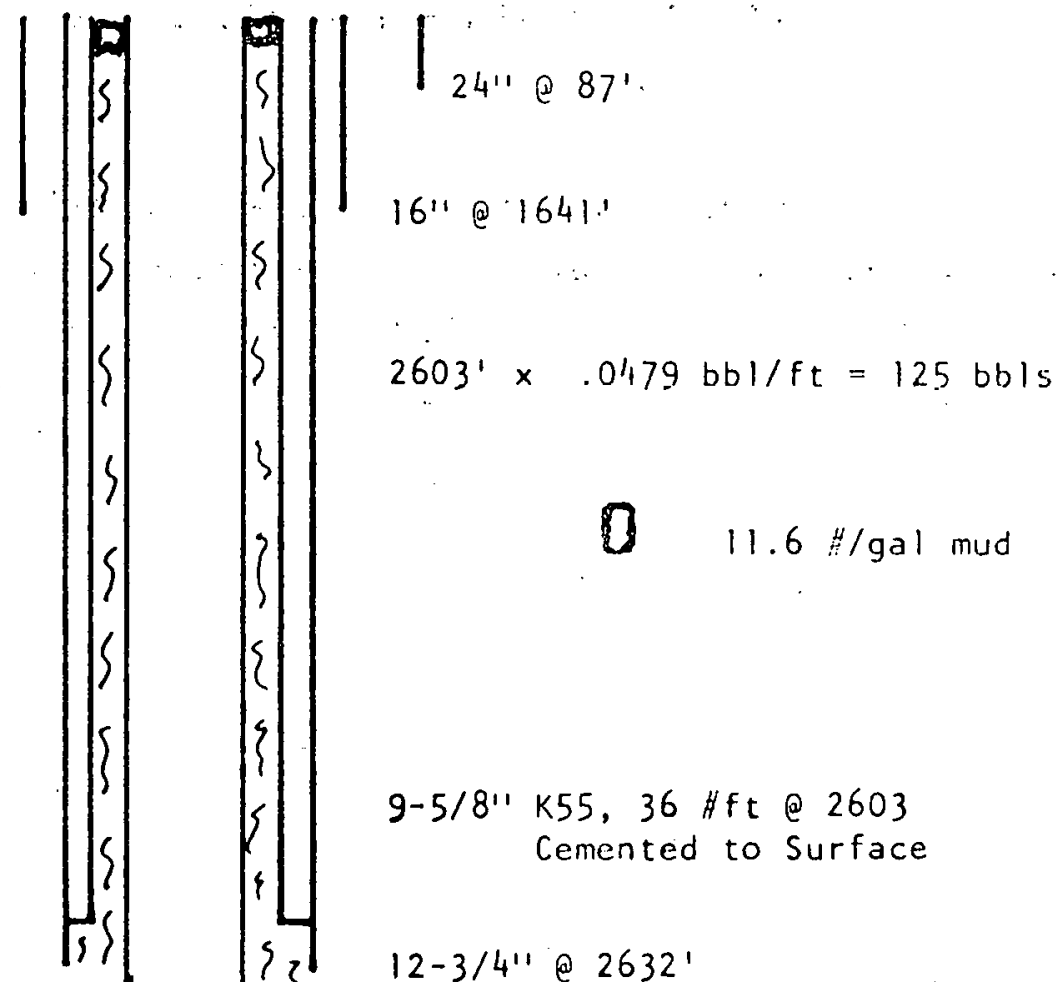

$9-5 / 811 \mathrm{~K} 55,36$ \#f @ 2603 Cemented to Surface

$12-3 / 4^{\prime \prime} @ 2632^{\prime}$

$652^{\prime}$ of 7 \#/gal oil in open hole Pressure exerted by oil $652^{\prime} \times .3633 \mathrm{psi} / \mathrm{ft}=237 \mathrm{psi}$

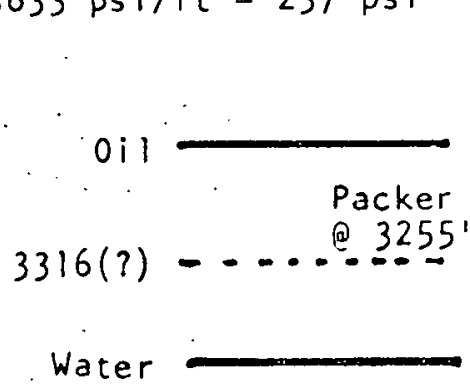

Pressure exerted below packer 1202 psi (Figure 12)

$$
\text { (After Louis Records \& Associates) }
$$

Figure 2-C

Cavern Pressure Reduced to 50 psi Potential Condition on Well 6 with Well Dead Before Pulling Casing. 
After pulling 14 joints of 5-1/2" tubing, the pressure in the annulus opposite the packer (corrected for depth, and annulus fill-up with 14 bbls of 11.6 \#/gal mud) would have been 1035 psi. (Figure 13) (Figure 2-D).

$$
F i l 1-u p=14 \mathrm{bbls} \times 20.88 \mathrm{bbl}=292^{\prime} \mathrm{of}^{\prime} 11.6 \mathrm{Hlgal} \text { mud }
$$

$\begin{array}{llll}11.6 \text { \#/gal mud } & 292^{\prime} \times .6020 & =176 \mathrm{psi} \\ 11.6 \text { \#/gal mud } & 83^{\prime} \times .6020 & =50 \mathrm{ps} i \\ 7 & \# / g a l \text { oil } & \left(2603-292^{\prime}-83^{\prime}\right) \times .3633 & =\end{array}$


11.6 \#/gal fill-up mud 14 bbls - 292

Pressure from fili-up mud $292 \times .6020 \mathrm{psi} / \mathrm{ft} 176 \mathrm{psi}$

11.6 \#/gal kill mud 4 bbls - 33 !

Pressure from kill mud

$83^{\prime} \mathrm{x}^{\prime}: 6020^{\circ} \mathrm{psi} / \mathrm{ft}=50 \mathrm{psi}$

7 \#/gal oil 2228'

Pressure from oil

$2228^{\prime} \times .3633 \mathrm{psi} / \mathrm{ft}=809 \mathrm{psi}$

Annular pressure at packer $=1035 \mathrm{psi}$

Packer at B lowout (e) $2695^{\circ}$

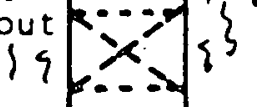

$2603^{\prime} \times .0479 \mathrm{bbl} / \mathrm{ft}=125 \mathrm{bbls}$

\section{$0 \quad 11.6 \% / g a l$ mud}

$9-5 / 8^{\prime \prime} \mathrm{K5}, 36$ \#ft @ 2603

Cemented to Surface

$12-3 / 4^{\prime \prime} @ 2632^{\prime}$

Top of Cavern e 3237

$3316(?)-\ldots \ldots$.

Water

$5-1 / 2^{\prime \prime}, \mathrm{K} 55,15.5 \# / \mathrm{ft} @ 3379.54$

Cavern Floor@3395'

(After Louis Records \& Associates)

Figure 2-D

Cavern Pressure Reduced to 50 psi Potential Condition on Well 6 After Pulling 14 Stands of Tubing. 
The Tubing Analysis

If the annulus pressure were drawn down to 50 psi, the tubing pressure would be 50 psi because a full column of oil in the tubing would balance the oil in the annulus.

To bring the tubing pressure to "0" 2 bbls of 11.6 \#/gal mud would have to be displaced into the top of tubing.

$$
\begin{aligned}
& .6020 \mathrm{psi} / \mathrm{ft} \times(\mathrm{Y}) \mathrm{ft}=50 \mathrm{psi} \\
& \text { (Y) } \mathrm{ft}_{\mathrm{t}}=83^{\prime} \\
& \text { and } \\
& 83^{\prime} \times .0238 \mathrm{bbls} / \mathrm{ft}=2 \mathrm{bbls}
\end{aligned}
$$

The tubing pressure at the packer would be the same as the annular pressure at the packer.

With 14 joints of tubing pulled 420 feet of mud is lost from the tubing top, including all of the kill mud. Pressure on the packer is:

$$
2693^{\prime} \times .3633=979 \mathrm{psi}
$$


U TUBE ANALYSIS

The proposed conditions for a 50 psi maximum pressure on the cavern can be represented as a "U" tube for the purpose of illustrating the hydraulic pressures on the TAM packer.

$$
\text { Well as a "U" Tube }
$$

INITIAL HYDRAULIC FORGES ON THE PACKER

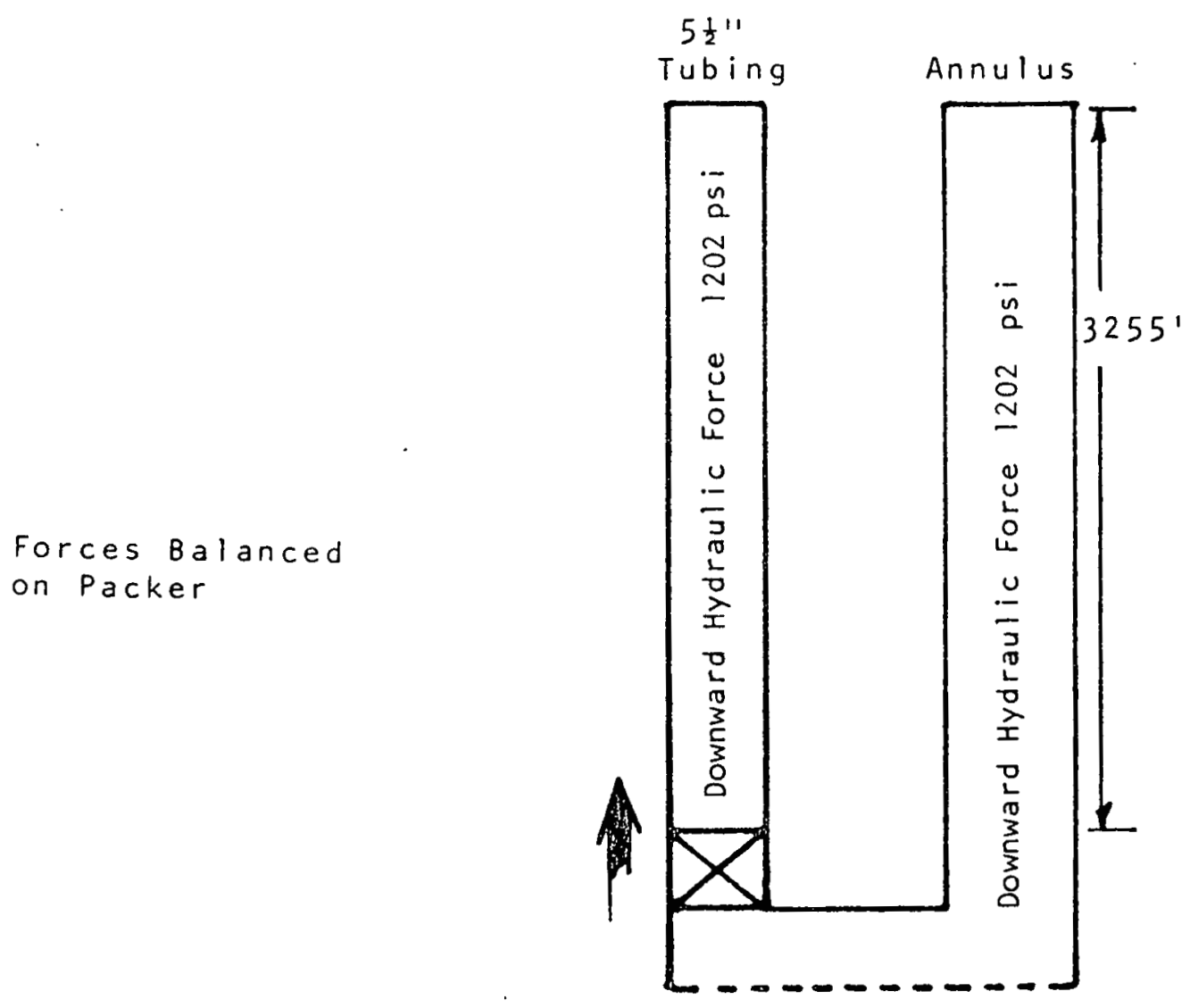

Figure 12 


\section{Well as a "U" Tube \\ HYDRAULIC FORCES AT THE DEPTH \\ THAT THE PACKER FAILED}
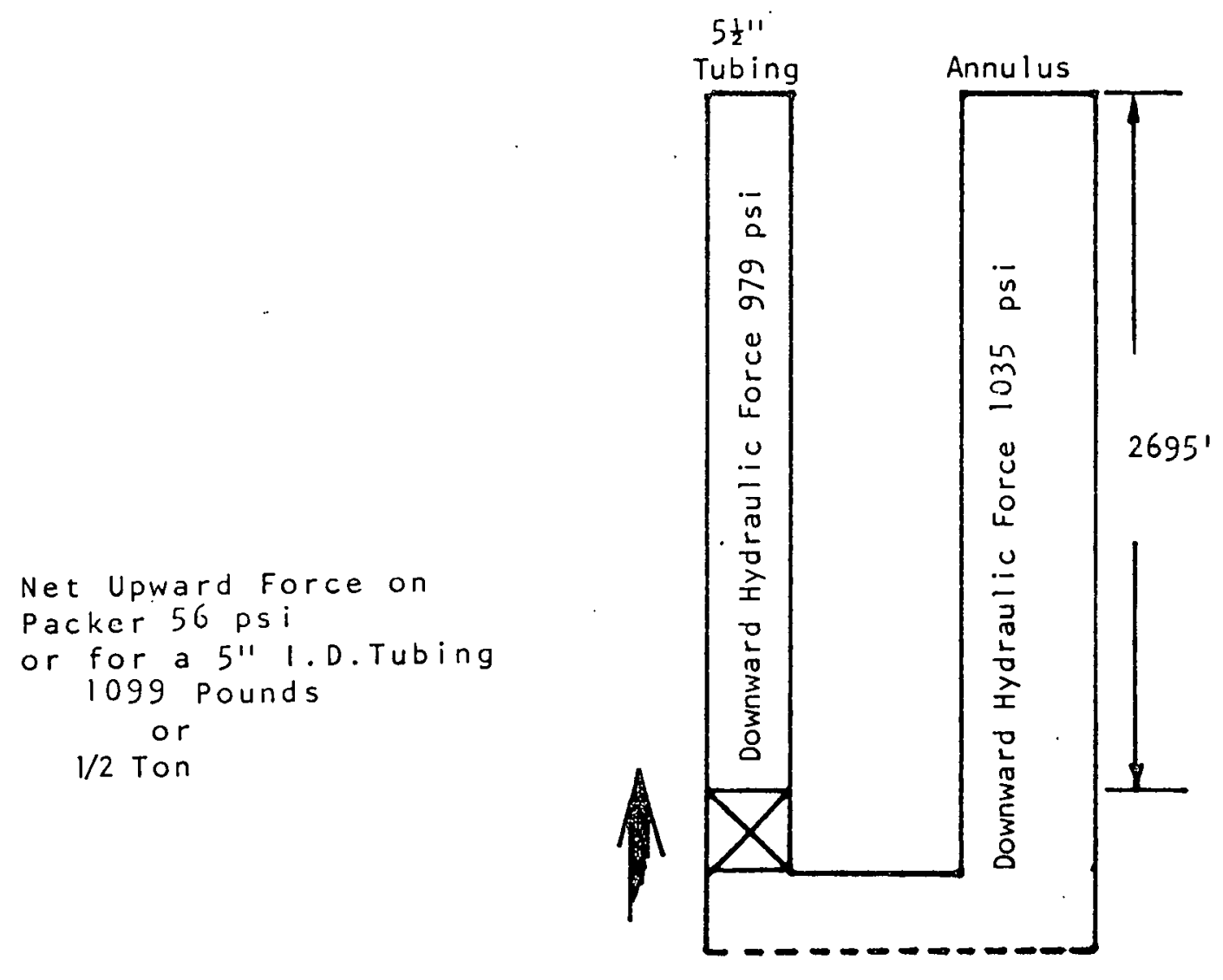

Figure 13 


\section{CONCLUSION}

Reducing the cavern pressure to 50 psi, using a lighter mud than 16 \#/gal to kill the annulus, and filling the tubing with oil could have reduced the differential pressure on the packer. It appears that the reduction in differential pressure across the packer should have been enough to avoid packer failure.

However, it appears that the risk of packer failure would still exist. Simply reducing cavern pressure is only reducing a small part of the risk. If cavern pressure is to be reduced, i.t must be reduced to "o" so that an oil flow can not occur. 
TASK 3 - ARRANGE FOR AND WITNESS PACKER TESTS IN

TAM INTERNATIONAL PLANT

Mr. Charles Ward, Senior (Engineering) Associate with Maurer Engineering Inc. and who is a Registered Professional Engineer in the State of Texas undertook this task in the absence of Mr. Rehm.

TAM PACKER TESTS

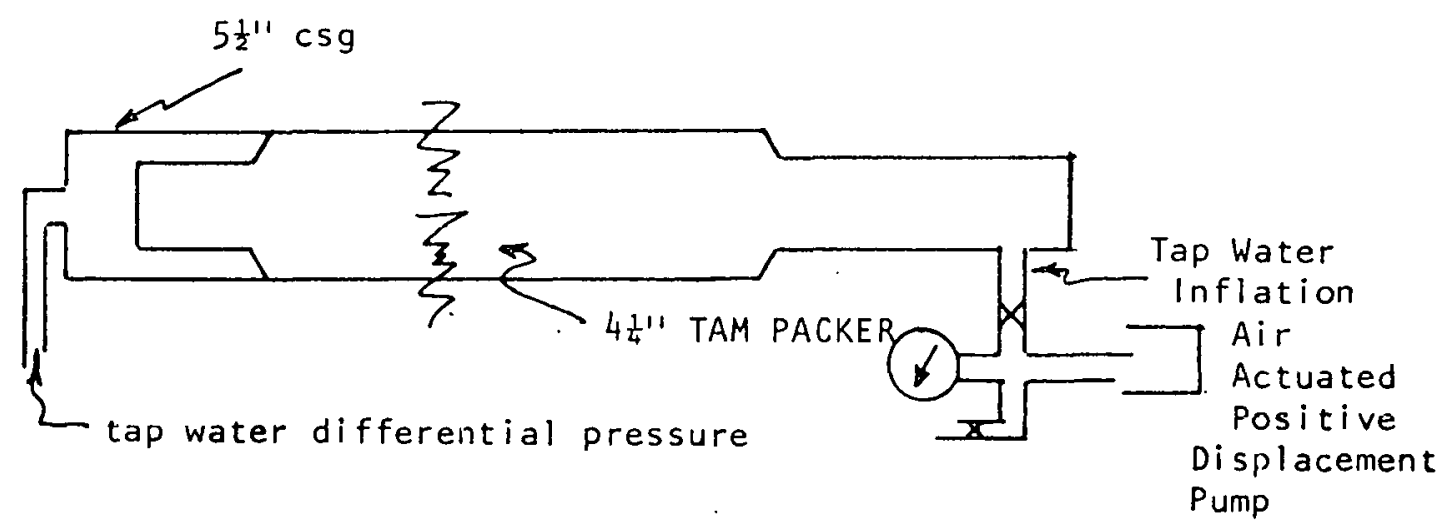

- 4-1/4" packer inside $5-1 / 2^{\prime \prime}$ casing

- Test \#1 Casing and Packer dry

- inflated to 2,500 psi using tap water

- differential pressure to 3,000 psi

- no movement of the packer 
- Test \#2 Casing wet with tap water, Packer wet with tap water and coated with salt. (There was no practical way at hand to use brine.)

- inflated to 2,500 psi with tap water

- 3,000 psi differential - held for about one minute until hose connection to plug in casing began to leak and differential dropped to 1,000 psi;

- at that time a small amount of water leaked out of the top of the packer mandrel. The hose connection was tightened and the differential pressure was increased. Packer began to slip at 800 psi.

- Packer reinflated to 2,500 psi; movement of packer in the casing was noted at a differential pressure of 1,100 psi.

- Test \#3 Inside of casing and outside of packer coated with $30-40 \mathrm{~W}$ cutting oil

- packer inflated to 2,500 psi;

- packer showed first movement at 550 psi; then held at $600+$ psi, but would move at $650+$ psi.

The "U" tube analysis in Figure 11, indicated that the differential force on the bottom of the packer was 400 to 500 psi when the packer slipped in Well 6. Since the tubing used 
on the test was clean, and there is reason to believe that there was salt or scale in the 5-1/2" tubing on Well 6 , it is not unreasonable to conclude that the packer slipped from excessive differential pressure under the well site conditions. This is, however, only a supposition and the packer tests for slippage are inconclusive when strictly applied to the assumed we 11 conditions.

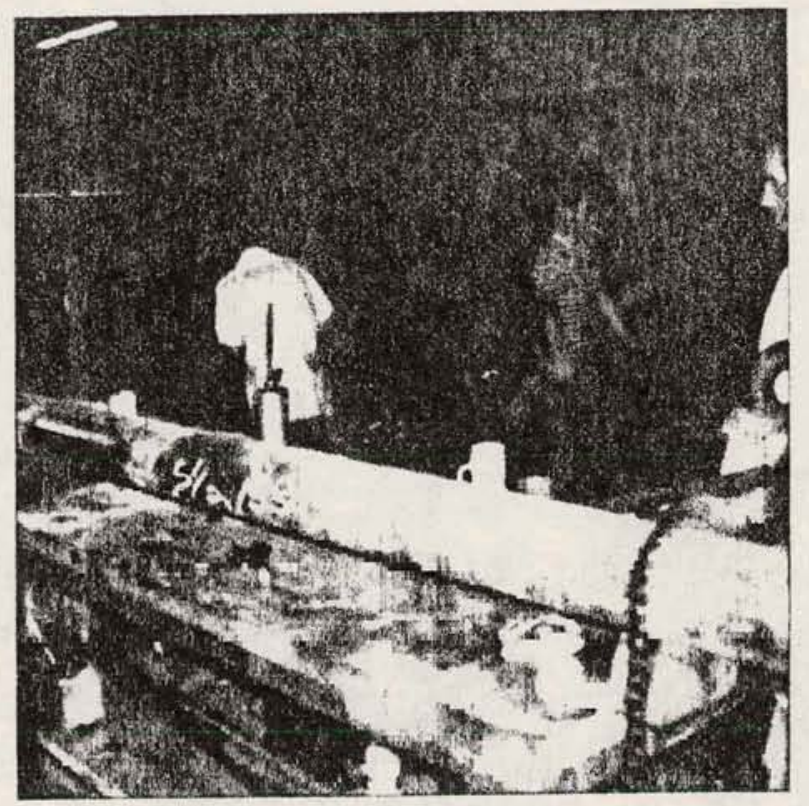

$5-1 / 2^{\prime \prime}$ CSG

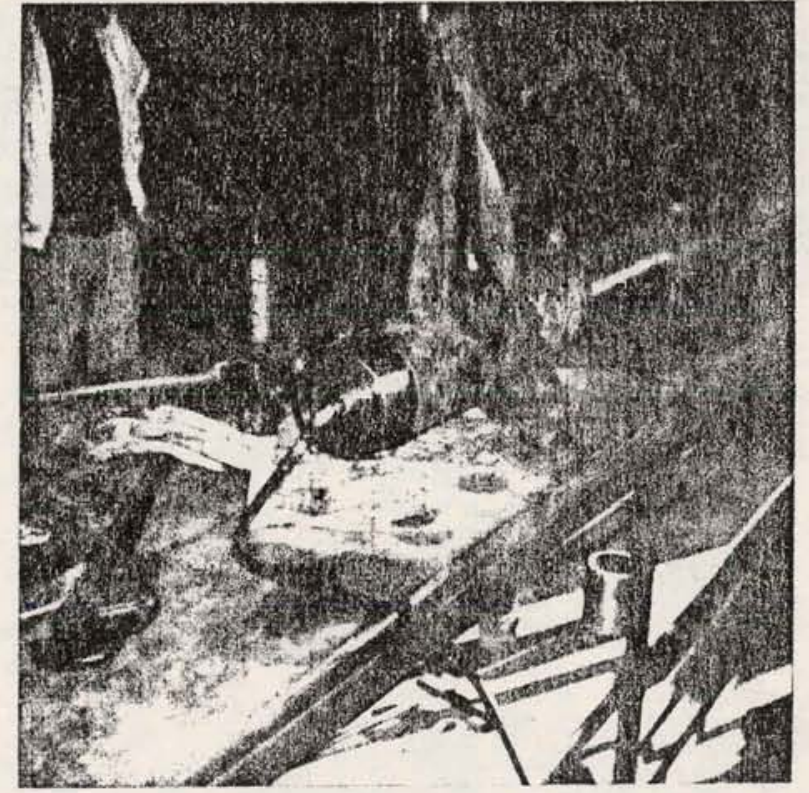

PLUG W/PRESSURE HOSE IN BOTTOM OF CSG 


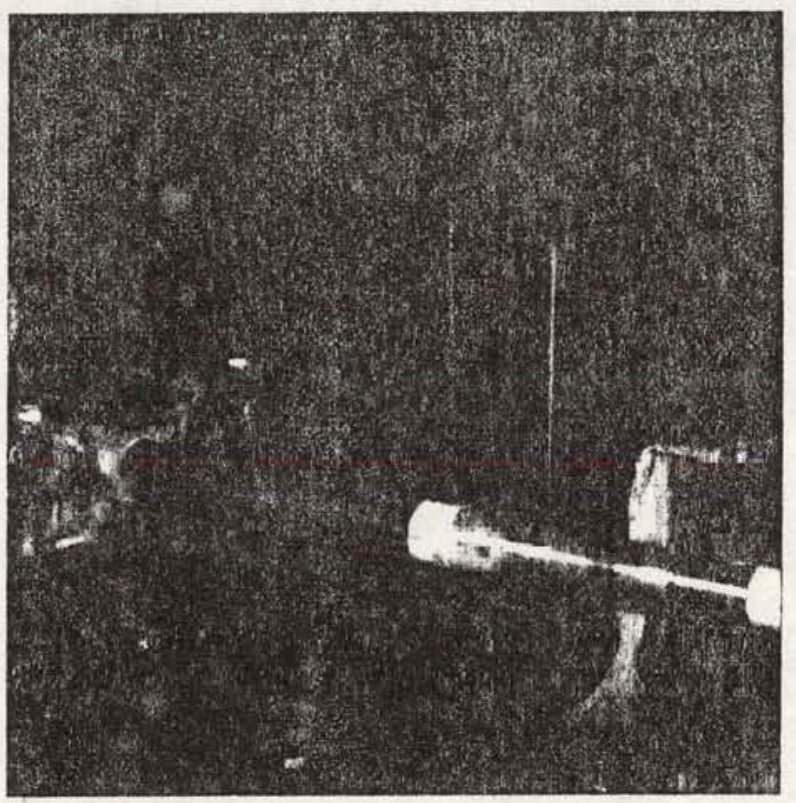

NEW TAM 4-1/4" PACKER INTO

$5-1 / 2^{\prime \prime}$ CSG

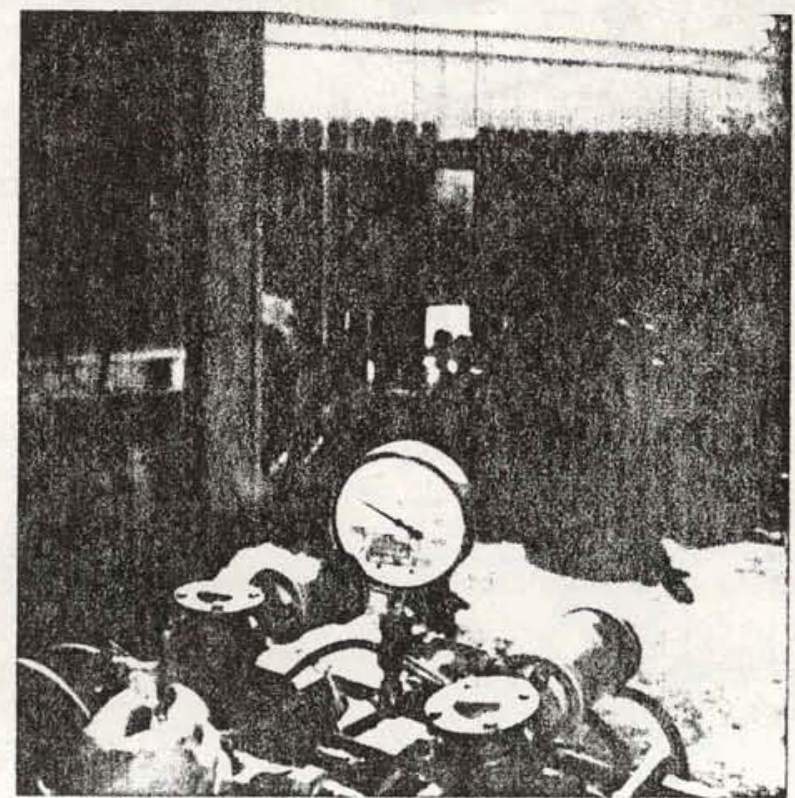

PACKER INFLATED TO 2,500 PS I

(1) 


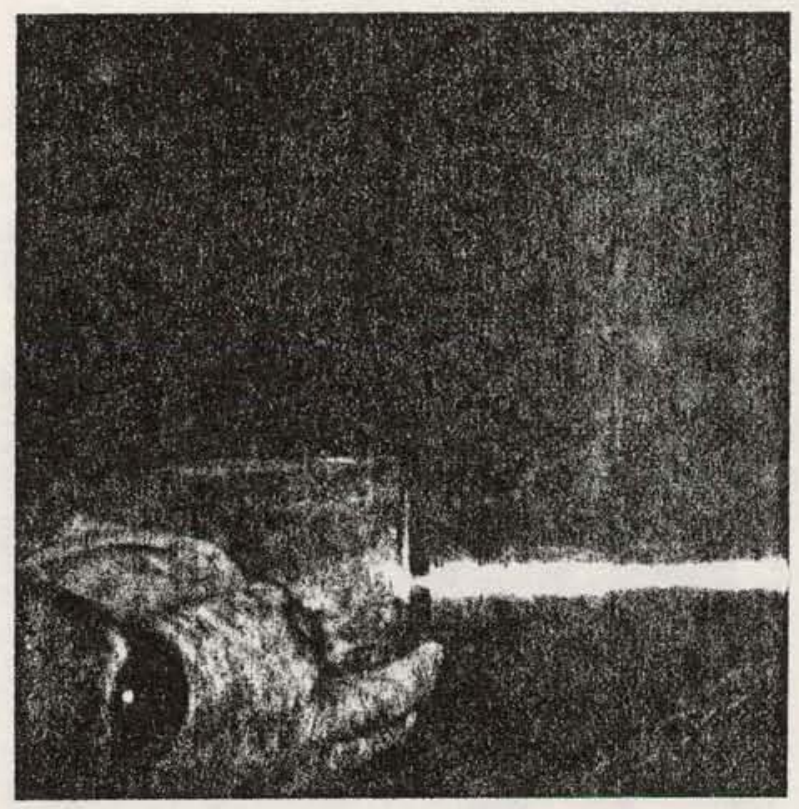

DRY START

(1)

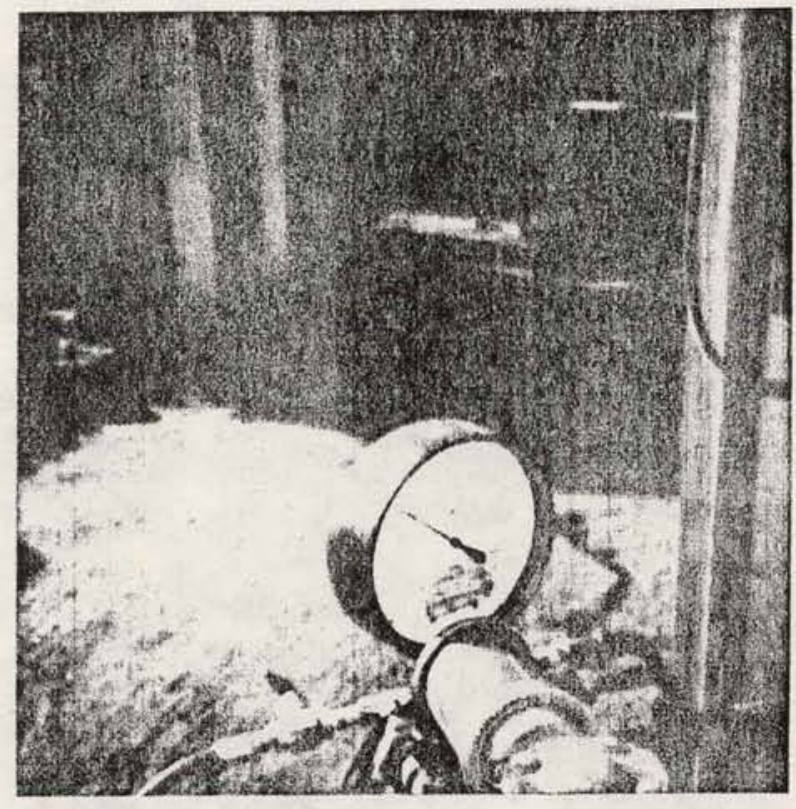

- DRY

- SET W/2,500 PSI

- TEST TO 3,000 PSI W/O SLIP

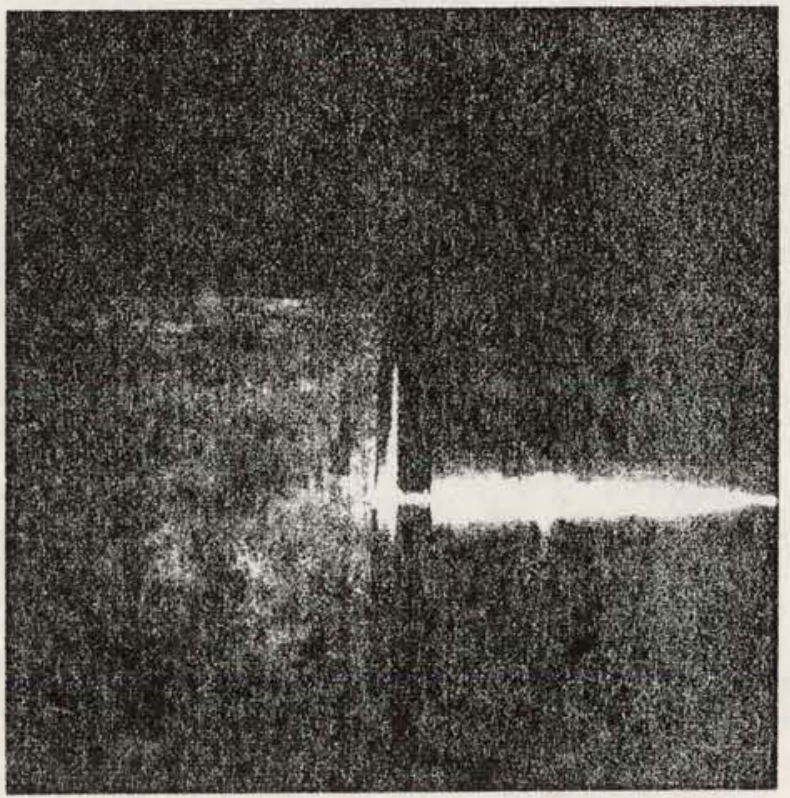

DRY FINISH

NO MOVEMENT

(1) 


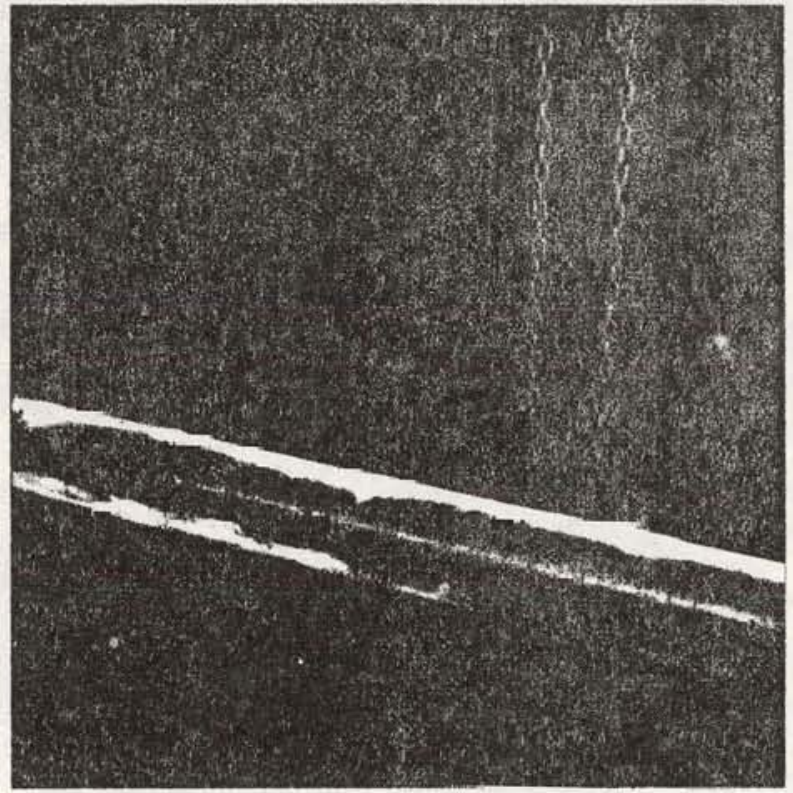

SALT ON PACKER

(2)

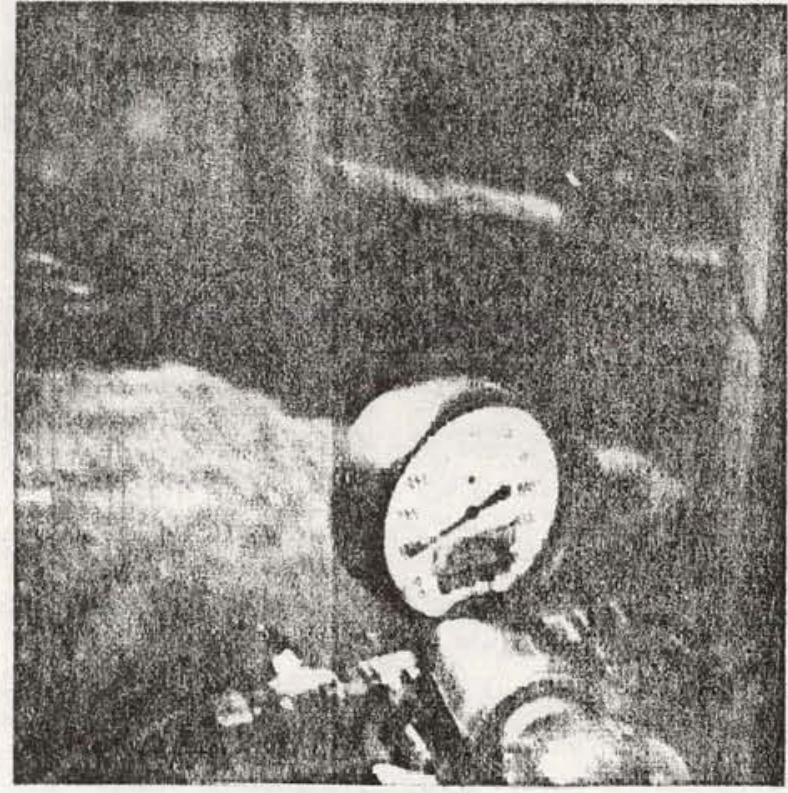

- INFLATED@ 2,500 PSI PACKER BEGAN TO MOVE AT 1,100 PSI W/SALT WATER

(2)

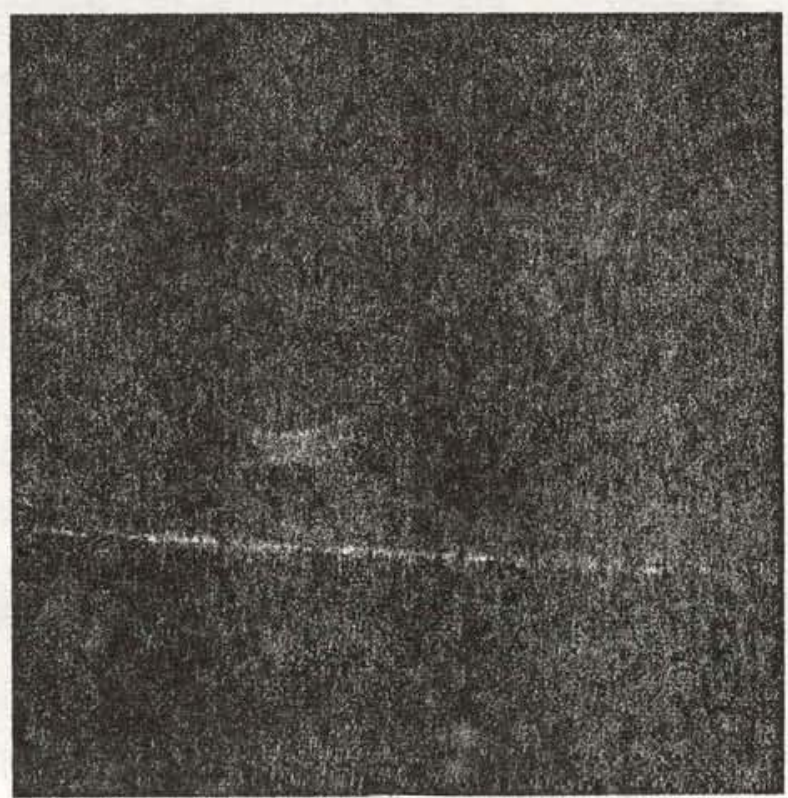

PACKER AFTER TEST $W / S A L T \&$ WATER

(2) 


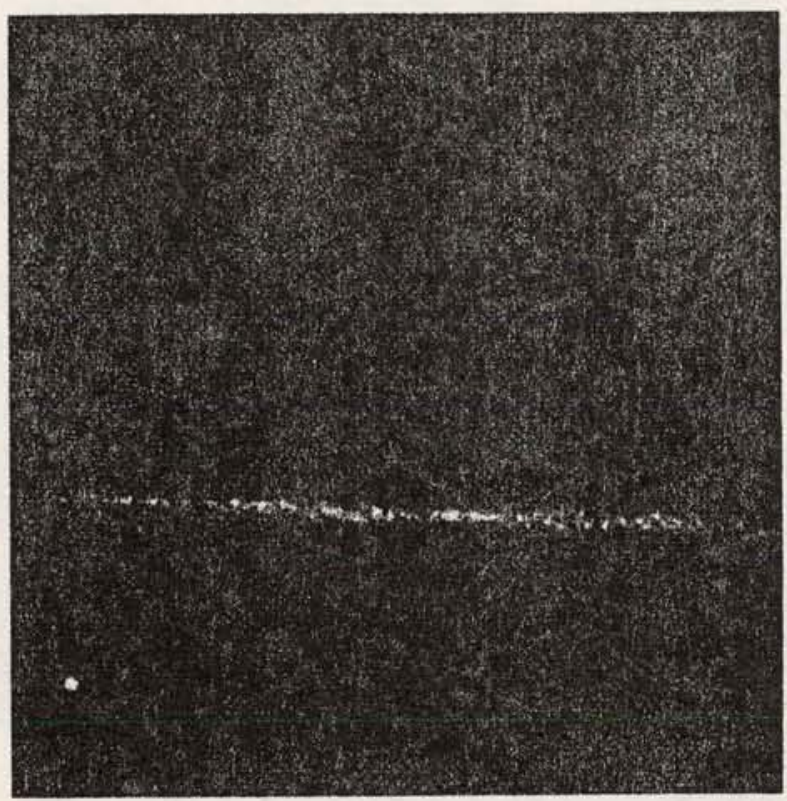

OIL COATED PACKER

(3)

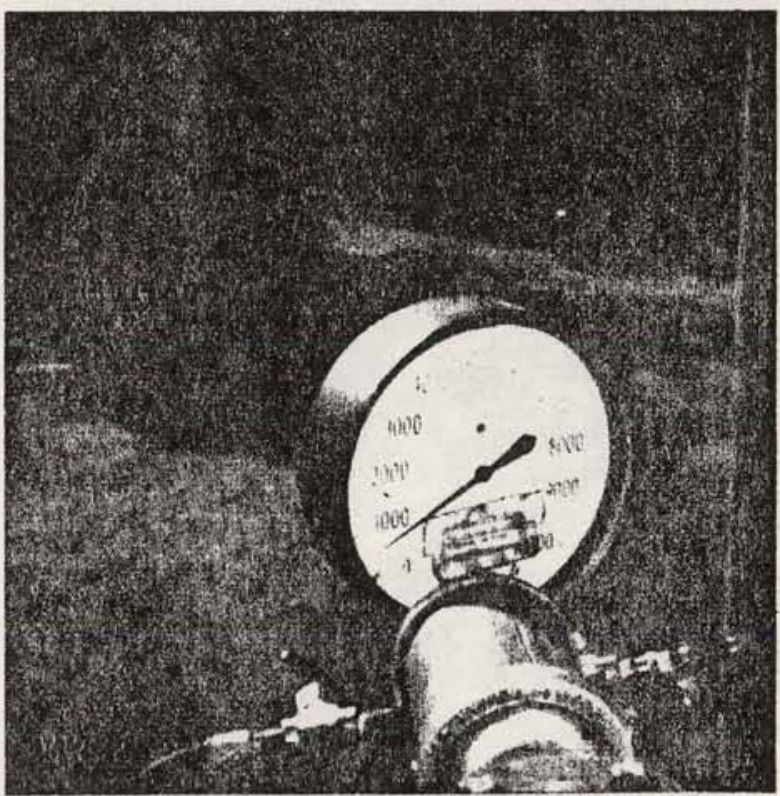

TEST $W / O I L$

PACKER SLIPPED@ 550 PSI

THEN HELD @ 650+ PSI

(3)

MOVED AT 700 PSI

46

A -181 
TASK 4 - ARRANGE FOR AND WITNESS THE DISASSEMBLY AND INSPECTION OF THE PACKER BODY USED

The actual packer from the Hackberry well was examined.

- all but a few inches of the steel braid and packer rubber at one end had been completely burned away;

- the packer mandrel was curved due to the heat;

- one joint at the top was unscrewed, a locking ring was removed and the valve tube was removed from the mandrel;

- remains of all of the 0-rings and the valve rubber were in proper place, but had been totally destroyed.

The packer parts will be retained by TAM until such time as the investigation of the blowout has been concluded.

Nothing conclusive could be determined from examining the packer.

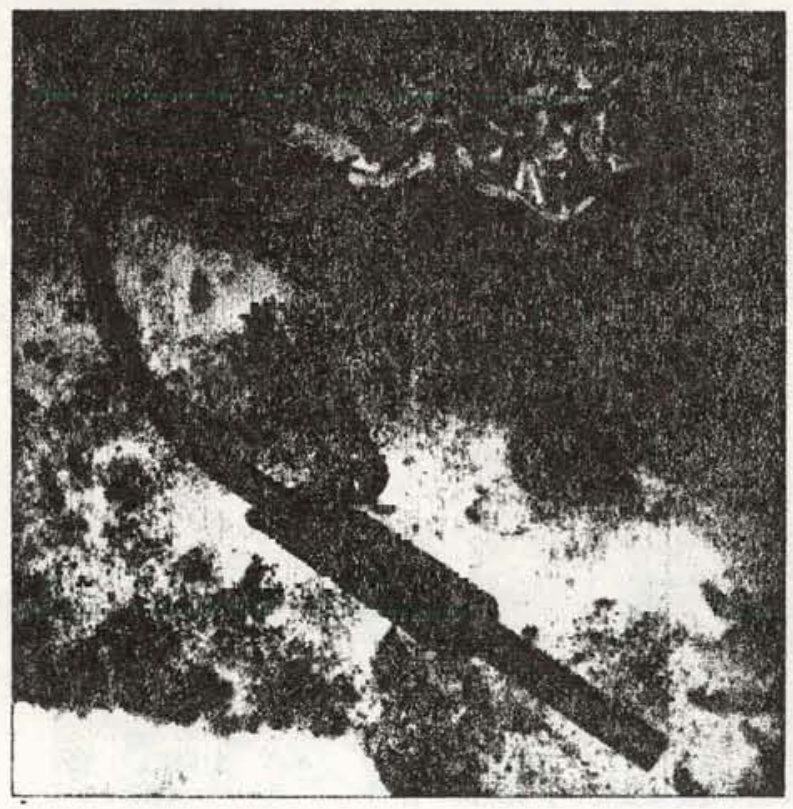

PIECES OF THE BURNED PACKER

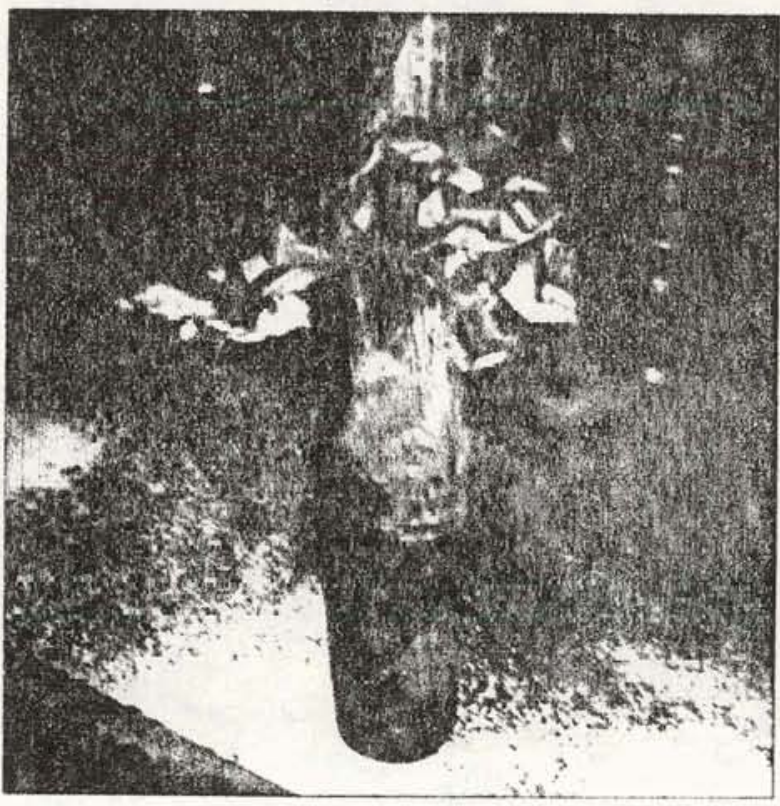

PIECE OF BURNED PACKER 


\section{TASK 5 - ASSESSMENT OF THE ADEQUACY AND/OR \\ SAFETY FEATURES OF THE WELLHEAD AND/OR DOWNHOLE ASSEMBLIES \\ PRESENTLY INSTALLED AT THE WEST HACKBERRY SITE}

Within the time and information available for the development of this report, it is difficult to document the conclusions reached in this task. Therefore, the following conclusions must be a matter of opinion and subject to challenge and further investigation.

1) There is no provision for a subsurface safety valve on any of the wells. So there is no automatic shut off for the wells in case the wellhead is damaged or destroyed by hurricane, site accidents, or political activists. Any damaged. wells would flow and possibly burn until the pressure in the cavern was depleted or until the well was plugged.

Cameron Parish, Louisiana, is in the middle of the Gulf Coast hurricane belt. Over the life of the site the danger of damage from hurricanes is very high.

2) The wellheads are not protected from damage by truck, bulidozer, or other vehicles. The wellhead and production tree must be protected by steel barriers. 


\section{RECOMMENDATIONS}

FOR AVOIDING FUTURE BLOWOUTS

ON WORKOVER OPERATIONS

The following recommendations are listed in approximate order of overall safety. The information and time are not available within the confines of this report to evaluate how practical or difficult it is to reduce cavern pressure or what the standards are on workover rigs: The recommendations then, must be further evaluated in light of these limitations.

1. Bleeding cavern pressure to a minimum 50 to 100 psi and balancing tubing and annulus by filling the tubing with oil before workover (or drilling) operations would make blowouts less likely. This wold be the safest and most assured method of avoiding future blowouts.

2. The blowout preventer stack should be equipped with shear rams when tubing is in the hole so that the rams can close the well in by shearing the tubing.

3. Double safety valves should always be used if the cavern is under pressure.

4. A stabbing valve for the tubing in use, with handles and full opening bore should be on the floor of the rig.

5. The workover rig should have a high enough substructure for at least two sets of rams and an annular preventer or stripping head. 
6. With respect to Recommendations $2,3,4$, and 5 , the selection process for the workover rig should be reevaluated. A long term contract for a rig suitable for the unique work at the site should be considered.

7. A better evaluation of workover programs and safety is needed. The Consultant, Louis Records and Associates, appears to be responsible for operations. It is unclear just what engineering and safety review is made of proposals nor how the proposals for operations are evaluated.

8. The use of inflatable packers should be reviewed. They are a valuable tool and should be used when needed. On the other hand, the use of an inflatable packer on Well 6 caused a blowout. 


\section{THIS PAGE}

\section{WAS INTENTIONALLY \\ LEFT BLANK}


APPENDIX IX

Press Releases

A-187 


\section{THIS PAGE}

\section{WAS INTENTIONALLY LEFT BLANK}


FROM: GENE CAMPBELL

U. S. DEPARTMENT OF ENERGY

$318 / 762-4211$

WEST HACKBERRY, LA. - A fire at the U.S. Department of Energy's Strategic Petroleum Reserve facility near Hackberry, Louisiana is reported "stable and under control today".

$0 i 1$, which originally gushed about 30 feet above the hole, has been reduced to a flat flow out of the pipe. This was achieved by reducing the pressure in the hole by draining oil into a nearby cavern and by removal of the oil that flowed out of the pipe.

When the fire started, pressure in the cavern was 650 pounds per square inch (PSI). This had been reduced to 50 PSI as of Saturday morning.

Flames that originally shot up 200 to 250 feet have been reduced to a height of 50 feet. These flames come primarily from oil in the diked area around the hole and surface oil from the sea shell bed surrounding the hole.

Construction work on other projects at the site continues as usual. DOE has ceased all movement of oil into other caverns.

Boots \& Coots, Inc., oil well fire fighters and blowout specialist from Houston, has been engaged by DOE to put out the fire. The fire fighters were on the scene just $21 / 2$ hours after the accident occured.

Boots \& Coots then began preparing the site for capping the well. Saturday, debris such as equipment, trucks and a 175-foot drilling rig near the bruning well were being removed. Removal of this red-hot metal is to reduce the possibility of re-ignition of the fire and clear the way for the fire fighters to move in equipment to fight the flame's source. 
FROM: GENE CAMPBELL

U.S. DEPT. OF ENERGY

$318 / 762-4211$

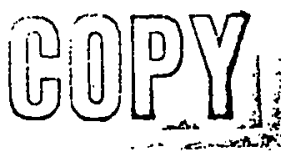

WEST HACKBERRY, LA.

Dön Mazur, Dept. of Energy's Project Manager from New Orleans, was on the scene shortly after the accident to take complet charge of the operation. An estimated 200 men are engaged in fighting the fire with excellent support from local communities and volunteer fire fighters.

After Boots \& Coots experts get close enough to see the condition of the wellhead and piping, they will then determine the method to be used in capping the well. It is expected to take from two to five days to complete the job.

A series of dikes has been constructed to contain oil flowing from the cavern to restrict environmental impact.

$0 i 1$ that leaked into Black Lake from the dike at water's edge has been held in a small area by containment booms put into place immediately by DOE. The Coast Guard is on the scene to support the operation. The Coast Guard's Gulf Coast Strike Force arrived at Hackberry Thursday night.

The wind has assisted in restricting the oil to an area about 800 yards along the shoreline and about 150 yards onto the water in a crescent shaped area. However, smote and heat from the fire have prevented a start on actually cleaning up the area.

It is estimated that the loss of $0 i 1$ from the cavern will total between 60,000 and 70,000 barrels by the time the well is capped. The cavern contains seven million barrels of oil. 


\section{FROM: GENE CAMPBELL}

U.S. DEPARTMENT OF ENERGY

$318 / 762-4211$

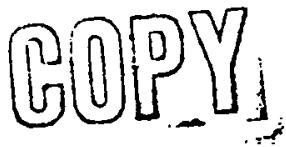

WEST HACKBERRY, LA.

A visitor to the site late Friday was Gov. Edwin Edwards of Louisiana, who viewed the fire with Gen. Joe Delusa, who is the director of the oil storage program from Washington, D. C.

Edwards told Deluca that though such accidents were to be expected in the oil business, that he was distressed at the loss of life and injury, but was satisfied that professionals were in charge, and that appropriate fire and pollution control measures were underway.

Bradley Bergeron, 22, who was injured in the accident, is reported improving in a Baton Rouge, La., burn center. Bergeron was one of two injured. Clarence Simon, 38, died a few hours after the fire. The rest of the 20 men on the platform at the time escaped without injury. All employees have been accounted for.

0il spill cleanup is proceeding along with the Boots \& Coots efforts to put out the fire. Other construction work is continuing. 0il fill to other caverns will be resumed only after thorough site safety checkouts have been completed. 
FÓR IMMEDIATE RELEASE

NOTE TO EDITORS:

DOE STATEMENT ON WESṪ HACKBERRY FIRE

(1) A.M., EDT, 9/22/78)

A fire which started Thursday afternoon at the Department of Energy's Strategic Petroleum Reservé facility near Hackberry, Louisiana, is expected to be extinguished late today or early tomorrow, DOE officials said today. Two workers were burned, one fatally.

The fire, which began about 4:05 p.m., CDT, may result in the loss of about 40,000 barrels of oil. Some seven million barrels already are in the storage cavern where the fire occurred. The fire is expected to have minimal effect on the overall SPR program.

The fire continues at the surface of one of the oil storage sites. DOE officials are on the scene, along with several fire departments from Cameron Parish and a professional oil-fire fighting team from Houston, Texas. Officials say the fire will not spread to the cavern itself, which is located more than 3000 feet below, and has an overall capacity of 12 million barrels.

The accident occurred while workmen were removing the piping in the well casing which connects the deep storage covern with the surface. Plugs had been set in a lower portion of the piping to prevent the pressurized oil from flowing to the surface. Apparently the plugs failed, allowing the oil to escape.

The released oil was ignited and is burning withina a contain. ment area around the well. 


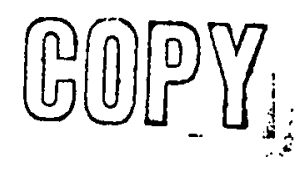

It is estimated that oil initially was flowing from the well at about 2000 barrels per hour, and that about 40,000 barrels may flow from the well before cavern pressure is reduced enough to stop the fire and plug the well. Some oil has leaked from the containment area into nearby $\mathrm{Black}$ Lake. Coast Guard and contractor crews are on the lake to contain and recover the oil.

The storage cavern is about 150 feet in height and 885 feet at its maximum diameter. It is one of five similar caverns located deep within a massive salt dome structure near the town of Hackberry. The site is about 12 air miles southwest of Lake Charles, near the Gulf coast.

The Government plans to store 50 million barrels of oil in these five caverns as part of the Strategic Petroleum Reserve program which is being developed to reduce the Nation's vulnerability to interruptions of foreign oil supplies. Altogether, more than 42 million barrels of oil are now in storage under the SPR program at West Hackberry and two other sites.

$$
\text { - DOE - }
$$

News Media Contact: Jim Griffin, 202/566-9418

John Donnelly, 202/566-9418 


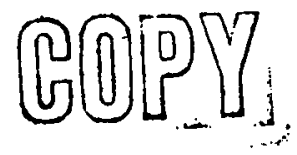

FOR IMMEDIATE RELEASE

SEPTEMBER 25, 1978

DOE APPOINTS BOARD TO INVESTIGATE

STRATEGIC PETROLEUM RESERVE FIRE

A committee to conduct an investigation of the explosion and fire last week at the Department of Energy's (DOE) Strategic Petroleum Reserve facility near Hackberry, Louisiana, was appointed today by Ruth C. Clasen, DOE's Assistant Secretary for Environment.

The members of the investigation committee are: Phillip C. White, chairman, a private energy consultant who was Assistant Administrator for Fossil Energy at the U.S. Energy Research and Development Administration; John N. Murphy, Director of the Pittsburgh Mines Safety Research Center for the U.S. Bureau of Mines; George Dix of the Office of DOE's Assistant Secretary for Environment; Glen Stafford of the Office of DOE's Assistant Secretary for Energy Technology; and Phillip Low of DOE's Inspector General's Office.

Mrs. Clasen said, "This committee will report directly to me about the details of this accident. The investigation is to take preference over all other prior commitments of the committee members."

She requested that the committee members submit a report to her within 30 days.

The investigation committee will seek to determine the nature and extent of the accident, including its cost and its effects on the Strategic Petroleum Reserve program; the cause of the accident; and a judgment of actions with need to be taken to avoid similar occurrences. 
News Media Contacts: Len Arst, 202/376-4272

John Donne11y, 202/566-9418 


\author{
FOR IMMEDIATE RELEASE \\ OCTOBER 3, 1978 \\ DOE ESTABLISHES CLAIMS OFFICE AT SITE OF \\ STRATEGIC PETROLEUM RESERVE FIRE IN LOUISIANA
}

The Department of Energy (DOE) has established a claims office to handle individual claims for damages caused by a recent fire at the Strategic Petroleum Reserve site at West Hackberry, Louisiana.

$D O E$ is contacting property owners in the surrounding community whose property may have been damaged by particles and smoke plumes caused by the fire. Individuals with potential claims for damages should send the claims directly to:

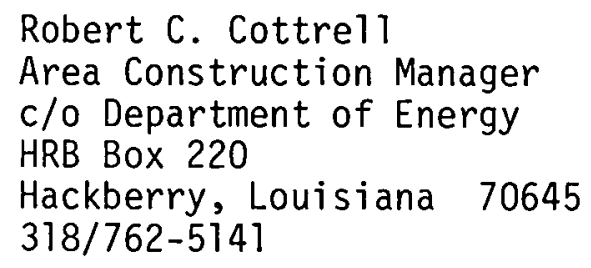

Last Saturday, oil technology sepcialists replaced the permanent control cap on a pipeline where the fire broke out on September 21. The pipe had been temporarily plugges on September 26 .

One man was burned fatally and another sustained serious injuries as a result of the accident.

DOE estimates that approximately 68,000 barrels of $0 i 1$ gushed out of the pipe while the fire was burning. Of this, about 33,000 barrels burned and DOE is now determining how much of the 35,000 barrels being recovered will be reinjected into storage or sold as waste oil. 


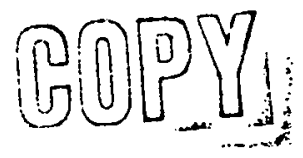

About one-half hour after the oil release began, a series of booms was laid on the lake. The booms contained the oil in a relatively small area along the shore. Studies are underway to determine the best methods for cleaning up the remaining oil on both lake and shore.

"The mobilization of both men and equipment was accomplished quickly and professionally," said Donald W. Hazur, SPR New Orleans Project Office Manager, who directed much of the oil recovery effort. "The oil was contained and picked up with great efficiency. We are particularly grateful for all the assistance which we received from various Federal, state and local agencies, as well as the DOE contractor personnel."

A DOE-appointed five-man investigation board is conducting a study of the causes of the fire, and ways to prevent similar accidents from occurring. Its report is due to be delivered to DOE within a month.

DOE has also arranged with the Department of Commerce for speedy reimbursement of fire-fighting costs to the six voluntary and two paid fire departments which helped fight the fire. The claims office is also coordinating this activity.

News Media Contact: Jim Griffin or John Donnelly, 202/566-9418 


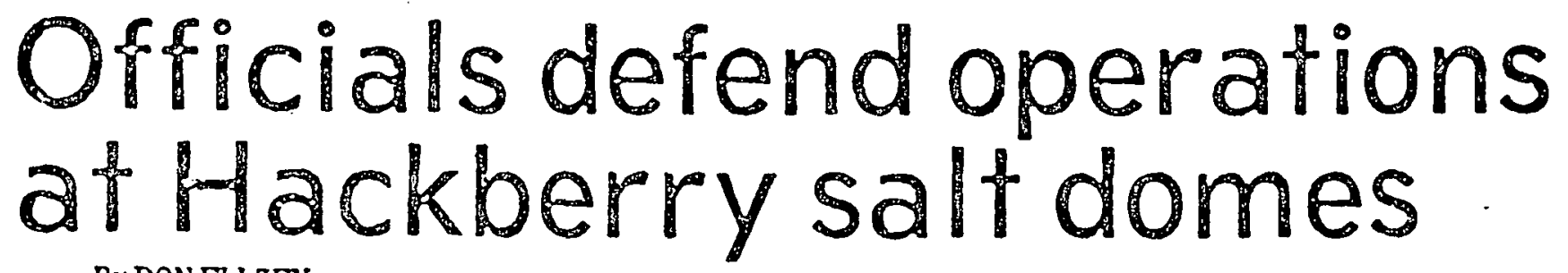

By DON ELLZEY

American Press Slaff Wriler. (Relaled story, Page 2)

A lederal officlal denied Friday that the U.S. Depart. ment of Energy (DOE) is less cuncented with the life that was lost in the Hackberry Siralegic Peiroleum Reserve (SFR) fire Sept 21 than wlth painting a rosy plclure of the storage operation for the public.

Yet, officials stop - at no lengths to defend the operalional procedures at the lacility and are emphatic that the federal" personnel in charge are qualified. They especiaily defend the overall supervision at the projech vehemently denylng that supenisory personnel have in any way neglected their duties in pursult of other activities in this small Cameron Parish community.

: Meanuhlle, Gov. Edwln EdHards and U.S. Rep. Henson Moore have in effect said bumbling and inexperienced bureaucrals paved the way for the explosion and fire that left one man dead and another seriously injured.

And late this week the American Press was toid that a government boat was used at 'axpayers' expense by federal employees and guests for a Sepl. 16 joytide complete with beer and female companionship, that there have been reports of confidential bid information being leaked to competing contractors, that storage domes adjacent to the fatal cavern were bled prior to the wells being reworked, that satety regulations were violated, and that there seems to be confusion among federal officlals as to who is in charge at the site.

Beginning at 10 a.m. Loday, net. 7, Sen J. Bennett Jnhn will : be in the Contraband Room of the Lake Charles Civic Cenler.:. . ......

Grallitll copled by an employee from papers on the desk of a Jederal official al the slte indicates that lapses of professtonalism have Indced possibly occurred. The graf: fittl reads: $\because . . . . . .$. - I'm glad that I'm an American I'm glad that I'm iree $\because$ But I wish that I was a لltt]e $\because \cdots: \cdots: \cdots, \cdots$ dog $\because \cdots \cdots$ iis: And Carter was a tree. $\therefore$ iack Wilson, actlng site commander and supervisory' environmental englneer out of Washington, D.C., in an interview Friday moming delended the competency and integrity of the federal personnel and said the DOE was definitely not downplaying the death at the slorage dome. $\because \because \therefore \ldots$.

"Absolutely notl" : Hillson said.

He said the boat appropriately dubbed the "Skimmer" and used to remove oil spills, cost the taxpayers about $\$ 200$,000 . Wilson said he was not aware that a party was held on the boat involving four to five males and three to four fernales. The DOE would not condone such an activity at the taxpay'ers' expense, he said.

A lederal employee present for the interview acknowledged that there was a party, but said it was merely a "launching party." The boat had recenlly been launched at the Amoco dock near the dome sile, he said. The only liquor was a bottje of vine used for the christening, the employee sald. The females were the wives of the males participatIng in the ceremonies.

A witness said the boat was away from the dock for about tour hours.

Wilson discrinter claims have recelved sasety and first aid tralning, he sald.

He sald the government has a quota - preferably called a "goal" or "fill schedule" - on the amount of oll to be pumped into the caverns. The goal is one billion barrels by 1985 , and 100 million barrels by Dec. 31, 1978, Wilson said.

He sald no safety shortcuts were taken at Cavern No. 6 in order to meet the goal.

Wilson heatedly defended the qualificalions and superv!sory ability of the site director of operations, who is in charge of the domes and the oil storage. When asked If a know]jedgeable supervisor would not as a salety consideration have bled the dome to reduce pressure belore allowing a crew to rework the well, Wijson sald the supervisor would have had no authority to hall the work, ever If he knew the crew's llfe was in danger. 


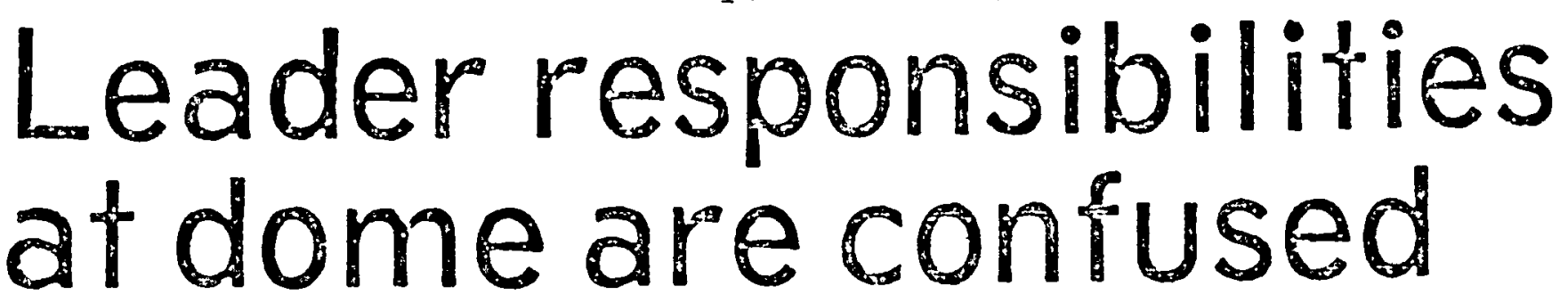

HACKBERRY - "Regard. less of that W'llson sald about chaln of command, I would slop any uncafe act II I kaw it. There's no point in taking chances," sald Maurlce Grobet, res!dent U.S. Department of Engery (DOE) engneer at the Hackberry Strate gic Pétroleum Reserve (SPR) slte bere in response to remarks by another lederal olficial.

Jack Wilson, acting slte commander and supervisory environmental engtneer out of W'ashington, D.C., bad sald in an earller Inlervlew Friday that DOE personnel at the salt oome slorage slle rould have had no authorlty to stop a crew from reworking a wiell even if the officlals knew the crew would be in danger.

Wilson sald that in the lederal chain of command, nelther Graber nor the disector of operations would have been authorized to stop the viork. Once the order is given from a higher level, local offlcials cannol countermand those orders, he sald.

The contradictions amplify the confusion that has existed at the lederal oil storage faclity since the fire even to the polnt of controversy over who is actually in command at the site and command responsibilitles.

Wilson sald Frlday that Graber is in charge of the overall stte operations. Graber denied the clalm, saying he is in charge - of construction. Thomas Petty is in sole charge of operations, which includes the storage domes and related activities, Graber said.

He said that if a life was in danger or the situation so warranted, be would not besitate lo countermand an order.
Asked If Pelty should have know's the dome pressure should have boen reduced, HU. son sajd, "I'm certain in the back of his mind he (Petty) knew the dome was under pressure and guestioned the salei,."

Graber said domes adjacent to Cavern No. 6, which erupled in names Sept. 21, w'ere bled (depressurized) prior to the kells being reworked. Cavern No. 6 was nol completely de pressurized because it contatned about seven million barrets of oll, he said. It rould have been difficult and expensive to remove the oil and replace it once the well was reworked. $\therefore . . . . \quad \ldots . . . .$. ,

There have beco reports that enforcement of salety regula. thons at the slorage site has been lax. According to the reports, employees were given no safety training and no training in extinguishing oll iires. Some fire extingulshers have been installed, but employees would not know whlch extinguisber to use for a particular type of tire:.....

Electrical cables carrving 23,000 to 43,000 volts have been buried at the site atthoul a condult pumps bave been operated without belng grounded and rifthout auto matic shutdouns. For a utlle, there were no catwialks around the wellheads, according to the accounts.

"They jusi dug a trench and threw them (the cables) in and covered them up with only the insulation," the press was told. "Lel a local contraclor or company do that and OSHA (the federal Occupatlonal Safety and Heallh Administratlon) would hang them."

About four months ago a cable was reportedly blth causing a minor exp̧losion, but no
Graber, gruff bul a refreshingly candid federal speciman, agreed that some of the cable was lald wilthoul e condult but was done wilth authorizallon. He sald he wes not aweice of the explosion, ard that $10 \mathrm{hls}$ knowiledge OSHA officials have not lnspected the site.

he aiso sald all saiety rules are not being followed, but qualified the stalement.

"I don't know' of any place in the world where all safety practices are observed at all times," he sald. "I was not ax'are of any vlolation of salety procedures.".......

Safety tralning has been provided, and the pumps are grounded and have automatic temperature and vibrator shutoff devlces, he sald.

"I reallze we have been In 8 :hurry, but safety has not been disregarded," he sald.

As for the cause of the explosion, Graber said In his opin. Ion it was a gas bubble, not the pressure in the dome.

Another theory is that the explosion was caused by a spark from a generalor or engine.

Graber agreed that the pressure could have been reduced prlor to the Horkover crew golng onto the site.

He sald that to his recollection there bas never been a lormal meeting of supervisors and other higher echelon personnel at the site to discuss operatlons and plnpoint polenthal problem areas. Numerous Inlormal meetings bave been beld dally. Graber sald if anyone at the site requested $a$ ' formal meeting, he was not aviare of th and that be defl: nitely would not have denied such a request.

As for confidential bld Information being leaked, he sald be could nnt say for sure It had
"But:1 wowd bope not"." Graber sald . "As for reports recelved by the press that the machinery vias in mollon to promote to federal stalus a Parsnns.Gil. bane uperatioes superiniend. ent who is also allegidly a close associate of Pelty, Graber sald he had heard re ports aboul the promotion.

Allen Fruge, a DOE consultIng engineer, also confirmed a report that he refused to allow two volunleer firemen from the Hackberry Volunleer Fire Department to enter the main gate at 2 a.m. on Friday, Sept. 22, about 10 hours after the exploslon.

Graber, explaining the inctdenh sald sufficient liremen were already at the site. Horkmen had encountered problems moving equipment Inlo the area because of the liremen's cars parked along. side the road leading to the dome, he sald.

"You may not agree, but the reason for not letting them in was valid," Graber sald.

He sald the government sppreciales the services of the firemen-paid and volunteerand it is his understanding the government w'll cover all equipment and material expenses.-ELLZEY 


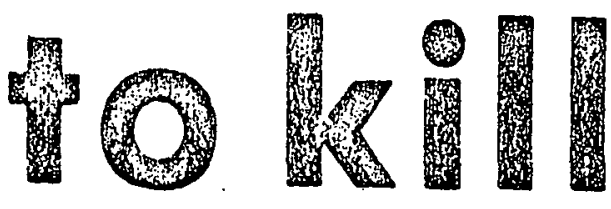

HACKBERRY, La. (AP) Experts who fight fires in the oil fields throughout the world failed Sunday in their. first attempt to snuff out a stubborn and expensive blaze at the nation's showcase Strategic Petroleum Reserve here.

"It didn't work," said Gene Campbell of the U.S. Department of Energy: "They'll try again tomorrow.".

The blaze began Thursday night, following an explosion that killed one man and seriously burned another as some 20 workmen scrambled for their lives.

Offlcials fear the blazing oil; spewing from a cavern holding 7 million barrels of crude, will stain an $\$ 8$ billion federal project to store oil in Gulf Coast salt domes as a hedge against Arab boycotts.

Firefighters Asgar "Boots" Hansen and Edgar "Coots" Matthews tried Sunday to force salt water down the blazing mouth of the well to stifle it momentarily.

Then their men would plug and seal the well before a new geyser could erupt.

"They thought possibly if they pumped salt brine into the hole - it's heavier than oil - it would force the oil down into the hole.

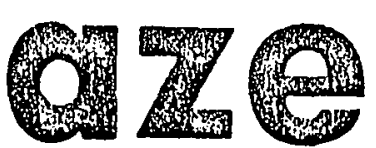

"But Boots said it was like if you put a 30-foot pipe into the middle of the Superdome and started pumping. water. The water just fell into the cavern and the oil just kept coming out," Campbell said.

He said the firefighters would try a different attack Monday.

"What he's going to try and do is knock that pipe down. See, what they tried today was the easy way.

"The trouble with knocking that pipe down is it goes all the way down into the cavern, the bottom of which is about 3,500 feet. They'll have to fish it out and that takes time and money. 


\section{'PRiggest fire' I hope l'll ever see'

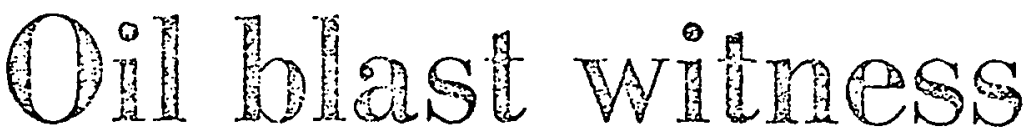

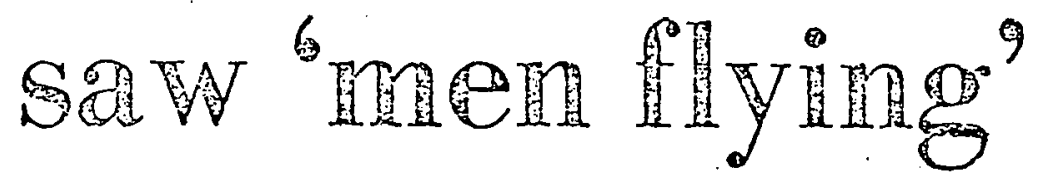

Stafl Special to The News

WEST' HACKBERRY, La. - "One minute I looked and everything was fine. Then I turned around and I heard the thing explode, and I saw men flying everywhere."

George LeBove, 35, was describing the scene at the federal governinent's salt dome storage facility when one of the rigs exploded Thursday afternoon.

"There was nothing really special about what they were doing. No one was taking any special precautions, it was completely routine," said LeBove, who was potring concrete about 40 feet from the site of the blast.

He said he ran toward the derrick to help the 15 men who had been on the rig at the time of the explosion. He said most of the men jumped safely to the mud below and where not injured.

"But we had to move quick because that fire begin to spread," LeBove said.

"The black oil was flying and there vas a lot of noise, and I saw a few names," said LeBove, who lives in Hackberry.

"The hames were shooting up about 50 or 60 feet and they soon began to spread all over the place."

"I've been working in oilfields ever since I got out of high school," said LeBove. "And in all those years I've only seen one other fire, but it was nothing compared to this. This is the biggest fire I hope I'll ever see."

The fire soon enveloped the derrick the men were working on and raged out of control within the 200-footsquare area over the salt dome. At its peak late Thursday night, LeBove said names leapt as high as 200 feet and the fire erupted in furnace-like blasts as the oil bubbled from the ground.

"There was nothing we could do right away because it was too hot." said LeBove, who has worked at the site since its dedication in July 1977. "The Hackberry Fire Department came a little bit after 4:30 p.m., but theie was nothing they could do either. They just tricd to shoot water on the llames so the fire would cool and we could get closer." LeBove and other employees of the New Orleans contracting firm of Parsons-Gilbane, inc., continued to aid the firefighters throughout Thursday night and into Friday moraing. 


\section{6 ... what do I lnow about oil fires"}

\section{Fighting Lousiana derrick fire, weary volunteers experience frustration}

\section{BS STEVE, KENNY}

Sizll Sititer of The ticar

WEST Y.ACYBERPY, La. - Buddy Miller !coked around him early Friday morning and vondered what he was doing in the middlc of a raging oil der rickfire.

Above inick clouds of black oily smoke obscured the sun and bclow an inferso rayed, and Miller, a 27-year-old welcer and father of two, was trying to putiliout.

"It was almost like 1 just woke up." said Miller, assistant chief of the 7-man Carlyss. La., voiunteer firc department "Heli. what do I know about oil fires. A bir day for me is a grass fire in somebody's beck yard."

ililier was among about 100 men and women from the volunteer fire dejartments surrounding iay, isolated West Hackberry trying to extinguisi the fire at the 6 million-barrel federal oi! storage facility.

Fire departrents from as far away as Fort Neches, Texas, responded to West hachiorry's call for heip an 0 :l derrick caught fire Thrusday aftezoon at the federally controlled salt dorse.

The department from Carlyss, a commuity of about 500, 10 miles nort? of the salt come site was ore of the first to respond.

"We est rere less than 30 ininutes after the damn thing blew up," Miller said at 9 a.m. Friday as he prepared to go home for the first time since he arrived at the site 16 hours earlier.

The entire Carlyss fire department and one of its three engines arrived Thursday afternoon to fight the blaze. But by Friday morning, only Miller and Chief Willard Darbonde and the smoke-blackened fire truck were left.

"Those otber guys we had just coulda't stand the beat, so they hac to leave but we stayed on." said Miller.

"Its so frustrating because we've been fighting it since yesterday and the fire is exactly the same now as it was then. We tried to put it out but you can hear all that bluck oil bubbling out of the ground and catching on fire."

Miller was one of the volunteer fire. man who manned the hoses containing the "light water" that helped douse the flames early Friday.

"They got us out in little tiny boats (in the dike surrounding the burned. out rig) with toese hoses connecting to a Coast Guard boat. And then they made me stand up on one of those evees surrounding the fire and pour this foam on to the fire," Miller said.

"It was just then that I realized I didn't know' what I was doing " he said.

"With all that smokc you would turn around and you couldn't see the guy standinf resit to you. it was very hard to tell exactly who was dolng what sieep. when and how."

In the confusion, the Carlyss fire department misplaced $60 \mathrm{C}$ feet of fire hose. The chief later found the hose, but it was clogged. with oil and may have to be replaced. Milier said.

The assistant fire chief said he was going home to a nice big breakfast of ham and eggs and then was going to
"But we'll be back out here Soturday because it will still be going then." Mil ler said. "and I guess I"ll stay out here until they get the thing out.

"There's only one thing I want to know," be said trying to brush the oil off bis raincoat, "how do you get this junk off? I think my' wife is going to kill me." 


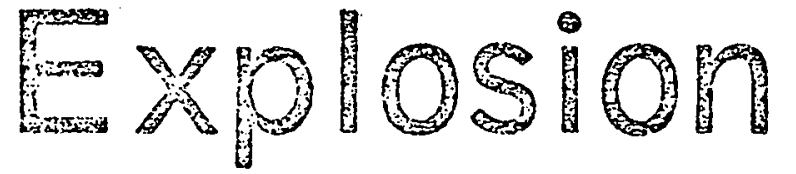

BY DON ELLZEY

American Press Staff Writer

HACKBERRY - The federal Strategic Petroleum Reserve (SPR) site herc remained in a state of confusion Friday following an explosion Thursday afternoon that left one man dead and a second hospitalized in critical condition.

The site is administered by the U.S. Department of Energy (DOE). Friday morning DOE officials were scurrying around in an obrious state of confusion as the media attcmpted on the onc hand to obtain information about the blast and area firemen on the olher fought to contain the blazing gas well.

Representatives of the media from Baton Rouge; New Orlears, Lafayette and other areas were left standing in the broiling sun for hours awaiting a bricfing with DOE officials. The briefings were promised periodically but a hitch always dcreloped. A Baton Rouge television crew reportedly arrived at the site at 3 a.m. Friday but had to wait until about 10 a.m. ivhile DOF officials pul their heads together to decide what to tcll the public.

In other developments befitting the mood at the site, a DOE official said he would "fill" a reporter if the reporter printed his coininents about Bill Parker, SPR deputy project man:ager, and Tom Lankford, SPR public information officer.

Then, late Friday afternoon the DOE Public Information Office: (PIO) out of Dallas, Texas, refused to confirm whether all crewmen working on the blazing rig have been accounted for.

Geine Campbell of the DOE Dallas office, who kept reporters waiting for hours white allegedly huddling with officials from llashington. D.C., said it was his understanding that all crewmen oin the rig have been accounted for. Howerer, Campbell refused to say that the headcotint is definitc.

DOE officials refused to allow reporters access to telephoicis. An American Press repoiter asked to speak to eilher Parier or Lankford. who had kept the press and law enforcement agencies informed during the chaotic hours following the blast Thursday night.

Allen Frtige. assistant resirlent engineer with the DOE. said that Parker and lankford would no longer be giving

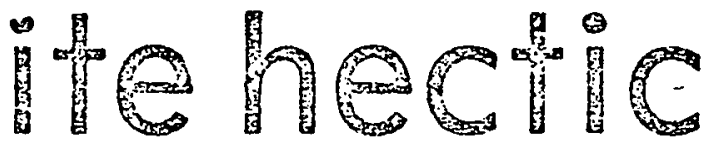

information to the media. Campbell had been brought in specifically for that purpose. Fruge saiul.

When asked the whercabouts of Parker and Lankford, Fruge said, "They've been booted back there (pointing to the blazing rig at the opposite end of the compound).

"They've been replaced by Cimplell because of all that half correct information in the newspaper," he said, apparently referring to the Associated Press story in a Batoin Rouge morning newspaper.

"And if you print what l've just said, I'll kill you," Fruge said, stalking back toward the headquarters building.

At about 10:15 a.m. a law enforcement agent persuaded Campbell and the DOE officials to meet with the media representatives.

A source told the American Press later that the officials did not want to meet with the press.

During the question-and-answer session. Campbell said he was not fully knowledgeable about dovelopments at the Hackberry salt dome. Campbell agreed that the cause of the well blowout was a spark, but that an investigation was underway.

Asked if the blowout and subsequent oil spill in adjacent Black Lake could create an environmental problem, he said environmental problems are not unusual in oil fields.

Asked if the blowout would hurt the DCE's public relations campaign supporting the concept of oil storage in salt domes, Campbell said, "It won't help but it won't hurt."

He said the safety program at the DOE compound is "normal." When asked to be more specific. Campbell said he was not well versed in the pregram and coulci rot claborate.

Contrary to Fruge's remarks about the Friday Associated Press story. Campbsil said without hesitation that the slory was accurate in every respect. He made the comment on two occasions.

He said federal officials had made no calculations of the costs of extinguishing the blaze and cleanup operations.

Following the press conference, media representatives who had not slipped by lhe guards earier Friday morning and visite! the blazing well were given a tour by DOE officials. 


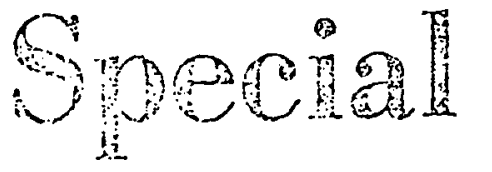

\section{BOSTEVEKLNNY \\ Stalf liriter of The News}

WEST HACKBRRRY, La. - Special fire. fignt:? from Houston mate the first effort litie ariday afternoon to extinguish the oil stoinge facility fire that has raged in West lackliegry for more than 24 hours.

Firefighters, und the direction of Focits Hansen and Coots Matthews - formet.. protreses of faried petro?eum firefiginer Red nidair - and U.S. Department of Energy offecisls, togan a drilling operation in relicye vindergrowind pressure, which is fleging the fire at the nation's giant oil resejvestorage silt doma.

MAlitifys DOES not expect the fire to be extinguished for "iwo or three days," sairl Geme Campball, Doks spokesman. Off:cials apect between so.010-70.060 harrels of ojl -..worth up io sos mblion - vilil be lost froit the 1.3 million-larrel facility by the titic lhe fire is ont.

the workmen began sinking a 2-incli stcol pipdiale into tine giant storage cavesh jocited 3,820 feet below Biack Lake, is miles soniluyesi of lake Charles. Jat., to drain ofi sonte of the silt wate: in the doine, thus relioving ilse pressure.

pije sali dome is filled with 7 million barrols of ni! and 6 millical harrets of saltwater. Cenpluall soid. As oil is stored in the diace sulluater is pumper? out of the jannmade cilvern.

Aluut 100 volumteer firen:er: from seven locial communities have kept the fire contaibed to the zoo-foot-sg!tare dikes that sur. rowad the storilfe fachlity's tivo derricks. Sev'n fire engines have pumped water to cool the fire since? p.m. Thumsdigs allow. jug tirufighters to get whimn 50 icet of the bliluzit.

AN USESIBATED anom! of oil has leaked from the dikes iato Black lake but If has rot ioniled. Campincil sidel tha firefighters apparently latve plugred the leati and no more oil is spilling into the likle.

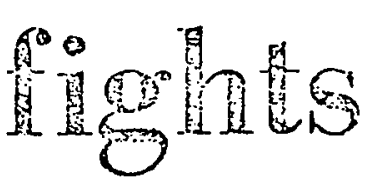

The burning derrick is on the south shore of the lake.

No new injuries have been reported in the fire. Campbell said. One workman. Clar. ence Simien, 40, of Abheyville; died Thursday night in Baton Rouge General Hospital after suffering 2nd-and 3rd-degree burns in Thursday afternoon's blasi. A second man, Bradley Bergeron, 37; of liew lberia. La., remained in critical but stable condition at the hospital Friduy afternoon with 2nd-degree burns over 65 percent of his body.

Both Simien and Bergeron were standing on the 80-foot derrick when it exploded

Voluntcers respond to the call; witness reciils tise moment of the explosion; Louiviana governor biancs poor iederal planring. Stories on Păge $25 \mathrm{~A}$.

at 4:20 p.m. Thursday. Thirteen other men. who were standing higher on the rig. escaped serious injury when they managed to jump to the juad bejow.

Those 13 men vere the first in be intorviewed in a DOEi investigation into what caused the derrick to explotle. The explo. sion occiured, officials sáid. during whi:t was "quite a routine and normal operation in the oil field."

Officials speculate the blast was cansed by spaiks from the well head's casing as it was removed to cap the storage facility. Campbeli said the derrick was equipled with a "blov:-out preventer," but it apparently failed to work.

Firefighiers also staged a practice attemp! to put out the flames about $7 \mathrm{am}$. Friciay.

USING ONF, Const Guard hoat and sereral alumintini rowboats, the inlunteer firefighters sprated an arcal of the fire with "light water." a chemical compound designed specifically for fighting oi well fires.

"The firefighters came from the Coast
Guard boat and headed for the fire lik Marines," said Dwight Willians, one c special firefighters frum Houston. "I fire hose from the boit, they silraye. fire with the light water until we ha fire almost to the well head."

The mannever was only an cxperi to determinte the effectivenuss of water in cxtinguishing the flinges, lams said. The fire could not be guished completely until the prissure ing oil to the slirface is relieved, he ack

Campoell said light water will "prol be used" after cilough of the sialt wat the underground storage facilit: siphoned off to relieve the pressure.

Firefighters then will use the water to douse the names, he said, an. well heat will be capped.

The burning well hearl is cilly or four tapped into the nudersroind dorne. It was the only weil head not ca at the time of the blast.

FlKislaxters attempted to move a ond 80 -foor derrick located aboli: 200 y from the fire but were unable io $d$ Thursday nighi. By Friday norning. derrick hall rot leen nelted by he int heat, as officials feared it would he. bitt scorched biack hy the oily darti ciouds cover the 43,000-square-foot salt done si

None of the four other West liaclit salt domes being contracted by Par: Gilbane, Inc., of Hackberry, La., and l beneath Black Lake has been affecte the fire.

Together. the five silt dontes are part of Energy Secreary Jumes Sclult ger's pet project to thwart a second $A$ ra embargo.

"The fire will not harm the jroj future," said DOE project maniger biil. ler of the comtroversia! year old sto facilities. "The projec! will we inni: hecanse the sociciary says yoi have $k$ them where they live. The Arabs can" all that oil." 
HACKBERRY, La. slowly getting back to been assured by the (AP) - A firc-blackened normal. area where \$1 million In Washington, Rep.
worth of imported crude John Breaux, D-La., said oil went up in smoke cool- he had asked the Departed cown Wednesday and ment of Energy to a scum of spilled crude reassess its $\$ 20$ billion was skimmed off a near- project to store a billion by lake.

Despite a secondary whether it has serious fire that erupted in a sec- basic flaws.

tion of the hot ashes, keeping firemen busy for nine hours, the Department of Energy's huge oil storage facility here was
The oil is being stored in caverns scoured out inside underground salt domes along the Gulf Coast. It would be a six to nine month emergency supply in case of another Arab oil boycott.

"I have requested an outside investigation of the cause of the firc," Breaux said. "I have
Department of Energy

that such an investigation

will be conducted with a) final report by tho end of October."

The surprise fire erupted on Sept. 21 while a workover drilling c rew was repairing the casing of a well extending down 3,042 feet into the top of storage cavern No. 6.

Seven million barrels of crude were in the cavern. It also contained pressure of about 650 pounds per square inch. The pressure blew past a shutoff valve in the well shaft, oil sprayed up and into the air, and before it ended an estimated 70,000 barrels was lost. A barre] is 42 gallons. 


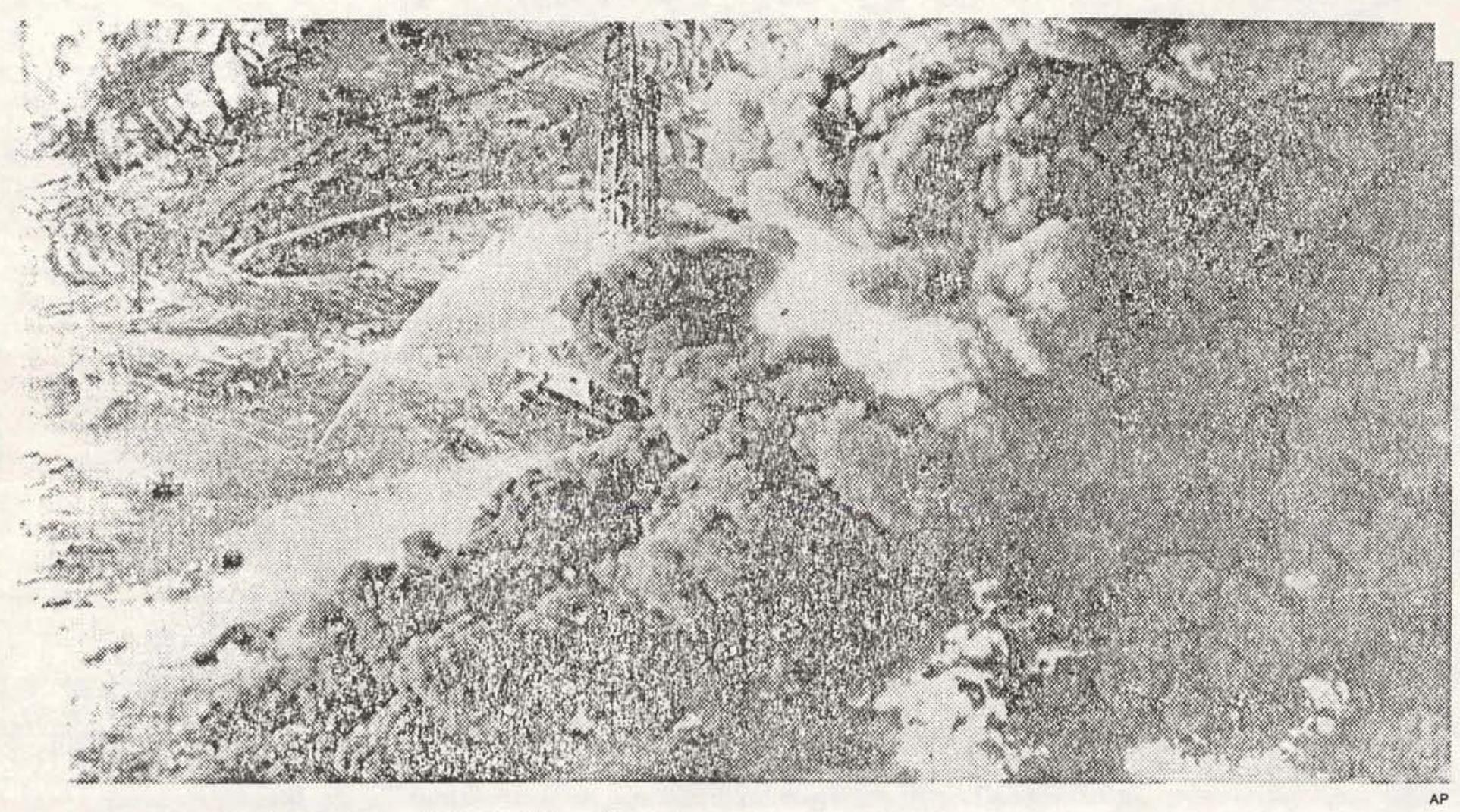

Flames, smoke rise from giant oil fire in West Hackberry, La.

\section{Coastal oil fire}

\section{fatal, expensive}

\section{but no setback}

HACKBERRY, La. (AP) - A towering pillar of flames billowed over an alligator-infested swamp of palmetto and sawgrass today following an explosion that left one man dead and another seriously injured at the showcase storage site of the nation's strategic petroleum reserves.

The fire, visible 25 miles away, is expected to burn for at least two days. It is fed from an underground cavern - 10 stories high and as big as a city block - that holds 7 million barrels of crude oil being stored as a hedge against foreign oil em. bargos.

The Hackberry site is part of an $\$ 8$ million fed. eral program that has 43 million barrels of imported crude stored in caverns deep inside some 130 Gulf Coast salt domes. Other storage sites are in Bryan Mound, Texas, near Freeport, Bayou Choc- taw, La., and Weeks Island, La.

Before is is over, the Strategic Petroleum Reserve of the Department of Energy hopes to have an oil bank of up to one billion barrels of Arabian crude stashed away for emergency use such as another Arab oil embargo.

The spectacular fire at Hackberry was an expensive complication - but not regarded as a serious setback in this unusual project born of world politics.

The fire roared up a six-inch drill pipe during routine maintenance late Thursday and caught about 20 men on a steel drilling rig, of ficials said. Two men were burned while four dived to safety in a mudbank and the others clambered down a staircase just ahead of the flames. The heat melted the drilling rig.

"We don't know what happened," said Bill Parker, deputy project manager.

But workmen said the fire was touched off by a spark that was struck while they were pulling a drilling bit up the pipe.

Earthen dikes were hastily pushed up to contain the flames in a 200 -square-foot puddle. 


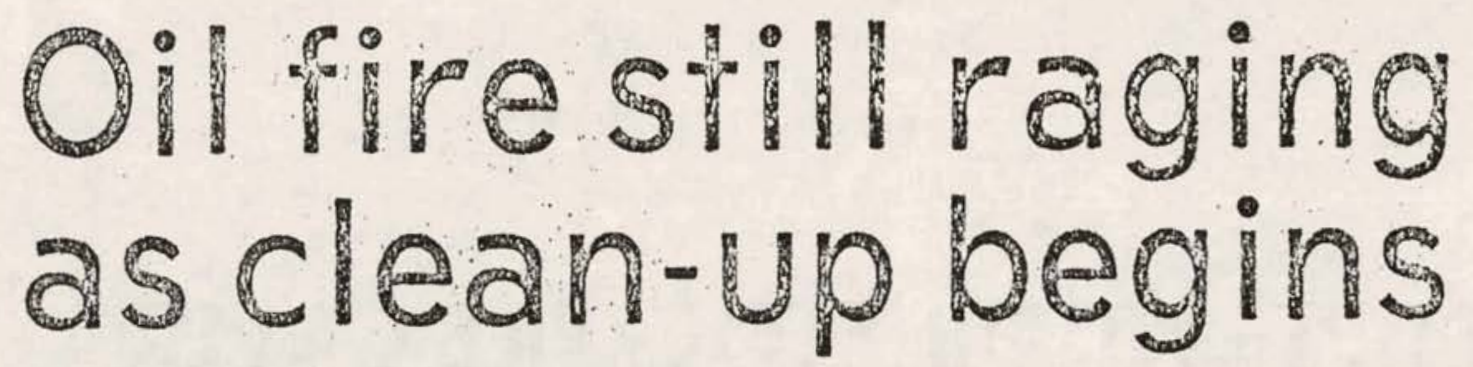

By ANN MURCHISON American Press Staff Writer HACKBERRY - An oil well fire-fighting team - using large Caterpillars and other equipment - began Saturday moving debris away from the site of a raging fire at the Department of Energy's Strategic Petroleum Reserve site here.

Charred cargo, equipment, a 175 -foot drilling rig and trucks were pulled from the site. Removing the red-hot metal reduces the possibility of reIgniting the fire and clears the way for the fire fighters to move in equipment to fight the inferno.

Gene Campbell, spokesman for the Department of Energy's regional office in Dallas, said there is no time schedule on when the fire fighters will attempt to snuff out the fire. However, once the method of capping the well is deter. mined, it is expected to take from two toflve days.

The smoke and heat from the blaze: have retarded attempts to actually start cleaning up the area.

The explosion that set off the fire occurred. Thursday afternoon as workmen on a drilling ilg were changing a wellhead casing during a workover. One man died and another was seriously injured.

Flames were still shooting about 50 feet above the wellhead Saturday and billowing black smoke rose high above the site. Oil, which originally gushed nearly 30 feet above the hole, has been reduced to a flat flow out of the site.

The wind at the fire scene is brisk and gusty. However, Campbell said, It has assisted In restricting the oil to an area about 800 yards along the shoreline and 150 yards onto the water in a crescent shaped area.

Some 200 crewmen. fighting the fire with the ald of local Coast Guard is on hand to alr? communities and volunteer and support the containment fire fighters, appear un of the crude. daunted by the heat and, In an effort to restrict enviflames. ronmental impact; a seriès of

A spokesman at the site sald dikes has been constructed to reports indicate firemen en- contain oil flowing from the gaged by "Boots \& Contș". are cavern. , $\overrightarrow{1}$ being pald approximately $\$ 100^{\prime}$. Campbell sald construxejon per hour. work is continuing on 'btjer

"Boots \& Coots, Inc." is an profects at the sight. Horriver. vil well fire fighting team out DOF has halted all movepien: of Houston. of oil into other caverns.

Sccurity has been tight, with iccording to Campbell, oil guards posted at strategic fill to other caverns will be points within the facility. In resumed after ste saicty inthe past, the news media had spections have been combeen herded into a small cor- pleted.

ner at the facility walting in The explosion prompted a the sun for as long as six hours trip to the site by (jen. Ioe for reports on the fire. Delucal of Wastington. I) ('.

Campbell sald things should director of the oil storater into: change "now that the crunch gram. Deluca toured the preaIs off and things have settled Friday with Gov. Edwiin-Eitdown. It was just a matter of wards. timing."

Other DOE officials from

Some oil from the cavern New Urleans and Dallas have leaked into Black Lake from remained at the site since lat. the dike at water's edge. The. Thursday night. 


\section{FIRE ERUPTS AT OIL STOCKPILE CAVERN}

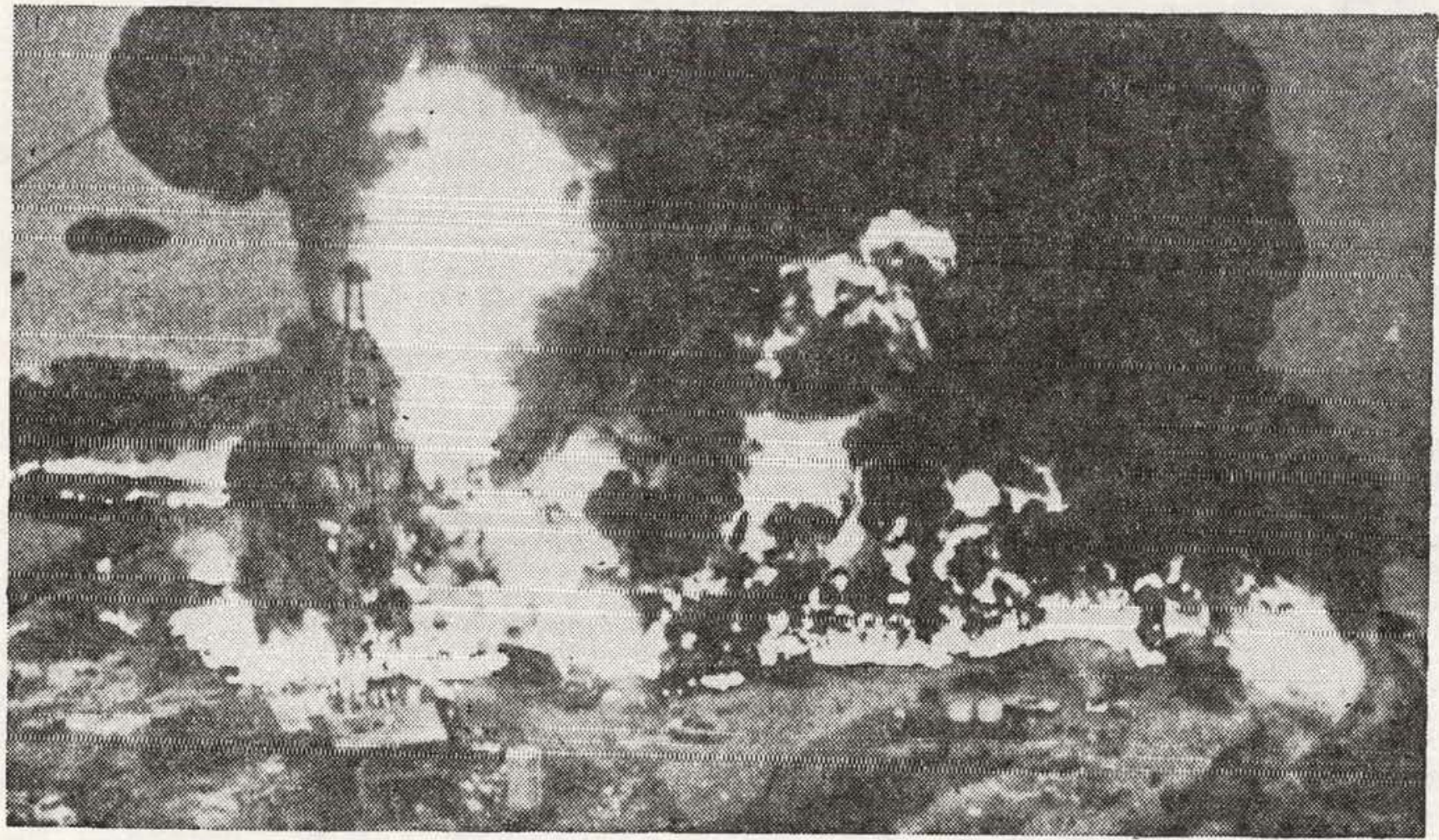

A 300-foot pillar of flame spews from burning ofl in an underground storage cavern at Hackberry, La., yesterday. Although the oil still burned fiercely three hours after it started, the fire was declared under control. One man was fatally burned and another hospitalized. Twenty men were working on the drilling rig when the fire erupted. They were sinking a hole into a "bottle" about 10 stories high, a block long and a block wide, containing seven million barrels of foreign oll. It is the showcase of four projects to store oil as a hedge against another embargo. The Hackberry area capacity has been set at 234 million barrels. 


\section{Oil dome fire} damage less than thought

HACKBERRY, La. (AP) - A six-day fire did surprisingly little damage to the $\$ 20$ billion project to bank a billion barrels of crude oil in huge underground caverns, an official said Wednesday.

Deputy Director Bill Parker said a preliminary survey made while the fire-blackened area over cavern No. was still cooling determined that only about 7,000 barrels of oil went up in smoke.

Officials had estimated 50,000 to 70,00042 -gallon barrels of cride would be lost.

Parker said 50,000 barrels probably spewed out of the $9 \% / 8$ inch wide, 3,042 feet deep well shaft before it was plugged Tuesday - but it turned out that much of it was being recovered.

He said most of the spewing crude oil apparently flowed into adjacent Black Lake, where hastily thrown up booms helped keep it corralled along 1,000 yards of shoreline.

"We have recovered about 28,000 barrels of crude from the lake, with suction pumps and other equipment, and it is loaded on barges, ready to be

\section{Oil dome fire damage said surprisingly small}

put back in the ground," Parker said.

Parker said the new assessment of the fire, the first disaster to hit the project, proved underground storage i safe, because had the oil been in tanks above ground it could have been a holocaust.

In this instance, he said, though 7 million barrels of oil were in the storage cavern, only oil spewing out at the surface was involved.

In Washington, Rep. John Breaux, D-La., said he had asked the Department of Energy to reassess its storage project to see $w$ ether it has serious basic flaws.

"I have requested an outside investigation of the fire," Breaux said. "I have been assured by the Department of Energy that such an investigation will be conducted with a final report by the end of October.'

The imported crude, most of it shipped from the Persian Gulf, is being stored in caverns scoured out inside salt dome formations along the Gulf Coast.

Project officials estimate the emergency reserve could offset the pinch of an Arab oil boycott for six to nine months.

There are six caverns here at Hackberry, the showcase facility of the project, w ich has four other major storage sites in Louisiana or Texas.

All losses will be covered by insurance, Parker said, including those of the Pelican Drilling Co. of Lafayette, La., which was doing a workover job on the well when it blew out last Thursday.

Pressure within the cavern, where 7 million barrels of oil were stored, blew oil up the shaft, past a shutoff valve which was supposed to prevent such accidents.

Parker said Coast Guard Rear Admiral Paul Yost from New Orleans checked out the cleanup of Black Lake 
BEAUMONT ENTERPRISE

Thursday, September 28, 1978

\section{Dome fire site cools}

HACKBERRY, La. slowly getting back to (AP) - A fire-blackened normal.

area where $\$ 1$ million In Washington, Rep. worth of imported crude John Breaux, D-La., said oil went up in smoke cool- he had asked the Departed down Wednesday and ment of Energy to a scum of spilled crude reassess its $\$ 20$ billion was skimmed off a near- project to store a billion by lake.

Despite a secondary fire that erupted in a section of the hot ashes, keeping firemen busy for nine hours, the Department of Energy's huge oil storage facility here was barrels of oil to see whether it has serious basic flaws.

The oil is being stored in caverns scoured out inside underground salt domes along the Gulf Coast. It would be a six to nine month emergency supply in case of anothe Arab oil boycott.

"I have requested an outside investigation of the cause of the fire," Breaux said. "I have been assured by the Department of Energy that such an investigation will be conducted with a final report by the end of October."

The surprise fire erupted on Sept. 21 while a workover drilling c rew was repairing the casing of a well extending down 3,042 feet into the top of storage cavern No. 6 .

Seven million barrels of crude were in the cavern. It also contained pressure of about 650 pounds per square inch. The pressure blew past a shutoff valve in the well shaft, oil sprayed up and into the air, and before it ended an estimated 70,000 barrels was lost. A barrel is 42 gallons. 
BEAUMONT ENTERPRISE

Friday, September 29, 1978

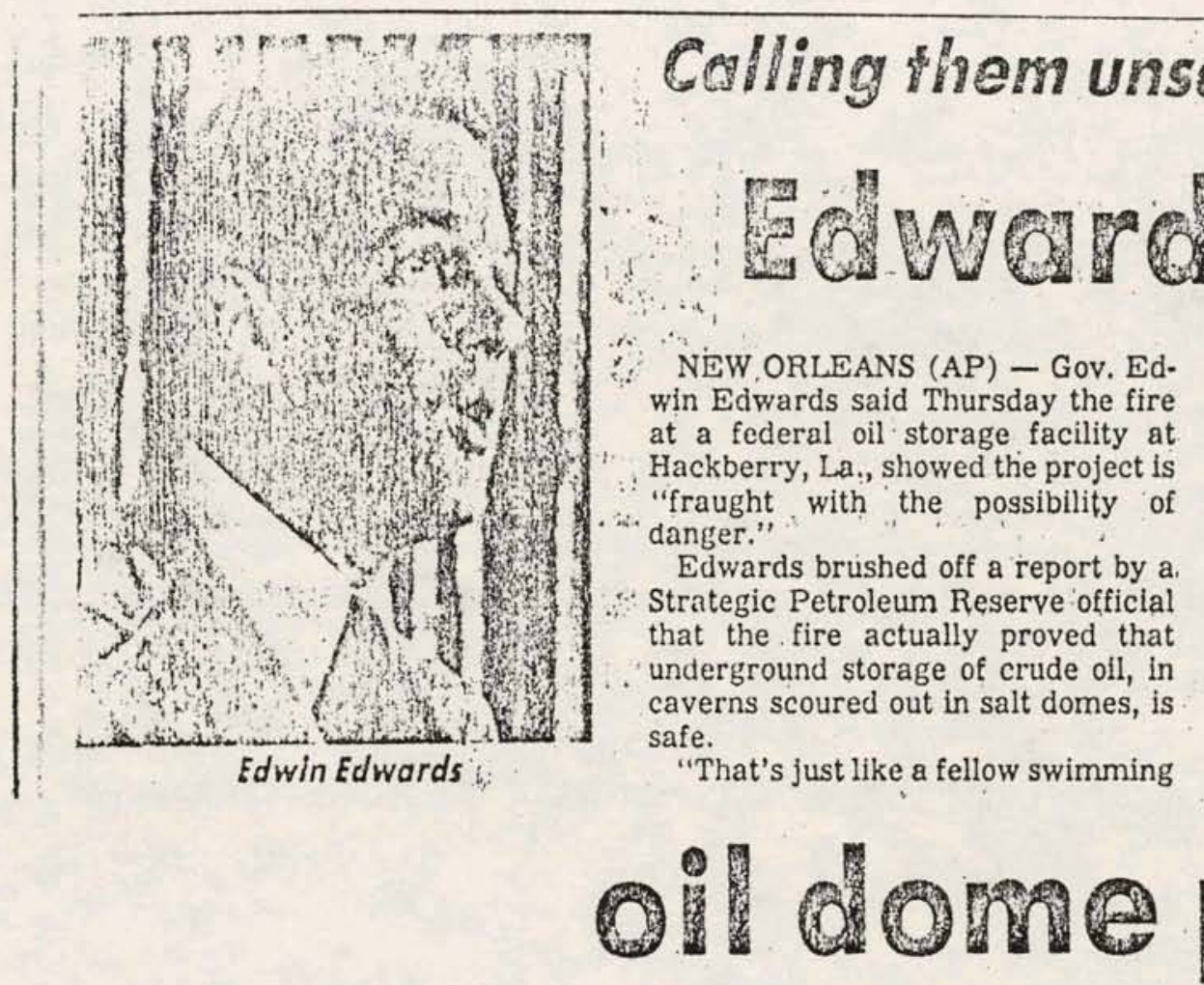

barrels of imported oil, said the fire actually did amazingly little damage.

The worst part of it, he said, was it killed one driller and left another badly burned.

Parker said cleanup crews recovered over 28,000 barrels of the crude oil that spewed up from a well shaft connecting to the storage cavern, over 3,000 feet below the ground.

Originally, Parker and other officials had estimated that 50,000 to to shore from boat that just sank telling a friend he'd like to sell him a boat that's 'safe to use in the water," Edwards said.

"We told the federal government when they started the program that putting oil underground under high pressure .... in an untried situation was fraught with the possiblity of danger," he added.

However, Bill Parker, deputy director of the $\$ 20$ billion Department of Energy project to store up a billion

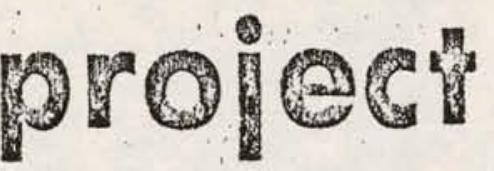

70,000 barrels of oil - $\$ 1$ million worth - would go up in black, greasy smoke in the fire that raged atop storage cavern No. 6 for nearly six days.

Instead, he said, about 50,000 barrels came up the pipe, as predicted, but much of it flowed into adjacent Black Lake, where it was corralled against 1,000 yards of shoreline by a system of floating booms.

Only about 7,080 barrels of oil actually burned, Parker sald. 


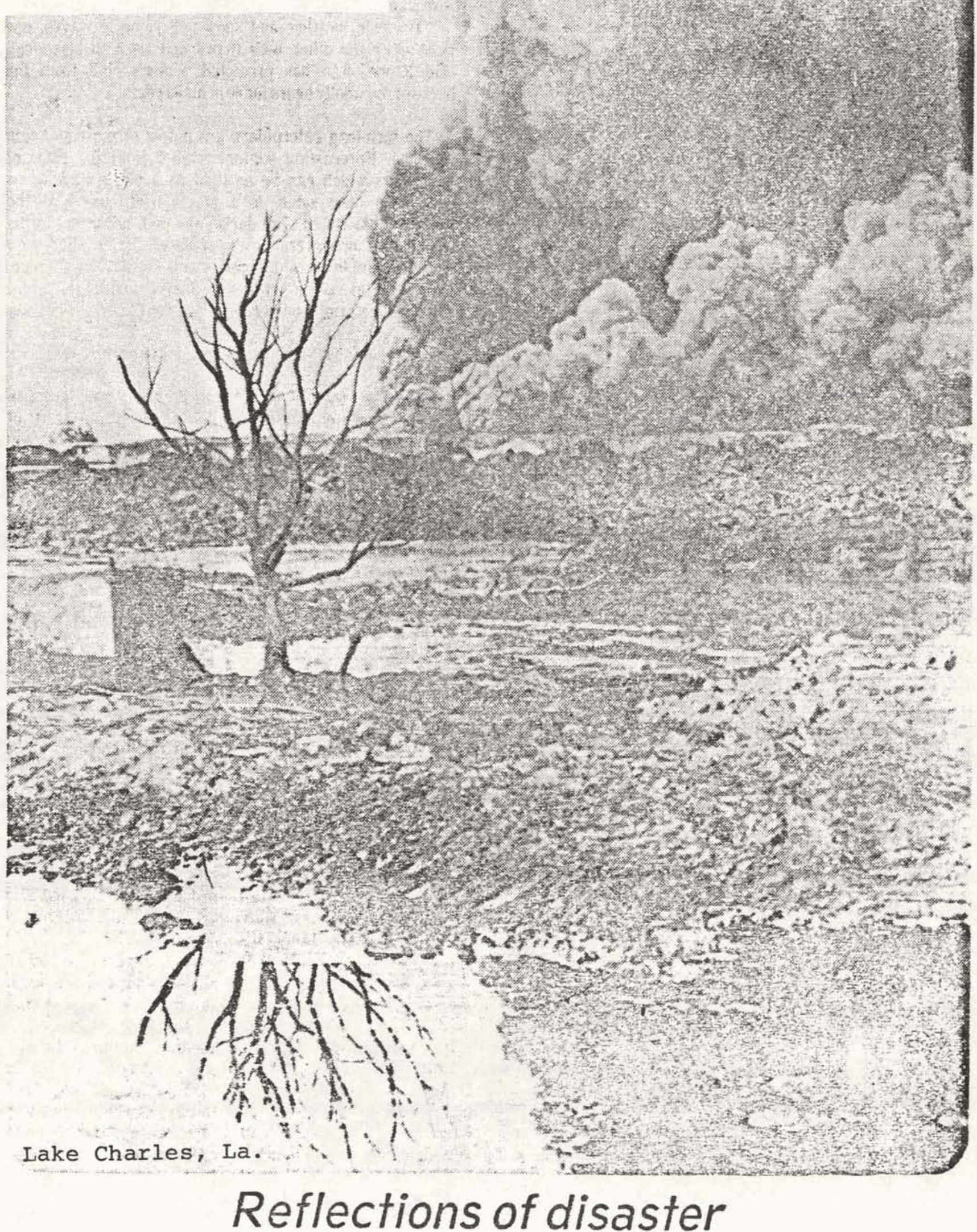

Little that was living within the levees of the Hackberry Strategic Petroleum Reserve (SPR) site remained alive after the fire at the crude oil storage dome fire was extinguished. The stark lifelessness of what was formerly a small tree is reflected in a pool of oil while in the background black smoke from the fire is belched skyward. The area was blackened with smoke, flame and oil. (American Press Photo by Don Ellzey) 


\title{
LAKE CHARLES AMERICAN PRESS
}

\author{
September 28, 1978
}

\section{SALTDOMEOIL FIRE

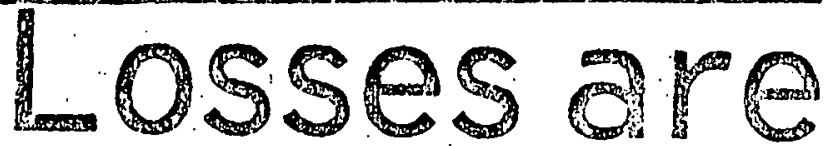

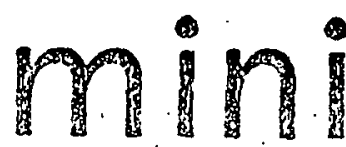

HACKBERRY, La.: (AP) A new assessment of the slxday fire fed by oil stored in an underground salt dome proves that the storage plan is safe and caused surprisingly little damage; says an official of the project.

Deputy Director Bill Parker sald Wednesday a prellminary survey made while the fireblackened area over cavern No. 6 was still cooling determined that only about 7,000 barrels of the 7 millionibarrels of oll in the vault went up in smoke.

If the oll had been In tanks above ground, he sald, it could have been a holocaust. In this' Instance, only oll spewing out at the surface was involved. Olficlals had estimated earllér that 50,000 to 70,000 t barrels of crude would be lost:! There as 42 gallons to a! barrel.
- Parker sald 50,000 barrels probably spewed out of the $95 / 3$-Inch wide, 3,012 -feet deep well shaft before it was plugged Tuesday:- but it turned out that much of it: was being recovered.: : : ${ }^{\prime} \quad: \quad \because \because \quad: \quad:$ i He said most of the spewing. Rear Admiral Paul Yost from crude oll apparently flowed : New Orleans checked out the Into adjacent : Black Lake, cleanup of Black -Lake and where booms "helped keep it : pronounced it "the : most corralled along 1,000 yards of professional, $:$ fastest, cleanest shoreline: "We have recovered about : "He said we could quote him on that," said Parker.

$\therefore$ Officials of $:$ the $: \$ 20$ : billion project estimate the emergency reserve could offset the pinch of an Arab. oil boventt

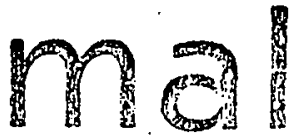

for six to nine months.

There are six caverns at : Hackberry, the showcase facility of the project, which has four other major storage silcs in Louisiana or Texas. 


\section{BEAUMONT SUNDAY INTERNATIONAL JOURNAL \\ September 24,1978}

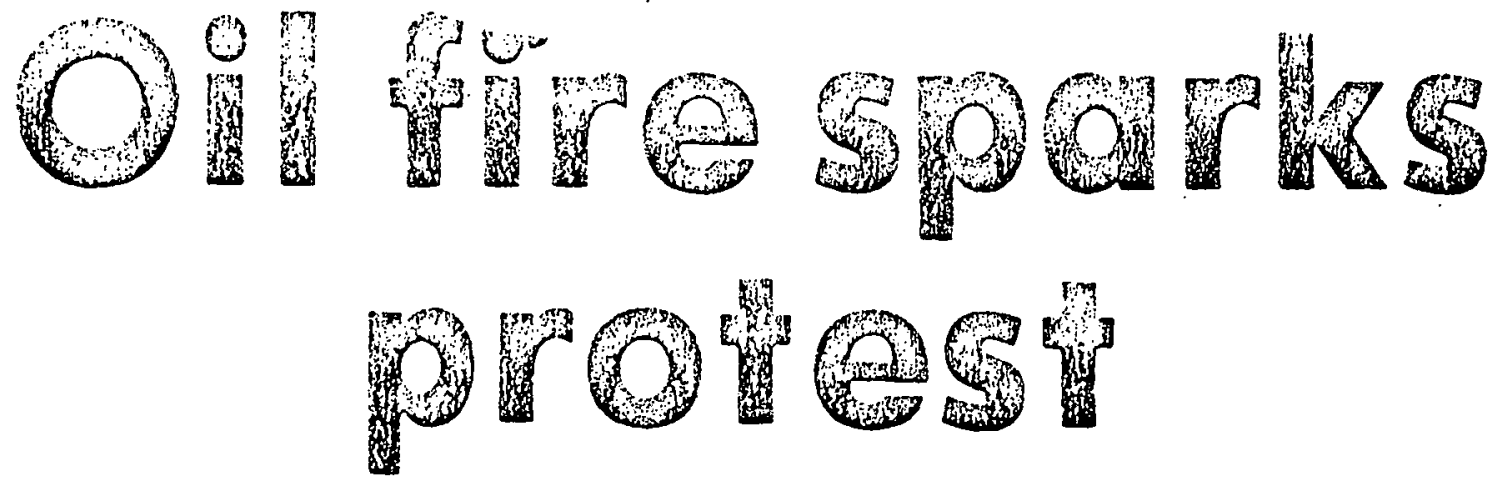

HACKBERRY, La. (AP) - The ex. plosion and fire - now in its fourth day - at the government's showcase oil storage facility has fueled cries of "we told you so" from area residents and Louisiana's governor.

"What happpcried, really shouldn't have," said James Lowery, 30, of Hackberry. "They are going to fast trying to meet a timetable - and they don't know what's happening. But that's federal bureacracy."

Stubborn pressure inside a huge underground vault kept oil flowing up a well shaft Salurday. It spills out of the shaft to feed into a lake of fire, contained by an earthern dike.

$\Lambda$ Department. Of - Energy spokesman said. it would be "'wo to five days" before.pressure in the storage vault equalizes, the flow stops and the fire is put out.

'The vault, a cavern. leached out deep inside a great salt dome, has a capacity of 13 million barrels. It was about half full. Between 50,000 and 70,000 barrels of the oil are expected to go up in smoke.

Damage will be in the millions. The crude cost the government about $\$ 14$ a barrel. The area around the cavern will have to be reworked and two rigs on the site are a loss.

The blowout that set off the fire came Thursday afternoon as workmen on a drilling rig were chang: ing casing during a routine workover abuve cavern No. 6. One man was killed and another seriously burned.

"The firefighters are doing general cleanup work in the area now," said Gene Campbell of the Department of Energy. "They've got to clean and cool things so they can go. in and decide how to put it out."
Some residents of the sparsely populated marshlands around the West Hackberry Crude Oil Storage Site said the accident was no surprise.

"We've been hearing that their safety procedures weren't too good," said John L. Callahan of Sulphur, a veteran oil field worker. "I guess they just don't have the know-how for what they're doing."

But federal officials and workers at the site deny safety procedures were lax.

"You read about these things once a week in the paper in oil fields," said George LaBoe, a mechanical inspector who was about a quarter of a mile away from the explosion. "It happened in 30 or 40 seconds."

Bill Parker, deputy projeçt manager for the Strategic Pretroleum Reserve Program, said the accident actual proves the giant salt caverns are safe for storing oil.

"If this would have happened at an above-ground facility, the lost would have been devastating," he said. "If there were tanks, a number of them would have gone up."

There are five caverns at West Hackberry. Only one other was in use, and it didn't catch fire.

The government is trying to store 1 billion barrels of crude by 1985 as a hedge against another Arab oil embargo. The reserve could supply for the country for six to eight months.

About 80 percent of the crude would be pumped into storage caverns scoured out in underground salt domes along the Gulf Coast in Louisiana and Texas. About 43 million barrels has been stored at four sites.

The $\$ 8$ billion federal project has never been popular in Louisiana.

"It's kind of like a shotgun wedding for Hackberry," said. Kenneth Ducote, a local police juror. "We just trying to make the best of it."

The governor, state officials, environmentalists and landowners fought the project. 
THE AUSTIN CITIZEN

September 22,1978

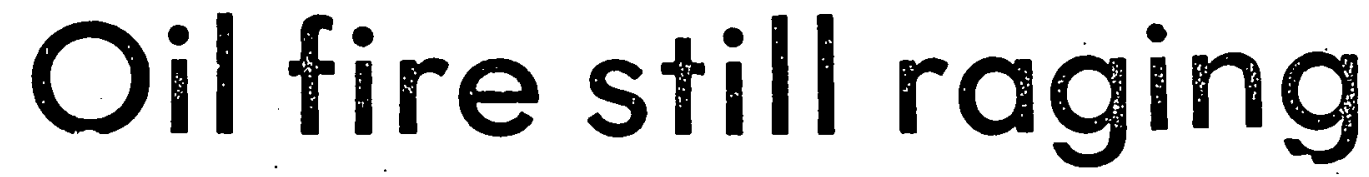

HACKBERRY, La. (UPI) Firefighting : crews early today sprayed the area around a raging fire in hopes of preventing another explosion at the federal government's 7 million barrel crude oil reserve cavern.

One man was killed and another critically..burned Thursday when an explosion of unknown origin rocked the reserve during loading operations. William Parker, a deputy director of the federal project, said crews would try to contain the blaze until daybreak.

"We will probably burn off about 25,000 to 30,000 barrels of oil until the pressure neutralizes," Parker said. "We have to get the fire out first."

The spectacular fire, which began Thursday about 4:20 p.m., loading oerations, shot vicious 300 -foot flames into the air, clearly visible from 30 miles away.

"It's a spectacular sight - just tremendous," said state police Sgt. John Prescott who lives in 20 miles away from the fire in Cameron Parish of extreme southwestern Louisiana. "If that dome were to go, they would have to move some people."

About 10 to 15 isolated farming families were placed on alert by police. but federal oil experts said the blaze was not likely to touch off the 7 million barrels of crude housed in the undergrnund cavern.

Baton Rouge General Hospital officials : said late Thursday that Clarence Simon, 38, of Abbeville, La., died at 8:40 p.m. shortly after he and Bradley Bergeron of New Iberia, La., were airlifted from Lake Charles Memorial Hospital. Bergeron was listed in critical condition.

State police said the first salvaging moves were to come today when heavy-duty bulldr\%: : atlompted to disengage a rig from the cavern area and move it to safety. 

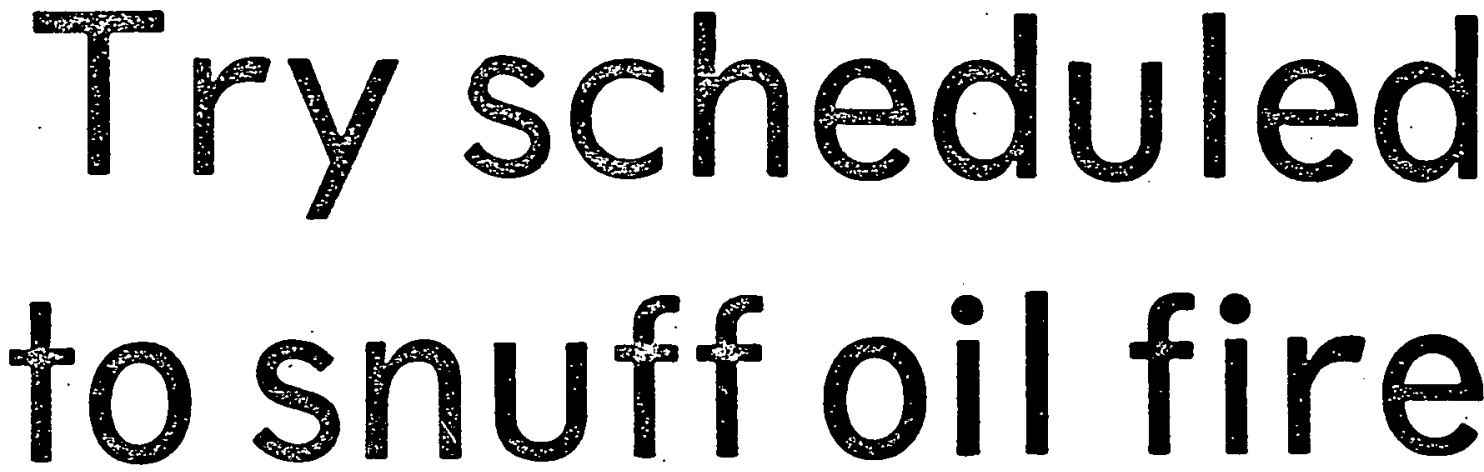

\section{By DON ELLZEY \\ American Press Staff Writer (Another story, Page 18)}

HACKBERRY - Weary firemen and oilfield blowout specialists were scheduled to make a second attempt today, Sept. 26, to extingish a blaze at the Hackberry salt dome oil storage site.

An attempt Sunday to force salt water down the well to stifle the blaze failed.

During today's attempt firemen will apply foam in the area around the burning well.

Oilfield blowout specialists Asgar "Boots" " Hansen" and Edgar "Coots" Matthews will then attempt to insert an expansion plug into the 95.8 inch well shaft. The plug should expand, halting the flow of oil and gas to the surface.

About 100 yards west and northwest of the dome fire crewmen are busy attempting to remove an estimated 30,000 barrels of crude oil that spilled into adjacent Black Lake. A U.S. Department of Energy (DOE) spokesman said MIonday afternoon that workmen expect to have most of the spillage removed by late today or Wednesday:-

By Monday afternoon the fire was burning at only about one-third the intensity of the past couple days. A firefighter said the blaze has now been contained to an area of about 20 yarós by 50 yards.

The intensity decreased because the pressure in the cavern where the oil is stored has dropped to almost zero, said Jim Friloux. DOE representative to the State of Louisiana. A small amount of oil is barely pouring over the rim of the well. The pressure needed to force this small amount of oil to the surface probably stems from a contraction of the cavem caused by the intense heat. Friloux said.
Pressure in the cavern when the well exploded was 650 pounds per square inch. The well shaft extends down 3,042 feet to the cavern.

Gene Campbell, Public Information Officer (PIO) out of the DOE's Dallas, Texas, office, said if attempts to extinguish the blaze today are successful, a cleanup opera- tion tion will get underway im. mediately.

Campbell said today that the contained about 7 million barplug was built especially for rels at the time of the explothe Hackberry well. He said 'sion.

the 7 inch plug will be inserted into the shaft and expanded in order to cut off the flow of oil to the surface.

The plug will be tested this morning, he said.

Campbell said a six member DOE investigative team ar. rived Sunday to begin a probe into the cause of the blowout and fire. The team will be at the site for two to three veeks. Campbell said.

An investigative team with the National Oceanic and Atmospheric Administration (NOA4) is also expected at the site today or Wednesday. The team will evaluate any eriironmental damage caused by the explosion. NOAA is under the U.S. Department of Commerce.

A spokesman said Monday the explosion was apparently caused by malfunctions of an expansion plug and an antiblowout device.

Cavern No. 6 is one of six salt domes at Hackberry that will be used by the DOE to store at least one billion barrels of oil as a bedge against another Arab oil embargo. The well at Cavern No. 6 was being worked over (put .. back into operation) when it exploded at about $4.45 \mathrm{p}$. . Thursday. One man died of injuriès received in the blast and another was hospitalized in serious "condition

The cavern, with a capacity of 13 million barrels of oil.

(n)

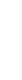




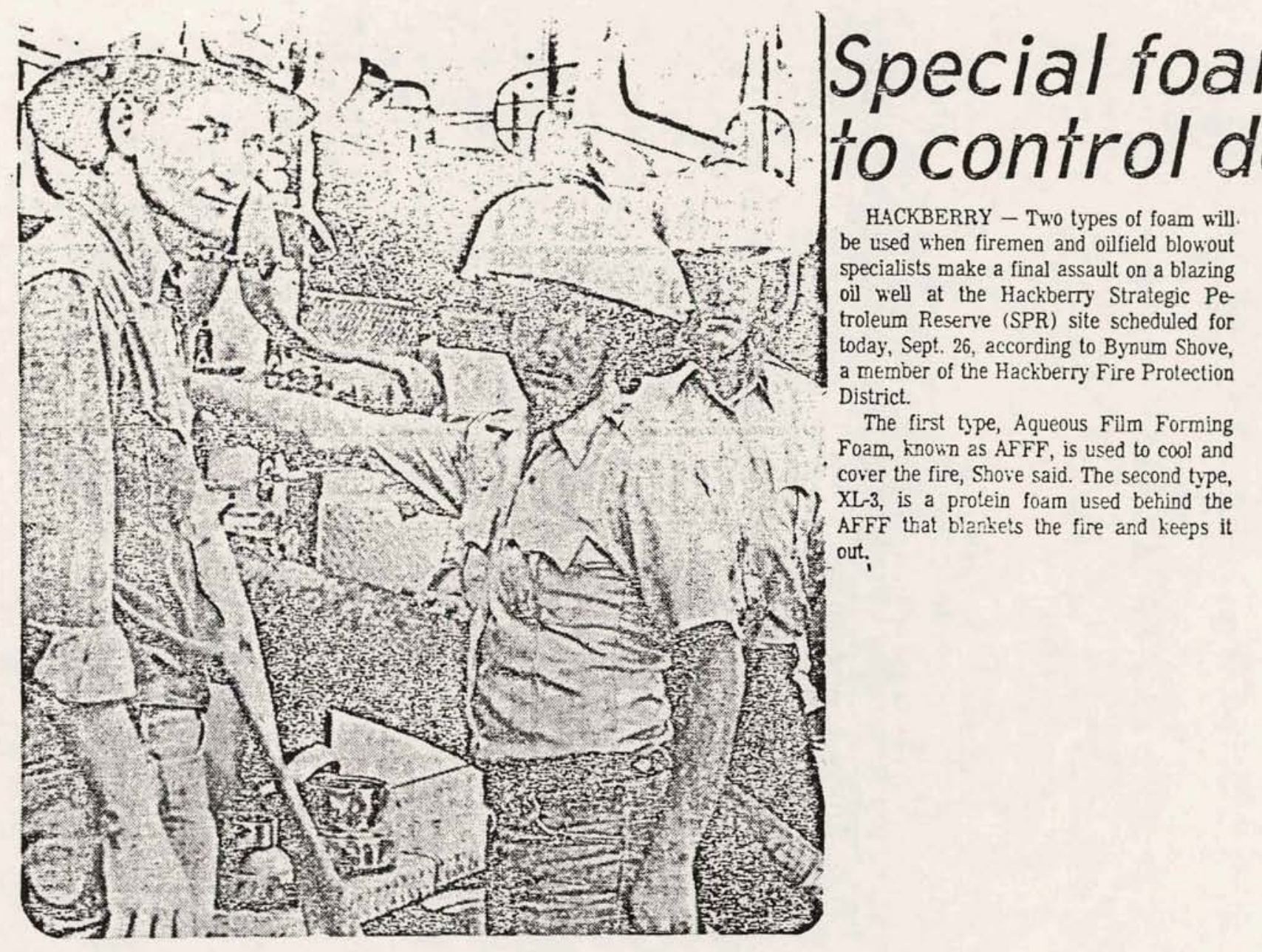

\section{Weary firemen}

These members of the Sulphur Fire Department have been at the scene of the Hackberry salt dome oil fire periodically since the well exploded Thursday afternoon. Firemen from 'Calcalsieu and Cameron pa- rishes who responded to the emergency supply men and equipment to contain the blaze. From front to back are Dennis Vice, Paul Patin and Frank Spicer. (American Press Photo)
An estimated 15-20 firemen will apply the foam using hoses, he said. Oilfield blowout specialists will then move in and attempt to plug the well.

Five trucks were unloading foam Monday afternoon, Shove said. Foam supplies at Beaumont, Texas, Baton Rouge and Lafayette have been exhausted. It is now being brought in from New Orleans and Houston, Texas.

"I'd estimate that $\$ 300000$ worth of foam has already been used," he said. "That's probably about 40,000 gallons." 


\section{Dome well shaft plugged;}

fire out

HACKBERRY, La. (AP) - A well shaft that had fed up to 70,000 barrels of crude oil from a huge underground storage vault into a lake of fire was plugged Tueeday.

It ended the fiery emergency at cavern No. 6 of the Department of Energy's $\$ 20$ billion Strategic Petroleum Reserve project to store up a billion barrels of oil as emergency supply.

A federal inquiry to determine what went wrong is expected to last another two or three weeks.

Boots and Coots Inc., a firm of troubleshooters who normally deal with wild oil wells, found this problem unique.

It wasn't a wild well, to be strangled with heavy mud or killed with precise explosions. It was a "tame" well draining off crude from a huge storage cavern, bigger than a 10-story building, scoured out deep inside a salt dome. The usual methods, especially explosives, were out of the question.

They solved the problem with a special rubber balloon, 7 feet long and 7 inches in diameter.

Working in a protective spray of foam and water, they used a long boom operated from a tractor to lower the empty balloon 10 feet down into the $9 \% / 8$ inch wide well shaft. Then it was inflated to 2,000 pounds of pressure, swelling against the steel casing, sealing off the shaft like a cork in a bottle of champagne.

When the fuel stopped flowing, firefighters with foam and water extinguished the flames in the 250 by 250 feet area, rimmed by earthern dikes, where the oil burned.

Cavern No. 6 held 6 million barrels of crude shipped in from the Persian Gulf when the fire started. The storage vault is one of a series created to hold a billion barrels of oil that will be kept as emergency supply in case of another Arab oil boycott.

Federal officials estimate the emergency supply would offset a ne boycott for six to nine months. 


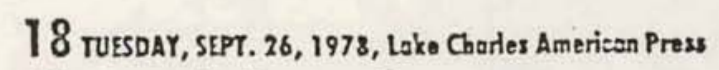

Salt dome fire is acid

\section{test for firemen}

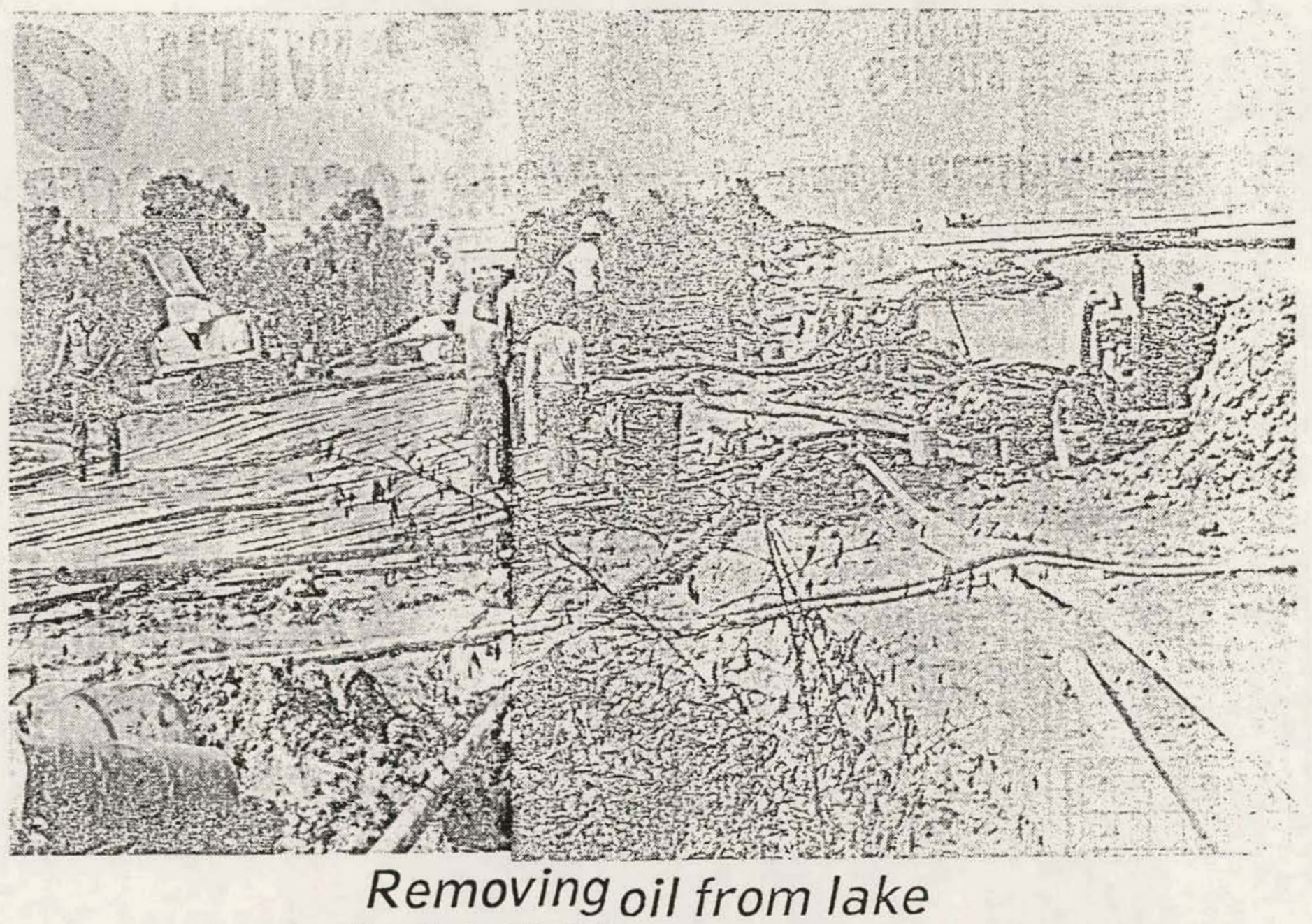

Attention has turned from the fire at the Hackberry salt dome oil storage site to the removing the estimated 30,000 barrels of oil that spilled into adjacent Black Lake. Cleanup crews anl machinery were working Monday afternoon to remove the

spillage. The oil on the lake has been contained with booms. An official at the site estimated the major portion of the operation should be completed by late today or Wednesday. (American Press Photo) 


\section{"Salt dome \\ By DON ELLZEY}

American Press Staff Firiter

HACKBERRY - A constant breeze. blows off Black Lake across the Hackberry Strategic Petroleum Reserve (SPR) site, filling the air with powdery, almost imperceptible dust.

At the north end of the site on the shore of the lake a fire has raged atop a salt dome half full of crude oil since Thursday afternoon-the result of a well blowout. It is here that 70 or more firemen from Calcasieu and Cameron parishes have virtually called home for nearly five days.

When the call went out for help Thursday afternoon they responded, coming from Hackberry, Sulphur, Carlyss, Cameron, Moss Bluff, West Lake and Lake Charies. They brought what they could-a pumper, foam, a couple tankers and most importantly, a spirit and willingness to see a job through under trying circumstances.

A few of the firefightersvolunteer and paid, men and women-have been at the oil dome fire for 72 consecutive hours. Others have rotated shifts around work and other activities.

"We got there at about 5 p.m. Thursday with a 1,500 gallon per minute pumper and have been there ever since," said C.D. Miller, chief of the Sulphur Fire Department.

"Certainly, it's rough on the firemen," Miller said. "It's fatiguing, hard work, and the hours are long."

At night firemen are on a constant vigil so that the fire does not spread or that the oil does not break through the levees into the lake. During the day, they are kept busy applying foam, checking equipment and always planning the next move toward extingishing the blaze.

A perpetual geyser of water is aimed at a rig near the blazing well, keeping it $\mathrm{coll}$ in order to prevent another explosion and fire.
Away from the heat of the fire the firemen must contend with the heat of the sun. There is no shade, except that provided by the trucks. Depending on the wind direction, the billowing pall of oil soaked black smoke occasionally curtains the area.

Perspiration mixes with oil and soot to blacken clothes and faces. And constantly the firemen are breathing the ever present smoke.

Miller said the Sulphur unit has averaged eight men on the scene around the clock. An average five to six men are on duty at night, and. 10 in the day. The unit's job has been to supply foam lines for the east side of the fire.

"We've also brought in six or seven volunteers," Miller said.

The huge tankers have been humming almost since the fire started.

"It's wearing the equipment some, but these big diesels are designed for hard work," he said. "And they're doing that perfectly."

A more serious concern is the salt, he said. Water from the lake is being used to $\mathrm{cool}$ a rig near the burning well. An estimated 8-10 hours will be needed to clean the pump and tank to remove the salt, Miller said.

"At first about all we were doing was fighting a holding battle," he said. "We were assigned to protect the rig and two additonal wells. We were able to do that."

Bynum Shove, a member of the Hackberry Fire Protection District, said that on a couple occasions the firemen came close: to extinguishing the blaze.

"But they couldn't cap the well so we had to back off," he said.

Shove said Chief Pay Burleigh of the Cameron Fire Department brought in a pumper and fire fighting unit to help man the west side of the containment area. Chief Willard Darbonne and the
Cariyss unit had three to six members plus a pumper at the site at all times.

The Moss Bluff unit sent a truck and crew for one day and West Lake has had personnel at the scene, Shove said.

He said that Mrs. Michael Kuk of the Moss Bluff Fire Department and Mickie Wilson of the West Lake unit, women firefighters, have been at the scene for $72^{\prime}$ consecutive hours. Kuk and Wilson are also emergency medical technicians, Shove said.

"The heat has been extreme," he said. "Firemen's clothes are insulated but the radiant heat would go straight through."

Firefighters who have been at the site for 72,24 and 16 hours eat and sleep on the perimeter, Shove said. The drilling contractors are providing the food.

The Hackberry Fire Department has fought $15-20$ oil fires, he said, although the dome fire is the first well fire.

"But an oil fire is an oil fire," he said. "The rules are the same. You must stop if from its source."

Miller and Sho:e said the units participating at the blaze will be reimbursed by the federal government. Shove said the Hackberry unit, a volunteer department, will determine if it will be necessary to make any manhour charges.

"Some of the men had to miss'work to do this," he said. "But don't let anyone tell you volunteer firefighters aren't great people. Everyone gave it everytring they had.

Louis Mosca, chief of the Lake Charles Fire Department, said the department sent two men and some foam to the Hachberry site.

"That was the extent of our participation," Mosca said.

He said the Lake Charles department was not officially requested to participate. He said some requests were re ceived by area deputies and other fire units. But Mosca said such requests are not considered official.

"One of the questions we always ask is "we'll send the foam but who'll pay for it," he said.

Mosca said the Lake Charles department's not being officially asked to participate may have been a lack of communication.

The 100 gallons of foam pro-

vided by the department-estimated at \$15 per gallon-was not used, he said.

However, Mosca said he could not say if the Lake Charles department would have participated even if requested to do so by officia! sources.

"We would have had to size up the situation," he said. "If a life had been in:olved. I wouldn't question it. But this wasn't that type of situation." 
STAR, September 25, 1978

\section{Effort to Control Oil Fire Fails}

HACKBERRY, La. - Texas oil firefighters are still trying to plug a gushing oil fire at a federal oil stockpile depot on top of a southwest Louisiana salt dome.

They failed in their first try yesterday.

Firefighters Asgar "Boots" Hansen and Eugene "Coots" Matthews had hoped to push back the flow of oil pouring out of the Hackberry salt dome long enough to cap the well.

Hansen explained, "It's like if you put a 30 -foo: pipe into the middle of the Superdome roof an started pouring water in it." 


\section{DODURELLEY \\ American Press Stafl Writer \\ (Another story, Page 18)}

HACKBERRY - Weary firemen and nilfieid blowout specialists were scheduled to make a second attempt today. Sept. 26, to extingish a blaze at the Hackberry salt dome oil storage site.

An attempl Sunday to force salt water down the well to stifle the blaze failed.

During today's attempt firemen will apply foam in the area around the burning well.

Oilfield blowout specialists Asgar "Boots" Ilansen and Edgar "Coots" Matthews will then attempt to insert an expansion plug into the 95 inch well shaft. The plug should expand, halting the flow of oil and gas to the surface.

About 100 yards w'est and northwest of the dome fire crewmen are busy attempting to remove an estimated 30.000 barrels of crude oil that spilled into adjacent Black Lake. $A$ U.S. Department of Energy (DOE) spokesman said Monday afternoion that workmen e pect to have most of the spillage removed by late today or Wednesday.

By Monday afternoon the fire was burning at only about one-third the intensity of the past couple days. A firefighter said the blaze has now been contained to an area of about 20 yards by 50 yards.

The intensity decreased because the pressure in the cavern where the oil is stored has dropped to almost zero, said Jim Friloux, DOE representative to the State of Louisiana. A small amount of oil is barely pouring over the rim of the well. The pressure needed to force this small amount of oil to the surface probably stems from a contraction of the cavern caused by the intense heat, Friloux said.

Pressure in the cavern when the well exploded was $650^{\circ}$ pounds per square inch. The well shait extends down 3,042 feet to the cavern.
Gene Campbell, Public Information Officer (PIO) out of the DOE's Dallas, Texas, office, said if attempts to extinguish the hlaze inday are successful, a cleanup operation will get underway immediately.

Campbell said today that the plug was built especially for the Hackberry well. He said the 7 inch plug will be inserted into the shaft and expanded in order to cut off the flow of oil to the surface.

The plug vill be tested this morning, he said.

Campbell said a six member DOE investigative team arrived Sunday to begin a probe into the cause of the blowout and fire. The team will be at the site for two to three weeks, Campbell said.

An investigative team with the National Oceanic and Atmospheric Administration (NOAA) is also expected at the site today or Wedinesday. The team will evaluate any environmental damage caused by the explosion. NOAA is under the U.S. Department of Commerce.

A spokesman said Monday the explosion was apparently caused by malfunctions of an expansion plug and an antiblowout device.

Cavern No. 6 is one of six salt domes at Hackberry that will be used by the DOE to store at least one billion barrels of oil as a hedge against another Arab oil embargo. The well at Cavern No. 6 was being worked "over" (put back into operation) $k: . .$. it $\therefore p^{3} \ldots \ldots \ldots$ about $4: 45$ p.m. Thursday. One man died of injuries received in the blast and another was hospitalized in serious condjtion.

The cavern, with a capacity of 13 million barrels of oil, contained about 7 million barrels at the time of the explosion. 


\section{APPENDIX XI}

TAM Brochure \& TAMI International Service Record 


\section{THIS PAGE}

\section{WAS INTENTIONALLY LEFT BLANK}




\section{AM NTENNAIONAL \\ Inflatable \\ Packer Systems \\ Marine Tools}

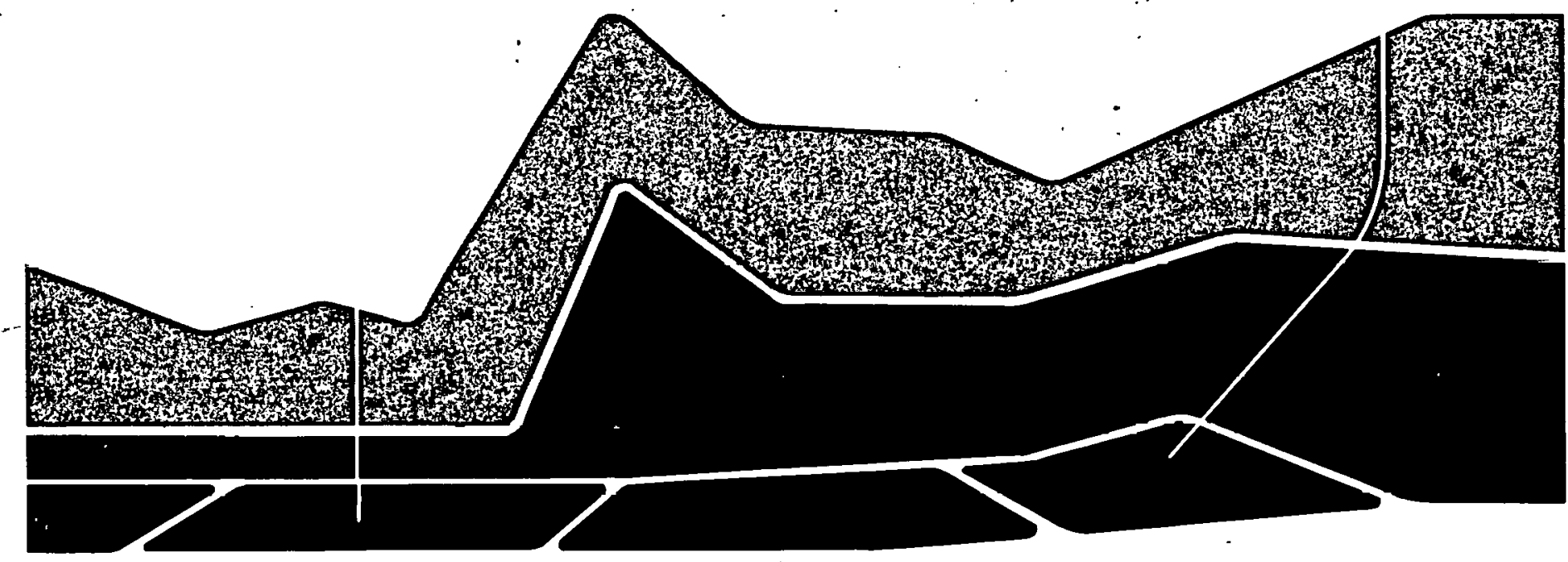

:a:

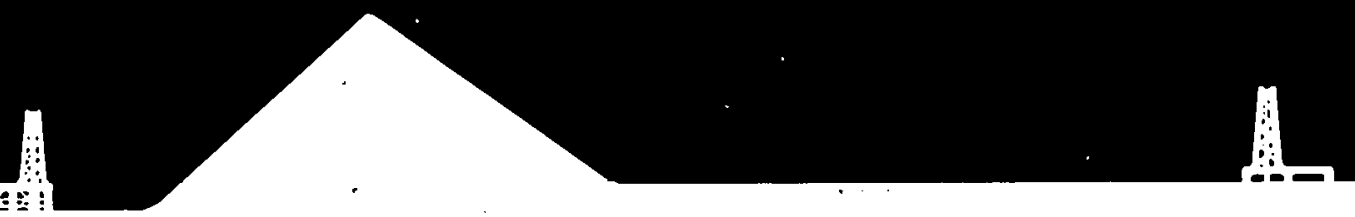

1978-1979 GENERAL CATALOG 


\section{TAM* International}

\section{Setting new standards for inflatable packers}

TAM International builds inflatable packers and accessories for a wide range of downhole applications, in open hole or in casing. All of these packers and accessories incorporate unique design innovations that eliminate operating problems encountered with other inflatable packers.

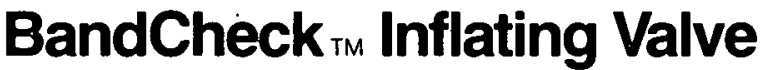

A TAM International exclusive, the BandCheck valve assures proper inflation and setting of all TAM inflatable packers. The BandCheck valve eliminates complex, costly and failure-prone check-valve assemblies without sacrificing performance. The simple BandCheck design provides large, unobstructed fluid ports to eliminate plugging problems and to speed packer inflation and setting. The testproven BandCheck is not susceptible to plugging, even when cement or heavy muds are used as the inflating fluid. Once the packer is set, the BandCheck securely seals the fluid ports against reverse flow, even if the fluid is contaminated.

\section{Simplified, Rugged Construction}

TAM International has engineered new manufacturing techniques that improve the overall structural integrity of TAM inflatable packers. By reducing the number of threaded connections in each packer, these techniques also have greatly simplified, packer construction and field redressing of retrievables.

\section{Tough Pack-Off Elements}

All TAM inflatable packers feature the strongest pack-off elements in the field, for long-life reliability.

Both Cable-Weave and Flex-Wire construction are designed to withstand high differential pressures and other extreme operating conditions. Some TAM inflatables are also available with a Steel-Belted element which offers a reduced packer OD. Inflatable elements are covered with a variety of tough, oil-resistant rubber compounds at TAM International's manufacturing facilities. The type of rubber used is carefully matched to the application in which the packers will be used. 


\section{Inflatable Packer Systems}

TamSet Inflatable/Retrievable Packer
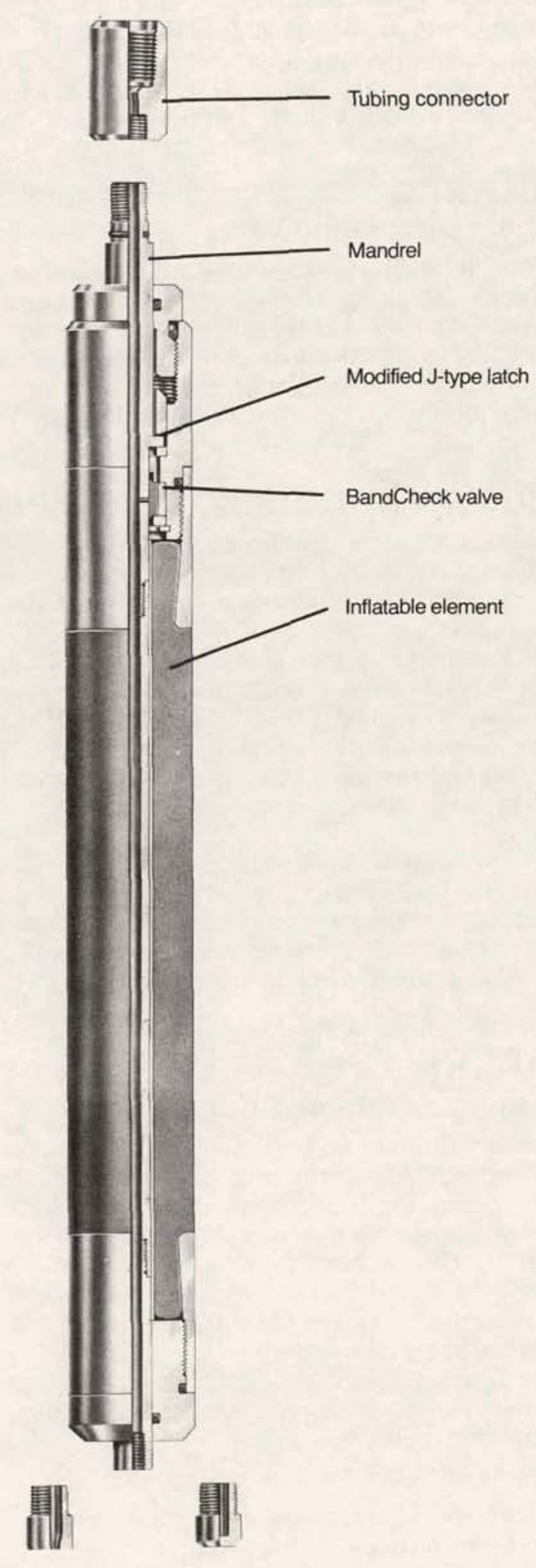

INTERNATIONAI

\section{TamSet $\mathrm{TM}$ \\ The Versatile Inflatable/Retrievable}

The versatile TamSet inflatable/retrievable packer offers swift, sure setting and retrieving for a wide variety of applications. When required, it can be unseated and relocated in the hole without tripping to the surface. The TamSet is the primary element in production systems (and in systems for testing and treating). TamSet packers can also be run in tandem assemblies, straddle-pack assemblies, or as inflatable/retrievable bridge plugs. TamSet packers can be run on tubing, drillpipe or drill collars.

\section{Basic Operation-Running and Setting}

Depending on the type of operation, TamSet inflatable/retrievable packers are run in with either the TamCon collet connector, TamDump circulating valve or tubing connector above the packer. At setting depth, a setting ball is dropped to seat in the mandrel choke and the packer is inflated to about $500 \mathrm{psi}$. After a few minutes to allow the inflatable element to conform to the formation walls, two or three points of slack will indicate whether the packer is firmly seated. Pressure is increased slowly to about 2,000 psi to fully set the packer and shear the setting ball through the choke, opening the mandrel for fluid flow.

\section{Basic Operation-Relocating, Retrieving}

TamSet inflatable/retrievables are easily deflated. A quarter turn to the left (positive stop) releases a modified J-type latch, which allows the mandrel to move upward, raising the mandrel ports above the BandCheck valve. Inflating fluid then flows back into the mandrel and the packer deflates for retrieval or relocation. If the packer is to be reset in the hole, another setting ball is dropped and the setting procedure is repeated.

\section{Retrievable Bridge Plug}

The TamSet is designed for use as a retrievable bridge plug for isolating lost-circulation zones, packing off at oil/water interface and other bridging applications. The standard TamSet packer is used with a bull plug in place of the ball choke. It is run with a TamCon collet connector as described in the Basic Operation section, except that no setting ball is required.

\section{Tandem Packer Assembly for increased seal length}

When formation conditions require extended seal length, two or more TamSet packers can be run in tandem using packer tube extensions and connector subs. The TamSet design allows the packers to be set simultaneously and retrieved in a single, simple operation.

See page 6347 for TamSet specifications. 


\section{TAM \\ nirimanom}
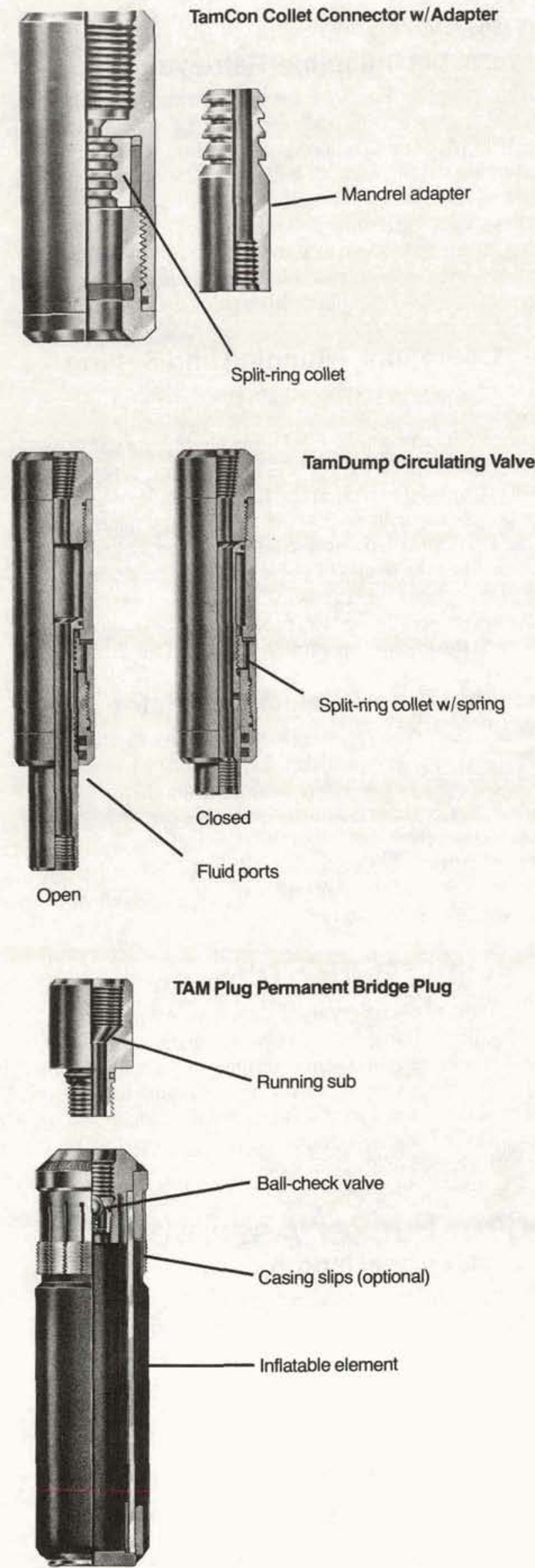

Inflatable Packer Systems

\section{TamCon $_{\mathrm{TM}}$ Collet Connector for running, retrieving TamSet packers}

The TamCon collet connector provides a quick, sure means for running TamSet packers, releasing them after setting, and then reattaching for retrieval. For running, the TamCon is made up on top of the TamSet. When the packer is set, the TamCon is released with five right-hand turns and pulled with the string. Reattaching for retrieval is made simply by the special split-ring design. The TamCon collet is run in on the bottom of the string and latches onto the packer simply by setting straight down.

\section{TamDump Compact Circulating Valve}

The TamDump is the most compact, easy-to-operate downhole circulating valve in the field. It is normally run above TamSet packers to permit fluid circulation above the packer. Large fluid ports allow higher circulation rates and prevent plugging. The TamDump is opened with five or six right-hand turns and is closed simply by slacking off.

\section{TruView $_{\text {тм }}$ Impression Packers}

TruView inflatable impression packers provide a fast and simple method for reproducing actual downhole conditions, such as formation fractures, damaged casing, perforated sections, and split pipe.

TruView impression packers are identical to TamSet retrievable bridge plugs, except that a specially formulated soft-rubber coating covers the OD of the inflatable element. When the TruView packer is inflated in the hole, it takes a 360-degree, three-dimensional impression of the hole or casing section and retains it for study at the surface.

TruView impression elements are interchangeable with standard TamSet elements, or they can be provided as special sleeves which can be installed over the standard elements. These packers are run and retrieved in the same manner as the TamSet retrievable bridge plug.

\section{TamPlug $_{\mathrm{TM}}$ \\ Permanent, Inflatable Bridge Plug}

The TamPlug is an economical nonretrievable inflatable packer designed for permanent bridge plug applications. For use in casing, the TamPlug is available with multiple, serrated slips which securely anchor the plug.

The TamPlug can be run on drillpipe or tubing. A simple ball-check valve permits fast inflation and reliable setting. Once the plug is set, the string and running sub are detached by right-hand rotation.

The TamPlug is the dependable, inexpensive way to seal off water zones, set cement plugs for sidetracking, and many other applications.

Contact TAM International for specifications and ordering information. 


\section{Inflatable Packer Systems}

Three-Zone Sand-Frac Sequence

Using TamSystem

(See Procedure at right)

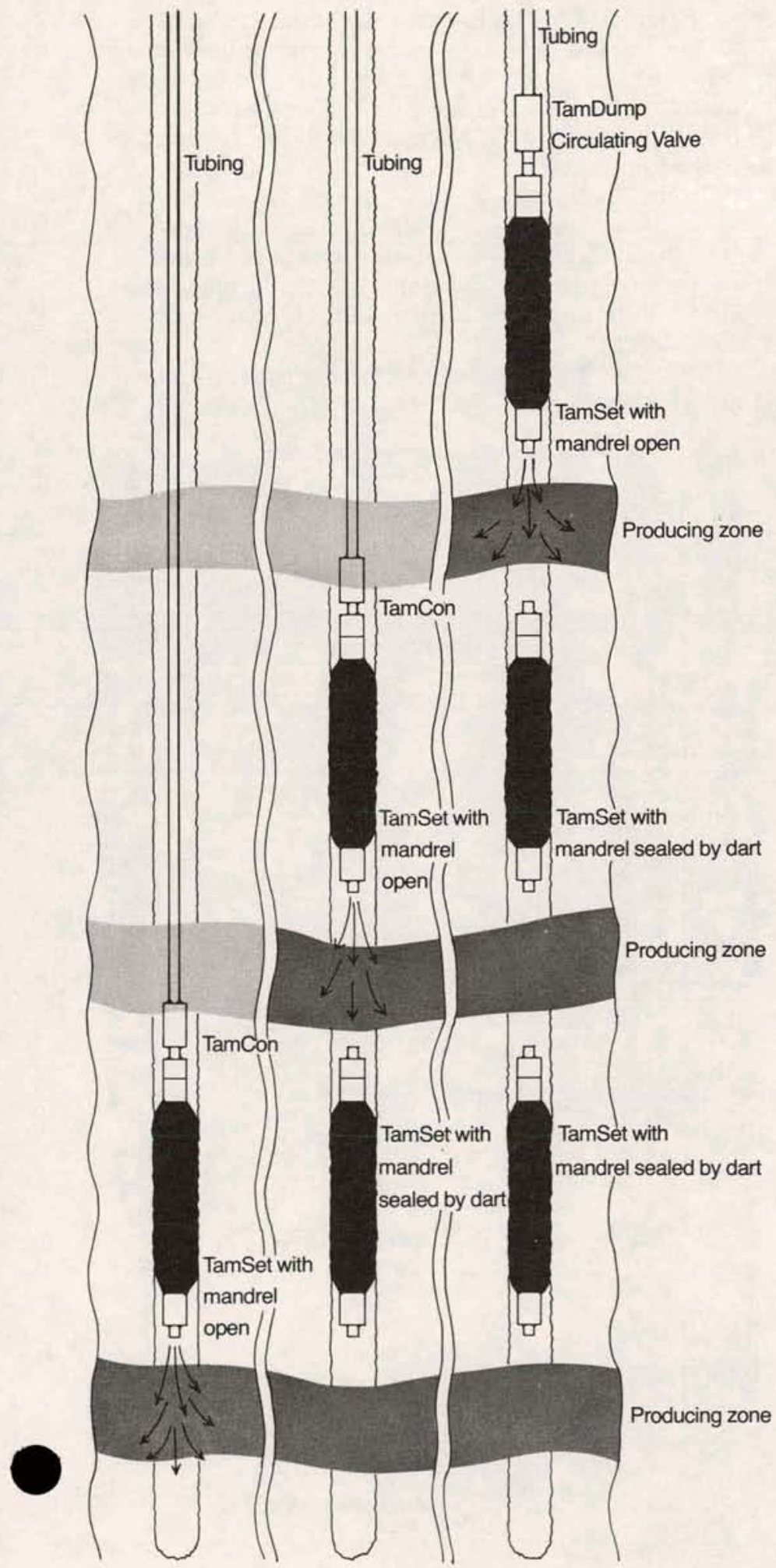

TamSystem ${ }_{\mathrm{TM}}$

for straddle-packing, testing and treating-fracturing, acidizing and squeezing single or multiple zones

The TamSystem features versatile TamSet inflatable packers with interchangeable accessories that can be combined for a wide range of applications. The accessories are:

- TamCon collet connector

- TamDump circulating valve

- Tubing connector

- Interchangeable ball choke and bull plugs

When it is necessary to work through a TamSet, the ball choke provides a means for setting the packer and then allowing flow through the packer mandrel. A ball is dropped to seal at the choke, and pressure is raised to about 2,000 psi to set the packer and shear the ball through the choke.

\section{Procedure for multi-zone operations}

The following sand-frac procedure illustrates the ease with which multiple, openhole zones can be treated using the TamSystem.

1. The first TamSet with a TamCon is run on tubing above the bottom zone and a ball is dropped to the ball choke. Pump pressure of 2,000 psi sets the packer and shears the ball through the choke.

2. After the bottom zone is treated by working through the TamSet, a dart is dropped to seal the packer bore. The TamCon and string are retrieved by turning to the right five turns and coming out of the hole.

3. The second TamSet is run in the same manner and set above the middle zone, which is now isolated above and below. Again, after treating, a dart is dropped to seal the packer bore and the TamCon and string are retrieved.

4. The third TamSet is run and set above the top zone. A TamDump circulating valve is used in place of the TamCon. When pumping into this last zone is complete, pressure is maintained on the formation by closing off at the surface.

5. After formation pressures have normalized, the TamDump is opened with a few turns to the right and any sand above the top packer is circulated out of the hole. The TamSet is deflated and retrieved by taking a quarter-turn left and pulling out of the hole.

6. The tubing string with a TamCon is washed down to the second packer by reverse circulation. The TamCon is reattached to the TamSet by setting straight down. Again, a quarter-turn left and pulling out deflates the packer for retrieval.

7. The last TamSet is retrieved just like the second, and the job is complete.

Contact TAM International for specifications and ordering information. 


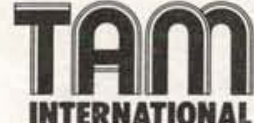

$\mathrm{TamCap}_{\text {тм }}$

\section{Casing Annulus Packers}

Sure-setting, reliable TamCap packers provide external pack-off for casing and liner strings, without sacrificing full internal opening. Each TamCap is actually a shortened joint of casing or liner, matched with the pipe being run, with the inflatable pack-off element added to the $\mathrm{OD}$. The OD of the inflatable element is kept to a minimum to assure fast, easy running in.

TamCap packers can be placed anywhere in the casing or liner string to permanently seal the annulus between the pipe and well bore. One or more TamCaps can be run to isolate and protect zones during cementing or gravelpacking operations, to isolate producing zones above and below perforation or to center and anchor casing and liner strings. TamCaps can be set simultaneously or individually as required.

TamCap packers feature the new BandCheck valve design and simplified high-strength construction pioneered by TAM International. Large-diameter fluid ports elimi-
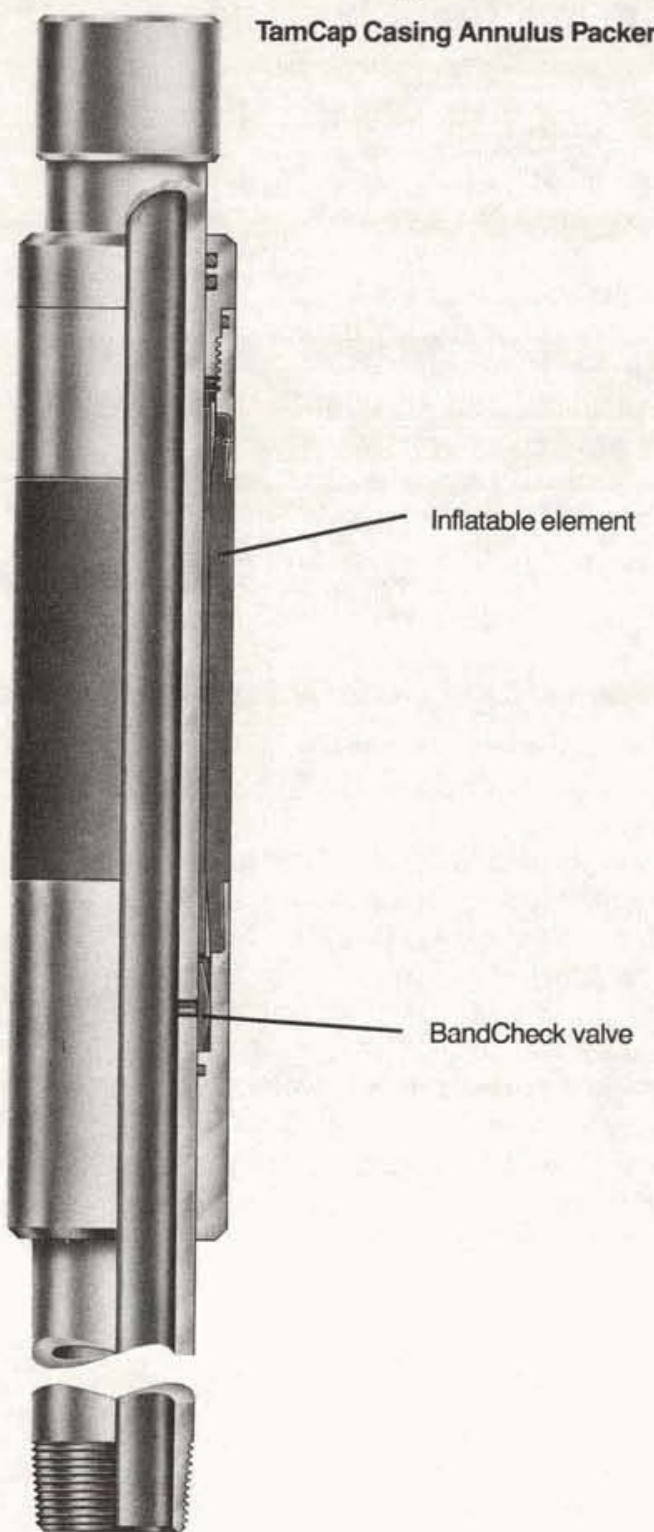

\section{Inflatable Packer Systems}

nate plugging and assure quick, problem-free inflation and setting.

See page 6347 for TamSet specifications.

\section{AnchorPack ${ }_{\text {TM }}$ Liner Hanger/Packer}

The TAM AnchorPack is a combination inflatable liner hanger and packer which is run as part of the liner string. When set, the AnchorPack suspends the liner inside the casing and provides a positive pack-off seal between the liner and the casing ID. It is most often used in gravelpacking operations.

The AnchorPack offers the same outstanding construction and operating advantages of TamCap packers, with the addition of hardened steel slips at one end of the pack-off element. These slips grip the ID of the casing when the AnchorPack is set, securely hanging the liner string.

Contact TAM International for specifications and ordering information.

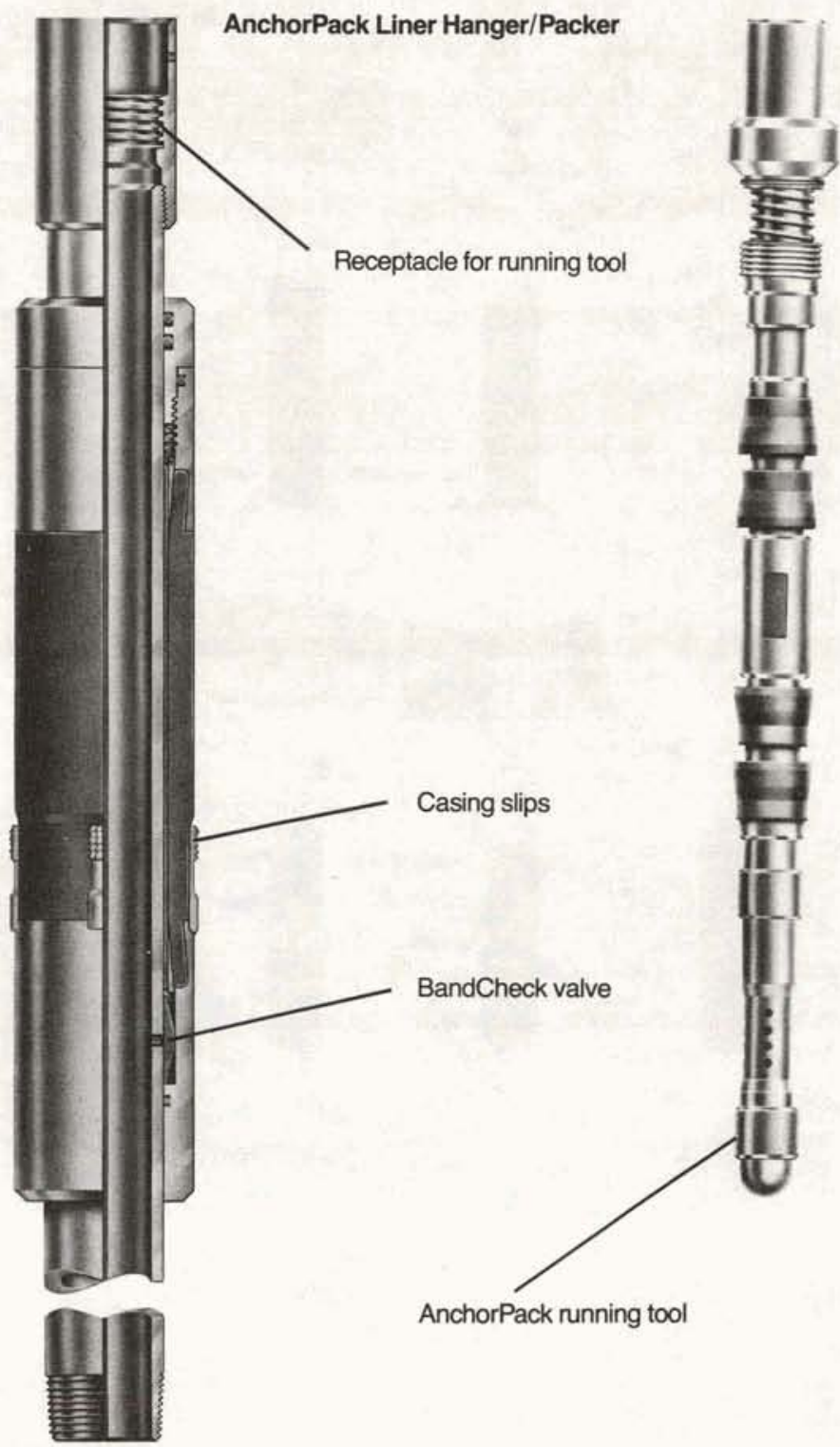


TAM PolySeal Port Collar

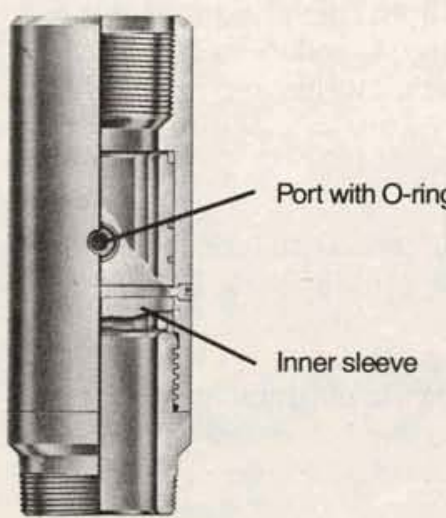

TAM Dual Tool

for Gravel-Packing/Cementing

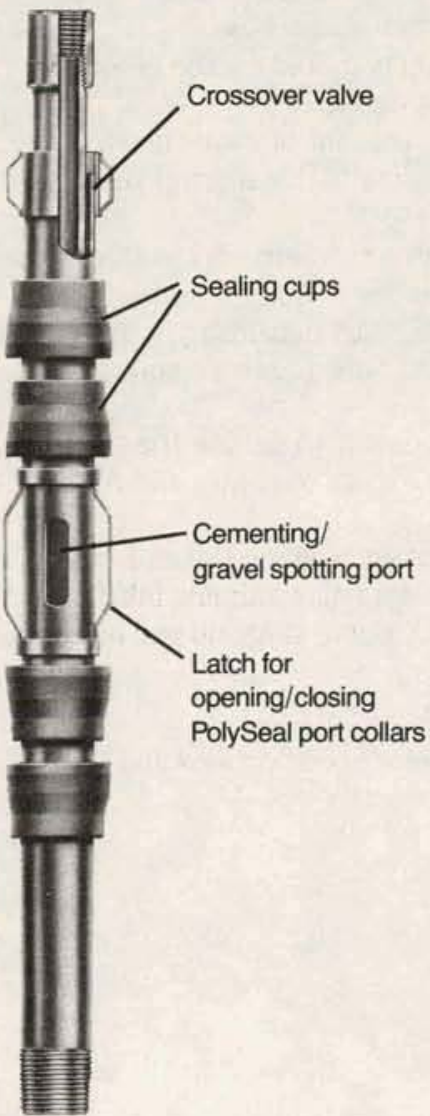

TAM FastPack Assembly for Two-Zone Gravel-Pack

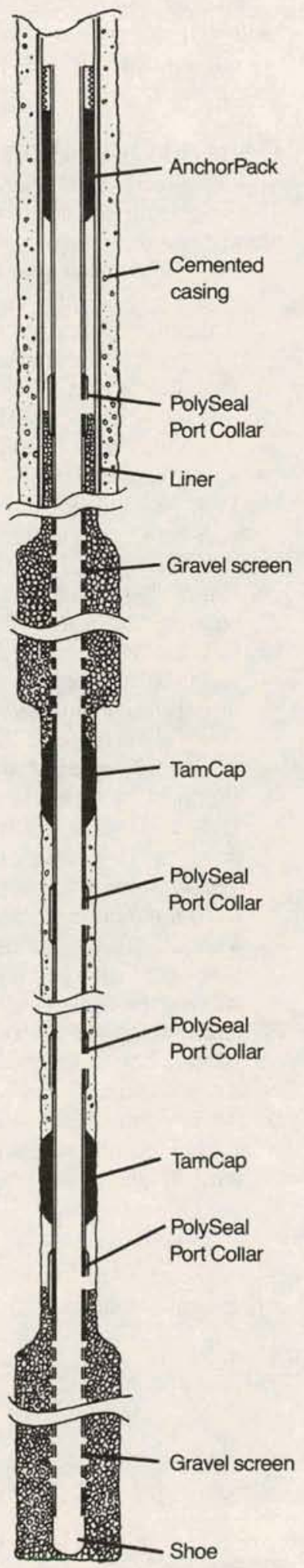

\section{PolySeal ${ }_{\mathrm{TM}}$ Port Collars}

TAM PolySeal port collars feature constant-torque operation for positive opening and closing during gravelpacking and cementing operations. These port collars maintain their position-either open or closed-so that "guessing" is eliminated and operations can be performed with confidence. Multiple port seals guard against leakage.

PolySeal port collars are run as part of the casing or liner string, providing a means for circulating gravel and for cementing casing. They are opened or closed by halfturn rotation using the TAM dual tool.

\section{FastPack $_{\text {тм }}$} Inflatable, open-hole gravel-pack system

The TAM FastPack system offers fast, simple operation and reliable performance for gravel-packing and cementing single or multiple zones. The system is designed for use in open holes and performs extremely well even in highly deviated holes.

The FastPack system consists of the following components:

- TamCap casing annulus packers

- AnchorPack liner hanger/packer

- AnchorPack running tool

- PolySeal port collars

- TAM dual tool for gravel-packing/cementing

All of these components incorporate exclusive design features which eliminate common operating problems associated with other inflatable gravel-packing systems.

\section{Typical Gravel-Pack Procedure}

The following FastPack procedure is typical for multiple-zone, open-hole gravel-pack operations. After the hole has been underreamed in the zones to be gravelpacked, the FastPack system is run as follows:

1. The gravel-pack assembly is as shown in the diagram.

2. Run the assembly in with the AnchorPack running tool in the AnchorPack. All PolySeal port collars are open.

3. Inflate and set the AnchorPack liner hanger/packer. Retrieve the running tool with right hand rotation.

4. Go back in the hole with the TAM Dual Tool on the tubing string. Locate and close all PolySeal port collars.

5. Again using the TAM Dual Tool, inflate and set each TamCap. Packer setting can be checked by opening a port collar between TamCaps, closing the crossover valve on the TAM Dual Tool and pressuring the annulus. Close the port collar and open the crossover valve after testing packer seat.

6. Open the bottom PolySeal port collar and pump gravel into the zone. Fluid reenters the string through the gravel-pack screen and flows through the crossover in the TAM Dual Tool back to the surface. Close the port collar.

7. Raise string and open the PolySeal port collar above the upper zone. Pump gravel into the zone and close the port collar.

8. Open PolySeal port collars between TamCap casing annulus packers and pump cement through the TAM Dual Tool and lower port collar. Close both port collars.

9. Remove excess cement by reverse circulation. 
TAM DS Rescue System

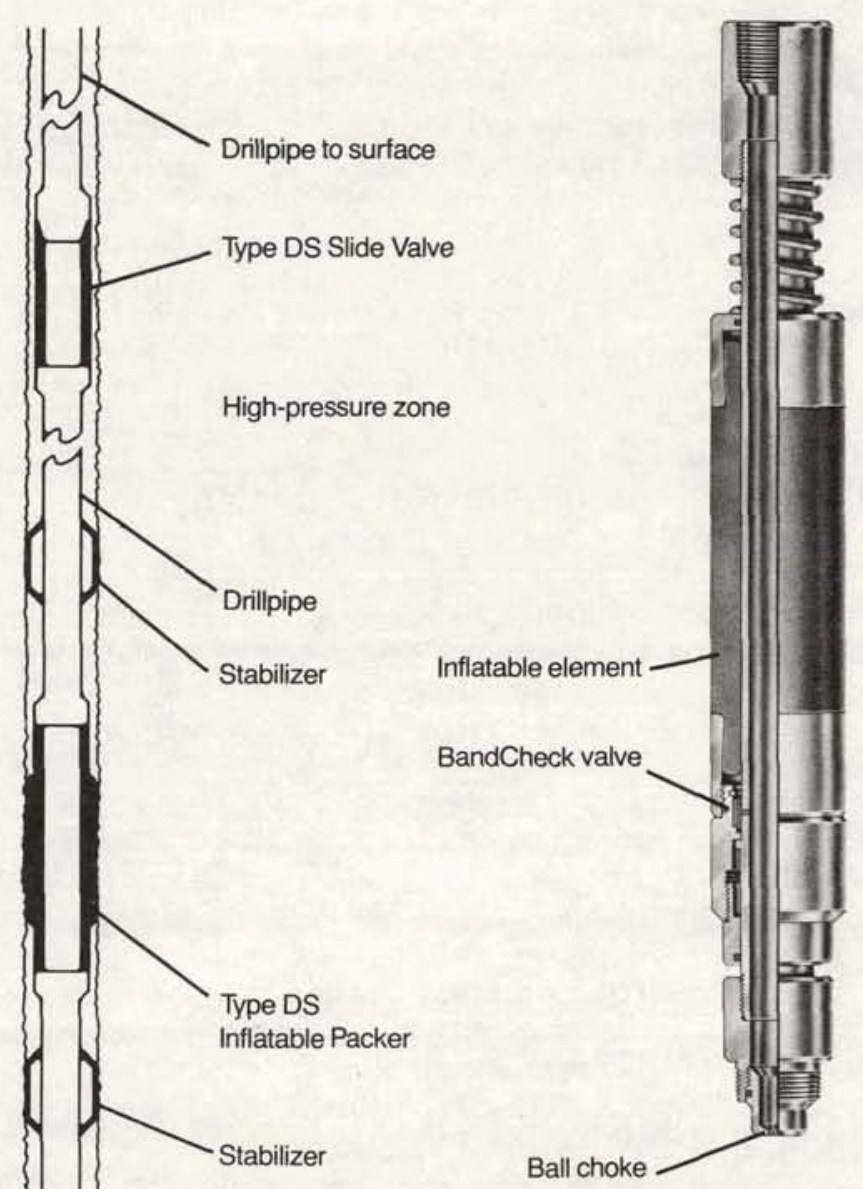

Bumper sub
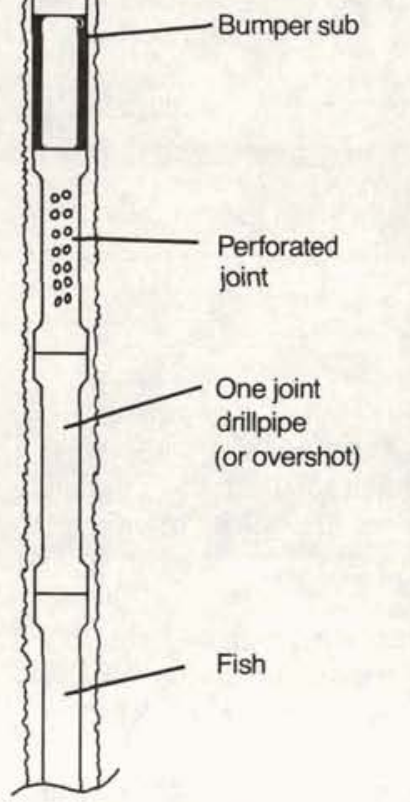

Low-pressure zone

\section{TAM DS Rescue ${ }_{\mathrm{T}}$ System frees differentially stuck drill string}

The TAM DS Rescue System is the reliable method for freeing drillstrings stuck as a result of differential pressure. The system is adaptable for both stationary and floating rigs. A modified TamSet inflatable packer and a special slide valve are combined to provide a means of isolating a low-pressure zone from high-pressure zones. Mud weight can then be adjusted to reduce hydrostatic pressure against the low-pressure formation, freeing the drillstring.

\section{General Operation}

This is a typical operating procedure for floating rigs. The drillstring is stuck in a low-pressure zone below a high-pressure zone.

1. Back off drillstring at freepoint.

2. Make up assembly as shown in diagram. Space out drillpipe with pup joints so that kelly valve will be above rotary after tagging fish and closing bumper sub.

3. Install slide valve shear bar inside kelly above partially opened kelly valve. Make up kelly to string.

4. Tag and secure fish. Take strain with motion compensator to stroke out bumper sub.

5. Pressure to 1,500 psi to set inflatable packer. Increase pressure to shear packer-setting ball through packer choke.

6. Pump slowly against formation and packer to make sure packer is set. Observe annulus for circulation.

7. Release pressure on drillpipe. Open kelly valve to drop shear bar to open breakout plugs in slide valve. Circulate through slide valve ports to clean hole.

8. Place slide valve ball in pump manifold via the bleed-off valve and pump it down past the kelly.

9. Pump ball and precalculated amount of water down to slide valve. Ball will seat in slide valve, forcing sleeve down to close valve ports.

The drillpipe and low-pressure zone are now isolated from the high-pressure zone.

10. Vent drillpipe to atmosphere, thus equalizing hydrostatic pressure and formation pore pressure and freeing the drillstring.

11. Slack off with motion compensator to deflate the packer. Lower kelly drive bushings to rotary and rotate string slowly.

12. Bleed differential pressure from drillpipe through manifold bleed-off valve while maintaining annulus full of mud. When mud is equalized, pump slug and pull out of the hole.

Contact TAM International for specifications and ordering information. 
How to Use the Working Pressure Charts

Use these charts to select the proper size of TamSet or TamCap inflatable elements for your application. For the TamSet, for example, if the hole size is $6 \frac{1}{4}$ inches, any of five inflatable element sizes could be used, from 37/8 O.D. to $5 \frac{1 / 2}{2}$ O.D. The $5 \frac{1}{2}$ O.D. would withstand the highest differential pressure $(5,200$ psi as shown by the dotted line). The rated working pressure decreases as the O.D. of the inflatable element decreases.

\section{Standard TamSet Sizes}

\begin{tabular}{lcccccccccccc} 
O.D. $2 \frac{1}{1} 2$ & $27 / 8$ & 3 & $31 / 2$ & $37 / 8$ & $41 / 4$ & 5 & $51 / 4$ & $51 / 2$ & $61 / 4$ & 7 & $71 / 4$ \\
\hline I.D. & 1 & 1 & 1 & $11 / 2$ & $11 / 2$ & $11 \frac{1}{2}$ & $11 / 2$ & $11 / 2$ & $21 / 4$ & $21 / 4$ & $21 / 4$ & $21 / 4$
\end{tabular}

All TAMSET packers are approximately 81 inches overall. Larger inside diameters are available on request. Consult TAM International for special inflatable packer requirements.

TamSet Inflatable Element Outside Diameter, inches

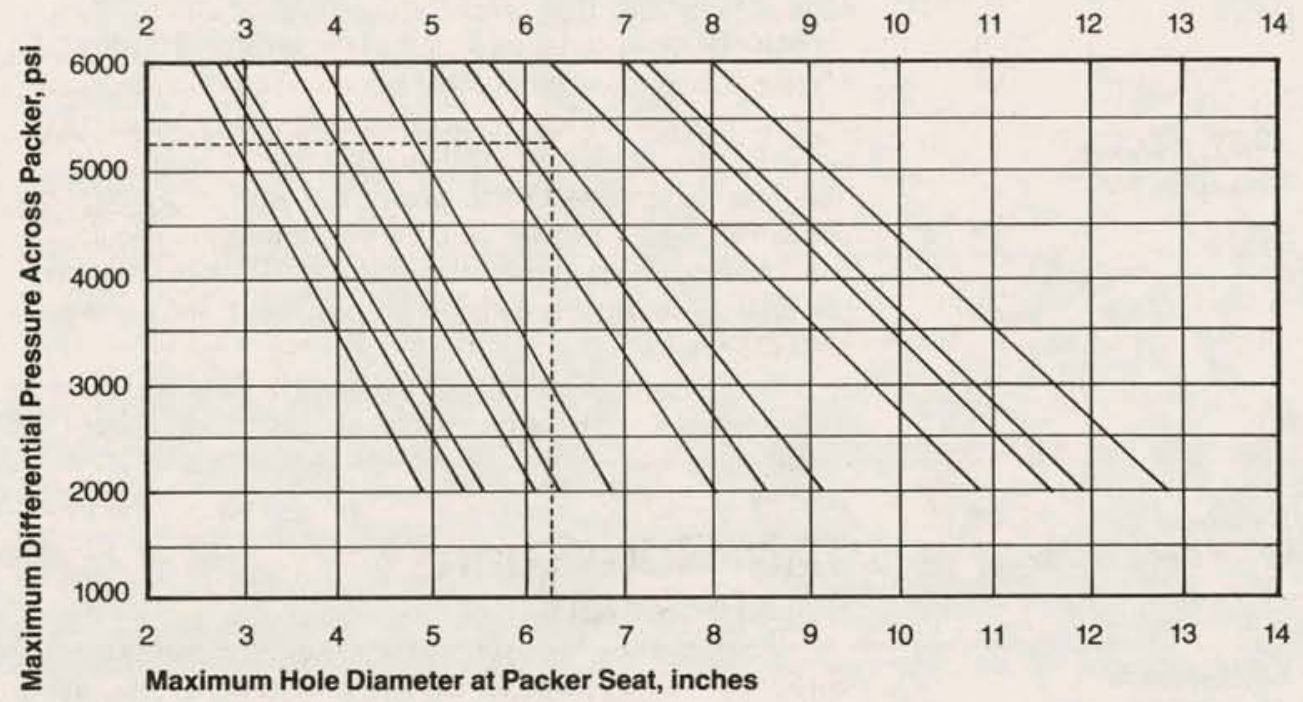

\section{Standard TamCap Sizes}

\begin{tabular}{|c|c|c|c|c|c|c|c|c|c|c|c|c|c|c|}
\hline MAXIMUM O.D. & $53 / 4$ & $61 / 2$ & 7 & $77 / 8$ & $81 / 4$ & 9 & $10 \frac{1}{4}$ & 11 & $12^{3 / 4}$ & $13^{3 / 4}$ & $151 / 2$ & $181 / 4$ & 21 & 24 \\
\hline NOMINAL CASING O.D. & $41 / 4$ & 5 & 5 & $65 \%$ & 7 & $75 / 8$ & $85 \%$ & $95 / 8$ & $10^{3 / 4}$ & $113 / 4$ & $133 / 8$ & 16 & $185 \%$ & 20 \\
\hline
\end{tabular}

NOTE: Special sizes available on request.

Maximum TamCap Outside Diameter, inches

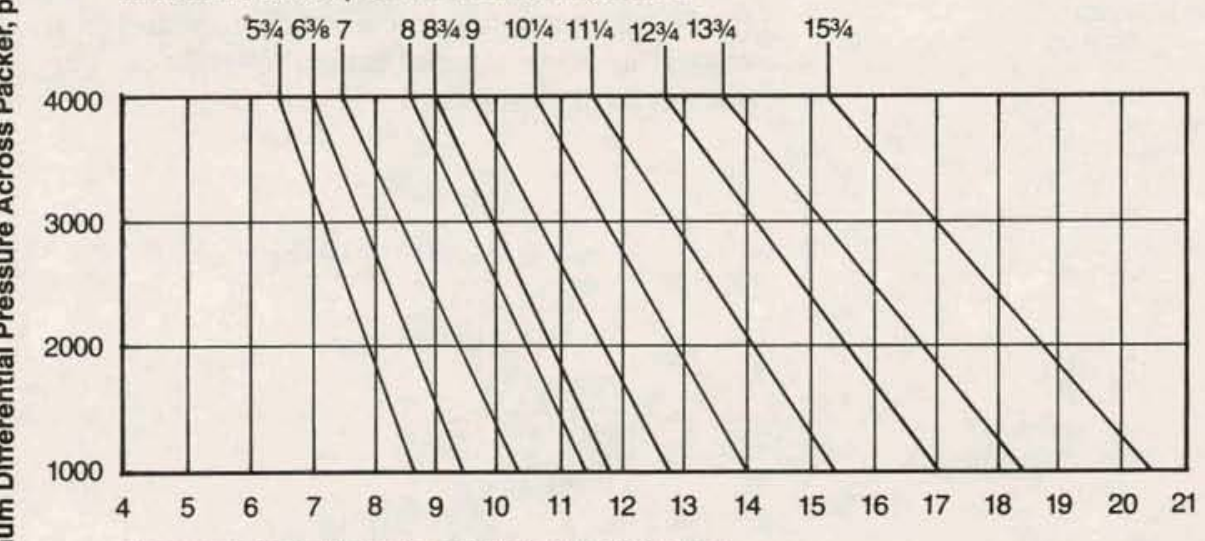

Maximum Hole Diameter at Packer Seat, inches 


\section{TAM \\ INTERNATIONAL}
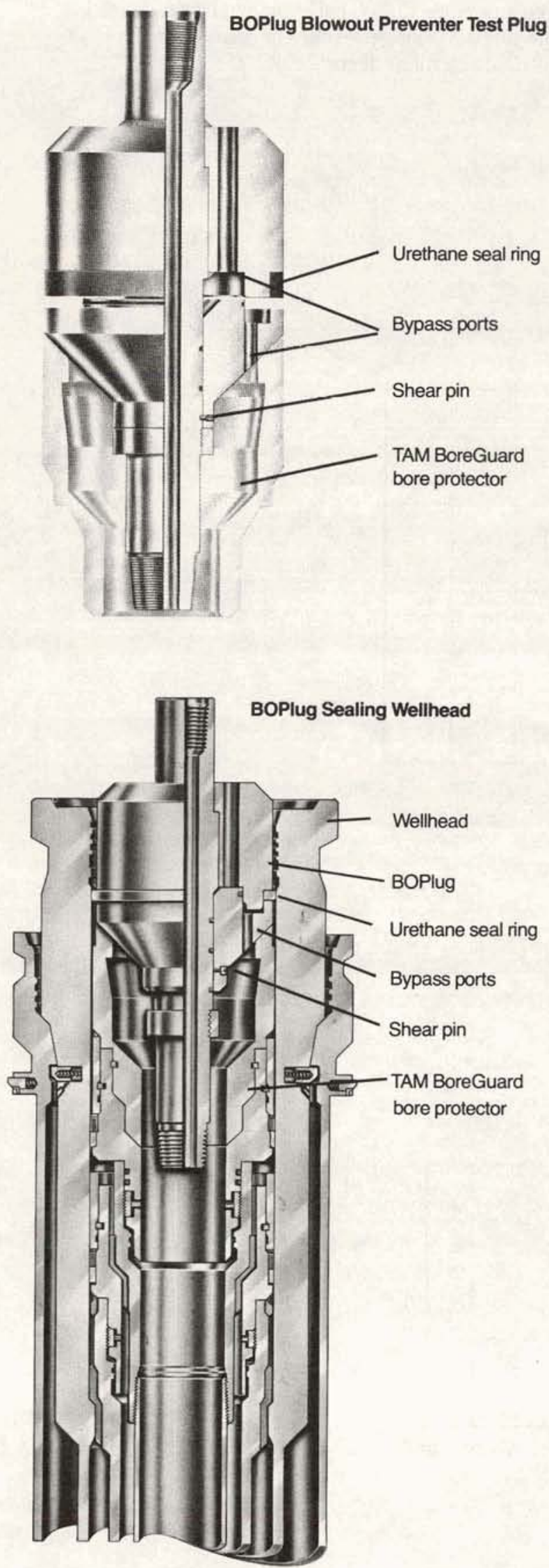

Marine Tools

\section{TAM BOPlug ${ }_{\mathrm{TM}}$ \\ Minimizes rig downtime for testing blowout preventers}

The BOPlug* is an easy-to-operate blowout preventer test plug that provides a positive annulus seal against the wellhead ID during BOP testing. The BOPlug features a patented urethane seal ring which is energized by string weight and annulus pressure. Sealing force increases as annulus pressure increases, so that the seal becomes self-energizing and leak-tight.

\section{Fast Running In, Easy Operation}

The BOPlug is run on drillpipe and is landed on either TAM BoreGuard bore protectors or on the top casing hanger assembly. BoreGuard protectors are compatible with the BOPlug and may be left in the wellhead during testing. Other protectors must be removed.

After the BOPlug has been landed, string weight is applied to shear the retaining pin. The upper body of the tool then moves downward, closing the internal bypass ports and placing pressure on the circumferential seal, which is forced out against the wellhead ID. After testing, the BOPlug is retrieved simply by picking up and coming out of the hole.

BOPlugs are available for use in $133 / 8,18^{3 / 4}$ and $21^{1 / 4}$ inch wellheads. Standard tool joint is $4 \frac{1}{2}$-inch IF; others can be supplied.

\section{TAM BoreGuard ${ }_{\mathrm{TM}}$ Bore Protectors}

TAM BoreGuard protectors protect the wellhead bore, upper casing hanger and seal assemblies. They are specially designed to be compatible with the TAM BOPlug, so they can be left in the wellhead during BOP testing. This saves two trips every time the BOP is tested, since other bore protectors must be removed before isolation testing can be performed, and must be replaced after testing.

BoreGuard protectors incorporate a special metal ring which locks into the seal assembly and insures that the protector cannot be forced out of the wellhead. A 20,000lb pull will retrieve BoreGuard protectors.

BoreGuard protectors are carefully manufactured to conform to the shape of upper hanger assemblies. They are available to fit all standard wellhead sizes.

*Manufactured under exclusive license from Continental Oil Company, patent pending. 


\section{TAM Hydraulic R/R Tool Easiest way yet to install, retrieve bore protectors}

TAM BoreGuard protectors can be installed or removed quickly and easily using the TAM Hydraulic Run/ Retrieve tool. Four simple, spring-energized latches hold the BoreGuard securely while going into the hole. There are no threads to foul, and no rotation is required. The tool is made up on drillpipe, and the bore is fully open for faster running in.

When the BoreGuard has been landed on the top casing hanger, fluid pressure is used to seat a plastic ball in the choke, and the bottom section of the tool becomes a piston. 1,000 psi pressure forces the piston downward, closing the latches and releasing the BoreGuard. After the tool is pulled from the bore protector, fluid pressure is used to force the plastic ball through the choke, and the tool and string are pulled dry.

To retrieve the BoreGuard, the Hydraulic R/R tool is simply run in the hole until it engages the protector. The integral jetting sub permits the ID of the BoreGuard to be jetted clean when the tool is run, assuring that the springenergized latches will secure the protector. The tool and protector are then pulled from the hole. After retrieval, a mechanical device closes the latches so the protector can be removed.

One TAM Hydraulic R/R tool can be used to run and retrieve all sizes of BoreGuard bore protectors.

TAM Hydraulic R/R Tool with BoreGuard Bore Protector

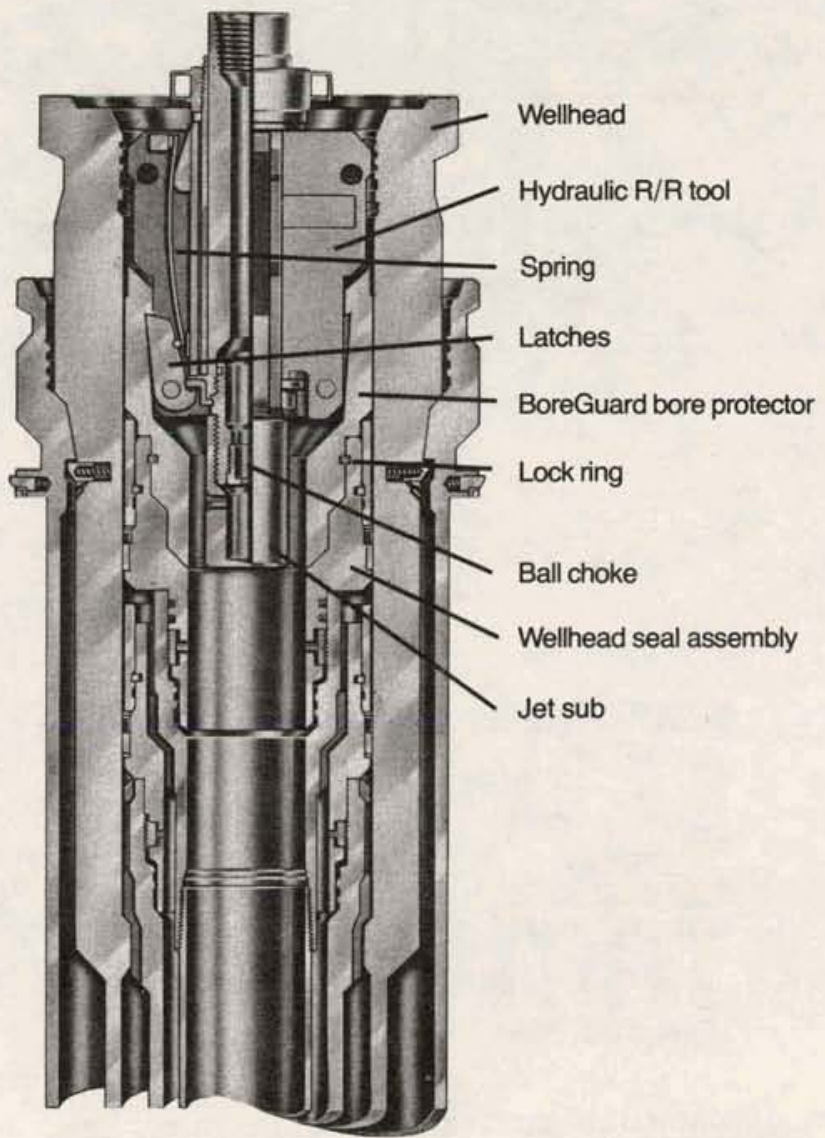

\section{Tam Type HD Wellhead Overshot}

- One-trip to sever casing, retrieve wellheads

- Positive latching-hydraulic release

- Vented base plate relieves pressure

- Retrieves all types of wellheads

- Will not damage wellhead

- Can be adapted to work with marine cutters

The TAM Type HD wellhead overshot is the reliable way to retrieve wellheads during plug-and-abandon operations. Four spring-energized latches securely grasp the wellhead when the overshot is landed. High-strength steel construction and strategically placed vents to relieve pressure insure that the wellhead will be held securely. Exclusive hydraulic system simplifies releasing overshot from the recovered wellhead. The Type HD has a maximum OD of 48 inches-will run through $49 \frac{1}{2} 2$-inch rotary, or can be made up on spider beams in moon pool if rotary is smaller. The TAM Type HD will retrieve any $183 / 4$-inch wellhead. A smaller size is available for retrieving any $135 / 8$ to $16 \frac{3}{4}$-inch wellhead.

\section{General Operation}

1. Run tool on grade "G" or S-135 drillpipe.

2. Run tool to within a few feet of spider beams in moon pool.

3. Suspend charge from eye bolt inside of overshot.

4. String power conductor through vent hole to charge.

5. Install two-arm guide to drillpipe and to guide lines.

6. Run overshot to wellhead, strapping power conductor to drillpipe.

7. Guide charge into wellhead using UTV camera.

8. Land overshot on wellhead with kelly and motion compensator. Take slight strain with compensator to insure overshot is locked onto wellhead.

9. Retrieve UTV camera.

10. Activate charge to sever casing below wellhead.

11. Retrieve wellhead and permanent guide base, landing out on spider beams in moon pool.

12. Remove guide arms from guide lines and overshot.

13. Pressure overshot to 1,500 psi to release overshot from wellhead.

\section{TAM Type HD Wellhead Overshot}

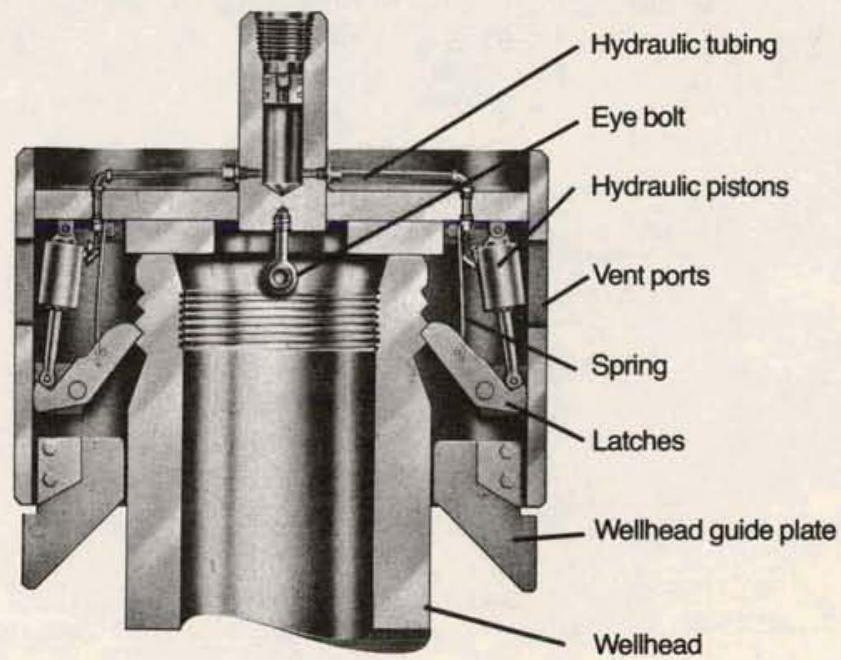




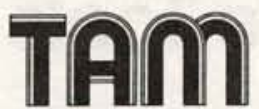

INTERNATIONAL

\section{TAM HGR/R}

for running, retrieving the temporary

\section{guide base}

- Exclusive hydraulic release

- Gimbal design stabs and releases at up to $10^{\circ}$ deflection

- Runs through $491 / 2$-inch rotary

- Holds guide base securely in rough waters

The TAM HGR/R is the fast, efficient and safe way to run and retrieve the temporary guide base. Four springloaded latches hold the guide base securely while running through the splash zone and down to the ocean floor. When the guide base has been landed, pump pressure is used to retract the latches and release the guide base. Unlike $\mathrm{J}$-type tools, the gimbal design of the HGR/R makes it easy to stab and pull out even when the guide base is as much as $10^{\circ}$ from vertical. For retrieving the guide base, the HGR/R is simply stabbed in until the spring-loaded latches secure the guide base.

\section{Running temporary guide base}

1. Land and rig up the temporary guide base on the spider beams.

2. Make up the TAM HGR/R in the rotary with plastic ball in the restricted throat of the tool.

3. Lower tool through the rotary and stab it into the temporary guide base.

4. Lower assembly to seafloor and land out using kelly and motion compensator.

5. Retract HGR/R latches by applying $1,000 \mathrm{psi}$ with rig pump.

6. Pull out of temporary guide base and increase pressure to shear the plastic ball through the choke, allowing string to be pulled dry.

7. Retrieve HGR/R.

\section{Retrieving temporary guide base}

1. Make up HGR/R in rotary with plastic ball in throat of the tool.

2. Install the two-arm guide at the moon pool.

3. Run the HGR/R and stab into temporary guide base.

4. Retrieve temporary guide base to spider beams.

5. Use mechanical release to retract the latches and retrieve the HGR/R.

\section{TAM Type HGR/R Temporary Guide Base Tool}

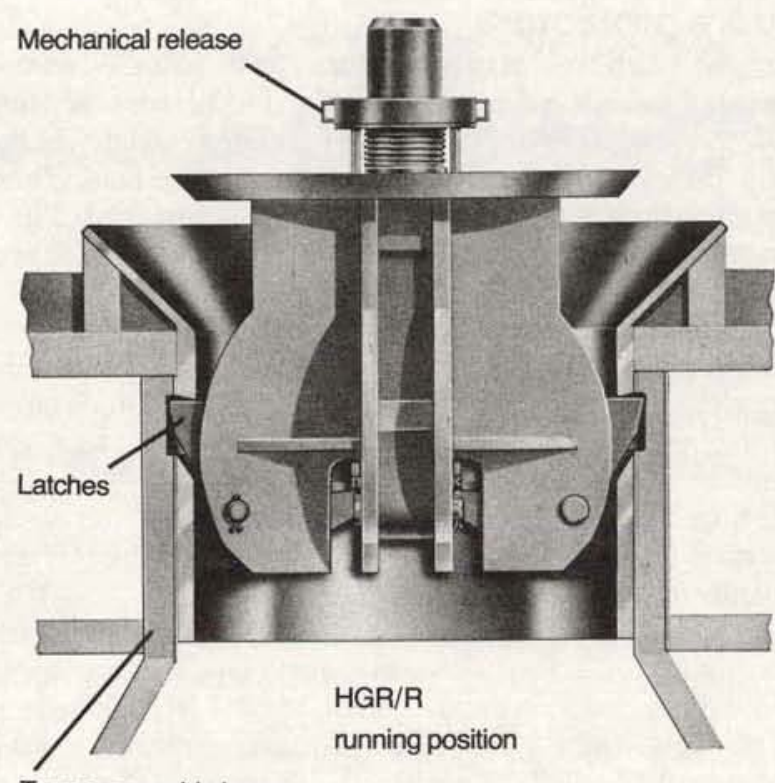

Temporary guide base

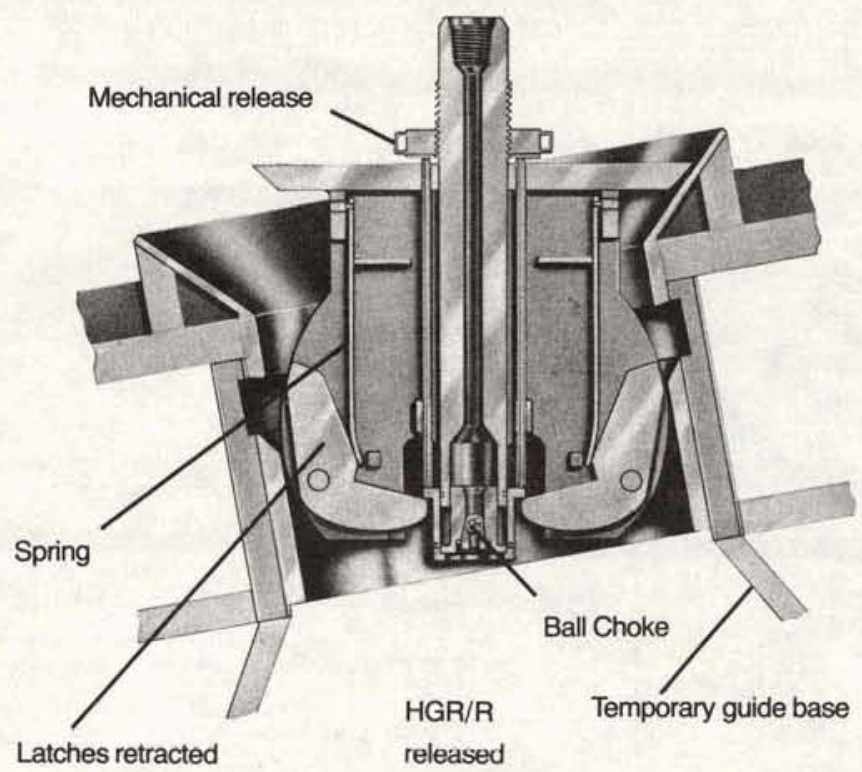


TAM INTERNATIONAL

4047 MOULISTER HOUSTON, TEXAS 77080 U.S.A.

PHONE - D13) 462.7617 - 462.7619
JOB REPORT

customer Lovis feeords

$\because$ No. D.D.E. 6

Block
Storace County $C_{A m E R C M}$

\section{Charge Ticket}

\# C200

Well Information

Surface Casing Size $1.23 / 5$

Other Casing Size

Liner Size

Open Hole Size
$95 \%$ Wt.
Wt.

Wt.

Depth from

Depth

2632

Depth

2608

Field HACKbExigy

State $\angle A$

Date $9-12-2.5$
SU.R Bottom Hole Temp.

\section{PERFORATIONS}

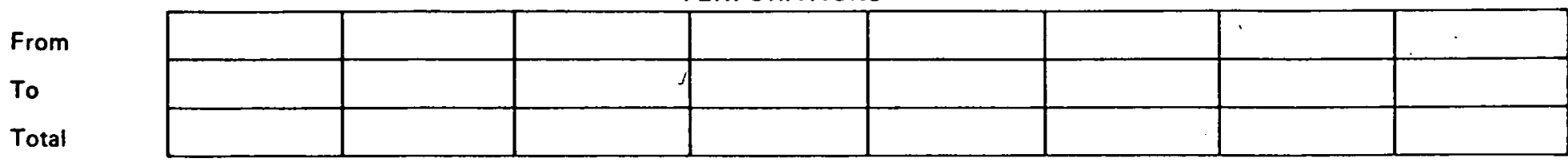

Type fluid in hole $B R$ ine $E^{\circ}$ o,L c'mud Vis

Work String Size $27 \%$

107

No. Jts. in hole

No. pups in hole

Tools ह' suls
Length 3.277 Length Length

Total Length

R.T.

Above G.t.

Tool set

10

3287.

3

3284. wt. $10^{\text {t }}$

Type Thread
$1 /-1 \theta^{\circ}$ Level

$O H \&$ NydR.'

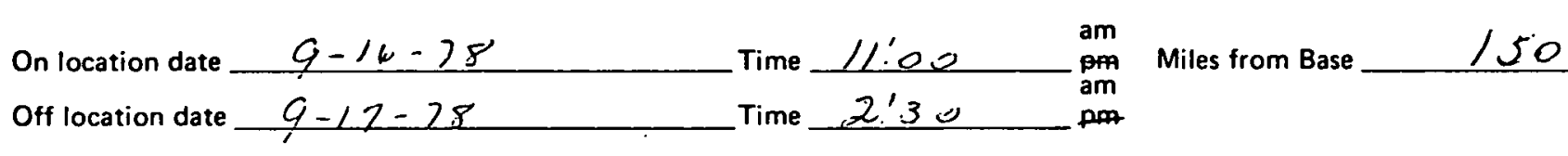

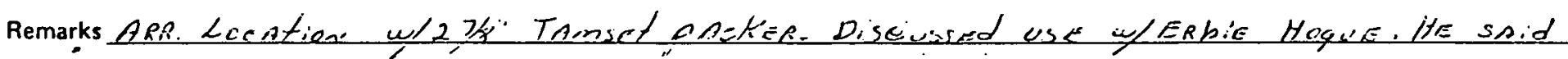

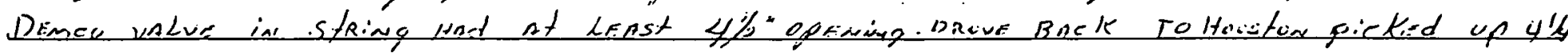

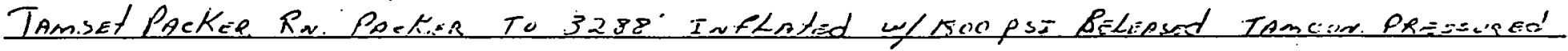

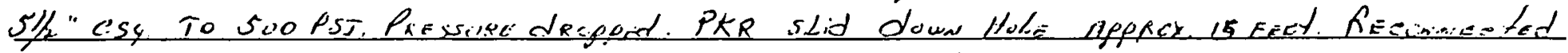

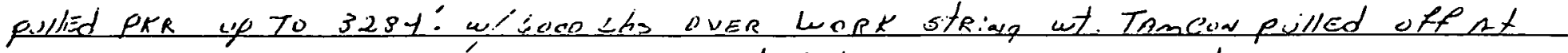

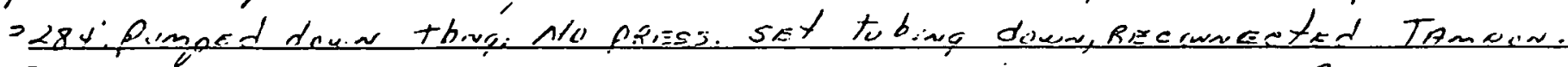

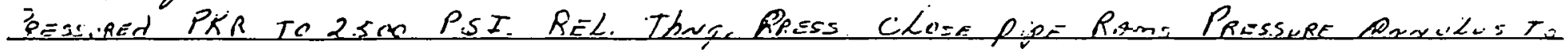

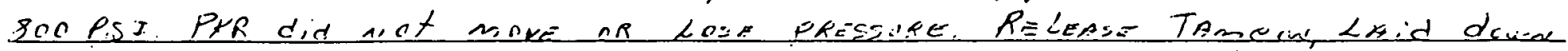

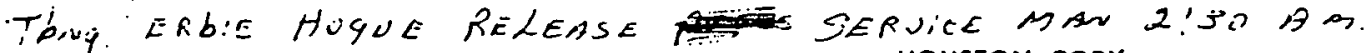


THIS PAGE

WAS INTENTIONALLY

LEFT BLANK 
APPENDIX XII

Workover Procedures

A- 243 


\section{THIS PAGE}

\section{WAS INTENTIONALLY LEFT BLANK}




\section{LOUIS RECORDS \& ASSOCIATES, INC. \\ P. 0. 00X 53693 , 0.c.s. \\ LAFAYETTE. LOUISIANA 70501}

October 5, 1978

Mr. Douglas Cariker

Parsons-Gilbane

800 Commerce Road, West

P. O. Box 23702

New Orleans, Louisiana 70183

Dear Mr. Cariker:

Procedure followed in working over well $\$ 6$ in West Hackberry field.

1. Pumped 75 bbls of 11.0 ll/gal mud into $51 / 2$ " casing through $2 "$ pipe on Larkin Heed and this volume equals 3151.26 feet.

2. Salt water returned in $1 "$ pipe which was suspended in casing.

3. Pulled 1" pipe out of hole ( 82 joints and one perforated pup joint).

4. Close well in with 6" ball valve - would not close - pumped in 34 bbls of 11.0 :l/gal mud. Well dead on $51 / 2$ " casing top - finally worked corrosicn out of $6^{\prime \prime}$ ball valve and closed it tightly:

5. Removed Larkin Head - 5 1/2" B5-2000 psi WOG.

6. Installed 6". blow out preventer with $27 / 8^{\prime \prime}$ pipe rams and blind rams.

7. Shut 6" blind rams.

8. Pumped 30 bbls of 11.0 ll/gal mud into $51 / 2^{\prime \prime}$ casing through connection under blind rams.

9. Well dead.

10. Went in hole vith Tamset bridge plug, mfg. "420011, length of 96", packer element was 66" long and it had a 4.25" I.D. on bottom of $27 / 8$ " $\mathrm{PH}-6$ tubing.

11. Set Tamset bridge plug at 3285 feet. Tested bridge plug by pressuring up at surface to 800 psi in $27 / 8^{\prime \prime}$ tubing and $51 / 2^{\prime \prime}$ casing annulus. Bridge plug held in place.

12. Pulled 2 7/8" PH-6 tubing out of hole.

13. Rig up to pump into annulus between $51 / 2^{\prime \prime}$ casing and $95 / 8^{\prime \prime}$ casing. 
14. Pumped 155 bbls of 11.0 ll/gal mud having a funnel viscosity of 165 seconds into annulus between $51 / 2^{\prime \prime}$ casing and $95 / 8^{\prime \prime}$ casing.

15. Removed 6" blow out preventers.

16. Removed 6" Demco ball valve and National Supply Company pack off. Unload 10" blow out preventers. Unusual size $8^{\prime \prime}$ flange on $x$-mas tree thought to have been 2000 psi working pressure but was actually 150 psi working pressure.

17. Re-installed 6" Denco ball valve, waited 30 hours for correct flange connections.

18. Attempted to kill 40 psi on annulus. Brought pressure to zero in three hours with 106 bbls of 11.6 非/gal mud.

19. Removed 6" ball valve and installed double studded adapter, 8" flange to 10" flange.

20. Installed 10" pipe ram with a 10" flange and added a full closure bag type preventer on top of pipe ram preventer. All surface pressure on both oil side annulus and $51 / 2^{\prime \prime}$ casing had zero psi.

21. Rigged up casing tools to pull $51 / 2 "$ casing annulus pressure to 40 psi while rigging up casing tools.

22. Pumped 60 bbls of 16.0 作/gal mud with 180 viscosity into $51 / 2^{\prime \prime} \times 9{ }^{\prime} 5 / 8^{\prime \prime}$ annulus. Shut in pressure was $250 \mathrm{psi}$ on annulus after six hours. Shut down and waited for daylight to be able to see better.

23. Pumped 108 bbls of 11.6 非/gal mud with +185 viscosity into annulus. Bleed back 10 bbls, had 150 psi annulus pressure.

24. Pumped 68 bbls of 11.6 \#/bal mud into annulus. Still had 150 psi annulus pressure.

25. Pumped 50 bbls of 16.0 ll/gal mud with +185 viscusity and attalned zero psi at surface on annulus with no flow back.

26. Checked pressure on $51 / 2^{\prime \prime}$ casing and it was zero pressure. Opened annular blow out preventers.

27. Mud level in annulus at approximately 100 feet. Filled the hole full with 16.0 k/gal mud on annulus side.

28. Rigged up and pulled 13 joints of $51 / 2 "$ casing which was full of mud. Addec a barrel of 16 位 mud into annulus for each joint removed.

29. Pulled 14th joint, unscrewed it from $51 / 2^{\prime \prime}$ casing string and was laying it down through $V$-door when well came in through $51 / 2^{\prime \prime}$ casing. Tried to screw in a $51 / 2^{\prime \prime} \times 2^{\prime \prime}$ swage with $2^{\prime \prime}$ valve, into $51 / 2$ " casing but flow from well would not permit it. Three separate attempts were made to screw swage into $51 / 2$ " casing. Two inch valve was open on these attempts. 
30. Salt water mud was blown from hole followed by Tamset bridge plug and then followed by oil. The $51 / 2^{\prime \prime}$ casing was then at 2820 feet.

31. Diesel engine on rig ran away probably due to gas from oil entering its air supply. An attempt was made to kill this engine on driller's console with kill switch but it did not work.

32. Diesel engine exploded and set oil on fire.

33. Two men of Pelican's had gone to the engine to stop it and just reached it when it exploded, set the oil on fire, and severely burned them.

34. The oil continued to burn until the ofl pressure from the cavern decreased to near zero at the ground level.

35. A boom attached to a caterpillar dozer pulled the $x$-mas tree which broke off at ground level away from the hole. The $51 / 2^{\prime \prime}$ casing fell to the bottom of the hole leaving the $95 / 8^{\prime \prime}$ casing open.

36. A $95 / 8^{\prime \prime}$ Tamset bridge plug was run in the hole and set and it sealed off further flow from the cavern.

37. After the fire within the dikes was extinguished an excavation was made around the well piping.

38. A pipe cutter then cut off the $24^{\prime \prime}$ casing, the $16^{\prime \prime}$ casing, the $127 / 8^{\prime \prime}$ casin and the $95 / 8^{\prime \prime}$ casing. Details supplies to us showed $20^{\prime \prime}$ casing, $16^{\prime \prime}$ casing $123 / 4^{\prime \prime}$ casing and $95 / 8^{\prime \prime}$ casing.

39. A Brajen head flange was welded to the $127 / 8^{\prime \prime}$ casing, slips set between the $95 / 3^{\prime \prime}$ casing.

40. A 12 " x. 10" spool was bolted to the 12" flange and packing materlal injected to seal between the $127 / 8 "$ casing and the $95 / 8^{\prime \prime}$ casing was energized.

41. A 10" Cameron ball valve was installed on the 10" flange in an open position as the $27 / 8^{\prime \prime}$ pipe that held the $95 / 8^{\prime \prime}$ Tamset bridge plug was still in the hole.

42. A Cameron blow out preventer with blind rams was mounted on top of the $10^{\prime \prime}$ valve.

43. A second Cameron blow out preventer with pipe ram was mounted on top of the first preventer.

44. A few barrels of mud weighing 10.3 作/gal was pumped into the well bore to bring pressure to 200 psi above $95 / 8^{\prime \prime}$ casing Tamset plug from a connection point on the bottom of the blind ram preventer.

45. The Tamset bridge plug inside the $95 / 8^{\prime \prime}$ casing was depressured and deflated 
46. A total of $160 \mathrm{bbls}$ of 10.3 非/gal was pumped into the $95 / 8^{\prime \prime}$ casing.

47. When the surface pressure reached zero pressure, the Tamset bridge plug was withdrawn.

48. The 10" valve on the well was closed shutting the well in.

49. The blow out preventers, the blind rams, and the pipe rams were removed.

50. A second 10" Cameron ball valve was installed above the first valve.

51. A Companion connection flange was added above the second $10^{\prime \prime}$ ball valve leaving a $2^{\prime \prime}$ connection to which was connected a $2^{\prime \prime}$ ball valve. Well was completely closed in.

Hydraulic Conditions Existing at Time of Blow Out

1. Bottom of cavern - 3395 feet

2. Top of cavern - 3237 feet

3. Interface between oil and salt water - 3316 feet approximately

4. Original botton of $51 / 2^{\prime \prime}$ casing - 3380 feet

5. Bottom of. $95 / 8^{\prime \prime}$ casing - 2603 feet

6. Bottom of $51 / 2^{\prime \prime}$ casing when well blew out - 2820 feet
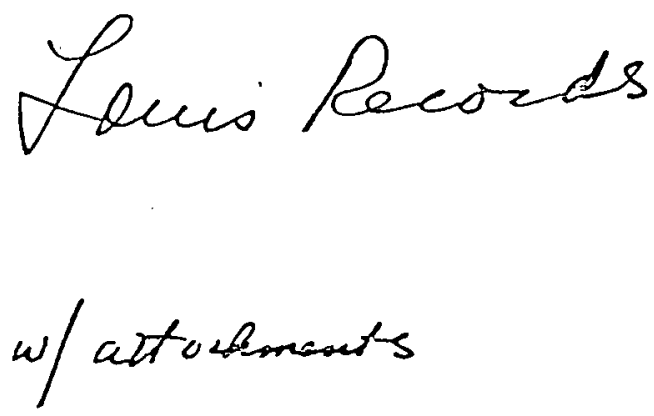
Bottom of $51 / 2$ " tubing a 2820 feet

Bottom of $95 / 8$ " casing e 2603 feet

Annulus Volume per foot $.0773-.0294=.0479 \mathrm{bbls}$ per foot

$51 / 2^{\prime \prime}$ tubing volume per foot $=.0238 \mathrm{bbls} / \mathrm{ft}:$

\section{HYDROSTATIC PRESSURE AT 2820 FEET}

1. "Inside $51 / 2$ " tubing with 1 in/gal mud

2820 feet $x .571 \mathrm{psi} / \mathrm{ft}=1610 \mathrm{psi}$

2. In annulus between $51 / 2^{\prime \prime}$ tubing and 9 5/8" casing a 2820 feet

a. 64 bbls " of $16.0 \% / g a 1$ mud

$64 \mathrm{bbll}^{\prime} \mathrm{s} \div .0479 \mathrm{bbls}$ per ft. $=1336 \mathrm{feet}$

1336 feet $\mathrm{x} .831=1110$ psi

b. $\quad 71$ bisis of 11.6 l: gal müd

1484 feet $x .602=893$ psi

Total pressure in annulus d 2820 feet was 2003 psi

Differential pressure across packer was 393 psi

Tamset bridge plug should have sustained a 4900 psi differential 
MYDROSTATIC PRESSLRE'S

AT BOTTOM OF 51/2"TLBING Q2820 far

WHEN WELL NO 6 BLEW OLT

TOD MUD WEIGHT IA ANNULUS

$64 \mathrm{b6} / \mathrm{s}$ of $16.0 \mathrm{1b} / \mathrm{gal}$ med $=1336 \mathrm{ft}$

$7 \mathrm{bb} / \mathrm{s}$ of $11.6 \mathrm{~kb} / \mathrm{gal}$ mud $=1484 \mathrm{ft}$.

1336 feet $x .831 \mathrm{ps} / / \mathrm{gt}=1110 \mathrm{ps}$

1484 feet $x .602$ pso $/ \mathrm{fr}^{\mathrm{r}}=893$ psi

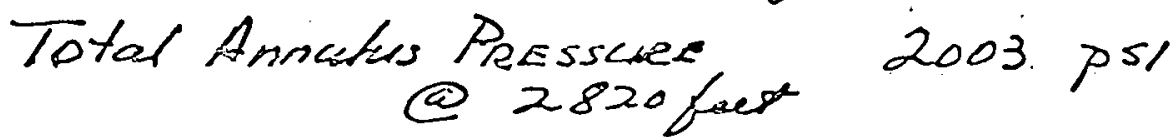

MUD WEIGAT IN 5/2"THBING.

676 bls@2820fact of 11.016/gal mud

$$
2820 \times .501 p^{51} \text { fot }=1610.22 \mathrm{ps} 1
$$

Differental Phersure from on Nuws to inside of 51/2"tubing when Tamset Bersat Dumb Blew out 2003pss- 1610.psi- 393 pss

$A=250$ 
Employer's

First Report

of Injury
MID-CONTINENT UNDERWRITERS, InC.

PHONE: $581-5597$

WHITNEY BUILDING

NEW ORLEANS, LOUISIANA 70130

\section{Righ 11 CLARENCE.Simon}

\begin{tabular}{|c|c|c|}
\hline Emoloyer & $\begin{array}{l}\text { 1. } \\
\text { 2. } \\
\text { 3. } \\
\text { 4. }\end{array}$ & 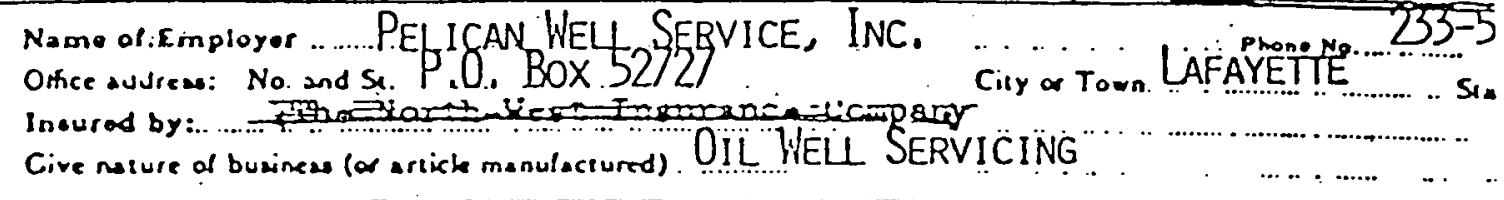 \\
\hline
\end{tabular}

3. (4) Lexation of plant or place where sccident axcurred .. DOE HAC KBERRY DOME

\begin{tabular}{|c|c|}
\hline$\bullet$ & 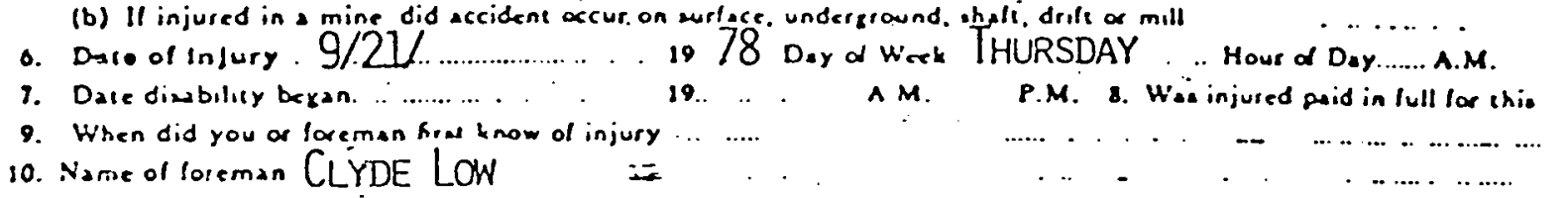 \\
\hline & 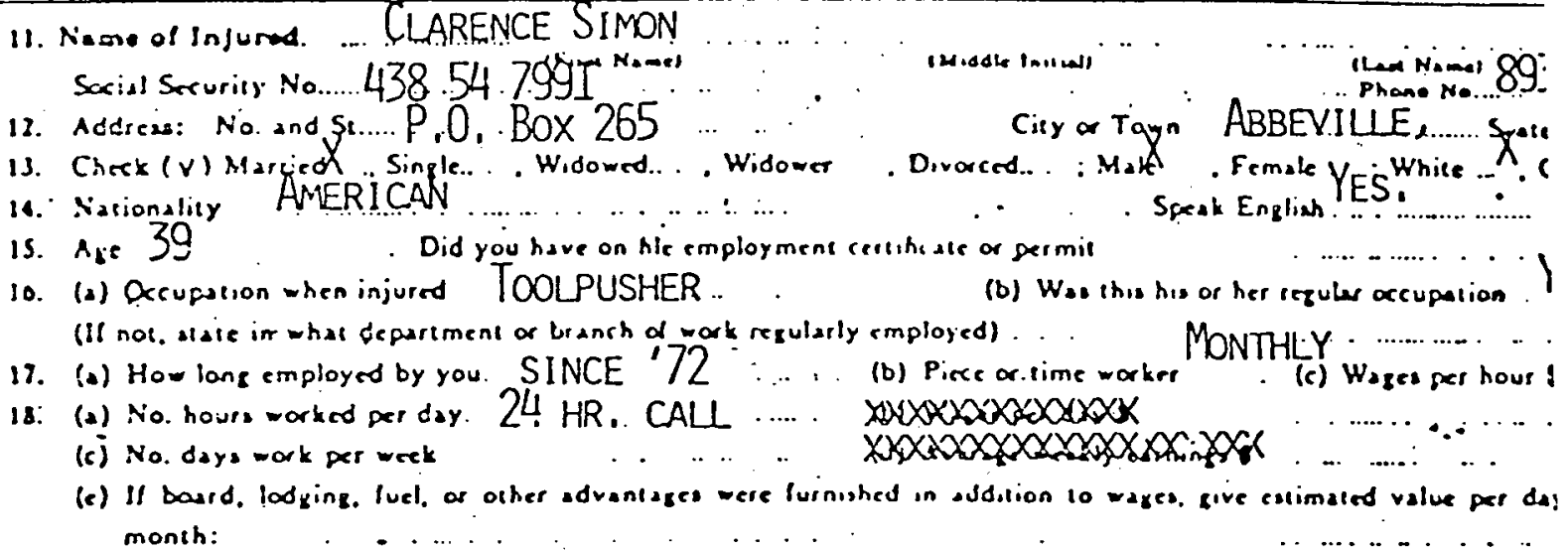 \\
\hline
\end{tabular}

19. Machine, tool or (thing causing injuls:

20 Kind of power, (hand, loot. steam. elc.). 21. Part of machanc on whesh accident oxciutred.

22. (a) W21 alety appliance or regulation provided........... . . . (b) Was it in ume as rime...........

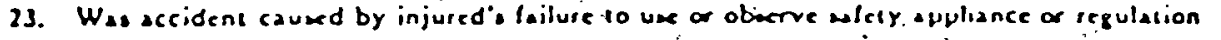

of Injury

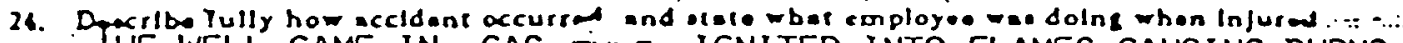
- IHE WELL CAME IN GAS FUMES IGNITED... INTO FLAMES, CAUSING BURNS .OVER..60..

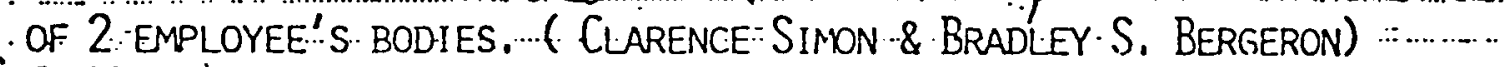

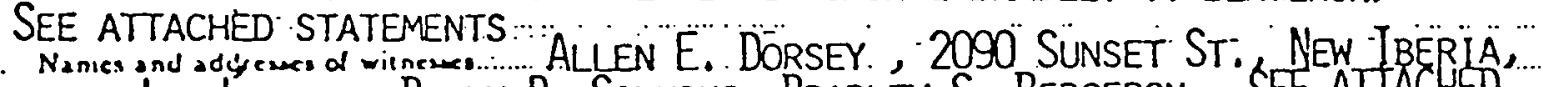

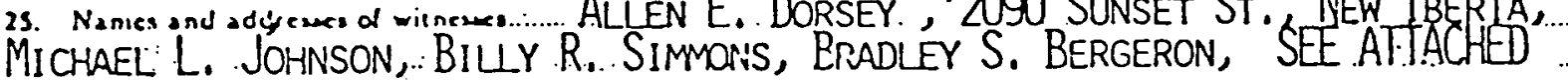

Nivise

26. Nature and localion of injury (dexcribe fully casct locstion ol ampulations of fractures, right or belt) . . ........... 60 TO $65 \%$ BURNS OVER. ENPLOYEE' S:-BODIES_. :

Infury

27. Prohulle lenxih of disclility. ....

28. He. Injured returnid to work $\mathrm{NO}$.........

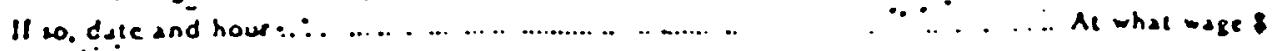

29. At wat acupation ... ..... (2) Nime and addrese of physicien BATON ROUGE.. GENERAL HOSPITAL \& LAKE CHARLES MEMX (b) Name and addiess of toopital...... BATON ROUGE, LA. 


\section{Employer's First Report of Injury}

MID-CONTINENT UNDEAWHITERS. InC.

PHONE: $581-55 \% 7$

WHITNEY BUILDING

NEW ORLEANS, LOUISIANA 70130

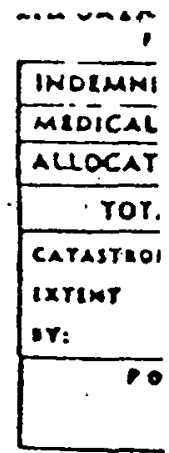

\section{Rig \# 11 Clarence Simon}

\begin{tabular}{|c|c|}
\hline \multirow{3}{*}{ Employer } & I Nam of Employar .... PELICAN WEL SERVICE, INC. \\
\hline & 2. OHee austeas: No. and Se... P.O BOX 52727 \\
\hline & 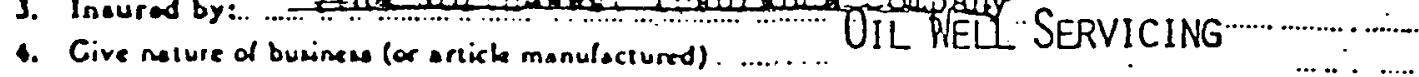 \\
\hline
\end{tabular}

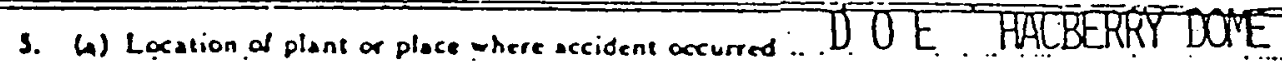

\begin{tabular}{|c|c|c|c|c|c|}
\hline $\operatorname{lmb}$ & 8. & $\begin{array}{l}\text { Date of Infury. } \\
\text { Date dimbility beyal } \\
\text { When did you or for } \\
\text { Name of foseman } \mathrm{L}\end{array}$ & 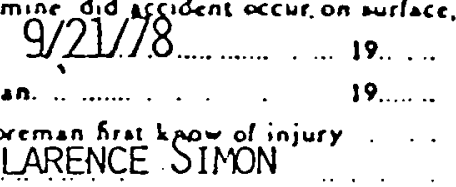 & $\begin{array}{l}\text { underground. } \\
\text { Day of Wisek } \\
\text { A.M. }\end{array}$ & 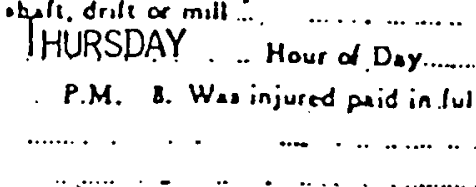 \\
\hline
\end{tabular}

\begin{tabular}{|c|c|}
\hline & 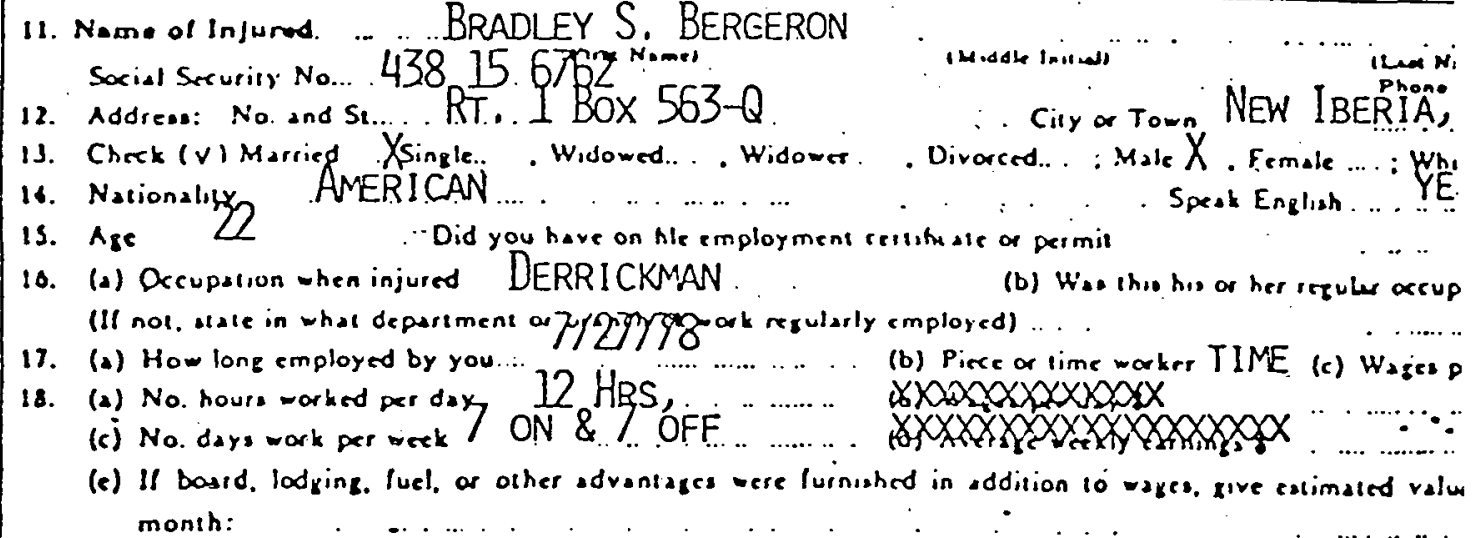 \\
\hline
\end{tabular}

19. Machine, tool or thing causing injury. ........... 20. Kind al power. (ha slesm. cic.).

21. Part of machine on wheh accident accurred.

22. (a) Was wicty appliance or requlation provided............... . ... ...... (b) Was it in ux at lime...

23. Was accident caused by injured's lailure to ux or oburve sulcey appliance or regulation

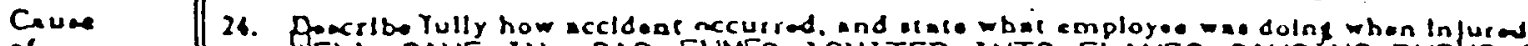

of

Infury

WEL CAME IN, GAS FUMES IGNITED INTO FLANES CAUSING BURNS OVER EO 2 EMPLOYEE'S BODIES.*. (CLARENCE SIMON \& BRADIEY S. BERGERON)

25. Names and addrears of ritnemen... ALIEN E. DORSEY, MICHAEL L. JOHNSON, BILLY -. SeE ATtACHED.

\begin{tabular}{|c|c|}
\hline $\begin{array}{l}\text { Noture } \\
\text { of } \\
\text { Infury }\end{array}$ & 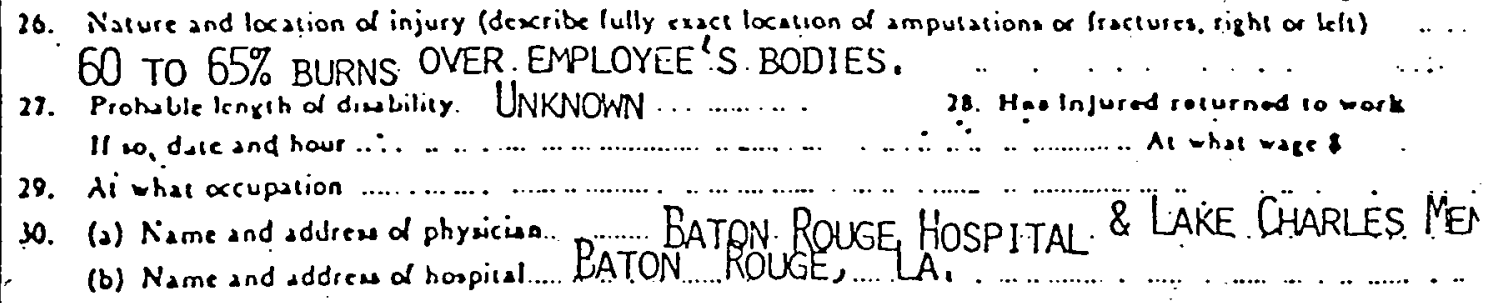 \\
\hline Canes & J1:" Has Infured dired $\ldots \ldots \ldots \ldots \ldots \ldots$ \\
\hline
\end{tabular}

Date of thro coment

$9 / 2278$

Del irani litri, Cra.... 


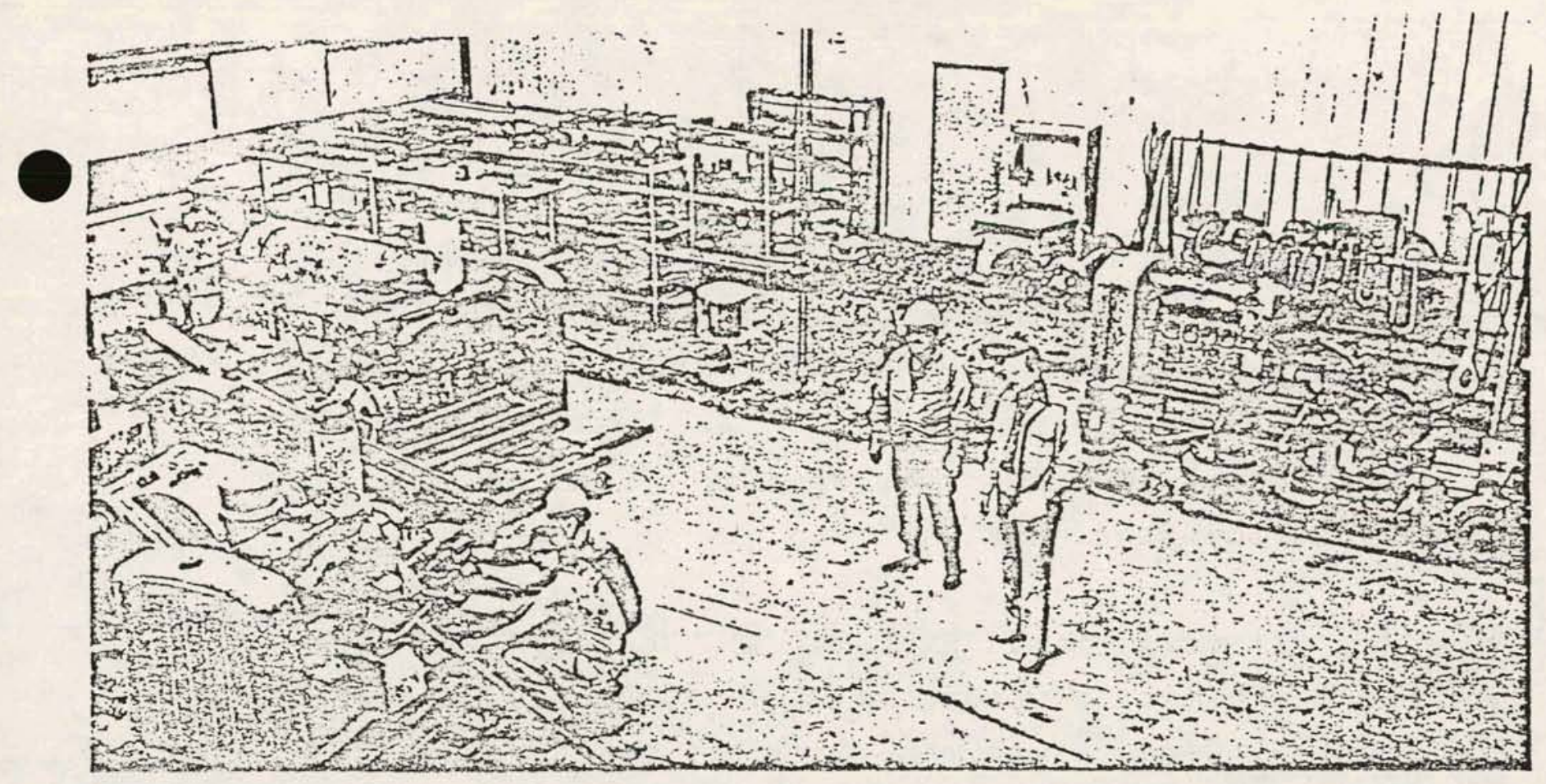

Cecil Guinn (right), president of Pelican Well, and shop foreman Andrew Gaspard check on an equipment maintenance project.

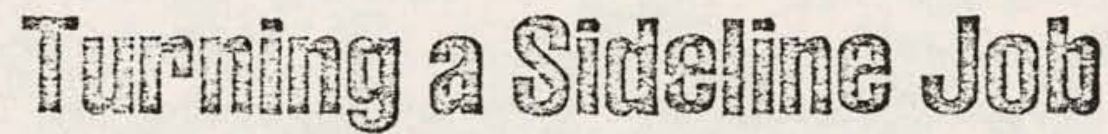

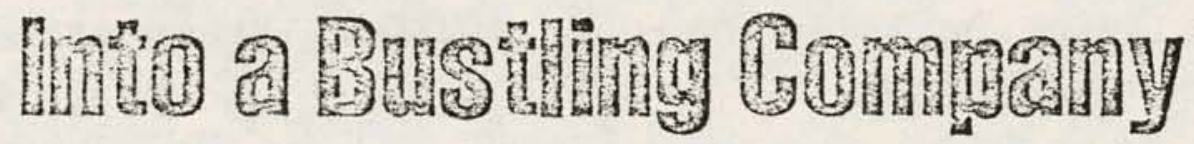

BACK IN 1957, while Cecil Guinn was an agent for Cummings. Inc., a gas-lift valve company later purchased by Otis Engineering Corp., he bought one swab truck and operated it as a sideline job.

Today, 20 years later, this part-time job has become one of South Louisiana's most diversified workover operations.

Known as Pelican Well Servicelnc., the company has one swab truck and eight workover rigs includingtone barge rig. Included are up-to-date pumps and other modern equipment needed for workover jobs.

The company has grown to 120 employees and now has headquarters and two warehouses containing $12,000 \mathrm{sq} f t$ r.ear Lafayette's Oil Center.

In 1957. Guinn formed a partnership with G. W. George Riley of Baton Rouge. After three years, they had grown to two swab trucks and one workover rig, which was a converted swab truck. A year later Guinn bought Riley's inlerest and quit his job at Otis. It was time to devote his full effort to Pelican Well.

How does he look back on such a move?

"I've always loved the oil business, and I've been around the industry 30 to 35 years. I like machinery and good quipment. I like to see things work", he says. "It was a big decision for me 20 years ago when I was employed by Otis. Ileft a good salary and a lot of benefits a large company can olfer. But things worked out well for me."

In 1959 the company moved into its present location on Pinehurst Street. By 1961 it has grown to two swab trucks and three workover rigs. But now Guinn found his busioess more than he alone could operate, so he turned to II. E. "Bill" Person who at the time was with a major oil company. Person became VP in charge of operatons. In 1971 , the company had two swab trucks and seven workover rigs.

But 1973 was really the year of expansion for Pelican Well, the year it acquired two more land rigs and an inland barge rig. Offices were enlarged and renovated to meet growing needs of the company.

How has the workover business changed in the last 20 years?

"Rigs have improved 100 percent," says Guinn. "All equipment is much, much better than it used to be."

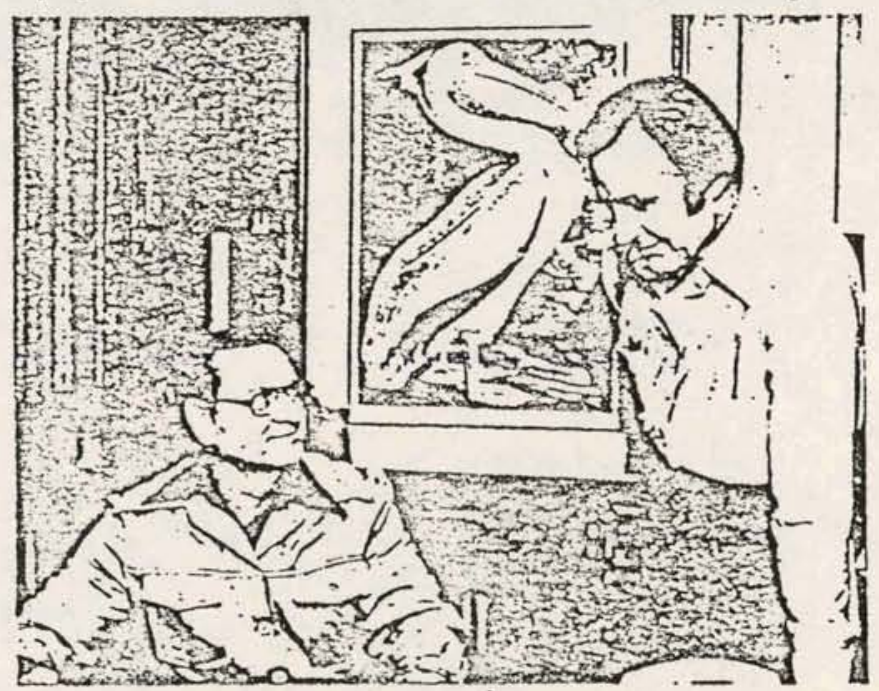

Pelican Well's president and founder Cecil Guinn (right) and VP Bill Person talk workover business. 
Since that article was written and published, Mr. Cecil Guinn has passed away. Mr. Person is no longer employed by the firm.

Mrs. Cecil Guinn is now President, and Mr. Charlie Moncla is Vice President.

Rig \#11 is a Franks Explorer 11 "Rocket." We were working $4-4$ man crews on the rig. A. Dorsey, J. Robertson, E. Simon, H. Comeaux were the drillers of the crew. The men were working $7-7$ shifts of 12 hours a day. We had two tool pushers, Leroy Bowman and Clarence Simon (deceased). Prior to going to work for the DOE in 1978, this rig worked for Crystal Diamond Salt Company (operated by Texaco); working at Jefferson Island - February; C.F. Brawn at Lewisburg - March; McMoran at Buros - April and May; Wainoco. of Holly Beach - June and July; Pel Tex at Duson - July and August; and then DOE on Sept 12.

The month of January and part of February the rig was in the yard being rebuilt. At that particular time $\$ 6 j, 000.00$ was spent on the rig, getting it in first class shape. 


\section{SEQUENCE OF REPORTIYG}

W1th Respect to Blow Out at W.O. \#6

West Hackberry $9 / 21 / 78$

$4: 45$

$4: 50-5: 30$

$5: 35$

$5: 55$

$6: 05$

$6: 08$

$6: 12$

$6: 15$

$6: 16$

$6: 19$

$6: 25$

$7: 05-7: 20$
Enile Senac called - Talked to Woodson

Informed us No. 6 at West Eackberry was ON FIRE.

Reported to Ron Wilson P/G, Ruggs Stapleton P/G

Called National Response Control

Raymond Miller (reported)

Raymond Eenry, Red Adair - Told sequence

Richard Hattoberg flying from Amarillo to West Hackberry

Cameron Parish Sherriff's Office

Patrick Levry (reported)

Louisiana State Police

Sgt. Adcock (reported)

U.S. EPA No duty officer will call back

Louisiana Department of Consezvation - no answer

Oi1 \& Eazardous Material Epill

Reporting Service no answer

Louisiana Department of Wildlife and Fisheries

Lloyd Bienvenue (reported):

Oil \& Fazardous Material Spill - number changed and unaile to get new number.

EPA Dallas - Wallace Copper (reported) 


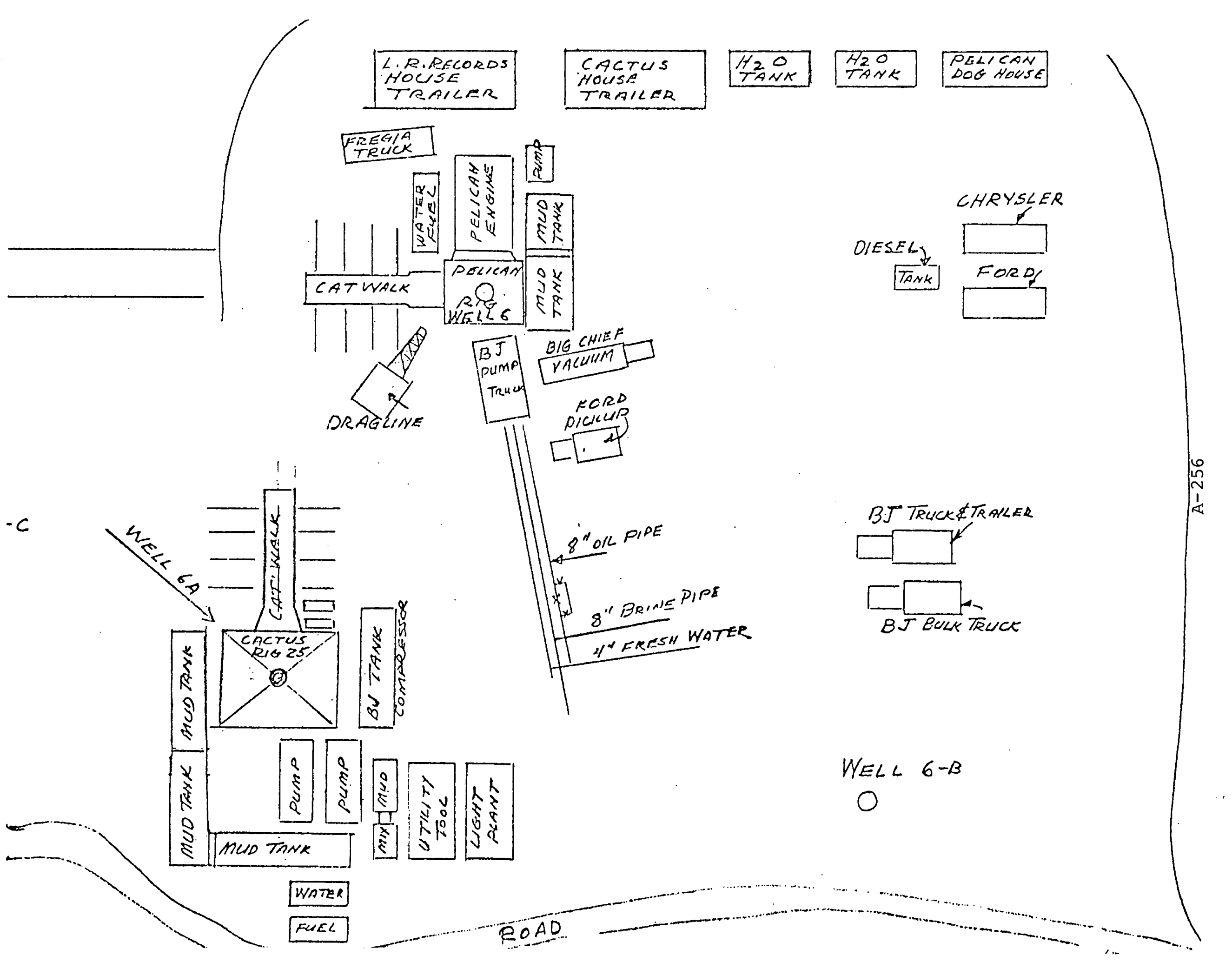




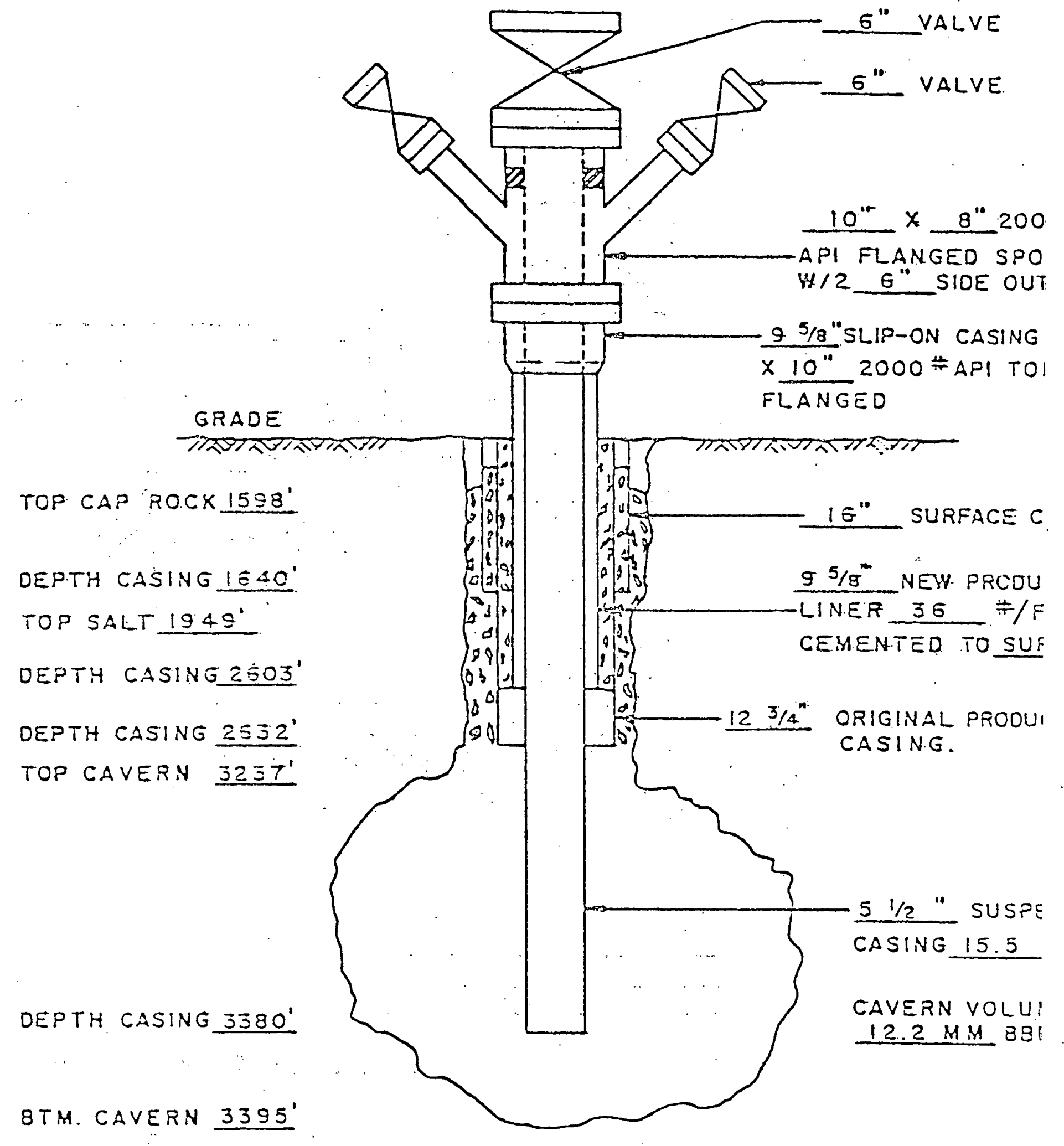

WORK COMPLETED ON

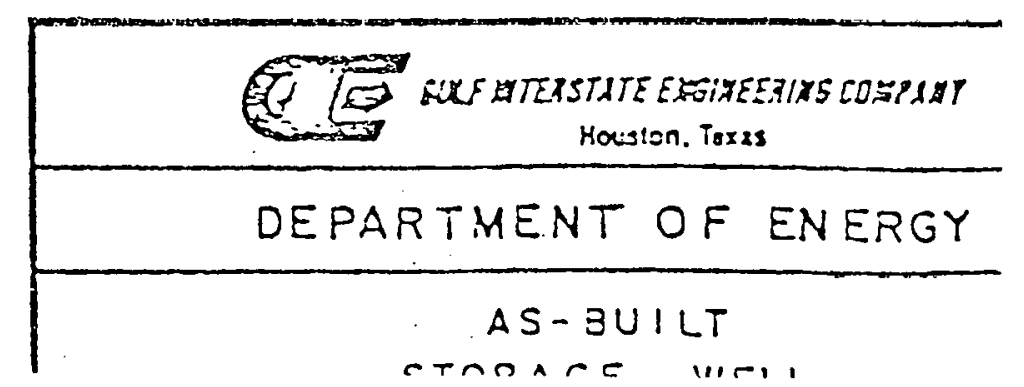




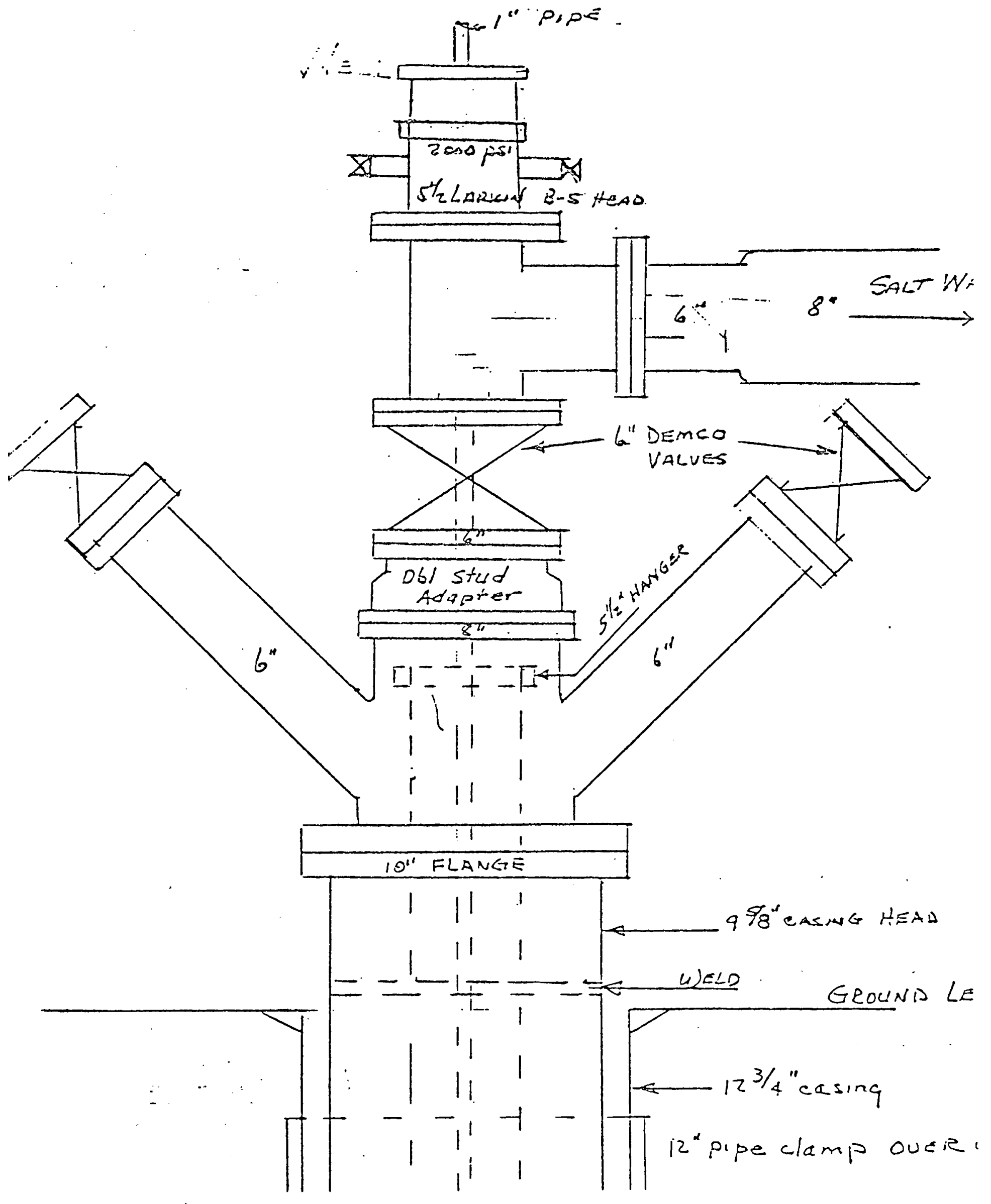


Ho 6 HELL CONFIGURATION

WHILE SETTING

TAM BRIDGE PLUG

$$
27 / 8 \cdot T U \theta_{1 N G}
$$

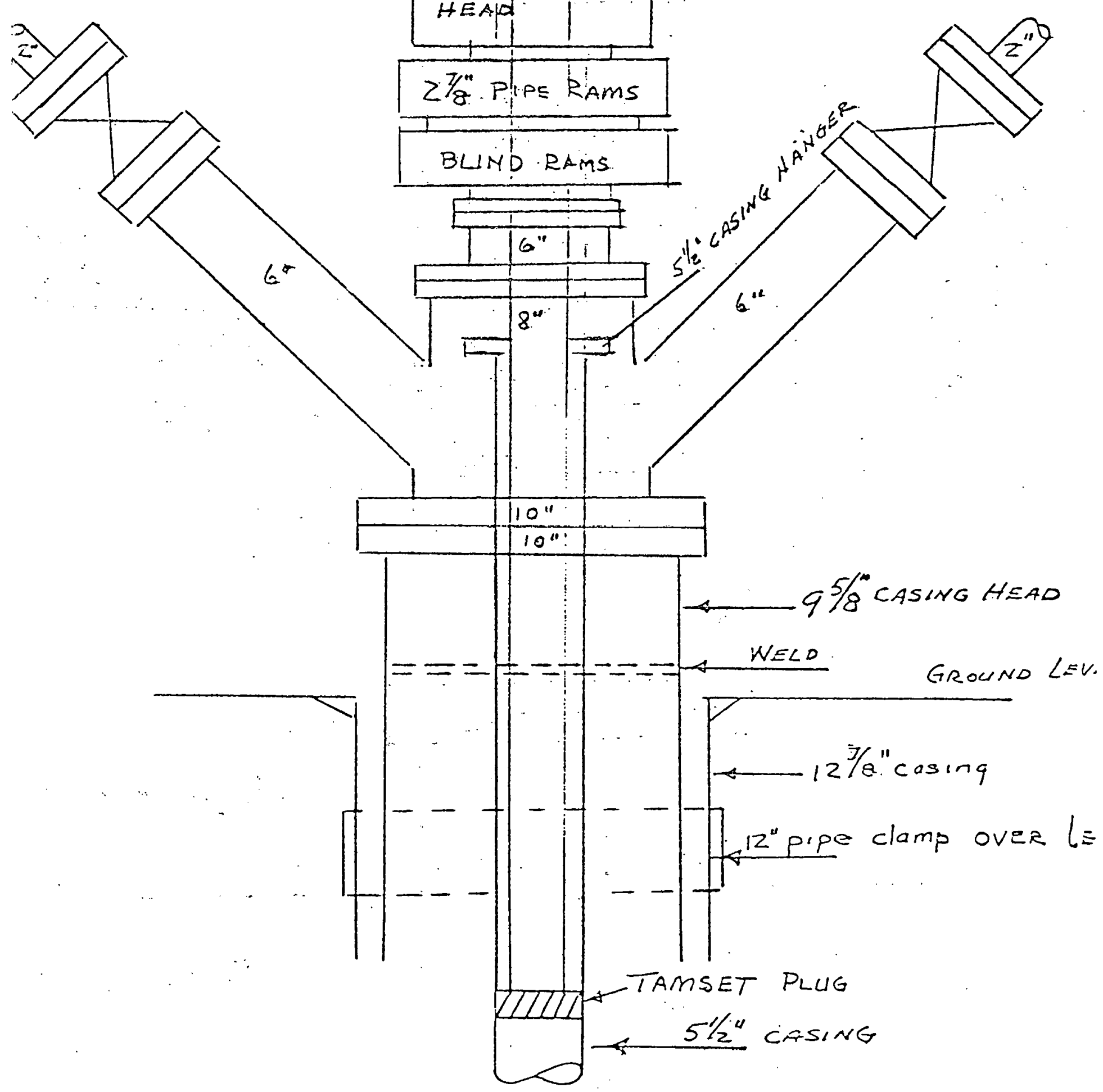

$A-259$ 
Configuration of WELL HEAD @ Time of Blowout west act berry WELL NC. 6
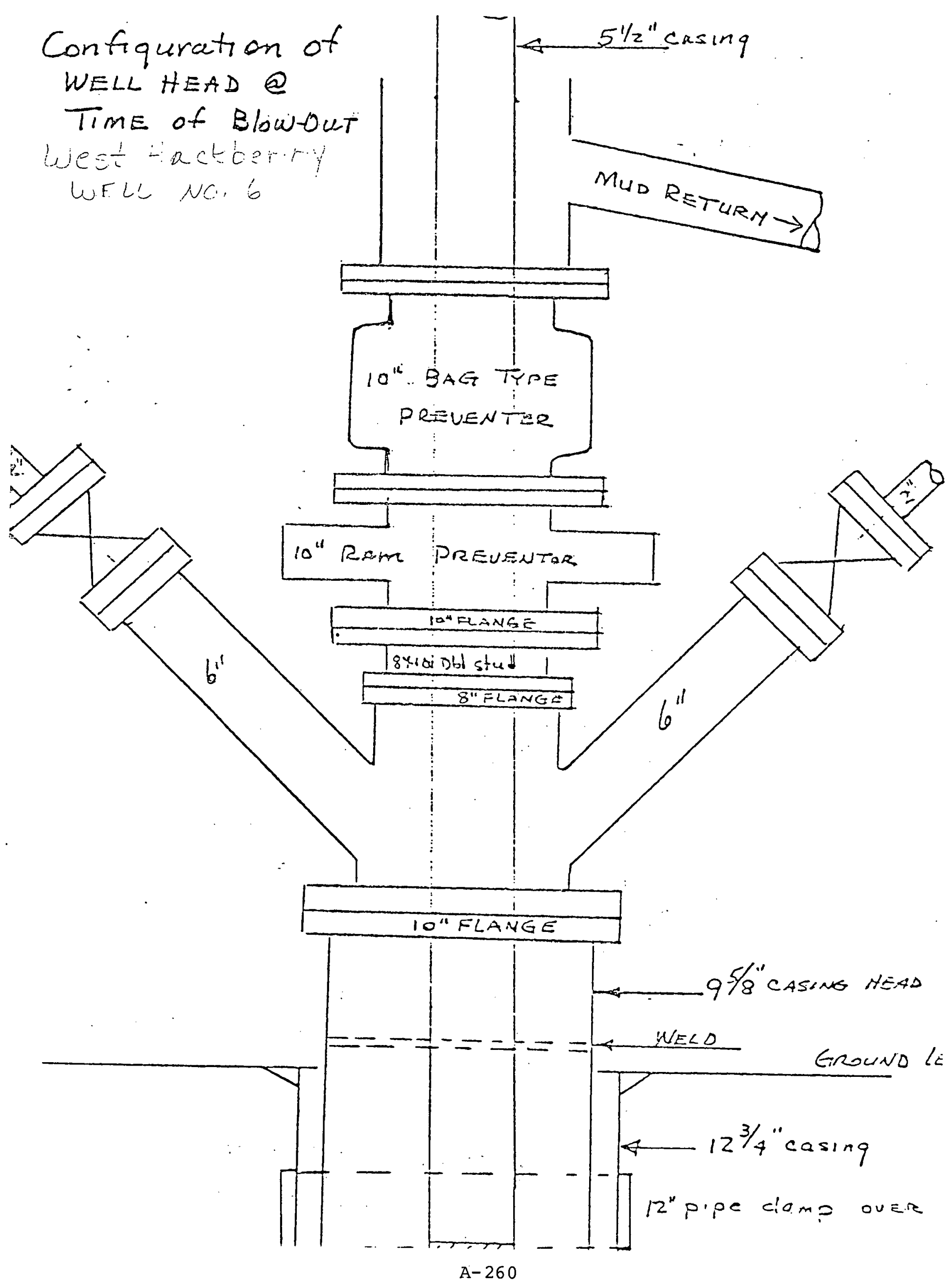
Completed Well No 6 WEST HACKBERRY

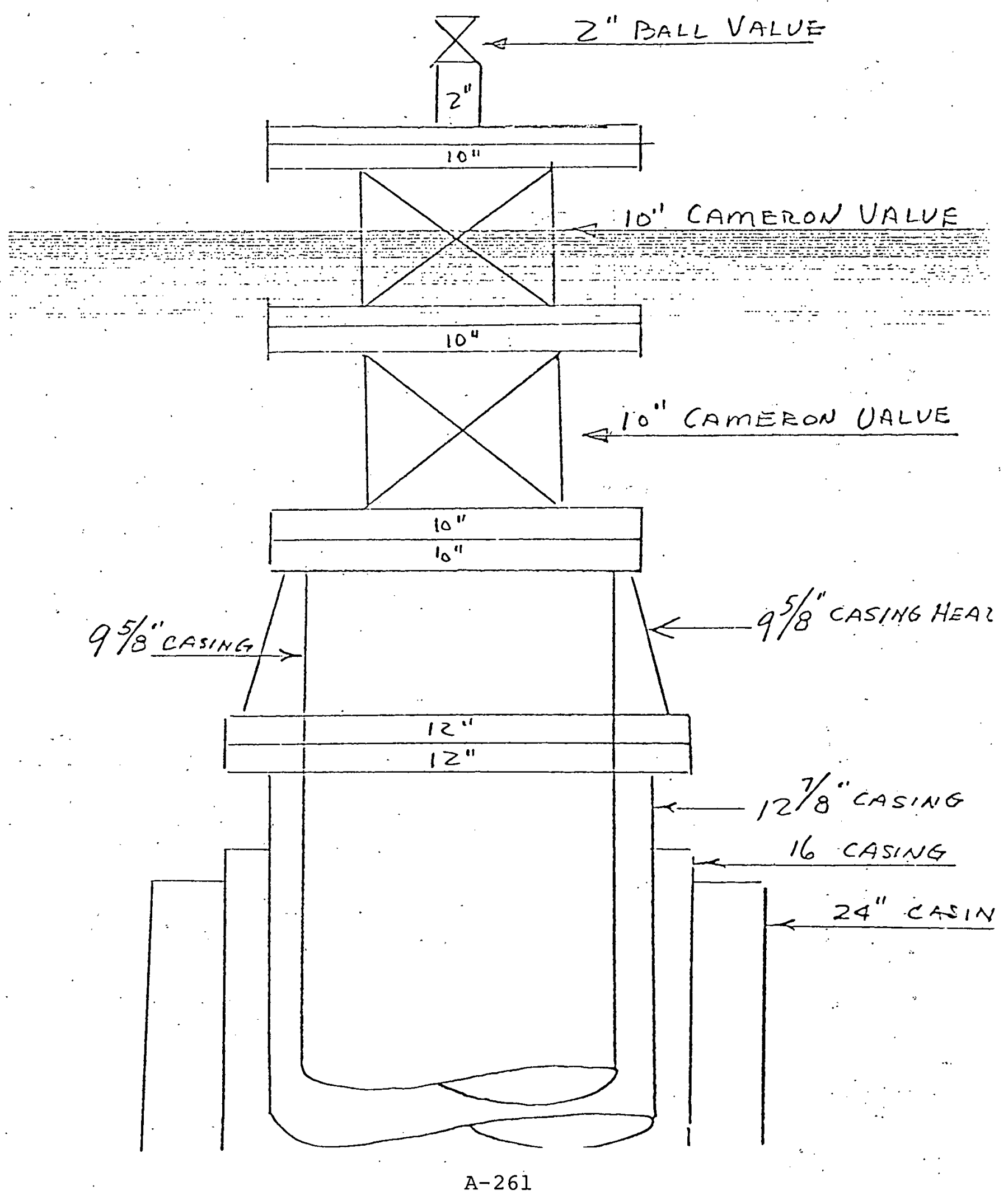


(1)

INTERPIATIOHAL

$$
\begin{aligned}
& \text { fi. No } \\
& 4.20011
\end{aligned}
$$

TamSet Inflatable/Retrievable Packer

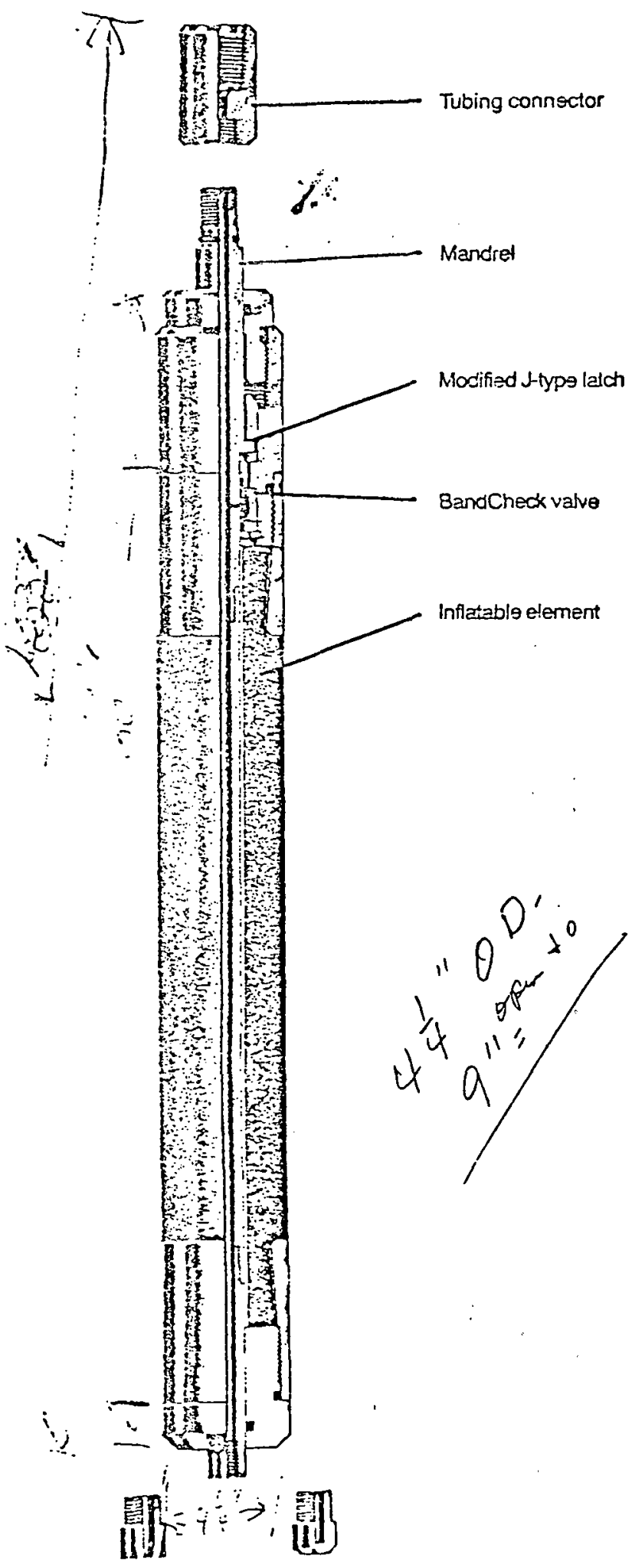

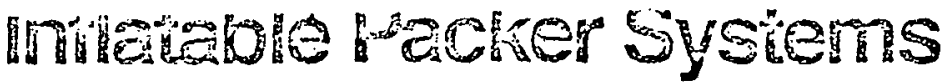

\section{TamSetim \\ The Versatila Inflatable/Retrievable}

The versalile Tauset in $n$ atable/retrievable packer offers swift, sure setting and retrieving for a wide variety of applications. When required, it can be unseated and relocated in the hole without tripping to the surface. The TamSet is the prinary element in production systems (and in systems for testing and treating). TamSet packers can also be run in tandem assemblies, straddle-pack assemblies, or as inlatable/retrievable bridge plugs. TamSet packers can be run on tubing, drillpipe or drill collars.

\section{Basic Operation-Running and Setting}

Depending on the type of operation, TamSet inflatable/retrievable packers are run in with either the TanCon collet connector, TamDump circulating valve or tubing connector above the packer. At setting depth, a setting ball is dropped to seat in the mandrel cho'se and the packer is inflated to about 500 psi. After a few minutes to allow the inflatable element to conform to the formation walls, two or three points of slack will indicate whether the pacter is firmly seated. Pressure is increased slowly to about 2,000 psi to fully set the packer and shear the setting ball through the choke, opening the mandrel for fluid flow.

\section{Basic Operation-Relocating, Retrieving}

TamSet inflatable/retrievables are easily deflated. A quarter turn to the left (positive stop) releases a modified $J$-type latch, which allows the mandrel to move upivard, raising the inandrel ports above the BandGheck valve. Inflating fluid then flows back into the mandrel and the packer deflates for retrieval or relocation. If the pacher is to be reset in the hole, another setting ball is dropped and the setting procedure is repeated.

\section{Retriavable Bridge Plug}

The TamSet is desizned for use as a retrievable bridge plug for isolating lost-circulation zones, packing off . at oil/water interface and other bnidging applications. The standard TamSet packer is used with a bull plug in place of the ball choke. It is run with a TamCon collet connector as described in the Basic Operation section, except that no setting ball is required.

\section{Tandem Packer Assembly for increased seal length}

When formation conditions require extended seal length, two or more TamSet packers can be run in tandem. using packer tube extensions and connector subs. The TamSet design allows the packers to be set simultaneously and retrieved in a single, simple operation.

See page 6347 for TamSet specifications. 
How to Use the Working Pressure Charts

Use these charts to select the proper size of TamSet or

TamCap inflatable elements for your application. For the

TamSet, for example, if the hole size is $6 y_{4}$ inches, any of

five inflatable element sizes could be used, from 3\%8 O.D. to $51 / 2$ O.D. The 51/2 O.D. would withstand the highest differential pressure $(5,200$ psi as shown by the dotted line). The rated working pressure decreases as the O.D. of the inflatable element decreases.

Standard TamSet Sizes

\begin{tabular}{llllllllllll}
\hline O.D. $2^{1 / 2}$ & $27 / 8$ & 3 & $31 / 2$ & $37 / 8$ & $41 / 4$ & 5 & $.51 / 4$ & $51 / 2$ & $61 / 4$ & 7 & $71 / 4$ \\
\hline
\end{tabular}

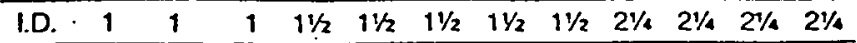

All TAMSET packers are approximalely 81 inches overall. Larger inside diameters are available on request. Consult TAM International tor special inflatable packer requirements.

TamSet Inflatable Element Outside Diameter, inches

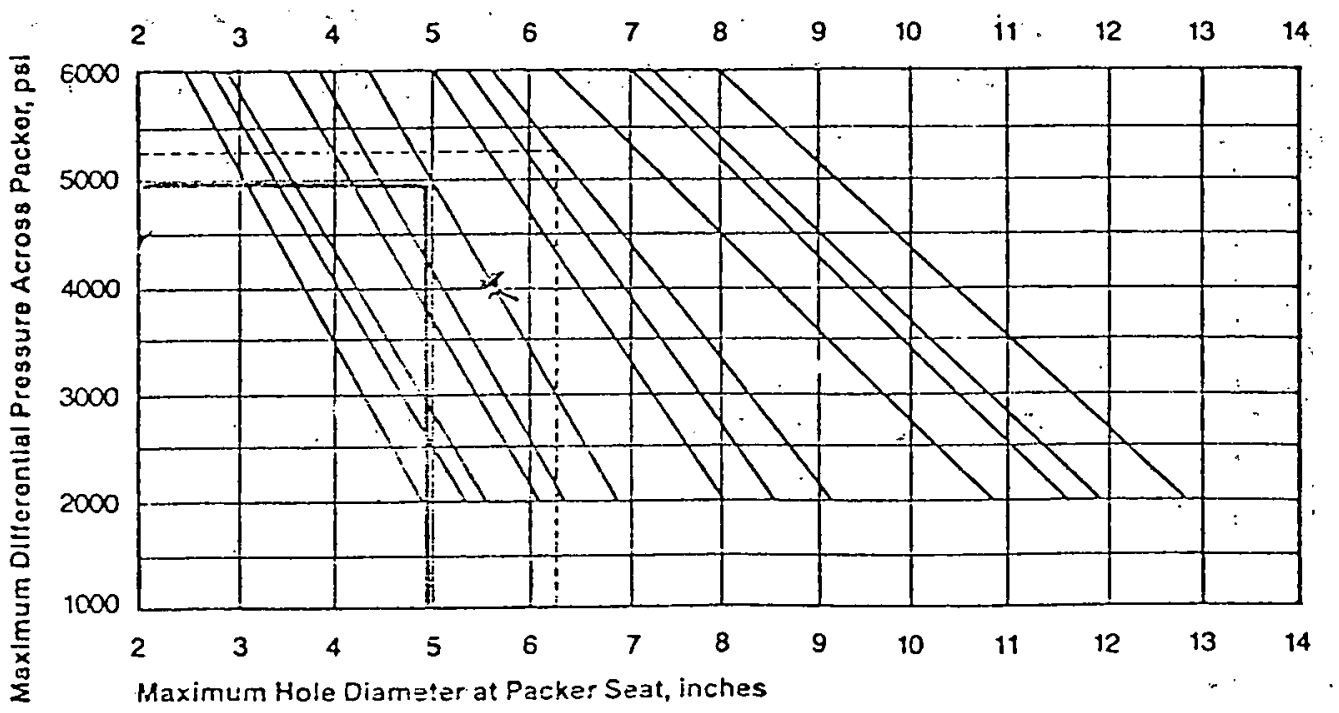

\section{Standard TamCap Sizes}

\begin{tabular}{|c|c|c|c|c|c|c|c|c|c|c|c|c|c|c|}
\hline MAXIMUMN O.D. & $5 \% / 4$ & $61 / 2$ & 7 & $7 / 8$ & $81 / 4$ & 9 & $10 \% / 4$ & 11 & $12 y_{4}$ & $133 / 4$ & $151 / 2$ & $18 \%$ & 21 & 24 \\
\hline NOMINAL CASING O.D. & $41 / 4$ & 5 & 5 & 658 & 7 & $7 \times 8$ & 856 & 948 & $10 x_{4}$ & $113 / 4$ & $13 \% 8$ & .16 & 1856 & 20 \\
\hline
\end{tabular}

NOTE: Special sizes available on request.

Maximum TamCap Outside Diameter, inches

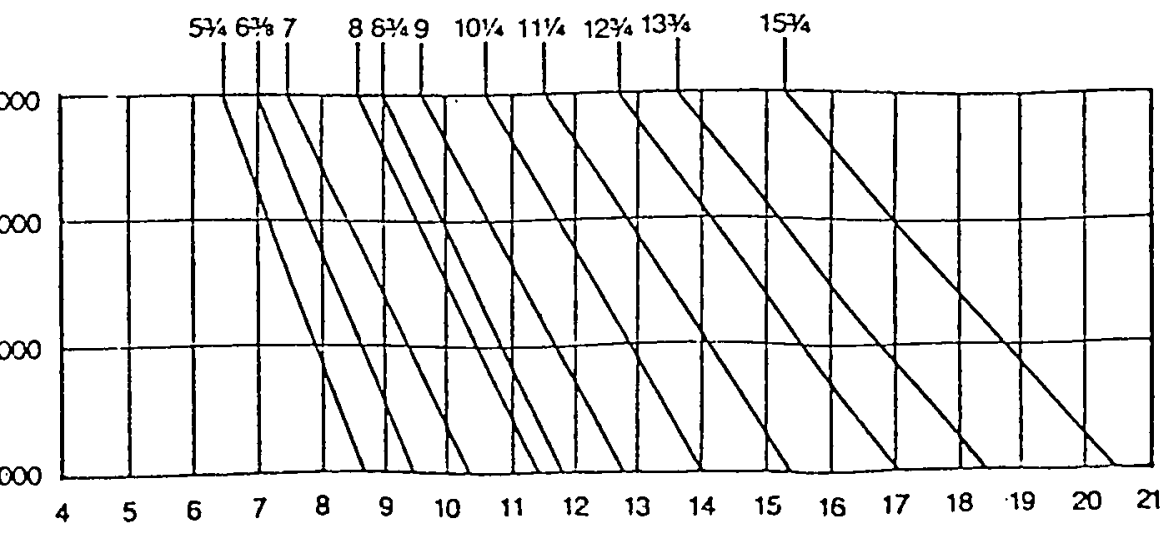

Maximum Hole Dlameter at Packer Seat, Inchas 


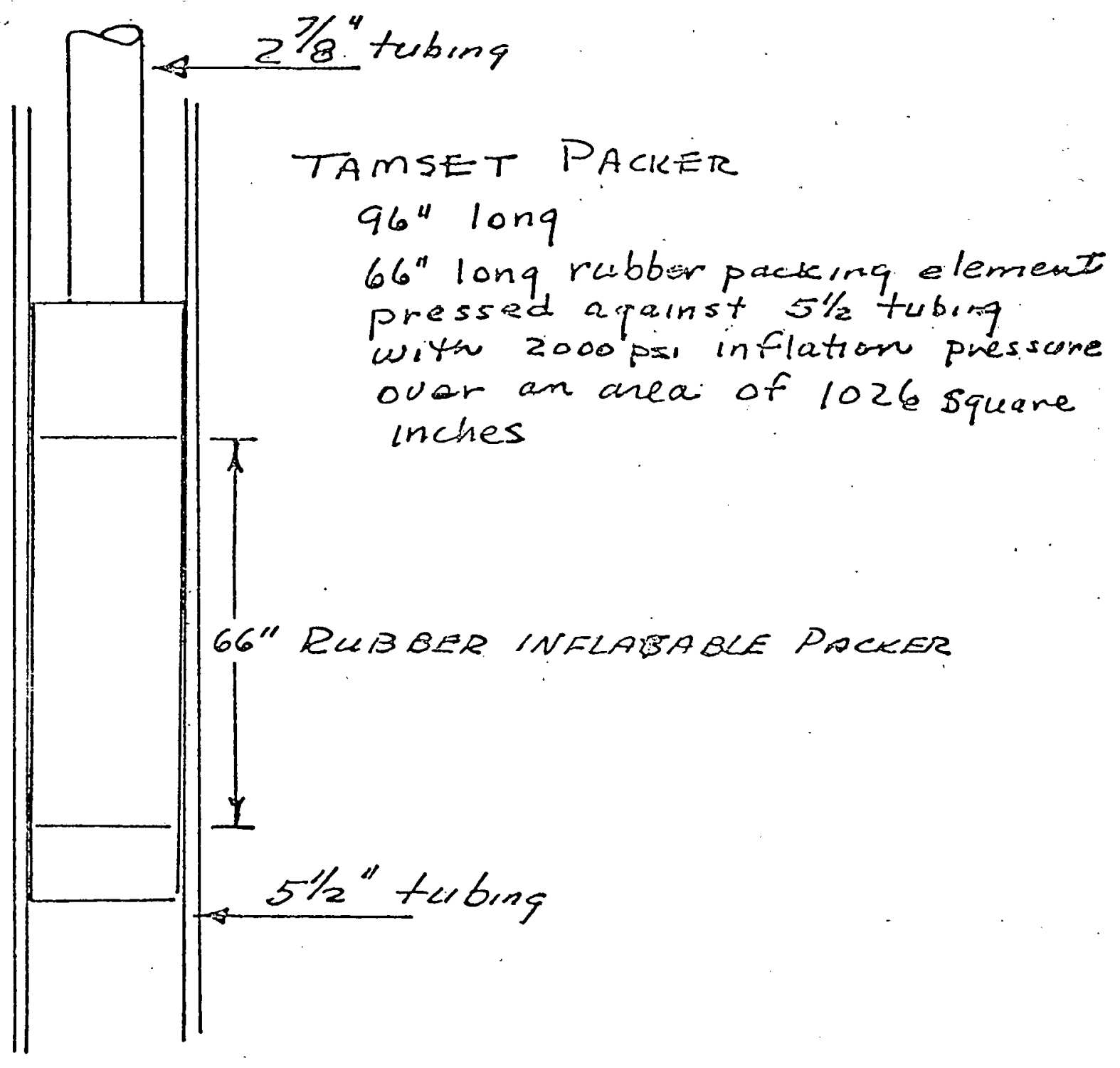

A- 264 
APPENDIX XIII

Drilling Reports

$A-265$ 


\section{THIS PAGE}

\section{WAS INTENTIONALLY}

LEFT BLANK 
LOUIS RICORDS \& ASSOCIATES, INC. (?)

SITE $B O F$ JOD NO.

1 CASING SET: SIZE

REPORT NO. DAYS FROM SPUD
DAILY DRILLING PROGRESS REPS DATE $4-12-78$

\section{PRESENT OPERATION}

DEPTH AND FORMATION

BI.T \#

JETS SIZE/MAKE/TYPE

BIT \# SIZE SIZE/MAKE/TYPE

JETS SIZE

ROTARY RPM

PUNP \#1: LINER SIZE

PUMP \#2: LINER SIZE

NUD: TYPE

NUD PROPERTIES: WT. $\mathrm{IV} / \mathrm{YP} \perp 1$ OPERATIONS LAST 24 HRS Elowine Brite Erower 《t DEDTH WELL NOLCE:

FT. TOOL PUSHER ESTIMATED DAYS TO COMPLETE GRADE: T ANNULAR VELOSITY WEIGHT ON BIT STROKE __ PRESSURE PSI SPM STROKE __ PRESSURE PSI SPM MUD CONPANY WL $\quad$ PH
FTGE IAST 24 HRS SERIAL NO.

GRADE: T SERIAL NO. B G GPM GPM VIS WL $\mathrm{CL} \_\mathrm{CA}$

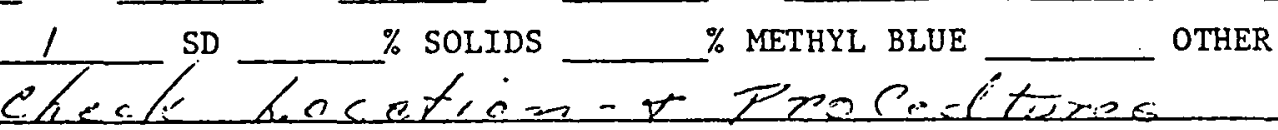
To Peduee tinessiste

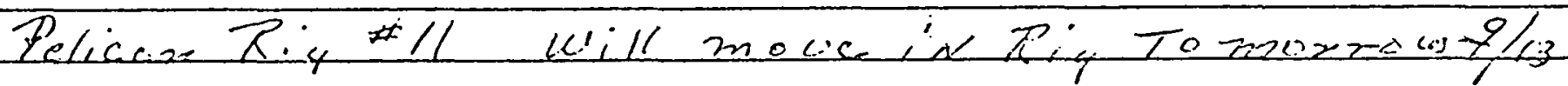
Lork Quer

Bottom Hole Assembly

Accidents

DAILY NUD $\operatorname{COST}$

DAILY RIG

CINA. NUD COST

DAILY SUPPLIES \& SERVICES ifcos

(Include rig fuel if operator's $\cos t$ ) CUAN. SUPPLIES \& SERVICES Operating time hrs. Rig repalr EQUIPNENT CORRENTS nRTLLING FORENLN iT. SUI'T.

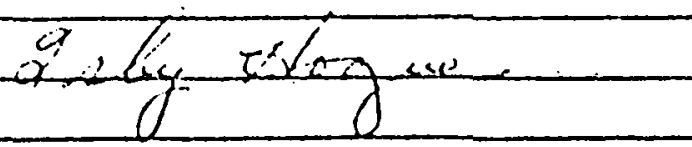

CURA, RIG

TOTAL DAILY COST

400

*total cura. cost Aco hrs. Total down time

DRILLING SUPT. ASST. SUPT.

- Approved, Louls Records \& Associates, Inc. 
LOUIS RECORDS \& ASSOCINTES, INC DAILY DRILLING PROGRESS REP DATE $9-13-48$

SITE DOF JOB No.

LAST CASING SET: SIZE DEDTH well no. Go contractor Pe.licirn: ire 11 FT. TOOL PUSHER _ ECETESOT REPORT NO. 2 DAYS FROM SPUD _ _ ESTIMATED DAYS TO CORPLETE

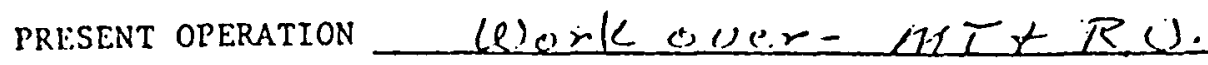
DEPTH AND FORMIATION FTGE LAST 24 HRS

BIT \# SIZE/MAKE/TYPE

JETS SIZE

FTGE HRS

BIT $\#$ SIZE/MAKE/TYPE

JETS SIZE

ROTARY RPM

PUMP \#1: LINER SIZE

PUMP \#2: LINER SIZE MUD: TYPE

MUD PROPERTIES: WT. IV/YP 1 GELS FTGE WEIGHT ON BIT WEICHT ON BIT STROKE STROKE MUD COMPANY. HRS

PRESSURE
PRESSURE SERIAL No.

GRADE: ${ }^{\mathrm{T}}$ SERIAL NO. ${ }^{\mathrm{B}} \longrightarrow \mathrm{G}$
SERIAL NO. GRADE: $T$ B G ANNULAR VELOSITY $\begin{array}{ll}\text { PSI } & \text { SPM } \\ \text { PSI } & \text { SPM } \\ & \text { GPM }\end{array}$ $\mathrm{WL} \mathrm{CL} \longrightarrow \mathrm{CA} \longrightarrow \mathrm{CA}$ $\%$ SOLIDS OTHER

\section{OPERATIONS LAST 24 HRS}

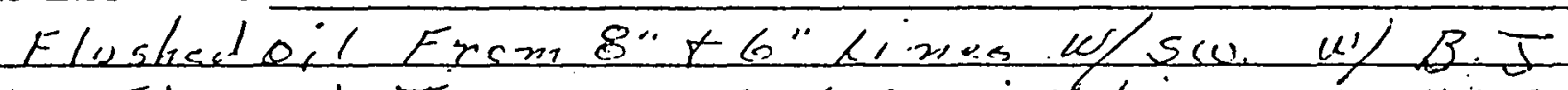

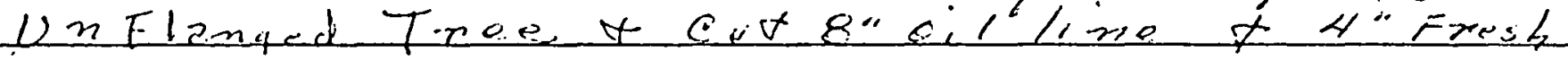
luterline

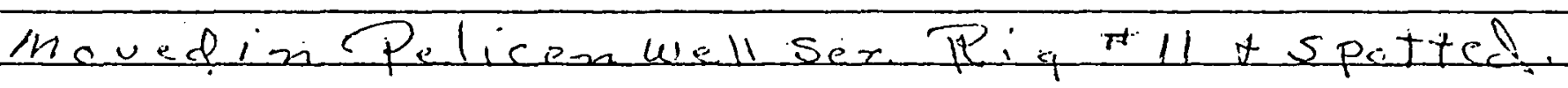

Bottom Hole Assembly

Accidents

DAILY NUD COST

CUNR. MUD COST

DAIII SUPPLIES \& SERVICES

(include rig fuel if operator's cost)

CUSC. SUPPLIES \& SERVICES

Operating time

RQQUIYIENT CONENTS

DRILLING FORELIN

ASST. SURT.

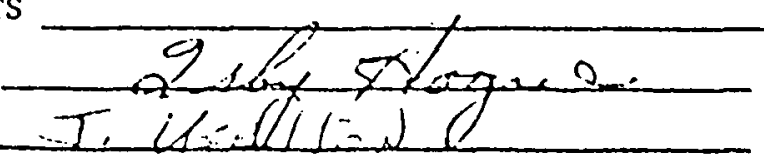

$M T-R O, R D+M O$

DAILY RIG

CURA. RIG

TOTAL DAILY COST

* total cusa. cost

hrs. Total down time

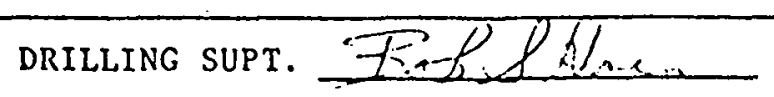
ASST. SURT.

- Approved, Louls Records \& Associates, Ine. 
DAILY DRILLING PROGRESS REPL

DATE $4-14-79$

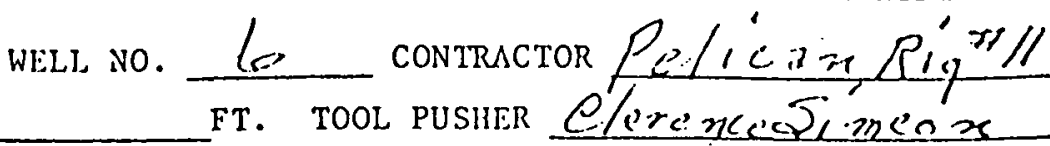

LOUIS RECORDS \& ASSOCIATES, INC

SITE DOE JOB NO.

- at casing set: sIze

....'ORT NO. 3 DAYS FROM SPUD

PRESENT OPERATION

DEPTH AND FORILTION

BIT SIZE/MAKE $/ T Y P E$

JETS SIZE

SIZE/MAKE/TYPE

BIT \# IZE

JETS SIZE

ROTARY RPM!

PUMP \#.1: LINER SIZE

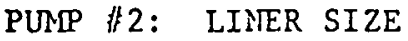

IND: TYPE

MUD PROPERTIES:

PV/YP $1 \quad$ GELS GELS FTGE STROKE ESTIMATED DAYS TO COMPLETE

DEDTH

FTGE LAST 24 HRS SERIAL NO.

GRADE: T B G FTGE UIRS HRS GRADE : $T$ B G ANNULAR VELOSITY WEIGHI ON BIT PRESSURE PSI SPM GPM STROKE PRESSURE PSI SPM GPM MUD COMPANY

MUD COMPAYY

OPERATIONS LAST 24 HRS

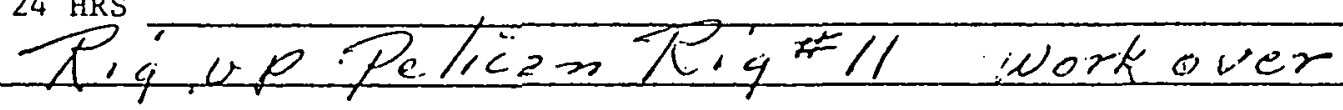

Haoled 175 bbls ll vis. $150-$ Salt cel znad

still Flaking Sis. Froma Pome-Pross-65 $5 i-150 x$

Bottom Hole Assembly

Accidents none

DAILY NUD COST

DAILY RIG

CURN. NUD COST

DAILY SUPPLIES \& SERVICES $1260-$ TOTAL DAILY $\cos T$

(include rig fucl if operator's'cost) CURM. SUPPLIES \& SERVICES 3023 Operating time 12 hrs. RIg repalr EQUIPMENT COIERENTS DRIILING. FOREMUN

iT. SUPT.

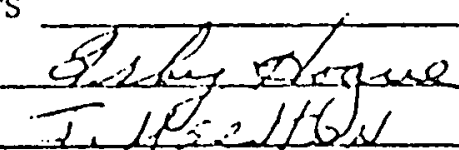
CURA. RIG

$15,000-$ 3260

*total cuial. cost hrs. Total down time DRILLING SUPT. ASST. SUPT. 
LOUIS RLCORES \& ASSOCIATES, INC! DAILY DRILLING PRoGRESS REIR DATE $9 \cdot 1.5 \cdot 78$

SITE D. O.F

LAST CASING SET: SIZE

REPORT NO.

PRESENT OPERATION

DEPTH AND FORMATION

BIT \# SIZE/MAKE/TYPE

JETS SIZE

DAYS FRON SPUD JOB NO.

Sim DEVTH
Well No. 6 contractor Pe/ Gajt/1/ ft. TOOL pusher e/erence Sinzec. ESTIMATED DAYS TO COMPLETE

BIT \# SIZE/MAKE/TYPE

JHTS SIZE FTGE HRS

ROTARY RPM WEIGHT.ON BIT

FTGE LAST 24 HRS

PUMP \#1: LINER SIZE STROKE PRESSURE PRESSURE SERIAL NO.

PUNP \#2: LINER SIZE STROKE HRS GRADE: T B G

MUD: TYPE MUD COMPANY

MUD PROPERTIES: WT VIS WL $\mathrm{PH}$ $\mathrm{CL}$ CA PF $\mathrm{PV} / \mathrm{YP} \quad$ GELS $/$ SD $\%$ SOLIDS $\%$ METHYL BLUE OTHER OPERATIONS LAST 24 HRS

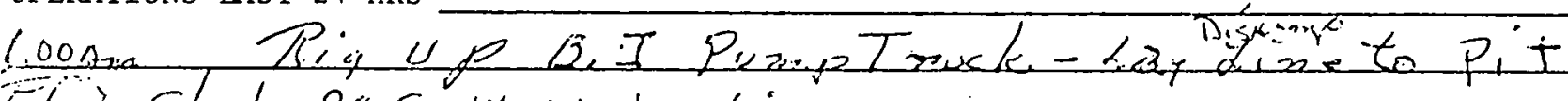

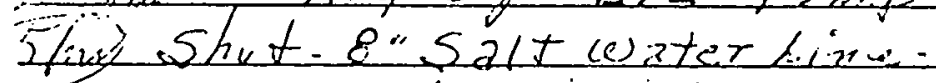

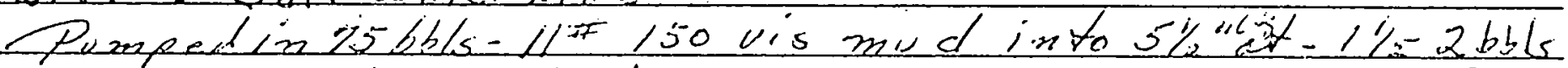
lam mingl"epextepit Gool sw Returns 5.Di weil deed-

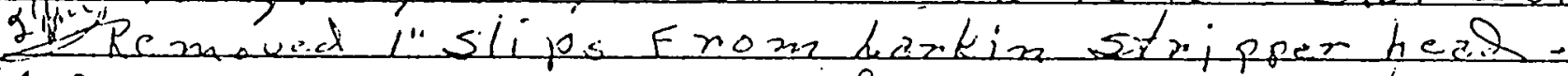

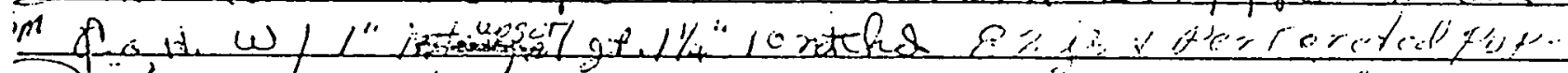

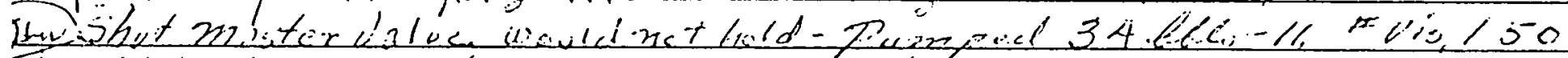

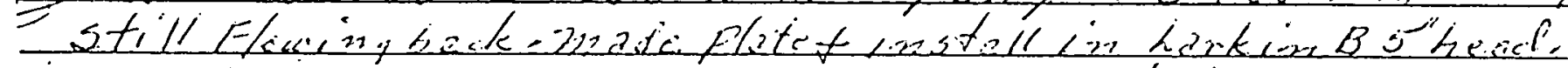

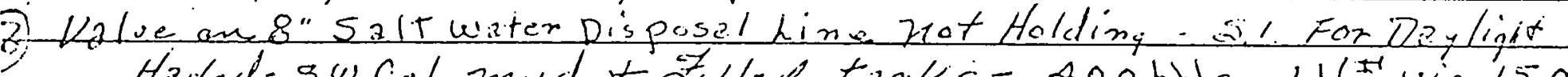

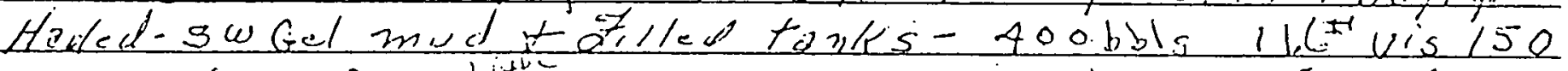

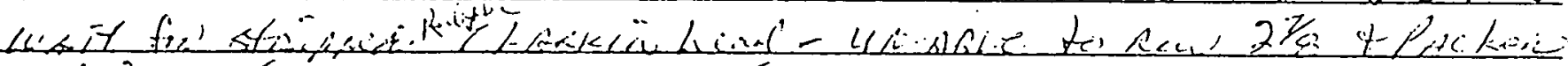

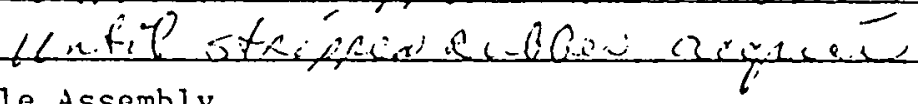

Bottom Hole Assembly

Accidents

DAILY NUD COST

CUNM. NUD COST

DAILY SUPPLIES \& SERVICES Respex $343 \%$

(include rig fuel if operator's cost) CUNM. SUPPLIES \& SERVICES operating time f2. (Q)ivise 4462 EQUIPMENT COMAENTS ORILLING FORESLAN ASST. SUPT.

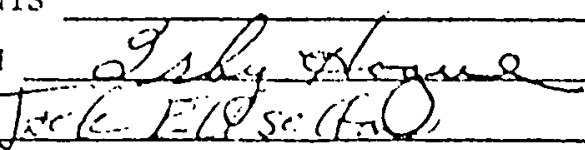

DAILY RIG

CUNA. RIG

TOTAL DAILY COST

*total cusm. cost hrs. Total down time 3850 18,850 \% 289 45909 0

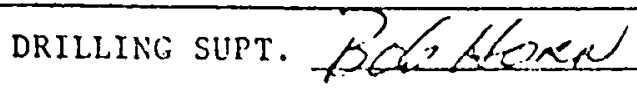
ASST. SURT. 
LOUIS RECORDS \& ASSOCIATES, INC?

DAILY DRILLING PROGRESS REP

DATE $9-16-25$

SITE DOE JOB NO.

I CASING SET: SIZE REPORT NO. 5 DAYS FROM SPUD DEDTH WEIL No. 6 contrnctor Pe:lican . $18 / 1$

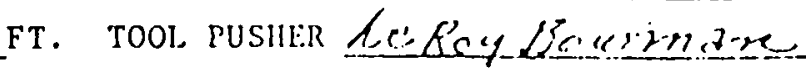
F.STIMTED DAYS TO COIPLETE

PRESENT OPERATION

DEPTH AND FORMATION

FTGE LAST 24 IIRS

BIT \#

SIZE/MAKE/TYPE

SERIAL NO.

JETS SIZE FTGE HRS

BIT if SIZE/MAKE/TYPE

JETS SIZE FTGE HRS

ROTARY RPM. WEIGHT ON BIT

PUIP $\# 1:$ LINER SIZE STROKE

PRESSURE GRADE: T B G

PUNP \# 2: LINER SIZE STROKE PRESSURE GRADE: T SERIAL NO.

MUD: TYPE MUD COMPANY

MUD PROPERTIES: WT. VIS

WL $\mathrm{PH}$ CL $\mathrm{CA}$ PF PV/YP 1 SD $\%$ SOLIDS $\%$ METHYL BLUE OTHER

OPERATIONS LAST 24 HRS

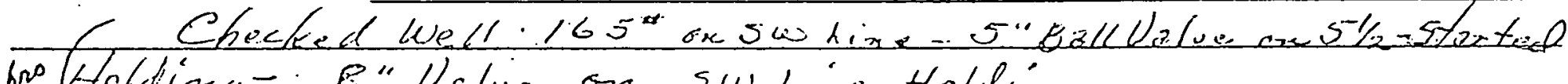

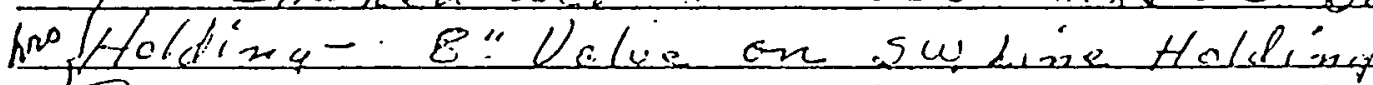

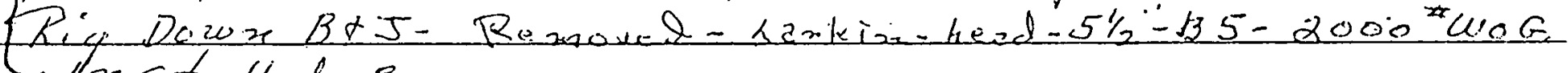
- Installed Bopo.

\section{Instelled suhstructure Chameal Pipe Pama to $27 / \% "$}

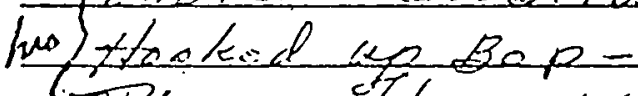

Mig up ofloce we tho torgoth 27\%" Tooks -

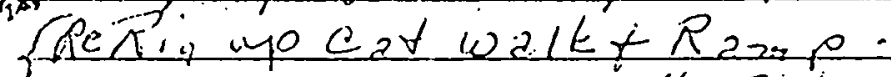

- measirad $11+g 52 \% " P h 6-$

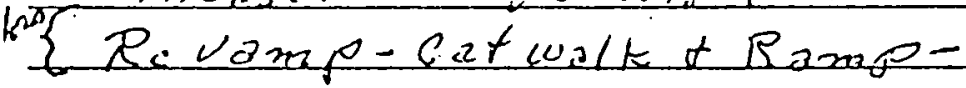

Bottom hole Assembly

Accidents

DAILY MUD COST

mix - $57064 / \mathrm{s} / 13^{*}$ yis 150 mudbaILY RIG 12,136

CUNA. RIG

3850

CUNM. NUD COST

15,347

TOTAL DAILY COST

(include rig fucl ii operator's cost)

CUNA. SUPFLIES \& SERVICES

21,809

Operating time

$24 \mathrm{hrs}$.

RiE repalr 22,700

EQUIPNENT CONNENTS

DRILLING FORERAN

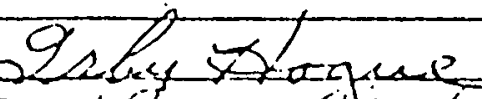

iT. SUPT.

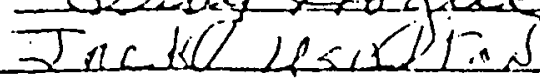

* total curar. cost hrs. Total down time

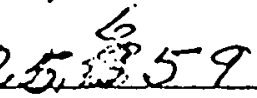

0

DRILI.ING SUPT. ASST. SUPT. 
LOUIS RECORISS \& ASSOCIATES, INC

SITE DOE JOB NO.

LAST CASING SET: SIZE

REPORT NO. 6 DAYS FROM SPUD
DAILY DRILLING PROGRESS RES

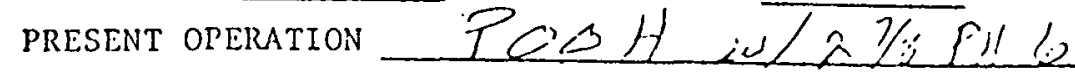

DEPTII AND FORNATION

BIT \# SIZE/MAKE/TYPE

JETS SIZE SIZE/MAKE/TYPE

BIT ff SIZE

JETS

RỚARY RPM FTGE WELL NO
ESTIN 12 DEDTH WEIGHT ON BIT FTGE IIRS HRS

PUMP \#1: LINER SIZE

PUNP \#2: LINER SIZE STROKE STROKE PRESSURE MUD COMPANY

MUD: TYPE VIS WL. GELS 1 SD $\%$ SOLIDS FTGE LAST 24 IIRS

MID PROPERTIES; WT $\mathrm{PV} / \mathrm{YP}$ 1 GELS

\section{OPERATIONS LAST 24 HRS}

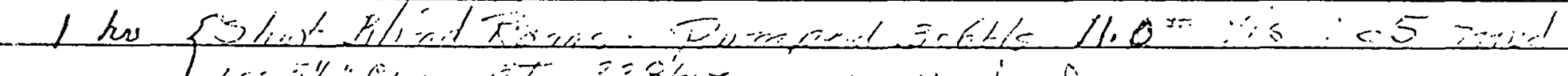

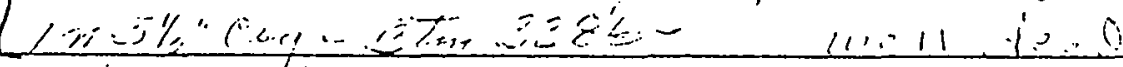

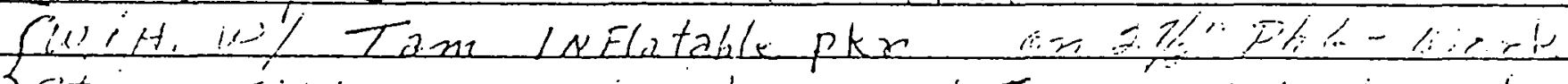

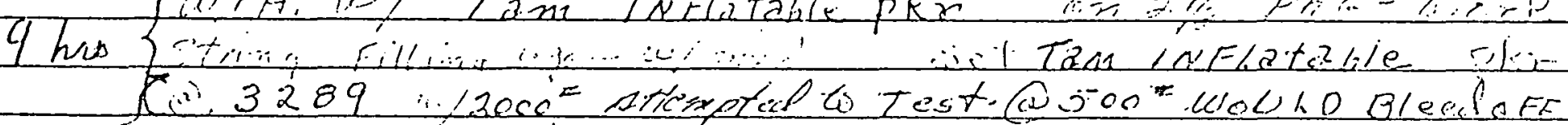

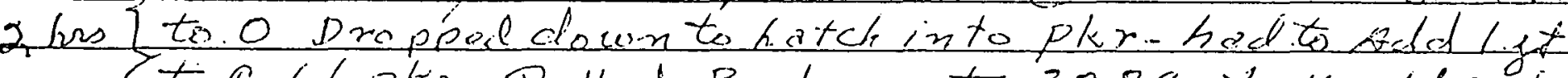

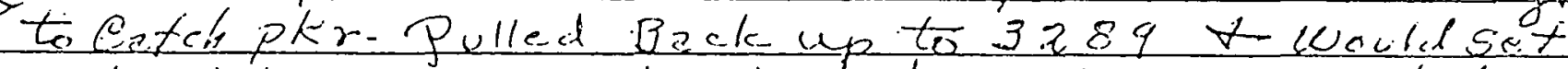

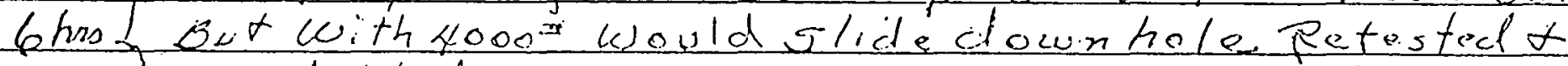

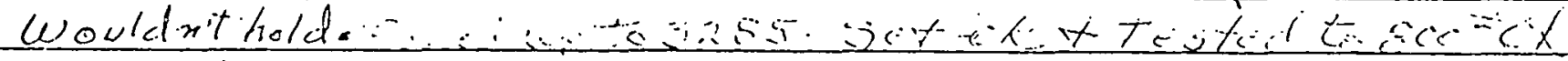

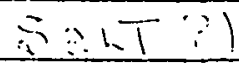

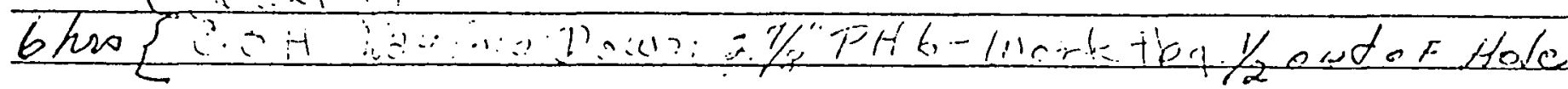

Bottom Hole issembly

Accidents

DAILY IND COST

CURAM. NUD COST

DAILY SUPPLIES \& SERVICES

12,136 18.86

(include rig fuel if operator's $\cos t$ ) CUNM. SUPPLIES \& SERVICES Operating tinc 24 hrs. 23,695 Rig repalr EQUIPNENT CONLTNTS DRILLING FORE:AN ASST. SUPT.
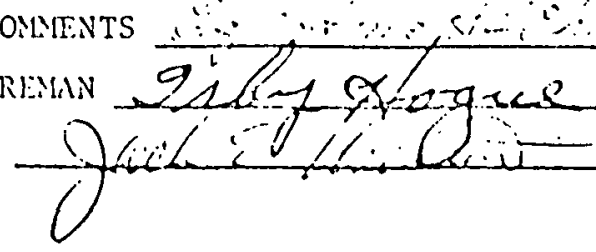

DAILY RIG

CUNA. RIG

TOTAL DAILY .COST

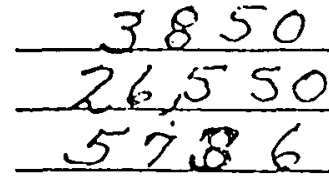

* total curr. cost 51,643 hrs. Total down time 0

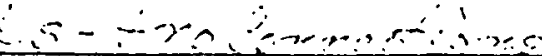

DRILLING SUIT. hectilicis ASST. SUPT.

- Approved, Louls Records \& Assoclates, Inc. 
LOUIS. RECORDS \& ASSOCIATES, INC SITE DOE JOB No.

T CASING SET: SIZE REPORT NO. IE $Z$ DAYS FROM SPUD PRESENT OPERATION

DEPTH AND FORMATION

BIT \# SIZEE/MNE/ TYPE

JETS SIZE SIZE/MAKE/TYPE

BIT \# SIZE

JiTS

R.OTARY RPM

PUMP \#1: LINER SIZE

PUMP \# 2: LINER SIZE

MUD: TYPE

MUD PROPERTIES: WT.

YN/YP GELS

OPIRATIONS LAST 24 HRS

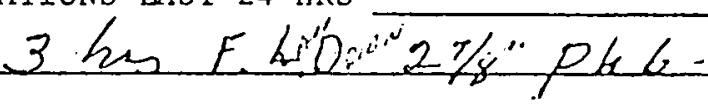

FTGE LAST 24 HRS SERIAL No.

GRADE: ${ }^{\mathrm{T}}{ }^{\mathrm{B}} \mathrm{C}$

SERIAL No.

GRADE: $T$

B G. ANNULAR VELOSITY WEIGHT. ON BIT STROKE PRESSURE PSI SPM GPM STROKE PRESSURE PSI SPM GPM MUD COMPANY VIS $\mathrm{k}$. \% SOLIDS $\mathrm{CL} \longrightarrow \mathrm{CA}$ $\mathrm{PF}$ OTHER

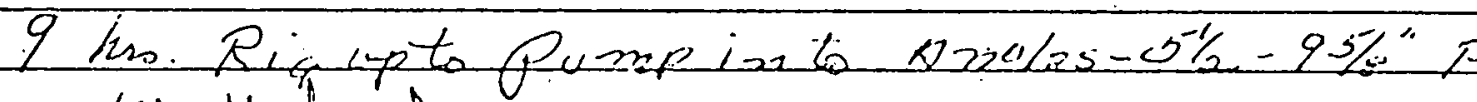 well dezed
Removed 6" Ro P.te i" Demce Ball Ualue -

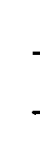 $1 / 4165 \mathrm{kis}$

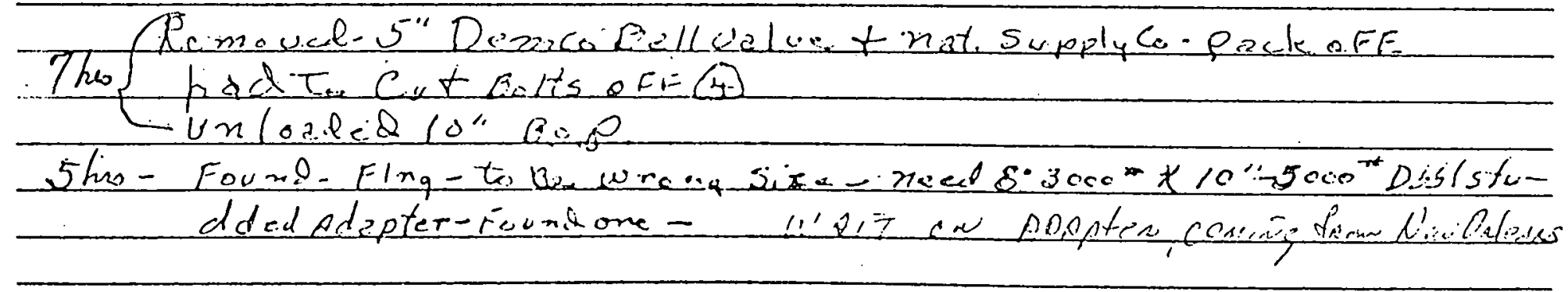

Bottom Hole Assembly

Accidents

DAILY NUD COST

CURA. AUD COST

DAILY SUPPLIES \& SERVICES

(include rig fuel if operator's cost)

CUNM. SUPPLIES \& SERVICES

Operating time 24 hrs.

EQUIPMENT COSRENTS

DRILLING FOREMN c)

iT. SUlT.

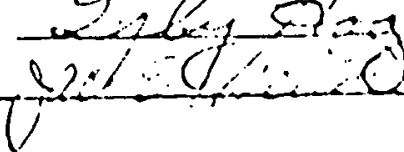

DAILY RIG

CURPI. RIG

TOTAL DAILY COST

*total cuirl. cost

hrs. Total down time

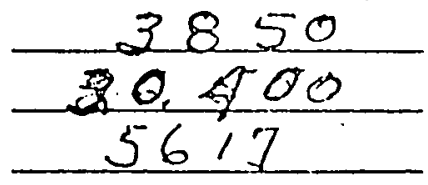

5617

25,462

Rli, repilr
DRILIING SUPT.

ASST. SUl'T.

- Approved, lows Rocordes s Asmolides, In 
LOUIS RECORDS \& ASSOCIATES, In] SITE (lisetfeckberry DOE JOB no. REPORT NO. 8 DAYS FROM SPUD PRESENT OPERATEON

DEPTH AND FORMATION

BIT \# SIZE/MINKE/TYPE

JETS SIZE SIZE/MAKE/TYPE

BIT. . Jits SIZE

ROTARY RPM

PUNP \#1: LINER SIZE

PUNP. \#2: LINER SILE

NUD: TYPE

MUD PROPERTIES: WT. $\mathrm{PV} / \mathrm{YP} 11$ FTGE WEIGHT ON BIT DEDTH

DALY DRLLLING PROGRESS REI

DATE $9-19-7 \%$

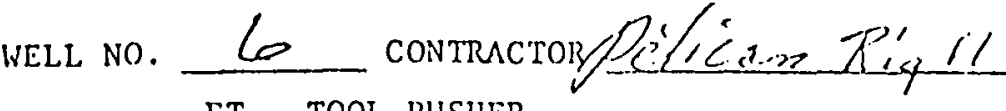
FT. TOOL PUSHER ESTIMATED DAYS TO COMPLETE

FTGE LAST 24 HRS SERIAL NO.

GRADE: T G ${ }^{B} G$

SERIAL NO.

GRADE: T B G ANNUTAR VELOSITY STROKE _ PRESSURE _ _ PSI SPM _ CPM STROKE _ PRESSURE _PSI SPM GPM IUD COMPANY

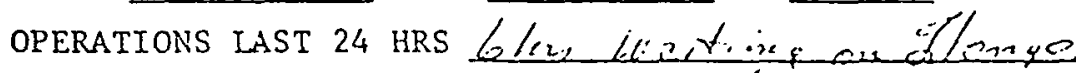

Reccived indister Fliprese-would not stix $3000 \times 8 "$

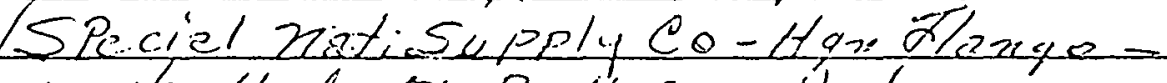

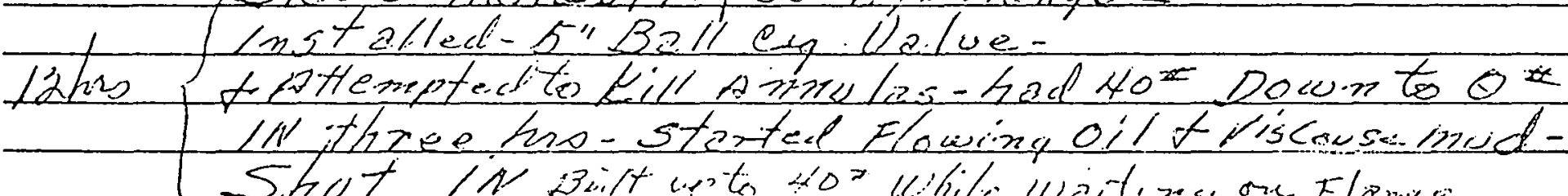

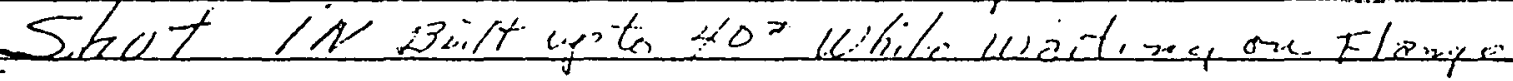

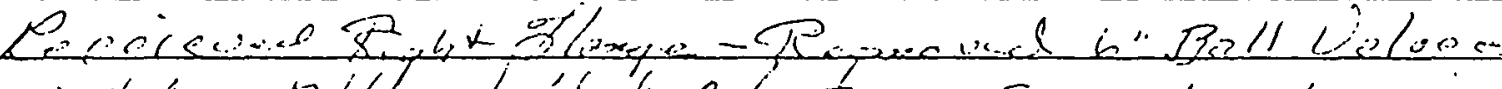

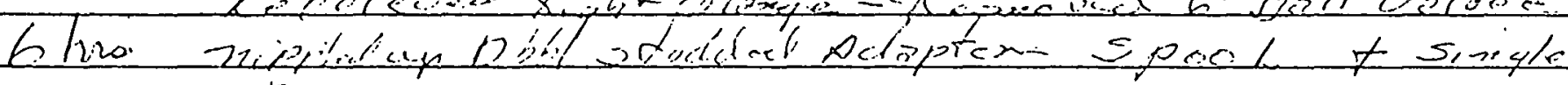
Bep

Bottom Hole Assembly

Accidents

DAILY MUD COST

CURM. IND COST

12136

DAILY SUPPLIES \& SERVICES

1038

(include rig fuel if operator's cost)

CUNA. SUPPLIES \& SERVICES

26,500

operating time _Ly hrs. Ris repili _a EQUIPNENT COIRENTS DRILLING FOREMN C)
ASST. SURT.
DAILY RIG

CUNM. RIG

TOTAL DAILY COST

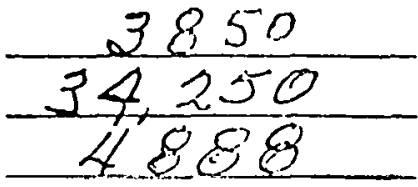

* total curs. cost

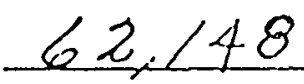

hrs. Total down time $Q$

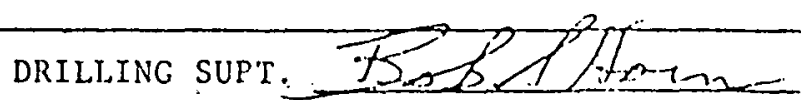
ASST. SUPT. 
I.OUIS RECORIS \& ASSOCInTES, Iive Woif Horlinberom SI'T: 120

- I CASING SET: SIZE .... ORT NO. 1 DAYS FRON SP(T)

PRESENT OPERATION DEPTH AND FORMTION

BIT \# SITE/MAKE/TYPE

JETS SIZE FTCE ícsid BIT. \# SIZE/MAKE/TYPE

mits SIZE

ROTARY RPM

PLNP \#1: LINER SIZE

PUMP $\| 2:$ LINER SIZE

MUD: TYPE

MUD PROPERTIES: WT.

PV/YP 1 GELS

OPERATIONS LAST 24 HRS

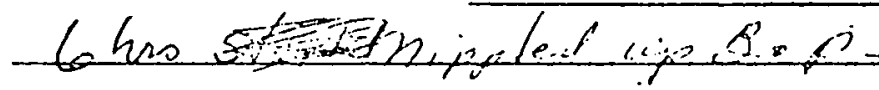

Lho.

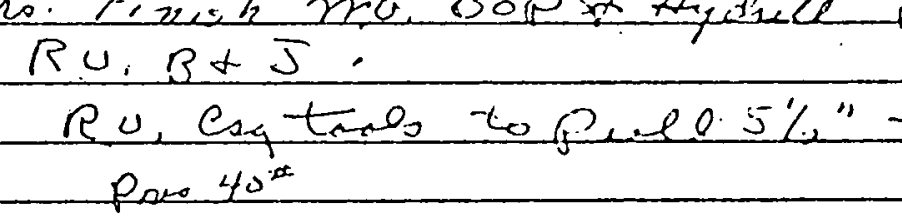
FICE. LIRS WEIGHT ON BIT IIRS STROKE PRESSIRE STROKE. PRESSURE MUD COMPAYY VIS $\quad$ hI $1 \quad \mathrm{SD}$ \% SOLIDS

DATE $9-26 \cdots$

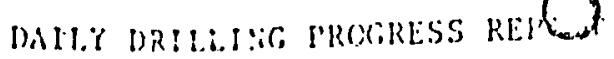
1):y
:2:!.1. : $: 0$. FitMATED DAYS TO COMPIETE

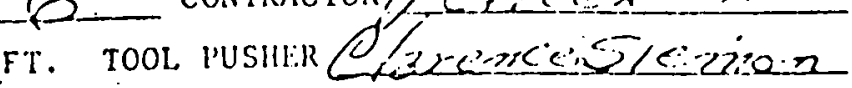
$\because \because 5 \%$

FTGE LAST 24 HRS SERIAL NO. GRUDE: T B G SERIAL No. CRADE: T B G ANALLAR VELOSITY PSI SPM GPM PSI SPM — GPM. $\mathrm{CL} \_\mathrm{CA}$. PE \% NETHYL BLUE OTHER

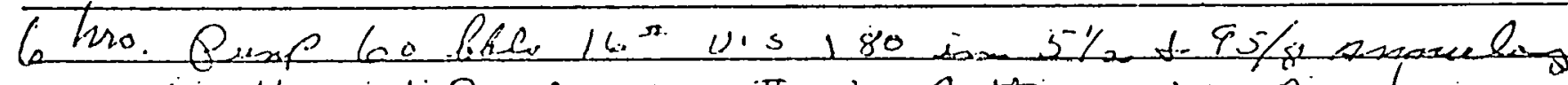

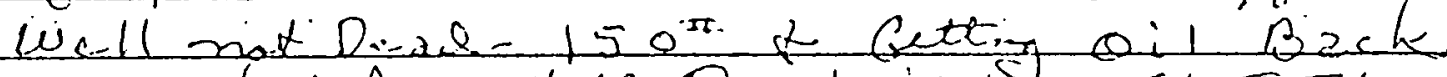

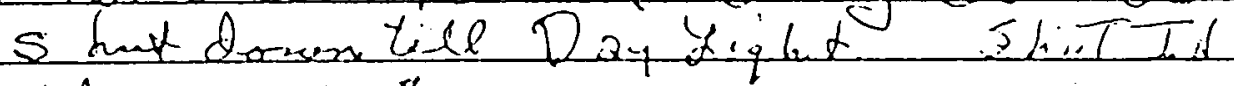 Preso the Anas $30^{\circ}$}

Bottom Hole issembly

Accidents Nis

DAILY NUD COST

CUMM. MUD COST

DAILY SUPPLIES \& SERVICES

(include rig fuel if opcrator's. cost) CURM. SUPPLIES \& SERVICES Operatine time 2. 2 hrs. 27603 EQUIPNENT COMNENTS DRTLLING FOREMLAN

;T. SUIT.

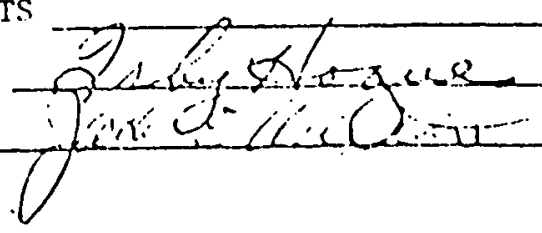

DAILY RIG

CURM. RIG

TOTAL DAILY COST

*total cuna. cost hrs. Total down tine 38,100 $495: 3$ 67,101 DRILLING supt. TS+T $+1, \ldots$ ASST. SURT.

- Approved, Louls Records \& Assoctates, Inc. 
l.OUIS REcorus is associntes, SITE West je Jois No.

UAST CASIIC SET: SIZE. REPORT NO. 9 DAYS FROS SPUD PRESENT OPERITLOA

DI:PTH AND FOR:ATIION

BIT \#— SIZE/MNKE/TYPE

JHTS SIZE $\longrightarrow$ FTGE_URS

BIT SIZE/MAKE/TYPE

Jists SIZE

ROTARY RPM

PLIP \#1: LINYR SIZE

PLIP \#2: LIIER SIZE

IUD: TYPE

FTGE WEIGHT ON BIT

MUD PROPERTIES: WT. STROKE STROKF. MUD COMPANY

V VIS _ _ it PY/YP 11 GELS SD $11 / 2$ SOLIDS PRESSURE PRESSURE GRNDE: T

\section{conTRACTOR} With, no. 6

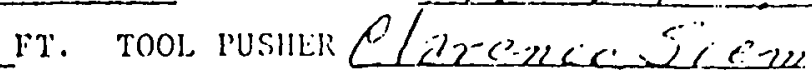
ESTIMTED DAYS TO COAPLETE

DEDTH

FTGE LAST 24 HRS

SERIAL NO.

SERIAL NO.

GRIDE: $T$

B

G

ANNULAR VELOSITY

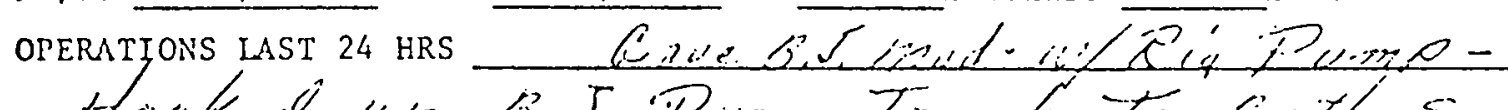

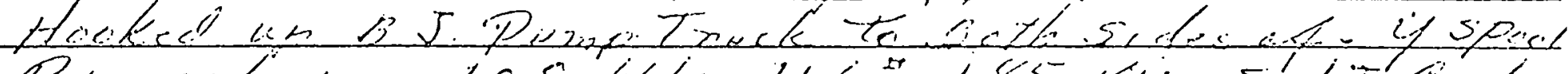

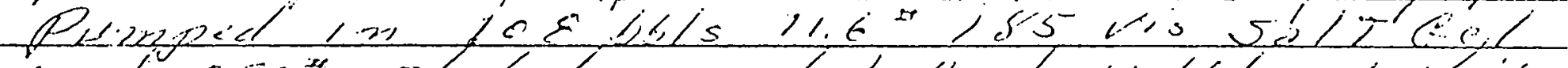

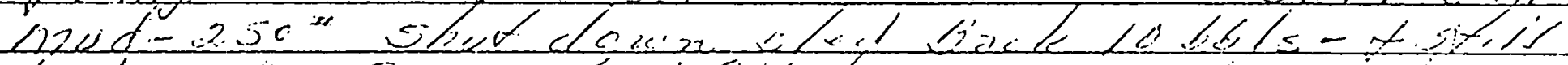

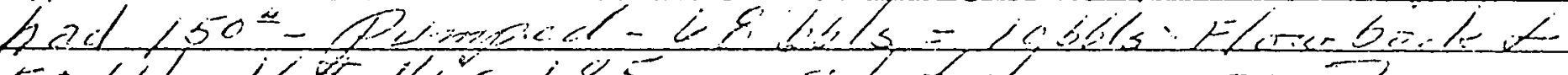

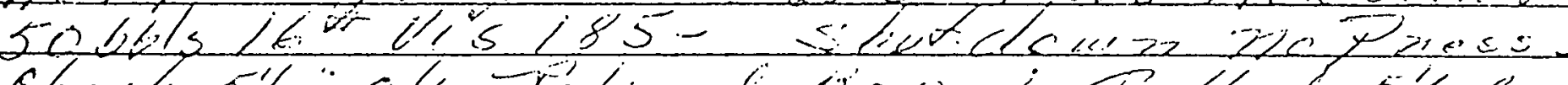

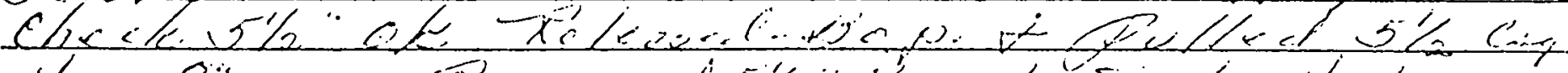
thopa

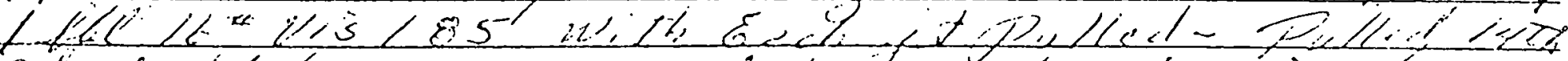

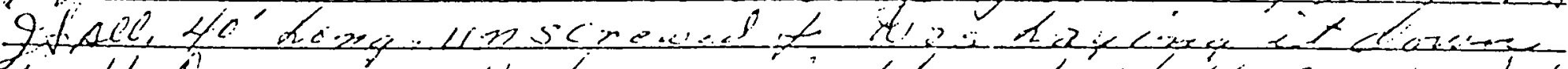

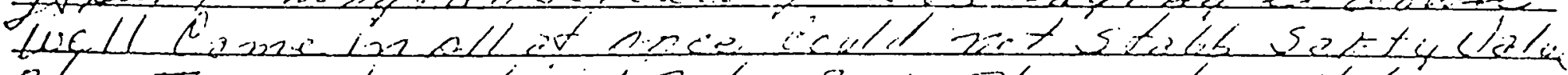

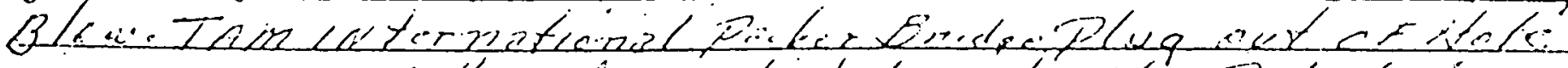

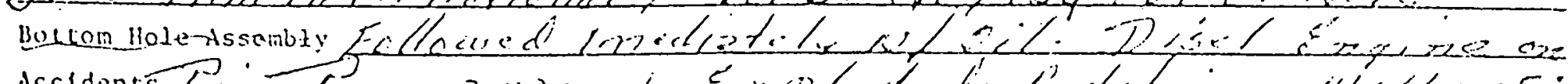

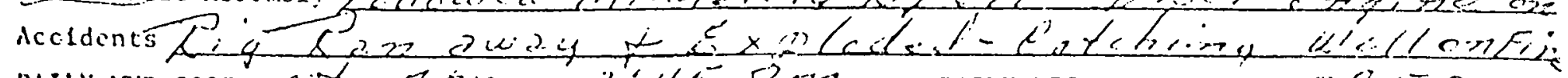

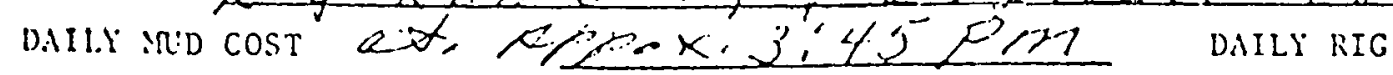

Cline IR'D COST

DAIL SLPLLIES S SERVICES

(Include rig fucl if operator's cost)

CliNe. SLPVIIES \& SERYICES

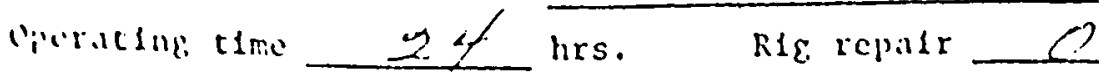

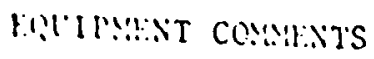

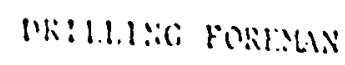

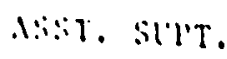

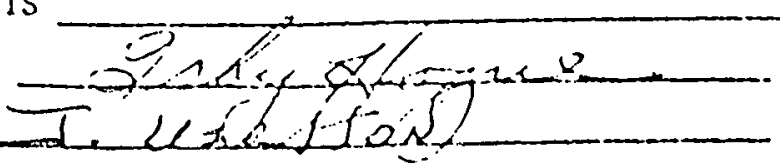

CLIL. RIG

TOTAL DAILL COST

*TOT:AL Clias. cost

hrs. Tocal down the (2)

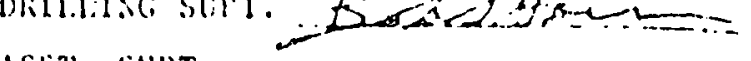
ASST. SUPT. 
I,OLISINNA DLTARTMENT OT CONSHEVATION

INSIOECTION A ENFCIRCENANT IJUISION

OPC) MEST HACKBLRRY

PACE 11

Conservation District LAKE CHARLES, LA.

$\underline{R E M A R S}$

Operaior's Represcintative

VERNON P. SANNER

Title DRILLING SIIE REPRESTLNTAIIVE

PARSONS-GIIBANE

Conservation District LAKE, CliniLE, LA.

On Thursday, September 21, a approximately 4:15PH Cavern 116 . Hell jl6, blev out, with a

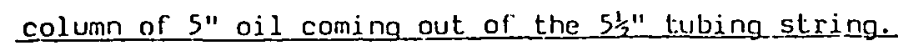

The events prior to this time and the events until this write up al $2: 00 \mathrm{PH}, 9 / 26 / 78$, are

as follows.

PELICAN HORK OVCR SERVICE RIC $\| 11$ was the rig employed to work the ve! I over.

LOUIS RECORDS INC. WERE EMPLOYCD AS CONSULTANTS. PARSONS-GILBANE WERE EMPLOYEO AS PRIMC

CONTRACTORS.

The reason for the work over was to lay the $5 \frac{1}{2}$ _tubing string down to make a slick hole of the vell, (no tubing string), and to repair the well, head, which had been seen leaking.

at the well head on two different occasions. (SEE AUTACHED)

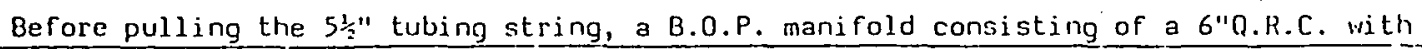

27/8" pipe rams and a 6" full closing Hydril was installed

When work commenced, the 5!' was hanging (e 3,380', approximately $37^{\prime}$ off bottom, and in

the brine portion of the cavern.

$11.6 \pi$ mud was pumped into the tubing. and the innnulus of the 9 5/8", which was set at 2,603 root and down the 1.D. of the 5t", to try to overcome the 6500. S. I.P.. Overcome pressure in the $5 \frac{1}{2} "$. but SOll remain on the annulus.

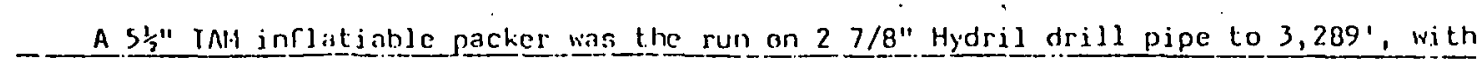

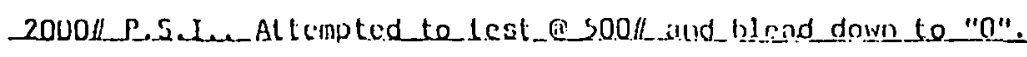

Went hack and lalched on to the packer. Set the packer again at 3,282'. It would set,

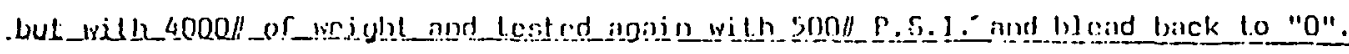

latchod on 10 parker agoin and pulled up to 3,205, and sel packer again, sot ok, and

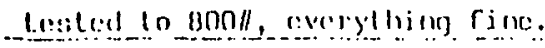




\section{IOU.JSIANA DI:PAITMENTI OF CONSERVATJON}

\section{INSPECIJION A ENFCIRCEMENT DIVISION}

PAGE \#2

$1,0) d$ Operator's Representative

Ciprator.

leaser Title

W.11.(s)

Conservation District

REMARKS

Laid down $27 / 8 "$ drill pipe.

Removed 6" B.O.P. stack and installed 10" Q.R.C. with 5k" pipe rams and a $10 "$ full clasing Hydril.

Pumped $16 \|$ mud in the annulus, and shut in pressure was "0".

i Started out of the hole with $5 \frac{1}{2}$ " and had 540 out of the hole, and was laying down casing. Last joint to be laid down was in the elevators in the V-Door, when mud started flowing out of $5 \frac{3}{2}$ " tubing.

Attempted to stab a safety plug on $5 \frac{1}{2} "$ tubing, but did not succeed.

TAM inflatiable packer did not hold, and came out of the $5 \frac{1}{2^{n}}$ tubing.

Packer was followed by $5 "$ column of oil, which added fuel to the diesel engines and caused them to run away, causing oil column to catch on fire.

Attempts vere made to shut engines down on Pelican Rig before fire.

After fire was started, Cactus Drilling Co. Rig $\# 25$, adjacent to Hell 16 , and drilling

Well $16 \mathrm{~A}$, shut down engines and generators, and evacuated area.

_. Injured_personnel from Pelican Rig ll11 were tended to and brought to the hospital.

Site alarm system was sounded and fire department were called and dispatched to the

scene and set up to try to extinguish blaze, unsuccessfully.

Oil contoinment booms were set up in Black Lake to contain oil spills.

Boots and Coots werc called out to extinguish fire.

Attcmpts were made to pull Cactus $1 / 25$ off of location. Did not succeed.

Area hoged down by rircmen for the remijnder of the night.

A double 2 3/8" tubing line was loid rrom Well $1 / 60$ to Caveen 177 and oil was pumped by

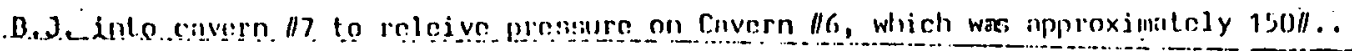


LOUSIANA DLPAITMENTE OF CONSERVATJON

INSPECTION A ENICARCEMIENT DIVISION

PAGE 3

rield

Operalor

1,asce

Will(s)

Conservation District
Operator's Represcntative

Title

\section{REMAR K'S}

Cactus Rig $\$ 25$ was tied onto and skidded off of location, approximately 75 . from well site $6 A$.

Boots and Coots, referred to hereafter as $B$ and $C_{\text {, }}$, were installing Mild Hell Inc. fire fighting equipment, 4" line to fire fighting mandrel, heavy. equipment and boom were being made ready to extinguish fire.

Additional retaining levees were added west of $\# 6$ pad to contain oil spills.

Additional oil booms wepe placed in the lake, and spill control pëople were on site.

A canal was dug 8.' wide from Black liake to $\# 6$ road approximately $600^{\prime}$, for fire pump suctions.

Started removing equipment and debris from around well site.

While attempting to remove rig sub-structure, well head was pulled loose approximately

1 below well head.

Continued fire fighting \& B. \& C. rigged up a. $2 \frac{1}{2} "$ stinger to a chicksan joint and stabbed into well from boom and pumped in brine water in an attempt to extinguish fire from well bore. This failed and This failed and well continued to burn $\Gamma_{\text {must }}$ be taken $\dot{i n t o}$ consideration that stinger operated inside $95 / 8 "$ as 5!" tubing had fallen down the hole when well head was removed.

Preparations were then made to run 7" inflatable IAll Retreivable Bridge Plug which inflate: to the I.D. of $95 / 8$ ".

Oil was only coming out of well hore to a height of $6^{\prime \prime}-1$ '.

- Packer arrives on location a approximatcly $6: 00 \mathrm{N1} \cdot$ on $9 / 26 / 78$, was put on a 2 7/8" [UJE

8 round tubing joint. llouked up to boum \& lowered approximately.4' inside 9 5/8". -

The packer wis set with 2000/I PS1, and flame riom woll bore was put out.

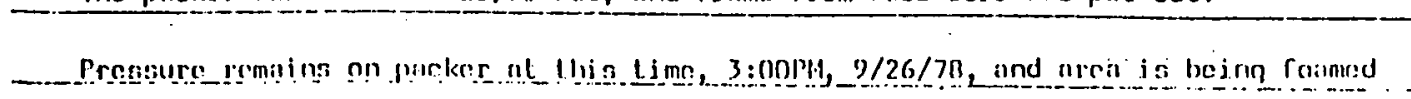




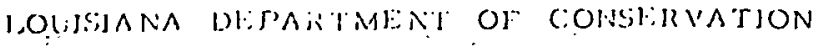

\section{INSHECHOIN R ENFCARCEMIENT DUVISION}

PAGE $/ 14$

indd

Oprerator

Lois:

$\mathrm{Ni} 11(s)$

Conservation District
Operasor's Representative

Title

down in properation to get to well bore.

Plans are then to use exterior cutters, install new well head on $95 / 8$ ", instal.1 B.D.P., and continue with clean up operations. Orders pending.

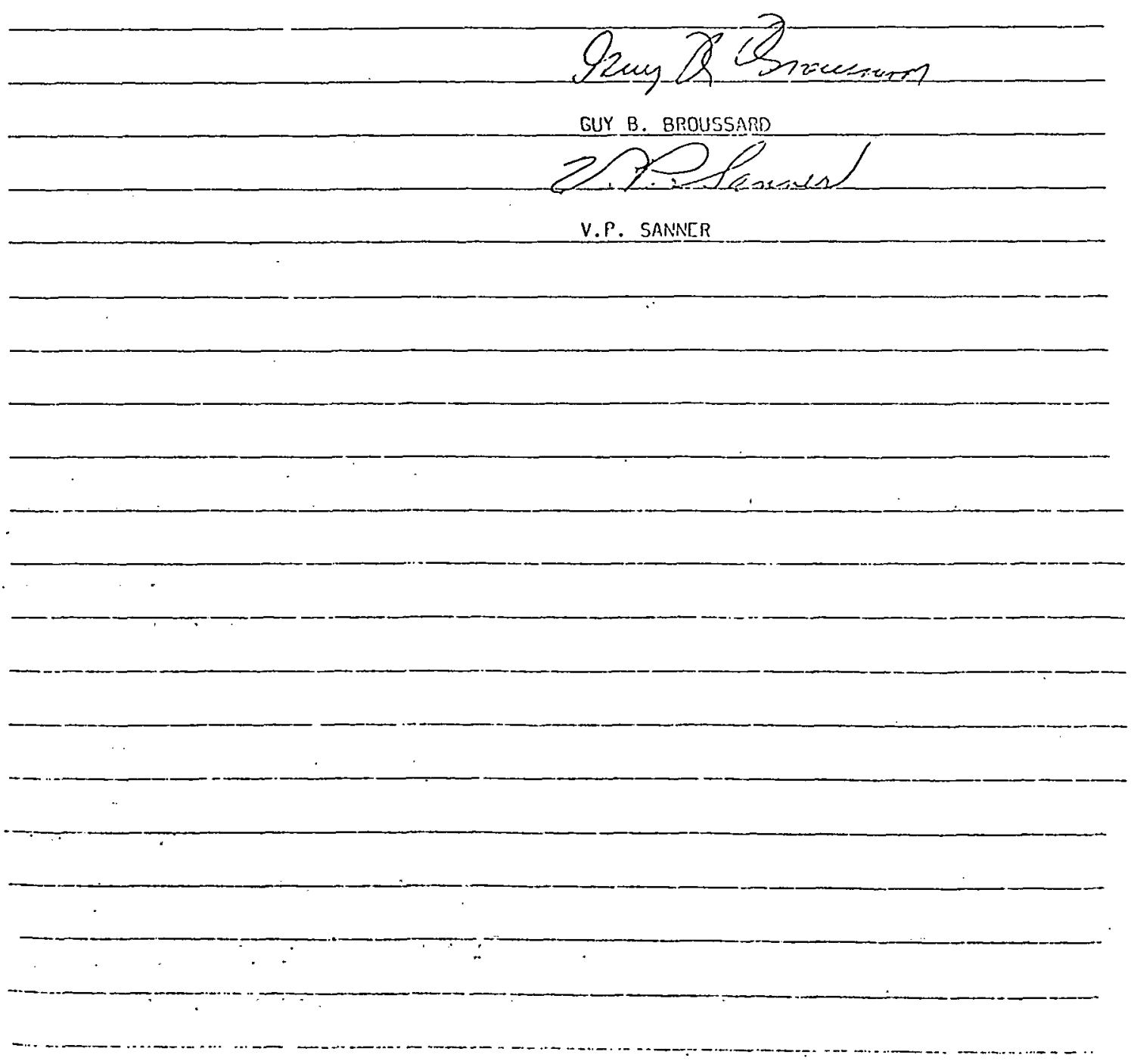




\section{APPENDIX XIV}

\section{List of organizations Helping at Fire}




\section{THIS PAGE}

\section{WAS INTENTIONALLY \\ LEFT BLANK}


PAFSCINS-GILBANE

A JOINT VENTURE

INTEROFFICE MEMORANDUM

TO: Donald R. Mazur, Project Manager, SPR Office

FROM: Ton Riggs, Claims Office, W. Hackberry

SUBJECT: LOCal Organizations that assisted in W. Hackberry Oil Fire
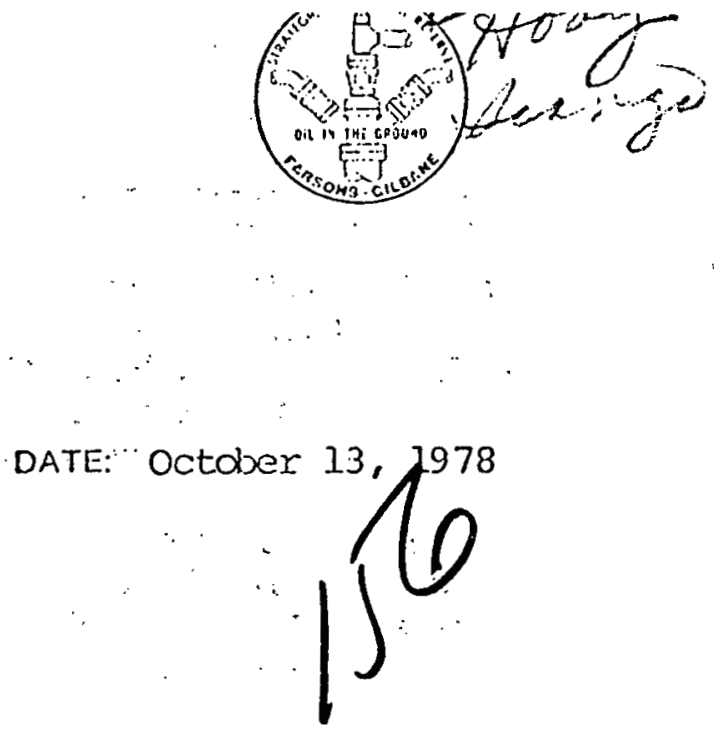

The attached list of nares and addresses was compiled by Jim Frilioux and myself. This list is to the best of our knowledge a complete list of all the local organizations which assisted during and after the fire. If you have any questions call (318) 762-3081 or (318) 762-8611.

Sincerely,

Your Reaper

TR/Db

$A-283$ 
FIRE DEIARTMENS MITAI NSSISTED AT OIL FIRE

Moss E.LuFf Fire Dept.

Chief: George Kuk

Addness: Rt. 5, BOX 331

Loss Bluff, LA 70601

* Mrs. Kuk was also on stand-by as redical Tech.

Sulphux Fire Dept.

Gief: C. D. Miller

Address: P.O. Box 197

" Sulphur, IA 70663

Westlake Fire Dept.

Oief: M. Micky Wilson

Address: Rt. 2, Box 1600

Westlake, LA 70669

Cameron Fire Dept.

Chief: Ray Burleigh

Address: P.O. Box 76

Cameron, LA 70631

Iake Charles Fire Dept.

Cnief: Lewis Mosca

Adorress: P.O. Box 1703

Lake Charles, IA 70602

Hackberry Voluntary Fire Dept.

Cnief: Ceralci Landry

Address: General Delivery

Hackberry, IA 70645

Carlyss Fire Dept.

Crief: Willard Darbonne

Address: General Dalivery

Carlyss, IA

POLTCE: JUROR FIRENAN WHO HEIPED DURIVG FIRE

Ken Ducote - Hackberry Police Juror

General Delivery

Hackberny, LA 70645

CANERON PARISH DEPUTIES WHO ASSISTED IN NOLIFYTNG LOCAL RESIDENIS AND SECURITY

Gief Deputy: Gene Constano

Address: Cameron Sheriffs Dept.

P.O. Box A

Caneron, LA 70631 
HTCRBERRY ITEUTIES

J. H. Polle

Alpha IabBove

Allen Hinton

Adidress: Ceneral Delivery

Hacriberry, IJA 70645

STATEE POLICE DEPARTNENI

Capt. Cliff Cabell

Iroop - I Lafayette, LA

MRI BOx 182

Capt. Clarence Barton

Troop - D Iake charles, IA

Tactical Squad South Lakeshore Drive

The tactical squad kept out all unauthorized people and set up barricades. 
THIS PAGE

\section{WAS INTENTIONALLY LEFT BLANK}


APPENDIX XV

List of Injured 


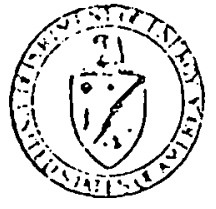

Department of Energy

P.O. Box 35228

2626 W. Mockingbird Lane

Dailas, Tx. 75235

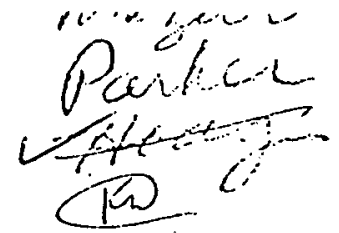

OCT 1 i 1978

MEIORAINDUM FOR PHILLIP S. HUGHES, Assistant Secretary for Intergovernment and Institutional Relations

FROM:

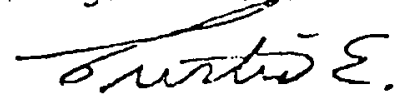
Curtis E. Carlson, Jr. Acting Regional Representative

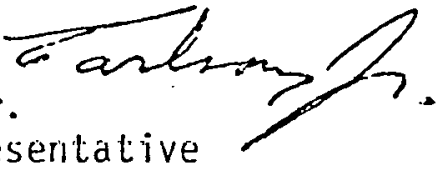
DOE - Region VI

SUBJECT: $\quad$ Region VI Activities Summary for September 1978

1. Support of SPRO

Region VI staff are providing continuing support to the Strategic Petroleum Reserve Office. Since the explosion and fire on September $2 i, 1978$, at the West Hackberry Storage Site, areas where assistance has been provided include Public Affairs, Intergovernmental, Environment, Citizen Claims, and support services for the Investigating Team. Assistance was also provided to Deputy Assistant Secretary Langenkamp during his visit to Louisiana at the time of the Oversight Hearings held by the Senate Subcommittee on Energy Production arid Supply, October 5-7, 1978.

2. Conservation

- At the request of the City of Tulsa, the Acting Regional Representative participated in a press conference with the liayor to announce that Tulsa had been awarded a DOE (through Argonne National Laboratory) contract under the Comprehensive Community Energy lianagement Program. City of Tulsa officials were very enthused about the program and the announcement was extensively covered by the Tulsa media.

- A total of eight Weatherization Program Monitoring Reviews were conducted in September, 1978 which included visits to fifteen Community Action Agencies and thirty-eight homes weatherized utilizing DOE funds. Four of the five states in Region VI were included in the reviews.

cc: DOE Region VI Principals

Regional Representatives 
The following. Iist indicates the dates, type of injury and treatment rendered by Milla Kuk of Moss Bluff and Micky Wilson of Westlake, the two Emergency Medical Technicians who were on the scene at the Hackberry, LA oil well fire.

DATE

$9 / 23$

$9 / 24$

$9 / 24$

$9 / 24$

$9 / 24$

$9 / 24$

$9 / 25$

$9 / 25$

$9 / 26$

$9 / 26$

$9 / 26$

$9 / 26$

Gerald Landry

$9 / 26$

$9 / 26$
VICTIM'S NAME

Overstreet

Overstreet

Chuck Eckstrom

John New

Gerald Landry

Glenn DeMoure1le

Allen Ardoin

Jeff Kelley

Glenn DeMourelle

Don Leedy

1111

Lawrence Kershaw

Don Batiste

Lester Latour
INJURY

1st deg. radiant heat burns to face 2nd deg. burn right wrist

blisters both heels gastric ulcer

fever blister

headache

1st deg. burn -

right forearm

slag in eyes

radiant heat burn neck area

* minor laceration left wrist

possible fracture

* minor laceration left wrist

heat exhaustion high blood pressure

possible fracture right ankle

piece of metal in left ring finger
TREATMENT

"P-K" burn ointmer

"P-K" ointment dressing

gauze dressing

"rolaids"

"P-K" ointment

aspirin

"Burntame" dressing

eye wash

"Burntame"

peroxide \&

"Foille" spray

wire splint-

sent to hospita]

peroxide -

"Foille" dressir

rapid cooling transported by Acadia Ambulance to hospital

towe1 "splint". sent to hospital

no treatment sent to hospitaj

* Men lost control of $2 \frac{1}{2} "$ charged line - watches were torn off their wrists, causing minor injuries. 
THIS PAGE

\section{WAS INTENTIONALLY \\ LEFT BLANK}


APPENDIX XVI

U.S. Accounting Office \& Comptroller General Reports

$A-291$ 
THIS PAGE

\section{WAS INTENTIONALLY \\ LEFT BLANK}




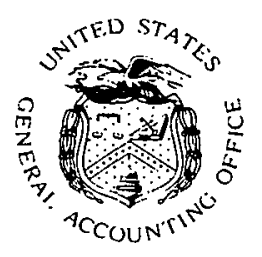

\section{UNITED STATES \\ GENERAL ACCOUNTING OFFICE}

\section{Need To Minimize Risks Of Using Salt Caverns For The Strategic Petroleum Reserve}

Under the Energy Policy and Conservation Act, the Department of Energy is required to create a Strategic Petroleum Reserve to provide protection against future disruptions in U.S. energy supplies. The Department is committed to having 500 million barrels of crude oil in storage by 1980 and thus far has been storing the oil in salt caverns located in the gulf coast area.

GAO's review of the cost and feasibility of salt cavern storage raised questions concerning the need for better information to reduce risks and uncertainties regarding the suitability of caverns for storage:

--Should the Department permit brining operations to continue in caverns after their testing and certification as suitable for crude oil storage without plans for assuring that they will remain suitable for storage after brining?

Should crude oil be stored in caverns before adequate information on their long-term suitability for storage is obtained? 


\section{UNITED STATES GENERAL ACCOUNTING OfFICE \\ WASHINGTON, D.C. 20548}

\section{ENERGY AND MINERALS}

DIVISION

B- 178205

The Honorable

The Secretary of Energy

Dear Mr. Secretary:

The General Accounting office (GAO) has been monitoring the Federal Energy Administration's (FEA) 1/ plans, actions and progress in developing the strategic Petroleum Reserve. As part of this effort, we have been reviewing the cost and feasibility of salt cavern storage. This letter discusses two issues raised during our review which warrant your consideration.

The first issue relates to permitting brining operations to continue in Government-owned caverns after the caverns have been tested and certified by FEA as suitable for crude oil storage. This concerns us from two standpoints: first, FEA does not have a formal system for controlling brine production at these caverns; and secondly, FEA does not plan to retest the caverns after production ceases.

The second issue pertains to pumping crude oil into certain caverns before completing an analysis of their long-term suitability for storage. Although FEA was not certain of the continued suitability of these caverns for storage until an analysis was completed of tests recently

1/ Although FEA is discussed throughout this report, our specific recommendations are addressed to the newly established Department of Energy (DOE) to which the functions of FEA were assigned on October 1 , 1977, pursuant to the Department of Energy Organization Act (P.L. 95-91). 
B-178205

performed on an adjacent cavern, FEA decided not to wait for test results on the adjacent cavern and began oil fill.

In our view, FEA had no assurance that the caverns in question would continue to be suitable for storage. This lack of assurance could have led to problems in recovering oil, program delays, and unnecessary costs to the Federal Government.

\section{BACKGROUND}

The Energy Policy and Conservation Act (P.L. 94-163) requires FEA to create a Strategic Petroleum Reserve (Reserve), the purpose of which is to diminish U.S. vulnerability to the effects of a severe interruption in energy supplies ana provide limited protection from the consequences of interruptions in petroleum proauct supplies. In December 1976. FEA submitted to the Congress a Strategic Petroleum Reserve Plan (Plan) which indicated that the Reserve would contain $150 \mathrm{mil-}$ lion barrels of oil by December 1978 ana $500 \mathrm{million}$ barrels by December 1982. However, in his April 1977 energy message. the President called for an expansion of the prograin to 1 billion barrels. Subsequently, FEA's May 1977 Plan amendment set new storage targets for the Reserve of $250 \mathrm{mill}$ ion barrels by December 1978 and $500 \mathrm{mill}$ ion barrels by December 1980. FEA plans to further amend the Plan to expand the Reserve to one billion barrels.

FEA has determined that oil for the Reserve will be stored in caverns within salt domes and in salt and limestone mines. To date. nine potential sites--four salt domes, three salt mines, and two limestone mines--with existing capacities totaling 402 million barrels have been identified by FEA for storage. of the four. salt domes. FEA has acouired three through condemnation proceedings. Information on the salt domes obtained through condemnation is summarized below. 
$B-178205$

Salt Dome

\begin{tabular}{|c|c|c|c|}
\hline Location: & $\begin{array}{l}\text { Ibervilie Parish. } \\
\text { Louisiana }\end{array}$ & $\begin{array}{c}\text { West Hackberry } \\
\text { Cameron Farish. } \\
\text { Louisiana }\end{array}$ & $\begin{array}{l}\text { Bryan Mound } \\
\text { Texia County }\end{array}$ \\
\hline $\begin{array}{l}\text { Number of existin } \\
\text { caverns planneo }\end{array}$ & & & \\
\hline for storage: & 10 & 5 & 4 \\
\hline $\begin{array}{l}\text { Existing stor- } \\
\text { age capacity: }\end{array}$ & $\begin{array}{l}74 \text { million } \\
\text { barrels }\end{array}$ & $\begin{array}{c}60 \text { million } \\
\text { barrels }\end{array}$ & $\begin{array}{l}63 \text { million } \\
\text { barrels }\end{array}$ \\
\hline $\begin{array}{l}\text { Estimated design } \\
\text { and construc- } \\
\text { tion costs for } \\
\text { existing cav- } \\
\text { erns: }\end{array}$ & $\$ 126,700,000$ & $\$ 62,500,000$ & $\$ 52,600,000$ \\
\hline $\begin{array}{l}\text { Previous opera- } \\
\text { tors: }\end{array}$ & $\begin{array}{l}\text { Allied Chemical } \\
\text { Company }\end{array}$ & Olin Corporation & $\begin{array}{l}\text { Dow Chemical } \\
\text { Company }\end{array}$ \\
\hline
\end{tabular}

The existing caverns in these salt domes were formed over the years from brining operations. Brining is a process whereby water is injected into a salt mass, dissolving the salt and creating a cavern, with the dissolved salt (brine) being forced out of the cavern through injection of more water.

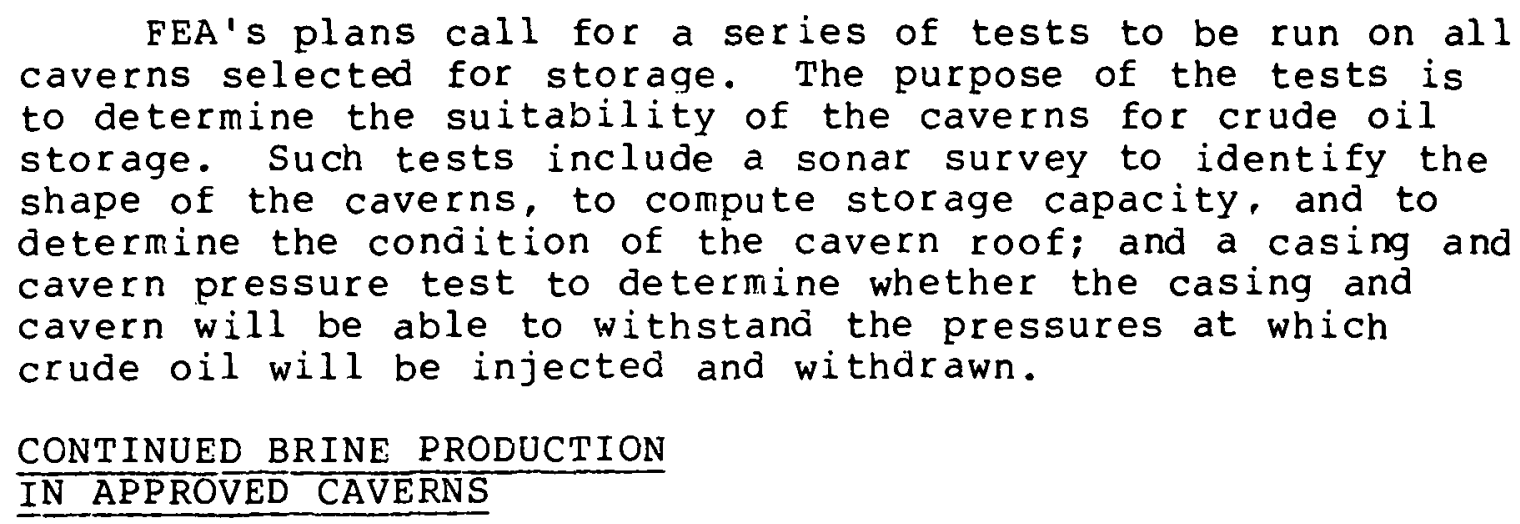
to determine the suitability of the caverns for crude oil storage. Such tests include a sonar survey to identify the shape of the caverns, to compute storage capacity, and to determine the conaition of the cavern roof; and a casing and cavern pressure test to determine whether the casing and cavern will be able to withstand the pressures at which crude oil will be injected and withdrawn.

CONTINUED BRINE PRODUCTION

IN APPROVED CAVERNS

As part of the condemnation proceedings, FEA permitted Allied Chemical Company and 01 in Corporation to continue brine production at Bayou Choctaw and west Hackberry, respectively. The condemnation agreement for Bayou Choctaw does not specify the number of caverns which will be available for continued brine production; however, the project manager for Bayou choctaw stated that the number was three. West Hackberry's 
$B-178205$

condemnation agreement specifically stated that three caverns will be available. These six caverns have a storage capacity of over $62.3 \mathrm{million}$ barrels, representing about 46 percent of the total existing storage capacity for the 15 caverns designated for storage in these two salt domes. At a national average composite price of $\$ 11.80$ a barrel, the oil to be stored in these six caverns is estimated to cost the Government about $\$ 735$ million. FEA officials told us that in order to assist in precluding further litigation which would delay the condemnation proceedings, FEA agreed to allow Allied and olin access to caverns at Bayou Choctaw and west Hackberry for brine production. Based on the advice of the Corps of Engineers--the contractors hired to appraise the storage sites-FEA decided that depriving the chemical companies of brine supplies would subject the Government to significant damage claims. An FEA official advised us that no written documentation was prepared in support of potential damage estimates since they were so obvious.

The agreements that FEA signed with the chemical companies specify the length of time the chemical companies are to receive brine supplies. In Allied's case, it is until such time Allied develops a replacement brine supply of its own, but not beyond December 31, 1980. In O1in's case, it is until May 1, 1978. FEA officials told us that Allied's brining needs are about 30,000 barrels a day and 01 in's average about 14,000 barrels a day. The agreements do not. however, specify the rate of production or the operating pressure at which the brine is to be produced.

At the same time that Allied and Olin are conducting brining operations, FEA plans to proceed with the design and construction necessary to prepare the sites for oil storage. Except for $\$ 6.2 \mathrm{million}$ to be spent for drilling injection wells, 1/ FEA has not determined how much of the estimated $\$ 18 \overline{9} \mathrm{mill}$ ion in design and construction costs for existing capacities at Bayou Choctaw and West Hackberry are attributable to the six caverns where brining operations will continue. Although we recognize that there are certain design and construction costs which will be incurred regardiess of the number of caverns or barrels of storage

1/ Contractor reports estimate that it will cost an average of $\$ 692,000$ to drill an injection well, and FEA plans to drill nine new injection wells in these six caverns. 
B-178205

capacity, we estimate the costs associated with the six caverns to be $\$ 87$ million. I/

FEA officials stated that there is no need to control brine production nor retest the caverns after brining is completed since they considered cavern damage to be low risk due to the experience of the chemical companies in producing brine and the small amount of brine to be produced. The contractor responsible for performing cavern tests for FEA agreed with FEA officials. However, these officials acknowledged that if a cavern is operated in excess of its maximum operating pressure, it could fracture causing it to be uñsuitable for storage. For each cavern rendered unsuitable for storage. FEA would have to find a suitable replacement cavern or construct a new one. Either situation, particularly the latter, would result in program delays and additional costs. These officials stated that even with proper rates of production and operating pressures, brining could still damage the caverns. For example, if too much salt is removed from the cavern roof, the seal around the casing, through which the crude is injected and withdrawn, could beg in to leak. Also fractures could develop in the caverns. Either type of change could result in the crude oil escaping to the caprock (the layer of rock strata directly above the salt dome) where it can be lost.

Officials of FEA's Strategic Petroleum Reserve Office, Office of Facility Construction. stated that they have no formal system to control the brining operations but inaicated that it could be done with minimal effort and expense. We discussed the type of testing necessary to assure cavern suitability after brining is completed, length of time to retest, and costs with FEA officials and the contractor. They stated that two tests would be necessary--a sonar survey and a casing

1/ Design and construction costs for existing storage capacity at Bayou Choctaw and west Hackberry are $\$ 189 \mathrm{mil-}$ iion-- $\$ 127 \mathrm{million}$ and $\$ 62$ million respectively. On the basis of $135 \mathrm{million}$ barrels of existing storage capacity, design and construction costs are equal to about $\$ 1.40$ a barrel. This per barrel amount multiplied by the $23.5 \mathrm{mill}$ ion barrels for the three caverns at Bayou Choctaw and the $38.8 \mathrm{million}$ barrels for the three caverns at West Hackberry equals a total of $\$ 87$ million. 
$B-1782015$

and cavern pressure test--which would take about two weeks per cavern and cost a total of about $\$ 90,000--\$ 15,000$ per cavern.

In discussing the possible loss of design and construction costs if the caverns were rendered unsuitable due to continued brine production, FEA officials stated that by delaying cavern design ana construction until after brining operations are completea, the chances for loss of design and construction funds would be eliminated but other factors must be taken into consideration such as the price of oil and inflation. They addea that postponing design and construction until after brining was completed would delay the program and possibly cause FEA to be unable to meet the administration's aoal of having 500 million barrels of oil in storage by December 22. 1980 . At the time of our review. however. FEA had not evaluatea what the impact on meeting the goals would be due to delaying some or all of design and construction activity. They stated that such an analysis, although time-consuming, could be performea.

In a November 10, 1977, meeting with DCE officials to discuss a draft of this report, they disagreed with several aspects of the report relative to the continued production of brine at Bayou Choctaw and liest Hackberry. These officials restatea their view that cavern damage as a result of continued brining is low risk and that retesting is unnecessary. They stated that the reasons for this view are (1) caverns are being tested for the ability to withstand pressure well above the acceptea industry standara pressure for brine production; (2) aue to the large size of the caverns. brining at temporary short-term operating pressures will not cause the overall cavern pressure to $r$ ise to dangerous levels; and (3) DOE has re-installea blanket oil in the caverns after testing and will insure that adequate blanket oil is maintained to guard against salt being washeci from the cavern roof. Futhermore, they cited the thickness of the salt roofs above the caverns as an adaitional factor that would quard against damage occurring.

The reasons cited above may minimize cavern damage. However, without a formal system to monitor brining operations. there is no assurance that safe operating pressures are maintained. FEA and its testing contractor have acknowledged 
$B-178205$

that brining can cause cavern damage. This would appear to be substantiated by the failure of five other caverns at Bayou Choctaw, previously used for brine production, to pass casing and cavern pressure testing.

\section{STORAGE PLANS AT BRYAN MOUND}

There are five caverns at the Bryan Mound salt dome. FEA began storing crude oil in cavern 2 on October 7,1977 ; in cavern 4 on November 14, 1977; and plans to use caverns 1 and 5 for storage. FEA considers the remaining cavern--cavern 3-to be too large for storage. In addition to being too large, certain questions have been raised about the suitability of cavern 3 for the storage of crude oil. Although cavern 3 was not selected for storage, its suitability for storage is important because of its location in relation to caverns selected for storage. A cavern's exact location and distance are considered in cavern design analysis to determine if caverns will grow together and the impact of such growth resulting from crude oil displacement cycles. FEA is using five such cycles for planning purposes and is assuming the storage sites will have to be emptied as many as five times because of major supply interruptions. Cavern enlargement is expected to occur during each displacement cycle. FEA made an analysis of caverns at Bryan Mound to determine location and distance. In our opinion, FEA's analysis of cavern 3 prior to beginning oil fill in an adjacent cavern was not adeguate to determine the extent to which cavern 3 would have compromised the other cavern's suitability for storage.

FEA first became aware of potential problems with cavern 3 in November 1976 when a preliminary design contractor submitted a report on the Bryan Mound storage caverns. The contractor's report proposed that $F E A$ insure that no future brining operations are conducted in cavern 3 by acquiring the cavern and, if possible, perform a directional survey of the cavern. Although the directional survey is necessary to enable FEA to determine the potential for other caverns to penetrate cavern 3 and the consequences of such penetration, tests to gather information on cavern 3 were not performed prior to oil fill. The Bryan Mound Project Manager (Project Manager) told us that FEA decided testing cavern 3 was unnecessary because FEA's analysis showed it would not have any impact on the other caverns. However, we believe that questions remain as to the accuracy of 
$B-178205$

this analysis which tenas to be supported by the fact that FEA decided to perform further testing on cavern 3, as discussed below. FEA's analysis was basea primarily on two documents; an aerial view diagram of the caverns and a table showing calculations of the effects of five displacement cycles on the aiameters of Bryan Mound storage caverns 1, 2, 4. and 5. The aerial view diagram was obtained from Dow Chemical Company-the previous operator of cavern 3. While we do not disagree with the manner in which the analysis was performed, we do not believe the information used was adequate since FEA did not obtain sonar and directional survey data to verify the location of cavern 3 on the aerial view diagram.

In August 1977 , both FEA and its contractor responsible for cavern testing anà certification became concerned about cavern 3. In an August 23, 1977, meeting attended by FEA and the contractor, the contractor strongly aovised that cavern 3 be tested. In a letter to FEA dated August 29, 1977 , the contractor expressed concern that cavern 3 might be penetrated during future oil displacement from caverns 2 and 4 . The contractor emphasized that an investigation of the cavern was imperative. In a letter to the contractor dated August 31 . 1977, FEA asked the contractor to submit a proposal for performing sonar and directional surveys on cavern 3. The FEA letter also requested that the proposal include fluid samples from various depths in cavern 3 . We were advised by the Project Manager that FEA was concerned over allegations that inaustrial waste had been dumped in cavern 3 .

We first discussed cavern 3 with FEA on september 19, 1977. No tests had been run at that time; but, based on a discussion with the Project Manager, it was our understanding that oil would not be stored at Bryan Mouna until cavern 3 had been tested and analyzed. Subsequently, the Froject Manager advised us that there were never plans to delay oil fill until cavern 3 had been tested and analyzed.

As stated on page 7, FEA began storing crude oil in cavern 2 on October 7, 1977, and in cavern 4 on November 14, 1977. As of November 29, 1977, about 1.5 million barrels had been stored in these caverns. Cavern testing began on November 2, 1977, and was completea November 9, 1977. We last discussed the status of the tests with the contractor on December 13, 1977. The contractor stated that they had com:pleted their analysis of the tests and had forwarded the test 
$B-178205$

results to DOE on November 28 and 29,1977 . The analysis indicated a minimum distance between cavern 3 and caverns 2 and 4 of 300 feet. (According to the Froject :nanager, FEA's initial analysis indicated $5 n$ feet.) Based on the 300 foot distance, the contractor concluded that caverns? and 4 would not penetrate cavern 3 after five displacement cycles. The contractor also concluded that there was no industrial ivaste stcre? in cavern 3.

We asked the froject Manager why PFA decided to have cavern ? tester and also why $T E A$ began oil fill hefore the tests were completed and analyzed. The Project Nanager stater? that the tests were made orimarily to confirm FEA's prior analysis of. cavern 3. Regarding oil fill, he advised that based on FEA's earlier analysis the risk was nonexistent. Specifically, he pointer out that PIA's calculations showed that after five cisplacement cycles there would still be an adexuate distance between cavern 3 and adjacent storage caverns.

Ne asked the testing contractor if he had objected to FEA about beginning oil fil. I before the tests were completed and analyzed in view of his position stated in the August 1977 correspondence. The contractor stated that he did not object because he believed that caverns 2 and 4 would not penetrate cavern 3 in the short-term--i.e., the first displacement cycle. Consequently, he believed there was no reason for FEA to interrupt storage operations until after cavern 3 had been tested and the results analyzed.

We discussed the cavern 3 situation with a spokesman for the Dow Chemical Company. It was his contention that it was unlikely that cavern 3 would have any effect on the other caverns. Dow has been unable, however, to locate test documentation to substantiate this contention. Nevertheless, the Dow spokesman was able to discuss with us some aspects of the cavern's history: He stated that now stopped brining the cavern in November 1967 because it would not hold pressure; that is, water was being pumped in hut brine was not returning to the surface. After testing the cavern in 1973, Dow concluded that it would not hold pressure because of a leak around the casing. The leak was consicered to be too difficult to repair and the cavern was abandoned. The spokesman added that, to his knowledge, no industrial waste ras been dumped in cavern 3. 
$B-178205$

After discussing this situation with FEA. FEA's testing contractor. and Dow Chemical. we believe that FEA proceeded with storage operations without first removing uncertainties pertaining to cavern 3. We believe that the initial analysis performed to determine the aistances between cavern 3 and the storage caverns was inadequate due to lack of complete information to verify the location of cavern 3. This is further supported by the results of tests recently performed on cavern 3 indicating that the minimum aistance between cavern 3 and caverns 2 and 4 is 300 feet- 200 feet ( 40 percent) less than FEA's earlier analysis indicated. Furthermore. although it now appears that no structural aamages or financial loss will result due to FEA's aecision to begin oil fill before the tests on cavern 3 were performea and analyzed, we believe that FEA took an unnecessary risk in view of the structural damages and financial loss that could have occurreō.

On November 10, 1977, we met with DOE officials to discuss a araft of our report. The officials still contend that there was no risk associated with beainning oil fill before performing tests on cavern 3. They statea that FEA's initial analysis was sufficient to determine the effects of five displacement cycles on the distances between cavern 3 and the storage caverns and that the tests which were recently completed were performed basically to confirm their initial analysis.

\section{CONCLUSIONS}

FEA after obtaining six salt caverns at Bayou Choctaw and West Hackberry, permitted the previous operators to continue proauction of brine after the caverns were testea and certified as suitable for crude oil storage. FEA. while acknowledging the possibility that brining can cause cavern aamage, believes the risk of such damage occurring is extremely low. In line with this belief. FEA does not routinely plan to monitor the brining operations. impose restrictions on the $r$ ate of brine proauction ana operating pressures, nor retest the caverns after brining has been completec before filling the caverns with crude oil.

Also, FEA began pumping cruàe oil at Bryan Mourd before completing an analysis of tests recently performed on cavern 3 
$B-178205$

which would have provided reliable information on the location and any impact that cavern 3 may have had on other caverns selected fcr stcrage. FEA c̈eterminec from their previous anclysis that there was adecuate äistance between cavern 3 ana aäjacent caverns and concluded risks asscciated with oil fill were nonexistent. GAO believes that the information used by FEA to make this initial analysis was inadecuate to inaicate that the risks were nonexistent anci. conseouently. FEA shoula have delayea oil fill until the recent tests were completed ana results analyzed. In our view. FEA äic not have acouluate assurance that the caverns where oil is being storec would not penetrate cavern 3 . We believe FEA dia not have that assurance until tests recently performed on cavern 3 were analyzed. This lack of assurance could have led to problems in recovering oil, proaram cielays. and unnecessary costs to the Federal Government.

In oraer to preclude the potential oroblems associated with continued brining at Bayou Choctan and West Hackberry, we believe the best alternative woula be for FEA to negotiate with the chemical companies to eliminate continued brining operations. If negotiations are successful. FEA coula then seek amendments to the conaemnation agreements which would $r \in-$ flect the newly-agreed-upon terms concerning continued brining. If negotiations fail, FEA could airectly petition the court for such an amendment, citing the failure of negotiations anci argue that the potential serious amage the continued brining may cause to the caverns recuires that it be eliminated. Wie recognize the costs for such an amenaiment could be substantial since it appears highly unlikely that the companies woula relinguish rights to the brine procuction without sorie form of compensation in return. However, we believe FEA shoula explore what the costs will be and then make a determination of whether they ought to pursue negotiations.

Although FEA officials stated that they did analyze the costs for seeking such an amendment, they informed us that no written documentation was prepared in support of damage estimates since they were so obvious. If. in fact. the amendment is too costly, FEA should still make every attempt to impose controls on the chemical companies' rates of brine production and operating pressures to help assure that the caverns continue to be suitable for storage. Nore importantly, as soon as brining operaticns are completeä, we believe that FEA shoula retest the caverns to determine if they are still suitable for storage. 
B-17820

Concerning the Bryan Mouna situation, we believe that FEA shoula not have begun oil fill until after tests on caverr 3 were performed and analyzed. We believe that there were uncertainties as to the long-range suitability of the other caverns for storage at the time FEA began oil fill and. consecuently. unnecessary risks were taken by FEA in view of the possible structural damages and financial loss that could have occurrea.

We recognize that tight time constraints were placed on FEA to complete the Strategic Petroleum Reserve Program and that, because of the newness and complexity of the program. some degree of $r$ isk will be involvea in implementing most decisions. Whenever risk can be reducea through additional information, however, we believe such information should be obtained. Our recommendations are aimed at developing better information to reduce the $r$ isk involved in salt cavern storage. In adaition to helping the Department of Energy minimize $r$ isk and uncertainty. this information should prove useful to the appropriations committees when considering reguests for program funds. since it will highlight the risks involved.

\section{RECOMMENDATIONS}

We recommend to the secretary, DOE, that in future oil fill decisions, every attempt be made to minimize risk and uncertainty, taking into consiaeration program delays ana costs.

Specifically, with respect to Bayou Choctaw ana west Hackberry, we recommena that the Secretary

--ajetermine the feasibility of amending the condemnation agreements to eliminate continuea brining operations by the chemical companies.

--institute a formal system for controlling the brining operations if the agreements are not amended to assure that brine is not being produced in excess of safe rates of production and operating pressures, and

--retest the caverns after brining has been completed. 
To minimize the financial loss to the Federal óovernment that could occur if any of the caverns at west Hackberry and Bayou Choctaw were rençered unsuitable for storage, we also recommend that the secretary assess the feasibility of postponing some design and construction until brining is completea. In making this decision, an assessment should be made of the impact that such postponement would have on program delays and costs.

As you know, section $236^{\circ}$ of the Legislative Reorganization Act of 1970 requires the head of a Federal agency to submit a written statement on actions taken on our recommendations to the Senate Committee on Government Affairs and the House Committee on Government Operations not later than 60 days after the date of the report and to the House and Senate Committees on Appropriations with the agency's first request for appropriations made more than 60 days after the date of the report.

We appreciate the cooperation received during our review and would be glad to discuss the contents of this letter in further detail should you so desire.

Sincerely yours,

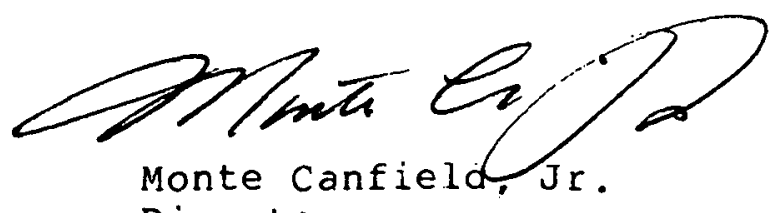

Director 
Copies of GAO reports are available to the general public at a cost of $\$ 1.00$ a copy. There is no charge for reports furnished to Members of Congress and congressional committee staff members. Officials of Federal, State, and local governments may receive up to 10 copies free of charge. Members of the press; college libraries, faculty members, and students: and non-profit organizations may receive up to 2 copies free of charge. Requests for larger quan. tities should be accompanied by payment.

Requesters entitled to reports without charge should address their requests to:

\author{
U.S. General Accounting Office \\ Distribution Section, Room 4522 \\ $441 \mathrm{G}$ Street, NW. \\ Washington, D.C. 20548
}

Requesters who are required to pay for reports should send their requests with checks or money orders to:

\author{
U.S. General Accounting Office \\ Disiribution Section \\ P.O. Box 1020 \\ Washington, D.C. 20013
}

Checks or money orders should be made payable to the U.S. General Accounting Office. Stamps or Superintendent of Documents coupons will not be accepted. Please do not send cash:

To expedite filling your order, use the report num. ber in the lower left corner and the date in the lower right corner of the front cover.

GAO reports are now available on microfiche. If such copies will meet your needs, be sure to specify that you want microfiche copies. 
AN EQUAL OPPORTUNITY EMPLOYER

UNITED STATES

GENERAL ACCOUNTING OFFICE

WASHINGTON, D.C. 20548

OFFICIAL BUSINESS

PENALTY FOR PRIVATE USE, $\$ 300$
POSTAGE AND FEES PAID

U. S. GENERAL ACCOUNTING OFFICE

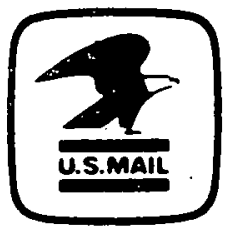

THIRD CLASS 


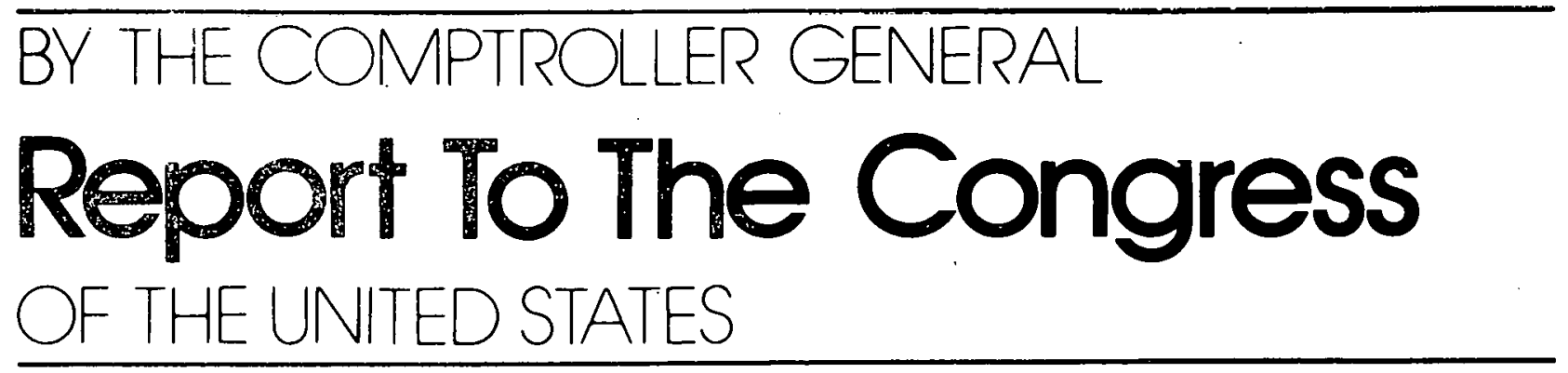

\section{Questionable Suitability Of Certain Salt Caverns And Mines For The Strategic Petroleum Reserve}

The Department of Energy is creating a petroleum reserve to protect against future disruptions in U.S. energy supplies. The Department is committed to storing 500 million barrels by 1980 and 1 billion barrels by 1985 . The crude oil will be stored underground in salt caverns and mines. Thus far, three salt cavern sites and one salt mine have been acquired to store this oil.

Tight time constraints coupled with the complex and technical nature of the program have resulted in the Department taking actions without adequate analysis to assure that risks are minimized. For example, the Department is planning to store oil above where mining operations are scheduled to begin in 1980 even though the Federal agency responsible for miner safety has said that serious or disastrous safety hazards to the miners and the oil storage area could result.

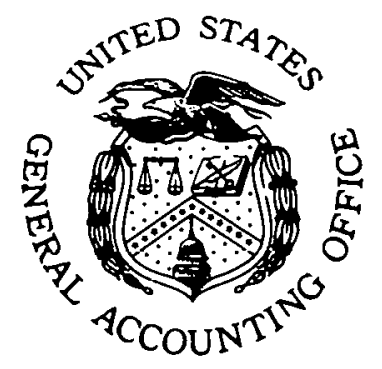


$B-178205$

To the President of the Senate and the Speaker of the House of Representatives

This report discusses actions taken by the Department of Energy without adequate analysis to assure that risks of using certain salt caverns and mines for the strategic petroleum reserve are minimized. The authorization of this reserve is the major action which has been legislated so far to lessen U.S. dependence on imported oil. This report is intended to make the Congress aware of the possible ramifications of $r$ isks being taken by the Department in implementing the reserve program, as well as alternatives available to minimize these risks.

We made our review pursuant to the Budget and Accounting Act of 1921 ( 31 U.S.C. 53), and the Accounting and Auditing Act of 1950 (31 U.S.C. 67).

We are sending copies of this report to the Director, Office of Management and Budget; the Secretaries of Energy and Labor; interested congressional committees; and other interested parties.

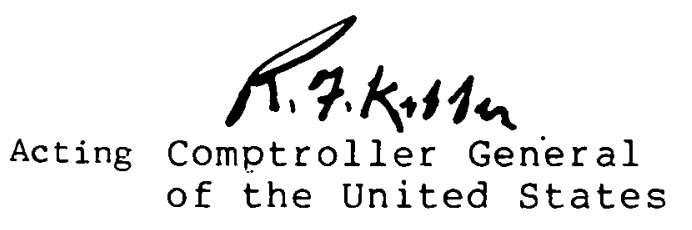


COMPTROLLER GENERAL'S

REPORT TO THE CONGRESS
QUESTIONABLE SUITABILITY

OF CERTAIN SALT CAVERNS AND

MINES FOR THE STRATEGIC

PETROLEUM RESERVE

D I G E $\underline{\mathrm{S}} \underline{\mathrm{T}}$

In December 1976, the Department of Energy submitted a plan to the Congress for 150 million barrels of reserve oil by December 1978 and 500 million barrels by 1982. Five months later, the Department accelerated the reserve targets to $250 \mathrm{mill}$ ion barrels by December 1978 and 500 million barrels by December 1980; currently, the Department plans to store 1 billion barrels by December 1985. The rationale for the acceleration was to provide the United States with increased petroleum supply protection as soon as practicable. The Department has revised its plans again and now expects to reach its 250. million barrel target by June or July of 1979 .

To reach these goals, the Department decided to concentrate initially on converting existing salt caverns and mines into storage areas, rather than constructing new caverns or mines. As of mid-June 1978, the Department had acquired four sites containing 19 salt caverns and one salt mine to be used for storing oil. (See p. 1.)

While the Department has not yet estimated the cost to store 1 billion barrels, it did estimate the cost to store $750 \mathrm{million}$ barrels at $\$ 14.4$ billion. (See p. 1.)

Storage targets for the reserve appear very ambitious, in view of the complex and technical nature of the program, and have had a dominant influence on Department actions and decisions. It is GAO's view that the Department has not allowed sufficient time to consider adequately the pros and cons of many of the decisions that have been and must be made to develop the reserve. Consequently. 
the tight time constraints for the reserve program, coupled with the fact that the program is new and complex, surround certain elements of the program with a degree of risk that may be unacceptably high. (See p. 17.$)$

POTENTIAL PROBLEMS OF

USING CERTAIN SALT

CAVERNS FOR STORAGE

of the 19 existing caverns the Department has acquired, 6 may not be suitable for long-term storage because they do not meet structural design standards for oil storage suitability and may grow together. Three of the six caverns already have been certified for storage. The other three have failed to pass tests. The Department has deferred a decision on whether to try to certify these three caverns until further study of the salt dome has been completed. ( See p. 6.)

The Department has mentioned two alternatives to continued use of these caverns if they are found to be unsuitable.

1. Abandon the unsuitable caverns and use additional cavern storage capacity that had been developed during withdrawal.

2. Use salt water to displace oil in the caverns during withdrawal so no additional growth could take place and the potentially unsuitable caverns would not grow together.

However, if these alternatives are unworkable, the Department may have to resort to acquiring other existing caverns or mines, or constructing new ones. Because of the significant problems that these six caverns could pose (loss of oil, program delays, and additional cost) GAO believes the Department should not proceed before alternative courses are examined. (see p. 7.) 
The salt mine that the Department has acquired may not be a suitable or practical facility for long-term crude oil storage because of problems disclosed by the Mining Safety and Health Administration, and because of the resulting potential legal and financial ramifications. Additional problems are:

- The Department's test program for determining the mine's suitability may not have been adequate, and interpretation of test results may be questionable. (See p. 8.)

--If Morton Salt Company mines salt 300 to 370 feet under the storage area, as planned, miners' safety and the integrity of the oil storage could be in jeopardy. (See p. 10.)

--If Morton Salt Company is prevented from mining as planned, adverse financial impact to Morton and nearby communities is possible and could result in legal action against the Department. (See p. 11.)

-A potential water problem exists which could result in oil washing out of the storage area damaging the environment. (See p. 12. )

These problems give rise to two basic questions: (1) is the mine structurally suitable for crude oil storage and (2) if so, is it cost effective in view of the additional expense that could be incurred to insure miner safety and integrity of oil storage? The resolution should consider minimizing adverse economic and social impact on all affected parties. The Department has agreed to enter into a memorandum of understanding with the Mining Safety and Health Administration to improve cooperation and develop a program that is in the best interest of the Government. (See p. 19.) 
NO DOCUMENTATION REGARDING

DEVIATIONS FROM CAVERN TEST

CRITERIA

Before the Department uses caverns to store oil, it has them tested by a contractor. The test program calls for a test at pressures higher than are expected to be experienced when crude oil is pumped in and out of the caverns. GAO found that two caverns were not tested to these pressure levels. Because the deviations were small, this may not, in and of itself, be a serious problem. However; the Department does not have a formal system to document allowable deviations from specified testing criteria. This could lead to unauthorized deviations or tendencies to approve unacceptable deviations from the test program. (See p. 5.)

\section{ADEQUACY OF STORAGE FACILITY} COST ESTIMATES

Accurate cost information is essential to appropriations committees when considering requests for program funds. This is particularly true with extremely high cost programs such as the strategic petroleum reserve. The cost estimates for acquisition, construction, and operation of reserve storage facilities were not adequately documented; however, the Department has taken steps to improve the adequacy. (See p. 15.)

RECOMMENDATIONS TO THE SECRETARY OF ENERGY

The Secretary, Department of Energy, should make every attempt to minimize risk, uncertainty, and when practicable, program costs to insure that oil is stored in suitable, stable storage facilities until needed.

Specifically. GAO recommends that the secretary

--stuajy the alternatives for minimizing the risk associated with using the potentially 
unsuitable caverns acquired for storage, making the study results available to the Congress;

--develop a formal system for documenting, before test completion, any acceptable deviations from pressure levels specified in the test program, and approvals for such deviations;

--delay further oil storage development at the salt mine until (1) the Mining Safety and Health Administration and the Department have jointly studied what additional testing is needed to insure that the salt mine is suitable for long-term crude oil storage and (2) the Department and the Mining Safety and Health Administration have worked together to develop a solution to the problems involved in using the salt mine for storage; and

--insure that all future cost estimates relating to the reserve program are adequately documented.

\section{COMMENTS ON DRAFT REPORT}

The Mining Safety and Health Administration sent GAO a copy of an April 24, 1978, memorandum to the Secretary of Labor stating that Department $" \star \star \star \star ~ p l a n n i n g$ for the active mining and oil storage within the same dome has the potential for serious to disastrous health and safety hazards to the miners"; and, the Department "continuing its present program in the manner planned would be an embarrassment to the Government." (See p. 20.)

The Morton Salt Company questioned certain facts and statements in GAO's report, including statements that the Mining safety and Health Administration had concerns about safety aspects of concurrent mining and oil storage at the mine. (See p. 20.) 
The Department of Energy addressed two general areas. First, it believes that GAO's concern over the potential for caverns growing together is unwarranted. However, the Department admitted that the possibility of caverns growing together after multiple withdrawals is real. Further, it said that it will develop plans for refill of the reserve which will include abandoning or modifying the use of certain caverns, if necessary. (See p. 22.)

GAO agrees that it is desirable to develop such plans. However, they should be based on a thorough study, including the costs and benefits, of alternatives to both (1) continued use of caverns which could grow together and (2) using altogether different storage facilities. (See p. 22.)

The second area was the safety of using the salt mine for oil storage. The Department said that there is no evidence, facts, or test data to indicate that the mine is not suitable for oil storage. It also said that there was no reason to delay storing oil at the site and that the planned mining operations, which could involve safety hazards, are not scheduled to begin until 1980. The Department believes that any necessary corrective actions can be taken before then. ( See p. 22.)

Because concerns raised by the Mining Safety and Health Administration have serious potential consequences, delay of further oil storage development at the mine, in GAO's opinion, is warranted until these concerns are put to rest. (See p. 19.) 


$$
\text { C } 0 n t e n t s
$$

Page

DIGEST

CHAPTER

INTRODUCTION

1

Crude oil storage in salt caverns 1

crude oil storage in conventional mines 2

POTENTIAL PROBLEMS RELATIVE TO SALT CAVERN

STORAGE 4

No documentation regarding deviations from cavern test criteria

potential problem of caverns growing together

QUESTIONABLE SUITABILITY OF A SALT MINE

PLANNED FOR CRUDE OIL STORAGE

DOE's mine testing program may not be adequate

Uncertain effects of continued mining below the oil storage area 10

potential water problem at Weeks Island 12

EFFECTS OF LONG-TERM STORAGE ON CEUDE OIL AND POTENTIAL LOSSES

Effects of long-term storage on the physical properties of crude oil potential crude losses

6 CONCLUSIONS, OBSERVATIONS, RECOMMENDATIONS, AND COMMENTS ON DRAFT REPORT

Potential problems of using certain salt caverns for storage

No documentation regarding deviations from cavern test criteria

Problems at the Weeks Island mine

Adequacy of storage facility cost estimates

Recommendations to the secretary of Energy

Comments on draft report 
CHAPTER

$\underline{\text { Page }}$

7. SCOPE OF REVIEW

APPENDIX

I

Comments on draft report

25

MSHA Comments

Morton Comments

25

DOE comments

28

34

\section{ABBREVIATIONS}

DOE

Department of Energy

EPA

Environmental Protection Agency

GAO General Accounting office

MSHA Mining Safety and Health Administration 


\section{CHAPTER 1}

INTRODUCTION

The Energy Folicy and Conservation Act (Public Law 94-163) requires the Department of Energy (DOE) 1/ to create a strategic petroleum reserve (reserve) to diminísh U.S. vulnerability to the effects of a severe interruption in energy supplies and to provide limited protection from the consequences of interruptions in petroleum product supplies. In December 1976 DOE submitted to the Congress a strategic petroleum reserve plan (plan) which stated that the reserve would contain 150 million barrels of oil by December 1978, and 500 million barrels by December 1982 .

In his April 1977 energy message, however, the president called for expanding. the program to 1 billion barrels. Subsequently. DOE's May 1977 plan amendment set new reserve targets of $250 \mathrm{mill}$ ion barrels by December 1978, and $500 \mathrm{million}$ barrels by December 1980; however. DOE does not expect to store the first $250 \mathrm{million}$ barrels until mid-1979. DOE expects to store 1 billion barrels by December 1985. While DOE has not yet estimated the cost of storing l billion barrels, DOE's estimated cost for storing 750 million barrels is $\$ 14.4$ bilIion.

DOE determined that underground storage was the least costly, most feasible way to store large amounts of oil. Consequently, oil for the reserve will be stored in salt caverns and in mines. Nine potential storage sites with existing capacities totaling 391 million barrels were initially identified. DOE, as of mid-June 1978, had acquired four of these sites through condemnation proceedings--three salt cavern sites and one salt mine. The acquired sites are in Texas and Louisiana near the Gulf coast.

CRUDE OIL STORAGE IN SALT CAVERNS

In the United States, salt caverns have been used for over 20 years to store petroleum products including fuel oil

1 /Many of the statements and actions attributed to DOE in this report were actually stated and performed by the Federal Energy Administration. For simplicity, however, DOE is referred to throughout the report. The functions of the Federal Energy Administration were transferred on October 1 , 1977. to DOE. 
and natural gas, but they have not been used to store crude oil. In France and West Germany, however, crude oil has been stored in salt caverns for several years.

Salt caverns are created by a fairly simple process called leaching or solution-mining. First, a well is drilled into the salt formation. The well is lined with steel casing which is set in cement to seal off freshwater beds and other formations. Freshwater or sea water is then pumped down a tube within the casing to dissolve the salt.

After leaching, the cavern contains a salt-water substance called brine. Crude oil can then be pumped down between the tubing and the casing to force the brine up through the tube. The oil floats on the remaining brine. Crude oil is withdrawn from a cavern by reversing the fill process. By pumping water down the tubing the crude oil is forced up between the tubing and the casing. The chart on page 3 shows the operation of a crude oil storage cavern.

CRUDE OIL STORAGE IN CONVENTIONAL MINES

Although no crude oil is stored in mines in the united States, it has been stored in an iron mine in France, a potassium mine in West Germany, and a coal mine in South Africa. The process of converting a mine for crude oil storage involves removing the oil production and shaft equipment, preparing the mine floor by installing a sump pump, grading the floor to insure drainage to the pump. and installing casing for oil fill and withdrawal. Unlike the salt caverns where water is used to displace crude oil, submersible pumps are used to withdraw oil from mines.

Potential problems relative to salt caverns and salt mines planned for storage are discussed in this report as well as the effects of long-term storage on the physical and chemical properties of crude oil, the potential for crude oil losses, and the estimated costs of the storage facilities. 
OIL STORAGE OPERATION IN A SALT DOME

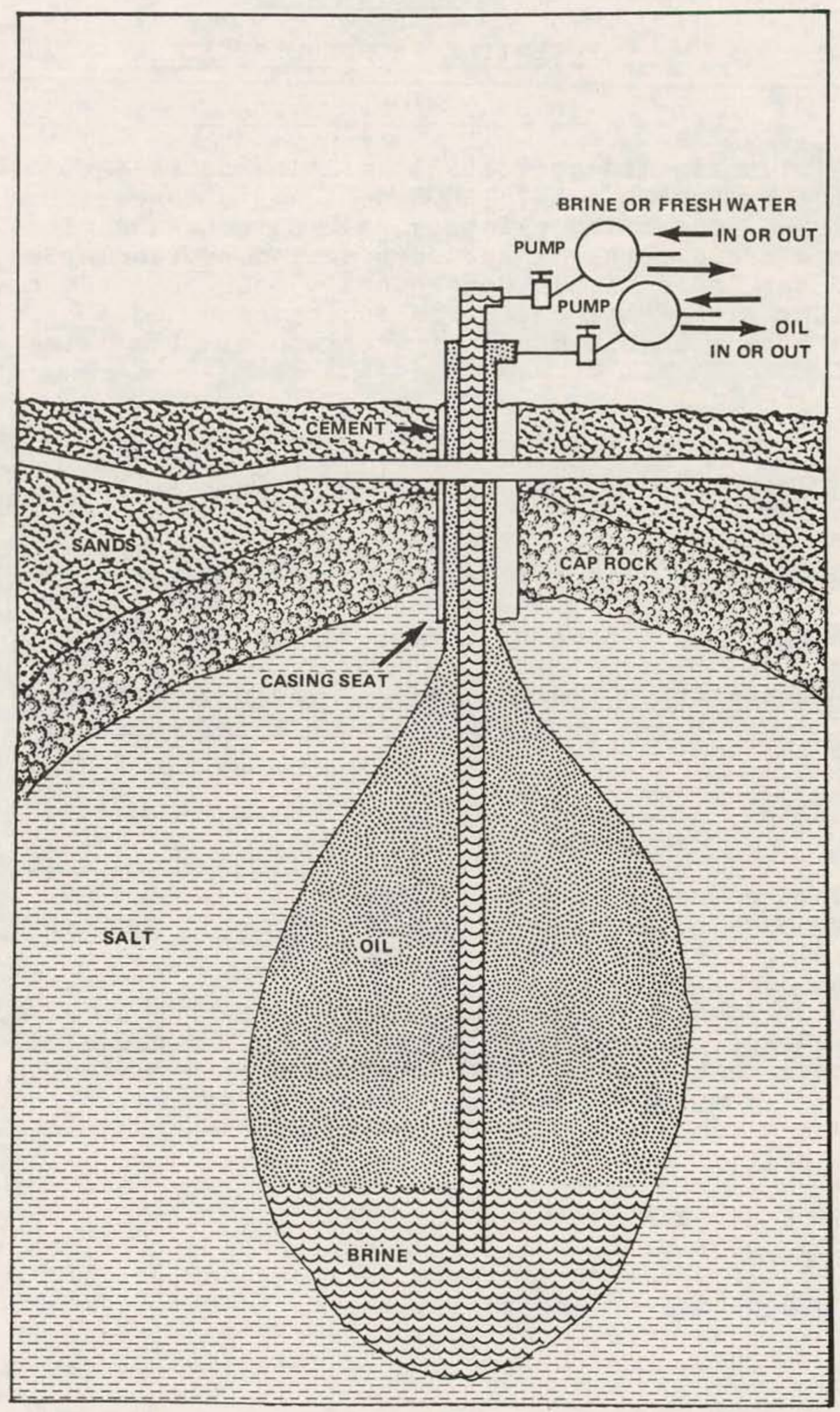




\section{CHAPTER 2}

POTENTIAL PROBLEMS RELATIVE

TO SALT CAVERN STORAGE

To attain its goal of 250 million barrels of oil in storage by December 1978, DOE deciajed to concentrate initially on converting existing salt caverns and mines into storage areas rather than constructing storage areas, which would take more time. Consequently, DOE acquired the following four sites that have existing caverns and a salt mine. These have a combined capacity of about 261 million barrels.

\begin{tabular}{|c|c|c|c|}
\hline Site & $\begin{array}{c}\text { Location } \\
\text { (Parish/County } \\
\text { and State) }\end{array}$ & $\begin{array}{c}\text { Type of } \\
\text { underground } \\
\text { storage }\end{array}$ & $\begin{array}{l}\text { existir } \\
\text { capacit } \\
\text { in barre } \\
\text { (millior }\end{array}$ \\
\hline Bayou Choctaw & Iberville, La. & Salt caverns & a $/ 74$ \\
\hline Bryan Mound & Brazoria, Tx. & Salt caverns & 62 \\
\hline West Hackberry & Cameron, La. & Salt caverns & 50 \\
\hline Weeks Island & New Iberia, La. & Salt mine & 75 \\
\hline Total & & & 26. \\
\hline
\end{tabular}

a/Plans to use 30 million of the 74 million barrels of capacity have been deferred until a study of the salt dome is completed.

DOE acguired a total of 19 salt caverns at Bayou Choctaw, West Hackberry, and Bryan Mound to use for crude oil storage. The caverns had been solution-mined over a period of years by chemical companies to obtain brine feedstock for their manufacturing processes. These caverns were not designed to store crude oil.

DOE hired a contractor to test the suitability of these caverns for storing oil. The contractor determines, through testing, if a cavern is suitable for crude oil storage. If the cavern is found suitable, the contractor certifies that the cavern is structurally sound for oil storage. As of April 7, 1978, the contractor had certified 11 caverns.

We found, however, that the contractor made certain small deviations from the testing program. More importantly, we are 
concerned that of the 19 salt caverns, 6 may not be suitable for long-term storage because they do not meet design standards for oil storage suitability preferred by companies who design, construct, and operate storage caverns. These six caverns have about a 55-million-barrel capacity worth about $\$ 669 \mathrm{milli}$ ion in oil. Three of these six caverns have already been certified and are to be used for storage. The other three caverns have failed to pass the tests for storage suitability.

NO DOCUMENTATION REGARDING DEVIATIONS FROM CAVERN TEST CRITERIA

The testing program calls for the caverns to be tested to measure resistance to fracturing at pressures which will be experienced when crude oil is pumped in and out of the caverns. To allow for a safety margin, the test program requires that caverns be tested at pressures higher than the planned operating pressures. We reviewed the contractor's cavern certification files to determine if tests were conducted in accordance with pressure criteria specified in the test program. Two caverns at west Hackberry--caverns number 6 and 9--were tested at pressures slightly below those specified in the cavern test program. For cavern 6 the test program called for 732 pounds of pressure, but the cavern was tested to 710 pounds of pressure. For cavern 9 the test program required 650 pounds of pressure, but the cavern was tested to 640 . These test pressures are 30 percent above the maximum planned operating pressure of the caverns according to DOE officials. According to the testing contractor, these deviations were acceptable because cavern testing is time consuming, and the additional time required to reach the specified pressure did not justify achieving the small increase in the safety factor. One DOE official told us that he had given verbal approval to the contractor to make the deviations. However, he said this approval had not been documented.

Another DOE official stated that DOE relies on the expertise and experience of the testing contractor for acceptable deviations from the testing program. Whenever the contractor believes the cavern is suitable after performing the tests --even with deviations--the contractor certifies the cavern. The official added, however, that after reviewing the certification document and the testing data on which the certification was based. DOE has the option of not accepting the certification. DOE did not exercise this option and accepted certifications on the two caverns which were tested at lower pressures than those specified in the test program. 
POTENTIAL PROBLEM OF CAVERNS GROWING

TOGETHER

The reserve is being designed to accommodate up to five fill and withdrawal cycles. DOE assumes that oil may have to be pumped into and out of storage five times during the 1 ife of the reserve. According to a DOE report, each such cycle can cause caverns to expand an estimated 14 percent. This expansion could change the configuration of the caverns, including height to diameter ratios. Most importantly, it could cause caverns to grow together, forming new caverns with completely different shapes and height to diameter ratios.

The relationship of cavern height to cavern diameter and the distance between caverns are important considerations when determining salt cavern structural stability and suitability for crude oil storage. These factors can indicate potential massive fracturing of the cavern walls or total collapse of the ceilings.

We attempted to identify specific criteria for cavern height to diameter ratios and minimum distance between caverns. We found, however, through discussions with officials representing firms experienced in designing, constructing, and operating storage caverns that specific criteria do not exist. We did find, however, that each company has preferred design standards, ranging from 3:1 to $10: 1$ for height to diameter ratios and from 270 to 575 feet for minimum distance between caverns. Moreover, a DOE contractor responsible for designing and constructing new caverns for the reserve is planning on a height to diameter ratio of $9: 1$ and a minimum distance between caverns of 520 feet.

Six caverns acquired for storage do not conform to these preferred design standards--caverns number 6 and 9 at west Hackberry and caverns 3, 11,13 , and 15 at Bayou Choctaw. For each of the six caverns, the distance from one or more other caverns is substantially less than the minimum preferred distance of 270 feet. Four of the caverns have a height to diameter ratio of less than the minimum preferred ratio of $3: 1$ -ranging from 2:1 to $1: 5$. Of the six caverns, three already have been certified suitable for crude oil storage. Caverns 3, 11 , and 13 at Bayou Choctaw failed to pass pressure tests.

We discussed this issue with DOE officials. They told us that three of the caverns--caverns 3,11 , and 13 at Bayou Choctaw--have already grown together and a decision on whether to use them has been deferred until further study of the salt dome has been completed. These officials also said that while they recognize that the potential exists for the remaining 
three caverns to grow together, they are still planning to use these caverns for storage.

DOE officials also told us that all caverns would be retested after each fill and withdrawal cycle to determine if the caverns remain structurally stable or suitable for oil storage. If caverns did not remain suitable, DOE said it could either (1) abandon the unsuitable caverns and use additional cavern storage capacity that would be developed during a withdrawal cycle or (2) use brine as a displacement fluid so that no additional growth could take place. In our view, unanswered questions remain as to the viability of these options. Regarding the first option, reserve plans call for refilling caverns only to their initial capacity so that cavern enlargement could be minimized and so that adequate withdrawal rates can be maintained. Regarding the second option, DOE is aware that using brine would be very expensive and that there could be environmental problems associated with its use. In summation, although DOE has pointed to these options as solutions, the questions that face the use of these options have not been answered. 
CHAPTER 3

QUESTIONABLE SUITABILITY OF A SALT

MINE PLANNED FOR CRUDE OIL STORAGE

Weeks Island Salt Mine, a storage site for the reserve program, has operated since 1902 and is now operated by Morton Salt Company. The mine consists of two levels; but the upper level has been abandoned since 1956 when production started on the lower level. DOE intenas to store about $75 \mathrm{million}$ barrels of oil in both levels, beginning in January 1979 .

DOE acquired a minimum amount of the salt dome at weeks Island so that mining activities there coula continue and any adverse economic impacts on Morton and nearby communities could be minimized. Morton is now developing a temporary mining level beside the oil storage area, and Morton officials stated that they will begin mining between 300 and 370 feet directly below the oil storage area in 1980 .

We looked into three aspects of the decision to store oil at this site: (1) the adequacy of DOE's program to test the existing mine for its suitability as a storage site, (2) the effects of mining below the oil storage area, and (3) a potential water problem at Weeks Island.

DOE'S MINE TESTING PROGRAM

MAY NOT BE ADEQUATE

DOE selected the same contractor that is testing and certifying salt caverns to test the mine's storage suitability. The contractor developed a mine testing program for DOE and subcontracted with a mining engineering and consulting firm to carry out the tests. On January 17, 1978, the contractor certified Weeks Island Salt Mine as suitable for crude oil storage.

Because of concern for the health and safety of the salt miners who could be working below the oil storage area, the Department of Labor's Mining Safety and Health Acoministration 
(MSHA) 1/ reviewed the DOE testing program that had been used as the basis for certifying the mine's suitability for storing oil. MSHA officials found that DOE's mine testing program was not adequate. Based on the number and type of salt samples tested, MSHA officials questioned how a reliable determination could be made that the mine is structurally suitable for oil storage. The salt samples that were taken, according to MSHA officials, are not representative of all conditions in the mine and the test results just as easily could have been interpreted that the mine is not suitable for oil storage.

Further, DOE tested only the lower level of the mine. But, MSHA believes that the upper level should also be tested because salt characteristics can change on a vertical plane. According to MSHA officials, because of the magnitude and cost of the reserve program, DOE is taking an unacceptably high risk in assuming that the salt characteristics in the upper level can be accurately projected based on data obtained from testing the lower level. DOE officials disagreed. They said that testing the upper level was not necessary because on a vertical plane, there are no significant changes in salt characteristics. They stated that any changes that do exist are a function of depth and, thus, can be calculated. DOE's conclusion, therefore, was that the lower level test generated data that could be extrapolated reliably to the upper level. Furthermore, DOE officials told us MSHA had refused to permit DOE to test the upper level.

We asked MSHA officials if they had refused to allow DOE to test in the upper level. MSHA officials stated that MSHA informed DOE officials that because the upper level is an abandoned mine, MSHA regulations require DOE to outline safety procedures for MSHA approval before DOE could enter the mine. DOE neither submitted the safety procedures nor again asked about testing the upper level, according to MSHA officials.

1/MSHA administers the enforcement provisions of the public laws and related standards and training programs to guard the health and safety of miners. MSHA was established March 9, 1978, and assumed the responsibilities of the Mining Enforcement and Safety Administration of the Department of the Interior. 
UNCERTAIN EFFECTS OF CONTINUED MINING BELOW THE OIL STORAGE AREA

A safe distance between the oil storage area and the new mining area is vital because of the potential for blowouts. Blowouts cause more salt than planned to be broken by blasting, resulting in rounded openings of various depths in the mine walls or ceilings. If Morton mines below the oil storage area, a blowout could occur in Morton's working mine, possibly extending to the oil storage area above and flooding the working mine with oil.

DOE's subcontractor responsible for testing the mine issued a final report on Weeks Island which recommended, "Neglecting the possibility of blowouts, a minimum web [salt] thickness of 300 feet should be provided to ensure the safety of mining operations below the oil storage facility." The report strongly recommended that mining below stored oil not be initiated until high-potential blowout areas could be positively predicted. According to the report, the consequences of a major blowout in a mine below stored oil could be disastrous and the risk of such occurrences must be eliminated to ensure the safety of miners and the integrity of oil storage.

According to Morton officials, the largest blowout that ever occurred at Weeks Island extended about 30 feet. Thus, because there will be between 300 and 370 feet of salt between the floor of the lower storage area and the roof of the proposed new mine, DOE and Morton officials believe that mining below the oil storage area as planned should be safe. DOE added, however, that sufficient study had not been done to predict and control blowouts. DOE further stated that, while unlikely, if blowouts were to damage the oil storage area, Morton would be totally responsible. Morton officials argue that, as long as Morton is not negligent in its mining activities, DOE would be financially liable for damage to the storage area and the mine below. In the event of mishap, the issue of financial responsibility, including possible negligence, by DOE. Morton, or others, would ultimately be determined in the Courts.

MSHA is concerned about the potential effects of blowouts at weeks Island. According to MSHA officials, even if small blowouts were to occur, cracks and fractures resulting from the blowout could extend to the oil storage area and oil could leak into the mine below. Blowouts have occurred in five of six Louisiana salt mines. MSHA recently reported the results of a limited study of blowouts; oil, gas, and water seepages; and existing mining conditions at weeks Island and all other Louisiana salt domes in that area. With respect to the Weeks Island blowout problem, the MSHA report concluded that weeks Island may be the most blowout-prone dome that was studied. The report also concluded that no practical means exist to assure that mining will not penetrate into a blowout-prone 
zone and that potential hazards are too great to permit mining 370 feet below oil storage. According to the report, unless facts are provided that assure a lesser distance is adequate, mining should not occur less than 650 feet below the oil storage area.

MSHA, however, believes that development of blowout evasion tactics may be possible through a more comprehensive study of the five Louisiana mines. MSHA estimated this study would take 1 year and would cost $\$ 300,000$. DOE has offered to provide financial and other assistance so that MSHA can conduct the necessary studies.

DOE officials stated that DOE is fully committed to protecting the health and safety of miners at Weeks Island. According to DOE, storage of oil in the existing mine does not present any immediate hazaras to miners or the oil storage area because Morton is currently working beside the storage area.

DOE officials state that they believe that the salt area it has acquired around the mine is adequate to protect the oil storage area and a future salt mine below. However, if MSHA determines that DOE's salt area acquisition is insufficient to protect miners and property, DOE will take all action necessary to insure site safety. This, according to DOE, would include acquisition of additional salt beneath the storage area either by purchase or by right of eminent domain.

Existing underground storage capacity in the Gulf coast is very limited, according to DOE; and there are no alternative sites to Weeks Island for $75 \mathrm{million}$ barrels of oil storage in the 1978-1979 time frame. No cost assessment has been made for the possible acquisition of additional salt beneath the existing mine, but DOE is prepared to assume this financial burden to protect miners and the oil storage area.

If MSHA precludes Morton from mining at Weeks Island or forces Morton to mine at a deeper level than planned. Morton officials stated that they would initiate legal action against DOE for, in effect, taking more salt in the dome than originally agreed to and paid for.

According to MSHA, a situation similar to Weeks Island may exist at Cote Blanche, one of the five potential sites identified for oil storage that DOE has not yet acquired. The Cote Blanche mineowner is planning to mine above the proposed oil storage area, according to MSHA. MSHA anticipates that the owner may also decide to mine beneath the proposed oil storage area because 900 million tons of salt could be recovered from such mining activity. MSHA officials further state 
that hazards to the health and safety of miners are a likely result of concurrent mining and oil storage at cote Blanche.

POTENTIAL WATER PROBLEM AT WEEKS ISLAND

The MSHA report concluded that a water infiltration problem exists at Weeks Island. If this problem is not controlled, the oil storage area could be destroyed, according to MSHA, and oil could be washed out of the storage area and pose a threat to the environment. Morton, in developing its temporary mine beside the oil storage area, encountered water flows which totalled 50 gallons per hour, according to MSHA. After certain corrective actions were taken, flows are now reported to be 4 to 5 gallons per hour.

DOE officials concur that water can be a serious problem. DOE also recognizes that water can leach openings in the salt and that determining the exact location of ground water at the edges of salt masses can be difficult. According to DOE, the water Morton encountered in the salt structure has been 1 inked to subsurface water outside the salt mine and water flows into the new mining area are being continuously monitored. DOE believes that techniques can be developed to avoid water inflows.

MSHA is concerned that, while water may be controlled at the new mine, it could change its path and enter the oil storage area. According to the MSHA report, a water leak into the Avery Island mine in Louisiana was plugged by cement. But, 6 months later the water rerouted itself into the mine 200 feet away. This rapid, unpredicted movement of water, according to MSHA, emphasized its concern about the water infiltration at Weeks Island. 


\section{CHAPTER 4 \\ EFFECTS OF LONG-TERM STORAGE ON \\ CRUDE OIL AND POTENTIAL LOSSES}

DOE plans to store 1 billion barrels of crude oil and possibly petroleum products in the reserve. Current planning provides for withdrawal of this oil only if there is a severe interruption in energy supplies. In this chapter we address (1) how long crude oil can be stored and still remain suitable for refining and (2) how much oil might be lost during storage.

EFFECTS OF LONG-TERM STORAGE ON THE

PHYSICAL PROPERTIES OF CRUDE OIL

DOE and petroleum company officials stated that, although the length of time crude oil can be stored in salt caverns or mines and remain suitable for refining is unknown, they believe long-term storage should not have any detrimental effects on crude oil. U.S. petroleum industry researchers have developed information concerning the effects of salt cavern storage on hydrocarbon stability, but this information is generally based on storage periods of less than 1 year.

The west German government has had crude oil stored in salt caverns for over 8 years--the longest period of time crude oil has been stored in salt caverns. DOE expects to contract with the west German company that constructed and is operating these caverns to obtain detailed information on the stability of the stored crude oil. DOE plans to award the contract costing about $\$ 250,000$ in mia-1978. The work will take about 1 year to complete.

One DOE official stated that after the caverns have been filled a year or so. DOE plans to sample the oil in the caverns and to test periodically the chemical composition of the crude oil. This information will then be given to refiners to make the necessary preparations to maximize product efficiency during any supply interruptions.

POTENTIAL CRUDE LOSSES

We discussed the potential for crude oil losses in salt caverns with DOE officials and with companies having experience in design, construction, and operation of salt caverns for crude oil storage--American petroleum companies, a west German company, and the Louisiana offshore oil port. We learned that there are generally three ways crude oil can be 
lost during storage: (1) leakage through cracks in the cavern, (2) loss during oil withdrawal, and (3) suspension of oil in brine.

If caverns remain structurally stable and do not crack, crude oil should not leak out of the caverns. During our discussions with officials of the American petroleum companies, the West German company, and the Louisiana offshore oil Port, we were told that because salt is impervious to petroleum, crude oil should not be lost due to absorption.

In commenting on the environmental impact statement DOE prepared for one of the storage sites, Environmental protection Aqency (EPA) officials stated that when oil is removed from the storage caverns, some oil will adhere to the cavern walls and will subsequently be suspended in the brine. EPA further stated that when oil is pumped back into the caverns, the displaced brine will carry the oil with it. According to DOE, the maximum amount of crude oil mixing with the brine during crude oil displacement would be about 18 parts per million. Applying the 18 parts per million estimate to a 1 billion barrel reserve, DOE can expect to lose about 18,000 barrels of oil (.0018 percent) during withdrawal operations.

DDE also stated that some oil will be suspended in brine near the oil-brine interface and concluded that the amount of suspended crude oil, commonly known as an emulsion, cannot be predicted. The emulsion amount can be minimized, however, by insuring that the oil-brine interface is not withdrawn from the cavern. The contractor who performed the engineering feasibility studies on new caverns for DOE suggested that the emulsified interface could be held in the cavern until its volume warranted treatment. As part of the German contract concerning the effects of long-term storage, studies will be conducted to determine if (1) unacceptable oil emulsions will be encountered and (2) treatment facilities are necessary for breaking the emulsion and recovering the oil. 


\section{CHAPTER 5}

\section{ADEQUACY OF STORAGE FACILITIES COST ESTIMATES}

In discharging its legislative and surveillance responsibilities, the Congress neeas information to evaluate the progress of Federal agencies in accomplishing program objectives and to identify problems needing resolution. Adequate program cost information is particularly essential.

In the strategic petroleum reserve plan submitted to the Congress in December 1976. DOE estimated that the costs to acguire, construct, and operate oil storage facilities would be $\$ 765.9$ million. A May 1977 amendment projected these costs to be $\$ 785.2 \mathrm{million.}$ DOE officials stated that acquisition costs contained in the plan were based on Corps of Engineers studies and that construction and operation costs were based on estimates contained in contractor studies made to assist in DOE's storage site selection process.

We did not analyze the adequacy of the cost estimates contained in the Corps of Engineers and contractor studies. We tried, however, to match the amounts in the corps of Engineers and contractor studies with the amounts contained in the plan and plan amendment. Except for a few instances, the amounts were not the same. We then tried to determine the reason for the differences. DOE officials advisea us that, for the most part, the basis for these differences was not documented and that it would be extremely difficult, if not impossible, to construct such documentation. DOE officials explained that adjustments were being made very quickly to the amounts and that there was not enough time for documentation.

Lack of documentation aside, we asked DOE officials to explain these differences to us. They could not fully explain these differences, but they stated that adjustments were being made for such technical factors as alternative pipeline linkups and dock facilities.

In a March 7, 1978, letter to the Controller, DOE, we asked for his views concerning the adequacy of reserve cost documentation as well as assistance in providing us this documentation. In a March 23, 1978, response, the controller agreed that there are problems in tracing the cost estimates back to contractor estimates because the adjustments were not well aocumented. The controller also agreed that it is important for the Congress to have adequate cost information and indicated that substantial DOE attention has been rendered to promote adequate cost estimates for new projects and effective project management control. 
The Controller also pointed out that in December 1977 , DOE completed a comprehensive review of the reserve program management, cost, and schedule. One of the resultant management decisions was that reliable cost estimates for construction and operation of the reserve facilities would be developed. 


\section{CHAPTER 6}

\section{CONCLUSIONS, OBSERVATIONS, RECOMMENDATIONS,}

\section{AND COMMENTS ON DRAFT REPORT}

In December 1976 DOE submitted a reserve plan to the Congress, stating that the reserve would contain 150 million barrels of oil by December 1978 and $500 \mathrm{million}$ barrels by 1982. Five months later, DOE accelerated the reserve targets to $250 \mathrm{million}$ barrels by December 1978 and $500 \mathrm{million}$ barrels by December 1980; and, currently, DOE plans to store 1 billion barrels by December 1985. The rationale for the acceleration was to provide the United States with increased petroleum supply protection as soon as practicable. DOE has revised its plans again and now expects to reach its $250 \mathrm{mil}-$ lion barrel target by June or July of 1979 .

We agree with DOE that it is desirable to provide the united states with petroleum supply protection as soon as practicable. In this regard, we believe that it is most important for DOE to insure that the reserve can be relied on to provide protection from the consequences of interruptions in energy supplies. DOE must, therefore, assure that oil is stored in facilities that will remain suitable for storage until the oil is needed.

We believe DOE's reserve storage targets are very ambitious in view of the complex and technical nature of the program. We further believe that the targets have had a dominant influence on DOE actions and decisions. It is our view that DOE has not allowed sufficient time to consider the pros and cons of many of the decisions that have been and must be made in developing the reserve.

Consequently, the tight time constraints for the reserve program coupled with the fact that the program is new and complex surround certain elements of the program with a degree of risk that may be unacceptably high. In the following sections we describe actions that DOE should take to minimize the risk.

POTENTIAL PROBLEMS OF USING CERTAIN SALT CAVERNS FOR STORAGE

of the 19 existing caverns DOE has acquired, 6 may not be suitable for long-term storage because they do not meet structural design standaras for oil storage suitability. The caverns are essentially too close to each other. Crude oil fill and withdrawal cycles could cause the six caverns to grow out to other caverns, forming new caverns with different dimensions. Three of the six caverns already have been 
certified for storage. The other three have failed to pass the tests for storage suitability. DOE has deferred a decision on whether to try to certify these three caverns until further study of the salt dome has been completed.

DOE has mentioned two alternatives to continued use of these caverns if they are found to be unsuitable to refill. DOE said it could abandon the unsuitable caverns and use additional cavern storage capacity that had been developed during a withdrawal cycle, or it would use brine as a displacement fluid so that no additional growth could take place. DOE has not fully studied these alternatives. It may be that these alternatives are unworkable. If so, DOE may have to resort to acquiring other existing caverns or mines, or constructing new caverns or mines. In view of the significant problems that these six caverns could pose (loss of oil, program delays, and additional costs) we believe it would be imprudent for DOE to proceed before alternative courses are examined.

NO DOCUMENTATION REGARDING DEVIATIONS FROM CAVERN TEST CRITERIA

The two caverns at the West Hackberry site were not tested to specified pressure levels in DOE's cavern test program. The deficiency may not be a serious problem, in itself, because the deviations were small. What may be serious is that DOE does not have a formal system for documenting allowable deviations from criteria specified in the test program before tests are completed. This could lead to unauthorized deviations or tendencies to approve unacceptable deviations from the test program, so time and money could be lost by retesting caverns to acceptable pressure levels.

PROBLEMS AT THE WEEKS ISLAND MINE

We are concerned that the Weeks Island mine may not be a suitable or practical facility for long-term crude oil storage because of the problems surfaced by MSHA officials and because of the resulting potential legal and financial ramifications. The following problems are involved in using the Weeks Island mine to store oil.

--The DOE test program used to determine the mine's suitability may not have been adequate and interpretation of test results may be questionable.

--If Morton mines salt 300 to 370 feet under the storage area, as planned, miners' safety and the integrity of the oil storage could be in jeopardy. 
--If MSHA precludes Morton from mining as planned, adverse financial impact to Morton and nearby communities is possible; furthermore, it could result in legal action against DOE.

- A potential water problem at Weeks Island could result in oil washing out of the storage area damaging the environment.

These problems can be focusea into two basic questions: (1) is the mine structurally suitable for crude oil storage, and (2) if so, is it cost effective in view of the additional expense that could be incurred to ensure miner safety and integrity of oil storage? Because of the potential consequences we have mentioned, these questions must be answered. In so doing, we believe that DOE must work with MSHA to develop a strategy whereby the interests and concerns of all affected parties--especially miner safety--are considered and placed in proper perspective. The resolution should give due consideration to minimizing adverse economic and social impact on all affected parties.

MSHA and DOE officials met recently to discuss the problems that MSHA believes exist at the Weeks Island mine. At the time of our report, the two agencies had not reached agreement on the problems nor on a strategy for resolving them. DOE has agreed to enter into a memorandum of understanding with MSHA to improve cooperation and develop a program that is in the best interest of the Government. We believe that DOE and MSHA must resolve these problems before any additional work is done to convert the mine to an oil storage area.

\section{ADEQUACY OF STORAGE FACILITY COST ESTIMATES}

Accurate cost information is essential to appropriations committees when considering requests for program funds. This is particularly true with such extremely high cost programs as the strategic petroleum reserve. The cost estimates for acquisition, construction, and operation of reserve storage facilities were not adequately documented. DOE has taken steps which we heartily endorse, however, to improve the adequacy of cost estimates for the reserve.

RECOMMENDATIONS TO THE SECRETARY

OF ENERGY

We recommend to the Secretary, Department of Energy, that every attempt be made to minimize risk, uncertainty, and program costs (when practicable), to insure that oil is stored in suitable, stable facilities until needed. 
Specifically, we recommend that the secretary

--study alternatives for minimizing the risk associated with using the potentially unsuitable caverns acquired for storage and make the study results available to the Congress;

--develop a formal system for documenting, before test completion, any acceptable deviations from pressure levels specified in the test program and approvals for such deviations;

--delay further oil storage development at Weeks Island until (1) MSHA and DOE have jointly studied what additional testing is needed to insure that the weeks Island salt mine is suitable for long-term crude oil storage and (2) DOE and MSHA have worked together to develop a solution to the problems involved in using the Weeks Island mine for storage; and

- -insure that all future cost estimates relating to the reserve program are adequately documented.

\section{COMMENTS ON DRAFT REPORT}

We sent a draft of this report to MSHA, DOE, and Morton for comment. Their comments are included as appendix $I$ in this report.

MSHA-comments

In responding to our report, MSHA sent us a copy of its March 1978 task force report on problems involved in using the Weeks Island mine for storage, and sent a memorandum dated April 24, 1978, transmitting the report to the secretary of Labor. This memorandum reflects MSHA's concerns and states, "Present DOE planning for the active mining and oil storage within the same dome has the potential for serious to disastrous health and safety hazards to the miners." The memorandum also states that the MSHA Task Force, "in their report identifies the problem of uncontrolled flows of water, which even with the absence of active mining, has the potential for destroying the integrity of an oil storage area;" and, "DOE continuing its present program in the manner planned would be an embarrassment to the Government."

\section{Morton-comments}

Morton responded to our draft report by giving some details on the history of the mine and how DOE acquired it. Morton's response stated that our report should recognize 
that Morton's continued mining at Weeks Island minimizes the disruption not only to the Company and nearby communities, but also to the work force, to the local economy, including businesses and suppliers serving Weeks Island, to the up-river distribution system of Morton, and to the many hundreds of rock salt customers served by Weeks Island. We agree, as evidenced by our conclusions, that DOE and MSHA should develop a strategy whereby the interests and concerns of all affected parties are considered and placed in proper perspective and that due consideration should be given to minimizing adverse economic and social impact on all affected parties.

Also, Morton questioned certain facts and statements in the report, including our statements that MSHA had concerns about safety aspects of concurrent mining and oil storage at Weeks Island. However, MSHA's task force report clearly expresses serious safety concerns with the mine and describes the factual bases for these concerns.

Morton considers 300 to 370 feet of salt between the oil storage area and the proposed mine below to be very safe based upon standard operating practices and a rock mechanic's study. Morton also states that, to its knowledge, it is presumptive and conjectural to conclude that a blowout could occur in Morton's working mine that might extend to the oil storage area above and flood the working mine with oil. Morton also states that cracks and fractures extending from a blowout in the proposed mine would not extend vertically to the oil storage area. Morton further states that criteria are available for predicting areas with blowout potential, and Morton plans to take measures to avoid blowout-prone areas in future mining.

We are not convinced that a 300 to 370 foot distance between the oil storage area and the proposed new mine is safe and believe it has been clearly demonstrated that further study is needed before a safe distance, if any, can be positively predicted. To our knowledge, nowhere in the world has any mining activity taken place below underground oil storage; and, therefore, there is no standard operating practice for mining below stored oil. Furthermore, the rock mechanic's study addressed safe distance from the standpoint of the proposed salt thickness being able to withstand the stress of the stored oil, and did not address the effects of a blowout. MSHA officials stated that adequate criteria is not available to be able to predict and control blowouts and that cracks and fractures do extend vertically. Furthermore, according to MSHA, no practical means exists to assure that mining will not penetrate into a blowout-prone zone. 


\section{DOE comments}

DOE's comments addressed two general areas. First, although DOE admitted that the possibility of caverns growing together after multiple withdrawals is real, DOE believes that our concern over the potential for caverns growing together is unwarranted. According to DOE, it will perform tests after each withdrawal to determine precisely the scope of cavern enlargement. DOE states that mitigating measures can be taken if these tests indicate that caverns could grow together after another fill and withdrawal cycle. Also, DOE intends to develop plans--to be furnished to the Congress--for abandoning or modifying the use of certain caverns if that should become necessary. We agree that it is desirable to develop such plans. However, such plans should be based on a thorough study, including the costs and benefits, of alternatives to both (1) continued use of caverns which could grow together and (2) using altogether different storage facilities. DOE has not fully studied these alternatives.

The second general area of DOE's comments was the desirability and safety of using the weeks Island salt mine for oil storage. DOE does not agree that the mine may not be suitable for oil storage. DOE said that no evidence, facts, or test data exists to indicate that the Weeks Island mine is not suitable for oil storage.

In so doing, DOE disagreed with a study done by its own testing contractor, which stated that "all areas of the mine have different test results" and recommended that both levels of the mine be tested. Further, DOE said that technical analyses performed by DOE contractors, which indicate that 300 feet of salt is desirable beneath the oil storage area, was based on, among other things, the potential for blowouts. This statement is inaccurate. A contractor's report DOE furnished to us to support this statement recommended, "Neglecting the possibilitg of blowouts, a minimum web [salt] thickness of 300 feet should be provided to ensure the safety of mining operations below the oil storage facility." (Underscoring provided.)

DOE described several other factual differences it had with our report. These differences underscore the disagreement between MSHA and DOE over the suitability of the salt mine for oil storage and the need for these agencies to work together to resolve the serious problems that are involved.

Finally, DOE states that it disagrees that all uncertainties (no matter how minimal) should be or can be fully resolved before proceeding with implementation of the reserve program and further states that the risks are of little consequence 
when compared with reduced protection which would result from delays in program development. While we agree that all uncertainties cannot be fully resolved, we do believe that the problems raised in this report are of significant concern to warrant that DOE take the corrective actions recommended. We further believe that delays are warranted to ensure that the reserve will be able to provide the degree of protection needed by the Nation to offset the impact of interruptions of oil imports. 
We conducted our review at DOE offices in washington, D.C: and Dallas, Texas; at the offices of the contractor responsible for testing and certifying storage caverns and mines; and at the Weeks Island, West Hackberry, and Bryan Mound storage sites.

We reviewed legislation, I iterature pertinent to underground storage, the storage site selection process, and cavern and mine test programs. We observed cavern and mine tests at three storage sites and interviewed DOE, MSHA, and contractor officials. from

We also obtained comments regarding underground storage

--two American petroleum companies which construct and operate underground storage caverns;

-a rock mechanics authority who is conducting research on the dimensions and stability of salt caverns;

--officials from Louisiana offshore Oil Port--the deepwater port planned for construction in the Gulf of Mexico--which will use salt caverns for onshore facilities;

--Government officials associated with the Federal Republic of Germany's crude oil storage program; and

--a German company which constructs and operates salt caverns for oil storage. 


\section{U.S. DEPARTMENT OF LABOR MINE SAFETY AND HEALTH ADMINISTRATION \\ 4015 Wilson Boulevard \\ Arlington, Virginia 22203}

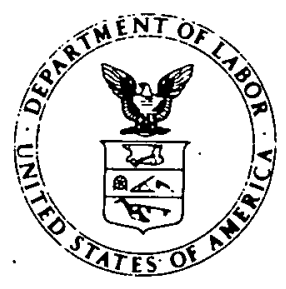

JUL $\cap ? 9978$

Mr. Gregory J. Ahart

Director, Human Resources Division

United States General Accounting Office

Washington, D.C. 20548

Dear Mr. Ahart:

The Mine Safety and Health Administration, Department of Labor, has completed their review of the drafts of a proposed report, "Questionable Suitability of Certain Salt Caverns and Mines for the Strategic Petroleum Reserve." Additionally, we have met with several members of your staff and discussed with them the first and second drafts of the report.

In March, the Five Island Salt Domes (LA) were investigated by members of the Mine Safety and Health Administration's Underground Storage Task Force and South Central District enforcement personnel to study the blowout phenomena, permeability and oil, gas, and water seepages, and to observe existing mining conditions. Their findings address some of the issues raised in your report. A copy of the Mine Safety and Health Administration Task Force Report is enclosed. The information contained in this report may be of assistance to you.

We have appreciated the opportunity to review your report and discuss with your staff its findings. If we can provide any further information, please do not hesitate to contact us.

Your interest in our mine safety and health program is greatly appreciated.

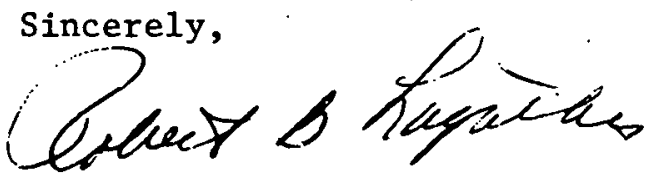

Robert B: Lagather

Assistant Secretary

for Mine Safety and Health

Enclosures 


\title{
$? 4$
}

\author{
MERORALDU: FOR: SECPETARY OF IABOR \\ FROS: \\ ROEERT P. iA.GATHET Signed Robert R. Lagather \\ Ass18tart Secretary \\ for Mine Safety and lealth \\ SUBJECT : \\ Department of Labor Involverent with the \\ jattonsl Storaga Petroleun lieserve Prograd
}

The Presilent has sct a strateglc Petrolcwn Reserve (SF!) goal

for the storage of one billion barrcls of $\partial 11$ by 1993. The Departvent of Ener.y (ion) has a current fiil scienuie of 125 rillion barrels

In underground etorege by ti:e end of 1975. The :Ine Safetp and Health Adbinfstration tindersta:is shat most of tlis oli vill le stored in tro mines, Weits Island and Cotc Elanche, wich are in sult comes alons the Loulsirna Gulf Coast. The Spt prorrain 1s besen nr sctive minin?

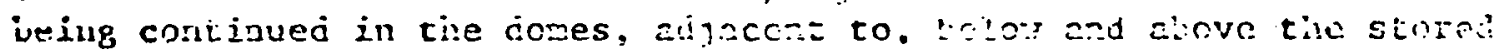
o11. Unfortunately, DOE has rot adytsed ist: of its future plonitre, and we do rot krow if otizer "hual-purpose" mires aie tecirs considerer?.

In early 1976, :islin was advised of tie possible nillzation of mines for the strateric storace of pezoleun. It bas sct until late 1976, however, that isila recelved a Eras13111ty stüly ircm Dor, cricritrd to the acononics of the oil storace ?:criat, for revic: and cortent. Recogniafing the potential inzards to any miners and mining nctivlites

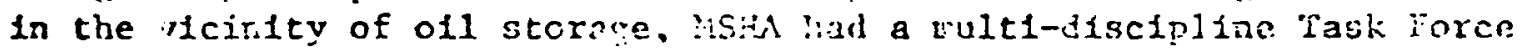
investl.jate the technical feasibil1ty of cual-purpose nincs. Finey lave wet witi IJOE, It3 consultanes and contractors, and the ninc operators, from sa:-1y 1977 to vnry reccntiy, to digcuss and revlev thelr proposed plans. Additionally, the Tagk Force lavest1gated the Hceks Islard and Cote BI inche nines, and the other three salt domes cunnrising the live Island ifnes. Information on tic "blcwout" phenomena, strata pericablllty. setpages of ofl, gia and watcr and the olnins cparations was gatherel. The tnitaraction between the nining operations and tine stored oll was then developed.

The Tas: Force 1nvestigation of the Five Islands Salt lincs has bean ccoplet:d. A copy of thelr report 18 ottached for your information. Their cinclusions and recommendations have been revieved by H!SHA' 8

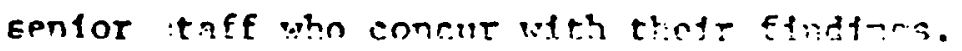


Interdepartmentai conflicts will arlse from dual-pirpose mines. llowever, it 18 in DOE's ard the lation's best interr.st to mine adfacent to the stored o1l. For example, the Cote Blanche salt dome has at least $700 \mathrm{mill1}$ on tons of econorically rccoverable nalt outside of the

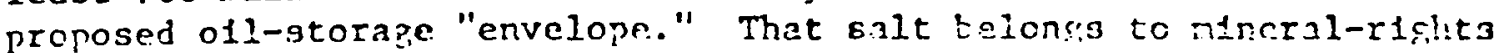
holderb; re estimate royslties of $\$ 300,000$ per year (acout $19 \mathrm{c} / \mathrm{ton}$ ) and a full purchase price of at least $\$ 80$ million. The superfor pur1ty end color of that salt and 1 ts relatively low encrey cemand 1 a processtng make it destrablo to textlle, food procegsing, and crentcal, anong other industries. Its low cost to mine and its rcady access to riart.ct wake that salt more economically attractive than nost other deposits in the country. Additionally, mine wages and tares are critical to the local comunities and the State.

Fresent DOR planning for the active mining and ofl etcrage within the sane dome has the potentlal for serfous to ri-nctrous health and safety hazards to the miners. In the lis!la rcyort on the five Island :1nes, recomendations a re inclided vinfcilil milisate against those hazards. However, DOE, thelr ccri:itints and the mine operators may be reluctant to consider our recor indations.

Should the present course of action be contfined iy not, wa w11 have

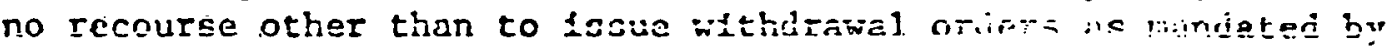
Section 104 of Puhlic Law 95-164, tiae Federal :i-s Salety and tiealth Act of 1977. Such action can be expected to atvesaly affect the negotistione between DOE and the wine choratore sitos teine constdered for the SPR progray, as vell as create 0 i : $:=12$, al and eocial problews for the affected storape site and eurrou iinr araa. A:!ditionally, the Task Force in their report 1dentifisis the probles of uncontrolled flcws of vater, which even with the strence of active miniag, has the potential for destroying tie intersity of en $0: 1$

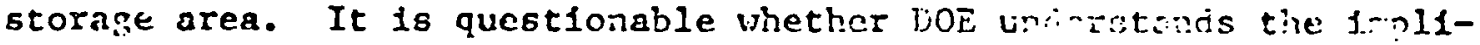
cations related to uncontrolled waterilows.

The above briefly sumarlzes ISSHA's Involvement wjth JOE's O1l Btorare program. I belleve that the DOE continuing 1ta nresent prosran in the Danner planned would be an embarrassaent to the Governoent. Ar your convenience, I would apprechate the opportunity of further discussion un this matter.

Attachnents 


\section{原 \\ MORTON SALT COMPANY}

OIVISION UF MOR:ON-NSAWICH

May 22, 1978

Mr. Monte Canfield, Jr.

Director

United States General Accounting Office

Energy and Minerals Division

Washington, D. C. 20548

Dear Mr. Canfield:

On April 28, 1978, we received your letter dated April 26 to John Kolbas, enclosing for our comment sections of a draft report of potential problems with using certain salt caverns and mines under the Strategic Petroleum Reserve Program. We met with Ralph Calloway and Lucille Perholtz to discuss our comments at their request.

We are pleased that you provided us with the opportunity to comment on a matter that is of extreme importance to us, to our employees, and to the local community.

It may be best to begin with a little history as background. Morton and its predecessor in interest have been producing salt from Weeks Is land since the turn of the century. Morton is the owner of Weeks Island, and carries on not only rock salt mining, but also solution mining, milling, processing, packaging and loading operations. Morton Chemical, another Division of Morton-Norwich Products, Inc., operates a chemical plant on the Island which uses salt produced at Weeks Island as feedstock, and is in the process of building a new, additional chemical plant at a cost of $\$ 15,000,000$.

DOE chose the Weeks Island rock salt mine as one of four sites for the Early Strategic Reserve. DOE advised Morton that it would acquire the mine based upon negotiated terms and conditions or, absent such, would take the mine by condemnation. Morton did.not solicit this acquisition, and Morton was, in reality, a forced - and not a willing - seller. Negotiations with DOE were carried on, and consummated, based on the condition that DOE was acquiring only that properly needed for oil storage; namcly, the subterranean mine and appurtenances and easements. Morton would continue to own the surface buildings and facilities and the remainder of the salt dome from which it could continue to produce salt. The actual transfer of title to the property and payment of the $\$ 30,000,000$ consideration were by means of condemnation, instituted by the Department of Justice in the U. S. District Court in Lafayette, Louisiana.

We trust that you appreciate that these arrangements were undertaken for a multitude of reasons. Obviously, the cost to the Government was minimized 
Mr. Monte Canfield r.

Page Two

U. S. GAO

$5 / 22 / 78$

Re: Weeks Island (MSD)

by not taking all of Weeks Is land, but rather taking only that deemed necessary by DOE. It also minimizes the dis ruption not only to the Company and the nearby communities, but also to the work force, to the local economy, including businesses and suppliers serving Weeks Island, to the up-river distribution system of Morton, and to the many hundreds of rock salt customers served by Weeks Is land. Your report iails to adequately recognize these important benefits to be gained by Morton being able to continue to mine at Weeks Island.

In a portion of your draft report, you discuss what is titled: "Uncertain Effects of Continuing Mining Below the Oil Storage Area, " and cite two problem areas, blowouts and boreholes. With reference to the blowout problem, we have several comments. First, we certainly agree that a safe distance between the oil storage area and the new mining area is vital. Our goal, as yours, is to identify "what is safe." We trust you appreciate that all mining operations, as most other things in life, are not absolutely free from any and all risk. Rather, the attempt has to be to identify what is safe to a reasonable degree of certainty and what is the nature and extent of the risk. We believe we have done this by analyzing the risk objectively and realistically, and by planning our new, permanent mining level at a depth of 370 feet beneath the oil storage. Only the sump area of the present production shaft (18 feet in diameter) will be as near as 300 feet.

We consider this sill thickness to be very safe based upon standard operating practices of Morton and the industry in general, and upon rock mechanic's considerations. The results of a finite element analysis performed at the University of Dlinois confirms this view, which analys is is documented in a report by A. J. Hendron, Jr. entitled, "Preliminary Finite Element Study of Proposed Third Level Mine at Weeks Island with Oil Storage in Levels 1 and $2 "$ dated May 23, 1977.

We question your factual bas is for concluding that "a blowout could occur in Morton's working mine that might extend to the oil storage area above and flood the working mine with oil. " Such would require a blowout of at least 370 feet, vertical dimension, which, as far as we.know, is simply presumptive and conjectural. The largest blowout ever experienced at Weeks. Island extended thrity feet long and ten feet in diameter, not the 100 feet referred to on Page 12 of your draft report. We suspect your reference to a reported 100-foot blowout was in connection with another salt dome. Please recognize that salt domes are different, with different characteristics.

With reference to your Page 12, first paragraph, world-wide experience indicates that various criteria are available for predicting areas with blowout potential, and your attention is directed to the following reference material: Proceedings of the 1966 Leipzeig Conference on Sudden Outbursts. A study, recommended by MSHA, is being undertaken through Dames \& Moore, consultants in earth sciences, to develop criteria to fit our local situation. The scope of this study is set forth in the attachment, with the intent being to complete the study by September, 1978. 
Mr. Munte Canfield, Jr.

U. S. GAO

Re: Weeks Is land (MSD)
Page Three

$5 / 22 / 78$

With reference to your Page 12, second paragraph, DOE is quoted as being of the opinion that "sufficient study had not been done to predict and control blowouts." We do not object to DOE or MSHA undertaking further studies to the extent either believes necessary. The study we are undertaking, referred to in the prior paragraph, could greatly ameliorate the concerns.

The reference in your report to the salt company being totally responsible for a blowout which would cause damage to the oil storage area is an erroneous assumption. Liability is a legal question that depends upon the various facts and circumstances. We would hope that DOE recognizes its responsibil. ity to utilize the property it acquired by condemnation from Morton in a manner that does not cause damage to Morton, as the adjacent property owner, or does not otherwise deprive Morton of the use of its property.

In the final paragraph of Page 12, the statement attributed to MSHA about fractures and cracks is rather confusing. Only if a blowout occurred spontaneously at the floor of the oil storage can it be envisioned that fracturing would extend downward-to the roof (free face) of the mine below. Even then, horizontal stress in the separating sill pillar would tend to seal the fracture. If the reverse were true; that is, a blowout occurrence in the roof of the new mine, all expelled salt would move out of the opening, and any cracks would parallel the remote end of the opening created, as evidenced by the blowouts in salt and potash mines throughout the world. It should be understood that the gas in a blowout is usually $\mathrm{CO}_{2}$ and does not explode, but merely breaks through the thin wall created in its proximity by the advancing face.

You should recognize that the blowout-prone zones at Weeks Island have a pattern related to relict bedding planes in areas of metamorphism. These contorted planes are vertical in attitude, and their downward projection will simply be avoided in mining a lower level. Probe drilling will be carried out routinely in the new mine so that potential blowouts will be identified and bled off harmlessly.

It is also important that you recognize that mining directly below the present mined area offers the best opportunity for avoiding sudden blowout problems. The vertical attitude of the geology provides the basis for identifying potential blow-out zones in the new mine in that the new mine level below should be substantially a "carbon copy" of the existing mine, where we have identified the location of the blowout areas. We intend to avoid such areas in our future mining.

With reference to problems with boreholes on your Pages 13 and 14, we do have records of all boreholes, and none of the holes is deep enough to reach the new level. We intend to plug all of them with non-shrinking grout. Furthermore, we intend, as an additional safety precaution, to treat all 
Mr. Monte Canfield, Jr.

Page Four

U. S. GAO

$5 / 22 / 78$

Re: Weeks Is land (MSD)

holes as if they were improperly plugged and, even though properly plugged, we intend, in future mining beneath, to mine a round the $m$, leaving them in the center of a substantial pillar. Even if the implausible occurred, it would be entirely possible to insert a packer and valve into a vertical borehole in the mine roof under full-head-of-oil conditions. I/

One final point needs to be made. References in your report to MSHA's opinions are not supported by the Agency's representations to us. We have, from the beginning, attempted to work closely with MESA, its predecessor, and have proceeded only after getting its approval in concept. We have not been advised that this concept is no longer acceptable or that it would present an imminent danger to our workforce.

We hope our comments are of assistance to you in understanding what is involved at Weeks Island. We, like you, are interested in the safe implementation of the Strategic Petroleum Reserve Program at Weeks Island. To the extent there exist unreasonable risks and unsafe conditions, we wish to be aware of them, and. would be happy to work with DOE, MSHA, and/or $\mathrm{GAO}$ in solving them.

Please be sure to advise us if you would like any additional information. Again, we appreciate this opportunity to provide you with our comments.

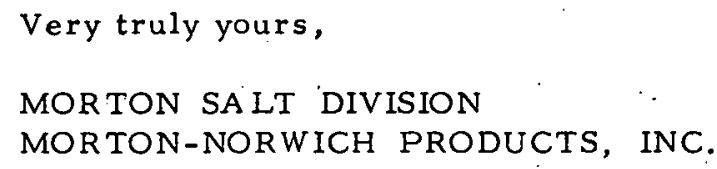

JMK:nhm

Attachments

I/GAO note--The issue of boreholes is no longer addressed in this report because additional information we obtained led us to conclude that the boreholes had been located. 


\section{ATTACHMLNT}

Sudden Outburst Study:

1. Catalog location and size.

2. Gather samples of expelled salt, if possible.

3. Make physical and chemical comparison of expelled versus "normal" salt.

4. Sample wall rock of cavities for anomalous salt.

5. Probe-drill suspect zones, core and analyze.

6. Map geology in known zones.

7. Attempt gas analysis, expelled and "normal."

8. Measure gas pressure.

9. Observe sudden outburst cavities in other mines and comment.

10. Plot zones if identifiable on both mining levels.

11. Vertical (or slightly inclined, based on geology) drill holes in zones. Limited upward and downward depths. 
1. On current mine map, plot location of all positively identified sudden outbursts. Indicate in a key the size of the outbursts referenced to their location number. Note trends so that probe drilling for others may be undertaken intelligently.

2. In some cases expelled salt may be still available for analysis and comparison to backgrounf "normal" salt. Decrepitation upon solution or heating, microscopic examination, petrofabric comparisons, etc.

3. See 2 above, also spectroscopic analysis for trace element: may be undertaken (expelled.vs. normal).

4. If no expelled salt can be positively identified, perhaps wall rock of outburst cavities may prove anomalous.

5. Drilling and coring along identified trends may produce samples that can be "fingerprinted" so that future mining can utilize similar techniques. If possible, drilling should be done through a packer with a provision for catching a gas or fluid sample..

6. The mappable geology in outburst prone zones may be sufficiently unique to allow future prediction based on this parameter.

7. To the extent that gas samples can be collected, they should be analyzed for composition.

8. See 5 above; if packer can be closed in sufficiently quickly, gas pressures can be gauged.

9. Seek permission, through MESA, to observe similar phenomena in the four other Louisiana salt mines. Do not attempt in-depth study, but gather comments (and perhaps samples).

10. Map geology if possible in superposed position on upper level; if structure deivates from vertical, make proper allowance.

11. It would be highly desirable, if time permits, to drill vertically (or parallel to slightly inclined structure), both upward and downward, in known zones or exactly at the locus of an existing outburst. This has the best chance of proving or dispelling the theory that outburst zones parallel structure, and, therefore, are predictable on lower mining. levels. Also; with luck, gas prossure variances (or similarities) may be observed. 


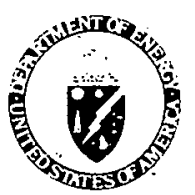

L.epartment of Energy

Washington, D.C. 205.15

July 18,1978

Mr. Monte Canfield, Jr., Director

Energy and Minerals Division

U. S. General Accounting Office

Washington, D. C. 20548

Dear Mr. Canfield:

Thank you for the opportunity to review and comment on the GAO draft report entitled "Questionable Suitability of Certain Salt Caverns And Mines For The Strategic Petroleum Reserve." Our views with respect to the text of the report and recommendations made by GAO are discussed below.

The GAO report addresses a number of geological and engineering aspects of petroleum storage in salt domes. It discusses some of the technical issues which the Department and its contractors have identified and considered during the technical evaluation and design of SPR sites.

We believe that GAO's concern. over DOE's cavern certification program and the potential for caverns to grow together is unwarranted because:

- DOE's cavern certification program consists of more tests than the pressure tests referred to in the report. Directional surveys, sonar surveys and cement bond logs are an integral part of the certification program to assure the structural stability and integrity of all solution-mined caverns which have been certified.

- As the report points out, pressure tests conducted for the two caverns cited in GAO's report were performed at pressure 30 percent above the planned maximum operating pressure.

- Caverns currently planned for SPR oil storage have passed all certification tests and are satisfactory for at least one fill and withdrawal cycle. At no time has there been any evidence that certified caverns are not suitable for, oil storage. DOE monitoring during oil fill operations shows that there has been no oil loss in any of the caverns currently being filled. 
- The possibility for caverns to coalesce after multiple withdrawals is real. The actual nature of cavern growth is difficult to predict and tests will be performed after each withdrawal to determine precisely the ..scope of cavern enlargement.

- If tests indicate that one or more caverns could coalesce after another fill and withdrawal, mitigating measures can be taken. For example, it is a common industry practice to use brine as a displacement fluid during withdrawal to prevent any future?. cavern growth.

DOE intends to develop plans for refill of the reserve in the event of a withdrawal which will include plans for abandoning or modifying the. use of certain caverns if necessary. When such plans are developed, they will be furnished. to the Congress.

Also, we will develop a formal system or procedure for documenting cavern test results including procedures for assuring appropriate approvals of any deviations from test criteria.

We do not agree, with the conclusion that the Weeks Island storage site may not be suitable for oil storage.

- GAO's finding that all areas of the mine had different test results is inaccurate. The test results did not give an indication that the mine was not-suitable for storage. Al1 variances in measurements were within the sensitivity bands. of, the test equipment used.

- Areas selected as test locations within the mine were those which have the highest probability of failure during oil storage. Tests were performed in the lower level of the mine because the greatest pressures will result at this level. Salt characteristics are considered to be equivalent between the upper and lower levels of the mine.

- Close visual inspection of all portions of the mine was performed as part of the mine certification program.: Furthermore, extensive mine conversion work being performed in both the upper and lower portions of the mine continues to confirm that the mine is totally suitable for oil storage:

- Technical analyses performed by DOE contractors indicate that 300 feet of salt is desirable beneath the oil storage to insure the integrity of the site. This evaluation was based on the structural nature of the mine and salt dome; the possibility of 
Mr. Monte Canfield, Jr. $\quad-3-\quad$ July 18, 1978

a mining operation below the storage area and the potential for blowouts. The question of web thickness was discussed with Mining Safety and Health Administration (MSHA) prior to acquiring the mine and no objections were raised by MSHA at that time about the 300 foot thickness. Accordingly, DOE's purchase of the mine included 300 feet of salt below the existing mine.

- Morton Salt Company's plans to mine below the storage area are contingent upon approval by MSHA. MSHA's concern that a mining operation below the oil storage could pose risks is based principally on the fact that little technical data and analysis is available on salt mine blowouts. If the planned MSHA study of blowouts indicates that the DOE property acquisition is insufficient, DOE will take all action necessary to insure site safety including acquisition of additional salt below the existing mine if necessary.

- Morton Salt Company is currently mining salt an area above and off to the side of DOE's property. Operations in this area are expected to continue through 1980 and do not jeopardize miner safety in any way. Morton is maintaining its salt production levels and DOE's acquisition of the mine has resulted in no unemployment or adverse economic impact.

- Water intrusion is a constant possibility in all salt mining operations. Modern mining techniques and practices are designed to avoid and control potential water problems. The Weeks Island mine has a 75-year record of safe operations. The water problem cited by GAO was encountered by Morton while excavating in a new area above and to the side of the oil storage area. Water inflow has been controlled and will continue to be monitored. The concrete bulkheads being installed in the mine by DOE to contain the stored oil would prevent any potential water inflow from reaching the oil storage area.

- GAO's comments on the outcome of Morton's plans to continue mining are highly speculative. Morton owns vast quantities of salt not only below the storage site but to all sides. The spector of unemployment, adverse flnancial impact, lack of miner safety and litigation are unwarranted at this time since MSHA is only beginning its evaluation process and Morton appears to have alternatives to mining below the oil storage area.

DOE cannot agree with GAO's recommendation to delay storage development and oil fill at the Weeks Island site. There is no evidence, facts, or 
test data to indicate that the mine is not suitable for oil storage. Morton's mining operations: through 1980 pose no health or safety hazard to miners or the oil storage area. Furthermore, there is adequate time and alternatives exist so that the issue of where Morton can safely and economically continue to mine salt at Weeks Island can be resolved. Delaying the use of the site for strategic petroleum storage will not contribute to the resolution of this issue.

On the other hand, delaying oil storage at the site will increase this nation's vulnerability to interruptions of oil imports. It is necessary to weigh the risk of the economic and social loss which could result without this SPR site against the risk of some impact on future mining in the salt dome. In addition, the cost of delaying or terminating DOE contractors, which are currently converting the mine for oil storage and are constructing oil distribution facilities, would be high with little or no benefit derived.

The concerns raised by GAO are being resolved and pose no serious risk to the integrity of the storage system. DOE agrees with GAO that the SPR Program should be developed to minimize risk. However, we disagree with GAO that all uncertainties (no matter how minimal) should be or can be fully resolved before proceeding with SPR implementation. The risks cited by GAO are of little consequence when compared with reduced protection to the nation which would result from delays in program development. Further, it is impossible to eliminate all risks that may be associated with any type of oil storage.

$$
\text { Sincerely, }
$$

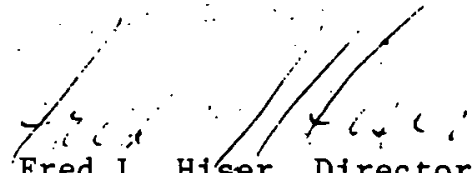

Fred L. Hiser, Director

Division of GAO Liaison

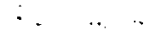

office of the Controller

(00304) 
Single copies of GAO reports are available free of charge. Requests (except by Members of Congress) for additional quantities should be accompanied by payment of $\$ 1.00$ per copy.

Requests for single copies (without charge) should be sent to:

U.S. General Accounting Office Distribution Section, Room 1518 $441 \mathrm{G}$ Street, NW.

Washington, DC 20548

Requests for multiple copies should be sent with checks or money orders to:

U.S. General Accounting Office

Distribution Section

P.O. Box 1020

Washington, DC 20013

Checks or money orders should be made payable to the U.S. General Accounting Office. NOTE: Stamps or Superintendent of Documents coupons will not be accepted.

\section{PLEASE DO NOT SEND CASH}

To expedite filling your order, use the report number and date in the lower right corner of the front cover.

GAO reports are now available on microfiche. If such copies will meet your needs, be sure to specify that you want microfiche copies. 
AN EQUAL OPPORTUNITY EMPLOYER

UNITED STATES

GENERAL ACCOUNTING OFFICE

WASHINGTON, D.C. 20548

OF FICIAL BUSINESS

PENALTY FOR PRIVATE USE, $\$ 300$
THIRD CLASS 
THIS PAGE

WAS INTENTIONALLY

LEFT BLANK 


\section{APPENDIX XVII}

Management Oversight Risk Tree Analysis 


\section{THIS PAGE \\ WAS INTENTIONALLY \\ LEFT BLANK}


Management Oversight Risk Tree Analysis

A. Causal Factors and Events Analysis Chart

B. Management Analysis Summary Chart

These charts are printed as separate inserts to the report because of their awkward size. Requests for copies should be directed to:

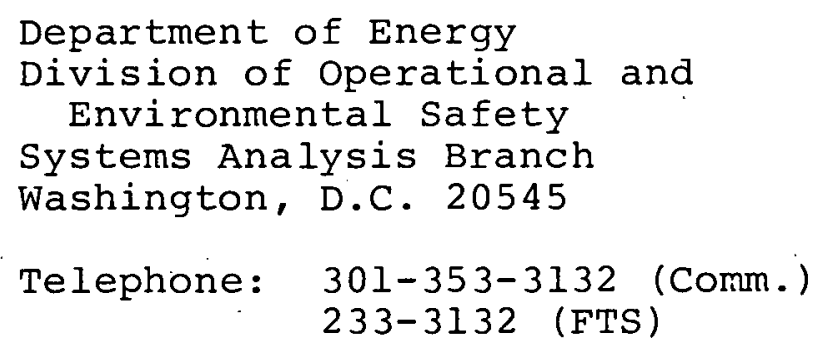

These are working charts that were used in part by the committee in the conduct of the investigation. They contain a number of items that are based on the subjective opinions of witnesses and/or the committee's consultants. Hence, the items on the charts may not be in complete agreement with the text of the report as set forth by the Committee members, since the committee used additional sources to verify its findings. 
THIS PAGE

\section{WAS INTENTIONALLY LEFT BLANK}


APPENDIX XVIII

Copy of Oct. 17, 1978, TWX, White to clusen

$A-363$ 


\section{THIS PAGE}

\section{WAS INTENTIONALLY \\ LEFT BLANK}




\section{U.S. DEPT. ZMERT \\ 1978 COT 10 : :.: Ii: is}

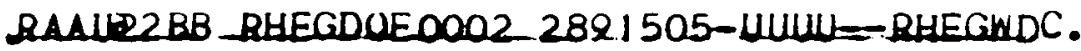

$Z^{N_{R}}$ UUUUUU

-T- RHEGWDC FOR RUTH CLUSEN ASST SEC ENVIRONMENT

RAAUIJAZ RUCHNNNO002 1200289-UUUU-RHEGDOE.

ZNR UUUUU

FM P.C.WHITE, COMMITIEE CHAIRMAN-MARVIN E DEMOSS DUE DALLAS

TO RUTH CIUSEN, ASEV

UNCLASSIFIED

BI

COMMI TTEES FINDINGS RAISE IMMEDIATE CONCERN REGARDING SAFETY OF CURRENT CAVERIN OPERATIUNS UNDER PRESSURE. STRONGLY URGE REVIEW OF ADEQUACY OF SAFETY EQUIPMENT AND PROCEDURES TO BE SURE THEY MEET GOOD OIL FIELD DRILLING PRACTICE. SHUULD BE APPLICABLE TO WORK OVERS AS WELL AS DRILLING AND ALI OPERATIONS UNDER PRESSURE. DETERI URATED CONDITION NO.6 WELL HEAD ON CAVERN 6 IMPLIES NEED TO CHECK OTHERS WITH SIMILAR HISTURY. CC\& GEN.J.DELUCA, SPR

BT

$\# 0002$ 
2 